\title{
Mesozoic tectonic history and geochronology of the Kular Dome, Russia and Bendeleben Mountains, Seward Peninsula, Alaska
}

Daniel B. Harris

West Virginia University

Follow this and additional works at: https://researchrepository.wvu.edu/etd

\section{Recommended Citation}

Harris, Daniel B., "Mesozoic tectonic history and geochronology of the Kular Dome, Russia and Bendeleben Mountains, Seward Peninsula, Alaska" (2011). Graduate Theses, Dissertations, and Problem Reports. 3426.

https://researchrepository.wvu.edu/etd/3426

This Dissertation is protected by copyright and/or related rights. It has been brought to you by the The Research Repository @ WVU with permission from the rights-holder(s). You are free to use this Dissertation in any way that is permitted by the copyright and related rights legislation that applies to your use. For other uses you must obtain permission from the rights-holder(s) directly, unless additional rights are indicated by a Creative Commons license in the record and/ or on the work itself. This Dissertation has been accepted for inclusion in WVU Graduate Theses, Dissertations, and Problem Reports collection by an authorized administrator of The Research Repository @ WVU.

For more information, please contact researchrepository@mail.wvu.edu. 


\title{
MESOZOIC TECTONIC HISTORY AND GEOCHRONOLOGY OF THE KULAR DOME, RUSSIA AND BENDELEBEN MOUNTAINS, SEWARD PENINSULA, ALASKA
}

\author{
Daniel B. Harris \\ Dissertation submitted to the \\ Eberly College of Arts and Sciences \\ at West Virginia University \\ in partial fulfillment of the requirements \\ for the degree of \\ Doctor of Philosophy \\ in \\ Geology \\ Jaime Toro, Ph.D., Chair \\ Patricia Campbell, Ph.D. \\ Dengliang Gao, Ph.D. \\ Helen Lang, Ph.D. \\ Amy Weislogel, Ph.D. \\ Department of Geology and Geography \\ Morgantown, West Virginia \\ 2011
}

Keywords: Kular; Russia; Bendeleben; Seward Peninsula; geochronology; zircon; U-Pb; pluton; Arctic tectonics

Copyright 2011 Daniel B. Harris 


\section{ABSTRACT \\ Mesozoic Tectonic History and Geochronology of the Kular Dome, Russia and Bendeleben Mountains, Seward Peninsula, Alaska}

Daniel B. Harris

The tectonic history responsible for formation of the major basins of the Arctic and movement of landmasses surrounding these basins remains unclear despite multidisciplinary efforts. Most studies focus on one of four potential movement pathways of the Arctic Alaska-Chukotka microplate during the Mesozoic and the relationship between this movement and formation of the Amerasian Basin. Due to difficulty in access and harsh climate of the Arctic Ocean, most geological studies focus on landmasses surrounding the Amerasian Basin. For this reason, we have conducted research in the Kular Dome of northern Russia and the Bendeleben Mountain Range of the Seward Peninsula, Alaska in an attempt to better constrain timing of emplacement of plutons in these areas and their associated tectonic conditions. For both areas, U-Pb zircon crystallization geochronology was performed on several samples collected from plutons responsible for gneiss dome formation during the Mesozoic. Dating of these plutons in tandem with field observation and thin section analysis of deformation suggests an extensional emplacement setting for both areas during the Middle to Late Cretaceous.

In the Kular Dome, intrusion of the Kular pluton occurred from approximately 111$103 \mathrm{Ma}$ along with extensional development of the nearby Yana fault, which was previously interpreted as a regional suture between deposits of the Kolyma-Omolon superterrane and passive-margin sequences of the Verkhoyansk Fold-Thrust Belt. Evidence for extensional emplacement of the Kular pluton includes top-down shear around mantled porphyroblasts plunging along gentle foliation away from the pluton and abundant low-offset normal faults in the area. The Kular Dome also falls into a north-south oriented belt of Late Cretaceous plutons interpreted to have been emplaced under regional extensional conditions based on geochemical discrimination diagrams.

Detrital zircon geochronology was also performed on seven samples collected from Triassic sandstones and Jurassic greywackes near the Kular Dome and compared to results from previously studied surrounding regions in Russia and the Arctic Alaska-Chukotka 
microplate in order to better define the relationship between the Arctic Alaska-Chukotka microplate and northern Russia during the Mesozoic. Results suggest that though the Chukotkan portion of the Arctic Alaska-Chukotka microplate was separated from the Kular Dome area during the Triassic, by the Tithonian it shared similar source regions for detrital zircon populations. Based on detrital zircon data from Chukotka, the Kular Dome, and the In'Yali Debin area, a new tectonic model for the formation of the Amerasian Basin and structures within is proposed. In this new model, Chukotka separated from and moved independently of the North Slope of Alaska during the Late Triassic-Early Jurassic, experiencing strike-slip emplacement along the northern coast of paleo-Russia and closed the South Anyui Ocean via transpression to form the South Anyui suture.

Geochronologic and geochemical results from the Bendeleben and Windy Creek plutons of the southeastern Seward Peninsula were also studied to better describe Arctic tectonic conditions during the Late Mesozoic. In this area, six samples were collected from the multiple lithologies seen within the Bendeleben and Windy Creek plutons and were also dated by zircon $\mathrm{U}-\mathrm{Pb}$ geochronology and analyzed for their major and trace element geochemistry. Results suggest that the Bendeleben and Windy Creek plutons were emplaced during multiple extensionally driven pulses of magmatism above a southwardretreating, northward-subducting slab causing extension in the overlying crust from about $104 \mathrm{Ma}$ to $83 \mathrm{Ma}$. The magma chamber at depth was experiencing continuous replenishment and liquid segregation causing stratification of the Bendeleben pluton. Magmas of the felsic cap, which now form the outer region of the Bendeleben pluton, were emplaced first, followed by subsequent intrusion of younger, mafic magma from below. Evidence for north-south directed extension during emplacement of the Bendeleben pluton was in the form of consistent east-west dike orientation in the Seward Peninsula, top-down shear in mantled garnet porphyroblasts from country rock surrounding the Bendeleben pluton, gentle foliation dip away from the pluton and stretching lineations around the pluton. Discrimination diagrams based on $\mathrm{Rb}, \mathrm{Nb}$ and $\mathrm{Y}$ concentrations from bulk rock samples supports a collisional or volcanic arc province and is consistent with emplacement in an extensional environment above a subducting plate. 


\section{Acknowledgements:}

The completion of this document would not have been possible without the aid of several close friends and colleagues. My advisor Jaime Toro has been an instructor, a mentor and a friend to me along this journey and has greatly encouraged me to be a better scientist, teacher and father. The field work and critical reviews necessary for this document were greatly aided by Jaime Toro, Elizabeth Miller of Stanford University, Andrei Prokopiev of the Russian Academy of Science, and Kalin McDannell who completed his master's degree at West Virginia University in Spring, 2011. These field excursions resulted not only in tremendous field experience and educational exercise, but also in adventure and appreciation of the great outdoors. We have all shared unforgettable experiences and for those memories I am forever grateful.

Funding for this project was provided by BP Exploration, West Virginia University, the USGS EDMAP program and the Explorer's Club Washington Group.

Special thanks are also in order for the members of my committee, including Patricia Campbell of Slippery Rock University, Amy Weislogel, Dengliang Gao and Helen Lang of West Virginia University. Their guidance and input has been greatly appreciated and were invaluable to the preparation of this document. The West Virginia University Geology department at large has also been instrumental in providing for me the necessary coursework, extracurricular education and guidance needed to develop into the researcher and teacher I have become.

I would also like to thank the laboratory technicians of both the Sensitive High Resolution Ion-Microprobe, Reverse Geometry (SHRIMP-RG) and Laser Ablation Multicollector Inductively Coupled Plasma Mass Spectrometry (LA-MC-ICPMS) 
instruments from Stanford and Arizona State Universities respectively. Joe Wooden, Brad Ito, Marty Grove, Charles Bacon and all other scientists of the SHRIMP-RG were instrumental in creating smooth operating procedures for an immensely complicated machine who all show an impressive level of dedication to their craft. George Gehrels and all assistant laboratory technicians for the Arizona LaserChron Center also display an outstanding dedication to maintaining a smooth and user-friendly interface for detrital zircon dating and were beyond value for their help during analysis.

Last of all, I would like to thank my family and friends for their constant support and advice. My wife, son, parents and sister were always available for support in the best and worst of times and were an irreplaceable factor in the success of this endeavor.

\section{Daniel Harris}




\section{Table of Contents}

Preface

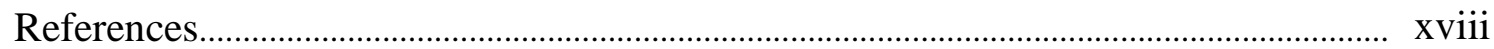

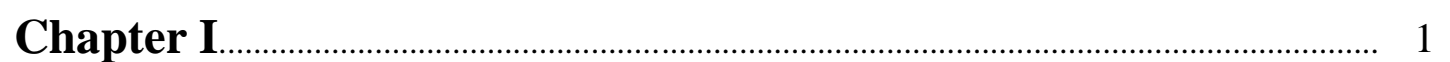

Magmatic evolution and U-Pb geochronology of the Kular Dome as evidence for Middle Cretaceous extension in northeastern Russia

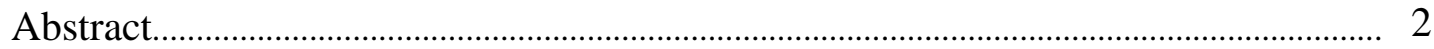

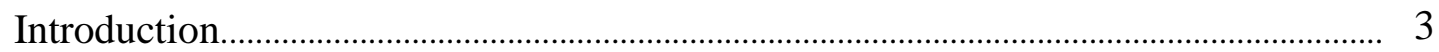

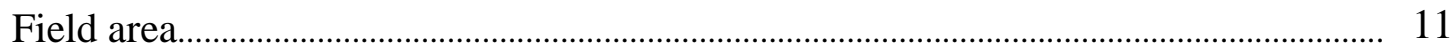

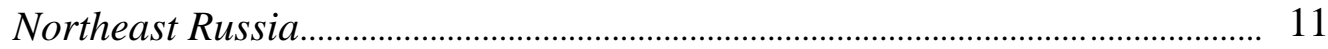

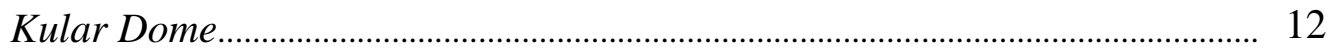

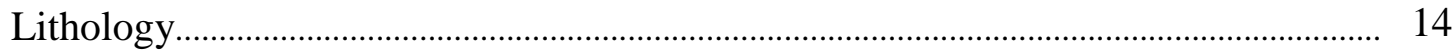

Mesozoic sedimentary units............................................................................. 14

Kular pluton .............................................................................................. 17

Paleozoic metasediments...................................................................................... 18

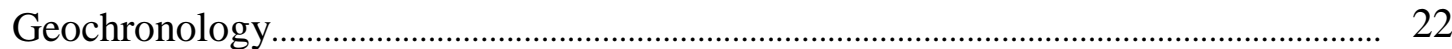

Sensitive High-Resolution Ion Microprobe - Reverse Geometry ...................... 22

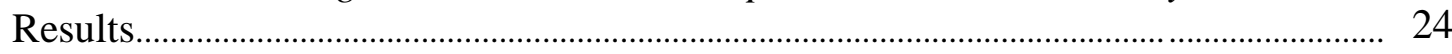

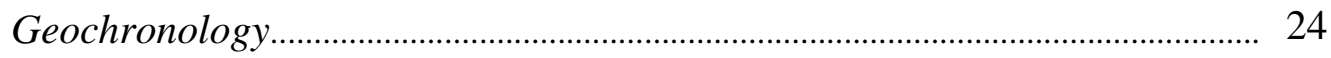

Sample 08DH08 …...................................................................................... 28

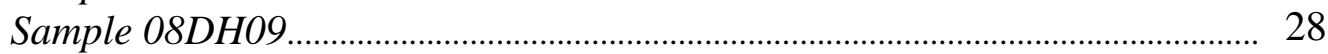

Sample 08DH1 1........................................................................................... 29

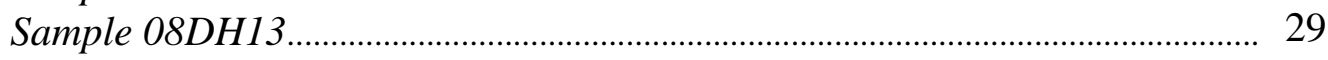

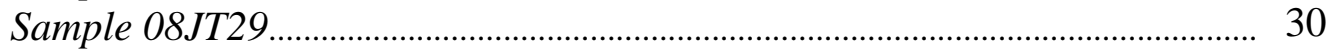

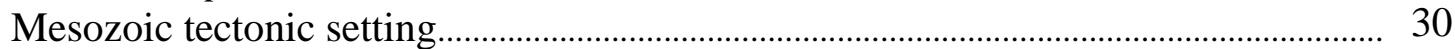

Late Jurassic-Early Cretaceous compression...................................................... 30

Middle Cretaceous extension.................................................................................. 32

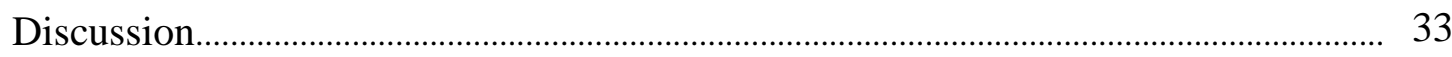

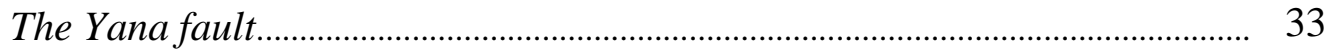

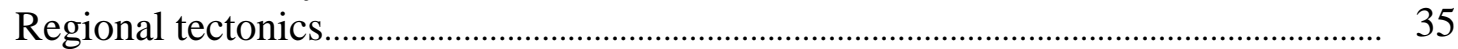

Pluton emplacement and extensional tectonics............................................... 35

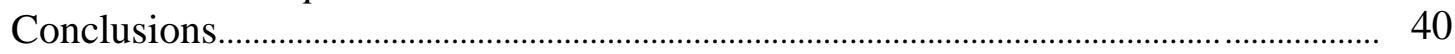

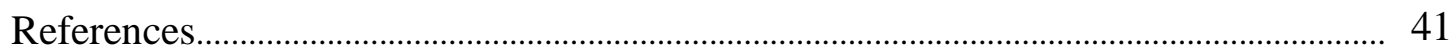

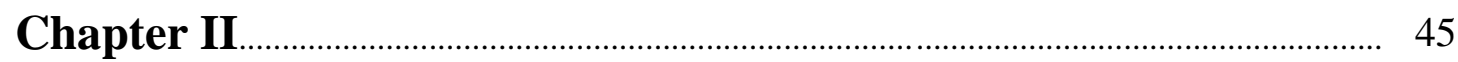

Detrital zircon U-Pb geochronology of Mesozoic sandstones from the Lower Yana River, northern Russia

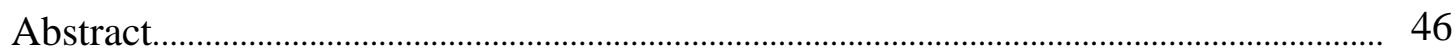

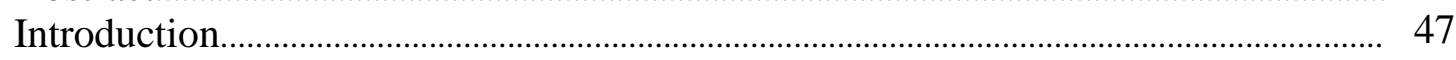

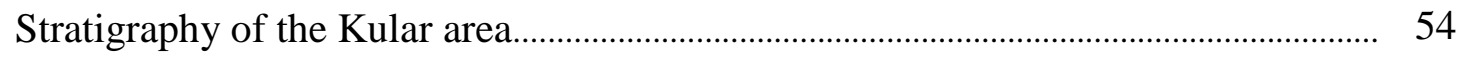




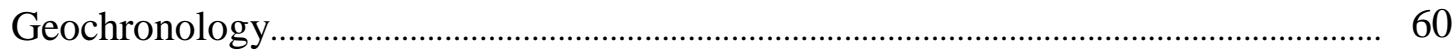

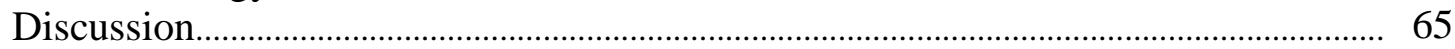

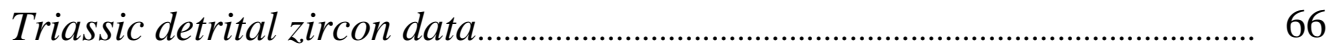

Jurassic detrital zircon data................................................................................ 70

Triassic to Jurassic transition ................................................................................ 72

Tectonic implications of detrital zircon data....................................................... 75

New model for development of the Amerasian Basin............................................ 76

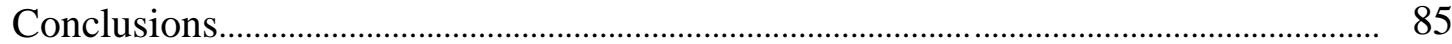

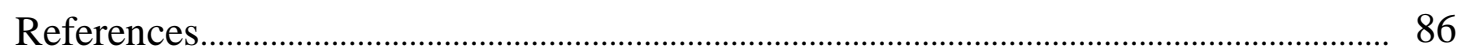

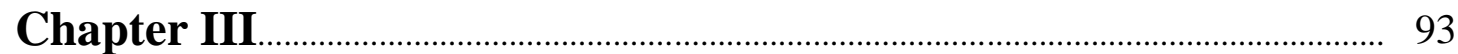

Geochronology and tectonic evolution of the Bendeleben and Windy Creek plutons as an analogue to the nearby Kigluaik pluton: Seward Peninsula, Alaska

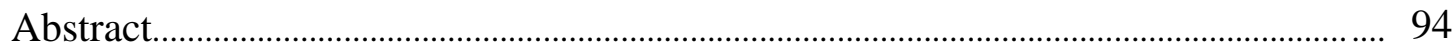

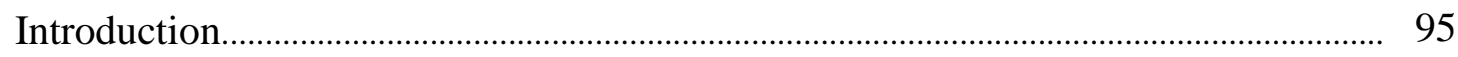

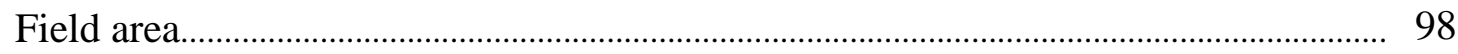

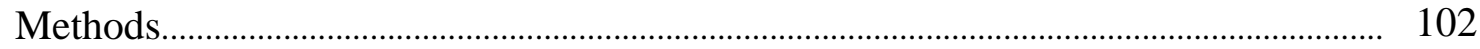

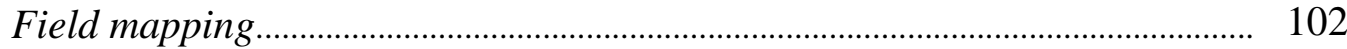

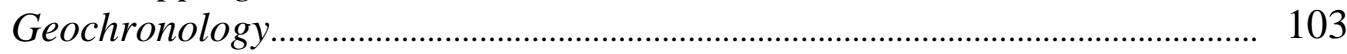

Bulk geochemistry................................................................................... 105

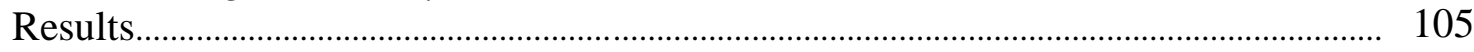

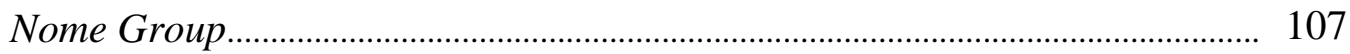

Kigluaik Metamorphic Complex...................................................................... 110

Structural fabrics....................................................................................... 111

Bendeleben pluton.................................................................................................. 113

Windy Creek pluton ............................................................................................. 116

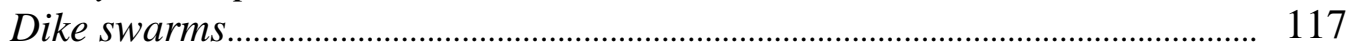

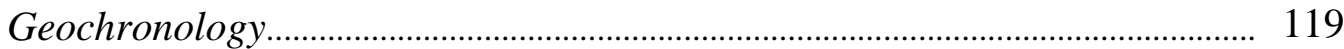

O9BEN20 - Pegmatite .............................................................................. 119

O9BEN26 - Bendeleben pluton, alkali-feldspar granite....................... 124

O9BEN29 - Bendeleben pluton, monzogranite ....................................... 125

09BEN61 - Bendeleben pluton, gabbro....................................................... 125

09BEN63 - Bendeleben pluton, alkali-feldspar granite........................ 125

09BEN73 - Windy Creek pluton, alkali-feldspar granite.................... 126

Trace element and REE.......................................................................................... 126

Zircon Ti concentration geothermometry .......................................................... 136

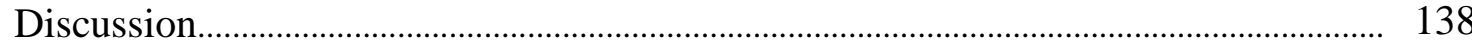

Relationship between the Bendeleben and Windy Creek plutons..................... 138

Pluton emplacement.................................................................................................... 142

Cretaceous tectonic setting of the Seward Peninsula....................................... 148

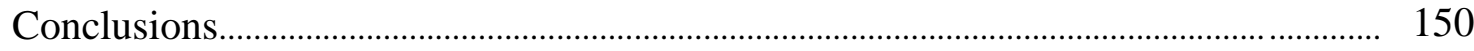

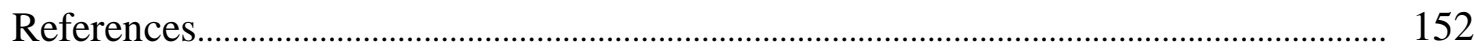




\section{List of Tables}

Chapter I

Table 1: Results from SHRIMP-RG analysis of igneous zircons from Kular granite.

Chapter II

Table 1: Kolmogorov-Smirnov test results for all samples collected from the Kular area.

64

Table 2: Presence or absence of dated zircons within specific age ranges from various locations

Chapter III

Table 1: Geochemical results from samples collected in the Bendeleben and northern Darby ranges.

Table 2: U-Pb SHRIMP-RG dated geochronologic results for samples collected from the Bendeleben and Windy Creek plutons

Table 3: Chondrite-normalized REE content of zircons collected from the Bendeleben and Windy Creek plutons

Table 4: Chondrite-normalized $\mathrm{Ce}$ and Eu ratios of zircons collected from the Bendeleben and Windy Creek plutons

Table 5: Crystallization temperatures for magmatic samples collected in the Bendeleben and Windy Creek plutons 


\section{List of Figures}

Preface

Figure 1: Schematic models describing the formation of the Amerasian Basin of the modern Arctic.

\section{Chapter I}

Figure 1: Russia location map.....

4

Figure 2: Arctic polar view of the relationship between the Gakkel Ridge, Laptev

Sea and Kular Dome

Figure 3: Generalized geology bordering the Kular Dome field area..

Figure 4: Generalized tectonic and terrane map of the Kular Dome area................... 8

Figure 5: Field map and igneous geochronology sample locations for the Kular Dome.

Figure 6: Equal-area plots of foliations and stretched andalusite porphyroblast lineations seen in units of the Kular Dome.

Figure 7: Quartz grain boundary migration preserved in the biotite granite of the Kular pluton.

Figure 8: Andalusite prevalence and muscovite replacement in metapelites near the Kular Dome.

Figure 9: Andalusite stretching deformation and sense of shear from mantled porphyroblasts...

Figure 10: Concordia diagrams for igneous zircons from Kular Dome..................... 25

Figure 11: Weighted mean age diagrams for igneous zircons from Kular Dome.... 26

Figure 12: Late Cretaceous plate vectors for the North American plate relative to the Eurasian plate superimposed on modern bathymetry

\section{Chapter II}

Figure 1: Location map for detrital zircon studies compared in this study and simplified rotational model for opening of the Canada Basin.

Figure 2: Generalized tectonic and terrane map of the Kular area................................ 51

Figure 3: Kular field area and location of detrital zircon samples collected for U-

$\mathrm{Pb}$ geochronology..

Figure 4: Vertical bedding in Triassic sandstones and flute casts seen along bottom bedding surface of Jurassic strata.

Figure 5: Probability density plots and ternary provenance diagrams for Kular data

Figure 6: Age ranges of detrital zircons collected from locations surrounding the Amerasian Basin

Figure 7: Schematic Mesozoic to present plate reconstruction for the motion of various continental fragments of the Arctic. 


\section{Chapter III}

Figure 1: Generalized geologic map of the Seward Peninsula and Bering Strait region.

Figure 2: Field map and zircon geochronology sample locations for the eastern

Bendeleben Mountain range.

Figure 3: Muscovite schist outcrop and oriented photomicrographs of biotitegarnet schists showing sense of shear.

Figure 4: Equal-area stereonet plots of foliations and lineations within units of the Kigluaik Metamorphic Complex.

Figure 5: Ternary diagram of plutonic rocks from igneous samples of the Bendeleben and Windy Creek plutons

Figure 6: Pegmatite intrusion through impure diopside-bearing marble unit in the Bendeleben Mountains

Figure 7: Concordia plots for U-Pb zircon ages from samples collected from a pegmatite dike and the Bendeleben and Windy Creek plutons

Figure 8: Weighted mean U-Pb ages for zircons from samples collected within a pegmatite dike and the Bendeleben and Windy Creek plutons

Figure 9: Trace element discrimination diagram for intrusive samples collected from the Bendeleben and Windy Creek plutons

Figure 10: Plate reconstruction for the motion and location of various continental fragments of the Arctic during the Late Jurassic and Late Cretaceous

Figure 11: Trace element concentrations in ppm plotted against $\mathrm{SiO}_{2}$ expressed as weight $\%$ in discrimination diagrams.

Figure 12: Trace element concentrations in ppm plotted against sample age

Figure 13: Chondrite-normalized REE concentrations of zircons from a pegmatite dike and the Bendeleben and Windy Creek plutons

Figure 14: Topographic differences between the Bendeleben Mountains and the relatively longer-exposed northern Darby Mountains.

\section{List of Plates}

Plate 1: Updated geologic map of the eastern Bendeleben Mountains and northern Darby Mountains, scale 1:24000. 


\section{List of Appendices}

Appendix 1: Cathodoluminesence photomicrographs of zircons separated from igneous samples collected from the Kular pluton.

Appendix 2: Complete data from SHRIMP-RG analysis of zircons separated from igneous samples collected from the Kular pluton.

Appendix 3: Cathodoluminesence photomicrographs of detrital zircons separated from samples collected from the Lower Yana River area.

Appendix 4: Complete data from LA-MC-ICPMS analysis of detrital zircons separated from samples from the Lower Yana River area

Appendix 5: AGEPICK results for detrital zircon populations from this study and referenced from the literature.

Appendix 6: Cathodoluminesence photomicrographs of zircons separated from igneous samples collected from the Bendeleben and Windy Creek plutons.....

Appendix 7: Complete data from SHRIMP-RG analysis of zircons separated from igneous samples collected from the Bendeleben and Windy Creek plutons.....

Appendix 8: Geochemistry results for samples collected from the Bendeleben and Windy Creek plutons 


\section{PREFACE}

A complete Mesozoic reconstruction capable of describing the movement pathways and the timing of movement for landmasses surrounding the modern Arctic, as well as formation of the numerous basins within the Arctic itself, has long remained enigmatic (see review in Lawver and Scotese, 1990). Geologic studies pertaining to this history have been attempted via many approaches, such as seismic imaging, dredging, paleontologic,

geochronologic, stratigraphic, etc., resulting in datasets as immense as they are diverse (e.g. Dove et al., 2010; Embry, 1990; Kuzmichev, 2009; Lebedeva-Ivanova et al., 2006; Miller et al., 2006). Most tectonic studies of the Arctic focus on the formation of the Amerasian Basin, which opened during the Mesozoic as a result of movement of the Arctic AlaskaChukotka microplate (AAC) which includes the North Slope and Seward Peninsula of Alaska, and Chukotka, the New Siberian Islands, Wrangel Island and the East Siberian Shelf of Russia (Figure 1).

Several models exist for the specific movement of this microplate including strike slip motion of the AAC either away from an initial location along the Barents Shelf (Figure 1a) or the Canadian Arctic Islands (Figure 1b), the "double windshield-wiper model" (Figure 1c) and the "rotational model" (Figure 1d) which is generally regarded as the most capable of describing data collected in and around the Amerasian Basin. 

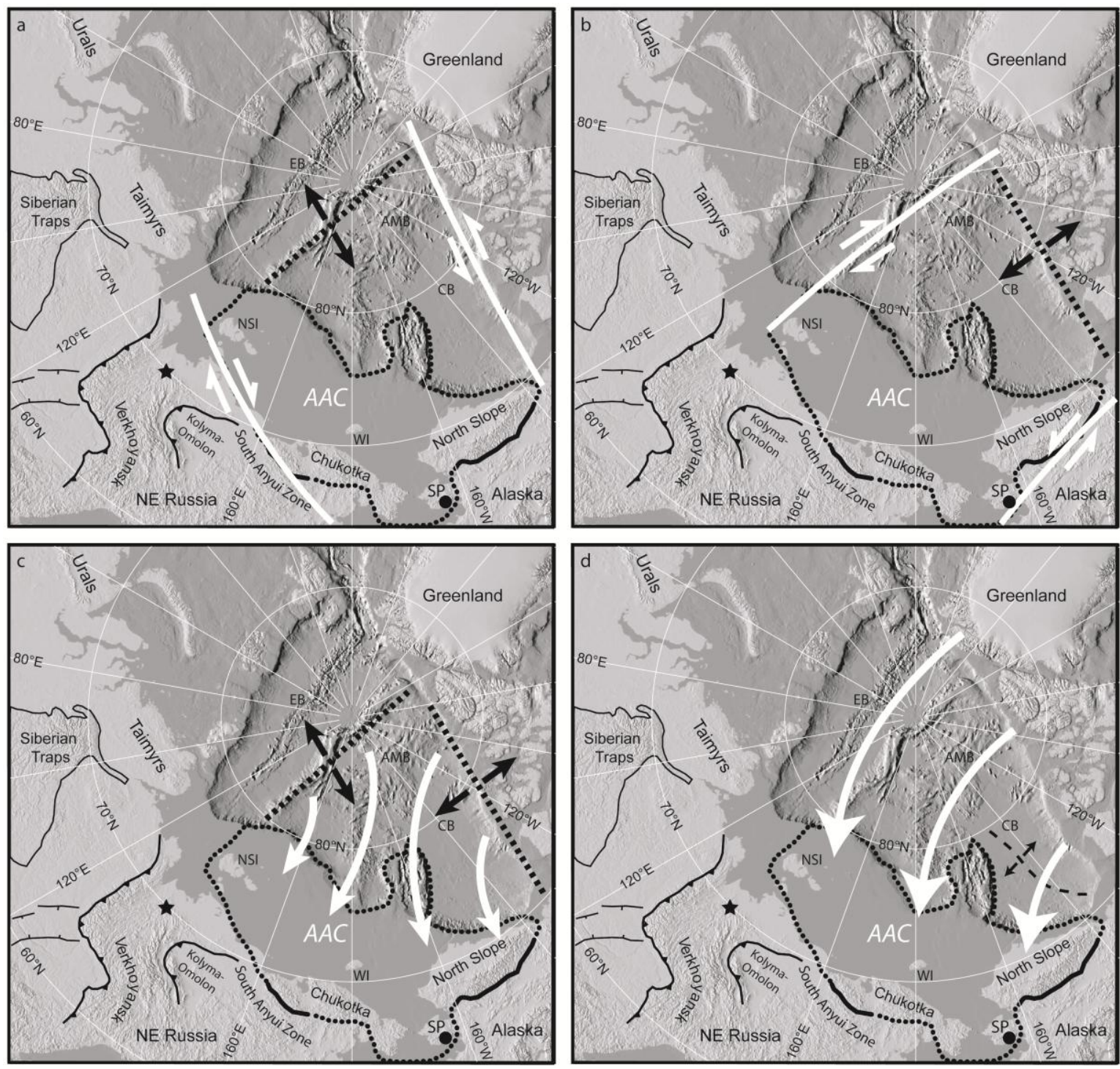

Figure 1: Multiple highly schematic models describing the formation of the Amerasian Basin of the modern Arctic including: a) strike-slip along the Canadian Arctic Islands and the Siberian shelf, b) strike-slip along the Barents shelf (restored) and northern Alaska, c) the double windshield-wiper model and d) the rotational model. AMB is the Amerasian Basin, AAC is the Arctic Alaska-Chukotka microplate, CB is the Canada Basin, EB is the Eurasian Basin, SP is the Seward Peninsula, WI is Wrangel Island and NSI are the New Siberian Islands. Base bathymetry maps are from the International Bathymetric Chart of the Arctic Ocean initiative (Jakobsson et al., 2008). The star indicates the location of the

Kular Dome and Lower Yana River area and the circle represents the Bendeleben Mountains location on each map. 
The rotational model was first proposed by Carey $(1955 ; 1958)$ based on a concept of oroclinal bending and was later modified for compatibility with plate tectonic theory by himself and many others over the following decades using a variety of rotational poles generally located near the MacKenzie Delta (e.g. Rickwood, 1970; Tailleur, 1969; Grantz et al., 1979; references in Lawver and Scotese, 1990 and Lawver et al., 2002). While this model is supported by several bodies of evidence including bathymetric data across the Canada Basin, facies trends across northern Alaska and the Canadian Arctic Islands, magnetic anomalies in the Canada Basin, and a variety of other studies summarized in Lawver et al. (2002), most data supports specific movement of northern Alaska away from the Canadian Arctic Islands with little data supporting a similar movement of Chukotka. Problems with various pathways for Chukotka in the rotational model include a substantial overlap with continental crust north of Greenland (modern coordinates) when restored to a pre-rift location (Rowley and Lottes, 1988) and inconsistencies in the detrital zircon record when comparing Chukotka and the New Siberian Islands to a pre-rift location near the Ural Mountains (Miller et al., 2010; Miller et al., 2008). This same detrital zircon record has been used as support for the strike-slip models (Figures 1a and 1b), though data are also compatible with the double windshield-wiper model (Figure 1c) (Miller et al., 2010).

The Chukotkan portion of the AAC is widely regarded to have formed a continuous landmass with the North Slope of Alaska during the Paleozoic based on a multitude of data summarized in Miller et al. (2006) though the coherency of this block during Mesozoic movement across the modern position of the Amerasian has been met with skepticism by some. The double windshield-wiper model describes an emplacement of the AAC involving the separate and independent movement of the Chukotkan and Alaskan portions 
of the AAC which retained an initial connection until the Middle Mesozoic (Amato et al., 2009; Miller et al., 2010; Miller et al., 2006). This model provides a solution to the continental overlap problem, is compatible with magmatic and faunal data from Alaska and Siberia and is consistent with the detrital zircon record for samples collected in Wrangel Island, Chukotka and the Seward Peninsula (Amato et al., 2009; Miller et al., 2010), however problems still exist in terms of timing and style of emplacement for a more complex movement path utilizing several independent blocks. Data presented in this document will add to the collective study regarding formation of the Amerasian Basin and general Mesozoic Arctic tectonic history via three independent studies of the structural setting and geochronology of the Kular gneiss dome of northern Russia and the Bendeleben gneiss dome and mountain range of the Seward Peninsula, Alaska. Due to the preference for each chapter to be written as a stand-alone, immediately publishable document, a certain amount of redundancy within the introduction to each chapter and this preface should be expected.

The first two chapters outline data collected during the summer of 2008 in and around the Kular Dome of northern Russia, located at $70.0^{\circ} \mathrm{N} / 134.3^{\circ} \mathrm{E}$ approximately 30 km west of the town of Ust' Kuyga and the Lower Yana River (Figure 1). Chapter I describes the specifics regarding emplacement of the Kular pluton where field evidence supports an extensional emplacement mechanism. This evidence was combined with granitic zircon U-Pb geochronology using data collected from the USGS/Stanford University operated Sensitive High Resolution Ion-Microprobe, Reverse Geometry (SHRIMP-RG) instrument to provide timing for emplacement as well as an extrapolated regional tectonic setting for the surrounding area. Results from this study combined with 
those performed nearby suggest that northern Russia was experiencing a diffuse extensional event which may have initiated as early as 110 Ma and was likely an early indicator for the eventual opening of the Gakkel ridge to the north during the Eocene.

Chapter II describes the sedimentation history for sandstones and greywackes located along the Lower Yana River directly south of the town of Ust' Kuyga, Russia and approximately $30 \mathrm{~km}$ east of the Kular pluton. U-Pb ages were calculated for detrital zircons extracted from samples collected also in 2008 and dated via laser-ablation multicollector inductively coupled plasma mass spectroscopy (LA-MC-ICPMS) at the University of Arizona LaserChron Center. Probability density functions of ages found from samples along the Lower Yana River were compared to samples of similar depositional age from various locations of the Arctic compiled from published literature in order to estimate the Mesozoic location of these landmasses based on probable depositional sources. Comparison of these data has led to a new proposed tectonic history describing the landmasses of the modern Arctic that is outlined in greater detail at the end of Chapter II.

The third chapter describes data collected in 2009 from the Bendeleben Mountain range in southeastern Seward Peninsula, Alaska where the Bendeleben pluton is exposed in the center of high-grade gneisses and schists of the Kigluaik Metamorphic Complex. The Bendeleben pluton is a lithologically diverse intrusion with localized areas ranging from gabbro to biotite-rich alkali-feldspar granite. The Windy Creek pluton, located directly east of the Bendeleben pluton in the northern reaches of the Darby Mountains was also examined in order to provide a complete emplacement history for igneous intrusives in the area. Field mapping performed by myself, Jaime Toro and Kalin McDannell resulted in an 
updated geologic map at a scale of 1:24000 (Plate 1) in addition to samples analyzed for structural setting, geochemistry and U-Pb geochronology. Geochemical samples included lithologies from each zone of the Bendeleben pluton, the Windy Creek pluton and each of the major metapelitic bodies surrounding each pluton. U-Pb zircon geochronology was performed on multiple samples collected from the Bendeleben and Windy Creek plutons, which were analyzed using the SHRIMP-RG. Results from our field area were compared to the Kigluaik pluton located approximately $90 \mathrm{~km}$ to the west and similar to the Bendeleben pluton in terms of lithology, emplacement mechanisms and emplacement timing. 


\section{References:}

Amato, J.M., Toro, J., Miller, E.L., Gehrels, G.E., Farmer, G.L., Gottlieb, E.S., and Till, A.B., 2009, Late Proterozoic-Paleozoic evolution of the Arctic Alaska-Chukotka terrane based on $\mathrm{U}-\mathrm{Pb}$ igneous and detrital zircon ages: Implications for Neoproterozoic paleogeographic reconstructions: GSA Bulletin, v. 121, p. 12191235.

Carey, S.W., 1955, The orocline concept in geotectonics: Royal Society of Tasmania Proceedings, v. 89, p. 255-288.

Carey, S.W., 1958, The tectonic approach to continental drift, in Proceedings, Continental drift; A symposium: Hobart, University of Tasmania, 177-355.

Dove, D., Coakley, B., Hopper, J., Kristoffersen, Y., and HLY Geophysics Team, 2010, Bathymetry, controlled source seismic and gravity observations of the Mendeleev ridge; implications for ridge structure, origin, and regional tectonics: Geophysical Journal International, v. 183, p. 481-502.

Embry, A.F., 1990, Geological and geophysical evidence in support of the hypothesis of anticlockwise rotation of northern Alaska: Marine Geology, v. 93, p. 317-329.

Grantz, A., Eittreim, S., and Dinter, D.A., 1979, Geology and tectonic development of the continental margin north of Alaska, in Keen, C.E., and Keen, M.J., eds., Crustal properties across passive continental margins: Tectonophysics, v. 59, p. 263-291.

Jakobsson, M., Macnab, R., Mayer, L., Anderson, R., Edwards, M., Hatzky, J., Schenke, H.-W., and Johnson, P., 2008, An improved bathymetric portrayal of the Arctic Ocean: Implications for ocean modeling and geological, geophysical and oceanographic analyses: Geophys. Res. Lett., v. 35

Kuzmichev, A.B., 2009, Where does the South Anyui suture go in the New Siberian Islands and Laptev Sea?: Implications for the Amerasia basin origin: Tectonophysics, v. 463, p. 86-108.

Lawver, L.A., Grantz, A., and Gahagan, L.M., 2002, Plate kinematic evolution of the present Arctic region since the Ordovician, in Miller, E.L., Grantz, A., and Klemperer, S.L., eds., Tectonic Evolution of the Bering Shelf - Chukchi Sea Arctic Margin and Adjacent Landmasses, Special Paper 360: Boulder, CO, The Geological Society of America, p. 333-358. 
Lawver, L.A., and Scotese, C.R., 1990, A review of tectonic models for the evolution of the Canada Basin, in Grantz, A., Johnson, L., and Sweeney, J.F., eds., The Arctic Ocean Region, v. L: Boulder, Colorado, Geological Society of America, p. 593618.

Lebedeva-Ivanova, N.N., Zamansky, Y.Y., Langinen, A.E., and Sorokin, M.Y., 2006, Seismic profiling across the Mendeleev Ridge at $82^{\circ} \mathrm{N}$ : evidence of continental crust: Geophysical Journal International, v. 165, p. 527-544.

Miller, E.L., Gehrels, G.E., Pease, V., and Sokolov, S., 2010, Stratigraphy and U-Pb detrital zircon geochronology of Wrangel Island, Russia: Implications for Arctic paleogeography: AAPG Bulletin, v. 94, p. 665-692.

Miller, E.L., Soloviev, A., Kuzmichev, A., Gehrels, G., Toro, J., and Tuchkova, M., 2008, Jurassic and Cretaceous foreland basin deposits of the Russian Arctic: Separated by the birth of the Makarov Basin?: Norwegian Journal of Geology, v. 88, p. 201-226.

Miller, E.L., Toro, J., Gehrels, G., Amato, J.M., Prokopiev, A., Tuchkova, M.I., Akinin, V.V., Dumitru, T.A., Moore, T.E., and Cecile, M.P., 2006, New insights into Arctic paleogeography and tectonics from $\mathrm{U}-\mathrm{Pb}$ detrital zircon geochronology: Tectonics, v. 25

Rickwood, F.K., 1970, The Prudhoe Bay field, in Adkison, W.L., and Brosgé, W.P., eds., Proceedings of the Geological Seminar on the North Slope of Alaska: American Association of Petroleum Petrologists, Pacific Section: Los Angeles, L1-L11.

Rowley, D.B., and Lottes, A.L., 1988, Plate kinematic reconstructions of the North Atlantic and Arctic: Late Jurassic to present: Tectonophysics, v. 155, p. 73-120.

Tailleur, I.L., 1969, Speculations on North Slope geology: Oil and Gas Journal, v. 67, p. 128-130. 


\title{
Chapter I
}

\section{Magmatic evolution and U-Pb geochronology of the Kular Dome as evidence for Middle Cretaceous extension in northeastern Russia}

\author{
D.B. Harris ${ }^{1}$, J. Toro ${ }^{1}$, E.L. Miller ${ }^{2}$ and A.V. Prokopiev ${ }^{3}$
}

\footnotetext{
${ }^{1}$ Department of Geology and Geography

West Virginia University

Morgantown, WV 26506-6300

(304) 293-5603

E-mail: dharri11@mix.wvu.edu; jtoro@wvu.edu

${ }^{2}$ Department of Geological and Environmental Sciences

Stanford University

Stanford, CA 94305-2115

(650) 723-0847

E-mail: elmiller@stanford.edu

${ }^{3}$ Diamond and Precious Metal Geology Institute

Siberian Branch of the Russian Academy of Sciences

Yakutsk, Russian Federation

E-mail: prokopiev@diamond.ysn.ru
} 


\begin{abstract}
:
The regional Mesozoic tectonic setting for northern Russia is an important consideration when examining processes responsible for formation of the Amerasian Basin and Verkhoyansk Fold-Thrust Belt. The Kular Dome, located at $70.0^{\circ} \mathrm{N} / 134.3^{\circ} \mathrm{E}$ lies just south of the Laptev Sea and approximately $30 \mathrm{~km}$ west of the Yana fault. This fault was previously interpreted as a thrust fault potentially related to suturing between the Kolyma-Omolon superterrane and passive margin sequences of the North Asian craton which were deformed into the Verkhoyansk FoldThrust Belt in the Late Jurassic. The Yana fault is, however, shown to be a local normal fault which formed under extensional deformation related to emplacement of the Kular pluton in the core of the Kular gneiss dome. Evidence collected from the Kular Dome in the form of topdown shear seen around mantled porphyroblasts along gently dipping $S_{2}$ foliation, stretched andalusite grains defining gentle plunge parallel to $S_{2}$ dip direction and small offset normal fault development suggests that the Kular pluton was emplaced under extensional conditions. Dating of the pluton via $\mathrm{U}-\mathrm{Pb}$ zircon geochronology of five samples collected from the Kular Dome yielded an emplacement age between 111.3 \pm 1.4 Ma and 103.2 \pm 0.9 Ma likely synchronous with extensional deformation and development of the Yana fault. The Kular Dome is also part of a north-south trending belt of Cretaceous plutons displaying continental within-plate extensional geochemical signatures and shows a southward younging direction from the Laptev Sea in the north, along strike of the Eocene-aged Gakkel Ridge. Seismic modeling and geophysical profiling in the Laptev Sea indicates diffuse extension in this area as early as the Late Cretaceous, but was likely initiated earlier during emplacement of the north-south trending extensional plutonic belt.
\end{abstract}




\section{Introduction:}

A complete Mesozoic tectonic reconstruction for the Arctic capable of incorporating all of the diverse and extensive data collected from landmasses surrounding the Arctic basins remains elusive despite recent international efforts. In the Mesozoic, as the Amerasian Basin opened through a rifting process of uncertain geometry (see review in Lawver and Scotese, 1990), a series of terranes of both Arctic and Pacific affinities were accreted to North America and Russia (Amato et al., 2009; Layer et al., 2001). The first Mesozoic accretionary event on the Russian side occurred during the Late Jurassic when the Kolyma-Omolon superterrane collided with passive margin sequences deposited along the east coast of the North Asian craton, closing a basin initially formed during the Devonian (Khudoley and Prokopiev, 2007; Oxman, 2003; Parfenov, 1991). Following accretion of the Kolyma-Omolon superterrane, a subduction zone formed on the northern edge of the Asian continent as the Arctic Alaska-Chukotka microplate, which was likely originally a piece of North America (Amato et al., 2009; Amato et al., 2004; Embry, 1990; Grantz and May, 1983; Lawver et al., 2002; Miller et al., 2006), moved toward Russia from its initial location along the northern edge of the modern Canadian Arctic Islands coincident with opening of the Canada Basin in the Late Jurassic-Early Cretaceous (Lawver et al., 2002; Lawver and Scotese, 1990). The Arctic Alaska-Chukotka microplate includes the modern Seward Peninsula and North Slope of Alaska, and the Chukotka Peninsula, Wrangel Island, New Siberian Islands and large portions of the adjacent East Siberian continental shelf of Russia (Figure 1). Accretion of the Arctic Alaska-Chukotka microplate was finished by the Middle Cretaceous when a large continental margin volcanic arc, the Okhotsk-Chukotka Volcanic Belt, overlapped the suture. 

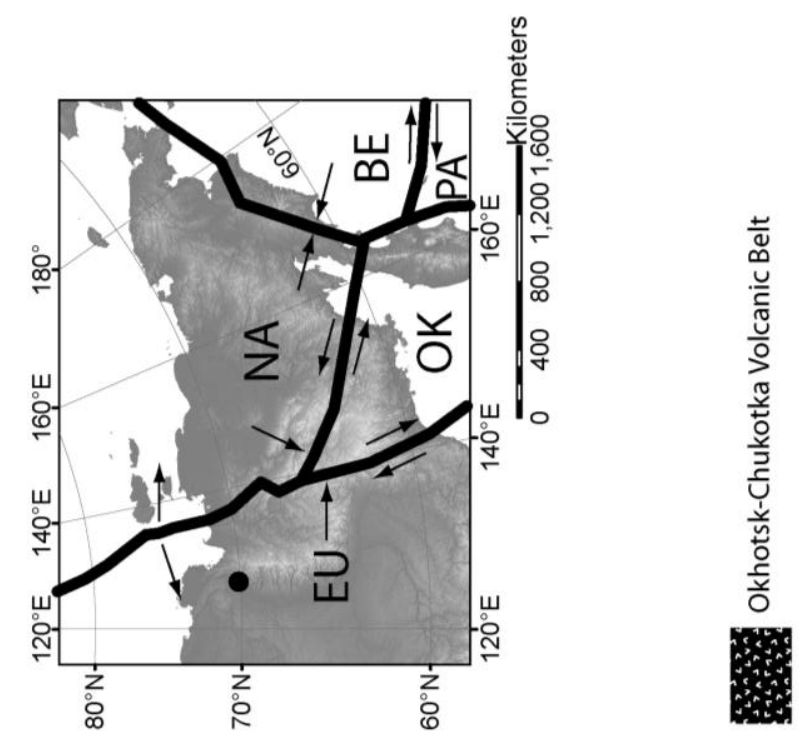

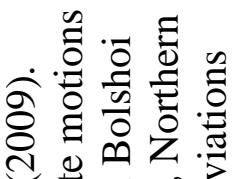
ปี

สं 元 光

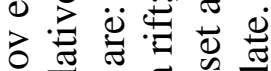

లై

๘

घ के व

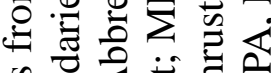

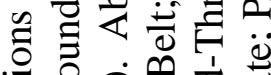

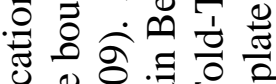

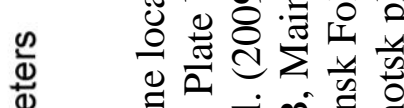

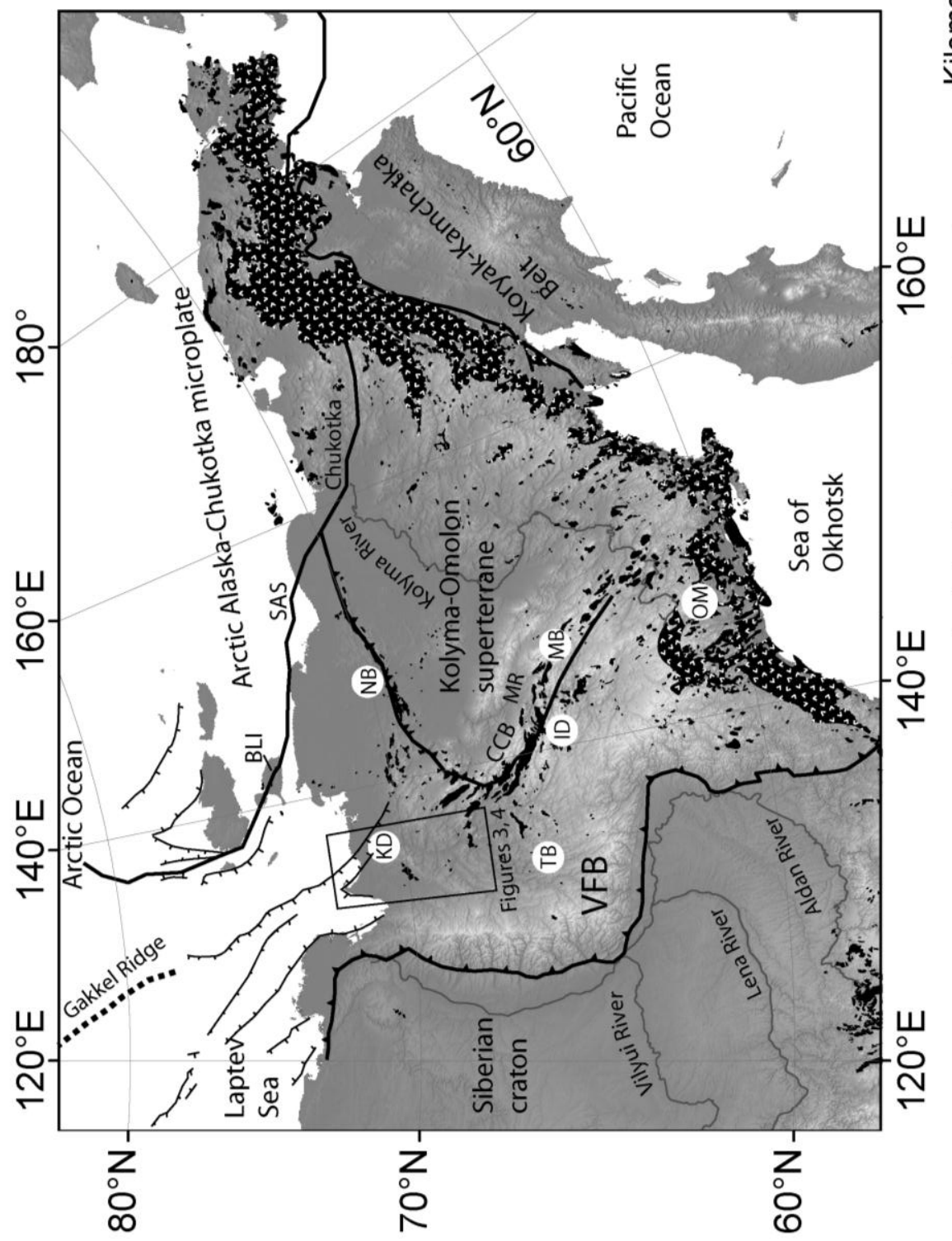

혼

ब ने के के

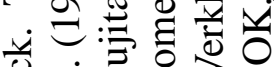

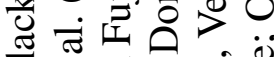

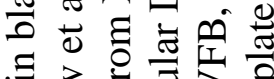

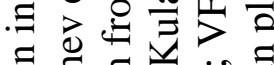

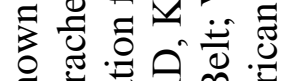

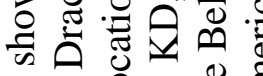

○)

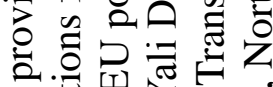

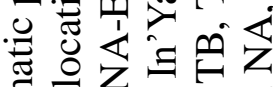

कू⿱

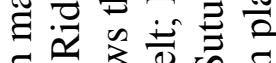

들

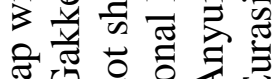

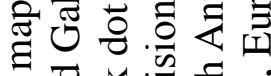

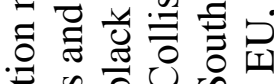

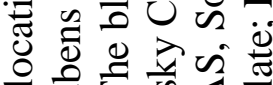

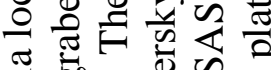

旗

ڤ

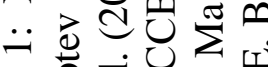

ए 䒕

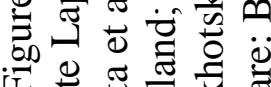

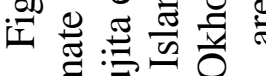

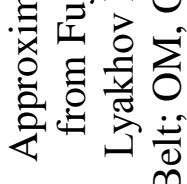


Shortly thereafter, a period of east-west extension in northeastern Russia and north-south extension in parts of Alaska, caused widespread granitic magmatism during the Middle to Late Cretaceous (Miller et al., 2002; Miller and Hudson, 1991; Miller et al., 2006). This Middle Cretaceous event is important because several models exist for the specific configuration and interaction between the local terranes and basins (Lawver and Scotese, 1990). Formation of the Amerasian Basin was followed by a shift in the locus of rifting to the north when the northern Mid-Atlantic spreading center propagated northward as the Gakkel Ridge of the Arctic in the Eocene to form the modern Eurasian Basin, the growth of which continues today (Figures 1 and 2). However, a long standing problem has been to understand how rifting was accommodated on land where the Arctic spreading center intersected the Siberian margin at the Laptev Sea (Figures 2, 3 and 4). Studies performed in northern and central Russia provide evidence of several episodes of both extensional and compressional deformation in line with the Gakkel Ridge and tracing eastward across central Russia in what is known as the Moma "rift" system (Figure 2) (Fujita et al., 1990), which has been tentatively dated as Neogene-Quaternary based on sediment infill, though the timing and specific nature of events responsible for formation remain controversial (Franke et al., 2000; Fujita et al., 2009; Paech et al., 1998). Studies of modern seismic activity in Russia suggest current poles of rotation for both the Eurasian plate and the North American plate directly south of the Laptev Sea near their shared plate boundary at a range of locations from $70^{\circ} \mathrm{N}, 126^{\circ} \mathrm{E}$ to $67^{\circ} \mathrm{N}, 132^{\circ} \mathrm{E}$ and potentially as far north as the Laptev Sea (Figure 1) (Franke et al., 2000; Fujita et al., 2009). A pole of rotation along or near this plate boundary would cause an expected change from extension in the Gakkel Ridge north of the pole to convergence along the Chersky Seismic Belt south of the pole, though modern focal mechanism studies indicate that the tectonic history for northern Russia may not have been so 


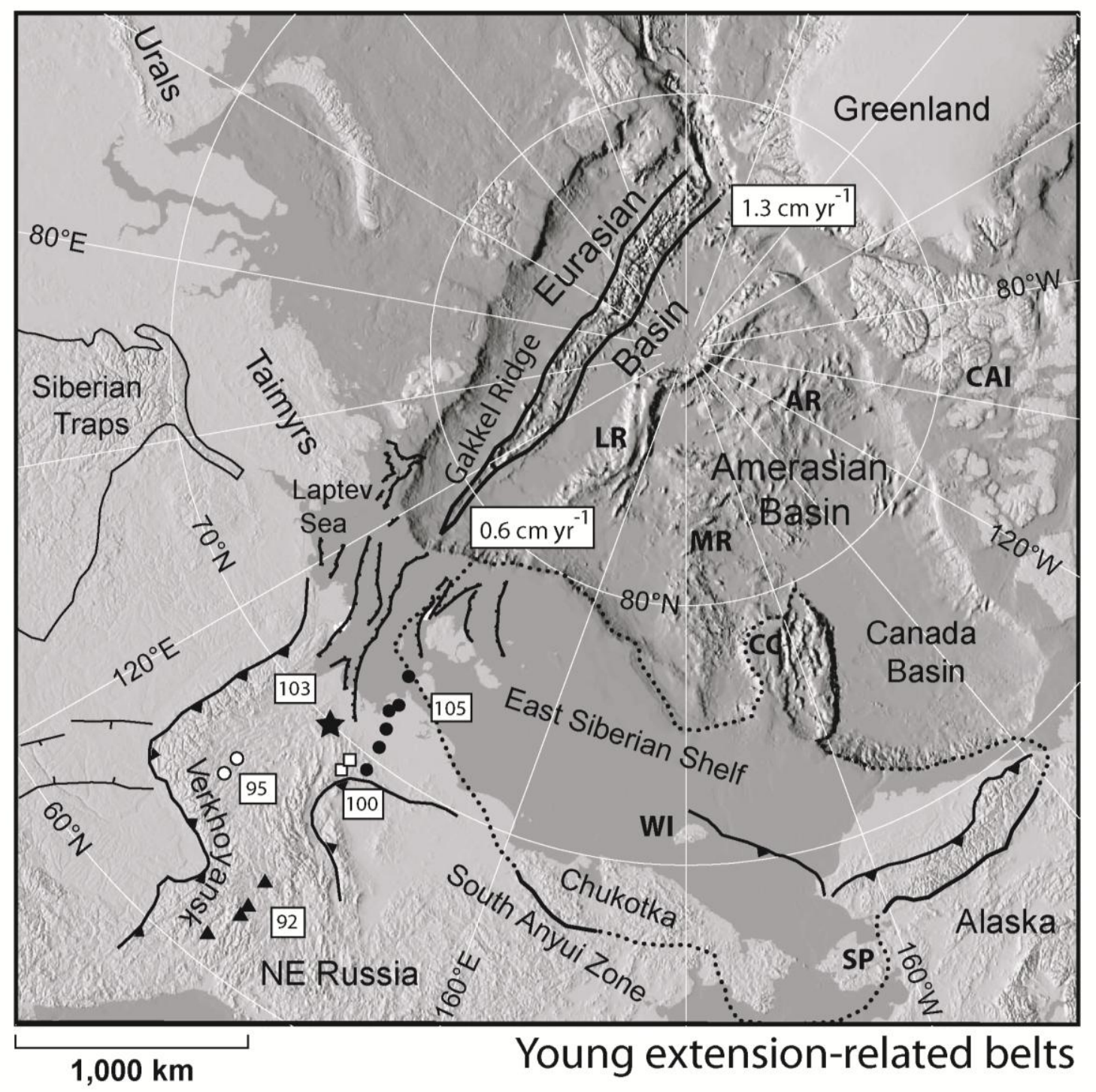
- Svyatoi Nos 105-106 Ma Ar-Ar
$\star$ Kular Dome 103-108 Ma U-Pb
- Deputatsky $100 \mathrm{Ma} \mathrm{K-Ar}$
- Endibal 95-97 Ma Ar-Ar
- South Verkhoyansk 92-107 Ma Ar-Ar

Figure 2: Arctic polar view of the relationship between the Gakkel Ridge, Laptev Sea and Kular Dome. Approximate minimum reported ages in Ma are for young igneous intrusive belts in northern Russia. ${ }^{40} \mathrm{Ar} /{ }^{39} \mathrm{Ar}$ and $\mathrm{K}$-Ar ages (shown in boxes) are from Layer et al. (2001) and Trunilina (1994) respectively. Gakkel Ridge spreading rates are from Jokat and Schmidt-

Aursch (2007), DeMets et al. (1994), Laptev Basin data are from Drachev et al. (1998), bathymetry is from IBCAO (Jakobsson et al., 2008). Abbreviations are: AR, Alpha Ridge; CAI, Canadian Arctic Islands; CC, Chukchi Cap; LR, Lomonosov Ridge; MR, Mendeleev Ridge; SP, Seward Peninsula; WI, Wrangel Island. 


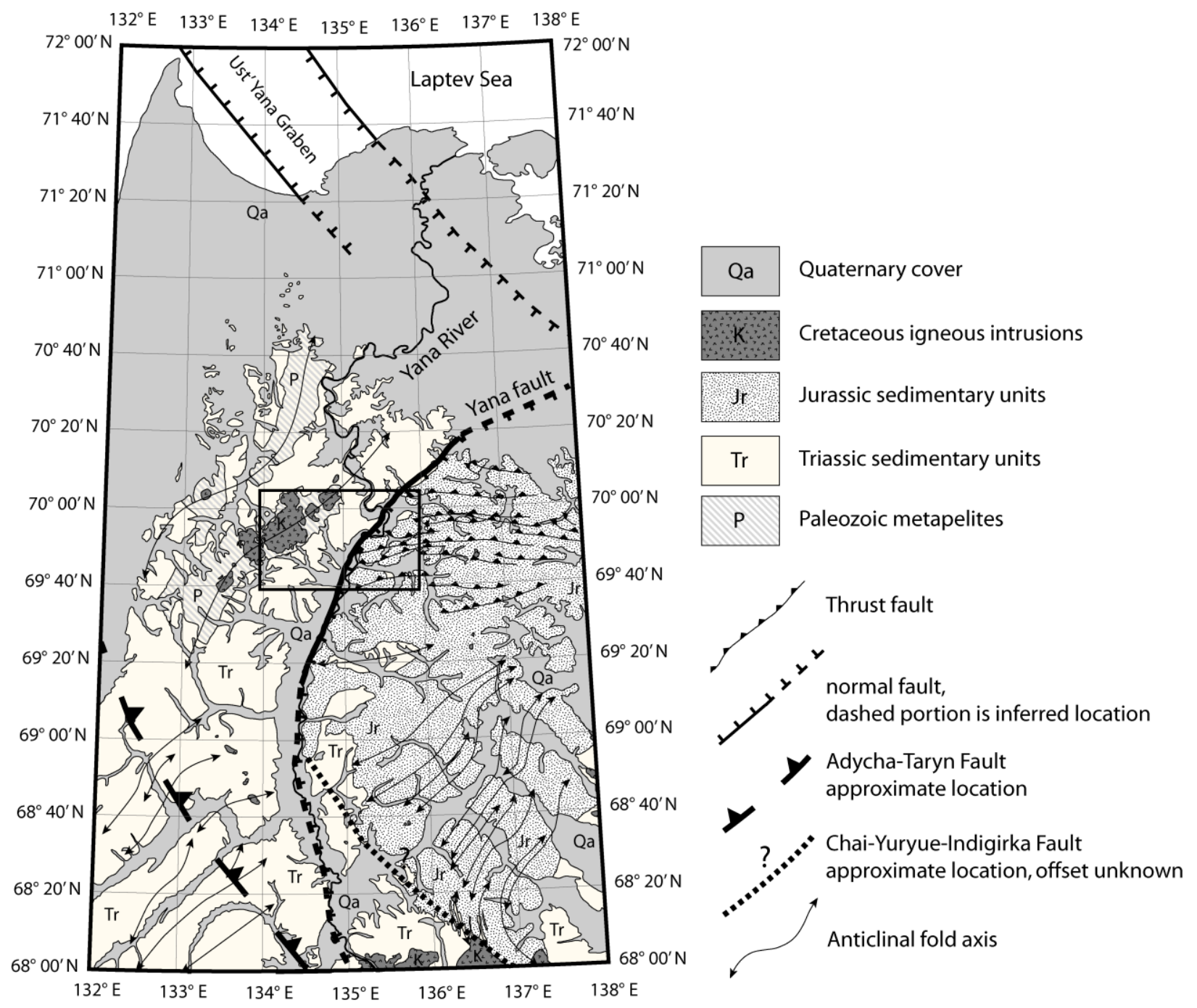

Figure 3: Generalized geology bordering the Kular Dome field area. Modified from Urzov et al. (1994), and Konstantinovsky (2007). See Figure 1 for location. The boxed area indicates the location of Figure 5. 


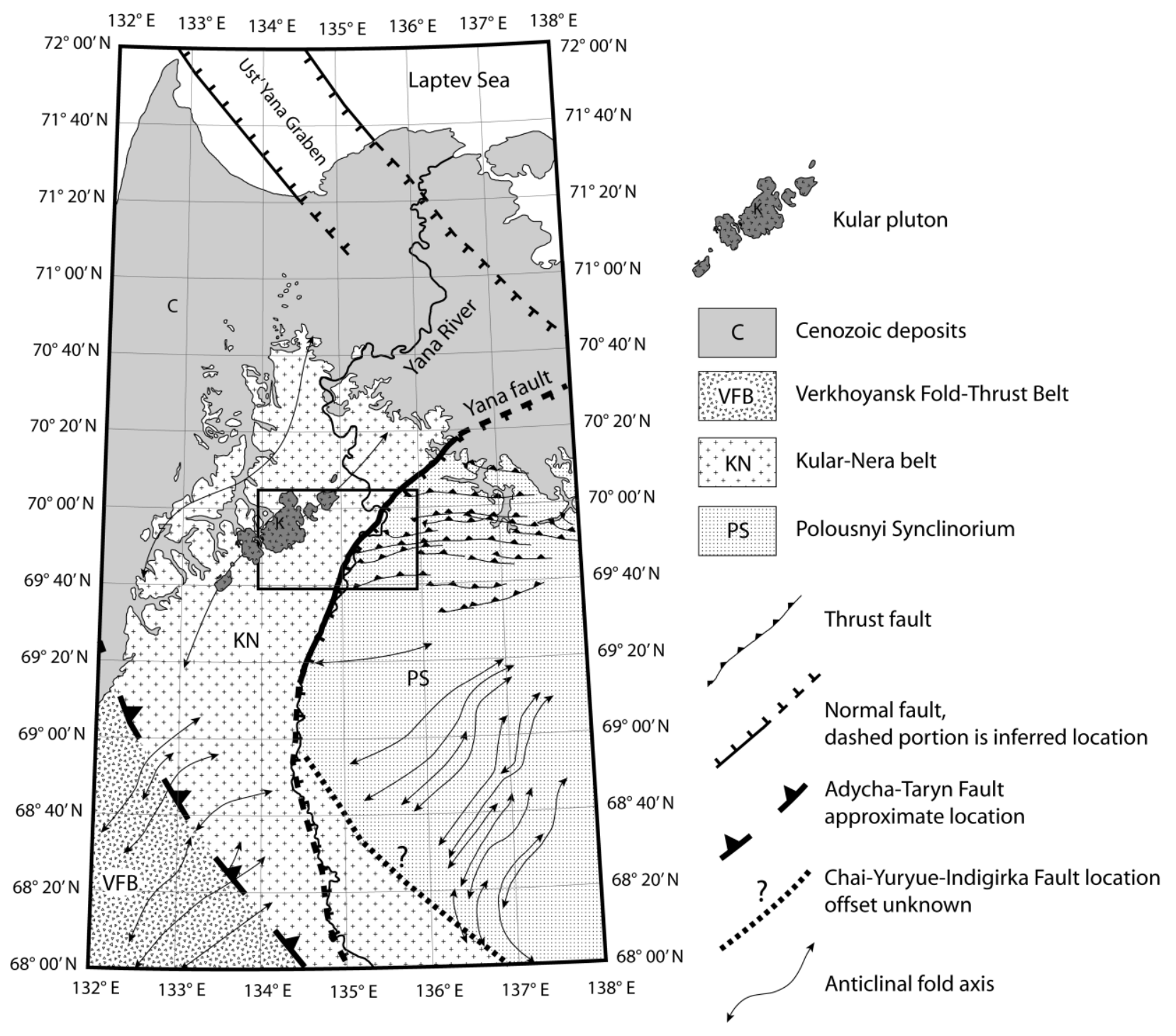

Figure 4: Generalized tectonic and terrane map of the Kular Dome area. Modified from Urzov et al. (1994), Konstantinovsky (2007) and Oxman (2003). See Figure 1 for location. The boxed area indicates the location of Figure 5. 
simple, instead involving a wide intraplate region of diffuse deformation (Fujita et al., 2009). Since continental rifting can precede continental drift by long periods of geologic time, it has been suggested that Cretaceous aged extension in northern Russia and the Laptev Sea may represent early evidence of continental rifting associated with the eventual opening of the Eurasian Basin during the Eocene (Drachev et al., 1998). For this reason, we have targeted the Kular Dome, located approximately $100 \mathrm{~km}$ south of the Laptev Sea where the Kular granitic pluton was emplaced into Triassic-Jurassic sedimentary units along strike with the Gakkel Ridge (Figures 2, 3 and 5). A Cretaceous extensional event would also provide a convenient explanation for a previously dated north-south trending belt of Late Cretaceous plutonism in northern Russia (Figure 2). Extension at this time could also be tied to closure of the South Anyui suture (Figure 1) causing eastern escape of the Asian continent similar to more recent structures in northeastern Asia formed during collision with India or as a backarc effect from westward subduction beneath Okhotsk-Chukotka (Layer et al., 2001). Formation of the South Anyui suture and closure of the South Anyui Ocean must have initiated by the Tithonian $(\sim 150$ Ma) because detrital zircons sourced from the Siberian craton are found in Late Jurassic Chukotkan stratigraphy (Miller et al., 2008) and must have ceased by $106 \mathrm{Ma}$ according to earliest volcanic ages of the Okhotsk-Chukotka Volcanic Belt which forms a continuous belt from the Uda River in southern Russia near the border with China to the eastern Chukchi Peninsula (Akinin and Miller, 2011). 


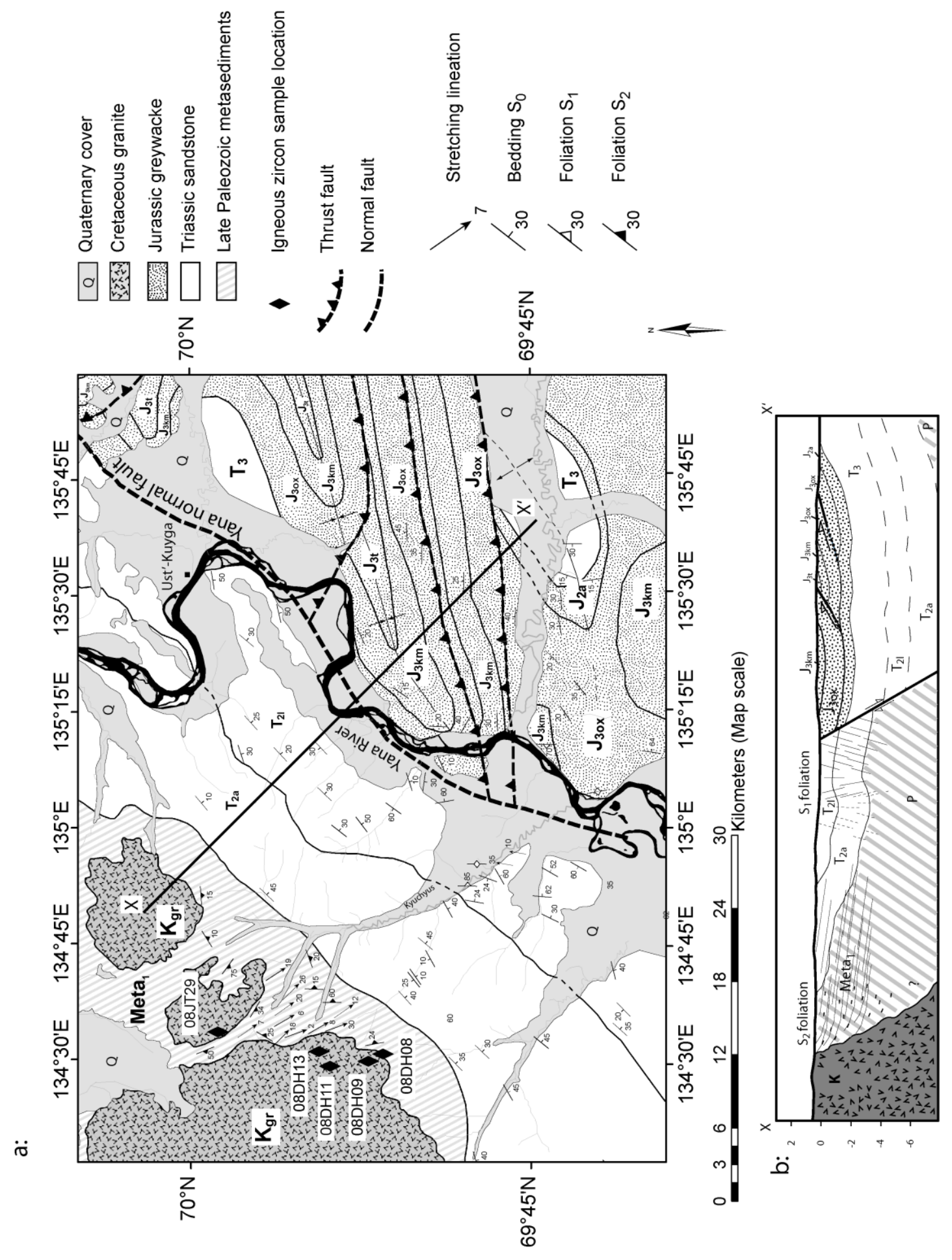

$\frac{0}{\frac{1}{0}}$

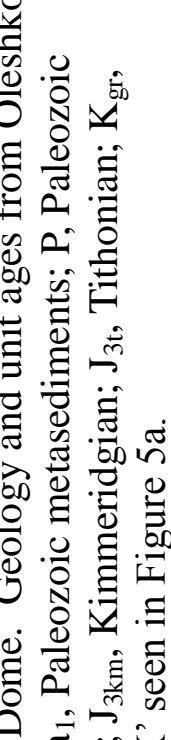

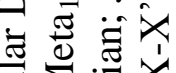

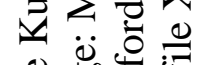

․

పี

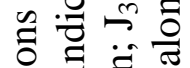

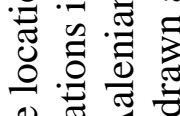

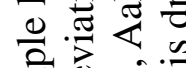

苛

希.

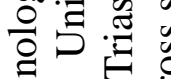

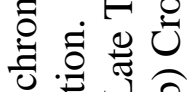

ช

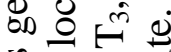

它范

施

.

동

स्षิष्ञ

寻充

严总莫

สิ थี

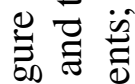

讯 


\section{Field area:}

\section{Northeast Russia:}

The overall structure of northern Russia is generally divided from west to east into the Siberian platform, the Verkhoyansk Fold-Thrust Belt, the Chersky Collisional Belt, the KolymaOmolon superterrane, the Okhotsk massif, and the Koryak and Kamchatka blocks, with the Arctic Alaska-Chukotka microplate situated along the northern coast (Parfenov et al., 2009) (Figure 1). Shelf sediments and turbidites currently seen in the Verkhoyansk Fold-Thrust Belt were initially accumulated in the immense Verkhoyansk passive margin along the entire eastern margin of the Siberian platform from the Late Paleozoic to the Late Jurassic. Though the passive margin of the Siberian platform and the platform itself show very different histories in terms of surface structures, they share a common basement, and the combined Verkhoyansk passive margin sequence and the Siberian platform together form the North Asian craton (Khudoley and Prokopiev, 2007). Rocks of the Verkhoyansk passive margin consist of Devonian-Carboniferous clastic sequences including rift-related gabbro and basalt with gypsum and anhydrite interbeds and Late Paleozoic-Early Mesozoic beds of deltaic mudstone, siltstone and sandstone (Khudoley and Prokopiev, 2007; Konstantinovsky, 2007; Oleshko, 1981; Oxman, 2003; Parfenov, 1991). The Kolyma-Omolon superterrane collided with the Verkhoyansk passive margin in the Late Jurassic to form the Verkhoyansk Fold-Thrust Belt which now defines the outer (foreland) part of the Verkhoyansk-Kolyma orogen, while the Chersky Collisional Belt to the east represents the inner (hinterland) region (Khudoley and Prokopiev, 2007). East of the Verkhoyansk Fold-Thrust Belt are several accreted terranes which experienced variable amounts of shortening and oblique strike-slip motion in the Mesozoic that are summarized in Parfenov et al. (2009). 


\section{Kular Dome:}

The Kular Dome is located at $70.0^{\circ} \mathrm{N} / 134.3^{\circ} \mathrm{E}$ just west of the Yana River in northern Russia within the northern Kular-Nera slate belt which is also referred to as the Kular-AyanYuryakh terrane (Konstantinovsky, 2007) (Figures 3, 4 and 5). The Kular-Nera belt extends for over $1500 \mathrm{~km}$ in length from northwest to southeast. It was likely formed as a deep-water trough infilled by Late Permian-Early Jurassic black shale and turbidite deep-water fan deposits from the nearby continental margin (Konstantinovsky, 2007; Oxman, 2003; Parfenov, 1991). Deformed Jurassic rocks from the South Polousnyi synclinorium are found east of the KularNera belt and are thought to be truncated by the Yana fault which has been most commonly interpreted as a westward thrust (Khudoley and Prokopiev, 2007; Konstantinovsky, 2007; Oxman, 2003; Parfenov, 1991), though results from this study and detrital zircon dating suggest otherwise (Harris et al., 2011, Chapter II, this volume). Middle to Late Jurassic synorogenic deposits of the Polousnyi synclinorium have experienced several compressional deformation events forming multiple fold-thrust structures with northwestern vergence in the central and southern region and south-southeastern vergence in the north (Figures 4 and 5) (Oxman, 2003; Urzov et al., 1994). Deep-water trough sediments preserved at depth near the Chai-YuryueCharky-Indigirka suture, which separates the Kular-Nera belt from the Polousnyi synclinorium approximately $60 \mathrm{~km}$ south of the Kular Dome (Figure 4), record a change in coastal depositional directions from northeast-directed sedimentation from the craton in the Triassic to southwest-directed sedimentation from the newly formed eastern Chersky cordillera (Konstantinovsky, 2007). Further east, the Chersky Collisional Belt (Figure 1) consists of several fault bounded allochthonous terranes of Paleozoic age and strike-slip bounded shear zones of ophiolite along with Late Mesozoic synorogenic deposits (Oxman, 2003). Directly west 
of the Kular-Nera belt is the Adycha El'gy zone of the western Verkhoyansk Fold-Thrust Belt, which is separated from the Kular-Nera by the Adycha-Taryn fault zone (Figure 4).

The Kular Dome can be described as a gneiss dome in that it represents an area with a plutonic core rimmed by contact metamorphosed metapelites (Yin, 2004). Southeast of the dome is a large fault that follows the Yana River (Figure 3) and is inferred to be either the northern trace of the Chai-Yuryue-Charky-Indigirka suture (Konstantinovsky, 2007; Parfenov, 1991), or the Yana thrust or strike-slip fault, which runs approximately parallel to the dome axis through the field area (Khudoley and Prokopiev, 2007; Oxman, 2003). The fault separates Triassic sedimentary units to the northwest from tightly folded Jurassic sediments to the southeast and is more likely to be a normal fault than the northern trace of the Chai-Yuryue-Charky-Indigirka suture. It will be referred to as the Yana fault in this paper. Development of the dome may be linked to several models of either extensional or compressional origin, though data from this study supports an extensional setting for the area during the Late Cretaceous. Normal faulting near the dome suggests emplacement of the granitic core through detachment related mechanisms thought to be in effect from 106 to $95 \mathrm{Ma}$ (see review in Layer et al., 2001; Yin, 2004). Extensional Cretaceous magmatism is potentially associated with formation of the Gakkel Ridge to the north based on alignment of multiple Middle Cretaceous intrusions in Russia with the Gakkel Ridge and grabens in the Laptev Sea, including the Ust' Yana Graben which extends into the continent north of the Kular Dome (Figures 3 and 4).

Within northern Russia, there were several stages of magmatic activity (Figure 1) that have been dated by zircon $\mathrm{U}-\mathrm{Pb}$ and biotite, hornblende and white mica ${ }^{40} \mathrm{Ar} /{ }^{39} \mathrm{Ar}$ methods (Layer et al., 2001). Based on ages and trace element analyses, these magmatic events have been organized into four belts (Figure 1), which include 1) the Late Jurassic-Early Cretaceous Main 
Belt, 2) the Early Cretaceous Northern Belt, 3) the Early Cretaceous Transverse Belts and 4) a series of Middle Cretaceous extensional belts (Figure 2). The Main Belt (160 Ma and 145-135 $\mathrm{Ma}$ ) is located along the western and southern boundaries of the Kolyma-Omolon superterrane and formed as an evolving arc above a subduction zone followed by collision resulting in quartz dioritic, granodioritic and monzogranitic plutonism (Layer et al., 2001). The Northern Belt and Transverse Belts were both emplaced from 138 to 120 Ma. The Northern Belt (138-120 Ma) is located along the northern margin of the Kolyma-Omolon superterrane and formed as a consequence of subduction prior to closure of the South Anyui Ocean. Tonalite, granodiorite, granite and syenite are the most common lithologies of the Northern Belt (Layer et al., 2001). The Transverse Belts (138-120 Ma) are composed of multiple extensionally-emplaced felsic and mafic magmatic lithologies and include plutons and dikes that radiate outwards from the Northern and Main Belts west of the Kolyma-Omolon superterrane (Layer et al., 2001). The remaining younger intrusions (106-95 Ma) fall into a north-south oriented belt of plutons emplaced during regional east-west extension that stretch from Bol'shoi Lyakhov Island in the north to the southern Verkhoyansk Range (Layer et al., 2001). Plutons of this belt show withinplate extensional trace element signatures and show a general younging trend from north to south (Figure 2). The Kular pluton is part of this younger intrusive suite.

\section{Lithology:}

Mesozoic sedimentary units:

Triassic sandstones found northwest of the Yana fault have been dated both paleontologically (Oleshko, 1981) and more recently by detrital zircon U-Pb geochronology 
(Harris et al., 2011, Chapter II, this volume). Ages of Triassic strata directly west of the fault range from Ladinian near the Yana River to Anisian towards the northwest in contact with metasediments bordering the Kular pluton. Triassic sandstones are quartz-rich with a $\mathrm{Q}_{\mathrm{t}}\left(=\mathrm{Q}_{\mathrm{m}}+\right.$ $\mathrm{Q}_{\mathrm{p}}$ ) range of 35-40\% (mostly monocrystalline), feldspars and plagioclase range of 20-25\%, iron oxide content of $2-15 \%$, and total lithic content up to $25 \%$ with subequal proportions of volcanics and sedimentary fragments. High volcanic content in Triassic sandstones is suggestive of a north Siberian source from Siberian Trap magmatic rocks to the northwest as this area represents the only nearby significant volcanic system during the Triassic. Total biotite and minor associated muscovite content can comprise up to $10 \%$ of samples but is generally much less common. These units are also commonly interlayered with thick red-colored mudstone beds which often show slump folds from fluid-supported soft-sediment deformation. Three units of Triassic strata $\left(\mathrm{T}_{2 \mathrm{a}}, \mathrm{T}_{21}\right.$ and $\left.\mathrm{T}_{3}\right)$ have been previously mapped in the study area with thicknesses from 1.5 to $2.5 \mathrm{~km}$ (Oleshko, 1981; Urzov et al., 1994). Though outcrop exposures of $\mathrm{T}_{21}$ were abundant near the Yana River, $\mathrm{T}_{2 \mathrm{a}}$ exposures were rare, mostly buried beneath cover, and $\mathrm{T}_{3}$ units were not seen during fieldwork for this study. $\mathrm{S}_{0}$ bedding measurements showed average strike values of northeast-southwest (Figure 6d) and were gently folded about northeast trending axes.

East of the Yana fault, Jurassic lithic greywackes dated paleontologically (Oleshko, 1981; Urzov et al., 1994) and by U-Pb detrital zircon geochronology from samples collected along the Yana River (Harris et al., 2011, Chapter II, this volume) yielded ages ranging from Oxfordian to Tithonian. These Jurassic units are found mostly east of the Yana fault and are quartz-rich lithic greywackes with about 20-30\% matrix, 5-10\% lithic fragments, 20-30\% monocrystalline quartz, 30-50\% feldspars, and minor biotite, white mica and iron oxides. Jurassic sediments are much higher in matrix content than the Triassic units, though grains were similar in terms of 
a:

$$
\mathrm{S}_{1} \text { cleavage in Jurassic units }
$$
No. of Data $=8$

Mean Principal Orientation $=012 / 80 \mathrm{E}$

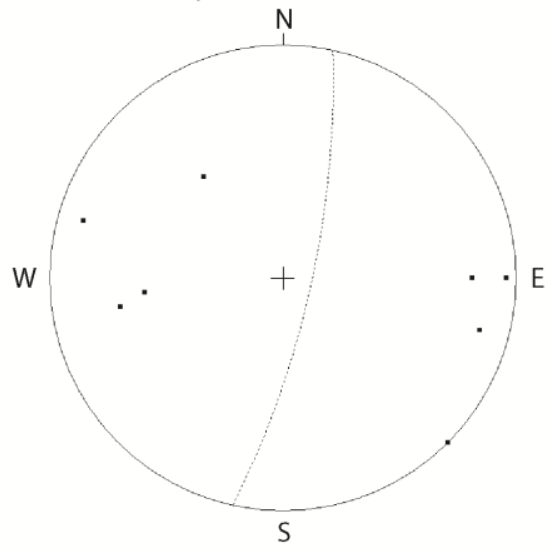

$\mathrm{S}_{1}$ cleavage in Triassic units near the Yana fault No. of Data $=16$

Mean Principal Orientation $=205 / 53$ NW

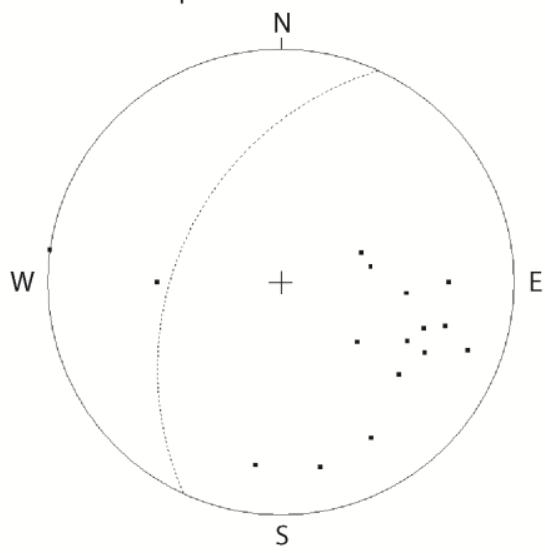

e:

$\mathrm{S}_{2}$ cleavage in Paleozoic metasediments near the Kular pluton No. of Data $=20$

Mean Principal Orientation $=029 / 9$ SE

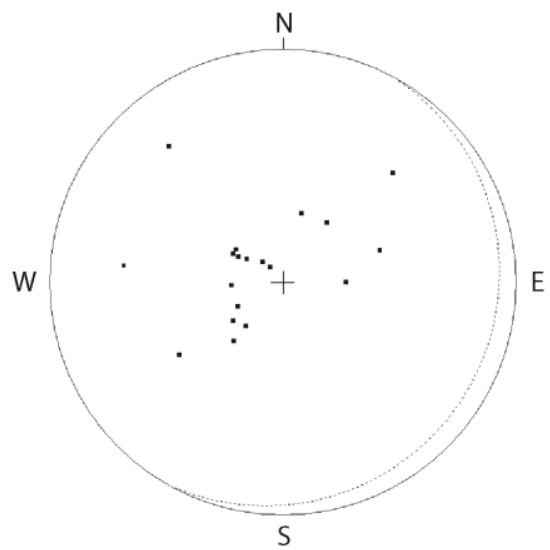

$\mathrm{S}_{0}$ bedding orientation of Jurassic units No. of Data $=20$

Mean Limb orientation $077 / 34$ NW/SE

d: $\quad S_{0}$ bedding orientation of Triassic units No. of Data $=60$

Mean Principal Orientation $=042 / 30$ SE

$\mathrm{N}$

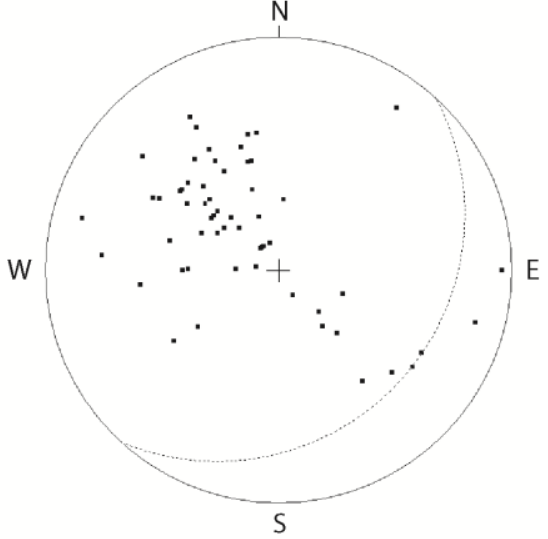

f: Stretched andalusite lineations near the Kular pluton No. of Data $=15$

Mean Principal Direction $=13 / 147$

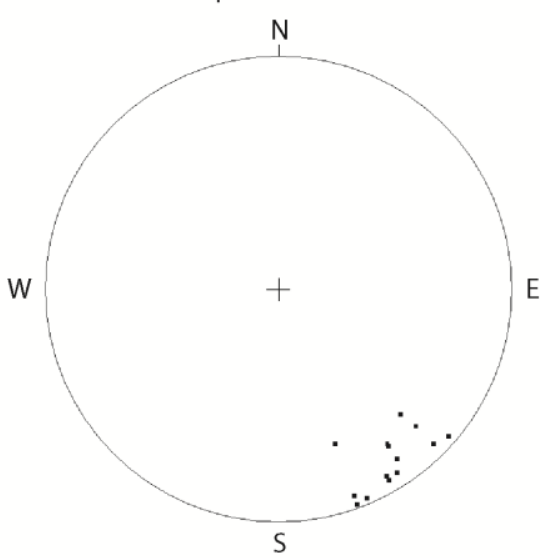

Figure 6: Equal-area plots of foliations and stretched andalusite porphyroblast lineations seen in units of the Kular Dome. Dashed lines indicate calculated mean foliations. Plots made using GEOrient, ver. 9.4.5 (Holcombe, 2010). 
composition. Four units of Jurassic strata have been previously mapped in the study area (Figure 5) with thicknesses ranging from 1.0 to $1.5 \mathrm{~km}$ (Oleshko, 1981). Slump-folded interbeds and silty conglomerate lenses up to one meter in thickness were also observed. While $\mathrm{S}_{0}$ bedding measurements have been folded along east-west trending axes east of the Yana fault (Figure 6b), vertical or near-vertical $S_{1}$ cleavages striking at an average of $012^{\circ}$ are seen commonly along the Yana fault, related to east-west compression during accretion of the Kolyma-Omolon superterrane (Figure 6a). Northwest of the Yana fault, in Triassic strata, $\mathrm{S}_{1}$ cleavage shallows with increasing distance from the fault. Based on 300-point count thin section analysis of several samples and comparison to provenance diagrams modeled after Dickinson et al. (1983), it was determined that Triassic sandstones were likely derived from a magmatic arc and that Jurassic greywackes were likely derived from a continental source (Harris et al., 2011, Chapter II, this volume).

\section{Kular pluton:}

The Kular Dome contains multiple large igneous intrusions including one large northeastsouthwest oriented igneous pluton exposed over approximately $250 \mathrm{~km}^{2}$ (Figures 3 and 5). Several plutonic intrusions lie along this northeast-southwest trend indicating emplacement within the core of a large anticlinal or oblong domal structure as branches of a deeper magma chamber. This field relationship is confirmed by consistent bedding dip away from the pluton on the northwest and southeast sides (Figure 5). The areas between each lobe of the intrusion are composed of Late Permian-Early Triassic metapelites with strongly crenulated fabrics. Petrology of the pluton is coarse biotite granite composed of 40-50\% quartz, 30-40\% K-feldspar, 5-10\% plagioclase and $10-15 \%$ biotite. Common accessory minerals include zircon, muscovite and 
apatite. Crystal sizes in granite samples are typically very coarse with quartz and feldspar grains commonly larger than one centimeter in diameter. Syn-cooling deformation is evident in the form of undulose or patchy quartz extinction resulting from high-temperature grain boundary migration (Figure 7), sericite formation and myremekite development. A weak foliation defined by aligned biotites and flattened quartz grains was noticed in one unoriented sample near the contact between the pluton and country rock but wasn't noticed elsewhere in thin section or outcrop.

\section{Paleozoic metasediments:}

Country rock found bordering the Kular pluton was composed of Early Triassic-Late Permian aged metapelites formed under moderate temperature, low-pressure conditions associated with intrusion as indicated by prevalence of andalusite poikiloblasts (Figure 8a). These metapelites show strain in the form of stretched andalusites at both micro- and macroscopic scale along with evidence of top-down shear along several grains as evidenced by fractures and grain mantling (Figure 9). Andalusites are abundant, contributing up to $10 \%$ of total rock volume in certain exposures. Between the lobes of the pluton, metapelites are commonly crenulated with lineations plunging away from the nearest pluton contact. In general, foliation strikes parallel to the nearest pluton margin (Figure 5).

Metapelites near the pluton are well foliated along $\mathrm{S}_{2}$, and are visible macroscopically and microscopically by alignment of opaques, elongated quartz crystals and biotites. $\mathrm{S}_{2}$ foliations near the pluton are generally shallowly dipping and strike parallel to the pluton margin (Figure 6e). With increasing proximity to the pluton, replacement of andalusite by white mica increases, commonly resulting in pseudomorphs recording initial orientation of andalusites prior 


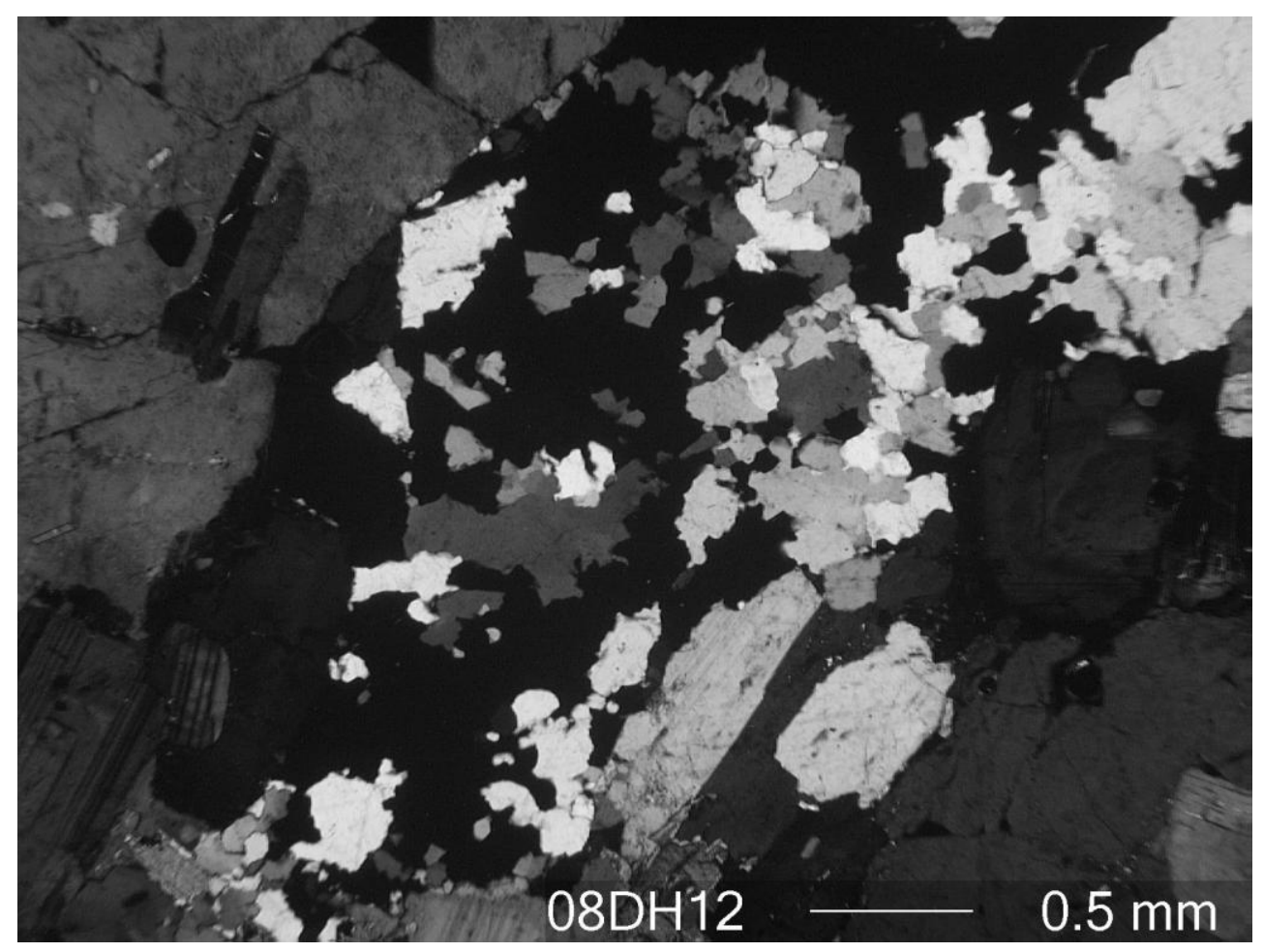

Figure 7: Quartz grain boundary migration preserved in the biotite granite of the Kular pluton. Strongly lobate contacts are common in samples collected from the pluton with bulging recrystallization apparent in several thin section samples. Picture taken under cross-polarizing light. 

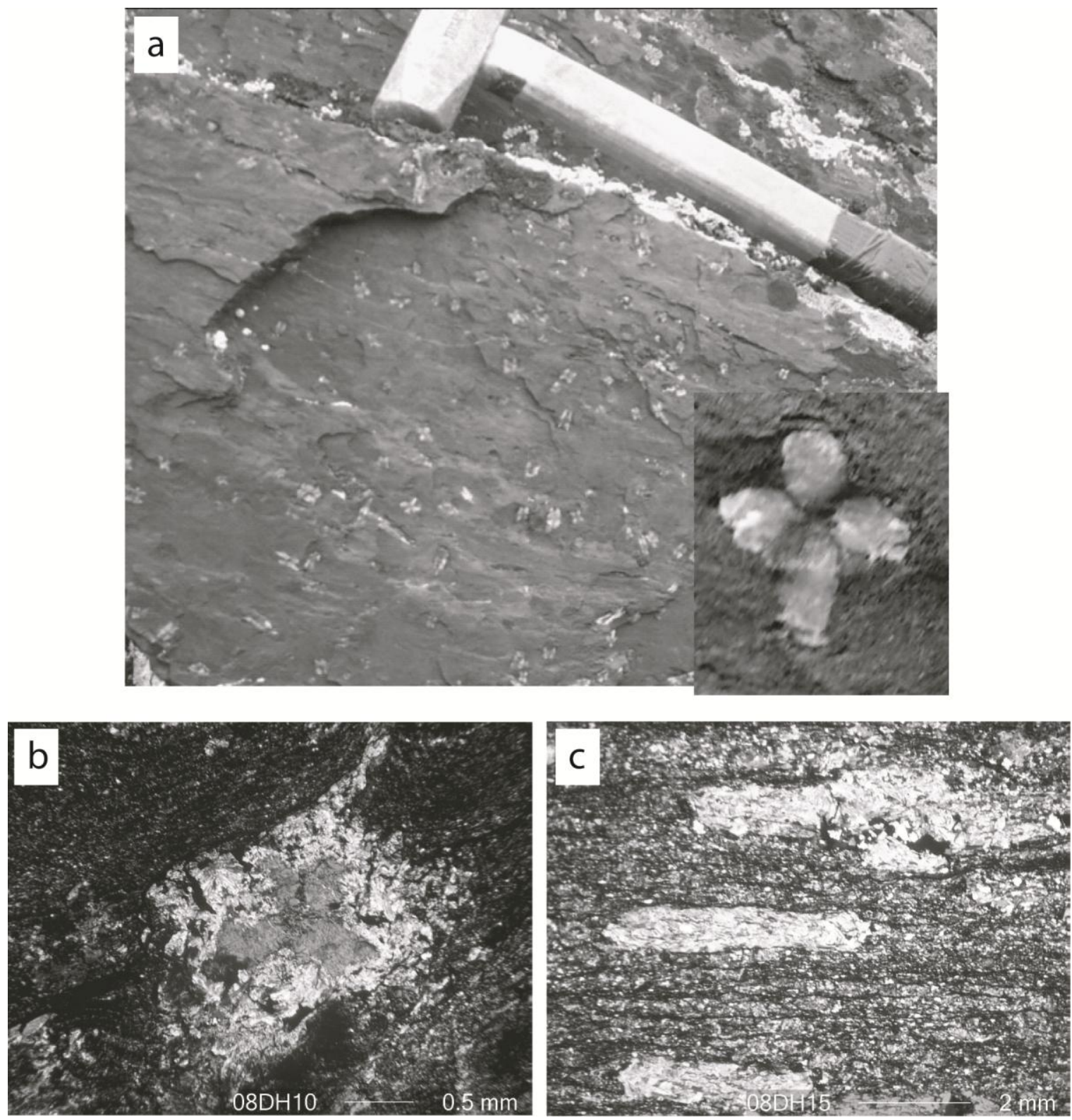

Figure 8: a) Andalusite prevalence in metapelites found near the Kular Dome. b) Crosspolarized photomicrographs of samples collected from Paleozoic metasediments showing that muscovite replacement of andalusite grains increases with proximity to the pluton to c) total replacement of andalusite by coarse-grained muscovite at the contact. 

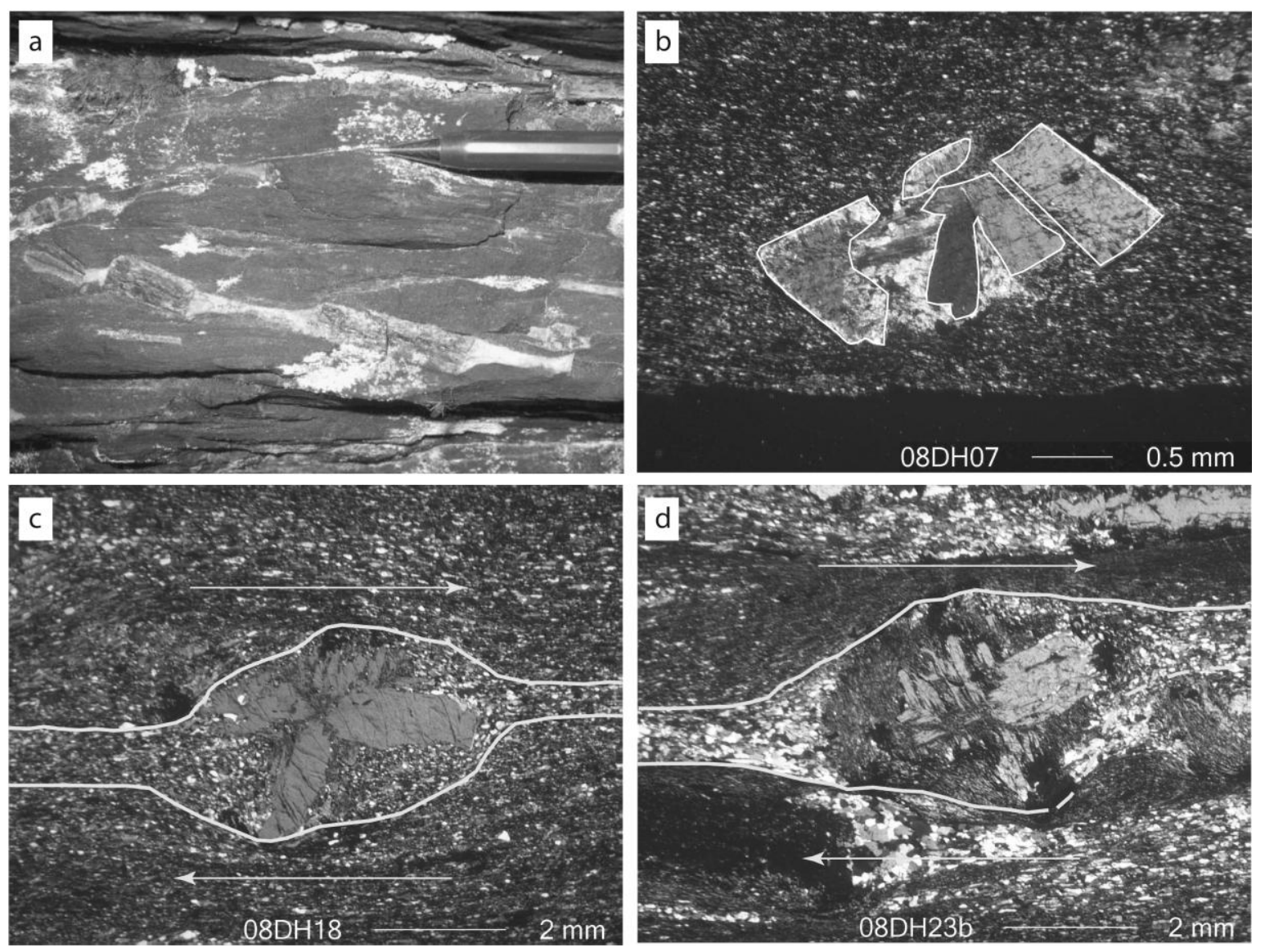

Figure 9: Andalusite stretching deformation at a) macroscopic and b) microscopic scale. c,d) Top-down shear from mantled porphyroblasts in thin section cut along $\mathrm{L}_{1}$ and oriented top-up and down-right in all photomicrographs. All photomicrographs were imaged under crosspolarized light. 
to replacement (Figures $8 \mathrm{~b}$ and $8 \mathrm{c}$ ). White mica in all pseudomorphs is randomly orientated and either did not record the state of stress during replacement or indicates low regional stress conditions during retrograde placement.

Andalusites were very commonly stretched near the pluton, showing obvious pull-apart zones in thin section, hand sample, and field observations (Figure 9). Thinning of andalusite grains along the long axis was also commonly observed in the field in the form of consistently oriented lineations as a result of grain stretching (Figure 9a). Strain measurements in three dimensions were not collected resulting in difficulty of assessing total strain by the Fry method or axial ratio comparison, but in a two dimensional sense, assuming initially equal lengths of andalusite short axes a and $\mathrm{b}$ in cross section (or $\mathrm{X} / \mathrm{Z}$ assuming no strain in the $\mathrm{Y}$ direction), strain was estimated at a ratio of 2.4 with approximately $60-85 \%$ elongation from analysis of thin section and several field photographs (Figure 9). Oriented thin sections commonly show topdown shear along foliations which regularly dip to the south; away from the pluton contact. Consistent top-down shear evidence was in the form of pressure shadows, bent andalusite grains and mica-filled fracture orientations in andalusite porphyroblasts (Figure 9).

\section{Geochronology:}

Sensitive High-Resolution Ion Microprobe - Reverse Geometry (SHRIMP-RG):

Zircons have proven useful for U-Pb geochronology due to their high mechanical and chemical resistance, high blocking temperature of around $800^{\circ} \mathrm{C}$, generally high $\mathrm{U}$ concentration, low common $\mathrm{Pb}$ retention during crystallization and abundance in both sedimentary and felsic igneous rocks. Geochronologic study of zircons utilizes the decay 
pathways of ${ }^{238} \mathrm{U}$ to ${ }^{206} \mathrm{~Pb},{ }^{235} \mathrm{U}$ to ${ }^{207} \mathrm{~Pb}$ and ${ }^{232} \mathrm{Th}$ to ${ }^{208} \mathrm{~Pb}$, although for age calculations, ${ }^{238} \mathrm{U} /{ }^{206} \mathrm{~Pb}$ ratios are typically used for ages less than $1.4 \mathrm{Ga}$ and ${ }^{207} \mathrm{~Pb} /{ }^{206} \mathrm{~Pb}$ ratios are used for ages greater than $1.4 \mathrm{Ga}$ due to the relatively low abundance of ${ }^{235} \mathrm{U}$ (Gehrels and Pullen, 2010), though concordant ages can be calculated by comparison of the two ratios.

We dated five samples from the Kular pluton using zircon U-Pb geochronology (Figure 5a). All samples were collected as bagged grab samples in the field from in-place outcrop or rubble at topographic high points when outcrop was unavailable. Rocks were cleared of all weathering rind prior to collection. Zircons were later separated using standard crushing, gravimetric and magnetic separation procedures at West Virginia University. Material that sank in methylene iodide (MEI, $\rho=3.3 \mathrm{~g} / \mathrm{cm}^{3}$ ) was picked through under a petrographic microscope to select inclusion and fracture free zircons for analysis. Picked grains were mounted in rows within $25 \mathrm{~mm}$ diameter, $6 \mathrm{~mm}$ thick pucks at the USGS-Stanford University SHRIMP-RG lab. Pucks prepared at the lab were polished to expose the inner structure of the zircons and coated with a thin film $(\sim 10 \mathrm{~nm})$ of gold in a Denton sputterer to minimize charge effects during analysis. Prior to analysis, all samples were imaged with cathodoluminesence (CL) using a JEOL JSM 5600 electron microscope and reflected light in order to observe internal grain structure and to aid in selection of targeted grains. At least five grains per sample were targeted and measured for their $\mathrm{U}-\mathrm{Th}-\mathrm{Pb}$ and REE concentrations using both cores and rims as determined by CL imaging (Appendix 1). Analytical spots approximately $30 \mu \mathrm{m}$ in diameter were sputtered with a primary oxygen ion $\left(\mathrm{O}_{2}{ }^{-}\right)$beam to release secondary ions which were focused into a secondary beam then counted (Coath and Long, 1994). An electrostatic analyser was used in the double-focusing mass spectrometer to reduce momentum effects caused by the magnetic separation of ions. Since a Reverse Geometry Microprobe was used, the magnet 
preceded the electrostatic analyser along the secondary beam path so that mass dispersion occurred early and only one mass was passed through the collector at any given time. This causes increased resolution for the SHRIMP-RG but sacrifices the multiple beam collection speed afforded by Forward Geometry analysis where the electrostatic analyser precedes the magnet. Reported results are from five averaged measurement cycles per grain which were then processed using Squid and Isoplot software (Ludwig, 2009). Error correction was performed by targeting standard R-33, which yields a SHRIMP age of 419.9 \pm 1.5 Ma (Black et al., 2004), one time per four sample grain analyses. For complete SHRIMP-RG routine procedures, see Williams (1998).

\section{Results:}

\section{Geochronology:}

Of the five samples collected from Kular, only samples 08DH09, 08DH11 and 08JT29 yielded concordant ages using ${ }^{207} \mathrm{~Pb} /{ }^{206} \mathrm{~Pb}$ vs. ${ }^{238} \mathrm{U} /{ }^{206} \mathrm{~Pb}$ ratios (Figure 10). The two remaining samples (08DH08 and 08DH13) yielded poorly concordant ages, and are instead reported as weighted mean ${ }^{207} \mathrm{~Pb}$-corrected ${ }^{206} \mathrm{~Pb} /{ }^{238} \mathrm{U}$ ages, though both concordia ages and weighted mean ages were calculated for each sample (Figures 10 and 11). Analyses with high U concentration, internal discordance or high common ${ }^{204} \mathrm{~Pb}$ were excluded from concordia and weighted mean age determination (Table 1). Concordia ages were calculated in Isoplot v.3.71 using $1 \sigma$ input errors in percent and output error of $2 \sigma$ or $95 \%$ confidence (Ludwig, 2009). Complete results from all geochronologic analyses are listed in Appendix 2, concordia results are shown in Figure 10 and weighted mean age results are shown in Figure 11. 
a:

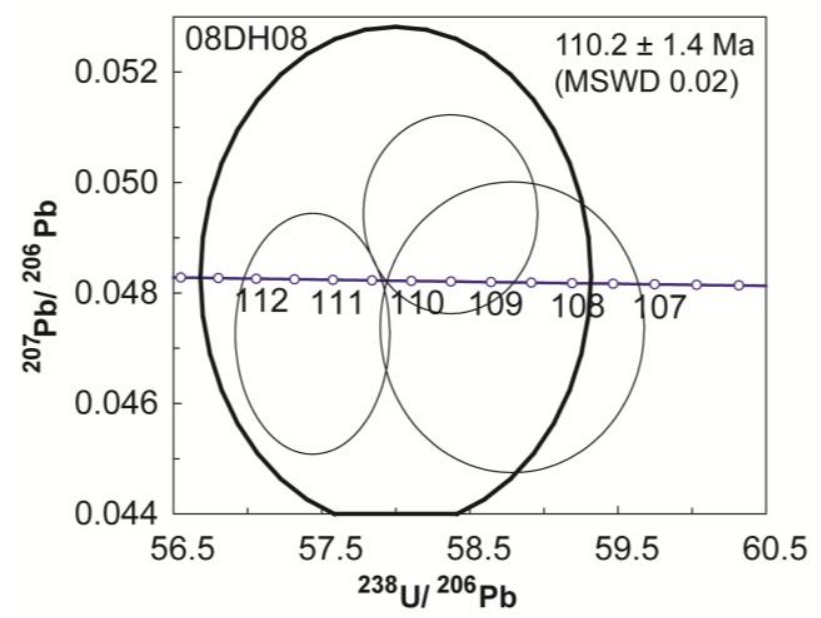

C:

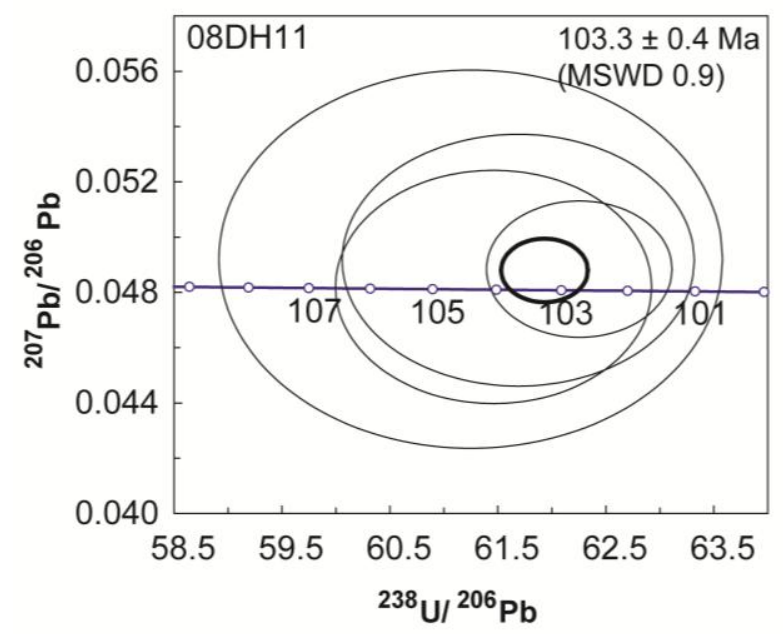

e:

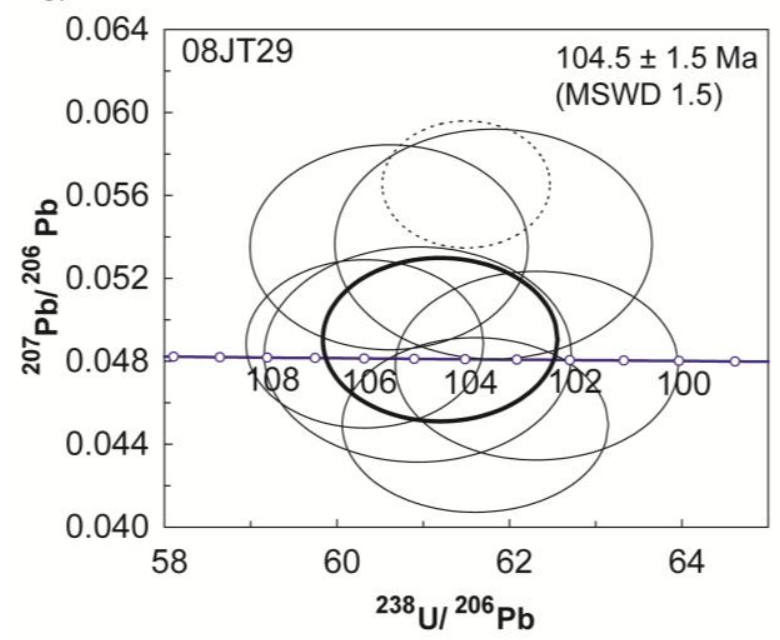

b:

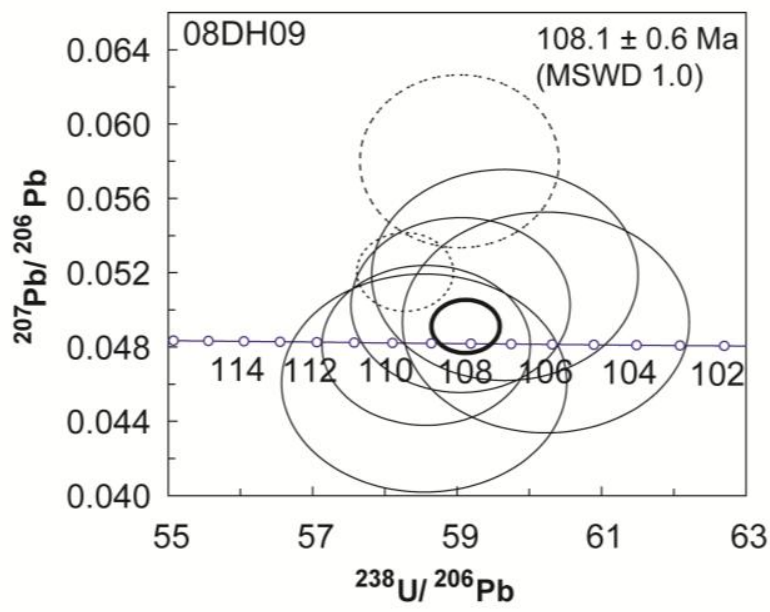

d:

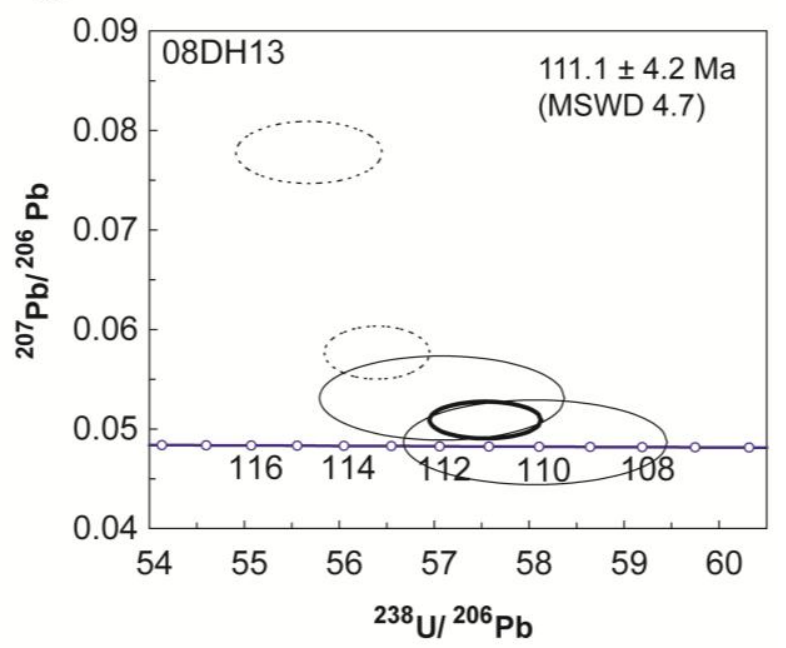

Figure 10: Concordia diagrams for igneous zircons from Kular Dome displaying calculated values and ellipses of error in ratios. Bold circles indicate calculated average ages by Isoplot (Ludwig, 2009), thin lines indicate individual spot ages, and dashed lines indicate spot ages not used for age determination based on visual discordance. Samples 08DH09, 08DH11 and 08JT29 yielded statistically concordant ages while samples $08 \mathrm{DH} 08$ and 08DH13 yielded statistically discordant ages. Sample locations in Figure 5. 

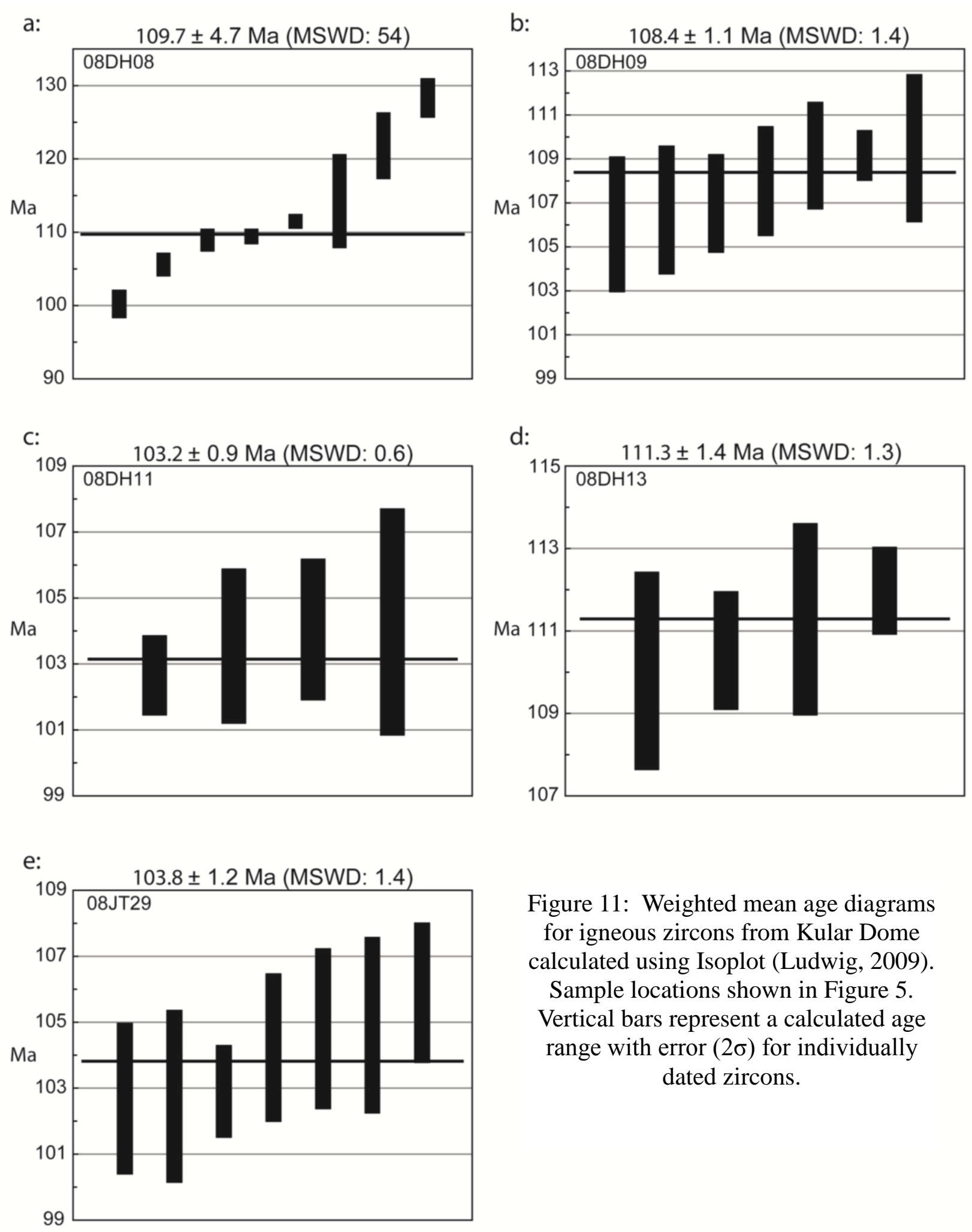

Figure 11: Weighted mean age diagrams for igneous zircons from Kular Dome calculated using Isoplot (Ludwig, 2009). Sample locations shown in Figure 5. Vertical bars represent a calculated age range with error $(2 \sigma)$ for individually dated zircons. 
Table 1: Results from SHRIMP-RG analysis of igneous zircons from Kular granite. In Isoplot v. 3.6 (Ludwig, 2009), only bold rows were used for concordia age analysis, all italicized rows (including bold) were used for weighted mean age calculations and gray rows were not used for analysis. Ages with lines through them have been rejected due to high $\mathrm{U}$, high ${ }^{204} \mathrm{~Pb}$ or discordance. Spot names ending with a "c" or " $\mathrm{r}$ " indicate targeting within the zircon core or rim respectively.

\begin{tabular}{|c|c|c|c|c|c|c|c|c|c|c|c|c|c|c|}
\hline Spot name & $\begin{array}{l}\text { \% common } \\
{ }^{206} \mathrm{~Pb}\end{array}$ & $\mathrm{U}(\mathrm{ppm})$ & $\begin{array}{c}\text { Th } \\
\text { (ppm) }\end{array}$ & ${ }^{232} \mathrm{Th} /{ }^{238} \mathrm{U}$ & $\begin{array}{c}{ }^{207} \mathrm{~Pb} \\
\text { corrected } \\
{ }^{206} \mathrm{~Pb} /{ }^{238} \mathrm{U}\end{array}$ & $1 \sigma$ error & $\begin{array}{c}{ }^{207} \mathrm{~Pb} \\
\text { corrected } \\
{ }^{206} \mathrm{~Pb} /{ }^{238} \mathrm{U} \\
\text { age }\end{array}$ & $1 \sigma$ error & $\begin{array}{c}\text { Total } \\
{ }^{238} \mathrm{U} /{ }^{206} \mathrm{~Pb}\end{array}$ & $\%$ error & $\begin{array}{c}\text { Total } \\
{ }^{207} \mathrm{~Pb} /{ }^{206} \mathrm{~Pb}\end{array}$ & $\%$ error & $\begin{array}{c}{ }^{204} \mathrm{~Pb} \\
\text { corrected } \\
{ }^{207} \mathrm{~Pb} /{ }^{206} \mathrm{~Pb}\end{array}$ & $\%$ error \\
\hline 08DH08-7c & 7.21 & 209 & 158 & 0.78 & .0131 & .0002 & 84.1 & 1.3 & 70.66 & 1.2 & .1049 & 7.0 & .0436 & 39.4 \\
\hline 08DH08-9r & 15.05 & 533 & 135 & 0.26 & .0156 & .0001 & 100.1 & 0.9 & 54.30 & 0.8 & .1675 & 1.6 & .0204 & 76.3 \\
\hline $08 D H 08-2 r$ & 7.05 & 1355 & 355 & 0.27 & .0165 & .0001 & 105.5 & 0.8 & 56.34 & 0.4 & .1041 & 3.9 & .0436 & 15.3 \\
\hline 08DH08-1r & -0.10 & 649 & 187 & 0.30 & .0170 & .0001 & 108.8 & 0.7 & 58.79 & 0.6 & .0474 & 2.3 & .0446 & 3.7 \\
\hline $08 D H 08-3 r$ & 0.15 & 1538 & 206 & 0.14 & .0171 & .0001 & 109.3 & 0.5 & 58.37 & 0.4 & .0494 & 1.5 & .0469 & 2.4 \\
\hline 08DH08-4r & -0.12 & 1757 & 232 & 0.14 & .0174 & .0001 & 111.4 & 0.4 & 57.44 & 0.4 & .0473 & 1.9 & .0473 & 1.9 \\
\hline $08 D H 08-11 c$ & 9.30 & 839 & 152 & 0.19 & .0179 & .0004 & 114.2 & 2.8 & 50.76 & 0.6 & .1222 & 14.0 & .0432 & 79.0 \\
\hline $08 D H 08-10 c$ & 21.40 & 196 & 194 & 1.03 & .0191 & .0003 & 121.8 & 1.9 & 41.21 & 1.1 & .2186 & 2.8 & .0529 & 44.3 \\
\hline 08DH08-6c & 0.36 & 376 & 30 & 0.08 & .0201 & .0002 & 128.3 & 1.0 & 49.56 & 0.8 & .0515 & 2.8 & .0493 & 4.0 \\
\hline 08DH08-12c & 2.91 & 290 & 373 & 1.33 & .0251 & .0002 & 159.5 & 1.4 & 38.75 & 0.8 & .0725 & 2.8 & .0477 & 12.2 \\
\hline 08DH08-5c & 0.51 & 122 & 66 & 0.56 & .0426 & .0005 & 269.1 & 2.8 & 23.34 & 1.0 & .0557 & 3.1 & .0506 & 6.2 \\
\hline 08DH08-c & 12.53 & 270 & 70 & 0.27 & .1481 & .0009 & 890.1 & 5.1 & 5.91 & 0.5 & .1728 & 0.6 & .1644 & 1.1 \\
\hline 08DH09-9c & 0.32 & 473 & 462 & 1.01 & .0162 & .0001 & 103.5 & 0.8 & 61.59 & 0.8 & .0506 & 2.7 & .0496 & 3.0 \\
\hline 08DH09-2c & 0.15 & 158 & 87 & 0.57 & .0166 & .0002 & 106.0 & 1.5 & 60.23 & 1.3 & .0493 & 4.9 & .0405 & 12.6 \\
\hline 08DH09-12c & 0.47 & 187 & 113 & 0.62 & .0167 & .0002 & 106.7 & 1.4 & 59.66 & 1.3 & .0519 & 4.5 & .0444 & 11.9 \\
\hline 08DH09-7c & 1.24 & 306 & 153 & 0.52 & .0167 & .0002 & 107.0 & 1.0 & 59.03 & 1.0 & .0580 & 3.3 & .0460 & 10.9 \\
\hline 08DH09-4c & 0.26 & 278 & 95 & 0.35 & .0169 & .0002 & 108.0 & 1.2 & 59.05 & 1.1 & .0503 & 3.8 & .0473 & 5.2 \\
\hline 08DH09-5c & -0.01 & 270 & 193 & 0.74 & .0171 & .0002 & 109.1 & 1.1 & 58.57 & 1.0 & .0481 & 3.7 & .0436 & 6.6 \\
\hline 08DH09-1C & 0.48 & 1307 & 810 & 0.64 & .0171 & .0001 & 109.1 & 0.5 & 58.28 & 0.5 & .0520 & 1.7 & .0484 & 3.1 \\
\hline 08DH09-6c & -0.27 & 144 & 82 & 0.58 & .0171 & .0002 & 109.5 & 1.5 & 58.54 & 1.4 & .0461 & 5.2 & .0377 & 12.9 \\
\hline 08DH09-8c & 1.12 & 1085 & 126 & 0.12 & .0217 & .0001 & 138.3 & 0.7 & 45.60 & 0.4 & .0578 & 3.9 & .0516 & 5.2 \\
\hline 08DH09-11c & 0.49 & 328 & 100 & 0.31 & .0240 & .0002 & 153.2 & 1.2 & 41.38 & 0.8 & .0530 & 2.6 & .0520 & 2.9 \\
\hline 08DH09-10c & 1.96 & 502 & 208 & 0.43 & .0556 & .0003 & 348.9 & 1.8 & 17.63 & 0.5 & .0692 & 1.3 & .0542 & 4.5 \\
\hline $08 D H 11-3 r$ & 0.10 & 840 & 206 & 0.25 & .0160 & .0001 & 102.6 & 0.6 & 62.25 & 0.6 & .0488 & 2.1 & .0462 & 3.4 \\
\hline $08 D H 11-1 c$ & 0.14 & 273 & 184 & 0.70 & .0162 & .0002 & 103.5 & 1.1 & 61.69 & 1.1 & .0492 & 3.8 & .0472 & 4.8 \\
\hline $08 D H 11-2 c$ & 0.01 & 291 & 78 & 0.28 & .0163 & .0002 & 104.0 & 1.0 & 61.46 & 1.0 & .0482 & 3.6 & .0482 & 3.6 \\
\hline 08DH11-7c & 0.14 & 135 & 102 & 0.78 & .0163 & .0003 & 104.3 & 1.7 & 61.25 & 1.6 & .0492 & 5.7 & .0492 & 5.7 \\
\hline $08 \mathrm{DH} 11-4 \mathrm{C}$ & 0.00 & 478 & 438 & 0.95 & .0167 & .0001 & 106.9 & 0.8 & 59.78 & 0.8 & .0481 & 2.7 & .0461 & 3.6 \\
\hline 08DH11-8r & 0.13 & 272 & 121 & 0.46 & .0170 & .0002 & 108.5 & 1.2 & 58.82 & 1.1 & .0492 & 3.9 & .0492 & 3.9 \\
\hline $08 \mathrm{DH} 11-6 \mathrm{c}$ & 0.12 & 770 & 107 & 0.14 & .0173 & .0001 & 110.5 & 0.7 & 57.78 & 0.7 & .0492 & 2.7 & .0492 & 2.7 \\
\hline 08DH11-5r & 1.09 & 118 & 85 & 0.74 & .3072 & .0027 & 1726.8 & 13.1 & 3.22 & 0.8 & .1152 & 0.9 & .1152 & 0.9 \\
\hline 08DH13-1c & 6.53 & 253 & 108 & 0.44 & .0160 & .0002 & 102.4 & 1.2 & 58.38 & 1.0 & .0999 & 4.5 & .0290 & 48.1 \\
\hline $08 D H 13-3 c$ & 0.06 & 254 & 170 & 0.69 & .0172 & .0002 & 110.0 & 1.1 & 58.07 & 1.0 & .0487 & 3.6 & .0463 & 5.2 \\
\hline $08 D H 13-5 r$ & 3.72 & 738 & 383 & 0.54 & .0173 & .0001 & 110.5 & 0.7 & 55.68 & 0.6 & .0778 & 1.6 & .0446 & 10.4 \\
\hline $08 D H 13-4 r$ & 0.61 & 279 & 117 & 0.43 & .0174 & .0002 & 111.3 & 1.0 & 57.08 & 0.9 & .0531 & 3.2 & .0478 & 6.2 \\
\hline $08 D H 13-2 r$ & 1.19 & 1355 & 234 & 0.18 & .0175 & .0001 & 112.0 & 0.5 & 56.40 & 0.4 & .0577 & 1.9 & .0469 & 5.0 \\
\hline 08JT29-12r & -0.04 & 241 & 181 & 0.78 & .0161 & .0002 & 102.7 & 1.1 & 62.32 & 1.1 & .0478 & 3.9 & .0434 & 8.8 \\
\hline 08JT29-8r & 0.70 & 181 & 58 & 0.33 & .0161 & .0002 & 102.7 & 1.3 & 61.81 & 1.2 & .0537 & 4.2 & .0484 & 7.2 \\
\hline 08JT29-6c & 1.06 & 641 & 611 & 0.98 & .0161 & .0001 & 102.9 & 0.7 & 61.50 & 0.6 & .0565 & 2.2 & .0494 & 5.3 \\
\hline 08JT29-5c & -0.40 & 246 & 128 & 0.54 & .0163 & .0002 & 104.2 & 1.1 & 61.60 & 1.0 & .0449 & 3.8 & .0403 & 8.9 \\
\hline 08JT29-1r & 0.68 & 205 & 128 & 0.64 & .0164 & .0002 & 104.8 & 1.2 & 60.60 & 1.1 & .0535 & 3.8 & .0535 & 3.8 \\
\hline 08JT29-9c & 0.03 & 199 & 119 & 0.62 & .0164 & .0002 & 104.9 & 1.3 & 60.94 & 1.2 & .0483 & 4.4 & .0483 & 4.4 \\
\hline 08JT29-7c & 0.09 & 336 & 48 & 0.15 & .0166 & .0002 & 105.9 & 1.0 & 60.32 & 0.9 & .0488 & 3.4 & .0488 & 3.4 \\
\hline 08JT29-2r & 0.16 & 678 & 64 & 0.10 & .0169 & .0001 & 107.9 & 0.7 & 59.14 & 0.6 & .0494 & 2.2 & .0478 & 2.8 \\
\hline 08JT29-3c & 0.06 & 1780 & 15 & 0.01 & .0186 & .0001 & 118.9 & 0.4 & 53.70 & 0.4 & .0489 & 1.3 & .0486 & 1.4 \\
\hline 08JT29-13c & 0.16 & 467 & 100 & 0.22 & .0251 & .0002 & 159.9 & 1.1 & 39.77 & 0.7 & .0505 & 2.4 & .0497 & 2.7 \\
\hline 08JT29-10c & 8.22 & 74 & 381 & 5.31 & .0595 & .0009 & 372.8 & 5.4 & 15.41 & 1.2 & .1203 & 4.9 & .0626 & 29.4 \\
\hline 08JT29-4c & 5.55 & 121 & 165 & 1.40 & .1700 & .0013 & 1012.3 & 7.2 & 5.55 & 0.7 & .1194 & 1.1 & .1095 & 2.0 \\
\hline
\end{tabular}




\section{Sample 08DH08:}

This sample yielded a small separate of very fine zircons, generally $150 \mu \mathrm{m}$ or less in length. In reflected light, zircons range from clear to honey colored and in CL show simple zoning and occasional xenocrystic cores with magmatic growth rims. Twelve grains were analyzed using four rims and eight cores. Results were highly discordant with no coherent age group showing most spot ages spanning 185 m.y. in the range of 84.1-269.1 Ma and one spot age of $890 \mathrm{Ma}$. Abnormally old ages are most likely the result of $\mathrm{Pb}$ inheritance causing lower ${ }^{207} \mathrm{~Pb} /{ }^{206} \mathrm{~Pb}$ and ${ }^{238} \mathrm{U} /{ }^{206} \mathrm{~Pb}$ ratios which produce older calculated ages. Analyses do show abnormally high ${ }^{206} \mathrm{~Pb}$ counts for grains with older ages (Appendix 2) and CL images show localized bright zones in these same zircons, suggestive of high $\mathrm{U} / \mathrm{Pb}$ ratios (Appendix 1). A concordia age of 110.2 $\pm 1.4 \mathrm{Ma}$ (MSWD 0.02) was calculated based only on U/Pb ratios from three grains shot within their rims. A weighted mean age of 109.7 $\pm 4.7 \mathrm{Ma}$ (MSWD 54) was determined based on eight grain analyses using both cores and rims. Four grain analyses were left out due to high discordance from the mean and rejection by Isoplot weighted mean modeling.

\section{Sample 08DH09:}

A large separate of small honey colored zircons in long doubly-terminated prisms up to $300 \mu \mathrm{m}$ in length and less than $100 \mu \mathrm{m}$ in diameter was collected from this sample. Under CL, almost all zircons display simple zoning with little evidence of metamorphic or magmatic overgrowth. All grains analyzed were targeted within the core to obtain similar initial crystallization ages. Four grains were excluded from all age calculations due to high $U$ or discordant flags leaving a total of seven available targets. A concordia age of $108.1 \pm 0.6 \mathrm{Ma}$ (MSWD 1.0) was calculated from six measurements excluding one spot for visual discordance. 
A weighted mean age of $108.4 \pm 1.1 \mathrm{Ma}$ (MSWD 1.4) was calculated from all seven grains.

\section{Sample 08DH11:}

This sample yielded sub-equal amounts of fat, rounded, honey colored zircons $(150 \mu \mathrm{m}$ in length and $100 \mu \mathrm{m}$ in diameter) and long, thin, clear zircons (up to $400 \mu \mathrm{m}$ in length and as thin as $25 \mu \mathrm{m}$ ). The fat zircons were commonly fractured and were generally too high in $\mathrm{U}$ concentration to be targeted and were therefore excluded from age determination. The thin zircons mostly showed simple zoning patterns with no evidence of magmatic or metamorphic overgrowth. Within the thin zircon population, eight grains were targeted with four analyses excluded for final age determination due to high common $\mathrm{Pb}^{204}$ flags or discordance. Four grains were used for final age determinations using three core shots and one rim shot to calculate a concordia age of $103.3 \pm 0.4 \mathrm{Ma}$ (MSWD 0.9) and a weighted mean age of $103.2 \pm 0.9 \mathrm{Ma}$ (MSWD 0.6).

\section{Sample 08DH13:}

This sample also yielded two separate splits of zircons, the first being fat, rounded honeycolored zircons generally $150-200 \mu \mathrm{m}$ in length and the second set being clear, heavily fractured and thinner at around $200 \mu \mathrm{m}$ in length. Under CL, zircons from the first set were very dark, suggestive of high $\mathrm{U}$ content. Zircons from the second set were very bright under CL suggesting $\mathrm{U}$ concentrations too low for analysis. While neither population was optimal for U-Pb dating, the second set of fractured, low $\mathrm{U}$ concentration zircons had a few fine zircons with ordinary zoning patterns, no overgrowths and little fracturing which were used for analysis. Because of this small population of useful zircons, sputtering was only performed on five grains with four targets in the thin population of zircons and one from the squat, honey-colored zircons. The one 
shot from the squat zircon was excluded from age determinations based on a high common $\mathrm{Pb}^{204}$ flag. The remaining four grains were shot using three rims and one core. Of these four shots, only two were used (one rim, one core) to produce a concordia age of 111.1 \pm 4.2 Ma (MSWD 4.7) and a weighted mean age from all four shots of 111.3 $\pm 1.4 \mathrm{Ma}$ (MSWD 1.3).

\section{Sample 08JT29:}

Our final sample yielded a small separate of fine doubly-terminated zircons typically 150$200 \mu \mathrm{m}$ long and 50-100 $\mu \mathrm{m}$ in diameter ranging from clear to pale tan in color. Grains were generally squat and rounded with magmatic overgrowths around cores that sometimes contained multiple randomly oriented inclusions. Complex inclusion-containing zircons were avoided for analysis. Twelve grains were targeted with a mix of rim and core shots. Five grains were excluded from age determination due to high common $\mathrm{Pb}^{204}$ and high $\mathrm{U}$ flags. Of the remaining grains, four cores and three rims were used in analysis to give a concordia age of $104.5 \pm 1.5 \mathrm{Ma}$ (MSWD 1.5) and a weighted mean age of 103.8 \pm 1.2 Ma (MSWD 1.4).

\section{Mesozoic tectonic setting:}

\section{Late Jurassic-Early Cretaceous compression:}

The Late Jurassic-Early Cretaceous is widely regarded as the time of collision between the Kolyma-Omolon superterrane and the Verkhoyansk passive margin along the east coast of the Siberian craton (Khudoley and Prokopiev, 2007; Parfenov, 1991). This collision caused widespread shortening within the basinal sedimentary deposits that previously formed as a consequence of Devonian rifting off the eastern margin of the Siberian craton. Compressional orogenesis in the area is thought to have ceased by 120 Ma based on overlapping sedimentary 
and volcanic sequences and granitic intrusive suite relationships (Miller et al., 2002). In the Kular Dome area, this compressional event created vertical or near-vertical $\mathrm{S}_{1}$ cleavages striking at an average of $032^{\circ}$ that are inferred to have formed synchronously within large, open folds pervasive in Triassic sedimentary units. Axes for these open-folds strike parallel to $S_{1}$ cleavages west of the Yana fault and are in agreement with a west-northwest orientation of collision between the Kolyma-Omolon superterrane and the North Asian craton during the Late Jurassic. East of the Yana fault, tight folds in thinner Jurassic strata with axes striking at approximately $070^{\circ}$ are seen. These folds and orientations of southward thrusted sheets within the Jurassic units strike approximately $075^{\circ}$ and are at odds with east-west collisional compression. Thrusts appear to be minor, typically dying out laterally over tens of kilometers and commonly show detachment along the base of $\mathbf{J}_{30 x}$ as indicated by repetition of exposed thrusts along the base of this unit (Figure 5). To the south, the Yana fault appears to either die out or bend to the east, following the Yana River. Thrust faults and fold axes in the neighboring Polousnyi Synclinorium range from east-west strikes in the north to an average strike of $035^{\circ}$ about $150 \mathrm{~km}$ southsoutheast of the study area (Figures 3 and 4).

The Chai-Yuryue-Charky-Indigirka suture (Figures 3 and 4) remains somewhat mysterious in that there is no clear agreement as to the specific nature or location of the fault in the north. The suture has been described as a thrust fault (Khudoley and Prokopiev, 2007; Oxman, 2003; Parfenov, 1991), a left-lateral strike-slip fault or a combination of the two (Konstantinovsky, 2007), though a right-lateral strike-slip fault as an escape structure for the northern Kular region should not be discounted either. While some maps place the location of this fault or a regional unnamed thrust fault through the Kular Dome area, these interpretations are inconsistent with our observations at the Kular Dome. It is generally accepted that the Adycha-Taryn fault, located directly west of the Kular-Nera belt (Figures 3 and 4) represents the 
eastern boundary of the Siberian craton and the location of the downgoing slab that resulted in suturing of incoming terrane material to the Verkhoyansk passive margin and is the boundary between the inner and outer Mesozoides (Parfenov, 1991). Comparison of detrital zircon populations collected along the Dyanishka River of the Verkhoyansk Fold-Thrust Belt, Lower Yana River and In'Yali Debin, however, supports a similar sedimentary source for these areas from the Triassic to the Jurassic and suggests a more eastern location for the limit of the Siberian craton during the Triassic and Jurassic (Harris et al., 2011, Chapter II, this volume). We suggest that the Yana normal fault, which parallels the Yana River in the Kular Dome area, is unrelated to the Adycha-Taryn fault to the west or to the Chai-Yuryue-Charky-Indigirka suture which either lies further east or is entirely absent in the north. Fault displacement is more likely to be normal than reverse in nature according to stratigraphic relationships across the fault assuming eastern dip and prevalent evidence of northwest-southeast directed extension in and around the Kular Dome.

\section{Middle Cretaceous extension:}

Compressional forces in the Kular Dome were the result of collision between the Kolyma-Omolon superterrane and the Siberian craton from roughly 150-135 Ma as determined by dating of faulted and folded granitic intrusions of the Main Belt (Layer et al., 2001; Oxman, 2003; Parfenov, 1991). However, evidence of extensional forces dominates the Paleozoic metasediments and Triassic units directly bordering and in close proximity to the pluton. The near-vertical $S_{1}$ foliations seen in Triassic sediments away from the pluton to the southeast near the Yana normal fault are gradually overprinted by a shallowly southeast dipping $\mathrm{S}_{2}$ foliation to the northwest (Figure 6e). Top to the southeast shear and stretching of andalusite grains from macroscopic and microscopic analysis of oriented thin sections of country rock southeast of the 
dome (Figure 9) as well as normal fault prevalence near the pluton are strong evidence supporting an extensional environment during emplacement of the Kular pluton. Outcrop-scale normal faults were also abundant along the Yana River, though commonly showing offset of 10 $\mathrm{m}$ or less. Grain-tail complexes seen in oriented thin sections around andalusite poikiloblasts show consistent top-down shear in foliations that dip gently away from the pluton. Lineations defined by stretched andalusite grains are commonly several centimeters in length and consistently display gentle southeast plunge away from the pluton (Figure 6f). Alignment of these lineations along shallow dip of $S_{2}$ foliations suggests synchronous development during emplacement of the Kular granite. Both ${ }^{207} \mathrm{~Pb} /{ }^{206} \mathrm{~Pb}$ vs. ${ }^{238} \mathrm{U} /{ }^{206} \mathrm{~Pb}$ concordia and ${ }^{207} \mathrm{~Pb}$-corrected ${ }^{206} \mathrm{~Pb} /{ }^{238} \mathrm{U}$ mean ages obtained from granitic zircons suggest a crystallization age for the Kular pluton between $111.3 \pm 1.4 \mathrm{Ma}$ and 103.2 \pm 0.9 Ma limiting timing of extension to the Middle Cretaceous. These ages match previous results by Layer et al. (2001) who reported a ${ }^{40} \mathrm{Ar} /{ }^{39} \mathrm{Ar}$ biotite age of 103 Ma for the Kular granite. Geochemical data also from Layer et al. (2001) indicate the likelihood of magma generation and emplacement within an extensional environment through plots of $\mathrm{Rb}, \mathrm{Nb}$ and $\mathrm{Y}$ concentrations using discrimination diagrams modeled after Pearce et al. (1984).

\section{Discussion:}

\section{The Yana fault:}

Though generally interpreted as a regional suture, the Yana fault is more likely to be a normal fault based on multiple observations including stratigraphic relationships across the Yana fault in the Kular Dome area, prevalence of smaller scale normal faults near the Yana fault and evidence of extensional emplacement of the Kular pluton. South of our field area, Triassic units 
seen only west of the Yana fault near the Kular Dome, outcrop in the cores of anticlines east of the mapped location of the fault (Figure 3) providing strong evidence that the Yana fault is not a suture between two areas with differing sedimentation histories and sources. To the north, the Yana fault is buried beneath Cenozoic cover and deposits of the Ust' Yana Basin. If, however, the Yana fault initially formed as a reverse fault under collisional forces as is commonly mapped, later reversal of dip-slip motion to form a normal fault during emplacement of the Kular pluton would be necessary to explain current stratigraphic relations across the fault (Figure 5). This conclusion is based on the likelihood of an initially westward thrusting direction in accordance with other large-scale regional faults associated with development of the Verkhoyansk FoldThrust Belt. The Yana fault also may represent a right-lateral strike-slip zone with minor dip-slip movement, similar to faults seen in the nearby Adycha El'gy zone and fold-thrust belt, or perhaps as a facilitator to the escape of the Kular-Nera block to the north under east-west compression related to orogenesis in the Late Jurassic. Strike-slip faults seen in the Adycha El'gy zone trend northeast and show right-lateral displacement, also matching the general orientation of strike-slip faults in the Verkhoyansk zone to the west (Parfenov, 1991). Regardless, the Yana fault must have some amount of dip-slip displacement due to the lack of unit alignment on opposite sides of the fault upon restoration by pure strike-slip motion. While development of a normal fault is a convenient answer to some of the inherent problems with the mapping of this structure, all interpretations except that of synchronous fault and dome development either fail to explain the presence of Triassic strata in the cores of some Jurassic folds across the fault in the south or are unnecessarily complicated. It is most likely that the Kular Dome represents an area which has experienced diffuse extension that has been accommodated by brittle deformation in the north and ductile deformation in the south synonymous with intrusion of the Kular granite. This provides a simple explanation for both the 
stratigraphic changes across the Yana fault and for exhumation of the Kular pluton and associated metsediments.

\section{Regional tectonics:}

\section{Pluton emplacement and extensional tectonics:}

Deformation in the Kular Dome area provides insight into the kinematics and timing of an extensional tectonic event in northern Russia during the Middle Cretaceous from 110 Ma to 92 Ma which may have persisted through the Eocene. Intrusion of the Kular pluton is inferred to have occurred between 111.3 \pm 1.4 Ma and 103.2 \pm 0.9 Ma based on igneous zircon $\mathrm{U}-\mathrm{Pb}$ geochronology, followed by mild fluid-assisted high-temperature deformation and rapid exhumation as suggested by grain-boundary migration preserved in quartz grains (Figure 7) (Trouw et al., 2010). Exhumation history is further constrained by an ${ }^{40} \mathrm{Ar} /{ }^{39} \mathrm{Ar}$ age of $102.9 \pm$ 0.5 Ma for muscovites and biotites collected from aplites, granites and monzonites within the Kular Range (Layer et al., 2001), suggesting cooling through $300-400^{\circ} \mathrm{C}$ soon after crystallization.

Fabrics in surrounding metasediments display strong evidence supporting emplacement of the Kular pluton within an extensional tectonic regime as described earlier. Timing of pluton intrusion is synchronous with that of a north-south oriented belt of relatively young intrusions in contrast to igneous rocks of the Main, Northern, and Transverse belts in the area. A study by Layer et al. (2001) groups these belts in terms of age and chemistry into four groups labeled "subduction belts" (aged approximately 160-113 Ma), "collisional belts" (aged 143-138 Ma), “old extensional belts" (aged 120-138 Ma) and "young extensional belts" (aged 92-107 Ma). The Kular granite falls into the "young extensional belt" category which is oriented 
approximately north-south, showing an apparent southward younging direction from Bol'shoi Lyakhov in the north, to the southern Verkhoyansk Range (Figure 2). A potential compressional mechanism for emplacement involves the potential for plutonic development via decompression melting beneath an asymmetric pop-up structure which then experienced overthickening and extension associated with gravity spreading in the highlands following compressional release. This interpretation does not explain the extension-related chemical data from Layer et al. (2001) collected for the "young extensional belt" group, which includes the Kular pluton, nor does it explain the structural features seen in the Kular Dome area and is therefore deemed unlikely. Emplacement mechanisms may also be similar to the nearby Transverse Belt which is proposed to have been emplaced through pressure drops associated with fracture propagation under extensional conditions (Parfenov, 1991).

The tectonic evolution of the modern Arctic during the Middle Cretaceous was dominated by the opening of the Amerasian and Canada Basins, most likely related to counterclockwise rotation of the Arctic Alaska-Chukotka microplate from its original position along the Canadian Arctic Islands, and western subduction of the Pacific plate beneath the Eurasian plate at the eastern edge of Russia causing trench retreat and slab-rollback (Layer et al., 2001) [see Harris et al., 2011, Chapter II, this volume for detailed discussion of the tectonic history]. The Alpha and Mendeleev Ridges and the Chukchi Cap (Figure 2) all display extensional structures and upon closing the Eurasian Basin (pre-Eocene) would have been located more proximal to the Barents Shelf in the Middle Cretaceous. Assuming trench rollback of the Pacific plate during northwestern subduction along the eastern shelf of Paleo-Russia, synchronous right-lateral motion associated with the opening of the Canada Basin and emplacement of the Chukotka portion of the Arctic Alaska-Chukotka microplate, east-west extension in the Laptev Sea area and continental northern Russia is likely (Figure 12). The orientation of this extensional trend 
matches well with graben timing and orientation in the Laptev Sea including the Ust' Yana Graben which extends into the continent north of the Kular Dome (Figures 3 and 4) (Drachev et al., 1998), young extensional belt orientation and structures of the Moma Rift system (Figure 2) which formed in the Early Cenozoic. For this paper, we refer to the "Moma Rift" as the sequence of half-grabens starting at the Laptev Sea and reaching southeast into central Siberia. Extensional features and restored poles of rotation for the Eurasian and North American plates during the Late Cretaceous-Early Cenozoic suggest extensional deformation reaching from the Gakkel Ridge to a point just south of the Laptev Sea where the poles of rotation for both the North American and Eurasian plates are found (Figure 1) (Franke et al., 2000; Fujita et al., 2009). While some have argued for the ongoing extensional deformation in the Moma Rift region, current seismic data and attenuation, and focal mechanism results support modern transpressional or compressional deformation reactivating initially extensional features (Cook et al., 1986; Franke et al., 2000; Fujita et al., 1990). Based on restorations of North Atlantic magnetic anomalies, Gaina et al. (2002) have demonstrated the potential for diffuse extension across the Laptev Sea and northern Russia from $79 \mathrm{Ma}$ to 68.7 Ma (Figure 12), though it is possible that extension resulting from competing tectonic forces caused extensional forces as early as $100 \mathrm{Ma}$ which is in agreement with a southward younging trend of plutons from northern Russia (Figure 1) (Layer et al., 2001). Though constraints on compressional deformation which resulted in formation of the Verkhoyansk Fold-Thrust Belt are limited to Late Jurassic-Middle Cretaceous time, opening of the Canada Basin altered the tectonic stresses of the area by the Late Cretaceous. Diffuse extension in northern Russia, which resulted in emplacement of a suite of plutonic intrusives, may have been an indication of early rifting of the Gakkel Ridge system. While magnetic anomalies in the Eurasian Basin show that new oceanic 


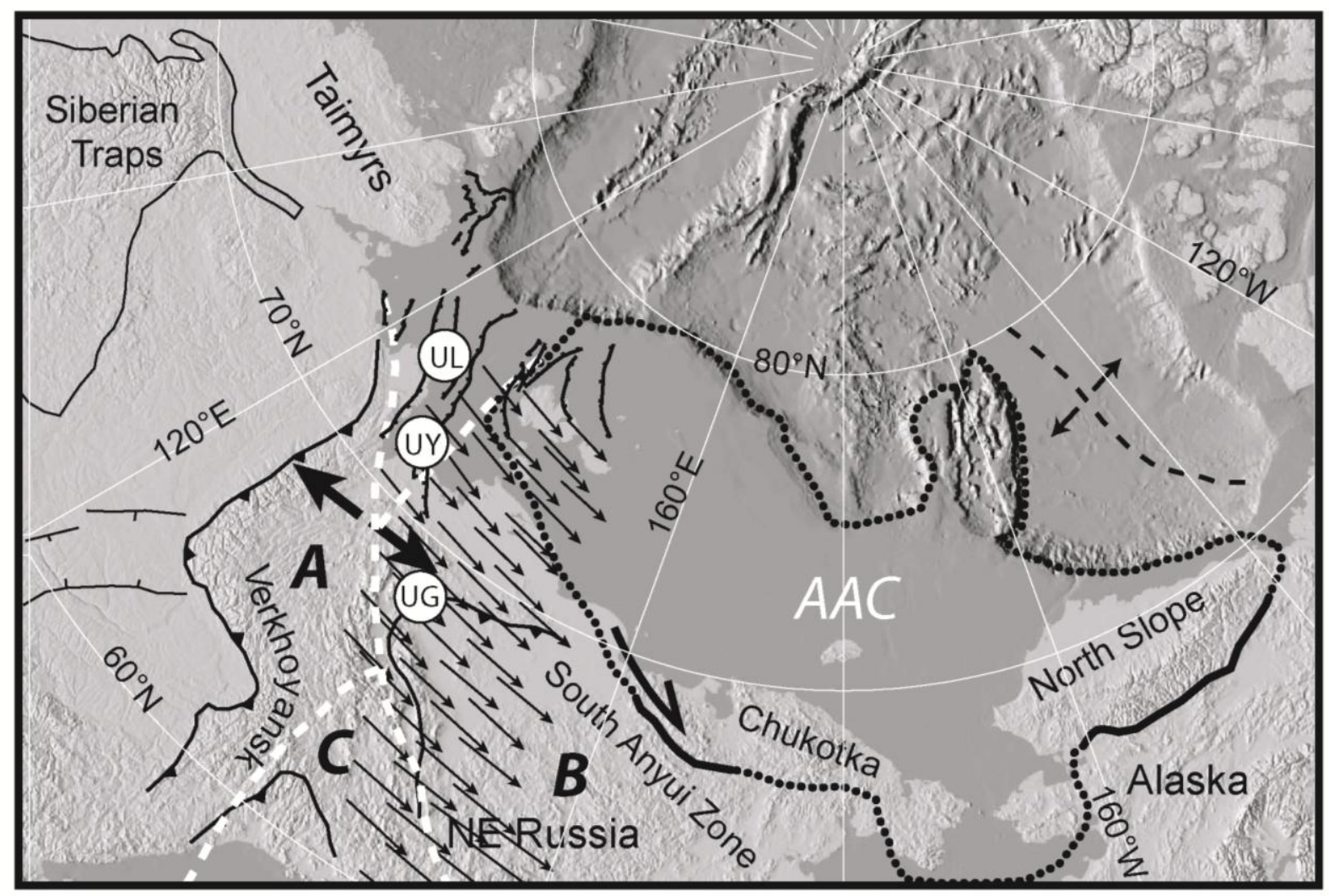

Figure 12: Late Cretaceous (79-68.7 Ma) plate vectors for the North American plate relative to the Eurasian plate (fixed) superimposed on modern bathymetry from IBCAO (Jakobsson et al., 2008). Plate vectors are from Gaina et al. (2002), holding the Eurasian plate stationary. The dashed black line represents the approximate boundary of the Arctic AlaskaChukotka microplate (AAC) and the dashed white line represents approximate plate boundaries between the Eurasian (A), North American (B) and Okhotsk (C) plates. Abbreviations are: UG, Uyandina Graben; UL, Ust' Lena Rift; UY, Ust' Yana Graben. Laptev Sea graben locations are from Drachev et al. (1998). 
crust was forming along the Gakkel Ridge in the Eocene, there is no direct evidence of when continental rifting initiated since there are no wells in the Laptev Sea. However, Drachev et al. (1998) interpreted the lowest reflective bed within the Ust' Lena Rift of the Laptev Graben system (Figure 12) as Late Cretaceous-Paleogene in age and the base of the Ust' Yana Graben (Figure 12) as the Late Paleocene, suggestive of Late Cretaceous rifting as a precursor to opening of the Gakkel Ridge.

While the timing of specific events that have caused both compressional and extensional structures in the Moma Rift region are poorly constrained, the orientation of the overall rift system is in-line with a regional extensional event for northern Russia (Fujita et al., 1990; Paech et al., 1998), which we propose to have been initiated as early as the Middle to Late Cretaceous. Modeling of continental deformation along the northern Moma Rift indicates the potential for rifting near the Laptev Sea as early as $79 \mathrm{Ma}$ (Gaina et al., 2002), so it seems reasonable that continental stretching may have been initiated prior to eventual graben formation to the southeast. The nearby Uyandina Graben (Figure 12) shows abundant extensional deformational features and no compressional features in the Upper Oligocene-Pleistocene clay, silt, conglomerate and lignite sediments (Paech et al., 1998), suggesting that while extension may have been initiated as early as the Middle Cretaceous, it may have resulted in minor deformation when spread across the continent until the Middle Paleogene when extension finally resulted in brittle deformation such as the Gakkel Ridge of the Eurasian Basin and graben development in the Moma Rift region. 


\section{Conclusions:}

Field data presented in this study supports an extensional setting for the Kular Dome area and northern Russia during the Cretaceous through presence of normal faults that cut Triassic sandstones and Jurassic greywackes, stretched andalusites in contact metamorphosed schists, and down-plunge shear of coarse grains observed in oriented thin section samples. The Kular Dome is a $111.3 \pm 1.4$ to $103.2 \pm 0.9 \mathrm{Ma}$ aged granite based on $\mathrm{U}-\mathrm{Pb}$ dating of igneous zircon and is thought to have been emplaced during a major east-west extensional event responsible for intrusion of a young series of plutons and dikes with extensional geochemical signatures from 110 to 92 Ma showing apparent southward younging (Layer et al., 2001). Orientation of this extensional episode is in agreement with potential forcing by opening of the Amerasian Basin of the Arctic and rollback above a westward subducting Pacific plate beneath the Eurasian plate during the Middle Cretaceous. The extensional event that created the Kular Dome and facilitated emplacement of this young extensional belt of granites is in-line with the modern strike of the Gakkel Ridge suggesting that an early Russian extensional event could have been a precursor to its eventual opening during the Eocene. This conclusion is also supported by the presence of Late Cretaceous deposits at the base of the Ust' Lena Rift of the Laptev Sea and Late Paleocene deposits at the base of the Ust' Yana Graben (Drachev et al., 1998) which are located between and along strike with the Gakkel Ridge to the north and the Kular Dome to the south. 


\section{References:}

Akinin, V.V., and Miller, E.L., 2011, Evolution of calc-alkaline magmas of the OkhotskChukotka volcanic belt: Petrology, v. 19, p. 237-277.

Amato, J.M., Toro, J., Miller, E.L., Gehrels, G.E., Farmer, G.L., Gottlieb, E.S., and Till, A.B., 2009, Late Proterozoic-Paleozoic evolution of the Arctic Alaska-Chukotka terrane based on $\mathrm{U}-\mathrm{Pb}$ igneous and detrital zircon ages: Implications for Neoproterozoic paleogeographic reconstructions: GSA Bulletin, v. 121, p. 1219-1235.

Amato, J.M., Toro, J., and Moore, T.E., 2004, Origin of the Bering Sea salient: Geological Society of America Special Paper 383, p. 131-144.

Black, L.P., Kamo, S.L., Allen, C.M., Davis, D.W., Aleinikoff, J.N., Valley, J.W., Mundil, R., Campbell, I.H., Korsch, R.J., Williams, I.S., and Foudoulis, C., 2004, Improved $206 \mathrm{~Pb} / 238 \mathrm{U}$ microprobe geochronology by the monitoring of a trace-element-related matrix effect; SHRIMP, ID-TIMS, ELA-ICP-MS and oxygen isotope documentation for a series of zircon standards: Chemical Geology, v. 205, p. 115-140.

Coath, C.D., and Long, J.V.P., 1994, A high-brightness duoplasmatron ion source for microprobe secondary-ion mass spectrometry: Review of Scientific Instruments, v. 66, p. 1018-1023.

Cook, D.B., Fujita, K., and McMullen, C.A., 1986, Present-day plate interactions in Northeast Asia: North American, Eurasian, and Okhotsk plates: Journal of Geodynamics, v. 6, p. $33-51$.

DeMets, C., Gordon, R.G., Argus, D.F., and Stein, S., 1994, Effect of recent revisions to the geomagnetic reversal time scale on estimates of current plate motions: Geophysical Research Letters, v. 21, p. 2191-2194.

Dickinson, W.R., Beard, L.S., Brakenridge, G.R., Erjavec, J.L., Ferguson, R.C., Inman, K.F., Knepp, R.A., Lindberg, F.A., and Ryberg, P.T., 1983, Provenance of North American Phanerozoic sandstones in relation to tectonic setting: Geological Society of America Bulletin, v. 94, p. 222-235.

Drachev, S.S., Savostin, L.A., Groshev, V.G., and Bruni, I.E., 1998, Structure and geology of the continental shelf of the Laptev Sea, Eastern Russian Arctic: Tectonophysics, v. 298, p. 357-393.

Embry, A.F., 1990, Geological and geophysical evidence in support of the hypothesis of anticlockwise rotation of northern Alaska: Marine Geology, v. 93, p. 317-329. 
Franke, D., Krüger, F., and Klinge, K., 2000, Tectonics of the Laptev Sea - Moma "rift" region: investigation with seismologic broadband data: Journal of Seismology, v. 4, p. 99-116.

Fujita, K., Cambray, F.W., and Velbel, M.A., 1990, Tectonics of the Laptev Sea and Moma rift systems, northeastern USSR: Marine Geology, v. 93, p. 95-118.

Fujita, K., Koz'min, B.M., Mackey, K.G., Riegel, S.A., McLean, M.S., and Imaev, V.S., 2009, Seismotectonics of the Chersky Seismic Belt, eastern Sakha Republic (Yakutia) and Magadan District, Russia, in Stone, D.B., Fujita, K., Layer, P.W., Miller, E.L., Prokopiev, A.V., and Toro, J., eds., Geology, geophysics and tectonics of Northeastern Russia: a tribute to Leonid Parfenov, Stephan Mueller Special Publication Series Volume 4, Copernicus Publications, p. 117-145.

Gaina, C., Roest, W.R., and Müller, R.D., 2002, Late Cretaceous - Cenozoic deformation of northeast Asia: Earth and Planetary Science Letters, v. 197, p. 273-286.

Gehrels, G., and Pullen, A., 2010, Introduction to U-Th-Pb geochronology using a laser-ablation multicollector ICP mass spectrometer: Anaheim, CA, Geological Society of America Short Course.

Grantz, A., and May, S.D., 1983, Rifting history and structural development of the continental margin north of Alaska, in Watkins, J.S., and Drake, C., eds., Studies in continental margin geology: American Association of Petroleum Geologists Memoir 34, p. 77-100.

Holcombe, R., 2010, GEOrient ver. 9.4.5: Kenmore, QLD, Australia.

Jakobsson, M., Macnab, R., Mayer, L., Anderson, R., Edwards, M., Hatzky, J., Schenke, H.-W., and Johnson, P., 2008, An improved bathymetric portrayal of the Arctic Ocean: Implications for ocean modeling and geological, geophysical and oceanographic analyses: Geophys. Res. Lett., v. 35

Jokat, W., and Schmidt-Aursch, M.C., 2007, Geophysical characteristics of the ultraslow spreading Gakkel Ridge, Arctic Ocean: Geophysical Journal International, v. 168, p. 983998.

Khudoley, A.K., and Prokopiev, A.V., 2007, Defining the eastern boundary of the North Asian craton from structural and subsidence history studies of the Verkhoyansk fold-and-thrust belt: GSA Special Papers, v. 433, p. 391-410.

Konstantinovsky, A.A., 2007, Structure and geodynamics of the Verkhoyansk Fold-Thrust Belt: Geotectonics, v. 41, p. 337-354.

Lawver, L.A., Grantz, A., and Gahagan, L.M., 2002, Plate kinematic evolution of the present 
Arctic region since the Ordovician, in Miller, E.L., Grantz, A., and Klemperer, S.L., eds., Tectonic Evolution of the Bering Shelf - Chukchi Sea - Arctic Margin and Adjacent Landmasses, Special Paper 360: Boulder, CO, The Geological Society of America, p. 333-358.

Lawver, L.A., and Scotese, C.R., 1990, A review of tectonic models for the evolution of the Canada Basin, in Grantz, A., Johnson, L., and Sweeney, J.F., eds., The Arctic Ocean Region, v. L: Boulder, Colorado, Geological Society of America, p. 593-618.

Layer, P.W., Newberry, R., Fujita, K., Parfenov, L., Trunilina, V., and Bakharev, A., 2001, Tectonic setting of the plutonic belts of Yakutia, northeast Russia, based on 40Ar/39Ar geochronology and trace element geochemistry: Geology, v. 29, p. 167-170.

Ludwig, K.R., 2009, Isoplot 3.6 Geochronological toolkit for Microsoft Excel, Special Publication No. 4: Berkeley, CA, Berkeley Geochronology Center, 1-77.

Miller, E.L., Gelman, M., Parfenov, L., and Hourigan, J., 2002, Tectonic setting of Mesozoic magmatism: A comparison between northeastern Russia and the North American Cordillera, in Miller, E.L., Grantz, A., and Klemperer, S.L., eds., Tectonic Evolution of the Bering Shelf - Chukchi Sea - Arctic Margin and Adjacent Landmasses, Special Paper 360: Boulder, CO, The Geological Society of America, p. 313-332.

Miller, E.L., and Hudson, T.L., 1991, Mid-Cretaceous extensional fragmentation of a JurassicEarly Cretaceous compressional orogen, Alaska: Tectonics, v. 10, p. 781-796.

Miller, E.L., Soloviev, A., Kuzmichev, A., Gehrels, G., Toro, J., and Tuchkova, M., 2008, Jurassic and Cretaceous foreland basin deposits of the Russian Arctic: Separated by the birth of the Makarov Basin?: Norwegian Journal of Geology, v. 88, p. 201-226.

Miller, E.L., Toro, J., Gehrels, G., Amato, J.M., Prokopiev, A., Tuchkova, M.I., Akinin, V.V., Dumitru, T.A., Moore, T.E., and Cecile, M.P., 2006, New insights into Arctic paleogeography and tectonics from $\mathrm{U}-\mathrm{Pb}$ detrital zircon geochronology: Tectonics, v. 25

Oleshko, B.M., 1981, The 1:200,000 State Geologic Map of the USSR. The Verkhoyansk series. Sheets Q-53-XIX-XX. Map and Explanatory notes: Moscow, Soyuzgeolfond, 85 (in Russian).

Oxman, V.S., 2003, Tectonic evolution of the Mesozoic Verkhoyansk-Kolyma belt (NE Asia): Tectonophysics, v. 365, p. 45-76.

Paech, H.-J., Prokopiev, A.V., Gosen, W.V., Grinenko, O.V., Smetannikova, L.I., and Belolyubskij, I.N., 1998, New results of the Moma rift system and coeval structures in 
Yakutia, Russian Federation: Polarforschung, v. 68, p. 59-63.

Parfenov, L.M., 1991, Tectonics of the Verkhoyansk-Kolyma Mesozoides in the context of plate tectonics: Tectonophysics, v. 199, p. 319-342.

Parfenov, L.M., Badarch, G., Berzin, N.A., Khanchuk, A.I., Kuzmin, M.I., Nokleberg, W.J., Prokopiev, A.V., Ogasawara, M., and Yan, H., 2009, Summary of Northeast Asia geodynamics and tectonics, in Stone, D.B., Fujita, K., Layer, P.W., Miller, E.L., Prokopiev, A.V., and Toro, J., eds., Geology, geophysics and tectonics of Northeastern Russia: a tribute to Leonid Parfenov, Stephan Mueller Special Publication Series Volume 4, Copernicus Publications, p. 11-33.

Pearce, J.A., Harris, N.B.W., and Tindle, A.G., 1984, Trace element discrimination diagrams for the tectonic interpretation of granitic rocks: Journal of Petrology, v. 25, p. 956-983.

Trouw, R.A.J., Passchier, C.W., and Wiersma, D.J., 2010, Atlas of Mylonites - and related microstructures: New York, Springer.

Trunilina, V.A., 1994, Geodynamic position, genesis and criteria for ore content of tin-bearing granitoids from the Yana-Kolyma region, in Seltmann, R., ed., Metallogeny of collisional orogens: Prague, Czech Geological Survey, p. 430-434.

Urzov, A.S., Prokopiev, V.S., and Spector, Y.L., 1994, Geologic map of Yakutia, scale 1:500000, Sheet 17 and 27, in Prokopiev, V.S., ed.

Williams, I.S., 1998, U-Th-Pb geochronology by ion-microprobe, in Kibben, M., Shanks, W., and Ridley, W., eds., Applications of Microanalytical Techniques to Understanding Mineralizing Process, Reviews in Economic Geology, v. 7: El Paso, TX, The Economic Geology Publishing Company, p. 1-36.

Yin, A., 2004, Gneiss domes and gneiss dome systems, in Whitney, D.L., Teyssier, C., and Siddoway, C.S., eds., Gneiss Domes in Orogeny, Special Paper 380: Boulder, CO, The Geological Society of America, p. 1-14. 


\title{
Chapter II
}

\section{Detrital zircon U-Pb geochronology of Mesozoic sandstones from the Lower Yana River, northern Russia}

\author{
D.B. Harris ${ }^{1}$, J. Toro ${ }^{1}$, E.L. Miller ${ }^{2}$ and A.V. Prokopiev ${ }^{3}$
}

\author{
${ }^{1}$ Department of Geology and Geography \\ West Virginia University \\ Morgantown, WV 26506-6300 \\ (304) 293-5603 \\ E-mail: dharri11@mix.wvu.edu; jtoro@wvu.edu \\ ${ }^{2}$ Department of Geological and Environmental Sciences \\ Stanford University \\ Stanford, CA 94305-2115 \\ (650) 723-0847 \\ E-mail: elmiller@stanford.edu \\ ${ }^{3}$ Diamond and Precious Metal Geology Institute \\ Siberian Branch of the Russian Academy of Sciences \\ Yakutsk, Russian Federation \\ E-mail: prokopiev@diamond.ysn.ru
}




\begin{abstract}
:
The formation of the Amerasian Basin remains enigmatic in terms of both timing and method of formation. Most models attempt to describe the movement of the Arctic Alaska-Chukotka microplate, which includes the New Siberian Islands, Wrangel Island, Chukotka and the Siberian Shelf of Russia as well as the North Slope and Seward Peninsula of Alaska. Movement of this microplate across the location of the modern Amerasian Basin is generally invoked to describe formation of the basin itself. Detrital zircon geochronology has been shown to be an inexpensive yet powerful method by which the tectonic correlation and proximity between multiple terranes over geologic time can be approximated. Seven detrital zircon samples to be dated for their U-Pb depositional ages were collected from Triassic sandstones and Late Jurassic greywackes from the Lower Yana River area. Triassic samples had detrital zircon age populations from 224-337, 341-387, 413-568, 738-825 and 1759-2011 Ma and Jurassic samples had detrital zircon age populations from 147-210, 223-396, 1639-2183 and 2281-3116 Ma. Comparison of detrital zircon ages from the Lower Yana River area to those dated from Chukotka, the Verkhoyansk Fold-Thrust Belt and the In'Yali Debin terrane suggests that Chukotka was separated from the North Asian craton during the Triassic. Jurassic detrital zircon age populations suggest that the Anyui Ocean had closed by the Tithonian via transpressional collision with northern Siberia. Integration of this data with previous multidisciplinary geologic studies has led to a new tectonic model describing the motion of the Arctic Alaska-Chukotka microplate across the Arctic during the Mesozoic as two separate, independently moving pieces in the Jurassic. Extension between the Alaskan and Russian portions of the Arctic Alaska-Chukotka microplate involving counterclockwise rotation of both during opening of the Canada Basin led to the composite strike-slip and extensional structures of the Alpha and Mendeleev Ridges. Chukotka likely moved from an initial position along the Barents Shelf eastward via dextral strike-slip motion along the north coast of Russia during the Late Jurassic to close the Anyui Ocean.
\end{abstract}




\section{Introduction:}

The tectonic history responsible for formation of the major basins of the Arctic has long been a topic of debate despite an increasing body of research. These efforts typically focus on the Amerasian Basin and its internal Canada Basin (see review in Lawver and Scotese, 1990) since the Eurasian Basin, located more proximal to the Barents Shelf of Siberia, is younger and has a more easily interpreted tectonic history (Figure 1a). Most models regarding the formation of the Amerasian Basin are described by entrapment of oceanic crust or sea-floor spreading, though the latter is given more common consideration. Sea floor spreading models utilize multiple interpretations of the movement and function of prominent features in and around the Amerasian Basin including the Lomonosov Ridge, the Alpha and Mendeleev Ridges, the Chukchi Cap, the Northwind Ridge and the Arctic Alaska-Chukotka microplate (AAC) which is of particular interest to this paper (Figure 1a). The AAC includes the North Slope and Seward Peninsula of Alaska, as well as Chukotka, the New Siberian Islands, Wrangel Island and the East-Siberian Shelf of northeast Russia. Similarity of stratigraphic records, magnetic anomalies, basin correlations and seismic profiles comparing northern Alaska to the Canadian Arctic Islands all support an opening of the Canada Basin involving counterclockwise rotation of the Alaskan portion of the AAC away from an original position along the Canadian Arctic Islands with proposed rifting ages from the Early Jurassic to the Early Cretaceous (Embry, 1990; Embry and Dixon, 1994; Grantz and May, 1983; Lawver et al., 2002) (Figure 1b). While there is an abundance of support for the pre-Canada Basin location of northern Alaska adjacent to the Canadian Arctic 


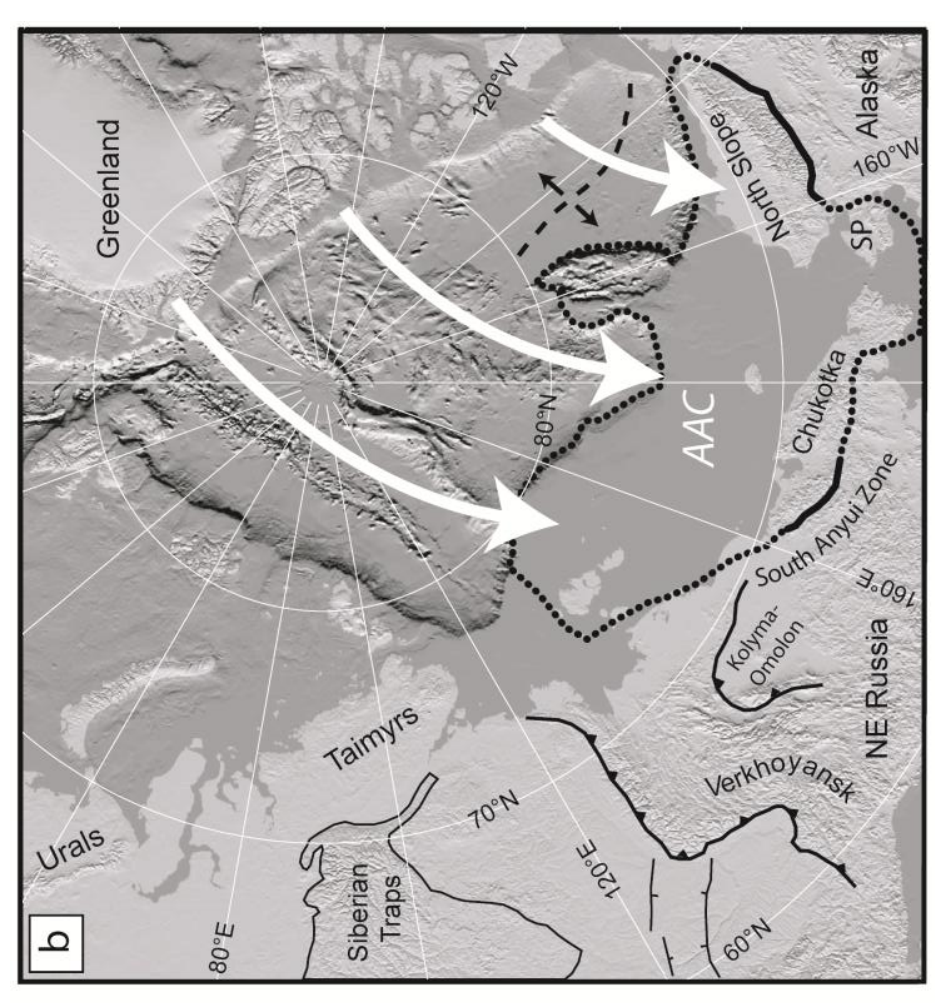

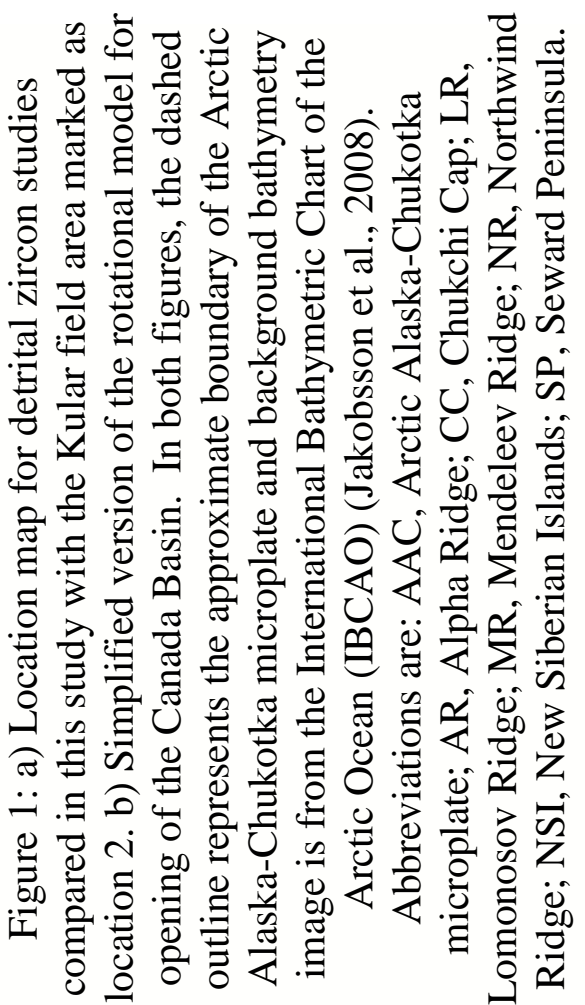

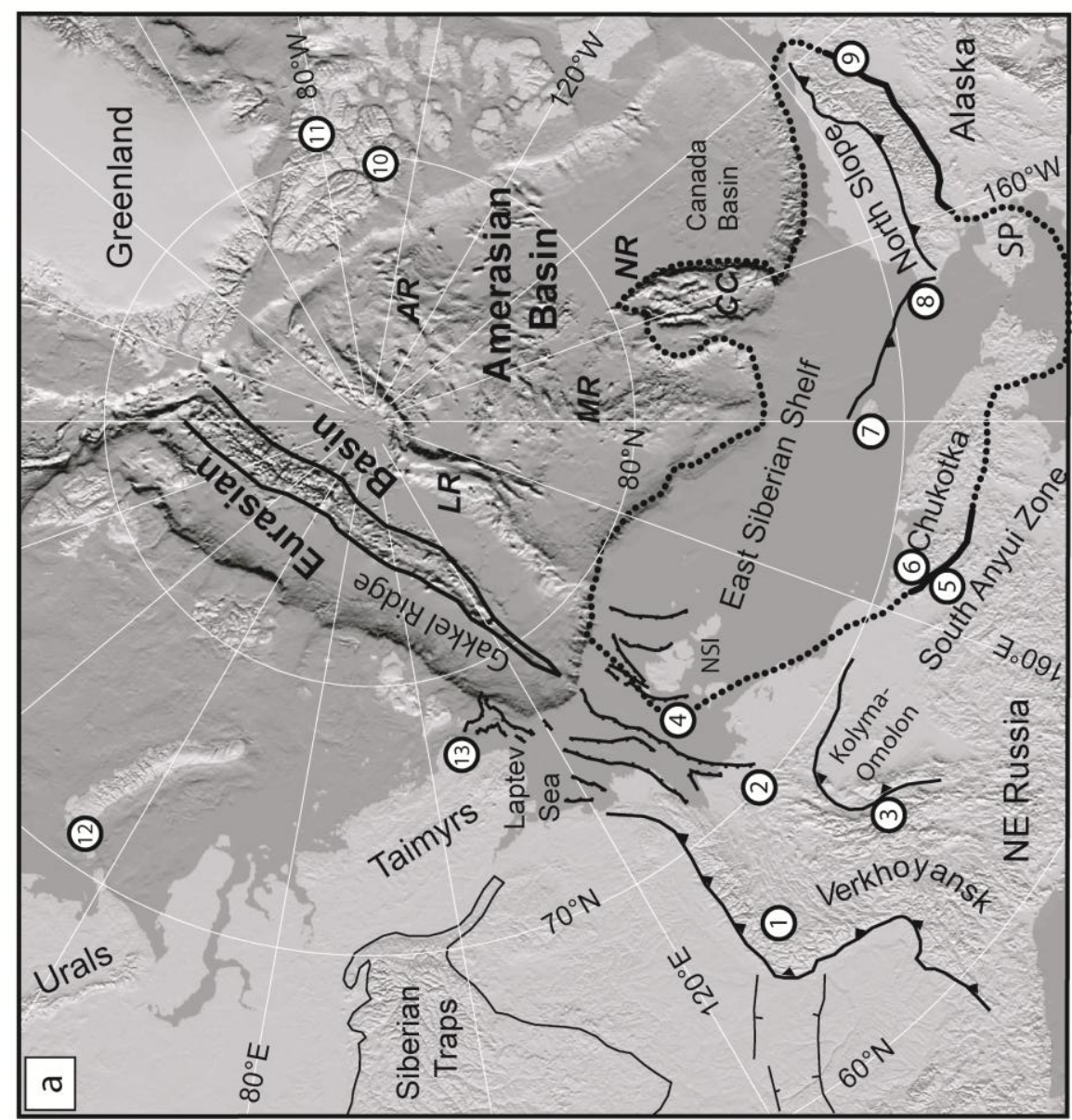

㞤

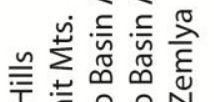

论 올옹

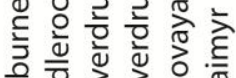

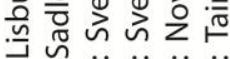

$\ddot{\infty}$ ö으름

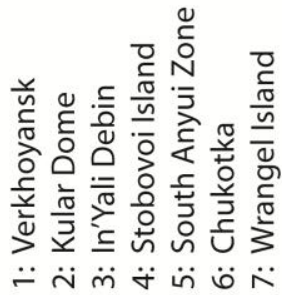

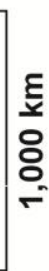


Islands, there is little evidence for the original location of Chukotka which is generally assumed to have been attached to the North Slope of Alaska and to have experienced a similar rotational movement. However, under current interpretations regarding the Mesozoic location of Arctic landmasses it is not possible to restore the AAC back to its pre-rift position if it is treated as a rigid, coherent block due to large overlap of pre-rift landmasses and significant space problems during continental drift. Using detrital zircon geochronologic data, Miller and others $(2008 ; 2006)$ suggested that Chukotka may have been disconnected from the Alaskan portion of the AAC and instead located closer to the Taimyr region prior to formation of the Amerasian Basin. They favor a dextral strike-slip emplacement of Chukotka and Wrangel Island along northern Siberia involving as much as $100 \%$ continental extension of the East Siberian Shelf. This pre-rift location of Chukotka ties in with a solution commonly referred to as the "windshield wiper model," which assumes that Chukotka experienced clockwise rotation away from the Barents Shelf to close the Anyui Ocean concurrently with counterclockwise rotation of the North Slope of Alaska away from the Canadian Arctic Islands. Placing Chukotka closer to the Taimyr Peninsula during the Triassic has particular merit as it alleviates the problem of overlap between the AAC and Greenland created by closing the Amerasian Basin using the rotational model. The Chukotka part of the AAC is assumed to have reached its final position during the Late Cretaceous along the northern Kolyma-Omolon superterrane which deformed passive margin sequences along the eastern edge of the North Asian craton to form the Verkhoyansk Fold-Thrust Belt in the Late Jurassic. The specific location of the suture between the Siberian platform and the Kolyma-Omolon superterrane has been difficult to define, though current interpretations suggest a location 
along the Adycha-Taryn fault which borders the Kular-Nera belt along its western boundary, separating it from the Verkhoyansk Fold-Thrust Belt (Figure 2) (Khudoley and Prokopiev, 2007).

Because of access difficulties to the Arctic basins, most studies are limited to research of the landmasses surrounding the Amerasian Basin. More specifically, detrital zircon geochronology has been shown to be a powerful tool for determining sedimentary provenance and for tectonic reconstructions when source regions can be identified (Andersen, 2005; Carrapa, 2010). Studies of modern river systems have shown that along a river transect, inputs of zircon from downstream sources can overprint upstream sources despite higher erosive rates in the headwaters (Cawood et al., 2003). This has important implications for tectonic reconstructions since under this conclusion a sampled detrital zircon population is more likely to have been deposited close to its original source than to have traveled a long distance. Though headwater zircon preservation may diminish downstream compared to more proximal sources, these signatures are present nonetheless and require long-distance transport. Results from a study of detrital zircons from sedimentary rocks in the Verkhoyansk Range of Siberia require transport of zircons for thousands of kilometers as well as persistence of the river responsible for deposition for up to 200 m.y. (Prokopiev et al., 2008). A similar study of marine and fluvial sandstones collected in the Colorado Plateau of the United States Cordillera suggests transport of detrital zircons from source regions in eastern and central Laurentia at times as far away as the Appalachian orogen along a trans-continental river system with headwaters in the southern Appalachian Mountains (Dickinson and Gehrels, 2009). These studies are strong support that long-distance transport of detrital zircons is possible 


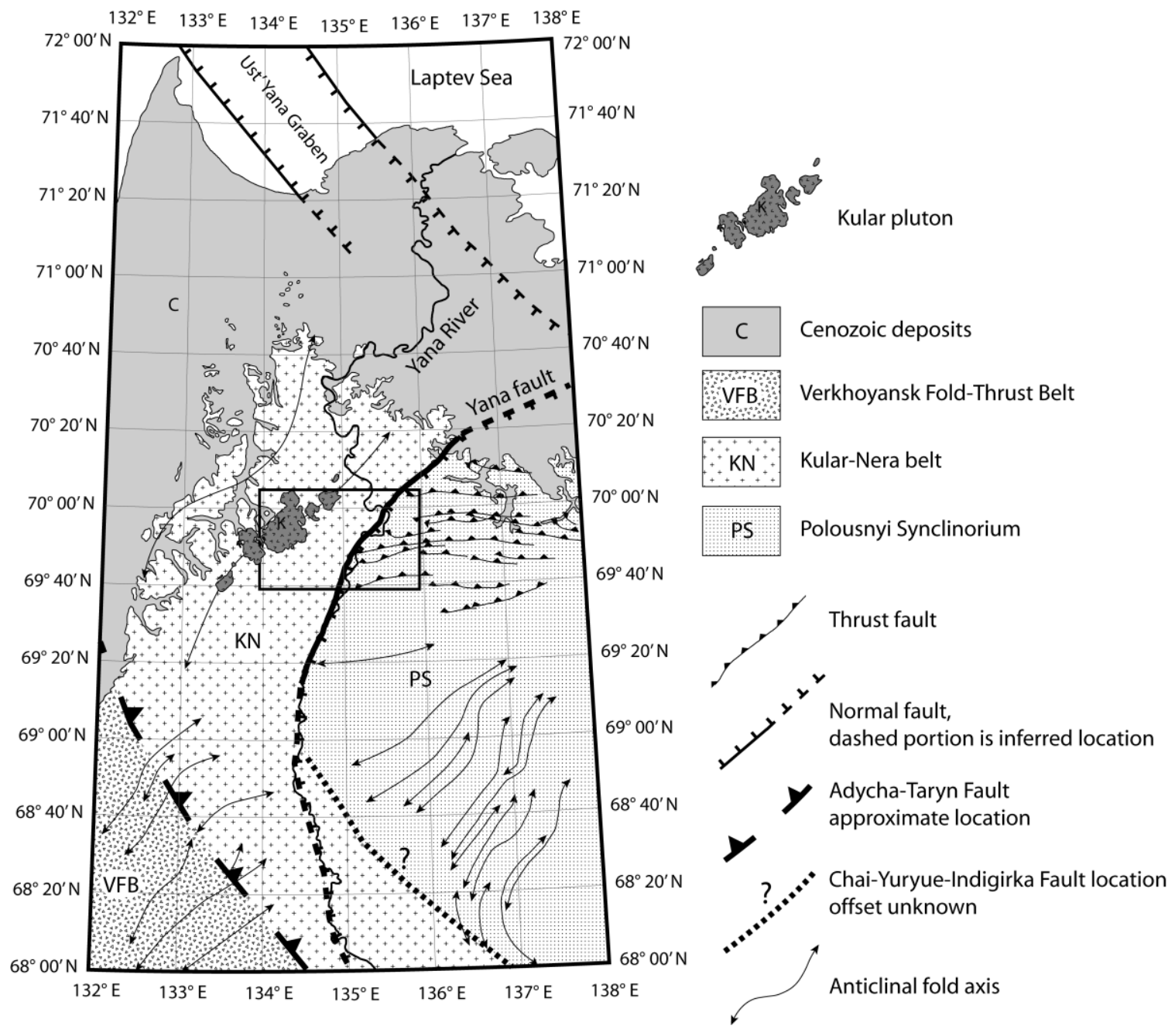

Figure 2: Generalized tectonic and terrane map of the Kular area. Modified from Urzov et al. (1994), Konstantinovsky (2007) and Oxman (2003). See Figure 1 for location. The central boxed area indicates the location of Figure 3. 
under the right circumstances. With the advent of laser-ablation multicollector inductively coupled plasma mass spectroscopy (LA-MC-ICPMS) the cost of individual zircon grain dating has gone down along with the rise in accuracy, speed and ease of analysis. Recent efforts towards the production of a detrital zircon database of Mesozoic $\mathrm{U}-\mathrm{Pb}$ ages for landmasses surrounding the Amerasian Basin have been instrumental in revealing its tectonic history (Miller et al., 2006).

The Kular Dome is located at approximately $70.0^{\circ} \mathrm{N} / 134.3^{\circ} \mathrm{E}$ about $135 \mathrm{~km}$ south of the Laptev Sea and about $30 \mathrm{~km}$ west of the Lower Yana River and Ust' Kuyga, Siberia. In this area, the Kular granite intrudes Paleozoic metasediments and Mesozoic sandstones and greywackes of the Kular-Nera slate belt (Harris et al., 2011, Chapter I, this volume; Parfenov, 1991) (Figure 3). The region can be classified as a gneiss dome defined as an igneous intrusion surrounded by contact metamorphosed strata in a domal structure (Yin, 2004). The intrusion which forms the center of the Kular Dome is an Early Cretaceous (Albian, 111-103 Ma) biotite granite that outcrops in multiple exposures along a northeast-southwest trend (Harris et al., 2011, Chapter I, this volume). The unit surrounding the pluton is an andalusite-bearing metapelite which displays topdown shear away from the pluton involving gently plunging stretched andalusites and mantled porphyroblasts (Harris et al., 2011, Chapter I, this volume). The next units outward from the pluton are Triassic aged sandstones with shale interbeds that display open folds along axes paralleling the long direction of the Kular granite (Figures 2 and 3). This unit continues to be exposed to the southeast until it reaches the Yana fault, an eastward dipping normal fault which separates Triassic units to the west from Jurassic aged greywackes to the east. In the Kular area, the fault location is defined by the Lower 

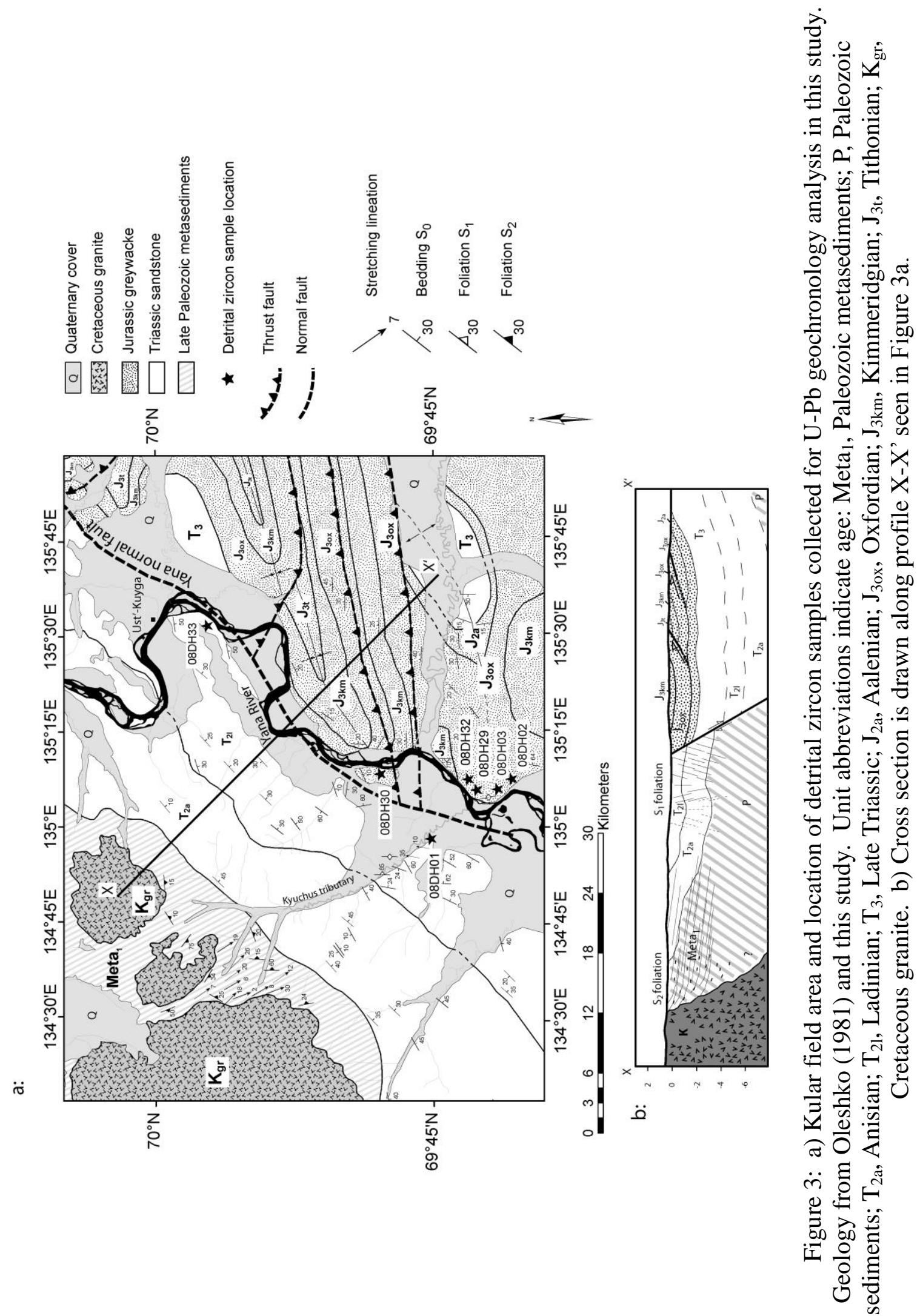
Yana River for some 30-40 km (Figures 2 and 3). The Jurassic sediments are tightly folded along axes striking approximately east-west and are cut by several southward vergent thrust faults with minor displacement.

The Lower Yana River area, describing the general area east of the Kular Dome surrounding the Yana fault and lower Yana River, has been selected for this study as it is located between the Verkhoyansk Fold-Thrust Belt and the AAC, two areas that are well studied and have abundant detrital zircon $\mathrm{U}-\mathrm{Pb}$ data for the Mesozoic. A study by Miller et al. (2010) has already compared Triassic detrital zircon geochronologic results from several areas surrounding the Amerasian Basin. Our data will serve as a supplement to the ongoing formation of a comprehensive Triassic dataset currently in preparation, and will add insight from Jurassic samples to the Mesozoic tectonic evolution of the Arctic. For brevity, the Lower Yana River area will be referred to as the Kular area as it only includes data collected along the Yana River east of the Kular Dome.

\section{Stratigraphy of the Kular area:}

Geologic maps of northeastern Russia place the Kular Dome and Triassic sequences of the Kular area within the Kular-Nera slate belt, an approximately 900-1200 $\mathrm{km}$ long belt of Late Permian-Early Jurassic black shale turbidites which extend from the Laptev Sea in the northwest to the Sea of Okhotsk in the southeast (Konstantinovsky, 2007; Oxman, 2003; Parfenov, 1991). These sequences are thought to have been deposited as continental basin fan deposits which formed after Middle to Late Paleozoic 
rifting (Oxman, 2003; Parfenov, 1991). Unconformably above the black shales are Middle to Late Jurassic deposits of the eastern Kular area and In'Yali Debin terrane, which is located directly east of Kular-Nera belt in the south (Figure 1a), and the Polousnyi synclinorium which is directly east in the north (Figure 2). To the west, the Kular-Nera slate belt is separated from the Verkhoyansk Fold-Thrust Belt by the AdychaTaryn fault zone (Figure 2).

In the Kular area, the relevant stratigraphy for this geochronologic study includes Triassic sandstone sequences of the Kular-Nera slate belt west of the Yana fault and tightly folded Jurassic greywackes within the Polousnyi Synclinorium east of the Yana fault (Figure 3). Russian geologic maps further separate these units by age as determined by paleontology (Oleshko, 1981; Urzov et al., 1994). These ages are supported by the detrital zircon data described later in this text and were therefore adopted in our updated maps for the area. Russian maps name the units based on their ages as $\mathrm{T}_{2 \mathrm{a}}$ (Anisian), $\mathrm{T}_{21}$ (Ladinian), $\mathrm{T}_{3}$ (Late Triassic), $\mathrm{J}_{30 \mathrm{x}}\left(\right.$ Oxfordian), $\mathrm{J}_{3 \mathrm{~km}}$ (Kimmeridgian) and $\mathrm{J}_{3 \mathrm{t}}$ (Tithonian) (Oleshko, 1981). While ages of these units have been defined based on their fossil content, which are supported by detrital zircon data, all observed Triassic units were lithologically similar and all observed Jurassic units were also lithologically similar within the field area. Eight thin sections were prepared using three samples from $T_{21}$ and five from $J_{30 x}$, though several outcrops were studied in the field from all mappable units. Unfortunately, in-place sedimentary outcrop was difficult to find away from the Yana River, so most data collection and observation was along a transect of this river from Ust' Kuyga to the Kyuchus mining operation near the confluence with the Kyuchus tributary (Figure 3). Due to the similarities in lithology between all Triassic units and all Jurassic 
units, for descriptive purposes, all mapped units will be referred to as either Jurassic greywackes or Triassic sandstones.

Triassic sandstones found west of the Yana fault show a general composition of $25 \%$ lithics with subequal proportions of volcanic and sedimentary fragments, $35-40 \%$ quartz, mostly monocrystalline with few polycrystalline grains, 20-25\% feldspars and 215\% opaque iron oxide material. High volcanic content in Triassic sandstones is indicative of a source area for sedimentation from the Siberian Traps to the northwest as this area represents the only significant nearby volcanic system during the Triassic. Total biotite with minor associated muscovite may locally comprise as much as $10 \%$ of sample volume, though is in general much less common. All grains are generally medium sized and angular with poorly defined grain boundaries. Laminated black shales and red colored mudstone interbeds, generally less than one millimeter thick, are also common and often show thin, soft-sediment, fluid-supported slump folds with wavelengths of one meter or less, rip-up clasts of partially lithified mud and burrows. Three Triassic units have been mapped in our field area previously based on their paleontological ages of $\mathrm{T}_{2 \mathrm{a}}$, $\mathrm{T}_{21}$ and $\mathrm{T}_{3}$ with thickness variations from 1.5 to $2.5 \mathrm{~km}$ (Oleshko, 1981; Urzov et al., 1994). These units generally dip gently to the southeast but are sometimes vertical (Figure 4a) and also commonly display near vertical to vertical pencil cleavage related to formation of the Verkhoyansk Fold-Thrust Belt during the Late Jurassic. A ternary plot of monocrystalline quartz, feldspar and total lithic content (QmFLt) based on multiple 300-point count analyses of thin sections of Triassic samples yields a magmatic arc as the most likely provenance according to diagrams developed by Dickinson et al. (1983) (Figure 5). 

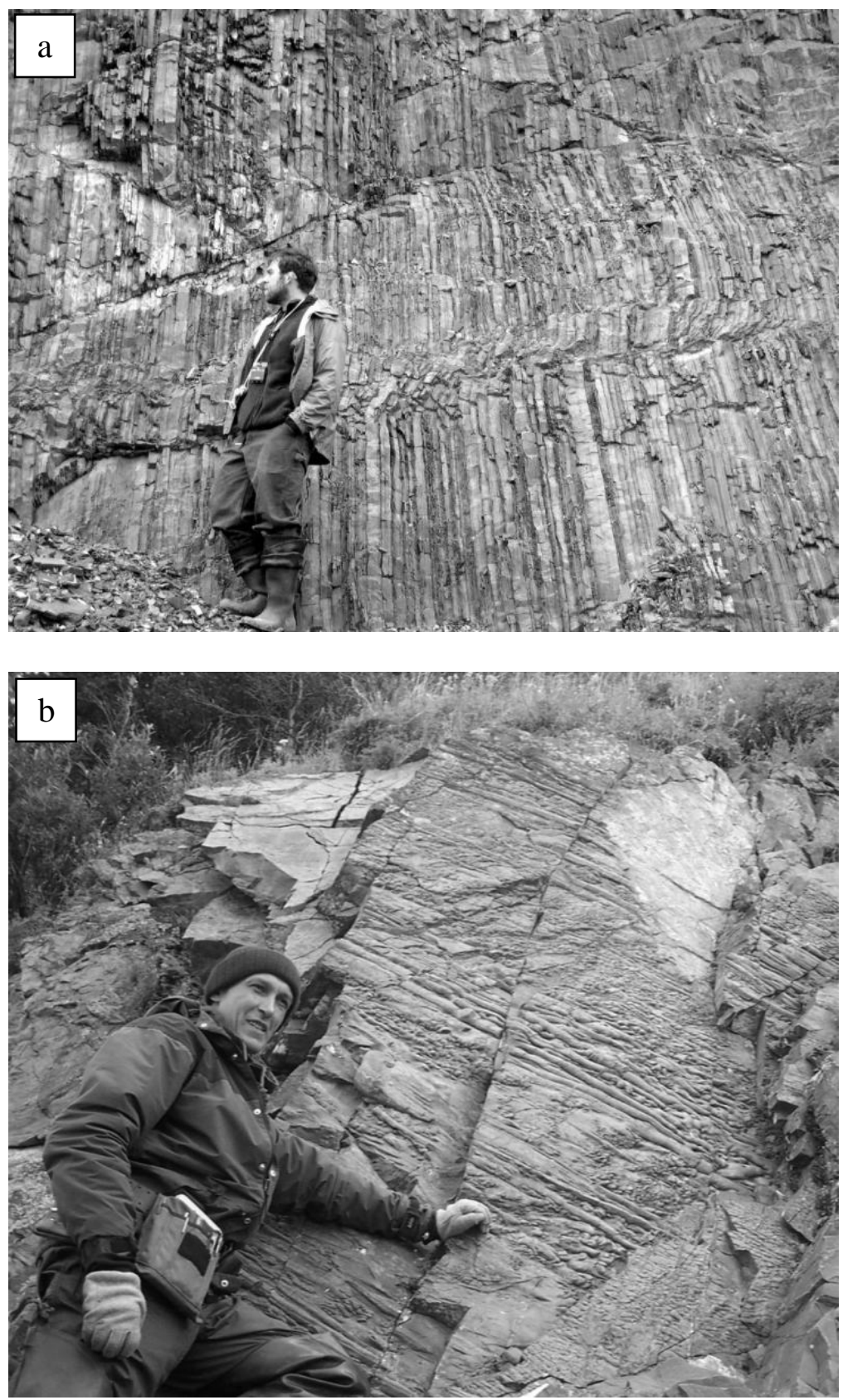

Figure 4: a) Vertical bedding in Triassic sandstones west of the Yana River. Two separate shear bands can be seen cutting the strata. View to the north. Cleavage at this location is $082 / 50 \mathrm{~S}$. b) Flute casts commonly seen along the bottom bedding surface of Jurassic strata along the Yana River. Orientations of the casts suggest an approximate paleocurrent direction of $032^{\circ}$ upon bed restoration. 


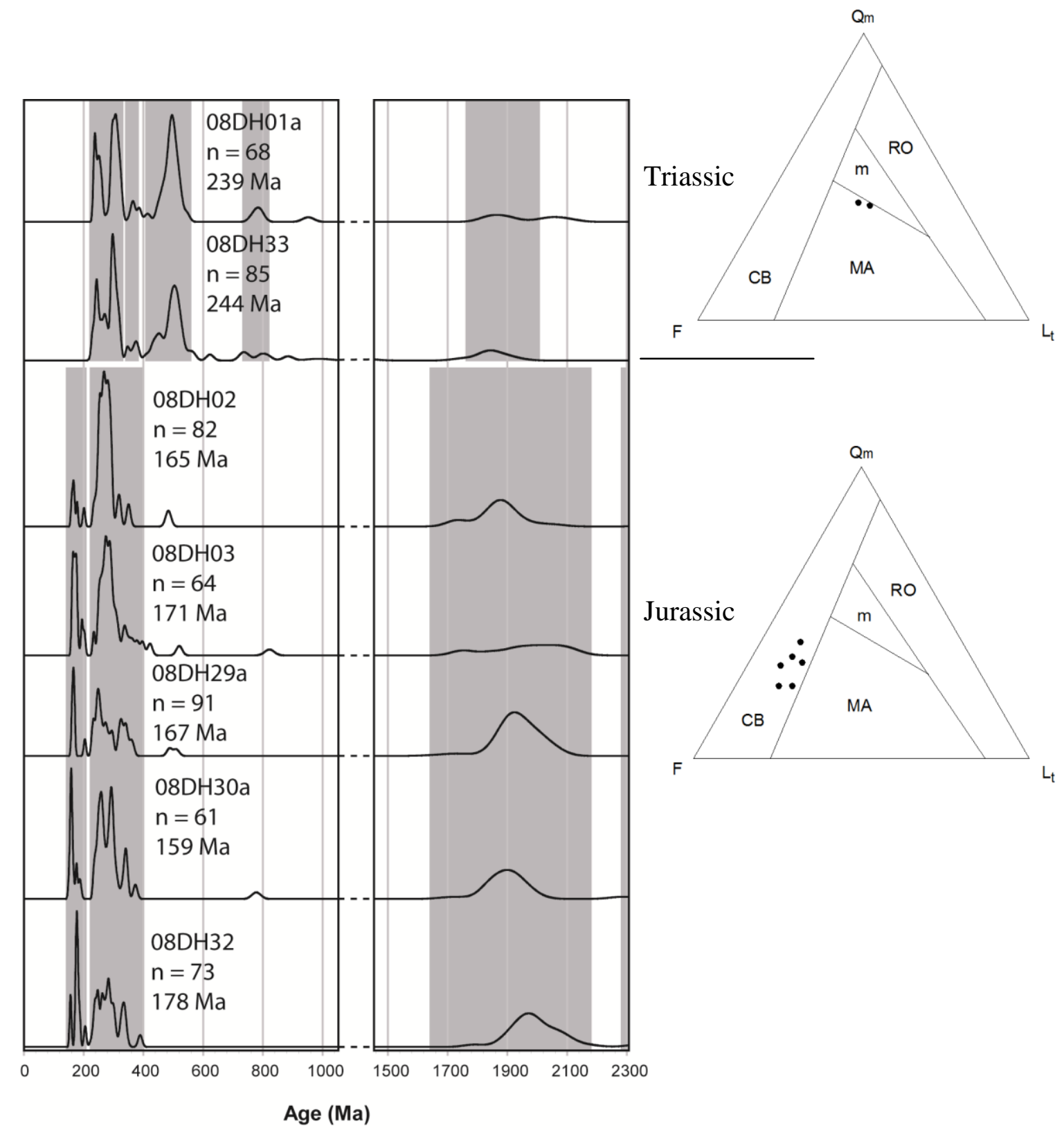

Figure 5: Probability density plots and ternary provenance diagrams for Kular data. Ages listed for each sample are inferred to be the maximum possible depositional age for each unit and are based on overlap of at least three overlapping ages within error as calculated by AGEPICK (Gehrels and Pullen, 2010). Ternary plots are based on 300-point counts

from thin section samples and plotted in fields defined by Dickinson et al. (1983). Abbreviations for the ternary diagrams are: Qm, monocrystalline quartz; F, Feldspars; $\mathrm{L}_{\mathrm{t}}$, total lithics. Provenance field abbreviations are: $\mathrm{CB}$, continental block; MA, magmatic arc; RO, recycled orogen; m, mixed. Sample locations seen in Figure 3a. 
Jurassic units east of the Yana fault are finer grained than Triassic units and have a high enough percent mud matrix to be classified as lithic greywackes. Clasts are angular and poorly sorted with grain sizes ranging from less than $30 \mu \mathrm{m}$ to $0.5 \mathrm{~mm}$. Samples are composed of 20-35\% matrix, 5-10\% lithic fragments with subequal proportions of volcanic grains and chert, $20-30 \%$ quartz, mostly monocrystalline, $30-35 \%$ feldspars, and minor amounts of white mica, biotite and opaque iron oxide. Bedding of Jurassic units was commonly massive with beds 5-6 m thick showing abundant laminated black shale and coal interbeds and occasional conglomerate lenses up to $2 \mathrm{~m}$ in diameter. Flat, rounded rip-up clasts similar to those found in Triassic units were also common along both the top and bottom of beds in Jurassic units. Reverse grading was visible in multiple locations along with prevalent slump-folding suggesting the likelihood of highenergy grain-flow deposition of turbidite sequences. Impressive flute casts several $\mathrm{cm}$ in thickness were also commonly visible on the underside of tilted layers suggestive of a paleocurrent direction of $032^{\circ}$ upon restoration of bedding (Figure $4 \mathrm{~b}$ ). Four previously mapped units are adopted for this study based on previously published paleontological ages and detrital zircon ages from $\mathrm{J}_{3 \mathrm{ox}}, \mathrm{J}_{3 \mathrm{~km}}$ and $\mathrm{J}_{3 \mathrm{t}}$ occurring within our field area. These units are exposed as open folds striking approximately east-west within northward vergent imbricated thrust packages east of the Yana fault (Figure 3). Unit thicknesses range from 0.6 to $1.3 \mathrm{~km}$ (Oleshko, 1981). A QmFLt plot based on multiple 300-point count analyses of thin sections suggests that a continental source is most likely for Jurassic samples (Dickinson et al., 1983) (Figure 5). 


\section{Geochronology:}

Geochronologic analysis of detrital zircons was performed on seven samples (two Triassic, five Jurassic) collected along the Yana River south of Ust' Kuyga (Figure 3) using LA-MC-ICPMS at the University of Arizona LaserChron Center. Samples were crushed and separated using standard gravimetric and magnetic separation techniques at West Virginia University. Following separation, grain mounts were created and polished at the LaserChron Center and were imaged using reflected light and cathodoluminesence (CL) (Appendix 3). No fewer than 100 grains per sample were randomly ablated using a $35 \mu \mathrm{m}$ diameter laser. For every five sample grains ablated, one standard grain (also added to each mount) was targeted. For this study, standard R33 was used, which yields an ID-TIMS age of 419.3 \pm 0.4 Ma (Black et al., 2004). Individual zircon grain ages were determined using ${ }^{238} \mathrm{U} /{ }^{206} \mathrm{~Pb}$ ratios for grains younger than $1.4 \mathrm{Ga}$ and ${ }^{207} \mathrm{~Pb} /{ }^{206} \mathrm{~Pb}$ ratios for grains older than $1.4 \mathrm{Ga}$ due to higher precision within these respective ranges (Gehrels and Pullen, 2010). Analyses with greater than $30 \%$ discordance or greater than $5 \%$ reverse discordance between ${ }^{238} \mathrm{U} /{ }^{206} \mathrm{~Pb}$ and ${ }^{207} \mathrm{~Pb} /{ }^{206} \mathrm{~Pb}$ ages were discarded. Of the grains ablated, $87 \%$ had a U/Th ratio less than 3 indicating a magmatic source (Hoskin and Black, 2000). All results are listed in Appendix 4. For more detailed information on the analytical process, see review of operating procedure in Gehrels and Pullen (2010) and Gehrels et al. (2006).

Results from geochronologic analysis of the Kular samples are listed in Appendix 4 and shown in probability density plots in Figure 5. Detrital zircon data from the Kular area are plotted in Figure 6 along with data compiled from previous studies in areas 


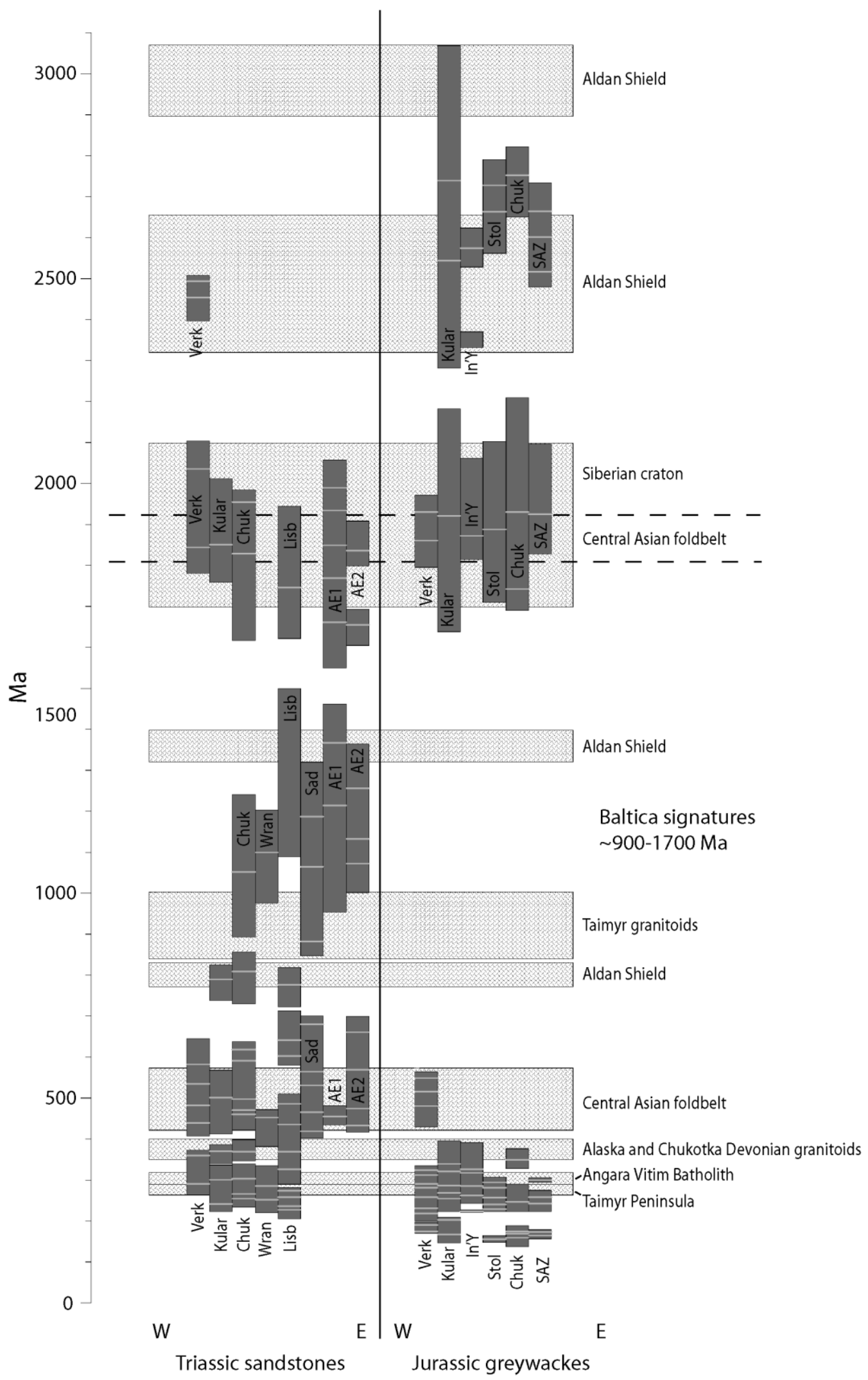


Figure 6: Age ranges of detrital zircons collected from locations surrounding the Amerasian Basin. Vertical dark gray boxes show age ranges compiled from literature and calculated with AGEPICK (Gehrels and Pullen, 2010). Data are ordered west to east from left to right with Triassic data on the far left and Jurassic data on the far right (locations shown in Figure 1). Light gray lines within age ranges show peak ages within their respective populations. Wide light gray boxes, labeled on the right, show potential granitic sources for the detrital zircons displayed. Kular and In'Yali Debin (In'Y) data from this study, and all other data, are listed in Appendix 5 and were compiled from the following sources: Triassic data: Verkhoyansk (Verk) from Prokopiev et al. (2008),

Chukotka (Chuk), Wrangel Isnald (Wran), Lisburne Peninsula (Lisb), Sadlerochit Mountains (Sad), Sverdrup Bain AE1 (AE1) and Sverdrup Basin AE2 (AE2) from Miller et al. (2006). Jurassic data: Verkhoyansk (Verk) from Prokopiev et al. (2008), Stolbovoi Island (Stol), Chukotka (Chuk) and South Anyui Zone (SAZ) from Miller et al. (2010). Magmatic source ages compiled from Miller et al. (2008), Miller et al. (2006), Scarrow et al. (2002), Prokopiev et al. (2008) and references listed in GSA data repository item 2008177. 
surrounding the Amerasian Basin (Appendix 5). Statistically likely age peaks and ranges (those which display greater than three overlapping ages within error) for each sample were chosen using the Arizona LaserChron Center AGEPICK program. AGEPICK uses calculated weighted mean ages, MSWD and uncertainty of individual grain ages to objectively determine peak ages and age ranges for detrital zircon samples (Gehrels and Pullen, 2010). For Kular data analyses any age errors from the original analysis that had a $1 \sigma$ less than $2 \%$ were adjusted up to $2 \%$ based on reproducibility of standards (McClelland, pers. comm., 2011). Provenance analyses were also performed using eight thin sections from the Kular area sedimentary units.

All samples were compared using Kolmogorov-Smirnov (K-S) tests using error from the calculated cumulative distribution function (Gehrels and Pullen, 2010; Press et al., 1992). Output values from K-S tests compare the difference between two distributions as a measure of the vertical separation of their cumulative probability plots. The output P-value from a K-S test is a measure of the probability that the measured difference between the two samples is the product of random sampling of the same parent population. P-values of zero imply that any similarity between the two samples is likely due to random chance. P-values near the maximum value of 1.0 suggest that there is low chance that the similarity is due to random chance alone and that the two populations are likely from the same "parent," or in this case magmatic source. Because of the calculated P-value among Triassic samples of 1.000 (Tables 1a and 1b), these samples have been combined for subsequent analysis into one plot diagnostic of Triassic sandstones (Figure 6). For the Jurassic samples, $08 \mathrm{DH} 02,08 \mathrm{DH} 03$ and $08 \mathrm{DH} 30$ a were determined to be similar and samples 08DH29a and 08DH32 were determined similar (Tables 1a and 1b). 
Table 1: a) Kolmogorov-Smirnov (K-S) test results for all samples collected from the Kular area. b) K-S test results for all samples from the Kular area with ages younger than $229 \mathrm{Ma}$ removed (age of the youngest Triassic zircon). Zircons younger than $229 \mathrm{Ma}$ are not considered as they represent additions based on depositional age. See Figure 3 for sample locations.

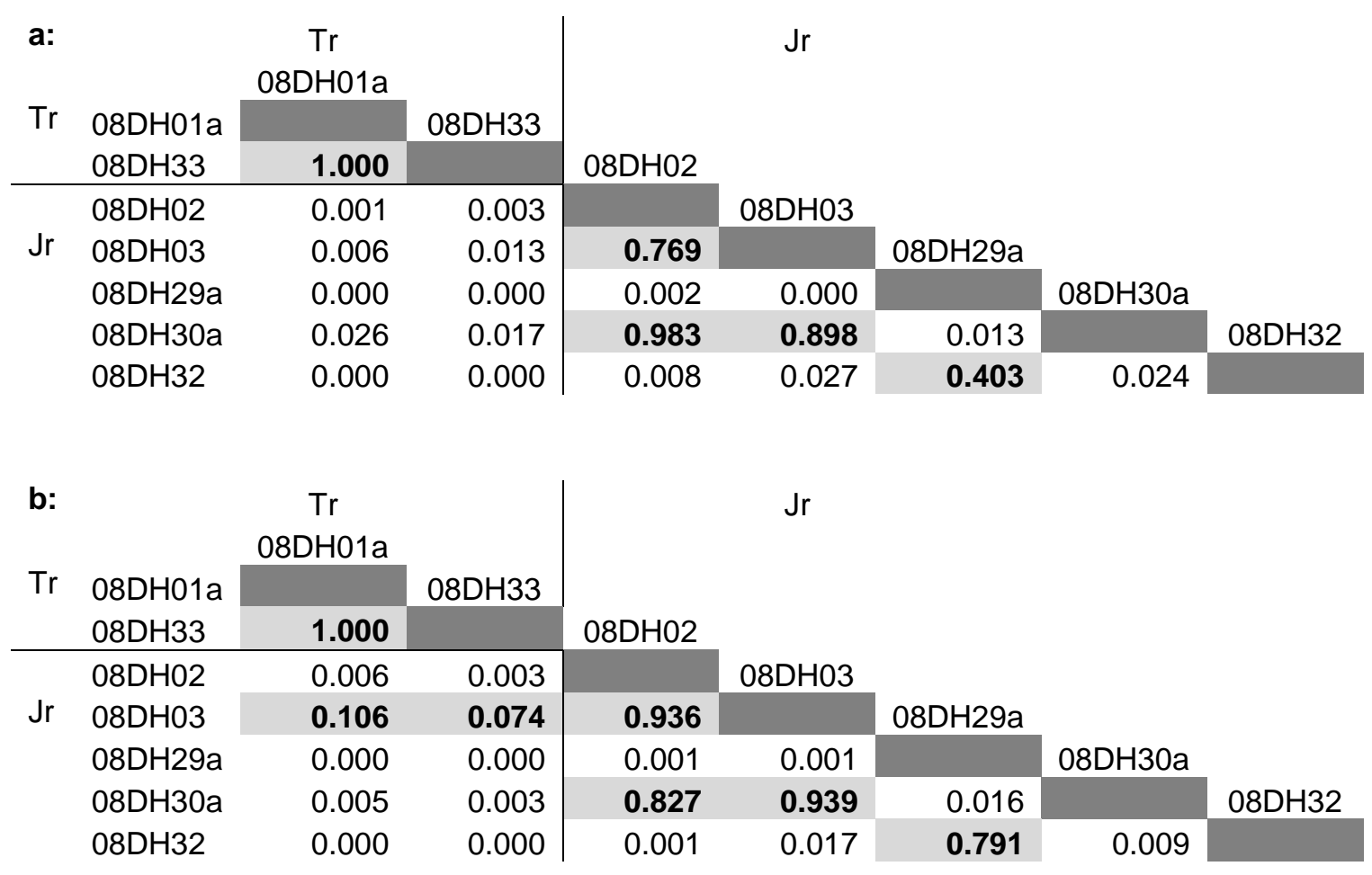


The main statistical (P-value) difference between individual Jurassic samples seems to be the contribution of grains older than 1.0 Ga (Figure 5).

Combined datasets for Kular Triassic and Jurassic detrital zircon peak ages were compared to similar datasets for regions surrounding the Amerasian Basin that potentially shared source areas during their respective periods of deposition. Combined Triassic data show peak ages at 242, 301, 370, 501, 789 and 1851 Ma with age ranges of 224-337, 341-387, 413-568, 738-825 and 1759-2011 Ma. Combined Jurassic data show peak ages at $167,203,255,269,287,321,339,1921,2544$ and 2739 Ma with age ranges of 147210, 223-396, 1639-2183 and 2281-3116 Ma. Age windows common to both Triassic and Jurassic Kular samples occur in the ranges of 223-396 Ma and 1639-2183 Ma. Jurassic samples differ from Triassic samples in that they have young zircon ages at 147$210 \mathrm{Ma}$ which are absent from Triassic samples due to depositional timing, but also display differences in older populations of zircons that can't be explained by timing of deposition alone (Figure 5). All Jurassic samples show a range of very old zircons of 2200-3100 Ma that is not evident in the Triassic samples. Jurassic samples are also missing a Late Proterozoic-Early Paleozoic (413-825 Ma) population of zircons that are abundant in the Triassic samples.

\section{Discussion:}

When possible, age ranges and peak ages using complete datasets from samples in the literature were calculated with AGEPICK and compiled into sets of representative age ranges for each location (Appendix 5, Figure 6). Most representative age ranges are 
based on multiple samples, though some were based on a single sample. Detrital zircon populations were compiled from the literature from multiple sources surrounding the Amerasian Basin and are described in the following sections, though zircons collected near Pevek, Russia and along the Dyanishka River within the Verkhoyansk Fold-Thrust Belt are most relevant to this discussion.

Zircons from Chukotka Triassic $5.5 \mathrm{~km}$ thick sequences of distal turbidites near Pevek, Russia were dated in Miller et al. (2006) and were supplemented with Jurassic zircons from nearby massive, well-cemented arkosic sandstones collected north of Bilibino to Pevek (Miller et al., 2008). Pennsylvanian-Jurassic detrital zircon samples diagnostic of Siberian cratonal passive margin sequences collected from the central Verkhoyansk Fold-Thrust Belt are described in greater detail in Prokopiev et al. (2008) and Miller et al. (2006). Units of the Verkhoyansk Fold-Thrust Belt are well exposed along the Dyanishka River just east of the Vilyui graben. Triassic samples from this area were from the Tolbon and Khedalichen Formations which were previously dated as Anisian-Ladinian and Carnian-Norian based on faunal data (Gradstein et al., 2004).

\section{Triassic detrital zircon data:}

Results from the Kular area are in agreement with interpretations by Miller and others $(2006,2008)$ that detrital zircon data from Chukotka and western Alaska place these areas more proximal to the Taimyr Peninsula and the Verkhoyansk Fold-Thrust Belt than to the Canadian Arctic during the Early Mesozoic. This observation is based on abundance of detrital zircons in Chukotka likely sourced from Taimyr granitoids and higher similarity of detrital zircon populations between Chukotka and Russian areas than 
between Chukotka and Laurentian areas (Figure 6). In Triassic samples, Chukotka and western Alaska display a different range of zircon ages than the Verkhoyansk Range while Triassic data from Kular shows similarities to both Chukotka and Verkhoyansk (Table 2). Specifically, both Kular and Chukotka Triassic samples have zircons in age ranges of 225-260 Ma and 730-850 Ma that are absent from Verkhoyansk Triassic samples (Figure 6). However, both Kular and the Verkhoyansk Range lack zircons in age ranges of 800-1000 Ma and 1000-1315 Ma that are present in Triassic Chukotka samples. The presence of Permo-Triassic zircons in Kular and Chukotka is significant since granitic rocks of this age are uncommon in Russia. Potential source areas for zircons of this age are the southern Taimyr Mountain range where doleritic sills aged 220-230 Ma and $250 \mathrm{Ma}$ A-type granites are common (Walderhaug et al., 2005) and the widespread Siberian Traps south of Taimyr which contain mafic volcanics with mean ages of approximately $250 \mathrm{Ma}$ (Dalrymple et al., 1995; Reichow et al., 2002; Renne and Basu, 1991). High volcanic fragment content seen in Kular area Triassic sandstone thin sections is further evidence of a Siberian Trap magmatic source for these samples. Zircons of these ages were likely carried eastward along a northerly river system which supplied clastic material to the northeastern part of the platform, the Kular area and to the Polousnyi synclinorium, but not to the more southern Verkhoyansk region which was fed mostly by the paleo-Lena River (Prokopiev et al., 2008). These ages are also absent from Sadlerochit Mountains and Sverdrup Basin data (Miller et al., 2006) despite other similarities to Triassic data from the AAC microplate. Another difference in Triassic detrital zircon data is the lack of 730-850 Ma zircons in the Verkhoyansk Range, but their presence in both Kular and Chukotka. In Miller et al. (2006), these zircons are suggested 
Table 2: Presence or absence of dated zircons within specific age ranges from locations compared in this study for both Jurassic and Triassic datasets. Refer to Figure 1 for locations. See text and Figure 6 for literary references. SAZ refers to the South Anyui Zone.

\begin{tabular}{|l|c|c|c|c|}
\hline TRIASSIC & $225-260 \mathrm{Ma}$ & $730-850$ & $850-1000 \mathrm{Ma}$ & $1000-1315 \mathrm{Ma}$ \\
\hline 1: Verkhoyansk & No & No & No & No \\
\hline 2: Kular & Yes & Yes & No & No \\
\hline 6: Chukotka & Yes & Yes & Yes & Yes \\
\hline
\end{tabular}

\begin{tabular}{|l|c|c|c|c|}
\hline JURASSIC & $225-260 \mathrm{Ma}$ & $730-850$ & $850-1000 \mathrm{Ma}$ & $1000-1315 \mathrm{Ma}$ \\
1: Verkhoyansk & Yes & No & No & No \\
\hline 2: Kular & Yes & No & No & No \\
\hline 6: Chukotka & Yes & No & No & No \\
\hline 5: SAZ & Yes & No & No & No \\
\hline 4: Stolbovoi & Yes & No & No & No \\
\hline 3: In'Yali Debin & Yes & No & No & No \\
\hline
\end{tabular}


to have also been from the Taimyr region. Another potential source for zircons of this age is the Baikalia region (Transbaikalia and Prebaikalia) to the south which is known to have granitic intrusions ranging in age from 772-831 Ma, though the lack of zircons of this age in the Verkhoyansk Range suggests that the Taimyr region is a more likely source for Chukotka and Kular. Zircons in the range of 850-1000 Ma and 1000-1315 Ma are prevalent in Triassic Chukotka samples, but are conspicuously absent from both Kular and the Verkhoyansk Range. Interestingly, zircons of this age were also seen in Triassic samples from Wrangel Island, western Alaska (Lisburne Hills) and eastern Alaska (Sadlerochit Mountains and the Sverdrup Basin) (Figure 6). Though all three areas show zircons in the range of 800-1800 Ma, differences in younger populations of zircons (less than $400 \mathrm{Ma}$ ) suggest that Chukotka and western Alaska may have shared sedimentation sources that were different from those feeding eastern Alaska during the Triassic. The presence of zircons from 800-1800 Ma in Triassic samples from Chukotka, Wrangel Island and western Alaska suggests a connection to 900-1700 Ma igneous intrusions found in Baltica that is further supported by deposition in these areas across upper Paleozoic platformal sediments underlain by Neoproterozoic rocks of the Timanides also associated with Baltica (Bingen et al., 2008 and references within; Miller et al., 2010). Triassic samples from Kular, Chukotka and Verkhoyansk all contain zircons in the range of 1600-2100 Ma which match basement ages from the Siberian craton. Similarities between all three sites (Chukotka, Kular and Verkhoyansk) suggest that they shared some sedimentation sources during the Triassic, though Chukotka and to a lesser extent, the Kular region, seem to have been fed by more varied sources as they contain zircons from age ranges not seen in the Verkhoyansk Range. These 
interpretations, including the similarity of detrital zircon ages seen in Chukotka and igneous ages from the Taimyr Peninsula, put Chukotka closer to the Russian shoreline prior to development of the Amerasian Basin than to the Canadian Arctic as is suggested by the rotational model for development of the Canada Basin.

\section{Jurassic detrital zircon data:}

Deposition of the Kular Jurassic units must have occurred following initiation of collision between the incoming Kolyma-Omolon superterrane and the Siberian platform. A stratigraphic unconformity between Early and Late Jurassic units (Parfenov, 1991) likely represents this change in structural setting, which is supported by differences between Triassic and Late Jurassic Kular detrital data. A potential source for the $162 \mathrm{Ma}$ peak seen in Jurassic samples is the Uyandina-Yasachnaya volcanic arc which developed in the Late Jurassic on the margin of the Kolyma-Omolon superterrane. The Kular area was situated closer to the colliding terrane than was the Dyanishka River (Verkhoyansk in Figure 1a), which remained more insulated from the effects of collision with the Kolyma-Omolon superterrane in the Jurassic. Because of this, Jurassic zircon signatures in the Kular region are potentially related to incoming arc signatures of the KolymaOmolon superterrane with zircons having likely been transported to the Lower Yana region as air fall deposits. Mixing in trench sediments at the front of the arc is unlikely because of a lack of stratigraphic evidence for mixing, consistency of zircon grain ages older than 229 Ma between Triassic and Jurassic strata and lack of volcanic material in Jurassic strata. A study of detrital zircons collected from the Eocene-aged Geste Formation of the Central Puna Plateau within the Andean orogenic belt has shown that air 
fall zircons from distant eruptive centers may be found in ash-free strata (DeCelles et al., 2007) and provides a potential analogue for deposition of air fall zircons within ash and volcanic fragment-free strata deposited near the Uyandina-Yasachnaya volcanic arc ahead of the Kolyma-Omolon superterrane. Jurassic aged samples collected from Jurassic units in the In'Yali Debin Synclinorium located directly east of the central Kular-Nera slate belt (Figure 1a), show a nearly identical zircon age distribution to the Kular area samples despite being located some $650 \mathrm{~km}$ to the southeast (Figure 6), suggesting the likelihood of a similar arc source with transport of zircons as air fall material. Western zircon source areas for older detrital grains are compatible with the interpretation that the Kular-Nera belt was a series of eastward deposited continentalslope fans (Konstantinovsky, 2007; Oxman, 2003), which likely also applies to deposition within the In'Yali Debin terrane. In'Yali Debin sediments are described as synorogenic and are inferred to have been deposited synchronously with collision of the Kolyma-Omolon superterrane from the east (Oxman, 2003), which could be a potential source for the Late Jurassic aged zircons found both in the In'Yali Debin and Kular as previously described. Differences in the detrital signal strength between the In'Yali Debin and Kular areas may be related to their large geographical separation. Both the In'Yali Debin terrane and Kular lack a 450-550 Ma range of zircons seen in the Verkhoyansk Range which is attributed to a source in the central Asian fold belt, supporting a disconnect between parts of the paleo-Lena River and the Kular Nera terrane caused by deformation associated with the impending Kolyma-Omolon superterrane collision. 


\section{Triassic to Jurassic transition:}

The differences in Triassic and Jurassic Kular detrital signatures suggest a large disturbance in the sedimentation system for northern Russia between 167 Ma and 242 Ma. While Triassic and Jurassic detrital data are relatively consistent in the Dyanishka River area of the Verkhoyansk Range with the only major changes being the expected addition of younger signatures to the Jurassic samples and the loss of zircons older than $2300 \mathrm{Ma}$, the Kular and Chukotka Triassic detrital signatures are very different from their Jurassic counterparts despite close proximity of sample collection (Figure 6). A K-S test of only Kular ages older than $229 \mathrm{Ma}$ (the age of the youngest Triassic zircon dated) from both Triassic and Jurassic samples supports two different populations based on calculated P-values (Table 1b). P-values from 0.713-0.939 were calculated between all pairs of Jurassic Kular samples and values of 1.000 were found between the two Triassic Kular samples while the highest P-value between any Triassic and Jurassic Kular sample pair was 0.026 (Table 1a). Upon removal of all zircons with ages less than $229 \mathrm{Ma}$ (the Jurassic input pulse), the highest P-value when comparing Jurassic Kular samples to Triassic Kular samples was 0.106 and statistical similarities were only seen between Triassic Kular samples and one Jurassic Kular sample (08DH03) (Table 1b). If these units had received sediment from similar sources during both the Triassic and Jurassic, as in the continual transport of sediment along the paleo-Lena River in the Dyanishka area (Prokopiev et al., 2008), Triassic aged signatures from Jurassic Kular samples would be similar to those seen in the Triassic Kular samples. However, Triassic samples collected from the Kular area include a dominant 400-500 Ma signature and a smaller 730-850 signature that are completely absent from Jurassic samples collected from the same area 
(Figure 5 and 6). These age ranges are most likely representative of source regions in the Central Asian foldbelt and Aldan Shield which were cut-off from deposition in the Kular area and In'Yali Debin (which also lacks Central Asian foldbelt and Aldan Shield zircon signatures in Jurassic samples) by the Late Jurassic (Figure 1a) due to compressional deformation to the west in the Verkhoyansk Fold-Thrust Belt, blocking eastward flow input from the paleo-Lena River.

Though Taimyr and Baltica zircon ages from 800-1800 Ma are common in Triassic Chukotka and western Alaska samples, suggesting close proximity between these areas in the Triassic, by the Jurassic none of the samples from similar geographic locations (South Anyui suture, Chukotka, Verkhoyansk, Kular, Stolbovoi Island, and In'Yali Debin) display zircons in this range. This suggests that by the Jurassic, these areas had likely become more closely linked geographically than they were in the Triassic and that they were also separated from the source of the 800-1800 Ma zircons by this time. Chukotka, Verkhoyansk and the Kular areas are, however, similar in terms of other age distributions and prominent peak ages in Triassic samples (Figure 6) indicating some similarity in sedimentation systems during the Triassic and further evidence that Chukotka was not separated from northern Russia during the Triassic as is suggested by the rotational model. Incorporating Jurassic detrital zircon data into emplacement models for Chukotka suggests that by the Tithonian, Chukotka was situated north of the Kular area, which is in agreement with Miller and others' (2008) conclusion that the South Anyui suture must have begun to form by the Tithonian, closing the Anyui Ocean. The youngest age in Kular Jurassic sediments is approximately 160 Ma and Kular Jurassic data matches Chukotka Jurassic data precluding separation of the two areas by an oceanic 
basin by the Late Jurassic despite likely separation in the Triassic. Further evidence supporting closure of the South Anyui Ocean by the Tithonian is the presence of zircons with likely source areas from south of the South Anyui suture $(1.7-2.1 \mathrm{Ga})$ found in Late Jurassic samples from Chukotka (Miller et al., 2008). Metamorphic mineral assemblages from ophiolitic complexes in the Chersky Range also indicate a possible collisional period between Chukotka and northern Russia as early as 170-174 Ma (Oxman, 2003; Parfenov, 1991).

Kular and Chukotka appear to have similar detrital zircon signatures in the Jurassic (Table 2) despite differences in the Triassic. Neither have zircons older than $2200 \mathrm{Ma}$ in Triassic samples, then both have zircons ranging in age of 1600-2800 Ma with wide age ranges older than $2200 \mathrm{Ma}$ and a matching age peak at $1920 \mathrm{Ma}$ in Jurassic samples, matching Aldan Shield ages seen in Triassic Verkhoyansk data. This means that the change in sedimentation source that added older zircon populations by the Late Jurassic (possibly Aldan Shield or equivalent basement) affected both Kular and Chukotka suggesting connection to a sedimentation system that had previously only reached the Verkhoyansk area. The absence of this 2200-3000 Ma signature in the Verkhoyansk Jurassic samples suggests both a change in the paleo-Lena River deposition as this age range was present in Triassic samples and also that the paleo-Lena was not responsible for transport of Aldan Shield zircons to Chukotka and the Kular area. It could be that as collision with the Kolyma-Omolon superterrane began, it formed a northwest-southeast oriented watershed where sediments from the Aldan Shield could have travelled up the northeast edge of the continent, bypassing the paleo-Lena River. So in the Triassic, this extra sedimentation source was likely just moving eastward into the 
basin and most sediments to Chukotka and Kular were coming through the Verkhoyansk area along the paleo-Lena River (Prokopiev et al., 2008). Following Jurassic accretion, this new pathway from the Aldan Shield could have bypassed the paleo-Lena River to the east and supplied an additional older population to both Chukotka and Kular, though both would still receive paleo-Lena sediments.

\section{Tectonic implications of detrital zircon data:}

Extensive work performed around the Canada Basin supports a Late JurassicEarly Cretaceous opening for the basin which is at odds with detrital data presented here if the Alaskan and Chukotkan portions of the AAC are treated as a coherent block during opening of the Canada Basin. Resolutions to this problem involve either rifting of the AAC away from the Canadian Arctic Islands earlier, during the Middle to Late Jurassic as one coherent block similar to the rotational model (Figure 1b), or separation of the Alaskan and Chukotkan portions of the AAC which would allow Chukotka to be near the Kular area during opening of the Canada Basin. Due to the strong support for Late Jurassic-Early Cretaceous opening of the Canada Basin involving rifting of the North Slope of Alaska away from the Canadian Arctic Islands [evidence summarized in preface of this document, Lawver and Scotese (1990) and Lawver et al. (2002)] we feel that the tectonic movement pathway for Chukotka was independent of the Alaskan portion of the AAC in the Mesozoic.

Detrital zircon data from these areas also suggest that the eastern margin of the Siberian craton and the location of the downgoing slab that resulted in suturing of incoming terrane material to the Verkhoyansk passive margin would have been further 
east of its presently interpreted location along the Adycha-Taryn fault west of the KularNera belt. The similarities seen between the Kular and Verkhoyansk data suggest that they were sedimentologically linked during the Triassic and into the Jurassic and not separated by a regional suture. Other interpretations placing a large thrust fault (the Yana fault) as a suture of separate terranes just east of the Kular Dome are likely also in error since the chronologic relationship of units across the fault support normal offset and the detrital data from this study link the Verkhoyansk Range to the Jurassic strata east of the Yana fault. Field investigation further supports this conclusion since evidence of extensional deformation is abundant in the form of stretched andalusites, top-down shear away from the pluton (mostly seen in mantled porphyroblasts of oriented thin sections) and gently southeast dipping $\mathrm{S}_{2}$ foliations south of the Kular pluton (Harris et al., 2011, Chapter I, this volume). Similar detrital zircon signatures between Triassic samples from the Kular area and the In'Yali Debin synclinorium (detrital zircon data from Triassic samples of the In'Yali Debin terrane excluded from this document at the request of Andrei Prokopiev) further dispute the existence of a large suture between the Kular-Nera slate belt and the eastern Polousnyi-Debin terrane.

New model for development of the Amerasian Basin:

Based on the available detrital zircon data for the Arctic an alternative model for the formation of the Amerasian Basin is proposed (Figure 7). It should be noted that the reconstruction presented here is based mostly on detrital zircon data presented in this paper and the detailed stratigraphic, paleontological, paleomagnetic and geophysical studies necessary for verification are beyond the scope of this paper. 

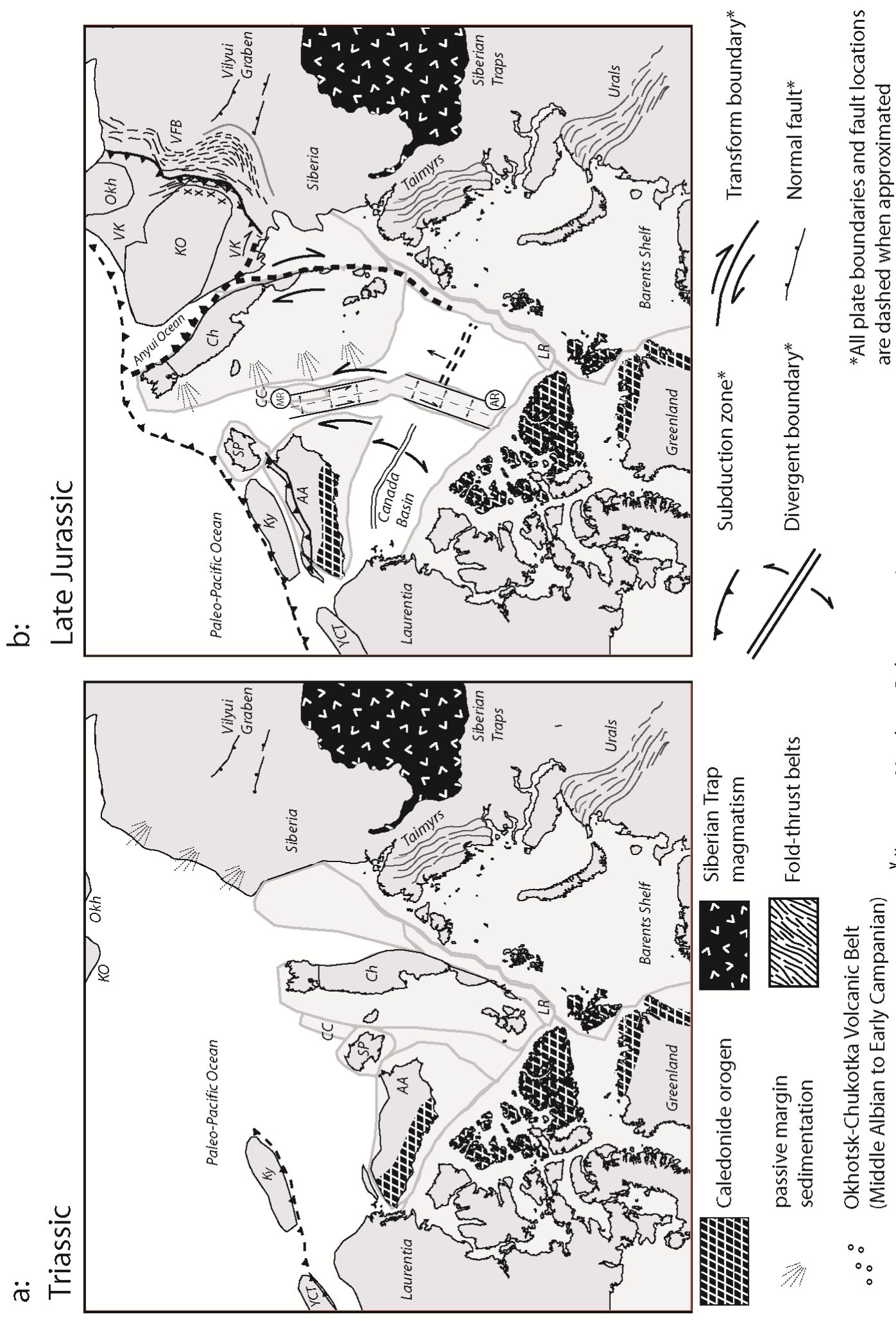

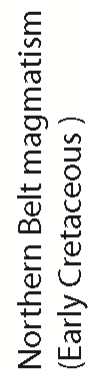

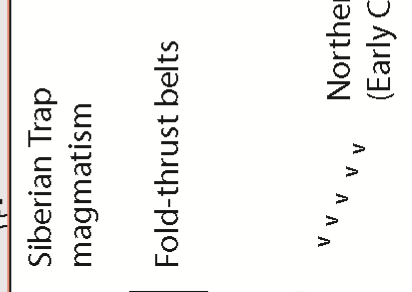

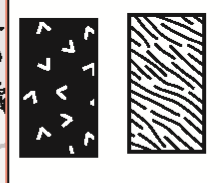

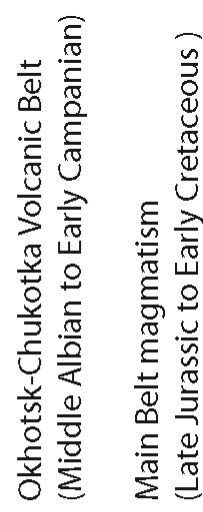

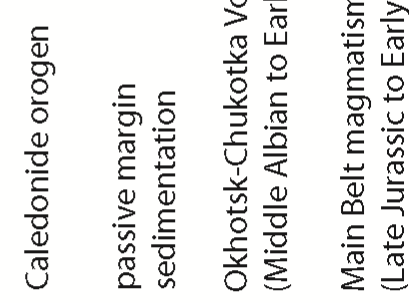

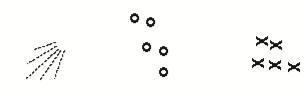



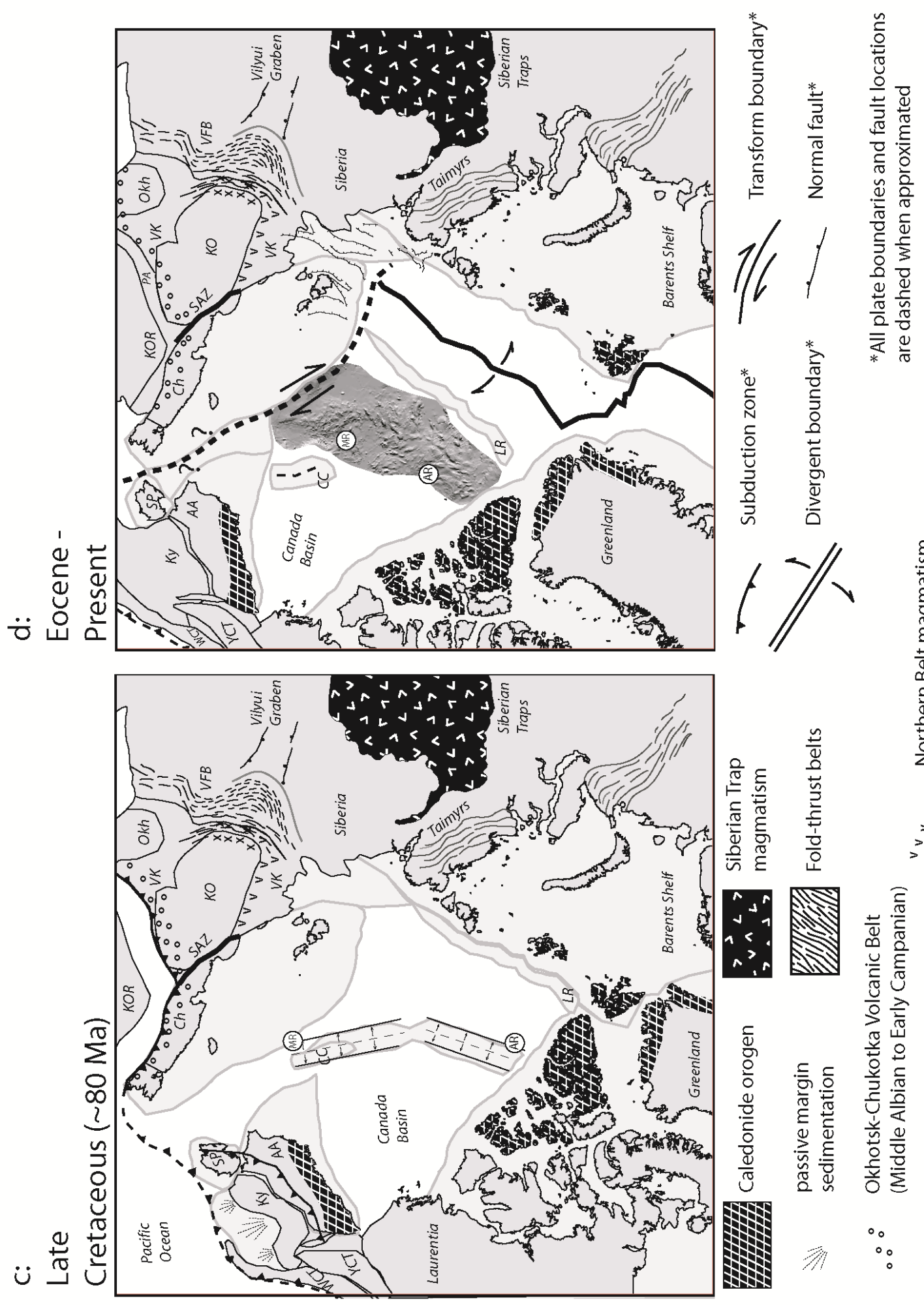

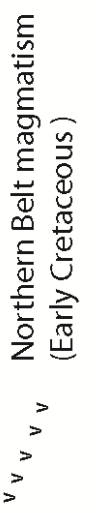

(1)

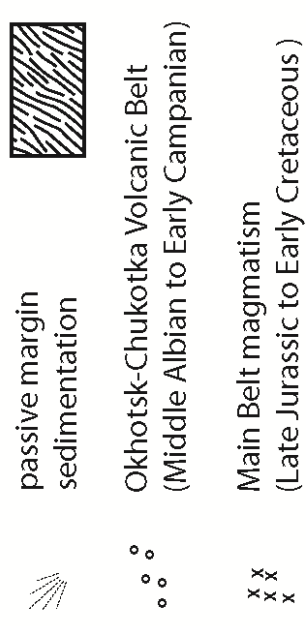

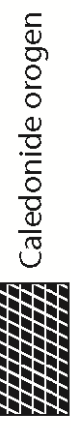


Figure 7: Schematic Mesozoic to present plate reconstruction for the motion of various continental fragments of the Arctic, see text for discussion. Alaska terrane accretion history from Plakfer and Berg (1994), evolution of Alaska chapter 33, South Anyui Suture info from Sokolov et al. (2009), Russian terrane accretionary history from Parfenov et al. (2009) and bathymetric images and approximate locations of the Alpha Ridge and Mendeleev Ridge are from Jakobsson et al. (2008) and Dove et al. (2010).

Magmatic arc ages are from Akinin and Miller (2011) and Layer et al. (2001). Abbreviations are: AA, Arctic Alaska; AR, Alpha Ridge; CC, Chukchi Cap; Ch, Chukotka; Kb, Koyukuk Basin; KO, Kolyma-Omolon superterrane; KOR, KoryakKamchatka tectonic collage; Ky, Koyukuk arc; LR, Lomonosov Ridge; MR, Mendeleev Ridge; Okh, Okhotsk terrane; PA, Penzhina-Anadyr tectonic collage; SAZ, South Anyui Suture zone; SP, Seward Peninsula; VFB, Verkhoyansk Fold-Thrust Belt; VK, Verkhoyansk tectonic collage; WCT, Wrangellia composite terrane; YCT, Yukon composite terrane. 
In the Triassic (Figure 7a), the AAC formed a continuous landmass with the North Slope of Alaska situated against the Canadian Arctic Islands and Chukotka near Taimyr. During this time, the Kolyma-Omolon and Okhotsk terranes were still separated from the North Asian craton by ocean while a passive margin sequence developed along the eastern coast of paleo-Russia. In this model, the Siberian Shelf is noticeably less extensive in the Triassic as compared to modern conditions as it has yet to experience Jurassic and Cretaceous sedimentation and extension responsible for its eventual extent (Vinogradov et al., 2006). Pre-extended continental crust which will evolve into the Alpha and Mendeleev Ridges in the Late Jurassic was also situated within the AAC at this time. During the Early to Late Jurassic, Chukotka experienced dextral strike-slip motion across northern Russia, bringing Chukotka to a location more proximal to the Kular area and gradually closing the Anyui Ocean as a transpressional basin to form the South Anyui suture (Figure 7b). By the Late Jurassic, collision between the KolymaOmolon superterrane, Okhotsk terrane and the passive margin sequences of eastern Russia formed the Verkhoyansk Fold-Thrust Belt. The Canada Basin had also begun formation via rifting between the North Slope of Alaska and the Canadian Arctic Islands by this time. Extension between Chukotka and the North Slope of Alaska during rotation is invoked in this model to explain formation of the Alpha and Mendeleev ridges via rifting of continental crust with a component of strike-slip deformation. By the Late Cretaceous (Figure 7c), Chukotka had completely closed the Anyui Ocean via transpression to form the South Anyui suture zone. Final emplacement of Chukotka must have occurred by $106 \mathrm{Ma}$ as earliest volcanic deposits of the Okhotsk-Chukotka Volcanic Belt of this age overlap the suture (Figure 7c) (Akinin and Miller, 2011). 
Spreading in the Canada Basin also caused collision in Alaska which had recently formed by a complex series of accretion events. From the Eocene to present (Figure 7d), the Gakkel Ridge opened as the northern trace of the Mid-Atlantic Ridge, separating the Lomonosov Ridge from its initial location along the Barents Shelf. A right-lateral transform fault along the northern boundary of the Siberian Shelf is invoked to explain motion associated with opening of the Eurasian Basin, though the location of this fault near Alaska is uncertain. Evidence from the eastern Seward Peninsula as well as the Hope and Norton Basins are supportive of north-south directed, right-lateral deformation in the Cenozoic (Dumitru et al., 1995).

In the proposed model, the AAC is broken into two separate pieces, the northern Alaska and Seward Peninsula portion and the Chukotka portion, which move independently of each other. Previous work along the North Slope of Alaska and the Canadian Arctic Islands provides a compelling case for rotational opening of the Canada Basin during the Late Jurassic-Early Cretaceous about a pole south of the Mackenzie Delta that is supported in this reconstruction (Carey, 1955; Carey, 1958; Lawver et al., 2002; Lawver and Scotese, 1990). The suggestion that the Chukotka portion of the AAC may have moved independently of the northern Alaska portion is not new, though the model presented here is at odds with the previously suggested movement pathway of the “double windshield wiper" model in which Chukotka experienced clockwise rotation away from its original location along the Barents Shelf. Our reconstruction places Chukotka and the New Siberian Islands along the Lomonosov Ridge as it was restored along the Barents Shelf. We also have a sliver of continental crust between the North 
Slope of Alaska and Chukotka in order to maintain detrital deposition pathways and basement consistency throughout the AAC.

The reconstruction proposed here is supported by the following observations:

1: The detrital data presented in this paper suggests that Chukotka was likely separated from the Siberian craton and Kular area during the Early Triassic, but by the Tithonian had become more closely linked with the Kular and Verkhoyansk areas.

2: Trap magmatism prevalent in the New Siberian Islands and Chukotka places these landmasses near the Siberian margin by approximately $250 \mathrm{Ma}$ and supports close proximity between these locations (Kuzmichev and Pease, 2007).

3: Dextral north-south oriented strike-slip faults associated with Early Cretaceous northeast-directed collisional features present in the western Anjou Islands of the New Siberian Islands (Kos'ko and Korago, 2009; Kuzmichev, 2009) support eastern translation of Chukotka along the Siberian continent in the Neocomian. Further evidence of this translation includes dextral strike-slip deformation of collisional features in the South Anyui suture zone and clockwise rotation of both the Vurguveem ophiolitic subterrane and rocks of Lower Cretaceous age (Sokolov et al., 2009; Sokolov et al., 2002).

4: Extensive evidence summarized in Amato et al. (2009) and Miller et al. (2006) supports the pre-Amerasian Basin location of components of the AAC in the Early Triassic. This evidence includes $\mathrm{Nd}$ and magmatic similarities between components of the AAC, the Caledonides and Taimyr, consistent 0.95-1.2 Ga plutonism intruding basement rocks in Novaya Zemlya, Franz Joseph Land and Severnaya Zemlya (Lorenz et al., 2011), faunal data and detrital zircon 
depositional data. Evidence supporting the initial connection between components of the AAC in the Paleozoic include a distinctive carbonate basement cover sequence, prevalent 1.1-2.0 Ga detrital zircons throughout the AAC related to a consistent basement sequence, faunal data and widespread coeval Late Proterozoic magmatism in parts of the AAC, Scotland, the Taimyrs and the Scandinavian Caledonides (Amato et al., 2009; Dumoulin et al., 2002; Miller et al., 2006).

5: Closure of the Anyui Ocean in the Late Jurassic as a transpressional basin is in agreement with studies by Sokolov and others $(2009 ; 2002)$ in which evidence of dextral strike-slip deformation in the late stages of collision provides an explanation for the absence of a prominent mountain range along the South Anyui suture while providing a means for ophiolite obduction. Nearby collisional areas such as the Verkhoyansk Fold-Thrust Belt, Chersky Range and Brooks Range of Alaska were all formed by basin closure near Siberia in the Late Mesozoic and all resulted in extensive high-relief mountain ranges. No such mountains exist along the entirety of the South Anyui suture, and so the collisional style was likely of a different nature than the areas previously described. For the South Anyui suture, a hybrid strike-slip/collisional closure of the basin involving oblique subduction is proposed (Figures $7 \mathrm{~b}$ and $7 \mathrm{c}$ ).

6: Numerous seismic and piston coring studies conducted across the Alpha and Mendeleev Ridges have provided robust datasets useful for determining the composition and formational history for these areas (Forsyth et al., 1986; Grantz et al., 2001; Jackson et al., 1986; Jokat, 2003; Langinen et al., 2009; Lebedeva- 
Ivanova et al., 2006) and their implications for the origin of the Alpha and Mendeleev Ridges are thoroughly reviewed in Dove et al. (2010). Geophysical, gravity, faunal and dredging datasets all support an overthickened oceanic crustal structure with formation as an oceanic plateau prior to the Cenozoic similar to the Manihiki or Ontong-Java plateaus (Dove et al., 2010; Forsyth et al., 1986; Jackson et al., 1986; Jokat, 2003). Alternative interpretations support formation of these ridges as rifted continental margins, citing crustal thicknesses abnormally high for oceanic crust, velocity structures suggestive of underplated continental crust and presence of continental material as evidenced by bottom sampling via piston coring and dredging (Lebedeva-Ivanova et al., 2006). Based on the available data, we feel as though compelling arguments are made for at least partial continental crust composition for the Alpha and Mendeleev Ridges and propose that these structures were continental in origin, though they now bear more resemblance to oceanic plateaus due to transtensional deformation and associated rift-related activity. Dove et al. (2010) provide evidence that the Alpha Ridge and Mendeleev Ridge were formed contiguously during the same tectonic event, which is in agreement with the tectonic model proposed here. The datasets described earlier also show evidence of extensional deformation in the form of grabens, half-grabens and normal faults as well as strike-slip faulting, also in agreement with our newly proposed model (Jackson et al., 1986, Dove et al., 2010). 


\section{Conclusions:}

In recent years, detrital zircon studies focusing on Wrangel Island and the Chukotka Peninsula have suggested that the Chukotka part of the AAC may have been disconnected from the Alaskan portion and instead have been closer to Siberia during the Neocomian than previously considered. Detrital zircon geochronology performed in the Kular area of northern Russia provides an important sedimentological link between previous studies performed in the Verkhoyansk Fold-Thrust Belt, Chukotka, and In'Yali Debin regions. Comparison of these results with those collected from landmasses surrounding the modern Amerasian Basin provides support for the separation of the Chukotka part of the AAC from the Alaskan portion and involving dextral strike-slip movement of Chukotka along the northern Siberian Shelf during the Late Jurassic-Early Cretaceous. Detrital zircon data from these landmasses in tandem with a growing body of data from a variety of geological disciplines has led to a newly proposed tectonic model for formation of the Amerasian Basin. The model provided in this paper is a hybrid of the rotational model and the double-windshield-wiper model that incorporates the respective strengths of both while also addressing some of the problems encountered in each. While this model is highly schematic in nature and certainly involves problems

of its own, it is another option to be considered for explanation of the tectonic history of the Amerasian Basin. Detrital zircon age peaks seen in Kular samples also match well with global records for prominent zircon age peaks, contributing to the global supercontinent cycle record of zircon preservation (Condie and Aster, 2009). 


\section{References:}

Akinin, V.V., and Miller, E.L., 2011, Evolution of calc-alkaline magmas of the OkhotskChukotka volcanic belt: Petrology, v. 19, p. 237-277.

Amato, J.M., Toro, J., Miller, E.L., Gehrels, G.E., Farmer, G.L., Gottlieb, E.S., and Till, A.B., 2009, Late Proterozoic-Paleozoic evolution of the Arctic Alaska-Chukotka terrane based on $\mathrm{U}-\mathrm{Pb}$ igneous and detrital zircon ages: Implications for Neoproterozoic paleogeographic reconstructions: GSA Bulletin, v. 121, p. 12191235.

Andersen, T., 2005, Detrital zircons as tracers of sedimentary provenance: limiting conditions from statistics and numerical simulation: Chemical Geology, v. 216, p. 249-270.

Bingen, B., Davis, W.J., Hamilton, M.A., Engvik, A.K., Stein, H.J., Skår, Ø., and Nordgulen, Ø., 2008, Geochronology of high-grade metamorphism in the Sveconorwegian belt, S. Norway: U-Pb, Th- $\mathrm{Pb}$ and Re-Os data: Norwegian Journal of Geology, v. 88, p. 13-42.

Black, L.P., Kamo, S.L., Allen, C.M., Davis, D.W., Aleinikoff, J.N., Valley, J.W., Mundil, R., Campbell, I.H., Korsch, R.J., Williams, I.S., and Foudoulis, C., 2004, Improved $206 \mathrm{~Pb} / 238 \mathrm{U}$ microprobe geochronology by the monitoring of a traceelement-related matrix effect; SHRIMP, ID-TIMS, ELA-ICP-MS and oxygen isotope documentation for a series of zircon standards: Chemical Geology, v. 205, p. $115-140$.

Carey, S.W., 1955, The orocline concept in geotectonics: Royal Society of Tasmania Proceedings, v. 89, p. 255-288.

Carey, S.W., 1958, The tectonic approach to continental drift, in Proceedings, Continental drift; A symposium: Hobart, University of Tasmania, 177-355.

Carrapa, B., 2010, Resolving tectonic problems by dating detrital minerals: Geology, v. 38, p. 191-192.

Cawood, P.A., Nemchin, A.A., Freeman, M., and Sircombe, K., 2003, Linking source and sedimentary basin: Detrital zircon record of sediment flux along a modern 
river system and implications for provenance studies: Earth and Planetary Science Letters, v. 210, p. 259-268.

Condie, K.C., and Aster, R.C., 2009, Zircon age episodicity and growth of continental crust: EOS transactions, American Geophysical Union, v. 90, p. 364.

Dalrymple, G.B., Czamanske, G.K., Fedorenko, V.A., Simonov, O.N., M.A.Lanphere, and Likhachev, A.P., 1995, A reconnaissance geochronologic study of orebearing and related rocks, Siberian Russia: Geochimica et Cosmochimica Acta, v. 59, p. 2071-2083.

DeCelles, P.G., Carrapa, B., and Gehrels, G.E., 2007, Detrital zircon U-Pb ages provide provenance and chronostratigraphic information from Eocene synorogenic deposits in northwestern Argentina: Geology, v. 35, p. 323-326.

Dickinson, W.R., Beard, L.S., Brakenridge, G.R., Erjavec, J.L., Ferguson, R.C., Inman, K.F., Knepp, R.A., Lindberg, F.A., and Ryberg, P.T., 1983, Provenance of North American Phanerozoic sandstones in relation to tectonic setting: Geological Society of America Bulletin, v. 94, p. 222-235.

Dickinson, W.R., and Gehrels, G.E., 2009, U-Pb ages of detrital zircons in Jurassic eolian and associated sandstones of the Colorado Plateau: Evidence for transcontinental dispersal and intraregional recycling of sediment: Geological Society of America Bulletin, v. 121, p. 408-433.

Dove, D., Coakley, B., Hopper, J., Kristoffersen, Y., and HLY Geophysics Team, 2010, Bathymetry, controlled source seismic and gravity observations of the Mendeleev ridge; implications for ridge structure, origin, and regional tectonics: Geophysical Journal International, v. 183, p. 481-502.

Dumitru, T.A., Miller, E.L., O'Sullivan, P.B., Amato, J.M., Hannula, K.A., Calvert, A.T., and Gans, P.B., 1995, Cretaceous to recent extension in the Bering Strait region, Alaska: Tectonics, v. 14, p. 549-563.

Dumoulin, J.A., Harris, A.G., Gagiev, M., Bradley, D.C., and Repetski, J.E., 2002, Lithostratigraphic, conodont, and other faunal links between lower Paleozoic strata in northern and central Alaska and northeastern Russia, in Miller, E.L., Grantz, A., and Klemperer, S.L., eds., Tectonic Evolution of the Bering Shelf - 
Chukchi Sea - Arctic Margin and Adjacent Landmasses, Special Paper 360:

Boulder, CO, The Geological Society of America, p. 291-312.

Embry, A.F., 1990, Geological and geophysical evidence in support of the hypothesis of anticlockwise rotation of northern Alaska: Marine Geology, v. 93, p. 317-329.

Embry, A.F., and Dixon, J., 1994, The age of the Amerasia basin, in Thurston, D.K., and Fujita, K., eds., Proceedings of the 1992 International Conference on Arctic Margins: Anchorage, Alaska, 289-294.

Forsyth, D.A., Asudeh, I., Green, A.G., and Jackson, H.R., 1986, Crustal structure of the northern Alpha Ridge beneath the Arctic Ocean: Nature, v. 322, p. 349-352.

Gehrels, G., and Pullen, A., 2010, Introduction to U-Th-Pb geochronology using a laserablation multicollector ICP mass spectrometer: Anaheim, CA, Geological Society of America Short Course.

Gehrels, G., Valencia, V., and Pullen, A., 2006, Detrital zircon geochronology by laserablation multicollector ICPMS at the Arizona Laserchron Center, in Olszewski, T., ed., Geochronology: Emerging Opportunities: Paleontology Society Papers, 12, 67-76.

Gradstein, F.M., Cooper, R.A., Sadler, P.M., Hinnov, L.A., Smith, A.G., Ogg, J.G., Villeneuve, M., McArthur, J.M., Howarth, R.J., Agterberg, F.P., Robb, L.J., Knoll, A.H., Plumb, K.A., Shields, G.A., Strauss, H., Veizer, J., Bleeker, W., Shergold, J.H., Melchin, M.J., House, M.R., Davydov, V., Wardlaw, B.R., Luterbacher, H.P., Ali, J.R., Brinkhuis, H., Hooker, J.J., Monechi, S., Powell, J., Röhl, U., Sanfilippo, A., Schmitz, B., Lourens, L., Hilgen, F., Shackleton, N.J., Laskar, J., Wilson, D., Gibbard, P., and Kolfschoten, T.v., 2004, A Geologic Time Scale 2004, in Gradstein, F.M., Ogg, J.G., and Smith, A.G., eds.: Cambridge, UK, Cambridge University Press.

Grantz, A., and May, S.D., 1983, Rifting history and structural development of the continental margin north of Alaska, in Watkins, J.S., and Drake, C., eds., Studies in continental margin geology: American Association of Petroleum Geologists Memoir 34, p. 77-100.

Grantz, A., Pease, V.L., Willard, D.A., Phillips, R.L., and Clark, D.L., 2001, Bedrock cores from 89 \{degrees\} North: Implications for the geologic framework and 
Neogene paleoceanography of Lomonosov Ridge and a tie to the Barents shelf: Geological Society of America Bulletin, v. 113, p. 1272-1281.

Hoskin, P.W.O., and Black, L.P., 2000, Metamorphic zircon formation by solid-state recrystallization of protolith igneous zircon: Journal of Metamorphic Geology, v. 18 , p. 423-439.

Jackson, H.R., Forsyth, D.A., and Johnson, G.L., 1986, Oceanic affinities of the Alpha Ridge, Arctic Ocean: Marine Geology, v. 73, p. 237-261.

Jakobsson, M., Macnab, R., Mayer, L., Anderson, R., Edwards, M., Hatzky, J., Schenke, H.-W., and Johnson, P., 2008, An improved bathymetric portrayal of the Arctic Ocean: Implications for ocean modeling and geological, geophysical and oceanographic analyses: Geophys. Res. Lett., v. 35

Jokat, W., 2003, Seismic investigations along the western sector of Alpha Ridge, Central Arctic Ocean: Geophysical Journal International, v. 152, p. 185-201.

Khudoley, A.K., and Prokopiev, A.V., 2007, Defining the eastern boundary of the North Asian craton from structural and subsidence history studies of the Verkhoyansk fold-and-thrust belt: GSA Special Papers, v. 433, p. 391-410.

Konstantinovsky, A.A., 2007, Structure and geodynamics of the Verkhoyansk FoldThrust Belt: Geotectonics, v. 41, p. 337-354.

Kos'ko, M., and Korago, E., 2009, Review of geology of the New Siberian Islands between the Laptev and the East Siberian Seas, North East Russia, in Stone, D.B., Fujita, K., Layer, P.W., Miller, E.L., Prokopiev, A.V., and Toro, J., eds., Geology, geophysics and tectonics of Northeastern Russia: a tribute to Leonid Parfenov, Stephan Mueller Special Publication Series Volume 4, Copernicus Publications, 45-64.

Kuzmichev, A.B., 2009, Where does the South Anyui suture go in the New Siberian Islands and Laptev Sea?: Implications for the Amerasia basin origin:

Tectonophysics, v. 463, p. 86-108.

Kuzmichev, A.B., and Pease, V.L., 2007, Siberian trap magmatism on the New Siberian Islands: constraints for Arctic Mesozoic plate tectonic reconstructions: Journal of the Geological Society, London, v. 164, p. 959-968. 
Langinen, A.E., Lebedeva-Ivanova, N.N., Gee, D.G., and Zamansky, Y.Y., 2009, Correlations between the Lomonosov Ridge, Marvin Spur and adjacent basins of the Arctic Ocean based on seismic data: Tectonophysics, v. 472, p. 309-322.

Lawver, L.A., Grantz, A., and Gahagan, L.M., 2002, Plate kinematic evolution of the present Arctic region since the Ordovician, in Miller, E.L., Grantz, A., and Klemperer, S.L., eds., Tectonic Evolution of the Bering Shelf - Chukchi Sea Arctic Margin and Adjacent Landmasses, Special Paper 360: Boulder, CO, The Geological Society of America, p. 333-358.

Lawver, L.A., and Scotese, C.R., 1990, A review of tectonic models for the evolution of the Canada Basin, in Grantz, A., Johnson, L., and Sweeney, J.F., eds., The Arctic Ocean Region, v. L: Boulder, Colorado, Geological Society of America, p. 593618.

Layer, P.W., Newberry, R., Fujita, K., Parfenov, L., Trunilina, V., and Bakharev, A., 2001, Tectonic setting of the plutonic belts of Yakutia, northeast Russia, based on 40Ar/39Ar geochronology and trace element geochemistry: Geology, v. 29, p. 167-170.

Lebedeva-Ivanova, N.N., Zamansky, Y.Y., Langinen, A.E., and Sorokin, M.Y., 2006, Seismic profiling across the Mendeleev Ridge at $82^{\circ} \mathrm{N}$ : evidence of continental crust: Geophysical Journal International, v. 165, p. 527-544.

Lorenz, H., Majka, J., Larionov, A., and Gee, D., 2011, Grenville-Scevonorwegian detrital zircon signatures in the High Arctic, from East Greenland to Severnaya Zemlya: Geophysical Research Abstracts, v. 13

Miller, E.L., Gehrels, G.E., Pease, V., and Sokolov, S., 2010, Stratigraphy and U-Pb detrital zircon geochronology of Wrangel Island, Russia: Implications for Arctic paleogeography: AAPG Bulletin, v. 94, p. 665-692.

Miller, E.L., Soloviev, A., Kuzmichev, A., Gehrels, G., Toro, J., and Tuchkova, M., 2008, Jurassic and Cretaceous foreland basin deposits of the Russian Arctic: Separated by the birth of the Makarov Basin?: Norwegian Journal of Geology, v. 88, p. 201-226.

Miller, E.L., Toro, J., Gehrels, G., Amato, J.M., Prokopiev, A., Tuchkova, M.I., Akinin, V.V., Dumitru, T.A., Moore, T.E., and Cecile, M.P., 2006, New insights into 
Arctic paleogeography and tectonics from $\mathrm{U}-\mathrm{Pb}$ detrital zircon geochronology: Tectonics, v. 25

Oleshko, B.M., 1981, The 1:200,000 State Geologic Map of the USSR. The Verkhoyansk series. Sheets Q-53-XIX-XX. Map and Explanatory notes: Moscow, Soyuzgeolfond, 85 (in Russian).

Oxman, V.S., 2003, Tectonic evolution of the Mesozoic Verkhoyansk-Kolyma belt (NE Asia): Tectonophysics, v. 365, p. 45-76.

Parfenov, L.M., 1991, Tectonics of the Verkhoyansk-Kolyma Mesozoides in the context of plate tectonics: Tectonophysics, v. 199, p. 319-342.

Parfenov, L.M., Badarch, G., Berzin, N.A., Khanchuk, A.I., Kuzmin, M.I., Nokleberg, W.J., Prokopiev, A.V., Ogasawara, M., and Yan, H., 2009, Summary of Northeast Asia geodynamics and tectonics, in Stone, D.B., Fujita, K., Layer, P.W., Miller, E.L., Prokopiev, A.V., and Toro, J., eds., Geology, geophysics and tectonics of Northeastern Russia: a tribute to Leonid Parfenov, Stephan Mueller Special Publication Series Volume 4, Copernicus Publications, p. 11-33.

Plafker, G., and Berg, H.C., 1994, Overview of the geology and tectonic evolution of Alaska, in Plafker, G., and Berg, H.C., eds., The Geology of Alaska, The Geology of North America, v. G-1: Boulder, Colorado, Geological Society of America.

Press, W.H., Teukolsky, S.A., Vetterling, W.T., and Flannery, B.P., 1992, Numerical Recipes in C: The Art of Scientific Computing. Second Edition: Cambridge, Cambridge University Press.

Prokopiev, A.V., Toro, J., Miller, E.L., and Gehrels, G.E., 2008, The paleo-Lena River 200 m.y. of transcontinental zircon transport in Siberia: Geology, v. 36, p. 699702.

Reichow, M.K., Saunders, A.D., White, R.V., Pringle, M.S., Al'Mukhamedov, A.I., Medvedev, A.I., and Kirda, N.P., 2002, 40Ar/39Ar Dates from the West Siberian Basin: Siberian Flood Basalt Province Doubled: Science, v. 296, p. 1846-1849.

Renne, P.R., and Basu, A.R., 1991, Rapid Eruption of the Siberian Traps Flood Basalts at the Permo-Triassic Boundary: Science, v. 253, p. 176-179.

Scarrow, J, H., Hetzel, R, Gorozhanin, V, M., Dinn, M, Glodny, J, Gerdes, A, Ayala, C, Montero, and P, 2002, Four decades of geochronological work in the Southern 
and Middle Urals: A review: Washington, DC, ETATS-UNIS, American Geophysical Union, 23 p.

Sokolov, S.D., Bondarenko, G.Y., Layer, P.W., and Kravchenko-Berezhnoy, I.R., 2009, South Anyui suture: tectono-stratigraphy, deformations, and principal tectonic events, in Stone, D.B., Fujita, K., Layer, P.W., Miller, E.L., Prokopiev, A.V., and Toro, J., eds., Geology, geophysics and tectonics of Northeastern Russia: a tribute to Leonid Parfenov, Stephan Mueller Special Publication Series Volume 4, Copernicus Publications, p. 201-221.

Sokolov, S.D., Bondarenko, G.Y., Morozov, O.L., Shekhovstov, V.A., Glotov, S.P., Ganelin, A.V., and Kravchenko-Berezhnoy, I.R., 2002, South Anyui suture, northeast Arctic Russia: Facts and problems, in Miller, E.L., Grantz, A., and Klemperer, S.L., eds., Tectonic Evolution of the Bering Shelf - Chukchi Sea Arctic Margin and Adjacent Landmasses, Special Paper 360: Boulder, CO, The Geological Society of America, p. 209-224.

Urzov, A.S., Prokopiev, V.S., and Spector, Y.L., 1994, Geologic map of Yakutia, scale 1:500000, Sheet 17 and 27, in Prokopiev, V.S., ed.

Vinogradov, V.A., Gusev, E.A., and Lopatin, B.G., 2006, Structure of the Russian eastern arctic shelf, ICAM IV Fourth International Conference on Continental Margins: Dartmouth, Nova Scotia, Canada, Natural Resources Canada, 90-98.

Walderhaug, H.J., Eide, E.A., Scott, R.A., Inger, S., and Golionko, E.G., 2005, Palaeomagnetism and 40Ar/39Ar geochronology from the South Taimyr igneous complex, Arctic Russia: a Middle-Late Triassic magmatic pulse after Siberian flood-basalt volcanism: Geophysical Journal International, v. 163, p. 501-517. Yin, A., 2004, Gneiss domes and gneiss dome systems, in Whitney, D.L., Teyssier, C., and Siddoway, C.S., eds., Gneiss Domes in Orogeny, Special Paper 380: Boulder, CO, The Geological Society of America, p. 1-14. 


\section{Chapter III}

\section{Geochronology and emplacement mechanisms of the Bendeleben and Windy Creek plutons above an extending arc, Seward Peninsula, Alaska.}

D.B. Harris ${ }^{1}$, J. Toro ${ }^{1}$, K. McDannell ${ }^{1}$, J.L. Wooden ${ }^{2}$

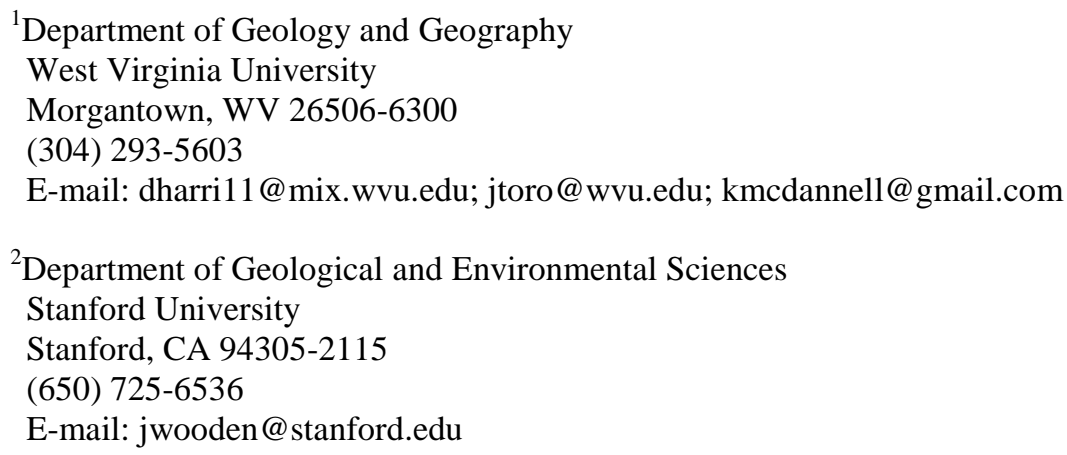




\section{Abstract:}

The Bendeleben and Windy Creek plutons of the Bendeleben and northern Darby Mountains, respectively, were emplaced during a multiple-phase injection event lasting from 104 to $82 \mathrm{Ma}$ in an extensional setting on the Seward Peninsula. This extensional episode is indicated by dike orientations, sheared mantles around garnet porphyroblasts, gentle foliation dip away from the plutons and consistent stretching lineations plunging away from the plutons, all documented in country rock surrounding both plutons. This interpretation is also in agreement with a proposed model for emplacement of the nearby Kigluaik pluton to the west along the Bendeleben normal fault involving north-south or north-northwest to south-southeast extension induced by slab-rollback above a southward retreating, northward subducting slab. Petrology of the Bendeleben pluton is diverse, showing multiple lithologies of differing ages. U-Pb zircon geochronology was performed on samples collected within the various lithologies of the Bendeleben and Windy Creek plutons. Within the central and eastern Bendeleben pluton, a central gabbro unit is the youngest at $82.8 \pm 0.5 \mathrm{Ma}$ and is bordered to the south by granodiorite with a minimum age of $86.1 \pm 0.3 \mathrm{Ma}$ as indicated by cross cutting relationships with a dated pegmatite dike. The outer rim of the Bendeleben pluton to the south is a $65 \mathrm{~km}^{2}$, biotite-rich alkali-feldspar granite. In the western part of the field area, this unit has a crystallization age of $95.9 \pm 1.0 \mathrm{Ma}$, but in the east it has an age of $84.6 \pm 0.4 \mathrm{Ma}$. The core of the pluton to the north is composed of monzogranite that was dated at $82.9 \pm 0.3$ Ma. Previous mapping along the western limit of the Bendeleben pluton outside of our study area has yielded a U-Pb age of $104 \pm 1.0 \mathrm{Ma}$. The Windy Creek pluton to the east is separated from the Bendeleben pluton by the Telephone Creek normal fault and is composed of homogenous alkali-feldspar granite dated at 96.3 $\pm 0.6 \mathrm{Ma}$. Metamorphic rocks of the Nome Group that border the Windy Creek pluton are low-grade schists and marble of the Nome Group. The higher grade metamorphic equivalent of the Nome Group, named the Kigluaik Metamorphic Complex, borders the Bendeleben pluton to the south and was contact metamorphosed during intrusion of the pluton. The 13 m.y. age range of intrusions in the Bendeleben pluton is suggestive of constant rejuvenation of a magma chamber at depth experiencing liquid segregation which was tapped repeatedly for magmatic pulses of the Bendeleben and Windy Creek plutons under extensional conditions. This is supported by $\mathrm{Rb}, \mathrm{Nb}$ and $\mathrm{Y}$ discrimination diagrams suggestive of magma generation under a syn-collisional or volcanic arc setting above a subducting slab. Timing of intrusion seen in the Bendeleben pluton matches that of the episodic eruptive nature of the Okhotsk-Chukotka Volcanic Belt which lies along strike with the Bendeleben pluton across the Bering Strait and stretches across most of Russia. Temperature of crystallization was modeled by Ti concentration in zircon and the results indicated emplacement temperatures for the Bendeleben pluton between $796^{\circ} \mathrm{C}$ and $836^{\circ} \mathrm{C}$. The Bendeleben pluton was later exhumed during a rapid uplift event along the Bendeleben normal fault thought to be active until 35 Ma with early uplift as early as 65 Ma based on apatite (U-Th)/He modelling. 


\section{Introduction:}

The Seward Peninsula is located along the west coast of modern Alaska within the southern salient of the Arctic Alaska-Chukotka microplate, which is thought to have reached its current relative position in the Late Jurassic-Early Cretaceous (Figure 1). Following accretion of the Arctic Alaska-Chukotka microplate, a period of extension accompanied by wide-spread granitic magmatism affected the entire Bering Strait region (Miller et al., 2009) as well as a more localized north-south extensional episode in the Seward Peninsula responsible for the formation of several gneiss domes and dike swarms. This Mid-Cretaceous event is important because several models exist for the specific configuration and interaction between the local terranes and basins (Amato et al., 2009; Hannula et al., 1995; Lawver et al., 2002; Miller and Hudson, 1991; Nelson and Colpron, 2007; Patton and Tailleur, 1977). The overall lack of detachment faulting and other brittle deformation structures around gneiss domes found in the Bering Strait region has led to skepticism regarding extensional deformation in the late Mesozoic for the Seward Peninsula; though recent work has provided strong evidence supporting this event (Amato et al., 2003; Amato et al., 1994; Klemperer et al., 2002a; Miller et al., 2002; Miller and Hudson, 1991; Wolf et al., 2002). Models for the Cretaceous tectonic behavior in the Bering Sea region include the following:

1: East-west compressive stress caused by opening of the Mid-Atlantic Ridge that produced a large oroclinal bending event (Patton and Tailleur, 1977). 

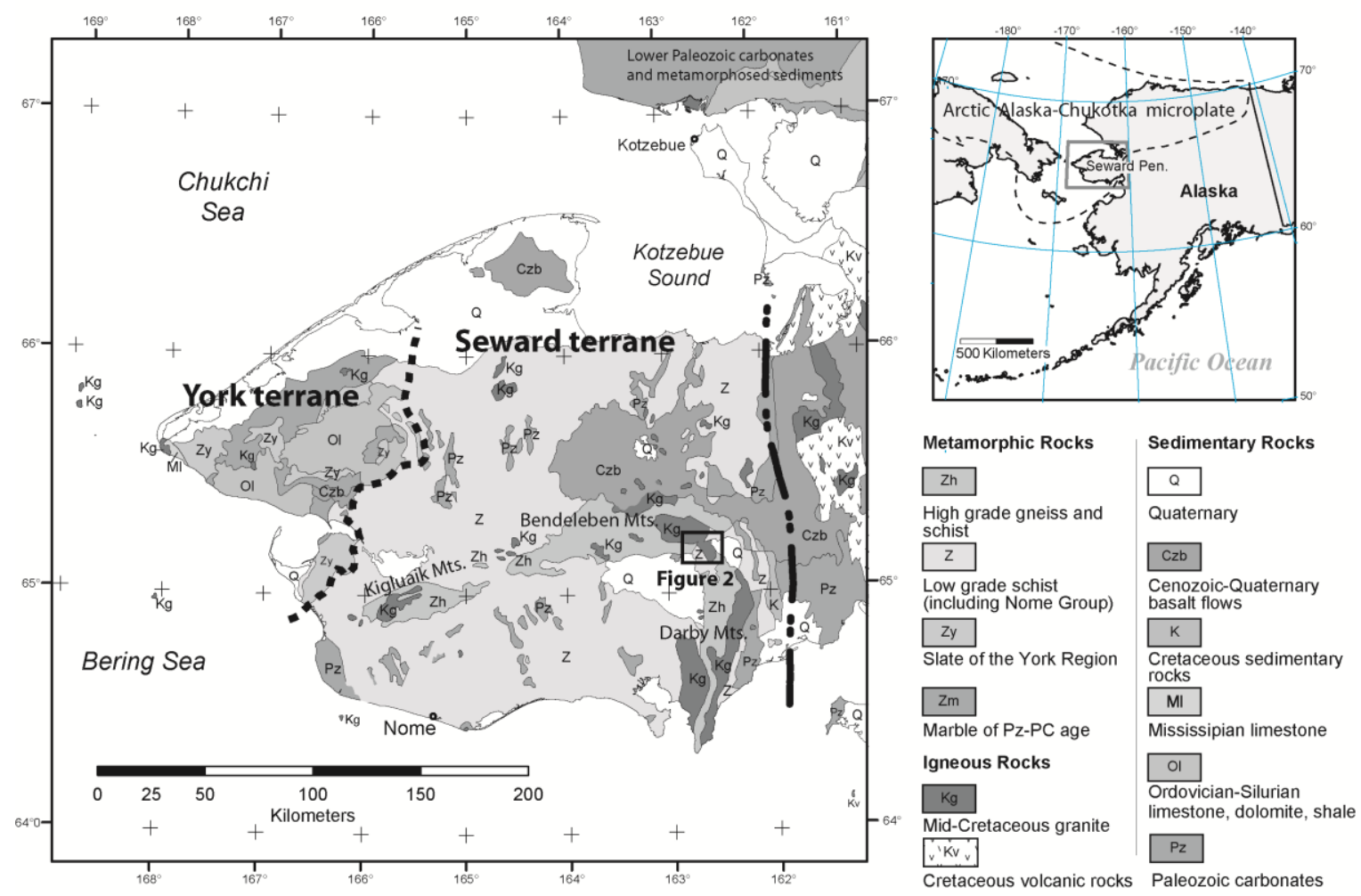

Kugruk fault zone eastern limit

Figure 1: Generalized geologic map of the Seward Peninsula and Bering Strait region. Digital data from Klemperer et al. (2002a) and related geographic information system database with geology from Till and Dumoulin (1994), Till et al. (2010) and Beikman (1980). 
2: Arc-continent collision resulting in high-pressure, low-temperature rocks overprinted by higher temperature assemblages as a result of crustal telescoping and subsequent thermal relaxation (Patrick and Lieberman, 1988).

3: North-south extensional models from thinning of the over-riding plate above a northward dipping subducting plate experiencing rollback and trench retreat (Amato and Miller, 1997).

4: Strike-slip models showing movement across potential conjugate shears east of the Seward Peninsula along the Kaltag fault and an unnamed fault separating the Seward terrane from the Yukon-Koyukuk basin (Amato et al., 2004).

The Bendeleben Mountains, located in southeastern Seward Peninsula, have been previously mapped as being cored by a large Cretaceous granitic pluton and so should prove valuable in deciphering the tectonic setting during the Cretaceous (Figure 1). Our data includes higher resolution mapping of the eastern Bendeleben Mountains (previously mapped by Moffit, 1913; Sainsbury, 1974; Till et al., 1986; and Till et al., 2010) as well as a geochronologic and geochemical study of the Bendeleben and Windy Creek plutons, which core the central and eastern Bendeleben Mountains, and the northern Darby Mountains. Results from this study provide evidence regarding the style and timing of Cretaceous tectonic events in the Seward Peninsula and involve a comparative study with the nearby Kigluaik gneiss dome (extensive results by J.M. Amato: Amato and Miller, 1997; Amato et al., 2002; Amato and Wright, 1997; Amato and Wright, 1998; Amato et al., 1994). 
An additional aspect of this study involves the mechanics of pluton emplacement into the shallow crust, a topic which has become controversial in recent years due to an increasing body of research in opposition to the long-accepted process of diapiric emplacement via stoping (Glazner and Bartley, 2006). Field mapping of plutons and their surrounding structures worldwide has greatly enhanced our understanding of emplacement mechanisms, but the topic is still under active research as several mechanisms have been proposed, often involving thoroughly studied field analogues (Daly, 1903; Glazner and Bartley, 2006; Glazner et al., 2004; McNulty et al., 1996; Miller, 2008; Molyneux and Hutton, 2000; Paterson and Fowler, 1993; Paterson and Vernon, 1995; Titus et al., 2005; Yin, 2004). The Cretaceous tectonic history of the Bendeleben and Windy Creek plutons is potentially similar to emplacement in a fault termination extensional setting of the Johnson Granite and Silver Pass Porphyries in the Sierra Nevada batholith which were suggested to have intruded via a series of dikes along local weaknesses induced by faulting in an extensional system (Titus et al., 2005). Other possible mechanisms include a ballooning mechanism like that proposed for the Ardara pluton, Ireland (Molyneux and Hutton, 2000) or a multiple phase dike fed emplacement as proposed for the McDoogle pluton of the Sierra Nevada batholith (Mahan et al., 2003).

\section{Field area:}

The Bendeleben and Windy Creek plutons are located at approximately $65.3^{\circ} \mathrm{N} / 163^{\circ} \mathrm{W}$ and $65.1^{\circ} \mathrm{N} / 162.6^{\circ} \mathrm{W}$ respectively, in southeastern Seward Peninsula (Figure 2, Plate 1). Cretaceous plutons are pervasive in this area, extending roughly west 


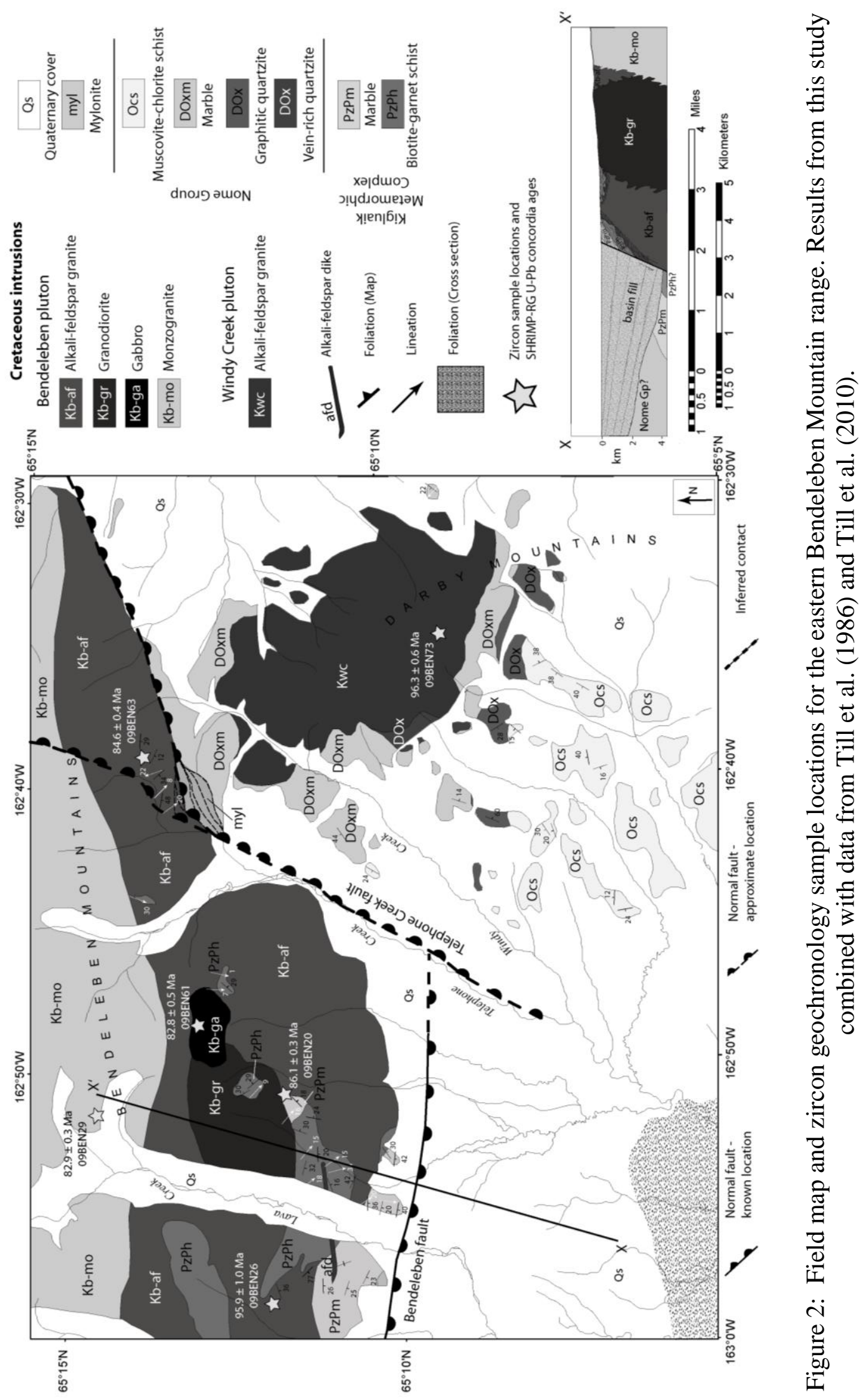


to east across the southern region of the Seward Peninsula before taking an abrupt ninety degree southward bend in the east at the transition from the Bendeleben Mountains to the Darby Mountains (Figure 1). The east-west oriented Bendeleben pluton crops out over approximately $140 \mathrm{~km}^{2}$ within our field area in the eastern Bendeleben Mountains and the Windy Creek pluton crops out over approximately $25 \mathrm{~km}^{2}$ in the north-south oriented Darby Mountains. The approximately $200 \mathrm{~km}^{2}$ Darby pluton crops out along the eastern edge of the Darby Mountains to the southeast. The Bendeleben pluton is separated from the Windy Creek pluton by the northeast-southwest striking Telephone Creek fault (Figure 2). The east-west striking high angle Bendeleben normal fault, which defines the southern edge of the Bendeleben Mountains, separates the mountains from a sedimentary basin (McCarthy's Marsh) to the south. These plutons and others to the west are theorized to be a driving force for the development of multiple gneiss domes found throughout the Seward Peninsula (Amato et al., 2003).

Lithology of the Seward Peninsula is broadly grouped into two terranes based on stratigraphy and metamorphic history, although the boundary between these terranes is poorly defined. The central and eastern portions of the peninsula are dominated by the Seward terrane, while the slightly smaller York terrane underlies most of the western peninsula and Bering Strait region and is beyond the scope of this study (Figure 1). The most diagnostic characteristics of the Seward terrane are its low to high-grade metamorphic rocks and intrusive granitoid plutons. Of the metamorphic suites, the most pervasive is the Nome Group, which has traditionally included four distinct metamorphosed units of quartz-rich schist and graphitic or chloritic marble thought to have evolved from Ordovician parent rock based on radiolarian and conodont dating (Till 
and Dumoulin, 1994). Recent detrital zircon geochronology suggests a more complicated mix of ages within each unit, however, and Cambrian to Silurian aged carbonate rocks exposed in thin fault slices have further complicated the sedimentological history (Amato et al., 2009). The Kigluaik Metamorphic Complex (as defined by Amato et al., 2009) is also found within the Seward terrane and is composed of granulite-facies gneiss and amphibolite-facies schist found adjacent to granitoid plutons of the Bendeleben and Darby Mountains. Within these ranges are high-grade amphibolite-, granulite- and greenschist-facies schists, metapelites and marbles. This unit was originally described as the Kigluaik Group by Moffit (1913) and subsequently in greater detail by Till and Dumoulin (1994), but has been redefined as the Kigluaik Metamorphic Complex by Amato et al. (2009) due to failure to meet "Group" classification standards of the International Commission on Stratigraphy.

Two deformation events proposed by Hannula et al. (1995) are each represented by their own foliation orientations and metamorphic assemblages within the Seward terrane. The first deformational event $\left(D_{1}\right)$ is indicated by $S_{1}$ foliations subparallel to lithologic layering that postdate an early high-pressure/low-temperature event $\left(\mathrm{M}_{1}\right)$ which formed pumpellyite- to actinolite-facies in the upper section (York terrane) and blueschist-facies in the lower section (Nome Group) (Figure 1). $\mathrm{S}_{1}$ foliations are thought to have formed during a subsequent greenschist-facies overprint $\left(\mathrm{M}_{2}\right)$ which occurred at the end of $\mathrm{D}_{1}$ before $120 \mathrm{Ma}$. This first event was the consequence of arc-continent collision along the southern Seward Peninsula and is thought by some to represent the only regional Mesozoic deformation event for the Seward Peninsula, having been followed only by decompression overprinting and thermal relaxation from exhumation 
(Patrick and Lieberman, 1988). A second deformational event $\left(D_{2}\right)$ is however supported by multiple studies and is indicated by subhorizontal metamorphic $\mathrm{S}_{2}$ foliations thought to have formed under regional extension with peak metamorphic conditions around 91 Ma (Amato et al., 1994) with continued metamorphism between 90 and $80 \mathrm{Ma}$ (Amato et al., 2003; Miller and Bunker, 1976). A weak northwest-southeast lineation defined by grain stretching is prevalent in Seward terrane units and becomes more common to the south. $\mathrm{D}_{2}$ structures formed as a consequence of a third high-temperature metamorphic event $\left(\mathrm{M}_{3}\right)$ responsible for an amphibolite- to granulite-facies overprint at depth as a consequence of plutonism in the core of the Kigluaik and Bendeleben gneiss domes with cooling and unroofing during or soon after $\mathrm{D}_{2}$ (Hannula et al., 1995).

Because there is no sharp break between the Nome Group and Kigluaik Metamorphic Complex, they are both inferred to have experienced the same highpressure, low-temperature metamorphic conditions presumably before $120 \mathrm{Ma}\left(\mathrm{D}_{1}, \mathrm{M}_{1^{-}}\right.$ $M_{2}$ ) which were later overprinted by a thermal event between 110-91 Ma at depth $\left(D_{2}\right)$ (Amato et al., 2003; Hannula et al., 1995) thought to have been caused by mafic magmatism (Amato et al., 1994). The Kigluaik Metamorphic Complex is therefore considered the metamorphically upgraded equivalent of Nome Group units.

\section{Methods:}

\section{Field mapping:}

Updated field maps compiled during and directly following field work performed in 2009 will be used towards the eventual compilation of a 1:24000 scale geologic map of 
the entire Bendeleben Mountain Range. Recent geologic mapping expeditions in the western and central Bendeleben Mountains performed from 2006 to 2007 have already resulted in several independent geochemical and geochronologic publications in addition to updated geologic maps for these areas (Gottlieb and Amato, 2007; Gottlieb and Amato, 2008a; Gottlieb and Amato, 2008b). During field work, hand samples were collected from all mappable units for thin section analysis. Thin section analysis involved identification of sense-of-shear indicators from oriented samples, 100-point grain counts and general visual analysis of country rock and granitic samples to determine specific lithology, deformation history, kinematics of deformation, mineral assemblages and metamorphic grade.

\section{Geochronology:}

During field investigation, granitic samples were collected from the Bendeleben pluton (5 samples) and Windy Creek pluton (1 sample) to be analyzed via zircon $\mathrm{U}-\mathrm{Pb}$ geochronology (Figure 2). Grab samples were collected either from in-place outcrop or from topographic high-points. Weathering rind was cleaned from all samples in the field prior to collection. Following return from the field, zircons were separated using standard crushing, magnetic and gravimetric procedures at West Virginia University. U$\mathrm{Pb}$ geochronology was performed at the USGS Sensitive High Resolution IonMicroprobe, Reverse Geometry (SHRIMP-RG) facility at Stanford University. At the lab, grain mounts were made by forming distinct rows of zircons for each sample on 25 $\mathrm{mm}$ diameter, $6 \mathrm{~mm}$ thick pucks. Pucks were then polished and coated with a thin film $(\sim 10 \mathrm{~nm})$ of gold in a Denton sputterer to minimize charge effects during analysis. 
Grains with simple or no zoning patterns were chosen for analysis following imaging by cathodoluminesence (CL) using a JEOL JSM 5600 electron microscope and reflected light (Appendix 6). Analytical spots approximately $30 \mu \mathrm{m}$ in diameter were sputtered using a Kratos Duoplasmatron sourced primary oxygen ion $\left(\mathrm{O}_{2}{ }^{-}\right)$beam (Coath and Long, 1994). Ions were separated by mass using a double-focusing mass spectrometer in a Reverse Geometry orientation where the magnet precedes an electrostatic analyser along the secondary beam path. Under this orientation, only one mass is passed through the collector at a time, causing increased resolution at the cost of slower analysis time. At least seven grains were targeted per sample and measured for their $\mathrm{U}-\mathrm{Th}-\mathrm{Pb}$ concentrations using a mix of cores and rims as determined by CL imaging to verify magmatic age. Reported analyses are the result of five averaged measurement cycles per targeted grain and processed using Squid and Isoplot software developed by Ludwig (2009) with complete results listed in Appendix 7. Standard R-33, which yields a combined SHRIMP age of 419.9 \pm 1.5 Ma (Black et al., 2004), was targeted one time per four sample grains and used for error correction. In addition to $\mathrm{U}-\mathrm{Th}-\mathrm{Pb}$ ions measured during SHRIMP-RG analysis, all zircons were also measured for Ti concentrations to be used for temperature of crystallization calculation modeled after Watson et al. (2006) and for their Rare Earth Element (REE) As-Yb series concentrations (La, Ce, Pr, Nd, Sm, Eu, Gd, Dy, Y, Er and Yb). Specific routine procedures for analysis via SHRIMP-RG are outlined in Williams (1998). 


\section{Bulk geochemistry:}

Eight samples were sent to the Washington State University (WSU) geoanalytical laboratory for major and trace element measurement via inductively coupled plasmamass spectrometry (ICP-MS) using an Agilent model 4500. Powdered samples were fused under low-dilution with di-lithium tetraborate flux followed by open-vial mixed digestion using hydrofluoric acid to remove silica and most of the flux (more than 90\%). Instrumental drift was corrected using $\mathrm{Ru}$, In and $\mathrm{Re}$ as internal standards. For more information on WSU methodology for ICP-MS geoanalytical work, see their website at <http://www.sees.wsu.edu/Geolab/note/icpms.html>. Five Bendeleben pluton samples, one Windy Creek pluton sample, one biotite-garnet schist sample from the Kigluaik Metamorphic Complex and one sample from the muscovite schist unit of the Nome Group were analyzed to better describe each unit. The five igneous samples collected from the Bendeleben pluton included a gabbro, monzogranite, pegmatite and two alkalifeldspar granites. One alkali-feldspar granite sample was sent from the Windy Creek pluton. All geochemical results are listed in Table 1 and Appendix 8.

\section{Results:}

Field data to be used in the composition of a higher-resolution, updated geologic map of the Bendeleben Mountains were compiled upon return from the field at a scale of 1:24,000 (Figure 2, Plate 1). Two separate packages of lithologies, the Nome Group and the Kigluaik Metamorphic Complex, comprise the country rock surrounding the plutons and are described below. 
Table 1: Geochemical results from samples collected in the Bendeleben and northern Darby ranges. Weight percentages were adjusted so that total percentage is $100 \%$. Kigluaik M.C. is the Kigluaik Metamorphic Complex. Abbreviations are: tr, trace elements; m, major elements.

\begin{tabular}{|c|c|c|c|c|c|c|c|c|}
\hline & \multicolumn{5}{|c|}{ Bendeleben pluton } & \multirow{3}{*}{$\begin{array}{c}\begin{array}{c}\text { Windy Creek } \\
\text { pluton }\end{array} \\
\text { 09BEN73 } \\
\text { alkali- } \\
\text { feldspar } \\
\text { granite }\end{array}$} & \multirow{3}{*}{$\begin{array}{c}\text { Kigluaik } \\
\text { M.C. } \\
\text { 09BEN13 } \\
\text { biotite- } \\
\text { garnet } \\
\text { schist }\end{array}$} & \multirow{3}{*}{$\begin{array}{c}\text { Nome } \\
\text { Group } \\
\text { 09BEN76 } \\
\text { muscovite } \\
\text { schist }\end{array}$} \\
\hline & 09BEN20 & 09BEN26 & 09BEN29 & 09BEN61 & 09BEN63 & & & \\
\hline & pegmatite & $\begin{array}{c}\text { alkali- } \\
\text { feldspar } \\
\text { granite }\end{array}$ & monzogranite & gabbro & $\begin{array}{l}\text { alkali- } \\
\text { feldspar } \\
\text { granite }\end{array}$ & & & \\
\hline \multicolumn{9}{|c|}{ Normalized Major Elements (Weight \%) } \\
\hline $\mathrm{SiO}_{2}$ & 75.2 & 72.4 & 72.2 & 60.6 & 70.9 & 67.2 & 70.0 & 57.2 \\
\hline $\mathrm{TiO}_{2}$ & 0.1 & 0.4 & 0.4 & 1.4 & 0.4 & 0.4 & 1.0 & 0.9 \\
\hline $\mathrm{Al}_{2} \mathrm{O}_{3}$ & 14.4 & 14.6 & 14.8 & 17.8 & 15.8 & 16.3 & 14.9 & 20.3 \\
\hline $\mathrm{FeO}^{*}$ & 0.5 & 1.8 & 2.0 & 5.5 & 2.5 & 2.7 & 7.2 & 8.9 \\
\hline $\mathrm{MnO}$ & 0.0 & 0.0 & 0.0 & 0.1 & 0.0 & 0.1 & 0.1 & 0.1 \\
\hline $\mathrm{MgO}$ & 0.2 & 0.3 & 0.5 & 1.6 & 0.6 & 0.8 & 2.8 & 5.6 \\
\hline $\mathrm{CaO}$ & 1.8 & 1.1 & 1.9 & 4.4 & 1.7 & 2.3 & 0.4 & 1.2 \\
\hline $\mathrm{Na}_{2} \mathrm{O}$ & 3.4 & 3.0 & 3.6 & 4.2 & 4.0 & 4.7 & 0.3 & 1.9 \\
\hline $\mathrm{K}_{2} \mathrm{O}$ & 4.1 & 6.3 & 4.5 & 3.9 & 3.8 & 5.4 & 3.2 & 3.8 \\
\hline $\mathrm{P}_{2} \mathrm{O}_{5}$ & 0.1 & 0.1 & 0.1 & 0.6 & 0.2 & 0.1 & 0.2 & 0.2 \\
\hline Total & 100.0 & 100.0 & 100.0 & 100.0 & 100.0 & 100.0 & 100.0 & 100.0 \\
\hline \multicolumn{9}{|c|}{ Unnormalized Trace Elements (ppm) } \\
\hline $\mathrm{Ni}$ & 5.5 & 4.8 & 3.9 & 7.3 & 3.0 & 7.7 & 57.1 & 103.9 \\
\hline $\mathrm{Cr}$ & 27.3 & 17.7 & 17.6 & 12.8 & 12.3 & 18.2 & 115.9 & 144.4 \\
\hline Sc & 2.4 & 2.1 & 4.3 & 6.6 & 4.6 & 2.8 & 17.5 & 23.9 \\
\hline$V$ & 3.5 & 9.4 & 17.5 & 50.6 & 22.3 & 35.6 & 145.2 & 143.6 \\
\hline$B a$ & 230.5 & 1062.2 & 1033.8 & 3055.2 & 862.6 & 1237.1 & 501.7 & 595.4 \\
\hline$R b$ & 184.7 & 296.2 & 195.6 & 105.7 & 260.4 & 253.7 & 167.2 & 145.5 \\
\hline$S r$ & 109.1 & 275.3 & 428.4 & 1604.4 & 401.3 & 876.2 & 24.8 & 91.7 \\
\hline$Z r$ & 124.3 & 305.3 & 194.6 & 474.3 & 205.2 & 307.9 & 289.3 & 167.8 \\
\hline$Y$ & 6.3 & 9.2 & 18.3 & 18.6 & 27.2 & 22.5 & 42.6 & 29.8 \\
\hline$N b$ & 7.6 & 13.2 & 12.9 & 24.7 & 21.5 & 30.0 & 16.7 & 13.1 \\
\hline $\mathrm{Ga}$ & 20.2 & 22.0 & 19.8 & 23.1 & 30.0 & 20.8 & 19.6 & 24.7 \\
\hline $\mathrm{Cu}$ & 11.2 & 3.9 & 1.6 & 5.7 & 0.7 & 2.9 & 18.4 & 76.8 \\
\hline$Z n$ & 20.2 & 56.6 & 45.6 & 122.9 & 91.1 & 47.3 & 122.7 & 125.3 \\
\hline$P b$ & 30.8 & 49.6 & 38.4 & 25.4 & 28.0 & 28.6 & 6.4 & 12.0 \\
\hline $\mathrm{La}$ & 8.3 & 108.9 & 53.1 & 134.2 & 80.3 & 94.3 & 44.9 & 33.1 \\
\hline $\mathrm{Ce}$ & 7.9 & 200.6 & 96.1 & 270.7 & 149.2 & 168.0 & 92.0 & 69.7 \\
\hline Th & 4.0 & 76.7 & 28.9 & 21.1 & 31.4 & 58.4 & 14.0 & 11.4 \\
\hline$N d$ & 3.8 & 64.7 & 36.9 & 100.3 & 53.4 & 56.9 & 40.2 & 30.0 \\
\hline$U$ & 2.7 & 5.3 & 6.4 & 4.0 & 5.2 & 4.9 & 5.1 & 1.9 \\
\hline Cs & 10.1 & 5.9 & 5.0 & 3.5 & 4.6 & 8.3 & 18.4 & 6.2 \\
\hline $\mathrm{Nb}+\mathrm{Y}$ & 13.9 & 22.4 & 31.2 & 43.3 & 48.7 & 52.5 & 59.3 & 42.9 \\
\hline sum tr. (ppm) & 834.3 & 2612.0 & 2289.9 & 6114.4 & 2343.0 & 3334.6 & 1819.0 & 1893.1 \\
\hline tr. (weight \%) & 0.1 & 0.3 & 0.2 & 0.6 & 0.2 & 0.3 & 0.2 & 0.2 \\
\hline $\begin{array}{l}\text { sum m.ttr. } \\
\text { (weight \%) }\end{array}$ & 98.3 & 98.9 & 99.3 & 99.4 & 98.8 & 98.2 & 97.4 & 95.0 \\
\hline
\end{tabular}




\section{Nome Group:}

The Nome Group was originally described by Moffit (1913) and more recently in greater detail by Till et al. (2010) as a package of blueschist- to greenschist-grade metamorphic sequences with Early-Middle Paleozoic and older protoliths, scattered carbonates, and small bodies of orthogneiss. Within the field area, we mapped three units of the Nome Group including: (1) a muscovite-rich, chlorite-bearing pelitic schist, (2) a crystalline, commonly foliated diopside-bearing marble unit and (3) a black graphitic quartzite which in places contains very high percentage of quartz veins. All Nome Group units seen within our field area were found east of the Telephone Creek fault that separates the Bendeleben pluton from the Windy Creek pluton.

The muscovite schist is most likely correlative with light-green to silver colored, mafic, feldspathic and calcareous schist units described by Till and Dumoulin (1994) and Till et al. (2010) as the Ordovician (based on relationship to surrounding units) Casadepega schist (Ocs). It has a tendency to outcrop in several-meter high tors (Figure 3a), contains common quartz veins up to $10 \mathrm{~cm}$ in thickness and is albite-bearing. Geochemical results further support the connection to mafic portions of the Casadepega schist unit due to higher normalized weight percentages of $\mathrm{FeO}(8.9 \%)$ and $\mathrm{MgO}(5.6 \%)$ and low $\mathrm{SiO}_{2}(57.2 \%)$ (Table 1) relative to other country rock units in the area. The schist is well foliated with prevalent millimeter to centimeter thick polycrystalline quartz lenses, inclusion-rich albite grains and high epidote content and can be easily recognized by its greasy sheen and dull green color. Minor chlorite and biotite can also be found, though the vast majority of the rock is composed of well foliated muscovite layers with 


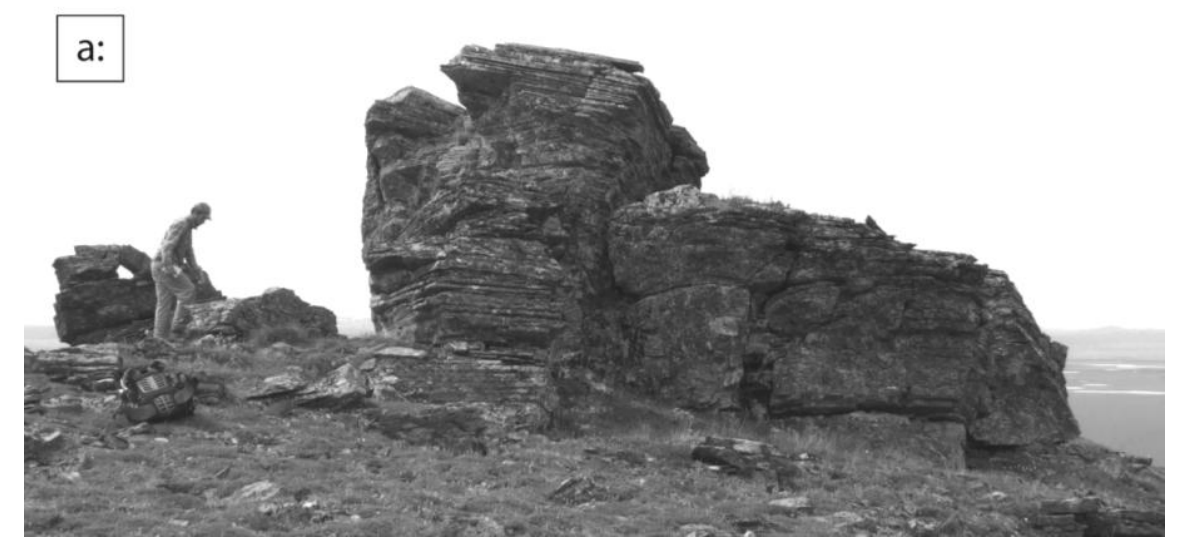

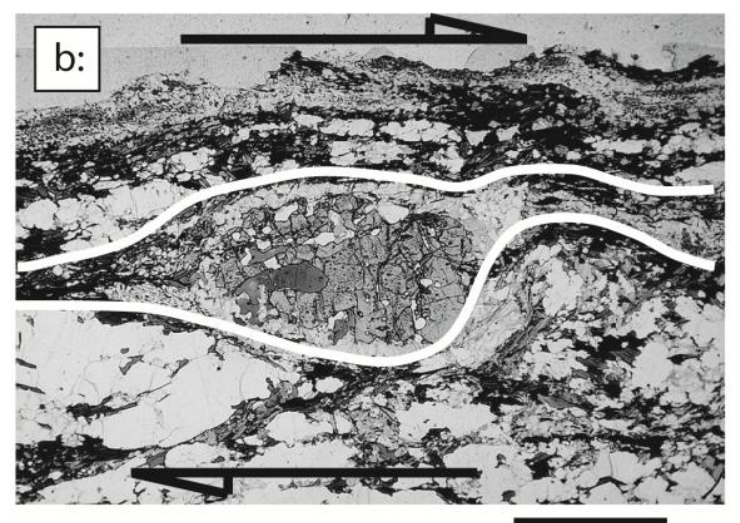

$2 \mathrm{~mm}$

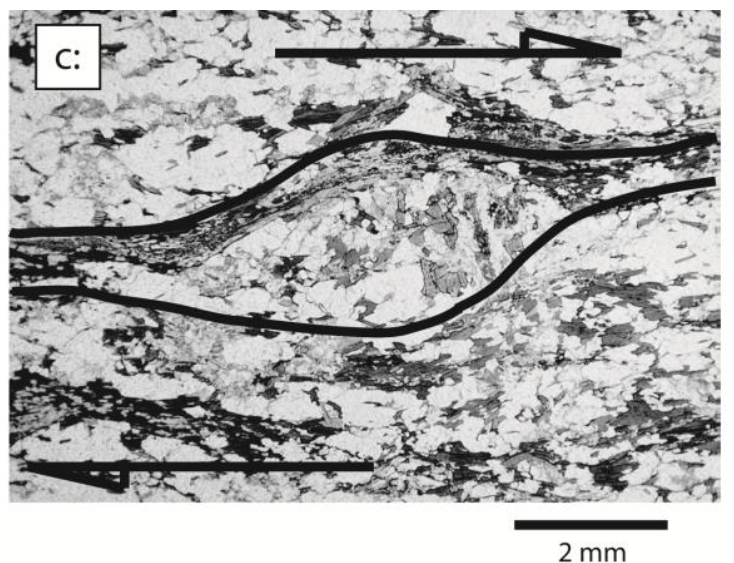

$2 \mathrm{~mm}$

Figure 3 a) Muscovite schist (Ocs) with gently south-dipping foliation as commonly exposed in several meter tall tors. b and c) Thin sections of biotite-garnet schist ( $\mathrm{PzPh})$ showing mantled garnet porphyroblasts with strain shadows. Both photomicrographs are oriented top-up with south towards the right. 
quartz-rich lenses. Thin section results from oriented samples show strong evidence of shear in the form of strain shadows and stretched grains. This unit was only seen south of the Windy Creek pluton and was separated from the pluton by units of marble and graphitic quartzite.

The impure marble unit of the Nome Group was found in closer proximity to and often in contact with the Windy Creek pluton and is correlative with a previously mapped unit (DOx) to the southeast that is a mix of marble, graphitic metasilicious rock and schist (Till et al., 2010). Marble units are easily visible in aerial photography both south of the Windy Creek pluton and also further west near the Bendeleben pluton as light gray exposures. Marble outcrops were well exposed and often in-place, though generally appearing only in lower-relief areas due to relative ease of weathering. Within the Nome Group this marble unit is strong, has a sugary appearance and is composed of millimeter sized crystals. Minor amounts of diopside were found in hand samples, though rare. Coloration of this unit varies from layered gray with prominent darker bands to pure white.

The graphitic quartzite unit was only seen near the southern edge of the Windy Creek pluton (Figure 2) and likely belongs to a part of the DOx unit defined by Till et al. (2010) as "black metasillicious rock." It is a very hard, black quartzite found in wellexposed in-place outcrop. At the contact with the Windy Creek pluton, this unit has a very high percentage of quartz-vein material, commonly up to $50 \%$ of the outcrop. Though generally exposed in sections less than one meter in thickness, this unit is common and mappable south of the Windy Creek pluton. 


\section{Kigluaik Metamorphic Complex:}

Our mappable units within the Kigluaik Metamorphic Complex include a quartzrich, garnet-bearing, pelitic biotite schist and a metamorphosed impure marble. These units are correlative with those described by Moffit (1913), Till and Dumoulin (1994) and Till et al. (2010) as the uppermost units of the Kigluaik "Group" and are thought to be the higher grade metamorphosed and structurally more deeply buried equivalents of Nome Group units.

The garnet-biotite schist is exposed directly south of, and in contact with, the Bendeleben pluton in either frost heaved boulder mounds or in-place outcrop (Figure 2). This unit was the most common metamorphic unit mapped in our field area and is correlative with parts of a Paleozoic-Proterozoic unit of high-grade metasedimentary and metaigneous rocks named by Till et al. (2010) as $\mathrm{PzPh}$. Although $\mathrm{PzPh}$, as defined by Till et al. (2010), describes a diverse package of metamorphic rocks, biotite-garnet schist was the only lithology from this unit observed in our field area. Diagnostic traits of the unit are high garnet and biotite content and well-foliated biotite layering, though samples from this unit also contain chlorite (likely retrograde), muscovite, apatite, K-feldspar, plagioclase, sillimanite and cordierite. Presence of garnet, sillimanite, cordierite and biotite within samples suggests stability at a temperature greater than $600^{\circ} \mathrm{C}$ at pressure less than $6 \mathrm{kbar}$ according to the $\mathrm{KFMASH}\left(\mathrm{SiO}_{2}-\mathrm{Al}_{2} \mathrm{O}_{3}-\mathrm{MgO}-\mathrm{FeO}-\mathrm{K}_{2} \mathrm{O}-\mathrm{H}_{2} \mathrm{O}\right)$ system (Spear, 1993), which is in agreement with contact metamorphism from the Bendeleben pluton.

Marble outcrops similar to those found in the Nome Group are seen further south of the Bendeleben pluton near the east-west striking Bendeleben normal fault. This 
marble unit is correlative with the Paleozoic-Proterozoic(?) PzPm unit described by Till et al. (2010) and the PzpCm unit of Till et al. (1986) (the more recent nomenclature, PzPm, is used in this study). This unit is very similar to marbles found within the DOx unit of the Nome Group, but has greater diopside content and is weaker and crumbly, making up the low relief regions in the foothills of the Bendeleben Mountains.

\section{Structural fabrics:}

While the pelitic schist unit (Ocs) of the Nome Group exposed south of the Windy Creek pluton is well-foliated, the typical nature of the outcrops as shifted tors led to inconsistency between measurements of both foliation and lineation. Impure marble outcrops of the DOx unit were generally poorly exposed leading to a paucity of field measurements.

The biotite-garnet schist unit $(\mathrm{PzPh})$ of the Kigluaik Metamorphic Complex is well foliated with strikes that average $085^{\circ}$ and dips that average $30^{\circ}$, mostly to the south (Figure 4a). Lineations within the Kigluaik Metamorphic Complex are defined by stretched quartz grains with an average trend of $153^{\circ}$ and gentle plunges between $10-20^{\circ}$ degrees (Figure 4c). Shear bands, mica fish and strain shadows around garnet porphyroblasts show top-down shear (Figures $3 \mathrm{~b}$ and 3c) and presence of biotite- and white mica-bordered shear zones from exposures are all indicative of extensional deformation. The marble unit of the Kigluaik Metamorphic Complex (PzPm), is generally well-foliated with strikes at an average of $092^{\circ}$ and dips at an average of $36^{\circ}$ consistently to the south (Figure 4b). 
a:

Kigluaik Metamorphic Complex

biotite-garnet schist

PzPh foliations

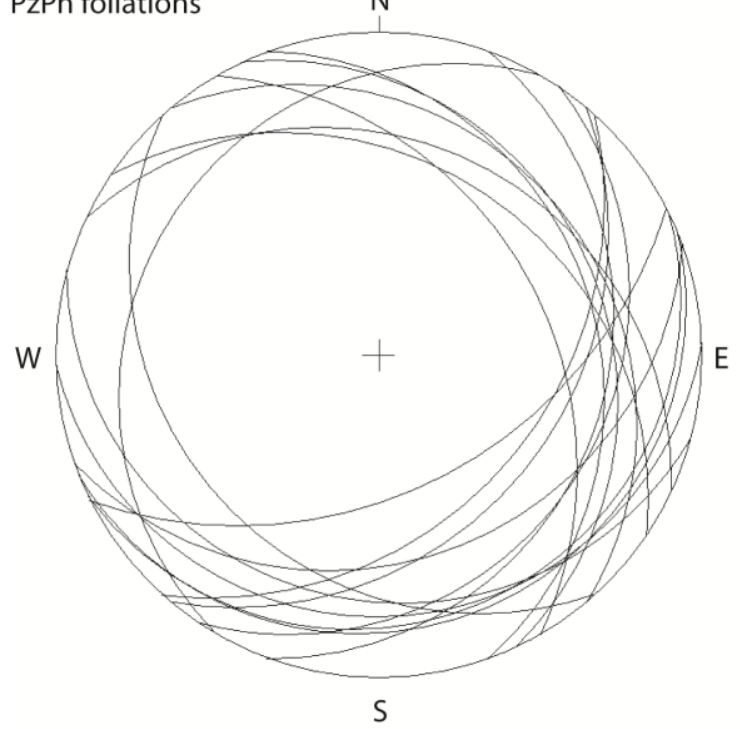

b:

Kigluaik Metamorphic Complex marble

PzPm foliations $\quad N$

W

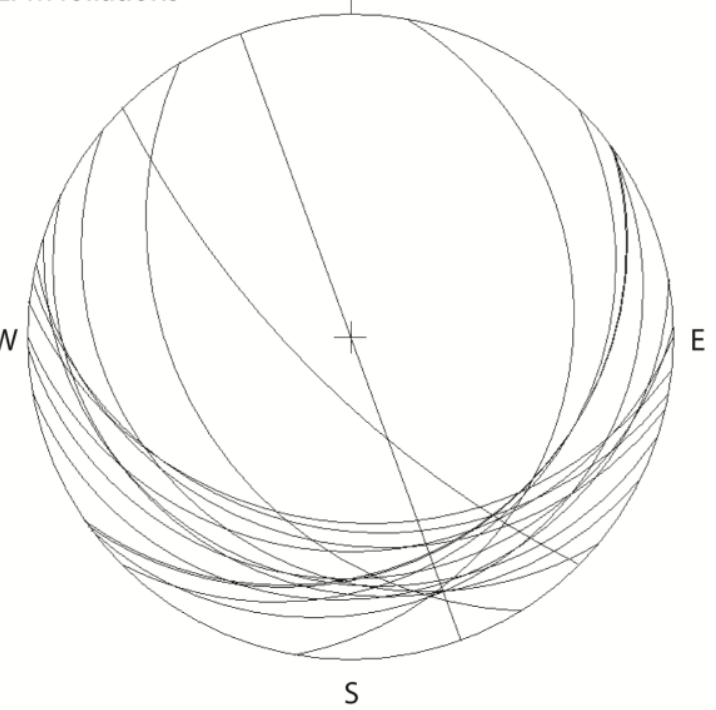

Kiglauik Metamorphic Complex biotite-garnet schist

PzPh lineations

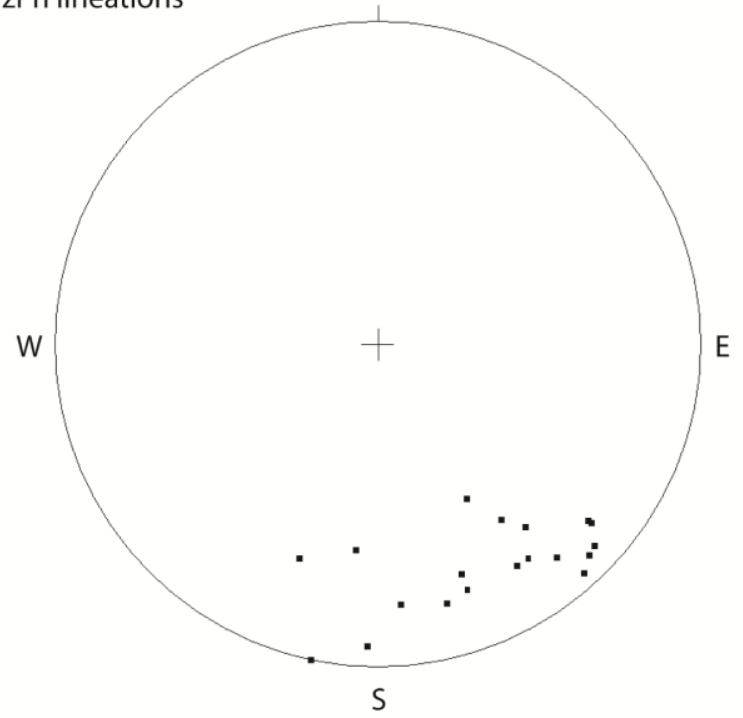

Figure 4: Equal-area stereonet plots of foliations and lineations within units of the Kigluaik Metamorphic Complex. Fabric orientation in Nome Group units were inconsistent. Plots made using GEOrient ver. 9.4.5 (Holcombe, 2010). 


\section{Bendeleben pluton:}

Analysis of hand samples, thin sections and field observations indicates that the Bendeleben pluton is actually composed of several igneous lithologies rather than one homogenous intrusion as was originally mapped, though most are rich in biotite; a common feature for Cretaceous intrusives of the Seward Peninsula (Amato and Miller, 1997; Amato et al., 2003). Within the study area, five separate mappable units within the Bendeleben pluton, ranging in composition from mafic to felsic, were recognized (Figures 2 and 5). Geochemical results from all igneous samples are summarized in Table 1. The gabbroic portion was the smallest mappable unit covering only approximately $2 \mathrm{~km}^{2}$ of the Bendeleben pluton exposure (Kb-ga, Figure 2). Normalized weight percents of major elements show relatively low $\mathrm{SiO}_{2}$ content $(59.8 \%)$, and relatively high $\mathrm{FeO}(5.5 \%), \mathrm{MgO}(1.6 \%)$ and $\mathrm{CaO}(4.4 \%)$ as compared to other intrusive lithologies mapped (Table 1). Point counts from thin section slides show average quartz, $\mathrm{K}$-feldspar and plagioclase (QAP) proportions from gabbro samples of $1 \%$ quartz, $<1 \%$ K-feldspar and 99\% plagioclase (Figure 5). Very high amounts of biotite (up to $30 \%$ of sample) were also seen, as well as minor amounts of sphene, epidote, hornblende and apatite. This unit is bordered to the west by a $9 \mathrm{~km}^{2}$ granodiorite unit ( $\mathrm{Kb}$-gr, Figure 2). Prevalent near the southern boundary of the granodiorite were multiple aplite and pegmatite intrusions, which locally cut through both the granodiorite and the country rock directly to the south. Geochemical analysis was not performed on any granodiorite samples. Thin section point count analysis shows average QAP proportions of $42 \%$ quartz, $18 \% \mathrm{~K}$-feldspar and $40 \%$ plagioclase from granodioritic samples. This unit is also very rich in biotite (approximately $10-20 \%$ of sample) and other minerals present 


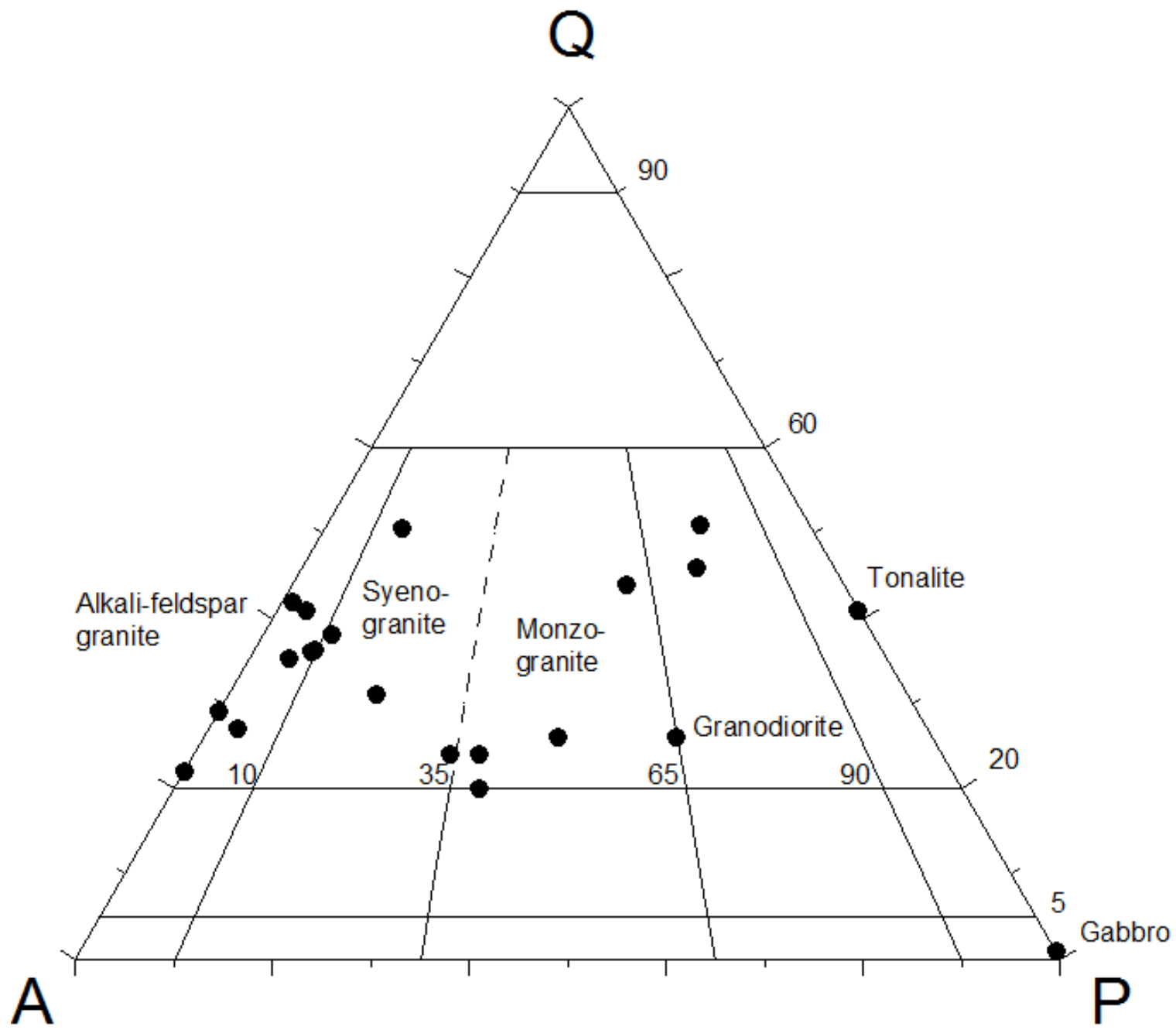

Figure 5: Ternary diagram of plutonic rocks from igneous samples of the Bendeleben and Windy Creek plutons. Classification of samples is based on modal content from point count analysis of thin sections. Field boundaries modified from Le Maitre et al. (2002). Q, A and P refer to quartz, alkali-feldspar and plagioclase content, respectively. 
include hornblende, sphene, apatite and zircon as well as rare garnet, epidote and muscovite. Surrounding the gabbro and granodiorite and extending east-west across the entire field area is a large (approximately $65 \mathrm{~km}^{2}$ ) body of alkali-feldspar granite ( $\mathrm{Kb}$-af, Figure 2). This unit extends another $10 \mathrm{~km}$ to the west of our field area with more details provided by Gottlieb and Amato (2008a). Chemical results from two alkali-feldspar granite samples show intermediate average normalized weight percents of $\mathrm{SiO}_{2}(71.2 \%)$, $\mathrm{FeO}(2.2 \%)$ and $\mathrm{MgO}(0.5 \%)$ and the highest average $\mathrm{K}_{2} \mathrm{O}(5.8 \%)$ weight percentages seen in the Bendeleben pluton (Table 1). Thin section point counts indicate average QAP proportions of $36 \%$ quartz, 59\% K-feldspar and 4\% plagioclase (Figure 5). Alkalifeldspar granites also contain common zircon, apatite and biotite (5-10\% of samples) and have trace amounts of sphene, amphibole, muscovite and chlorite. To the north, the interior of the Bendeleben pluton is composed entirely of monzogranite (Kb-mo) exposed over approximately $20 \mathrm{~km}^{2}$ within the field area and extending northward beyond it (Figure 2). Chemical results from this unit also show intermediate normalized weight percents of $\mathrm{SiO}_{2}(72.2 \%), \mathrm{FeO}(2.0 \%)$ and $\mathrm{MgO}(0.5 \%)$ (Table 1). Thin section analysis shows average QAP proportions of $24 \%$ quartz, $46 \% \mathrm{~K}$-feldspar and $31 \%$ plagioclase as well as minor amounts of biotite (5-15\% of sample), zircon, sericite, sphene, epidote, hornblende and muscovite (Figure 5).

The alkali-feldspar granite shows occasional biotite-defined foliation in the eastern part of the field area northwest of the Telephone Creek fault and east of a minor branching normal fault that cuts the Bendeleben pluton (Figure 2). Since this was the only granitic outcrop in our field area that displayed foliation, it was likely formed from interaction with the minor branching normal fault. If this foliation instead formed as a 
consequence of flow, then fault movement may have initiated before complete solidification of the Bendeleben pluton. Foliations here were at an average strike of $109^{\circ}$, approximately parallel to the fault, with an average dip of $29^{\circ}$ to the south.

A wedge shaped, high-strain mylonitic zone was exposed as a large field of rubble found along the Telephone Creek fault on the eastern margin of the Bendeleben pluton. In place outcrop was rare causing difficulty in determining shear zone orientation and kinematics. The mylonite was dominated by a well-foliated quartz groundmass with larger quartz and K-feldspar porphyroclasts, sericitized muscovite, garnet and minor epidote.

\section{Windy Creek pluton:}

The Windy Creek pluton, located southeast of the Bendeleben pluton, is composed of homogenous alkali-feldspar granite (Figure 5). The one sample analyzed for geochemistry shows relatively low $\mathrm{SiO}_{2}(67.2 \%)$ normalized weight percent content compared to similar units in the Bendeleben pluton and intermediate $\mathrm{FeO}(2.7 \%)$ and $\mathrm{MgO}(0.8 \%)$ content (Table 1$). \mathrm{K}_{2} \mathrm{O}$ normalized weight percent (5.4\%) was similar to values seen in the Bendeleben pluton. Point count analysis of thin sections gives average QAP proportions of 29\% quartz, 70\% K-feldspar and 1\% plagioclase (Figure 5). Thin section analysis also revealed presence of minor biotite, sphene, hornblende, zircon and apatite. Some locations near the rim of the pluton show mild evidence of foliation, but measurements were inconsistent. 


\section{Dike swarms:}

Within the Kigluaik Metamorphic Complex are several aplite dikes, aplite porphyry dikes, lamprophyres and pegmatites, which intrude biotite-garnet schist, marble and granodiorite exposures. Diabasic dike swarms prevalent in and around the Kigluaik gneiss dome to the west of the Bendeleben pluton and other dike swarms ranging in composition from diabasic to rhyolitic found in the Bendeleben, York and Darby Mountains are thought to have been emplaced during or directly following extensional deformation $\left(\mathrm{D}_{2}\right)$ from 90 to $80 \mathrm{Ma}$ (Amato et al., 2003; Amato and Wright, 1997; Amato et al., 1994; Miller and Bunker, 1976). In the Kigluaik dike complex, weighted-mean ${ }^{40} \mathrm{Ar} /{ }^{39} \mathrm{Ar}$ ages of dikes dated from groundmass and biotite samples range from approximately 80 to $84 \mathrm{Ma}$, approximately synonymous with $\mathrm{D}_{2}$ (Amato et al., 2003). Dike thicknesses in the Bendeleben Mountains range from as thin as a few centimeters to as thick as $50 \mathrm{~m}$ and were found intruding all types of lithologies mapped in the field area (Figure 6). Bearings of these dikes range from $075^{\circ}$ to $120^{\circ}$, though almost all are between $075^{\circ}$ and $095^{\circ}$ and all have dips between $80^{\circ}$ to the southeast and vertical. Aplites range from 0.5-1.0 m thick and are composed mostly of quartz and feldspar with minor garnet, chlorite and biotite, which define a weak foliation. Aplite porphyry dikes are composed of feldspar groundmass with subhedral quartz phenocrysts with trace amounts of muscovite and sphene and were heavily altered by fluid interaction to form common calcite. Normalized weight percents from a pegmatite unit bordering the granodiorite show the highest $\mathrm{SiO}_{2}(75.2 \%)$ content within the Bendeleben pluton and the lowest $\mathrm{FeO}(0.5 \%)$ and $\mathrm{MgO}(0.2 \%)$ content (Table 1$)$. The majority of the pegmatite is composed of quartz (36\%) and K-feldspar (52\%) crystals commonly greater than $1 \mathrm{~mm}$ 


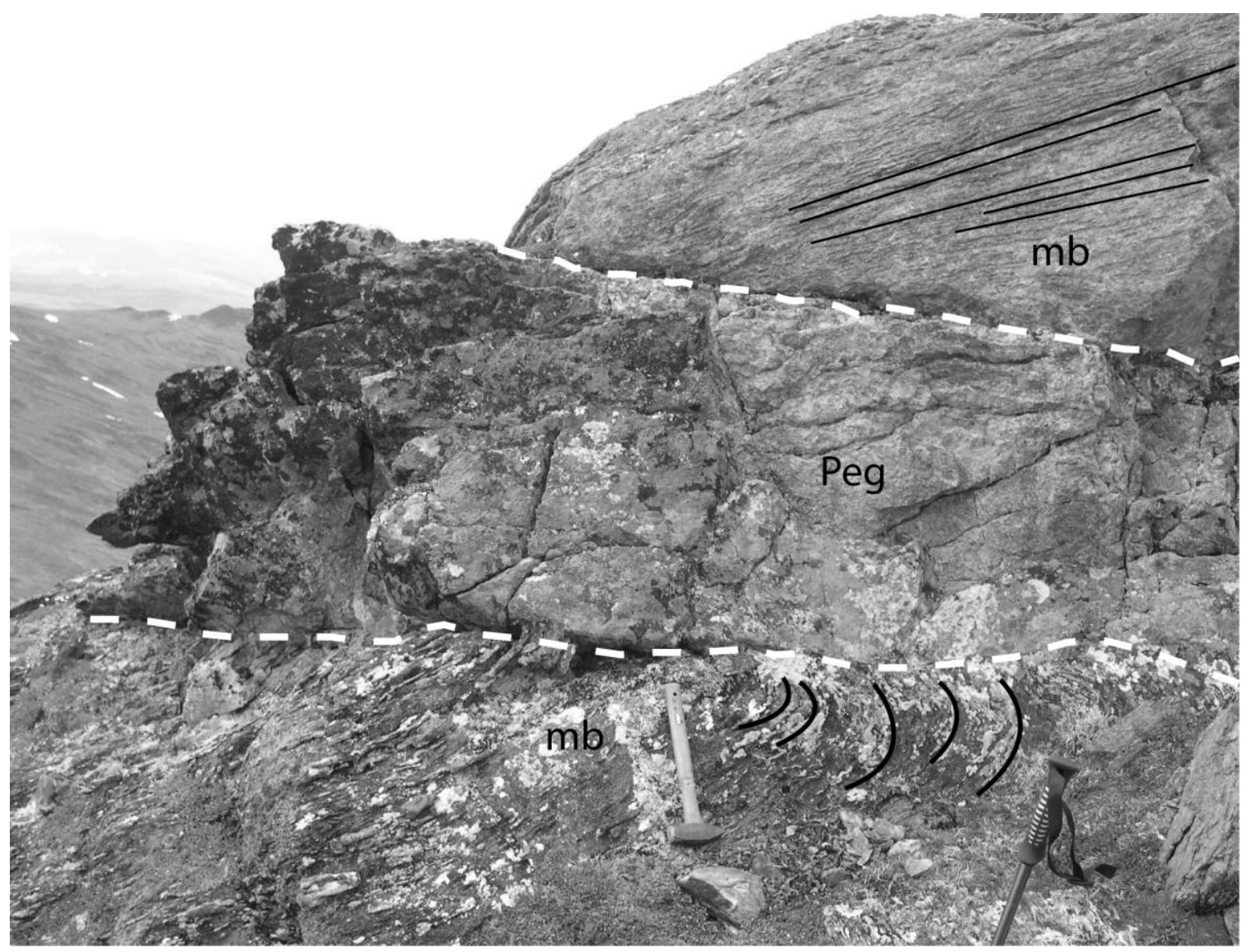

Figure 6: Pegmatite intrusion (Peg) through impure diopside-bearing marble unit (mb, $\mathrm{PzPm}$ ) in the Bendeleben Mountains. See text and Figure 2 for location. Sample 09BEN20 was collected from pegmatite at this location for geochronology and geochemistry and gave a concordant $\mathrm{U}-\mathrm{Pb}$ age of $86.1 \pm 0.3 \mathrm{Ma}$. View looking northwest. 
in diameter, though plagioclase $(7 \%)$, muscovite and sphene were also observed in thin section (Figure 5). A similar pegmatite unit bordering the nearby Kigluaik pluton was suggested to have been derived entirely by partial melting of the country rock based on isotopic composition (Amato and Wright, 1997) and is a possible analogue to pegmatite dikes in the Bendeleben Mountains.

\section{Geochronology:}

Five samples from the Bendeleben pluton and one sample from the Windy Creek pluton were dated using $\mathrm{U}-\mathrm{Pb}$ ratios measured from zircons at the Stanford University/USGS operated SHRIMP-RG instrument. Since the Bendeleben pluton is compositionally and texturally diverse, samples diagnostic of each sub-unit were dated (Figure 2). Discordant analyses, or those which yielded high ${ }^{204} \mathrm{~Pb}$ or very high $\mathrm{U}$ concentrations were discounted from age calculations. Some spots used in weighted mean plots were removed from concordia calculations due to visual misfit. All results are listed in Table 2 and Appendix 7 and shown in Tera-Wasserberg concordia plots in Figure 7 and in ${ }^{207} \mathrm{~Pb}$-corrected ${ }^{206} \mathrm{~Pb} /{ }^{238} \mathrm{U}$ weighted mean age plots in Figure 8. All analyzed grains range in size from 100 to $500 \mu \mathrm{m}$ in length and are largely free of inclusions, fractures and metamorphic overgrowths. See Figure 2 for all sample locations and Appendix 6 for CL images of all grains selected for analysis.

\section{BEN20 - Pegmatite cutting the Bendeleben pluton:}

Sample 09BEN20 was collected near the southern margin of the granodiorite unit, from a pegmatite dike that cuts through a marble outcrop (Figure 6). Though no sample 


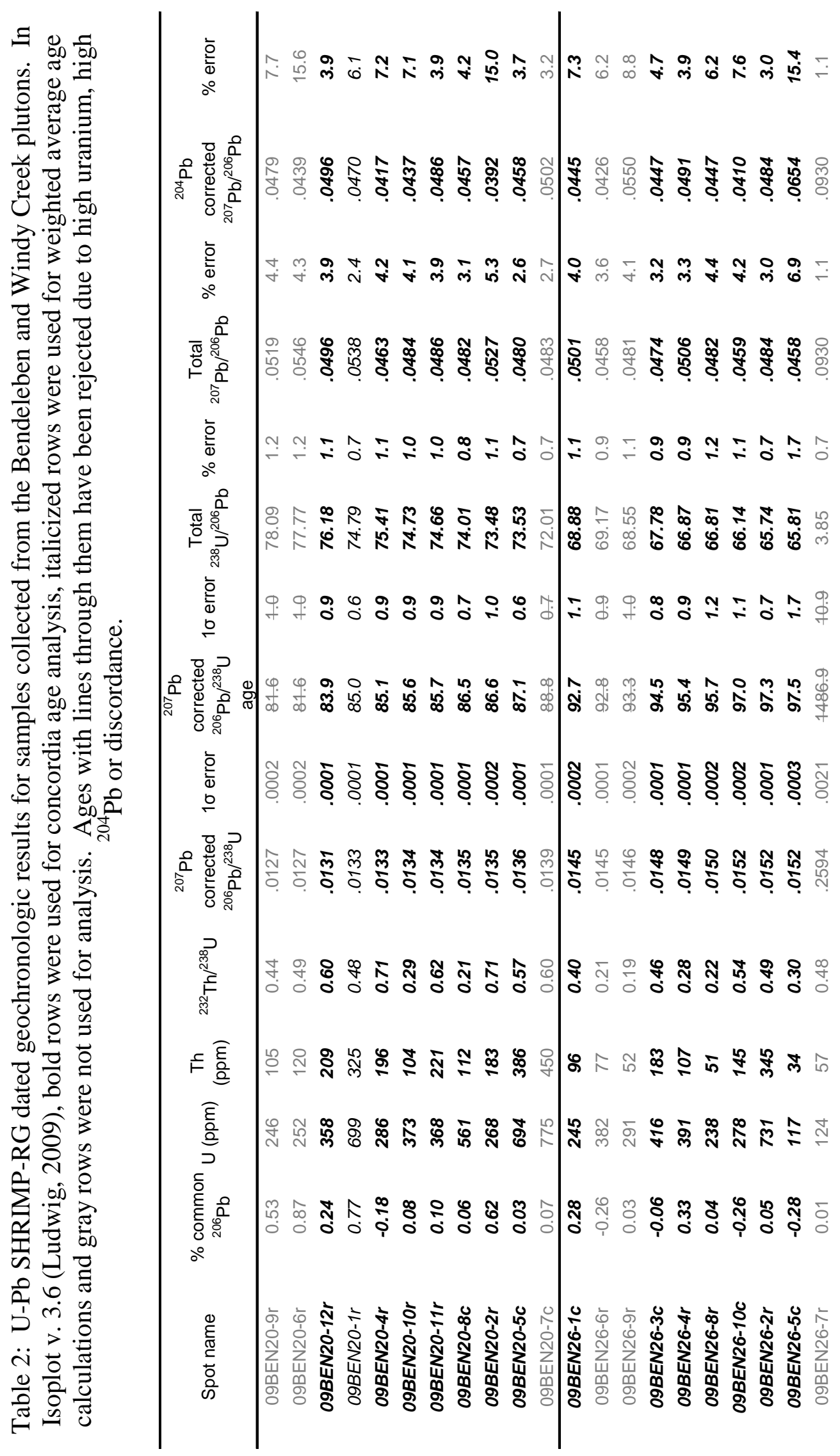




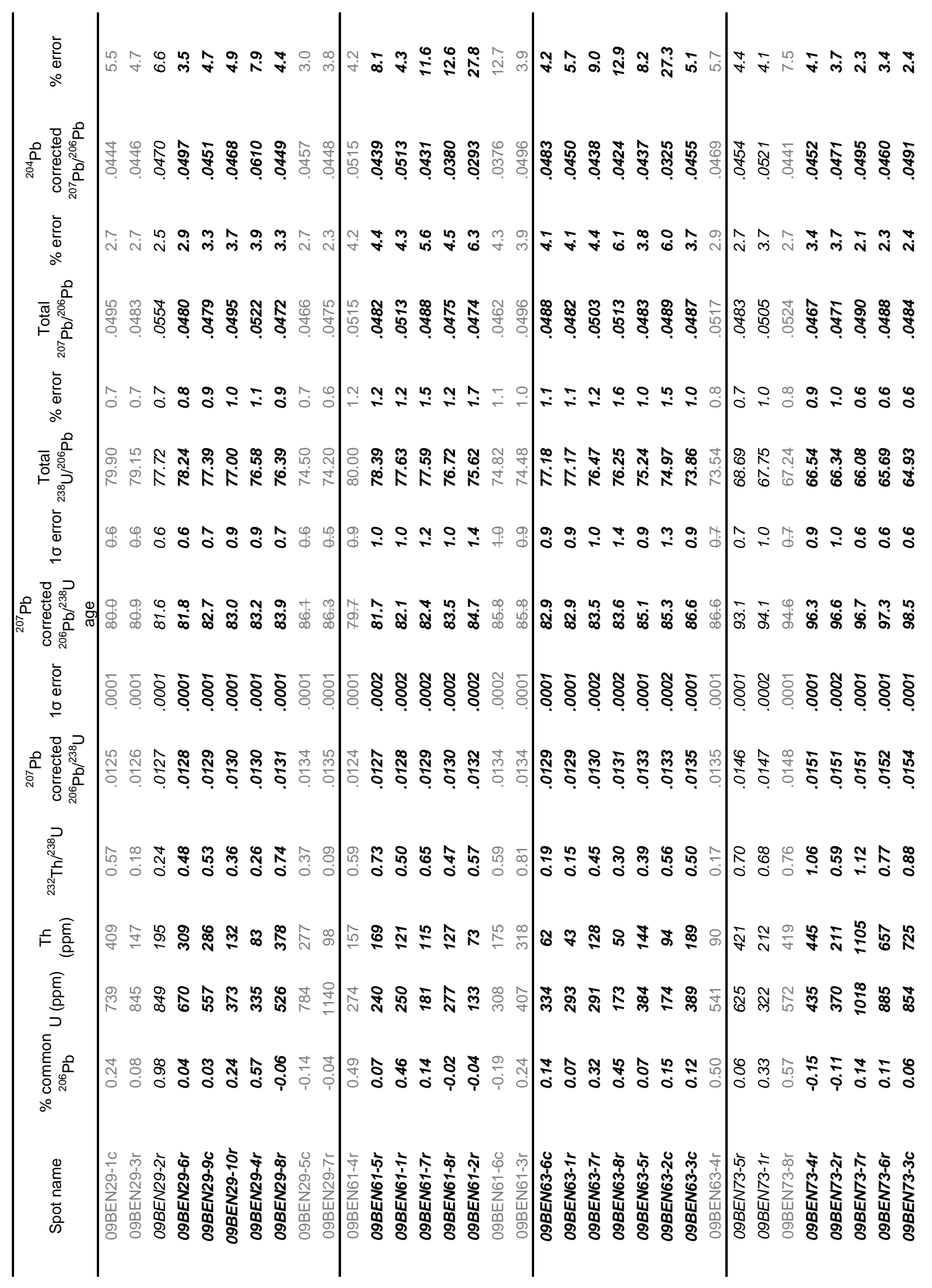



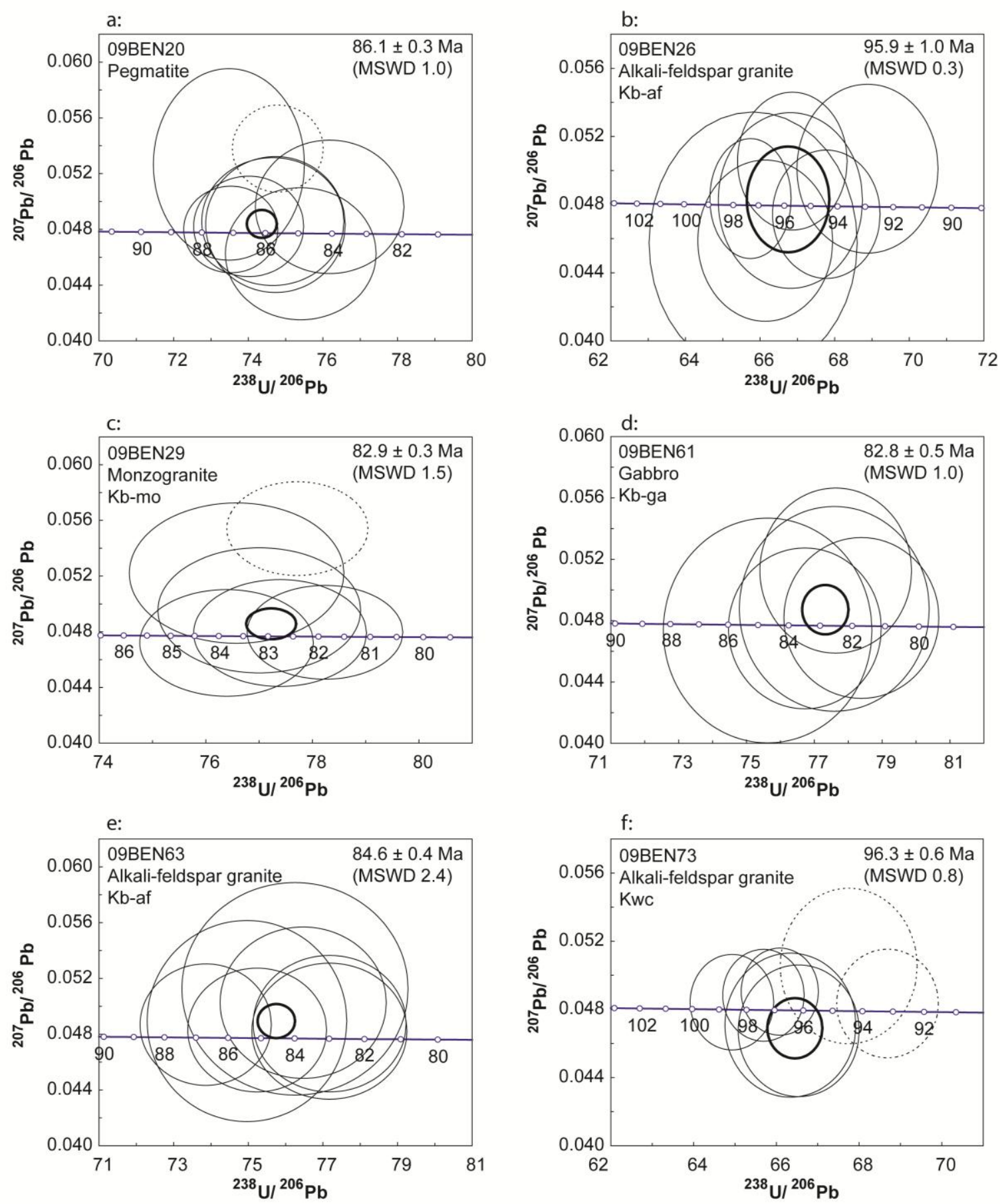

Figure 7: Concordia plots for $\mathrm{U}-\mathrm{Pb}$ zircon ages from samples collected from a pegmatite dike (a) and the Bendeleben (b-e) and Windy Creek (f) plutons. Plotted using Isoplot v. 3.6 (Ludwig, 2009). Dotted ellipses represent spot analyses removed for discordance, regular ellipses represent spots used for age determination and bold ellipses represent calculated concordia ages with error. 

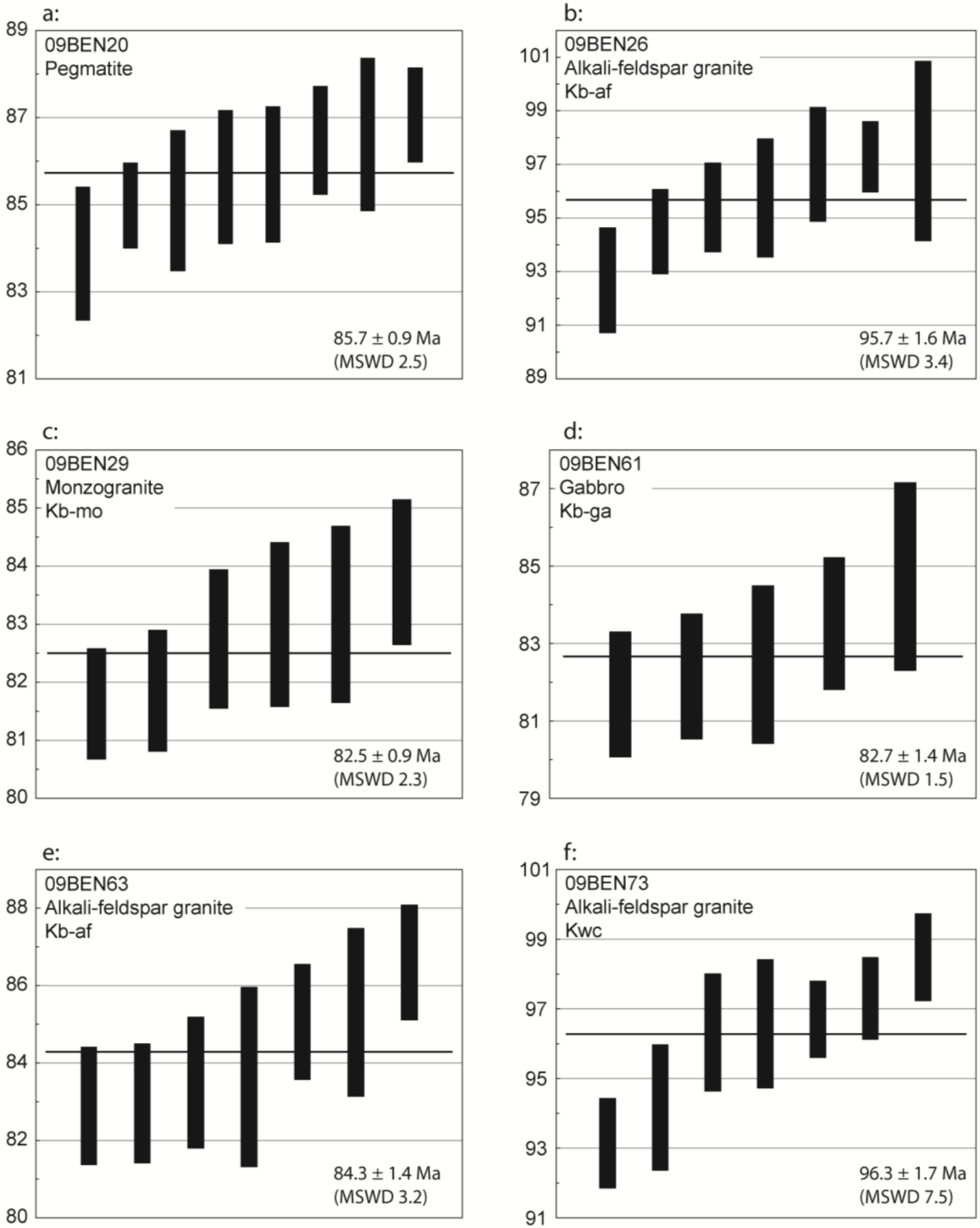

Figure 8: Weighted mean ${ }^{207} \mathrm{~Pb}$-corrected ${ }^{206} \mathrm{~Pb} /{ }^{238} \mathrm{U}$ ages for zircons from samples collected within a pegmatite dike (a) and the Bendeleben (b-e) and Windy Creek (f) plutons. Plotted using Isoplot v. 3.6 (Ludwig, 2009). 
was dated from the granodiorite, the southern region of this unit is dominated by pegmatitic dikes which intrude both the marble unit to the south and the granodiorite. Due to cross-cutting relationships of pegmatites intruding the granodiorite, the age of the pegmatite gives a minimum age for the granodiorite unit. Zircon grains ranged from stubby and equant to long and skinny and ranged in color from honey to clear. CL imaging revealed simple zoning patterns and a general lack of metamorphic overgrowth, inclusions or fractures. Eight grains were used for the final age determination using two core analyses and six rim analyses to calculate a concordia age of $86.1 \pm 0.3 \mathrm{Ma}$ (MSWD 1.0), excluding one spot for discordance, and a weighted mean age of $85.7 \pm 0.9 \mathrm{Ma}$.

09BEN26 - Bendeleben pluton, alkali-feldspar granite:

Sample 09BEN26 was collected from the biotite-rich alkali-feldspar granite unit near the western boundary of our field area and represents the westernmost sample collected. Zircons were almost entirely honey colored and subhedral. Separation yielded small amounts of zircon, mostly large in size around $300 \mu \mathrm{m}$ long. Grains that were dark under CL, indicative of high uranium concentrations, were avoided for analysis, as were grains with complex zoning or metamorphic rims. Seven grains were used for final age determination using four core analyses and three rim analyses to calculate a concordia age of $95.9 \pm 1.0 \mathrm{Ma}(\mathrm{MSWD} 0.3)$ and a weighted mean age of $95.7 \pm 1.6 \mathrm{Ma}$. Alkalifeldspar granite of this age is likely truncated by the younger mafic intrusives to the east, so this age is inferred to be accurate for all alkali-feldspar granites west of the granodiorite within our field area (Figure 2). 
09BEN29 - Bendeleben pluton, monzogranite:

Sample 09BEN29 was collected from the northern monzogranite unit. Zircons were mostly elongated, euhedral and clear and were rarely longer than $200 \mu \mathrm{m}$ in length. Most grains showed simple zoning patterns under CL, though a few showed metamorphic recrystallization. Six grains were used for final age determination using one core analysis and five rim analyses to calculate a concordia age of $82.9 \pm 0.3 \mathrm{Ma}$ (MSWD 1.5), excluding one spot for discordance, and a weighted mean age of $82.5 \pm 0.9$ Ma.

09BEN61 - Bendeleben pluton, gabbro:

Sample 09BEN61 was collected from the central gabbro unit and was the youngest sample dated by zircon geochronology in our field area. All zircons were elongated, euhedral and clear. Grains were generally bright under CL imaging and showed simple zoning patterns. Five grains were used for final age determination using only rim analyses to calculate a concordia age of $82.8 \pm 0.5 \mathrm{Ma}$ (MSWD 1.0) and a weighted mean age of $82.7 \pm 1.4 \mathrm{Ma}$.

09BEN63 - Bendeleben pluton, alkali-feldspar granite:

Sample 09BEN63 was collected from the alkali-feldspar granite unit in the northeastern region of the field area. Zircons were stubby and generally equant with either rounded or euhedral shapes and displayed a consistent honey-blonde color. Rounded grains had abundant zones of internal recrystallization and convolute zoning under CL (Corfu et al., 2003) and were avoided for analysis. Euhedral grains showed simple magmatic growth zoning and were used exclusively for analysis. Seven grains 
were used for final age determination using three core analyses and four rim analyses to calculate a concordia age of $84.6 \pm 0.4 \mathrm{Ma}$ (MSWD 2.4) and a weighted mean age of $84.3 \pm 1.4 \mathrm{Ma}$.

09BEN73 - Windy Creek pluton, alkali-feldspar granite:

Sample 09BEN73 was collected from the topographically highest point within the Windy Creek pluton and was the only sample dated from this unit. Zircons were bimodal in size with large ( 200 $\mu \mathrm{m}$ long), cloudy, honey-colored grains and small $(\sim 100 \mu \mathrm{m}$ long), clear grains. All zircons were dark under CL, but displayed simple zoning with no evidence for metamorphic overgrowth. Seven grains were used for final age determination using one core analysis and six rim analyses to calculate a concordia age of $96.3 \pm 0.6 \mathrm{Ma}$ (MSWD 0.8), excluding 2 spots for discordance, and a weighted mean age of $96.3 \pm 1.7 \mathrm{Ma}$.

\section{Trace element and REE}

Comparison of incompatible trace element concentrations of $\mathrm{Rb}$ to $\mathrm{Nb}+\mathrm{Y}$ has been shown to be useful in making interpretations as to the tectonic setting for intrusion of large igneous bodies into the shallow crust (Pearce et al., 1984). Ratios of $(\mathrm{Nb}+\mathrm{Y})$ to $\mathrm{Rb}$ in ppm for all plutonic bulk rock samples except the gabbro in the Bendeleben pluton plot along the boundary between the syn-collisional and volcanic arc fields of a trace element discrimination diagram modeled after Pearce et al. (1984) (Figure 9). The syncollisional field most accurately describes S-type granites formed under continentcontinent or arc-continent collisional settings where $\mathrm{Rb}$ values are enriched due to 


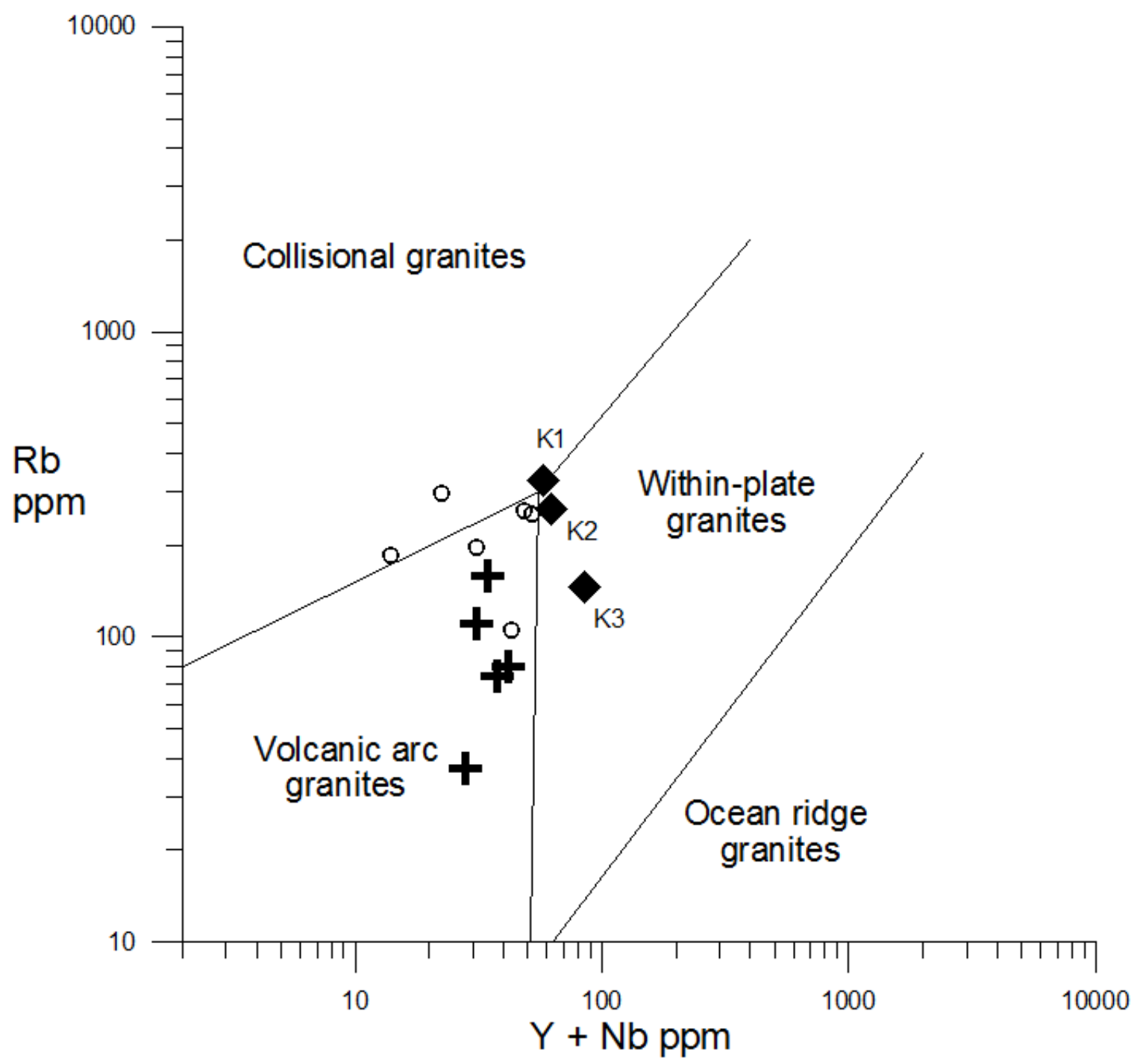

Figure 9: Trace element discrimination diagram modeled after Pearce et al. (1984) for intrusive samples collected from the Bendeleben and Windy Creek plutons (open circles), Kigluaik pluton (diamonds) (Amato and Wright, 1997) and Okhotsk-Chukotka Volcanic Belt (crosses) (Akinin and Miller, 2011). K1 represents the mafic root, K2 represents the mixing zone and K3 represents the felsic cap all from the Kigluaik pluton (Amato and Wright, 1997). 
volatile interaction with a subducting slab. The volcanic arc field describes granites intruded at active continental margins where subduction of oceanic crust is occurring. Samples from the Bendeleben pluton suggest that the magma generation which later fed multiple injection events from 104-82 Ma was likely initiated during the long-lived preCretaceous subduction setting for the Seward Peninsula along with terrane accretion via multiple arc and continental collision events. This interpretation is in agreement with the suggestion that Cretaceous plutonism in the Seward Peninsula is the result of slabrollback-induced extension above an actively subducting slab during the Cretaceous (Amato and Miller, 1997). In this case, rollback was caused as the northward subducting plate beneath Russia and the Seward Peninsula moved southward, causing extension in the overlying plate (Figure 10). The tendency of some samples to plot near the boundary between the volcanic arc and syn-collisional fields is suggestive of either generation in a $\mathrm{Rb}$-poor crust or of partial mixing between mantle and crust-derived magmas (Pearce et al., 1984). Data from the Kigluaik pluton plot near the triple junction between collisional, within-plate and volcanic arc granites, though the "felsic cap" plots in the within-plate field (Figure 9). Trace elemental data for volcanic samples from the Okhotsk-Chukotka Volcanic Belt (OCVB) at ages similar to the Bendeleben and Windy Creek plutons were also plotted in discrimination diagrams modeled after Pearce et al. (1984) and all fell into the volcanic arc field (Figure 9) descriptive of formation along an active subduction front. Plots of ppm $\mathrm{Y}, \mathrm{Rb}$ and $\mathrm{Nb}$ against weight percent $\mathrm{SiO}_{2}$ for samples in the Bendeleben and Windy Creek plutons also plot in fields supporting a combined collisional and volcanic arc setting for magma generation based on $\mathrm{Nb}$ and $\mathrm{Y}$ concentrations (Pearce et al., 1984), and are more likely to have intruded continental crust 
a:

Late Jurassic

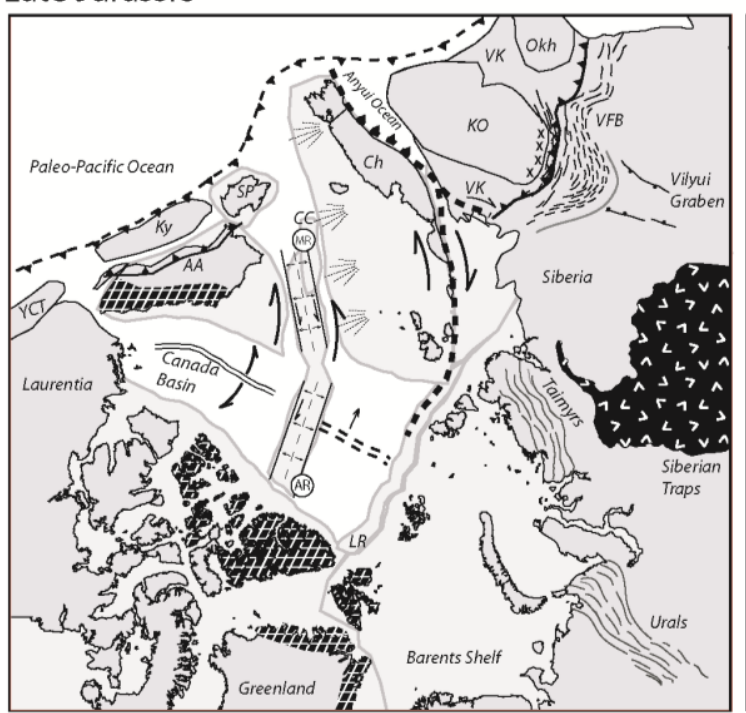

Caledonide orogen

passive margin sedimentation

$\therefore$ Okhotsk-Chukotka volcanic belt

(Middle Albian to Early Campanian)

$\underset{x}{x} \times \quad$ Main Belt magmatism

(Late Jurassic to Early Cretaceous) b: Late Cretaceous ( 80 Ma)

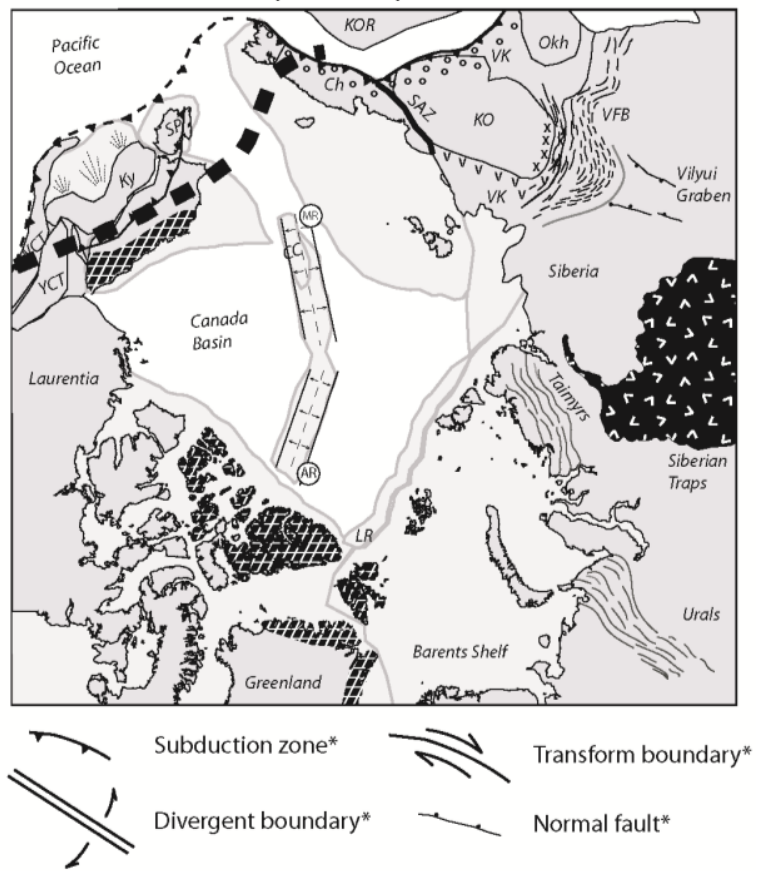

*All plate boundaries and fault locations are dashed when approximated

Figure 10: Schematic plate reconstruction for the motion and location of various continental fragments of the Arctic during the Late Jurassic (a) and Late Cretaceous (b) (Harris et al., 2011, chapter II, this volume). The heavy dashed line in Figure 10b shows the prior location of subduction during the Jurassic seen in Figure 10a. Alaska terrane accretion history from Plafker and Berg (1994), South Anyui Suture info from Sokolov et al. (2009), Russian terrane accretionary history from Parfenov et al. (2009) and bathymetric images and approximate locations of the Alpha Ridge and Mendeleev Ridge are from Jakobsson et al. (2008) and Dove et al. (2010). Magmatic arc ages are from Akinin and Miller (2011) and Layer et al. (2001). Abbreviations are: AA, Arctic Alaska; AR, Alpha

Ridge; CC, Chukchi Cap; Ch, Chukotka; Kb, Koyukuk basin; KO, Kolyma-Omolon superterrane; KOR, Koryak-Kamchatka tectonic collage; Ky, Koyukuk arc; LR, Lomonosov Ridge; MR, Mendeleev Ridge; Okh, Okhotsk terrane; PA, Penzhina-Anadyr tectonic collage; SAZ, South Anyui Suture zone; SP, Seward Peninsula; VFB,

Verkhoyansk Fold-Thrust Belt; VK, Verkhoyansk tectonic collage; WCT, Wrangellia composite terrane; YCT, Yukon composite terrane. 
than to be rift-related based on $\mathrm{Rb}$ concentrations (Figure 11). Samples from the Bendeleben pluton show a decrease in $\mathrm{Rb}$ concentrations along with younging of crystallization while $(\mathrm{Nb}+\mathrm{Y})$ concentrations show increase with younging (Figure 12). This is tentatively interpreted as gradual enrichment of incompatible elements in the melt phase of a core magma chamber leading to higher eventual concentrations in progressively younger intrusives. The gradual decrease of $\mathrm{Rb}$ concentrations is most likely related to the tendency of $\mathrm{Rb}$ to be incorporated into older alkali-feldspar granites as compared to younger, mafic lithologies.

Chondrite-normalized REE patterns for zircons that were collected from intrusive samples of our field area display similar patterns with minor differences (Figure 13, Table 3). Despite differences in relative REE amounts, zircons from all samples showed depletion in LREE and enrichment in HREE likely caused by similarity of HREE ionic radii to that of $\mathrm{Zr}$ leading to ease of substitution (Hoskin and Ireland, 2000). Negative $\mathrm{Eu}$ anomalies and positive $\mathrm{Ce}$ anomalies were also seen in zircons from all samples, which is a typical feature for chondrite-normalized REE in zircons (Hoskin and Ireland, 2000). Studies of zircon REE patterns as a tool for provenance indication have suggested that despite a diverse array of magma crystallization conditions, REE patterns are generally similar and are not typically useful in terms of provenance indication (Hoskin and Ireland, 2000; Sawka, 1988) though can be useful as source rock lithology indicators when found in detrital samples (Belousova et al., 2002).

Zircons from the pegmatite unit show relative enrichment in $\mathrm{La}, \mathrm{Pr}$ and $\mathrm{Nd}$ relative to other samples, but are similar in all other REE content. Zircons from all other intrusive samples from the Bendeleben pluton are similar in REE content despite 

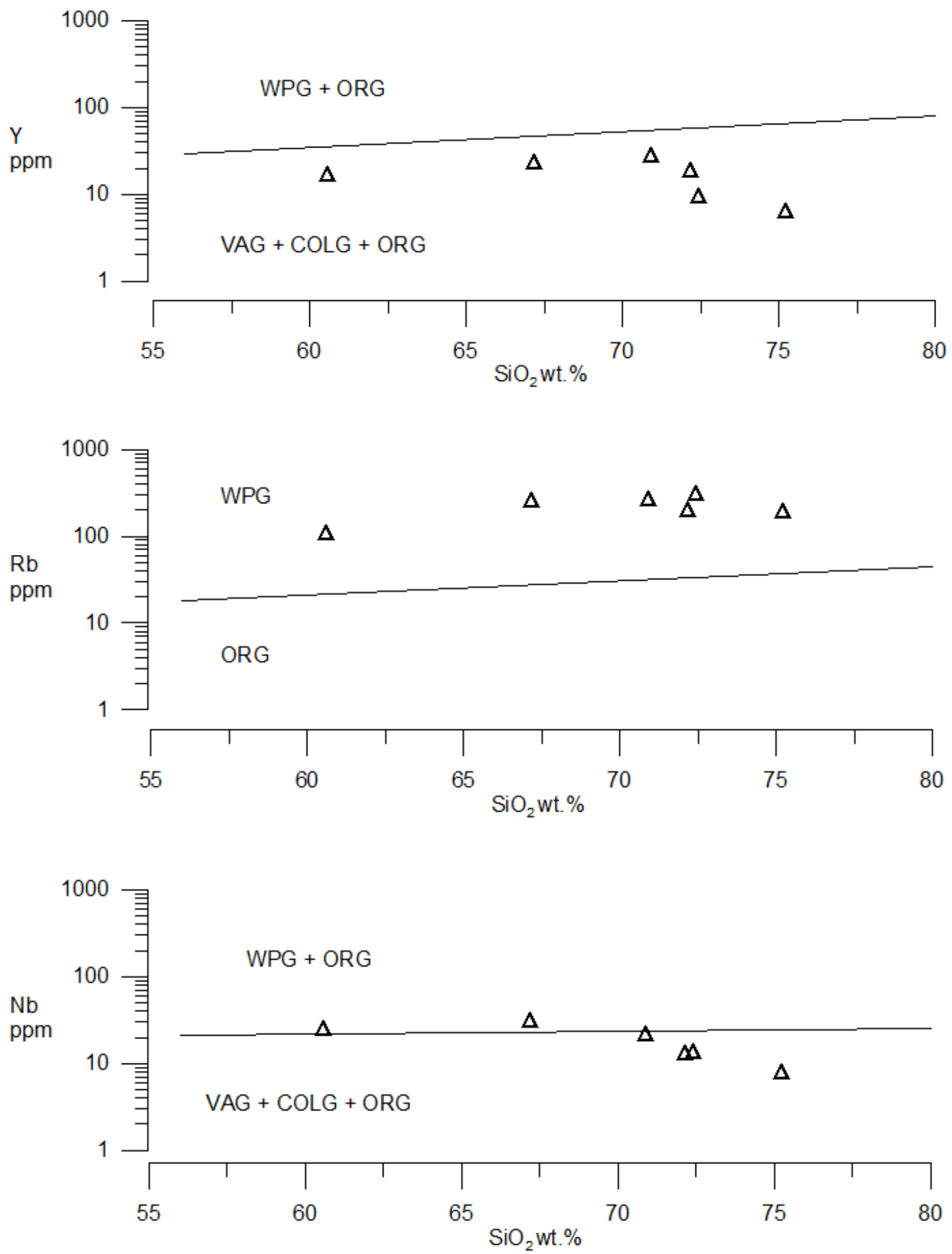

Figure 11: Trace element concentrations in ppm plotted against $\mathrm{SiO}_{2}$ expressed as weight $\%$ in discrimination diagrams modeled after Pearce et al. (1984). Abbreviations are: ocean ridge granites (ORG), volcanic arc granites (VAG), within-plate granites (WPG) and collisional granites (COLG). 

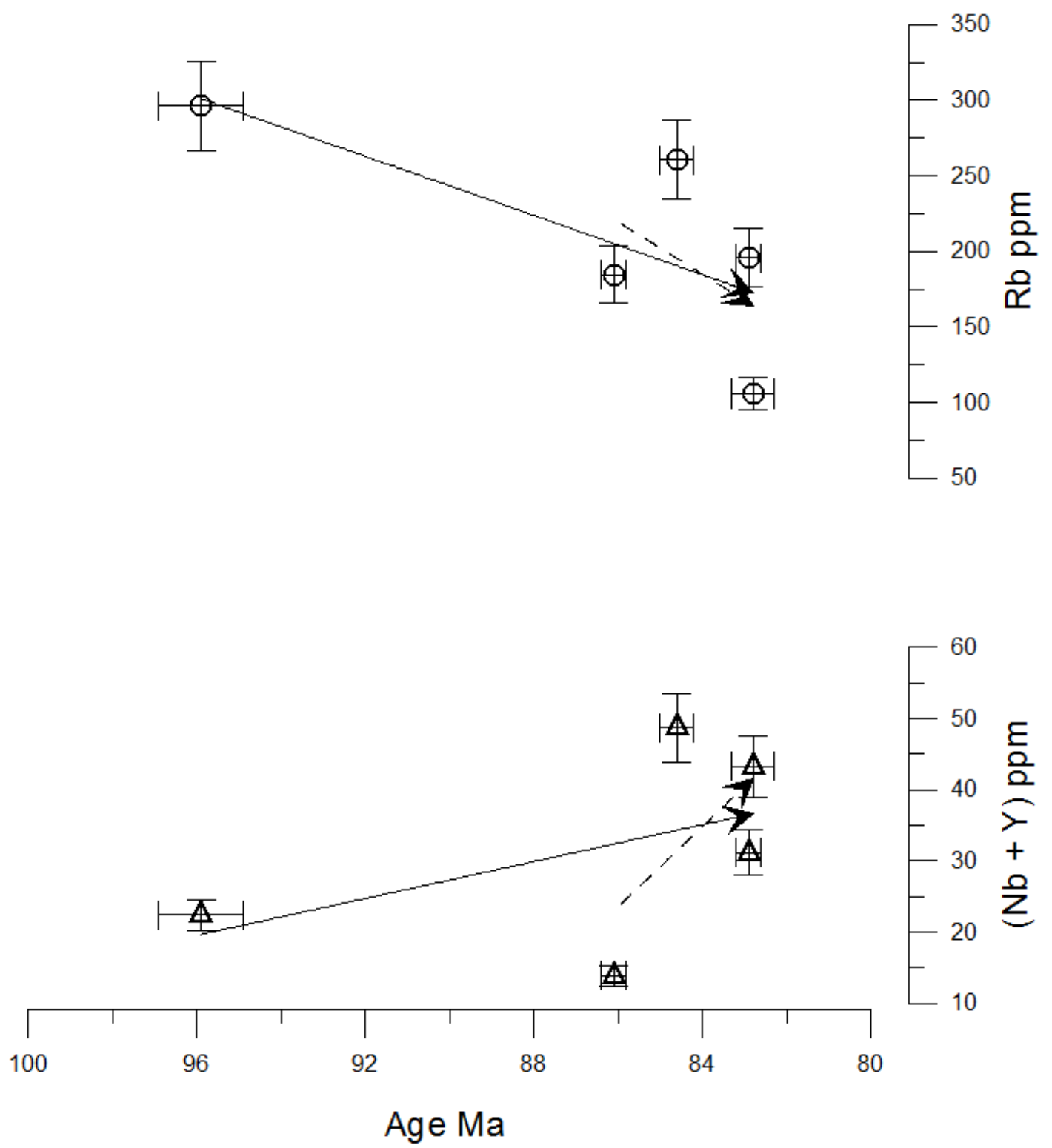

Figure 12: Trace element concentrations in ppm plotted against sample age. Note the difference in scale between $(\mathrm{Nb}+\mathrm{Y})$ and $\mathrm{Rb}$ concentrations. Solid lines show trends for all data and dashed lines show trends for the younger pulse of magmatism. Graphs do not incorporate any correction for variable lithology. 

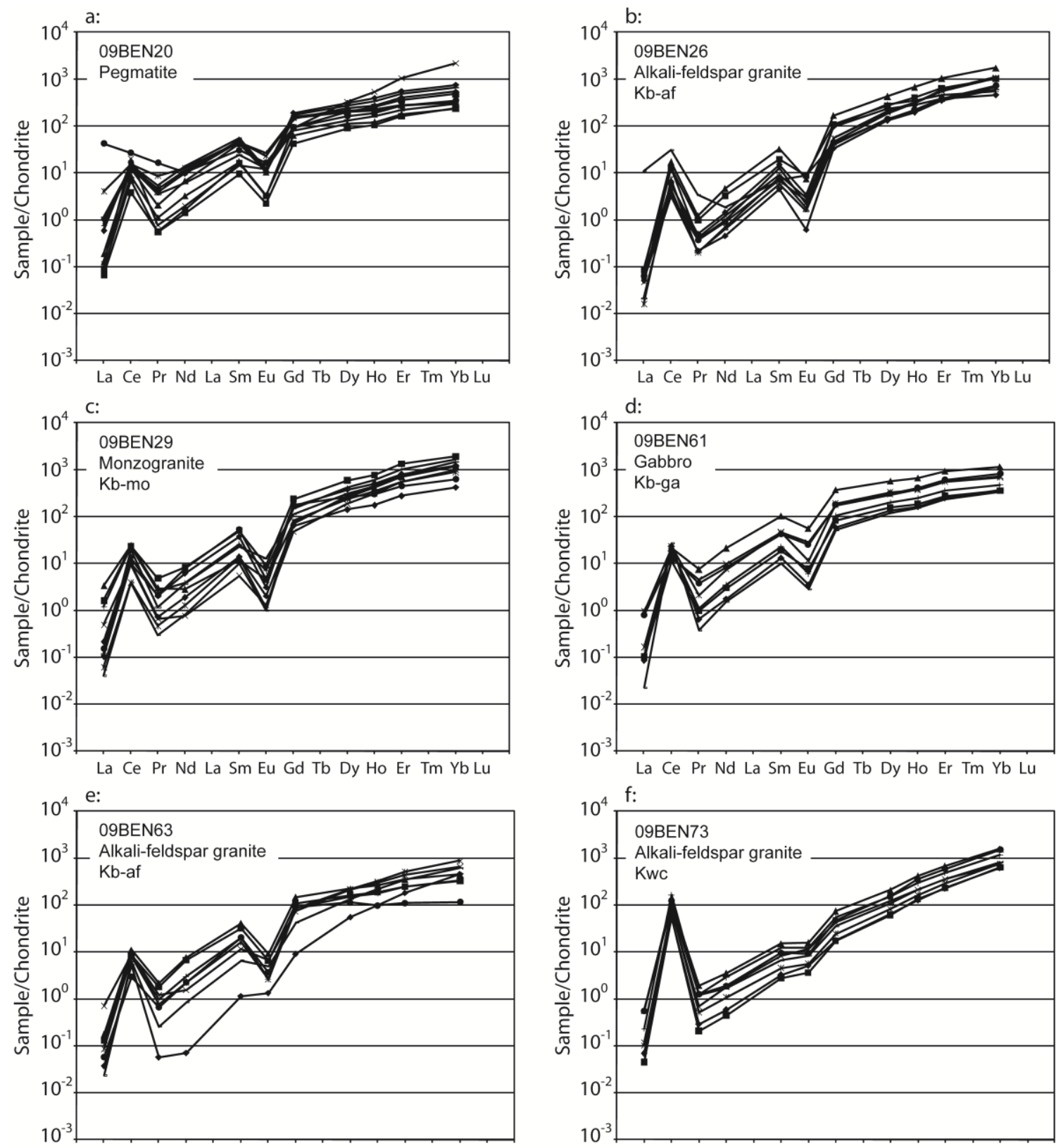

La Ce Pr Nd La Sm Eu Gd Tb Dy Ho Er Tm Yb Lu

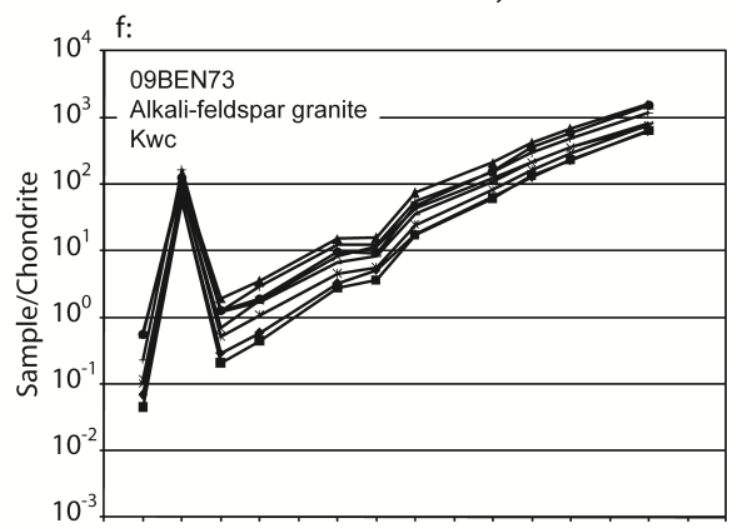

La Ce Pr Nd La Sm Eu Gd Tb Dy Ho Er Tm Yb Lu

Figure 13: Chondrite-normalized REE concentrations of zircons from samples collected within a pegmatite dike (a) and the Bendeleben (b-e) and Windy Creek (f) plutons. Data in Table 3. 
Table 3: Chondrite-normalized REE content of zircons collected from the Bendeleben and Windy Creek plutons. Plots in Figure 13.

\begin{tabular}{|c|c|c|c|c|c|c|c|c|c|c|c|}
\hline & $\mathrm{La}$ & $\mathrm{Ce}$ & $\operatorname{Pr}$ & $\mathrm{Nd}$ & $\mathrm{Sm}$ & $\mathrm{Eu}$ & $\mathrm{Gd}$ & Dy & Ho & $\mathrm{Er}$ & $\mathrm{Yb}$ \\
\hline Atomic \# & 57 & 58 & 59 & 60 & 62 & 63 & 64 & 66 & 67 & 68 & 70 \\
\hline 09BEN20-1 & 1.0 & 13.0 & 4.6 & 9.7 & 46.1 & 10.3 & 143.9 & 239.7 & 270.5 & 401.1 & 539.5 \\
\hline 09BEN20-2 & 4.0 & 15.5 & 8.6 & 12.5 & 45.3 & 22.7 & 145.6 & 196.9 & 214.9 & 267.2 & 314.5 \\
\hline 09BEN20-3 & 42.2 & 26.8 & 16.4 & 10.2 & 30.6 & 16.5 & 93.7 & 162.0 & 186.5 & 268.2 & 348.6 \\
\hline 09BEN20-4 & 0.8 & 12.9 & 4.5 & 11.2 & 44.1 & 26.7 & 145.0 & 201.6 & 211.4 & 272.9 & 320.3 \\
\hline 09BEN20-5 & 0.8 & 15.0 & 5.4 & 13.9 & 54.6 & 12.4 & 170.1 & 273.7 & 331.7 & 482.0 & 651.2 \\
\hline 09BEN20-6 & 1.1 & 13.3 & 3.5 & 6.1 & 23.8 & 12.4 & 80.2 & 131.7 & 159.8 & 218.5 & 297.9 \\
\hline 09BEN20-7 & 0.6 & 16.6 & 3.9 & 10.1 & 49.9 & 10.8 & 189.1 & 302.7 & 393.3 & 550.3 & 750.8 \\
\hline 09BEN20-8 & 0.1 & 3.8 & 0.6 & 1.6 & 16.1 & 3.2 & 93.0 & 199.6 & 254.9 & 361.0 & 478.1 \\
\hline 09BEN20-9 & 0.1 & 8.5 & 1.1 & 3.2 & 16.9 & 3.3 & 61.9 & 112.1 & 120.1 & 178.2 & 233.9 \\
\hline 09BEN20-10 & 0.1 & 6.9 & 0.5 & 1.4 & 9.4 & 2.2 & 41.8 & 88.2 & 104.8 & 158.6 & 238.7 \\
\hline 09BEN20-11 & 0.2 & 12.2 & 2.0 & 6.7 & 42.5 & 10.5 & 156.5 & 214.3 & 224.2 & 283.0 & 311.0 \\
\hline 09BEN20-12 & 0.1 & 20.1 & 0.8 & 2.0 & 14.5 & 12.0 & 89.1 & 324.9 & 533.6 & 1034.7 & 2187.7 \\
\hline 09BEN26-1 & 0.1 & 5.6 & 0.5 & 1.4 & 15.0 & 3.4 & 96.0 & 230.8 & 275.4 & 374.9 & 460.6 \\
\hline 09BEN26-2 & 0.1 & 17.2 & 1.2 & 4.7 & 32.6 & 7.6 & 168.2 & 429.6 & 674.8 & 1041.3 & 1737.9 \\
\hline 09BEN26-3 & 0.0 & 12.6 & 0.4 & 1.2 & 9.1 & 2.9 & 55.0 & 191.7 & 306.4 & 546.5 & 1039.9 \\
\hline 09BEN26-4 & 0.0 & 7.4 & 0.2 & 0.7 & 8.1 & 1.8 & 55.0 & 206.3 & 318.0 & 561.7 & 1069.2 \\
\hline 09BEN26-5 & 0.1 & 6.1 & 0.4 & 0.9 & 7.2 & 8.8 & 43.6 & 138.1 & 220.8 & 376.5 & 717.3 \\
\hline 09BEN26-6 & 0.1 & 3.4 & 0.4 & 1.0 & 12.9 & 2.1 & 97.9 & 289.6 & 348.0 & 462.4 & 542.8 \\
\hline 09BEN26-7 & 11.1 & 30.8 & 3.4 & 1.9 & 6.8 & 2.5 & 45.3 & 184.4 & 306.9 & 582.8 & 1112.2 \\
\hline 09BEN26-8 & 0.0 & 4.5 & 0.2 & 0.6 & 5.8 & 1.5 & 40.0 & 141.9 & 198.6 & 345.5 & 602.5 \\
\hline 09BEN26-9 & 0.1 & 3.2 & 0.2 & 0.5 & 4.5 & 0.6 & 33.2 & 131.2 & 196.4 & 349.3 & 684.3 \\
\hline 09BEN26-10 & 0.1 & 13.1 & 1.0 & 3.3 & 19.4 & 8.8 & 107.7 & 274.1 & 400.7 & 633.2 & 1023.1 \\
\hline 09BEN29-1 & 1.6 & 23.2 & 4.8 & 8.2 & 49.5 & 9.1 & 233.4 & 587.5 & 755.8 & 1316.8 & 1918.9 \\
\hline 09BEN29-2 & 3.3 & 24.0 & 3.0 & 2.8 & 11.7 & 4.6 & 74.8 & 253.6 & 411.9 & 695.3 & 1190.4 \\
\hline 09BEN29-3 & 0.5 & 9.3 & 0.7 & 0.8 & 5.5 & 1.3 & 47.1 & 185.5 & 305.3 & 543.9 & 988.8 \\
\hline 09BEN29-4 & 0.1 & 4.0 & 0.5 & 1.3 & 12.9 & 1.1 & 81.0 & 235.3 & 341.2 & 551.8 & 881.1 \\
\hline 09BEN29-5 & 0.2 & 9.8 & 2.1 & 7.8 & 52.4 & 4.6 & 177.8 & 264.6 & 300.7 & 445.8 & 618.1 \\
\hline 09BEN29-6 & 1.2 & 22.6 & 2.6 & 3.8 & 25.7 & 7.0 & 144.8 & 409.4 & 606.8 & 1013.5 & 1624.9 \\
\hline 09BEN29-7 & 0.0 & 3.9 & 0.3 & 0.8 & 9.9 & 1.0 & 70.3 & 269.8 & 456.0 & 760.2 & 1465.9 \\
\hline 09BEN29-8 & 0.1 & 19.4 & 1.2 & 3.7 & 22.5 & 12.8 & 111.9 & 304.0 & 437.9 & 741.0 & 1181.2 \\
\hline 09BEN29-9 & 0.2 & 13.1 & 2.0 & 6.1 & 37.1 & 3.1 & 164.9 & 372.6 & 499.5 & 796.0 & 1211.9 \\
\hline 09BEN29-10 & 0.1 & 10.0 & 0.7 & 1.9 & 13.8 & 2.0 & 63.3 & 140.5 & 174.5 & 275.4 & 419.7 \\
\hline
\end{tabular}




\begin{tabular}{|c|c|c|c|c|c|c|c|c|c|c|c|}
\hline & $\mathrm{La}$ & $\mathrm{Ce}$ & $\operatorname{Pr}$ & $\mathrm{Nd}$ & $\mathrm{Sm}$ & $\mathrm{Eu}$ & $\mathrm{Gd}$ & Dy & Ho & $\mathrm{Er}$ & $\mathrm{Yb}$ \\
\hline Atomic \# & 57 & 58 & 59 & 60 & 62 & 63 & 64 & 66 & 67 & 68 & 70 \\
\hline 09BEN61-1 & 0.1 & 23.5 & 0.6 & 1.8 & 13.2 & 3.5 & 58.7 & 133.1 & 161.5 & 249.8 & 362.5 \\
\hline 09BEN61-2 & 0.1 & 11.4 & 1.0 & 3.0 & 18.5 & 7.6 & 81.2 & 155.5 & 184.5 & 274.8 & 356.2 \\
\hline 09BEN61-3 & 0.9 & 21.2 & 7.5 & 21.3 & 102.7 & 55.4 & 370.3 & 565.8 & 662.3 & 931.9 & 1157.1 \\
\hline 09BEN61-4 & 1.0 & 13.1 & 4.5 & 9.7 & 45.8 & 27.8 & 173.0 & 291.0 & 377.5 & 539.3 & 717.2 \\
\hline 09BEN61-5 & 0.2 & 23.3 & 2.1 & 7.4 & 45.7 & 11.4 & 188.0 & 328.2 & 366.8 & 545.4 & 678.3 \\
\hline 09BEN61-6 & 0.8 & 13.9 & 3.8 & 8.2 & 42.5 & 25.0 & 174.5 & 305.6 & 405.1 & 594.8 & 812.6 \\
\hline 09BEN61-7 & 0.1 & 19.2 & 1.1 & 3.5 & 23.0 & 6.0 & 103.5 & 200.6 & 244.6 & 357.4 & 474.9 \\
\hline 09BEN61-8 & 0.0 & 26.8 & 0.4 & 1.5 & 10.1 & 2.8 & 51.4 & 118.7 & 153.0 & 231.7 & 334.2 \\
\hline 09BEN63-1 & 0.0 & 5.3 & 0.1 & 0.1 & 1.1 & 1.3 & 9.0 & 55.1 & 99.3 & 180.6 & 459.9 \\
\hline 09BEN63-2 & 0.1 & 8.6 & 1.8 & 6.7 & 32.0 & 6.4 & 109.0 & 162.8 & 187.1 & 249.1 & 328.1 \\
\hline 09BEN63-3 & 0.2 & 11.1 & 2.2 & 7.6 & 40.9 & 9.2 & 147.2 & 222.4 & 263.9 & 355.1 & 451.3 \\
\hline 09BEN63-4 & 0.7 & 8.8 & 1.2 & 1.5 & 11.6 & 6.6 & 74.3 & 208.9 & 292.7 & 436.0 & 666.1 \\
\hline 09BEN63-5 & 0.1 & 7.9 & 0.8 & 2.2 & 16.2 & 2.6 & 85.9 & 221.2 & 321.0 & 521.1 & 882.2 \\
\hline 09BEN63-6 & 0.1 & 2.9 & 0.7 & 2.2 & 20.4 & 3.6 & 90.2 & 114.3 & 97.7 & 111.0 & 115.6 \\
\hline 09BEN63-7 & 0.1 & 7.8 & 1.0 & 3.0 & 19.8 & 2.7 & 87.7 & 153.6 & 177.5 & 249.6 & 333.0 \\
\hline 09BEN63-8 & 0.0 & 6.2 & 0.3 & 0.8 & 6.5 & 4.9 & 42.1 & 132.6 & 215.9 & 344.3 & 610.4 \\
\hline 09BEN73-1 & 0.1 & 52.9 & 0.3 & 0.6 & 3.2 & 5.1 & 17.5 & 64.3 & 127.8 & 229.3 & 624.9 \\
\hline 09BEN73-2 & 0.0 & 54.6 & 0.2 & 0.4 & 2.8 & 3.6 & 17.1 & 60.6 & 134.3 & 228.7 & 638.0 \\
\hline 09BEN73-3 & 0.6 & 117.9 & 1.9 & 3.5 & 15.1 & 15.7 & 74.7 & 209.9 & 413.7 & 685.1 & 1581.6 \\
\hline 09BEN73-4 & 0.1 & 75.5 & 0.7 & 1.8 & 8.2 & 11.7 & 43.3 & 121.5 & 213.2 & 355.3 & 737.9 \\
\hline 09BEN73-5 & 0.1 & 78.9 & 0.5 & 1.1 & 4.5 & 5.6 & 24.4 & 80.9 & 162.9 & 289.1 & 764.2 \\
\hline 09BEN73-6 & 0.5 & 124.3 & 1.2 & 1.9 & 9.6 & 9.1 & 46.8 & 155.0 & 353.7 & 587.1 & 1510.9 \\
\hline 09BEN73-7 & 0.2 & 166.5 & 1.3 & 2.9 & 12.3 & 12.4 & 54.7 & 149.5 & 294.3 & 490.2 & 1167.8 \\
\hline 09BEN73-8 & 0.6 & 99.8 & 1.2 & 1.7 & 6.7 & 8.4 & 35.8 & 107.8 & 214.4 & 359.4 & 822.2 \\
\hline
\end{tabular}


difference in petrography. Zircons from the one sample collected from the Windy Creek pluton, however, are enriched in Ce by an order of magnitude relative to all other samples. Similarly, both $\mathrm{Ce} / \mathrm{Ce}^{*}$ and $\mathrm{Eu} / \mathrm{Eu}^{*}$ ratios are several times higher for zircons from the Windy Creek pluton than any lithologic unit of the Bendeleben pluton (Table 4) where $\mathrm{Ce}^{*}$ and $\mathrm{Eu}^{*}$ are the expected concentrations by interpolating bordering elements based on atomic number ( $\mathrm{La}$ and $\mathrm{Pr}$ for $\mathrm{Ce} e^{*}, \mathrm{Sm}$ and $\mathrm{Gd}$ for $\left.\mathrm{Eu}^{*}\right) . \mathrm{Ce} / \mathrm{Ce} *$ ratios for all samples are greater than 1, indicative of positive anomalies, and $\mathrm{Eu} / \mathrm{Eu}^{*}$ values for all samples are less than 1, indicative of negative anomalies (Figure 13, Table 4).

\section{Zircon Ti concentration geothermometry}

Titanium concentrations were measured for all samples collected from the Bendeleben and Windy Creek plutons and were used as indicators of approximate crystallization geothermometers based on modeling by Watson et al. (2006). By conducting a series of experiments in which synthetic zircons were crystallized and subsequently analyzed for their Ti concentrations under various temperatures, a general equation of:

$$
\log \left(\mathrm{Ti}_{\text {zircon }}\right)=(6.01 \pm 0.03)-\frac{5080 \pm 30}{\mathrm{~T}(\mathrm{~K})}
$$

was formed describing the dependence of Ti concentration in zircon structure to crystallization temperature (Watson et al., 2006). Results from samples collected in the Bendeleben pluton were similar to those for the Windy Creek pluton with a consistent crystallization temperature for all samples between $796^{\circ}$ and $836^{\circ} \mathrm{C}\left( \pm \sim 15^{\circ} \mathrm{C}\right)$ except 
Table 4: Chondrite-normalized $\mathrm{Ce}$ and Eu ratios of zircons collected from the Bendeleben and Windy Creek plutons.

\begin{tabular}{|c|c|c|c|c|c|}
\hline & $\mathrm{Ce} / \mathrm{Ce}^{*}$ & $\mathrm{Eu} / \mathrm{Eu}^{*}$ & & $\mathrm{Ce} / \mathrm{Ce}^{*}$ & $\mathrm{Eu} / \mathrm{Eu}^{*}$ \\
\hline 09BEN20-1 & 6 & 0.13 & 09BEN61-1 & 99 & 0.13 \\
\hline 09BEN20-2 & 3 & 0.28 & 09BEN61-2 & 36 & 0.20 \\
\hline 09BEN20-3 & 1 & 0.31 & 09BEN61-3 & 8 & 0.28 \\
\hline 09BEN20-4 & 7 & 0.33 & 09BEN61-4 & 6 & 0.31 \\
\hline 09BEN20-5 & 7 & 0.13 & 09BEN61-5 & 40 & 0.12 \\
\hline 09BEN20-6 & 7 & 0.28 & 09BEN61-6 & 8 & 0.29 \\
\hline 09BEN20-7 & 11 & 0.11 & 09BEN61-7 & 56 & 0.12 \\
\hline 09BEN20-8 & 20 & 0.08 & 09BEN61-8 & 292 & 0.12 \\
\hline 09BEN20-9 & 22 & 0.10 & & & \\
\hline 09BEN20-10 & 32 & 0.11 & & & \\
\hline 09BEN20-11 & 20 & 0.13 & 09BEN63-1 & 115 & 0.42 \\
\hline \multirow[t]{3}{*}{ 09BEN20-12 } & 68 & 0.33 & 09BEN63-2 & 17 & 0.11 \\
\hline & & & 09BEN63-3 & 18 & 0.12 \\
\hline & & & 09BEN63-4 & 10 & 0.23 \\
\hline 09BEN26-1 & 32 & 0.09 & 09BEN63-5 & 31 & 0.07 \\
\hline 09BEN26-2 & 56 & 0.10 & 09BEN63-6 & 15 & 0.08 \\
\hline 09BEN26-3 & 90 & 0.13 & 09BEN63-7 & 25 & 0.06 \\
\hline 09BEN26-4 & 133 & 0.09 & 09BEN63-8 & 81 & 0.30 \\
\hline 09BEN26-5 & 40 & 0.50 & & & \\
\hline 09BEN26-6 & 23 & 0.06 & & & \\
\hline 09BEN26-7 & 5 & 0.14 & 09BEN73-1 & 372 & 0.68 \\
\hline 09BEN26-8 & 68 & 0.10 & 09BEN73-2 & 568 & 0.52 \\
\hline 09BEN26-9 & 31 & 0.05 & 09BEN73-3 & 113 & 0.47 \\
\hline \multirow[t]{3}{*}{ 09BEN26-10 } & 46 & 0.19 & 09BEN73-4 & 284 & 0.62 \\
\hline & & & 09BEN73-5 & 321 & 0.53 \\
\hline & & & 09BEN73-6 & 150 & 0.43 \\
\hline 09BEN29-1 & 8 & 0.08 & 09BEN73-7 & 307 & 0.48 \\
\hline 09BEN29-2 & 8 & 0.16 & 09BEN73-8 & 118 & 0.54 \\
\hline 09BEN29-3 & 16 & 0.08 & & & \\
\hline 09BEN29-4 & 23 & 0.03 & & & \\
\hline 09BEN29-5 & 17 & 0.05 & & & \\
\hline 09BEN29-6 & 13 & 0.12 & & & \\
\hline 09BEN29-7 & 35 & 0.04 & & & \\
\hline 09BEN29-8 & 53 & 0.26 & & & \\
\hline 09BEN29-9 & 20 & 0.04 & & & \\
\hline 09BEN29-10 & 37 & 0.07 & & & \\
\hline
\end{tabular}


for the pegmatite unit (sample 09BEN20) which yielded a crystallization temperature of $911^{\circ} \mathrm{C}$ (Table 5).

\section{Discussion:}

\section{Relationship between the Bendeleben and Windy Creek plutons:}

The Telephone Creek fault mapped between the Bendeleben and Windy Creek plutons is an eastward dipping normal fault that separates the Bendeleben pluton and high-grade metamorphic rocks of the Kigluaik Metamorphic Complex from the Windy Creek pluton and greenschist-grade rocks of the Nome Group. On a more regional scale, this fault also separates the east-west trending Bendeleben Mountains from the northern part of the north-south trending Darby Mountains. Immediately obvious in the field is the discrepancy between topography of the landscapes in these two mountain belts (Figure 14). The Bendeleben Mountains are composed of high relief, jagged ridges with little vegetation cover at the summits. The Darby Mountains, in the eastern part of our field area, were much different, composed of lower-relief, broad, rounded peaks with prevalent vegetation cover (Figure 14). This is simplistic evidence that the Darby Mountains may represent longer exposure at the surface than the Bendeleben Mountains. The delayed exposure of the Bendeleben Mountains is most likely a consequence of exhumation of the Bendeleben Mountains along the Bendeleben fault to the south than exhumation along the Telephone Creek fault. Apatite (U-Th)/He dating is in agreement with young exhumation of the Bendeleben Mountains as average apatite ages dated from the Bendeleben pluton are $38.7 \pm 2.4$ Ma suggesting passage of the Bendeleben pluton 
Table 5: Crystallization temperatures for magmatic samples collected in the Bendeleben and Windy Creek plutons based on titanium concentrations (ppm) of zircons as measured via SHRIMP-RG. At the end of the sample names an $\mathrm{R}$ indicates a zircon rim analysis and a $\mathrm{C}$ indicates a zircon core analysis. Temperature modeling performed using equations defined by Watson et al. (2006).

\begin{tabular}{|c|c|c|c|c|c|}
\hline & Sample & Calculated $\mathrm{T}\left({ }^{\circ} \mathrm{C}\right)$ & $\mathrm{Ti}(\mathrm{ppm})$ & max calculated $\mathrm{T}\left({ }^{\circ} \mathrm{C}\right)$ & min calculated $\mathrm{T}\left({ }^{\circ} \mathrm{C}\right)$ \\
\hline \multirow{13}{*}{ 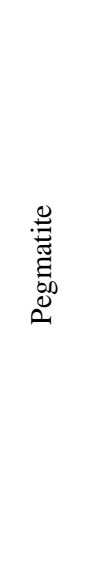 } & 09BEN20-1R & 916.2 & 54.7 & 931.7 & 900.9 \\
\hline & 09BEN20-2R & 987.8 & 95.7 & 1004.8 & 971.1 \\
\hline & 09BEN20-3R & 996.2 & 101.7 & 1013.4 & 979.3 \\
\hline & 09BEN20-4C & 939.9 & 66.3 & 955.9 & 924.2 \\
\hline & 09BEN20-5C & 958.1 & 76.5 & 974.4 & 942.0 \\
\hline & 09BEN20-6R & 912.2 & 52.9 & 927.6 & 897.0 \\
\hline & 09BEN20-7C & 967.2 & 82.0 & 983.8 & 950.9 \\
\hline & 09BEN20-8C & 845.6 & 29.4 & 859.7 & 831.7 \\
\hline & 09BEN20-9C & 893.8 & 45.3 & 908.8 & 878.9 \\
\hline & 09BEN20-10R & 832.6 & 26.0 & 846.4 & 819.0 \\
\hline & 09BEN20-11R & 930.4 & 61.5 & 946.2 & 914.9 \\
\hline & 09BEN20-12R & 762.2 & 12.7 & 774.8 & 749.9 \\
\hline & AVERAGE 09BEN20 & 911.9 & 58.7 & 927.3 & 896.7 \\
\hline \multirow{10}{*}{ 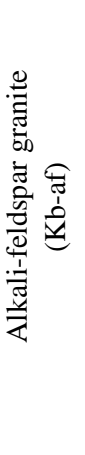 } & 09BEN26-1C & 815.5 & 22.0 & 829.0 & 802.1 \\
\hline & 09BEN26-2R & 791.4 & 17.3 & 804.5 & 778.5 \\
\hline & 09BEN26-3C & 801.0 & 19.1 & 814.3 & 787.9 \\
\hline & 09BEN26-4R & 736.3 & 9.5 & 748.4 & 724.4 \\
\hline & 09BEN26-5C & 833.9 & 26.3 & 847.7 & 820.2 \\
\hline & 09BEN26-6R & 808.8 & 20.6 & 822.2 & 795.6 \\
\hline & 09BEN26-7C & 840.6 & 28.1 & 854.6 & 826.8 \\
\hline & 09BEN26-8R & 779.4 & 15.2 & 792.3 & 766.8 \\
\hline & 09BEN26-9R & 764.1 & 12.9 & 776.6 & 751.7 \\
\hline & AVERAGE 09BEN26 & 796.8 & 19.0 & 809.9 & 783.8 \\
\hline \multirow{8}{*}{ 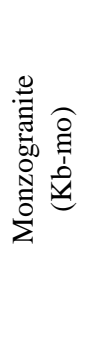 } & 09BEN29-1C & 774.6 & 14.5 & 787.3 & 762.0 \\
\hline & 09BEN29-2R & 801.9 & 19.2 & 815.1 & 788.8 \\
\hline & 09BEN29-3R & 699.7 & 6.1 & 711.1 & 688.4 \\
\hline & 09BEN29-4R & 866.2 & 35.5 & 880.7 & 851.9 \\
\hline & 09BEN29-5C & 913.1 & 53.3 & 928.5 & 897.9 \\
\hline & 09BEN29-6R & 766.2 & 13.2 & 778.8 & 753.8 \\
\hline & 09BEN29-8R & 818.0 & 22.6 & 831.5 & 804.6 \\
\hline & AVERAGE 09BEN29 & 805.7 & 23.5 & 819.0 & 792.5 \\
\hline
\end{tabular}




\begin{tabular}{|c|c|c|c|c|c|}
\hline & Sample & Calculated $\mathrm{T}\left({ }^{\circ} \mathrm{C}\right)$ & $\mathrm{Ti}(\mathrm{ppm})$ & max calculated $\mathrm{T}\left({ }^{\circ} \mathrm{C}\right)$ & min calculated $\mathrm{T}\left({ }^{\circ} \mathrm{C}\right)$ \\
\hline \multirow{9}{*}{ 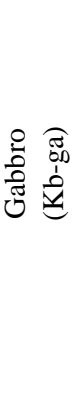 } & 09BEN61-1R & 839.1 & 27.7 & 853.0 & 825.3 \\
\hline & 09BEN61-2R & 767.7 & 13.5 & 780.3 & 755.3 \\
\hline & 09BEN61-3R & 838.9 & 27.6 & 852.8 & 825.1 \\
\hline & 09BEN61-4R & 844.2 & 29.0 & 858.2 & 830.3 \\
\hline & 09BEN61-5R & 861.0 & 33.9 & 875.4 & 846.8 \\
\hline & 09BEN61-6R & 859.2 & 33.4 & 873.6 & 845.1 \\
\hline & 09BEN61-7R & 878.0 & 39.5 & 892.7 & 863.4 \\
\hline & 09BEN61-8R & 812.5 & 21.4 & 825.9 & 799.2 \\
\hline & AVERAGE 09BEN61 & 837.6 & 28.2 & 851.5 & 823.8 \\
\hline \multirow{8}{*}{ 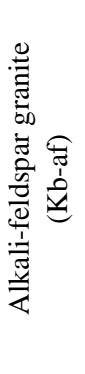 } & 09BEN63-1R & 669.4 & 4.2 & 680.3 & 658.7 \\
\hline & 09BEN63-2R & 951.4 & 72.6 & 967.6 & 935.4 \\
\hline & 09BEN63-3C & 882.2 & 41.0 & 897.0 & 867.6 \\
\hline & 09BEN63-4R & 738.3 & 9.7 & 750.4 & 726.4 \\
\hline & 09BEN63-5C & 855.9 & 32.4 & 870.2 & 841.8 \\
\hline & 09BEN63-6C & 908.7 & 51.4 & 924.0 & 893.6 \\
\hline & 09BEN63-8R & 805.7 & 20.0 & 819.1 & 792.6 \\
\hline & AVERAGE 09BEN63 & 830.2 & 33.0 & 844.1 & 816.6 \\
\hline \multirow{9}{*}{ 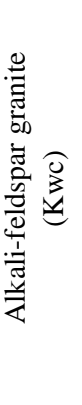 } & 09BEN73-1R & 792.1 & 17.4 & 805.2 & 779.2 \\
\hline & 09BEN73-2R & 809.3 & 20.7 & 822.7 & 796.1 \\
\hline & 09BEN73--3R & 792.4 & 17.4 & 805.4 & 779.4 \\
\hline & 09BEN73-4R & 846.2 & 29.6 & 860.3 & 832.3 \\
\hline & 09BEN73-5R & 786.8 & 16.5 & 799.8 & 774.0 \\
\hline & 09BEN73-6R & 775.4 & 14.6 & 788.2 & 762.8 \\
\hline & 09BEN73-7R & 826.0 & 24.4 & 839.7 & 812.4 \\
\hline & 09BEN73-8R & 780.0 & 15.3 & 792.9 & 767.3 \\
\hline & AVERAGE 09BEN73 & 801.0 & 19.5 & 814.3 & 787.9 \\
\hline
\end{tabular}




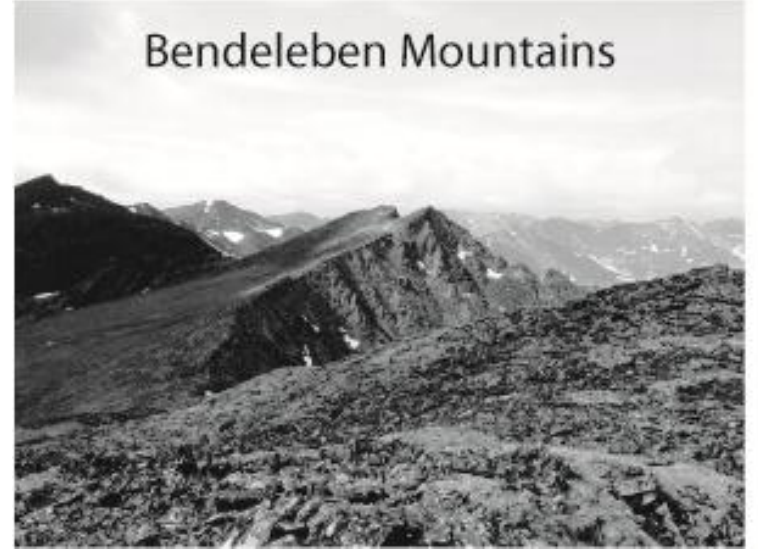

\section{Northern Darby Mountains}

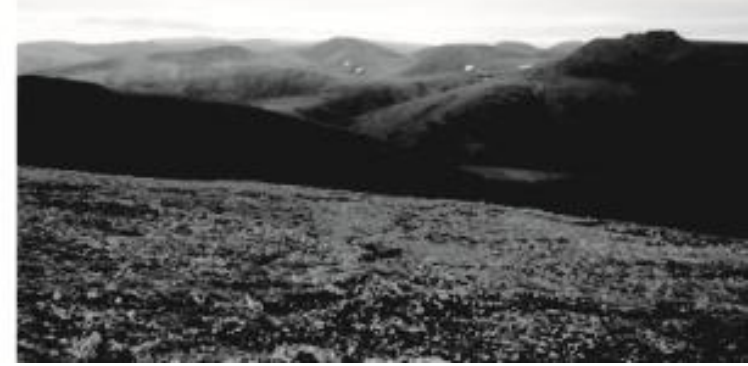

Figure 14: Topographic differences between the Bendeleben Mountains and the lessrugged and relatively longer-exposed northern Darby Mountains. 
through the $70^{\circ} \mathrm{He}$ closure isotherm in the Eocene (McDannell, 2011). A (U-Th)/He apatite age collected from the Windy Creek pluton was dated at $53 \pm 15 \mathrm{Ma}$ with error too great to be useful in terms of exhumation history relative to the Bendeleben pluton (McDannell, 2011). The higher metamorphic grade of country rock surrounding the Bendeleben pluton as compared with country rock surrounding the Windy Creek pluton suggests equilibration at a deeper, hotter level for the Bendeleben pluton than for the Windy Creek pluton assuming a simple regional isotherm structure. This observation is in agreement with the well-documented interpretation that the Kigluaik Metamorphic Complex represents a higher metamorphic grade equivalent of the stratigraphically higher Nome Group units. The presence of cordierite, garnet and biotite in the biotite-garnet schist unit of the Kigluaik Metamorphic Complex surrounding the Bendeleben pluton provides an important low pressure, high temperature constraint for metamorphic conditions for the country rock. U-Pb dating of metamorphic monazite from metapelites in the Kigluaik Metamorphic Complex suggests a minimum age for high-temperature metamorphism of $91 \mathrm{Ma}$, though heating could have been as early as $115 \mathrm{Ma}$ (Amato et al., 2002; Amato and Wright, 1998; Amato, pers. comm., 2011).

\section{Pluton emplacement:}

Data from the Bendeleben and Windy Creek granitoid plutons suggest emplacement during a multiple-phase injection event lasting about $20 \mathrm{~m}$.y. within an area experiencing north-south oriented extension during the Late Cretaceous. ${ }^{207} \mathrm{~Pb} /{ }^{206} \mathrm{~Pb}$ vs. ${ }^{238} \mathrm{U} /{ }^{206} \mathrm{~Pb}$ concordia and ${ }^{207} \mathrm{~Pb}$-corrected ${ }^{206} \mathrm{~Pb} /{ }^{238} \mathrm{U}$ mean SHRIMP-RG ages of zircons from the Bendeleben pluton range from 95.9 $\pm 1.0 \mathrm{Ma}$ in the center of the pluton (our 
western field area) to $84.6 \pm 0.4 \mathrm{Ma}$ at the eastern margin. Localized gabbro and granodiorite zones found intruding older, more felsic, rocks within the Bendeleben pluton are as young as $82.8 \pm 0.5 \mathrm{Ma}$. An age of $104 \pm 1 \mathrm{Ma}$ dated by $\mathrm{U}-\mathrm{Pb}$ zircon geochronology from outside of our field area at the western margin of the Bendeleben pluton (Gottlieb, 2008; Gottlieb and Amato, 2008b), implies a more complex history of magmatism than previously suggested. Orthogneisses and strained metasyenites bordering the Kigluaik pluton even further to the west have been dated by zircon $\mathrm{U}-\mathrm{Pb}$ geochronology at 105-115 Ma and are interpreted to represent limited early magmatic activity for the area (Amato and Wright, 1998). Stepwise dissolution of zircons collected from granodiorite within the mafic root of the Kigluaik pluton yielded an average age of $91 \mathrm{Ma}$ (Amato and Wright, 1998; Amato, pers. comm., 2011). Crystallization of this phase was described as the main stage of magmatism for the Kigluaik pluton (Amato and Wright, 1998) and predates mafic intrusives of the Bendeleben complex by $7 \mathrm{~m} . \mathrm{y}$. Combined zircon $\mathrm{U}-\mathrm{Pb}$ geochronologic results from the Kigluaik and Bendeleben plutons show a general younging trend of magmatism from west to east across the southern Seward Peninsula during the Cretaceous. Zircon geochronology and variable petrology within the Bendeleben pluton itself also support progressively eastward emplacement through multiple injection events. The absence of xenoliths from most pluton exposures, the diversity in crystallization ages and the diversity of pluton lithologies precludes intrusion via stoping and cooling as one coherent diapiric body.

Just across the Bering Sea to the west of the Seward Peninsula is the eastern Chukotka zone of the Okhotsk-Chukotka Volcanic Belt (OCVB) of Russia which stretches approximately $3250 \mathrm{~km}$ from the Uda River in southern Russia to the eastern 
Chukchi Peninsula of northeastern Russia. The OCVB was originally described as a Neocomian to Paleogene province of calc-alkaline volcanic deposits formed in a suprasubduction setting (Akinin and Miller, 2011). Recent work towards a more precise compilation of ages for Early Cretaceous felsic volcanism in the OCVB has shown that eruptions were of a discontinuous, pulsed nature (Akinin and Miller, 2011). New ages for volcanic activity in the OCVB have been measured at 105, 100, 96, 93-92, 87, 82 and $77 \mathrm{Ma}$ where events at 87 and 82 were most voluminous (Akinin and Miller, 2011). Plateau basalts emplaced around 77 Ma marked a change in tectonic setting from a subduction zone to a transform margin for the OCVB. Ages of plutonic intrusions from the Bendeleben Mountains all match very well with young volcanic events in the OCVB across the Bering Sea which were also induced by melting above a northward subducting plate resulting mostly in felsic volcanism (Akinin and Miller, 2011). Based on ages and geographical extent, it seems as though the OCVB and the Seward Peninsula may have been affected by a similar tectonic history responsible for Late Cretaceous magmatic and volcanic pulses involving extension above a subducting plate experiencing slab rollback (Figure 10).

Petrographic analysis of 85 samples collected from the plutons and surrounding country rock supports an extensional setting of the Seward Peninsula during the Cretaceous through observation of sense of shear indicators and well preserved high temperature sheared microfabrics in the metasediments. All are supportive of north-south directed extensional deformation and in agreement with previous studies of nearby gneiss domes and dike complexes in the Seward Peninsula (Amato et al., 2002; Amato et al., 2004). The nearby Kigluaik gneiss dome has been shown to contain numerous indicators 
of north-south oriented extension in Kigluaik Metamorphic Complex country rocks above the biotite-in isograd. These sense of shear indicators are very similar to those documented in the Bendeleben Mountains such as pressure shadow development around garnet porphyroblasts showing top-down shear, biotite and white mica decorated shear bands and north-south lineations formed via mineral stretching (Amato et al., 2002). Igneous rocks of the Bendeleben pluton are variable in composition showing an outer zone of alkali-feldspar granite with localized zones of granodiorite and gabbro and homogenous monzogranite toward the interior of the pluton. The gabbro and monzogranite units are suggestive of juvenile mafic magma injections into a magma chamber which had previously produced the older, more felsic rocks. Country rocks south of the Bendeleben pluton are southward-dipping well-foliated units of garnet and sillimanite-bearing schist and boudinaged marble with top-to-south sheared strain shadows. The Bendeleben pluton is separated to the southeast from the Windy Creek pluton by the Telephone Creek normal fault, and it is possible that the Windy Creek pluton represents a branch of the outer, alkali-feldspar granite margin of the Bendeleben pluton based on similarity of age and lithology. The crystallization age of $96.3 \pm 0.6 \mathrm{Ma}$ for the Windy Creek pluton matches well with the alkali-feldspar granite intrusion in the western Bendeleben pluton $(95.9 \pm 1.0 \mathrm{Ma})$ and could have been emplaced synchronously at distance. It is also possible that the Windy Creek pluton was a completely separate intrusion unrelated to the Bendeleben pluton, although lithologic and geochemical similarity and the close proximity between the two, especially when restoring the Telephone Creek fault, are strong evidence supporting a related emplacement history. 
The Bendeleben pluton shows several distinctive similarities to the nearby Kigluaik pluton including: 1) abundance of pegmatite near the upper contact, 2) granodioritic pluton composition near the upper contact and 3) common aplitic dikes in country rock near the pluton (Amato and Miller, 1997). The Kigluaik pluton has an intrusive age of $91 \mathrm{Ma}$ though some samples indicate limited magmatism as early as 110 Ma (Amato, pers. comm., 2011). The similarity in magma crystallization ages for the Kigluaik pluton and the Bendeleben pluton suggests emplacement of both bodies under similar tectonic conditions. The variable ages of petrologically different units seen in the Bendeleben Mountains also matches the episodic nature of emplacement proposed for the Kigluaik pluton where geochemical evidence is suggestive that a late-crystallizing mafic root and felsic cap were either comagmatic or derived from the same source prior to emplacement (Amato and Wright, 1997). For the Bendeleben pluton, and likely the Kigluaik pluton as well, modal composition becomes more mafic with younger crystallization. This pattern suggests influence from liquid density segregation processes like those proposed for the Mount Mazama magma chamber where rhyodacite eruption was followed by andesite and mafic crystal mush emplacement, though all originating from a single zoned magma chamber experiencing repeated recharge by a mafic parent magma (Druitt and Bacon, 1989). Multiple eastward progressing episodes of extension in the Kigluaik and Bendeleben Mountains likely led to initial crystallization of the "felsic cap" described by Amato and Miller (1997) which became the outer biotite-rich granite now found around the margins of both plutons. Continued periods of extension provided the subsequent pathways for intrusion of the lower, depleted mafic units into the younger "cap" providing the large time differentials documented in zircon crystallization 
ages. Replenishment of the magma chamber at depth by continuing subduction is invoked to explain the long lifetime of the magma chamber. As this slab experienced southward rollback, inducing extension in the over-riding plate, it also removed the magmatic source at depth, halting replenishment and intrusion by about $83 \mathrm{Ma}$.

The Bendeleben normal fault located south of the Bendeleben Mountains separates this range from an extensive basin, McCarthy's Marsh, to the south. Scarps ranging from 4-7 $\mathrm{m}$ high are preserved along the southern flank of the Bendeleben Mountain Range, bearing approximately east-west. This fault lies directly along strike with a north dipping normal fault located north of the Kigluaik Mountains to the west, suggesting continuation of an extensional system responsible for exposing both the Kigluaik and Bendeleben plutons and associated gneiss domes in the footwalls of both faults. Surface modeling based on apatite (U-Th)/He dating performed along a northsouth transect through the Bendeleben Mountains to the normal fault using Pecube (Braun, 2003) and HEFTY software (Ketcham, 2005) suggests development of this fault by the Late Eocene, although the entire block was likely experiencing episodic exhumation and extension since the Cretaceous with greatest amounts of exhumation from 65 to $55 \mathrm{Ma}$ (McDannell, 2011). These results match well with thermochronologic results from Calvert et al. (1999) who used the ${ }^{40} \mathrm{Ar} /{ }^{30} \mathrm{Ar}$ method to determine that the region surrounding the Kigluaik gneiss dome experienced cooling of hornblende through the $535^{\circ} \mathrm{C}$ isotherm between 86 and $82 \mathrm{Ma}$, cooling through mica $300^{\circ}-400^{\circ} \mathrm{C}$ isotherm around 85-83 Ma and variable $\mathrm{K}$-feldspar isotherm spectra $\left(300^{\circ}-150^{\circ} \mathrm{C}\right)$ cooling between 82 and 65 Ma consistent with initial rising of the Kigluaik gneiss dome and potentially the Bendeleben complex from mid-crustal levels between 110 and $82 \mathrm{Ma}$. 
Dumitru et al. (1995) determined a final core cooling age around $30 \mathrm{Ma}$ which matches an average cooling age modeled by McDannell (2011) through the $75^{\circ} \pm 5^{\circ} \mathrm{C}{ }^{4} \mathrm{He}$ apatite closure temperature (Reiners and Farley, 2001; Wolf et al., 1998; Wolf et al., 1996) of $38.7 \pm 2.4$ Ma. Modeling results by McDannell (2011) suggest an exhumation history for the Bendeleben pluton involving an initial unroofing and cooling period from 80-65 Ma, normal fault development and rapid exhumation from 65-55 Ma followed by slow uplift, unroofing and cooling until $30 \mathrm{Ma}$. Further topographic development occurred in the final 30 m.y. until the present, associated with a final $1 \mathrm{~km}$ of unroofing (McDannell, 2011).

Cretaceous tectonic setting of the Seward Peninsula:

Middle to Late Cretaceous extensional emplacement of Kigluaik and Bendeleben plutons in the Bering Strait region is well supported via the following evidence:

1: Crustal thickness of approximately $32 \mathrm{~km}$ beneath the Chukchi and inner Bering shelves matches closely with average global thickness values for extended continental crust (Klemperer et al., 2002b).

2: Velocity data and reflectivity are also in agreement with extensional fabrics formed in a previously overthickened (greater than $47 \mathrm{~km}$ thick) crust within the Seward Peninsula and Chukotka (Klemperer et al., 2002b; Wolf et al., 2002).

3: Average orientations of dike swarms abundant in the Seward Peninsula from the York, Bendeleben and Darby Mountains is also in support of north-northwest to southsoutheast oriented Middle to Late Cretaceous extension. Average strike orientation of dikes are $040^{\circ}$ from the York Mountains, $30-50^{\circ}$ from the Darby 
Mountains and $085^{\circ}$ from the Bendeleben Mountains (Amato et al., 2003 and this study). Dikes in the Kigluaik Mountains have an emplacement age of 84 Ma.

4: Consistent north-northwest to south-southeast stretching mineral lineations are abundant in the Seward terrane (Amato et al., 2002; Amato et al., 2004; this study).

5: Consistent sense of shear indicators in the metasediments found south of the Bendeleben pluton in the form of shallow south dipping foliations, mantled porphyroblasts showing top-down shear sense and plunging away from the pluton, centimeter scale normal faults and stretched mineral lineations plunging away from the pluton. Similar sense of shear indicators are also documented in the nearby Kigluaik gneiss dome, also indicating north-south extensional deformation (Amato et al., 2003; Amato et al., 2004).

6: Rapid Late Cretaceous exhumation of the Kigluaik and Bendeleben Mountains as documented by apatite (U-Th)/He and ${ }^{40} \mathrm{Ar} /{ }^{30} \mathrm{Ar}$ thermochronology (Calvert et al., 1999; McDannell, 2011).

The 91 Ma Kigluaik pluton is a close match to the Bendeleben pluton in terms of composition, age, orientation and interpreted emplacement history, and is located along strike of the Bendeleben normal fault to the west. For these reasons, it is likely also analogous to the Bendeleben pluton in terms of emplacement history. Extensive work performed on the Kigluaik pluton has provided strong evidence supporting north-south or north-northwest to south-southeast extensionally-driven emplacement, suggesting a similar style of emplacement for the Bendeleben pluton. There is also strong evidence 
suggesting that the Kigluaik pluton formed in a subduction-related setting based on isotopic and trace element data and comparisons to high-K mafic plutonic rocks generated in known subduction related settings in locations such as the Andes, Australia and Japan (Amato and Wright, 1997).

\section{Conclusions:}

This study supports the hypothesis that the southward retreat of a northward subducting slab beneath the Seward Peninsula caused Cretaceous extension in the overriding plate. This event would cause north-south or north-northwest to south-southeast directed extension in the Seward Peninsula and would explain the average orientation of dike swarms and the general shape of several Cretaceous intrusions such as the Bendeleben pluton. U-Pb zircon geochronologic data suggest that this extensionally driven emplacement most likely happened in a series of eastward younging pulses controlled by fracture-assisted emplacement from a large chamber of magma at depth. The occasional tapping of this chamber and associated depletion likely led to the compositional differences in the Bendeleben pluton. A similar history has been proposed for the nearby Kigluaik pluton and is supported by extensive evidence summarized previously.

Intrusion of the small gabbro unit at $82 \mathrm{Ma}$ through more felsic units which predate the gabbro by as much as $13 \mathrm{~m} . \mathrm{y}$. in our field area and $21 \mathrm{~m} . \mathrm{y}$. for the entire Bendeleben pluton represents the final stage of crystallization which affected the deepest portion of the magma chamber under continued extension. The Bendeleben pluton 
therefore represents the gradual depletion of a large, continually replenished, liquidsegregated magma chamber through multiple events of eastward progressing extension. This volatile-rich melt likely grew in a deep magma chamber induced by volatile-driven melting above a subducting slab until subsequent extension provided a pathway for upward intrusion of the more felsic capping units. These units were subsequently intruded by the lower mafic "root" during isolated periods of extension that affected the Seward Peninsula from 104 Ma to about 80 Ma. 


\section{References:}

Akinin, V.V., and Miller, E.L., 2011, Evolution of calc-alkaline magmas of the OkhotskChukotka volcanic belt: Petrology, v. 19, p. 237-277.

Amato, J.M., and Miller, E.L., 1997, Bedrock geologic map of the Kigluaik Mountains, Seward Peninsula, Alaska: Fairbanks, Alaska, State of Alaska Department of Natural Resources, 1-5.

Amato, J.M., Miller, E.L., and Hannula, K.A., 2002, Orthogonal flow directions in extending continental crust: An example from the Kigluaik gneiss dome, Seward Peninsula, Alaska, in Miller, E.L., Grantz, A., and Klemperer, S.L., eds., Tectonic Evolution of the Bering Shelf - Chukchi Sea - Arctic Margin and Adjacent Landmasses, Special Paper 360: Boulder, CO, The Geological Society of America, p. 133-146.

Amato, J.M., Miller, E.L., Wright, J.E., and McIntosh, W.C., 2003, Dike swarms on Seward Peninsula, Alaska, and their implications for the kinematics of Cretaceous extension in the Bering Strait region: Canadian Journal of Earth Sciences, v. 40, p. 865-886.

Amato, J.M., Toro, J., Miller, E.L., Gehrels, G.E., Farmer, G.L., Gottlieb, E.S., and Till, A.B., 2009, Late Proterozoic-Paleozoic evolution of the Arctic Alaska-Chukotka terrane based on $\mathrm{U}-\mathrm{Pb}$ igneous and detrital zircon ages: Implications for Neoproterozoic paleogeographic reconstructions: GSA Bulletin, v. 121, p. 12191235.

Amato, J.M., Toro, J., and Moore, T.E., 2004, Origin of the Bering Sea salient: Geological Society of America Special Paper 383, p. 131-144.

Amato, J.M., and Wright, J.E., 1997, Potassic mafic magmatism in the Kigluaik gneiss dome, northern Alaska: A geochemical study of arc magmatism in an extensional tectonic setting: Journal of Geophysical Research, v. 102, p. 8065-8084.

Amato, J.M., and Wright, J.E., 1998, Geochronologic investigations of magmatism and metamorphism within the Kigluaik Mountains gneiss dome, Seward Peninsula, Alaska, in Clough, J.G., and Larson, F., eds., Short Notes in Alaskan Geology 1997, State of Alaska Division of Geological and Geophysical Surveys, 1-21. 
Amato, J.M., Wright, J.E., Gans, P.B., and Miller, E.L., 1994, Magmatically induced metamorphism and deformation in the Kigluaik gneiss dome, Seward Peninsula, Alaska: Tectonics, v. 13, p. 515-527.

Beikman, H.M., 1980, Geologic map of Alaska, U. S. Geological Survey Map.

Belousova, E.A., Griffin, W.L., O'Reilly, S.Y., and Fisher, N.I., 2002, Igneous zircon: trace element composition as an indicator of source rock type: Contributions to Mineralogy and Petrology, v. 143, p. 602-622.

Black, L.P., Kamo, S.L., Allen, C.M., Davis, D.W., Aleinikoff, J.N., Valley, J.W., Mundil, R., Campbell, I.H., Korsch, R.J., Williams, I.S., and Foudoulis, C., 2004, Improved $206 \mathrm{~Pb} / 238 \mathrm{U}$ microprobe geochronology by the monitoring of a traceelement-related matrix effect; SHRIMP, ID-TIMS, ELA-ICP-MS and oxygen isotope documentation for a series of zircon standards: Chemical Geology, v. 205, p. 115-140.

Braun, J., 2003, Pecube: a new finite-element code to solve the 3D heat transport equation including the effects of a time-varying, finite amplitude surface topography: Computer \& Geosciences, v. 29, p. 787-794.

Calvert, A.T., Gans, P.B., and Amato, J.M., 1999, Diapiric ascent and cooling of a sillimanite gneiss dome revealed by 40Ar/39Ar thermochronology: the Kigluaik Mountains, Seward Peninsula, Alaska: Geological Society, London, Special Publications, v. 154, p. 205-232.

Coath, C.D., and Long, J.V.P., 1994, A high-brightness duoplasmatron ion source for microprobe secondary-ion mass spectrometry: Review of Scientific Instruments, v. 66, p. 1018-1023.

Corfu, F., Hanchar, J.M., Hoskin, P.W.O., and Kinny, P., 2003, Atlas of Zircon Textures, in Hanchar, J.M., and Hoskin, P.W.O., eds., Zircon, v. 53: Reviews in Mineralogy and Geochemistry: Washington D.C., The Mineralogical Society of America, p. 469-500.

Daly, R.A., 1903, The mechanics of igneous intrusion: American Journal of Science, v. 15 , p. 269-298.

Dove, D., Coakley, B., Hopper, J., Kristoffersen, Y., and HLY Geophysics Team, 2010, Bathymetry, controlled source seismic and gravity observations of the Mendeleev 
ridge; implications for ridge structure, origin, and regional tectonics: Geophysical Journal International, v. 183, p. 481-502.

Druitt, T.H., and Bacon, C.R., 1989, Petrology of the zoned calcalkaline magma chamber of Mount Mazama, Crater Lake, Oregon: Contrib Mineral Petrol, v. 101, p. 245259.

Dumitru, T.A., Miller, E.L., O'Sullivan, P.B., Amato, J.M., Hannula, K.A., Calvert, A.T., and Gans, P.B., 1995, Cretaceous to recent extension in the Bering Strait region, Alaska: Tectonics, v. 14, p. 549-563.

Glazner, A.F., and Bartley, J.M., 2006, Is stoping a volumetrically significant pluton emplacement process?: GSA Bulletin, v. 118, p. 1185-1195.

Glazner, A.F., Bartley, J.M., Coleman, D.S., Gray, W., and Taylor, R.Z., 2004, Are plutons assembled over millions of years by amalgamation from small magma chambers?: GSA Today, v. 14, p. 4-11.

Gottlieb, E.S., 2008, Geologic Mapping and Investigation of Cretaceous Magmatism and Deformation in the Bendeleben Metamorphic Complex, Seward Peninsula, Alaska: Las Cruces, New Mexico, New Mexico State University.

Gottlieb, E.S., and Amato, J.M., 2007, Geologic mapping, structural analysis, and geochronology of the Bendeleben Mountains metamorphic complex, Seward Peninsula, Alaska: The Geological Society of America abstracts with programs, v. 39

Gottlieb, E.S., and Amato, J.M., 2008a, Bedrock Geologic Map of the Western Bendeleben Mountains, Final EDMAP Report: Las Cruces, NM, New Mexico State University.

Gottlieb, E.S., and Amato, J.M., 2008b, Structural evolution, transition from anatectic to mantle-derived magmatism, and timing of exhumation; Bendeleben metamorphic complex, Seward Peninsula, Alaska, Geological Society of America, Cordilleran Section, 104th annual meeting; Geological Society of America, Rocky Mountain Section, 60th annual meeting: Las Vegas, NV, United States, Geological Society of America.

Hannula, K.A., Miller, E.L., Dumitru, T.A., Lee, J., and Rubin, C.M., 1995, Structural and metamorphic relations in the southwest Seward Peninsula, Alaska: Crustal 
extension and the unroofing of blueschists: Geological Society of America Bulletin, v. 107, p. 536-553.

Holcombe, R., 2010, GEOrient ver. 9.4.5: Kenmore, QLD, Australia.

Hoskin, P.W.O., and Ireland, T.R., 2000, Rare earth element chemistry of zircon and its use as a provenance indicator: Geology, v. 28, p. 627-630.

Jakobsson, M., Macnab, R., Mayer, L., Anderson, R., Edwards, M., Hatzky, J., Schenke, H.-W., and Johnson, P., 2008, An improved bathymetric portrayal of the Arctic Ocean: Implications for ocean modeling and geological, geophysical and oceanographic analyses: Geophys. Res. Lett., v. 35

Ketcham, R.A., 2005, Forward and inverse modeling of low-temperature thermochronometry data: Reviews in Mineralogy and Geochemistry, v. 58, p. 275-314.

Klemperer, S.L., Greninger, M.L., and Nokleberg, W.J., 2002a, Geographic information systems compilation of geophysical, geologic, and tectonic data for the Bering Shelf, Chukchi Sea, Arctic margin, and adjacent landmasses, in Miller, E.L., Grantz, A., and Klemperer, S.L., eds., Tectonic Evolution of the Bering Shelf Chukchi Sea - Arctic Margin and Adjacent Landmasses, Special paper 360: Boulder, CO, The Geological Society of America, p. 359-374.

Klemperer, S.L., Miller, E.L., Grantz, A., Scholl, D.W., and Bering-Chukchi Working Group, 2002b, Crustal structure of the Bering and Chukchi shelves: Deep seismic reflection profiles across the North American continent between Alaska and Russia, in Miller, E.L., Grantz, A., and Klemperer, S.L., eds., Tectonic Evolution of the Bering Shelf - Chukchi Sea - Arctic Margin and Adjacent Landmasses, Special paper 360: Boulder, CO, The Geological Society of America, p. 1-24.

Lawver, L.A., Grantz, A., and Gahagan, L.M., 2002, Plate kinematic evolution of the present Arctic region since the Ordovician, in Miller, E.L., Grantz, A., and Klemperer, S.L., eds., Tectonic Evolution of the Bering Shelf - Chukchi Sea Arctic Margin and Adjacent Landmasses, Special Paper 360: Boulder, CO, The Geological Society of America, p. 333-358.

Layer, P.W., Newberry, R., Fujita, K., Parfenov, L., Trunilina, V., and Bakharev, A., 2001, Tectonic setting of the plutonic belts of Yakutia, northeast Russia, based on 
40Ar/39Ar geochronology and trace element geochemistry: Geology, v. 29, p. $167-170$.

Le Maitre, R.W., Streckeisen, A., Zanettin, B., Le Bas, M.J., Bonin, B., Bateman, P., Bellieni, G., Dudek, A., Efremova, S., Keller, J., Lameyre, J., Sabine, P.A., Schmid, R., Sørensen, H., and Woolley, A.R., 2002, A Classification of Igneous Rocks and Glossary of Terms: Recommendations of the International Union of Geological Sciences Subcommission on the Systematics of Igneous Rocks., Cambridge University Press, 256.

Ludwig, K.R., 2009, Isoplot 3.6 Geochronological toolkit for Microsoft Excel, Special Publication No. 4: Berkeley, CA, Berkeley Geochronology Center, 1-77.

Mahan, K.H., Bartley, J.M., Coleman, D.S., Glazner, A.F., and Carl, B.S., 2003, Sheeted intrusion of the synkinematic McDoogle Pluton, Sierra Nevada, California: GSA Bulletin, v. 115, p. 1570-1582.

McDannell, K.T., 2011, Exhumation in the Bendeleben Mountains (Seward Peninsula, Alaska) Constrained by (U-Th)/He Thermochronology: Unpublished M.S. thesis, Morgantown, WV, West Virginia University.

McNulty, B.A., Tong, W., and Tobisch, O.T., 1996, Assembly of a dife-fed magma chamber: The Jackass Lakes pluton, central Sierra Nevada, California: GSA Bulletin, v. 108, p. 926-940.

Miller, E.L., Gelman, M., Parfenov, L., and Hourigan, J., 2002, Tectonic setting of Mesozoic magmatism: A comparison between northeastern Russia and the North American Cordillera, in Miller, E.L., Grantz, A., and Klemperer, S.L., eds., Tectonic Evolution of the Bering Shelf - Chukchi Sea - Arctic Margin and Adjacent Landmasses, Special Paper 360: Boulder, CO, The Geological Society of America, p. 313-332.

Miller, E.L., and Hudson, T.L., 1991, Mid-Cretaceous extensional fragmentation of a Jurassic-Early Cretaceous compressional orogen, Alaska: Tectonics, v. 10, p. 781796.

Miller, E.L., Katkov, S.M., Strickland, A., Toro, J., Akinin, V.V., and Dumitru, T.A., 2009, Geochronology and thermochronology of Cretaceous plutons and 
metamorphic country rocks, Anyui-Chukotka fold belt, North East Arctic Russia: Stephan Mueller Special Publication Series, v. 4, p. 157-175.

Miller, J.S., 2008, Assembling a pluton...one increment at a time: Geology, v. 36, p. 511512.

Miller, T.P., and Bunker, C.M., 1976, A reconnaissance study of the uranium and thorium contents of plutonic rocks of the southeastern Seward Peninsula, Alaska: U.S. Geological Survey Journal of Research, v. 4, p. 367-377.

Moffit, F.H., 1913, Geology of the Nome and Grade Central Quadrangles, Alaska: U.S. Geological Survey Bulletin, p. 1-140.

Molyneux, S.J., and Hutton, D.H.W., 2000, Evidence for significant granite space creation by the ballooning mechanism: The example of the Ardara Pluton, Ireland: GSA Bulletin, v. 112, p. 1543-1558.

Nelson, J., and Colpron, M., 2007, Tectonics and metallogeny of the British Columbia, Yukon and Alaskan Cordillera, 1.8 Ga to the present, in Goodfellow, W.D., ed., Mineral Deposits of Canada: A Synthesis of Major Deposit-Types, District Metallogeny, the Evolution of Geological Provinces, and Exploration Methods, Special publication No. 5, Geological Association of Canada, Mineral Deposits Division, p. 755-791.

Parfenov, L.M., Badarch, G., Berzin, N.A., Khanchuk, A.I., Kuzmin, M.I., Nokleberg, W.J., Prokopiev, A.V., Ogasawara, M., and Yan, H., 2009, Summary of Northeast Asia geodynamics and tectonics, in Stone, D.B., Fujita, K., Layer, P.W., Miller, E.L., Prokopiev, A.V., and Toro, J., eds., Geology, geophysics and tectonics of Northeastern Russia: a tribute to Leonid Parfenov, Stephan Mueller Special Publication Series Volume 4, Copernicus Publications, p. 11-33.

Paterson, S.R., and Fowler, T.K., Jr, 1993, Re-examining pluton emplacement processes: Journal of Structural Geology, v. 15, p. 191-206.

Paterson, S.R., and Vernon, R.H., 1995, Bursting the bubble of ballooning plutons: A return to nested diapirs emplaced by multiple processes: GSA Bulletin, v. 107, p. 1356-1380.

Patrick, B.E., and Lieberman, J.E., 1988, Thermal overprint on blueschists of the Seward Peninsula: The Lepontine in Alaska: Geology, v. 16, p. 1100-1103. 
Patton, W.W., Jr, and Tailleur, I.L., 1977, Evidence in the Bering Strait region for differential movement between North America and Eurasia: GSA Bulletin, v. 88, p. 1298-1304.

Pearce, J.A., Harris, N.B.W., and Tindle, A.G., 1984, Trace element discrimination diagrams for the tectonic interpretation of granitic rocks: Journal of Petrology, v. 25, p. 956-983.

Plafker, G., and Berg, H.C., 1994, Overview of the geology and tectonic evolution of Alaska, in Plafker, G., and Berg, H.C., eds., The Geology of Alaska, The Geology of North America, v. G-1: Boulder, Colorado, Geological Society of America.

Reiners, P.W., and Farley, K.A., 2001, Influence of crystal size on apatite (U-Th)/He thermochronology: an example from the Bighorn Mountains, Wyoming: Earth and Planetary Science Letters, v. 188, p. 413-420.

Sainsbury, C.L., 1974, Geologic map of the Bendeleben 1:250,000 quadrangle, Seward Peninsula, Alaska: Golden, CO, Air Samplex, 31.

Sawka, W.N., 1988, REE and trace element variations in accessory minerals and hornblende from the strongly zoned McMurry Meadows Pluton, California: Royal Society of Edinburgh Transactions, Earth Sciences, v. 79, p. 157-168.

Sokolov, S.D., Bondarenko, G.Y., Layer, P.W., and Kravchenko-Berezhnoy, I.R., 2009, South Anyui suture: tectono-stratigraphy, deformations, and principal tectonic events, in Stone, D.B., Fujita, K., Layer, P.W., Miller, E.L., Prokopiev, A.V., and Toro, J., eds., Geology, geophysics and tectonics of Northeastern Russia: a tribute to Leonid Parfenov, Stephan Mueller Special Publication Series Volume 4, Copernicus Publications, p. 201-221.

Spear, F.S., 1993, Metamorphic Phase Equilibria and Pressure-Temperature-Time Paths: Washington D.C., Mineralogical Society of America Monograph.

Till, A.B., and Dumoulin, J.A., 1994, Geology of the Seward Peninsula and Saint Lawrence Island, in Plafker, G., and Berg, H.C., eds., The Geology of North America, v. G-1: Boulder, Colorado, Geological Society of America, p. 141-152.

Till, A.B., Dumoulin, J.A., Gamble, B.M., Kaufman, D.S., and Carroll, P.I., 1986, Preliminary geologic map and fossil data, Solomon, Bendeleben, and southern 
Kotzebue Quadrangles, Seward Peninsula, Alaska, United States Department of the Interior Geological Survey, 9.

Till, A.B., Dumoulin, J.A., Werdon, M.B., and Bleick, H.A., 2010, Preliminary bedrock geologic map of the Seward Peninsula, Alaska, and accompanying conodont data, U.S. Geological Survey Open-File Report 2009-1254, 2 plates, scale 1:500,000, 1 pamphlet, 57p., and database.

Titus, S.J., Clark, R., and Tikoff, B., 2005, Geologic and geophysical investigation of two fine-grained granites, Sierra Nevada Batholith, California: Evidence for structural controls on emplacement and volcanism: GSA Bulletin, v. 117, p. 1256-1271.

Watson, E.B., Wark, D.A., and Thomas, J.B., 2006, Crystallization thermometers for zircon and rutile: Contrib Mineral Petrol, v. 151, p. 413-433.

Williams, I.S., 1998, U-Th-Pb geochronology by ion-microprobe, in Kibben, M., Shanks, W., and Ridley, W., eds., Applications of Microanalytical Techniques to Understanding Mineralizing Process, Reviews in Economic Geology, v. 7: El Paso, TX, The Economic Geology Publishing Company, p. 1-36.

Wolf, L.W., McCaleb, R.C., Stone, D.B., Brocher, T.M., Fujita, K., and Klemperer, S.L., 2002, Crustal structure across the Bering Strait, Alaska: Onshore recordings of a marine seismic survey, in Miller, E.L., Grantz, A., and Klemperer, S.L., eds., Tectonic Evolution of the Bering Shelf - Chukchi Sea - Arctic Margin and Adjacent Landmasses, Special paper 360: Boulder, CO, The Geological Society of America, p. 25-37.

Wolf, R.A., Farley, K.A., and Kass, D.M., 1998, Modeling of the temperature sensitivity of the apatite (U-Th)/He thermochronometer: Chemical Geology, v. 148, p. 105114.

Wolf, R.A., Farley, K.A., and Silver, L.T., 1996, Helium diffusion and low-temperature thermochronometry of apatite: Geochimica et Cosmochimica Acta, v. 60, p. 42314240.

Yin, A., 2004, Gneiss domes and gneiss dome systems, in Whitney, D.L., Teyssier, C., and Siddoway, C.S., eds., Gneiss Domes in Orogeny, Special Paper 380: Boulder, CO, The Geological Society of America, p. 1-14. 
Appendix 1: Cathodoluminesence photomicrographs of zircons separated from igneous samples collected from the Kular pluton. Circles indicate spot location for U-Pb SHRIMP-

RG analysis.

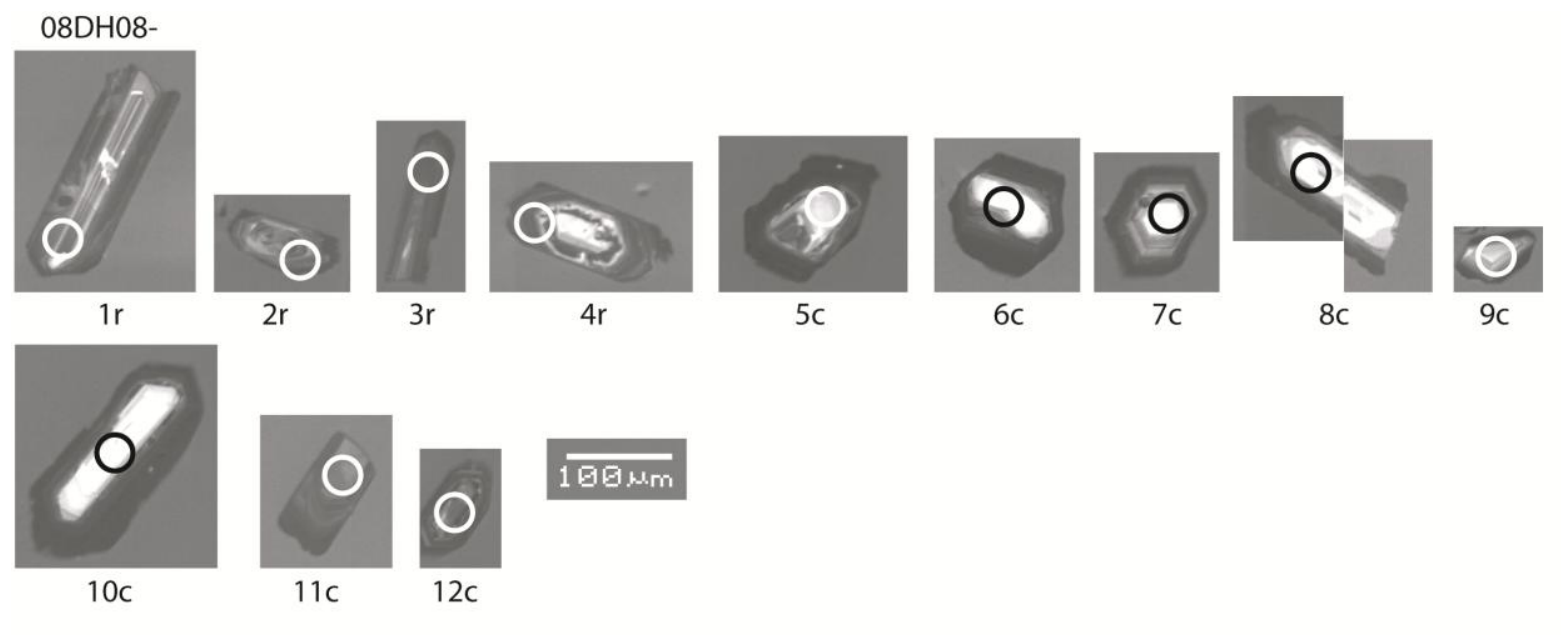

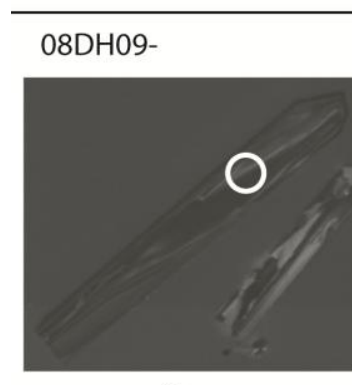

$1 c$

7c

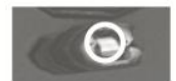

$8 c$

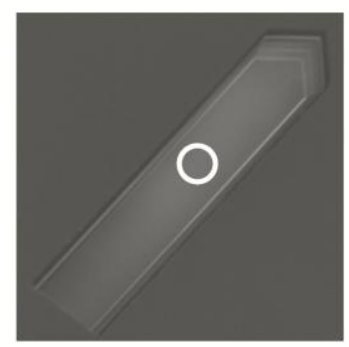

2c

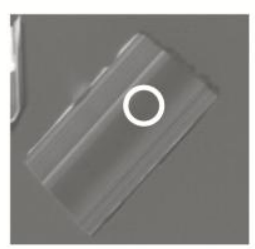

$9 c$

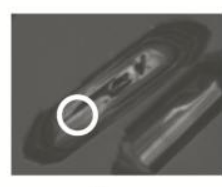

$3 c$

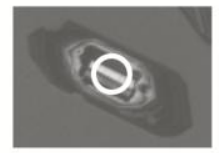

$10 \mathrm{c}$

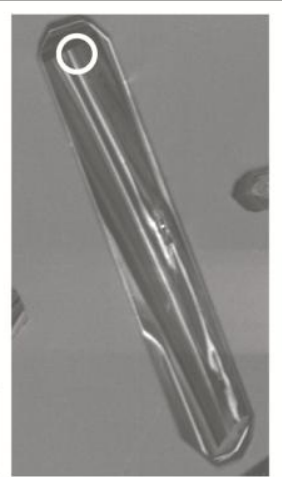

$3 r$

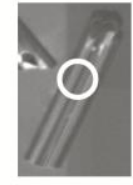

$4 c$

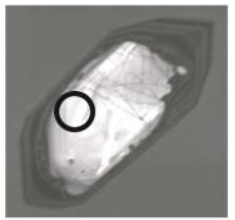

$5 r$
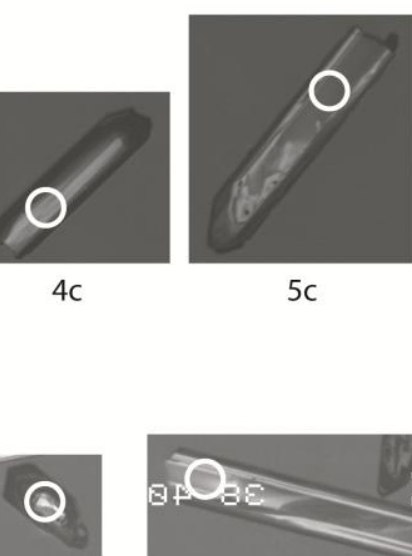

$11 c$
$5 c$

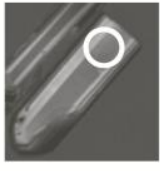

$6 c$

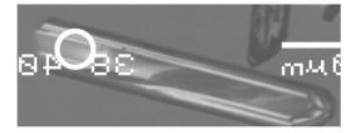

$12 \mathrm{c}$

\section{$1 \mathrm{GGmm}$}

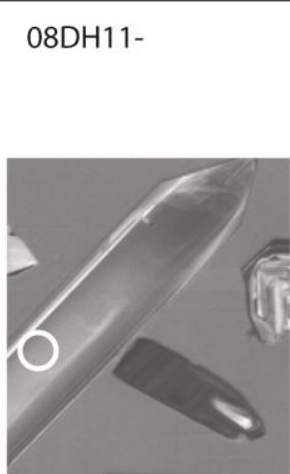

$1 c$

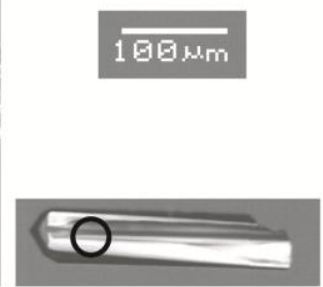

$2 c$

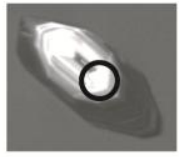

$6 c$

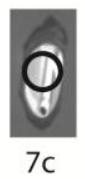


08DH13-

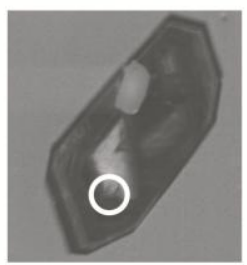

1c

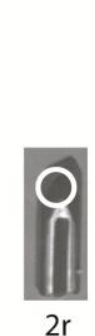

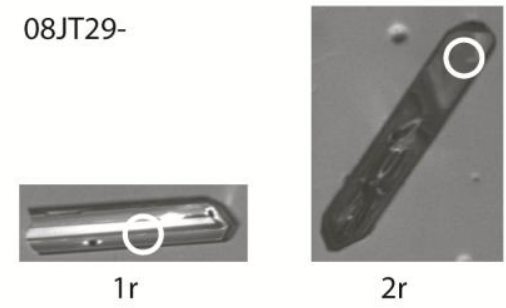

$2 r$

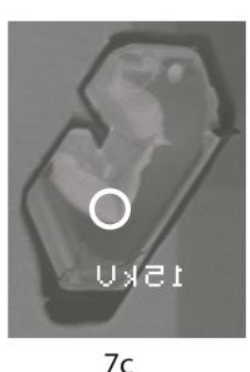

$7 c$

$1 \mathrm{r}$

\section{$\overline{100 \mu \mathrm{m}}$}

$3 c$ not imaged

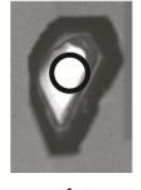

4c

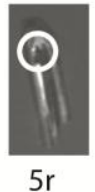

\section{$1 \overline{\mathrm{gG \mu m}}$}

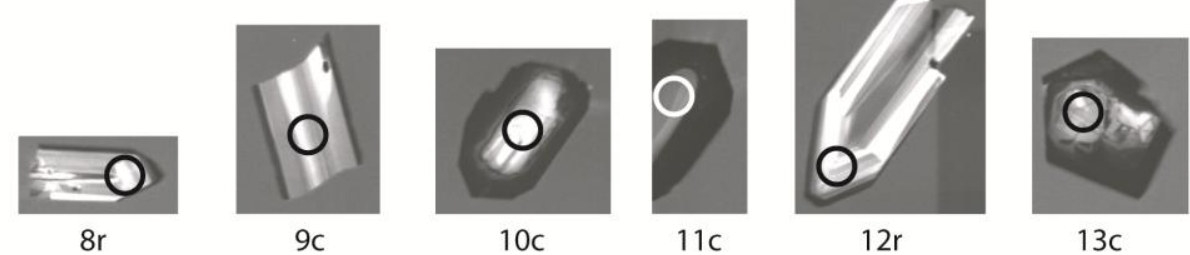

R33-

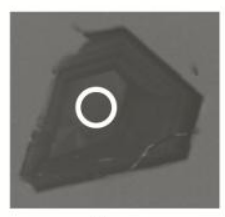

1 $\overline{15 \mathrm{Gm}}$

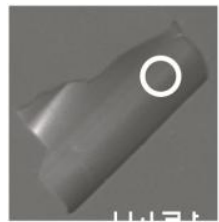

8

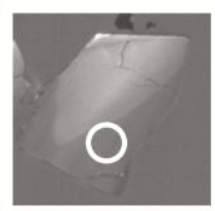

2

2

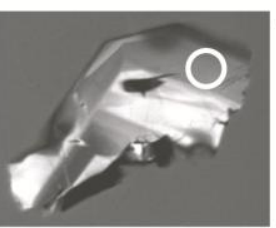

9

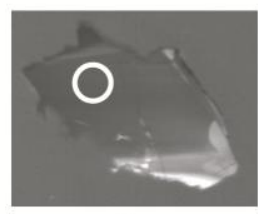

3

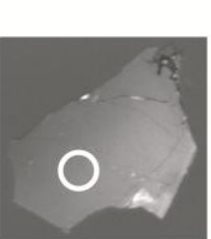

10

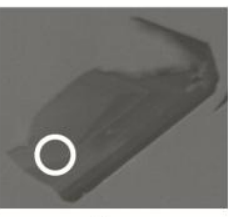

4

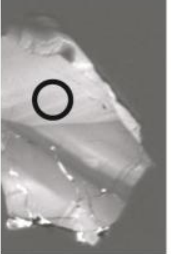

11

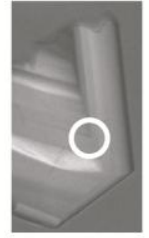

5

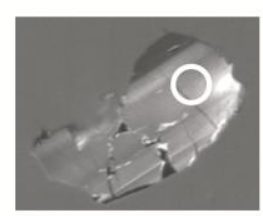

6

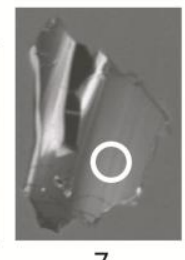

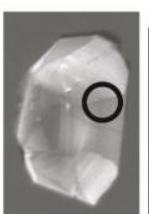

12

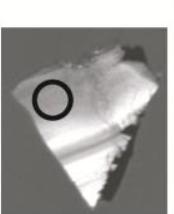

13

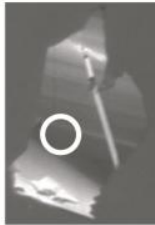

14

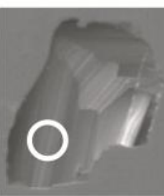

15 


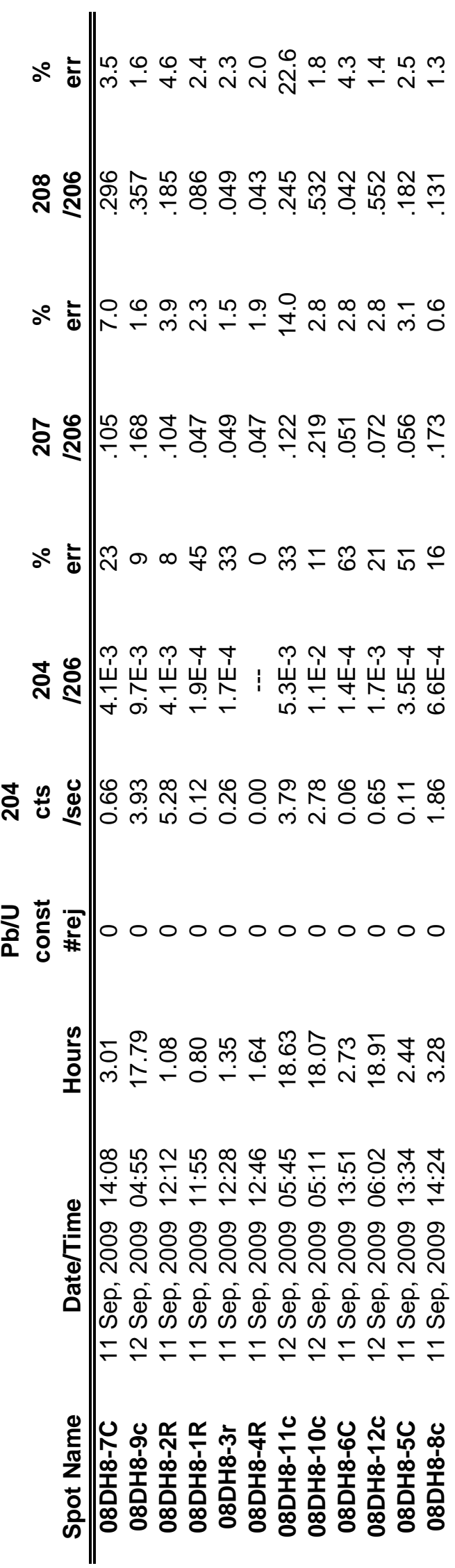




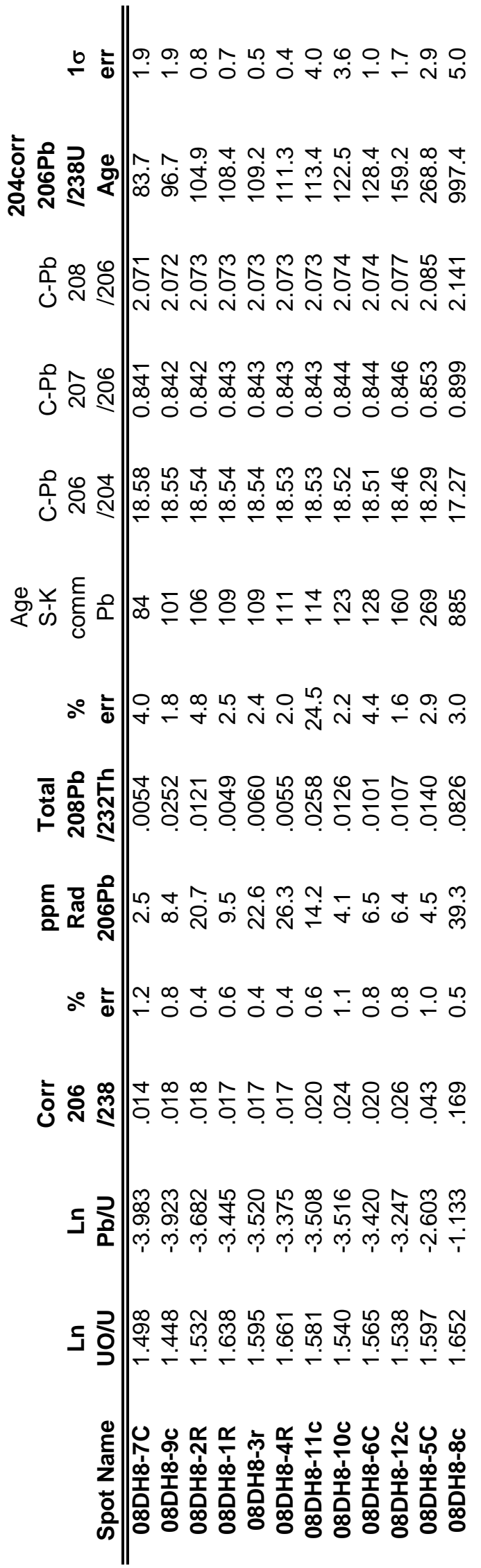




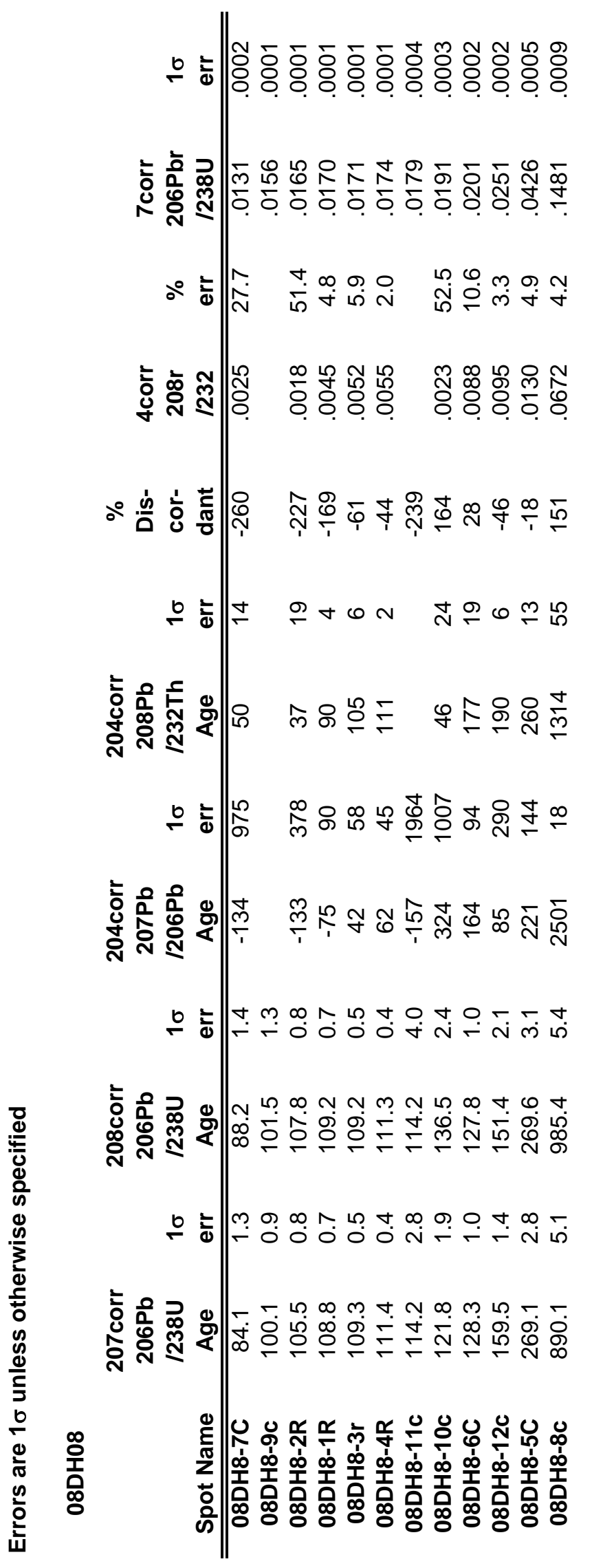




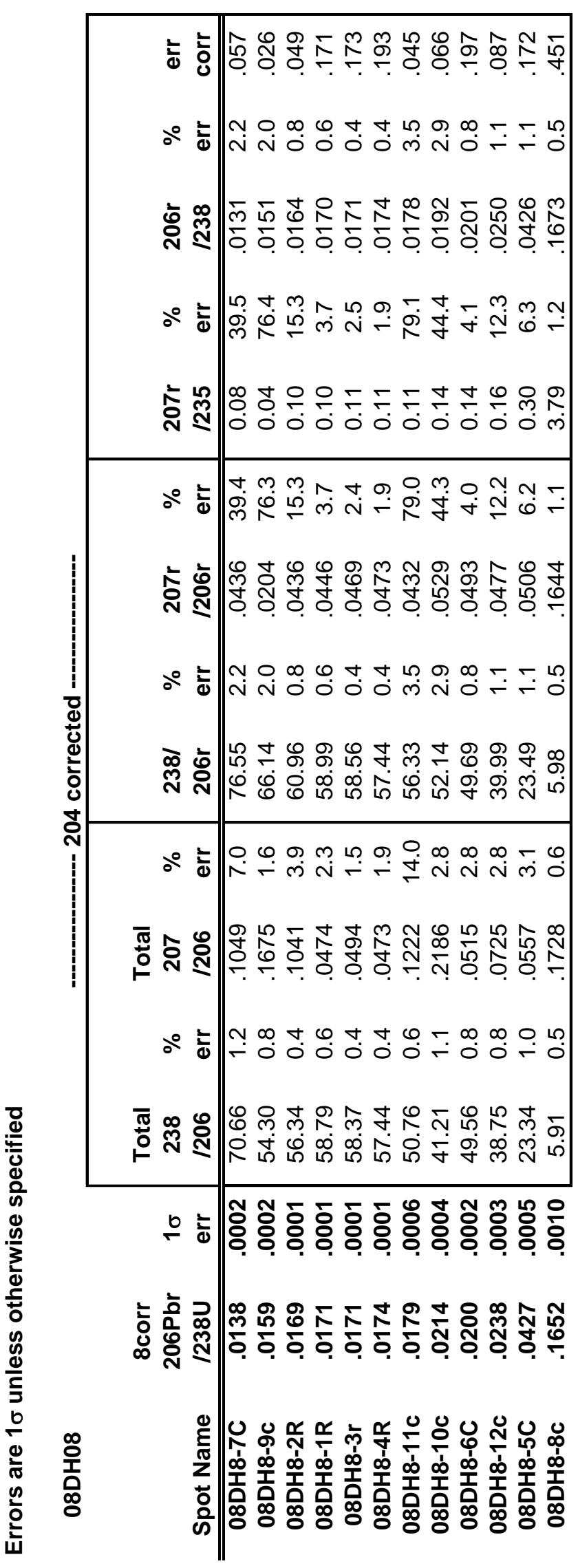




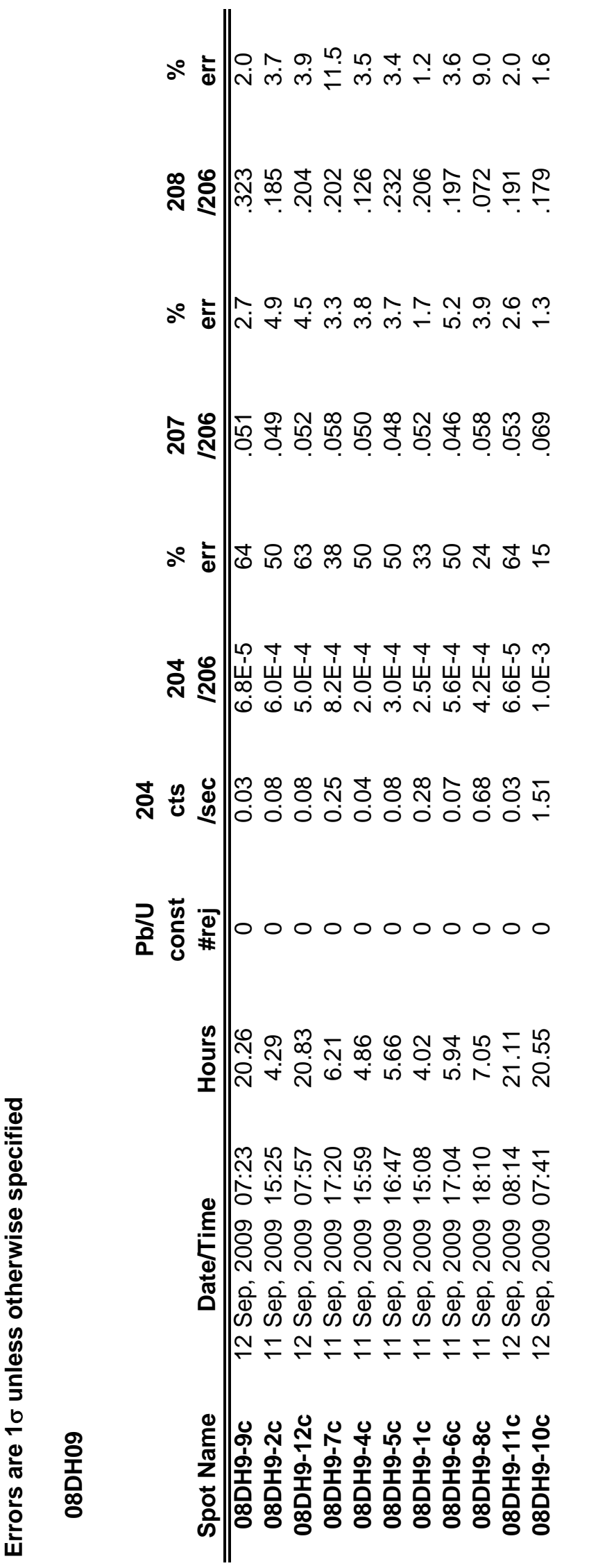

\begin{tabular}{|c|c|}
\hline 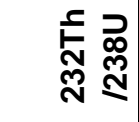 & 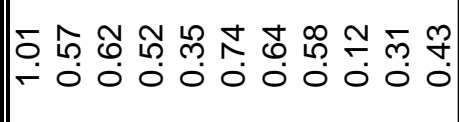 \\
\hline 흥다 & 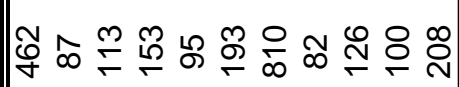 \\
\hline$\frac{E}{\frac{2}{2}} \supset$ & 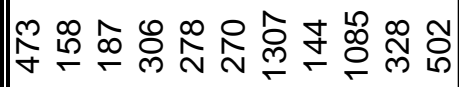 \\
\hline ○ & 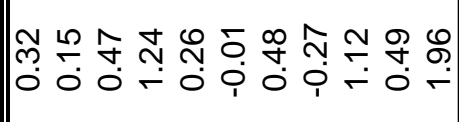 \\
\hline$\circ 0$ & هִ مْاء \\
\hline ํํㅇ & $\mid$ \\
\hline 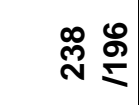 & |l \\
\hline$\circ \vdots$ & 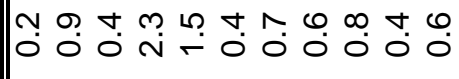 \\
\hline$\stackrel{\leftarrow}{\sim} \underset{\sim}{\infty}$ & 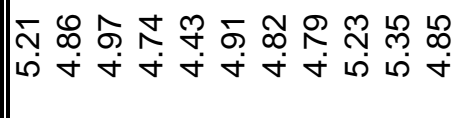 \\
\hline$\circ ㅎ$ & |ن \\
\hline$\stackrel{\infty}{\sim} \stackrel{\leftarrow}{\stackrel{L}{N}}$ & | \\
\hline$\circ \frac{t}{0}$ & 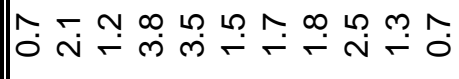 \\
\hline 。̊ & 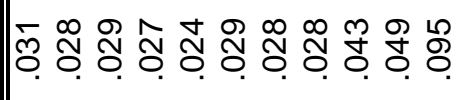 \\
\hline 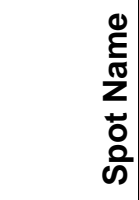 & 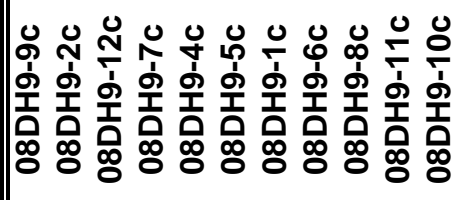 \\
\hline
\end{tabular}




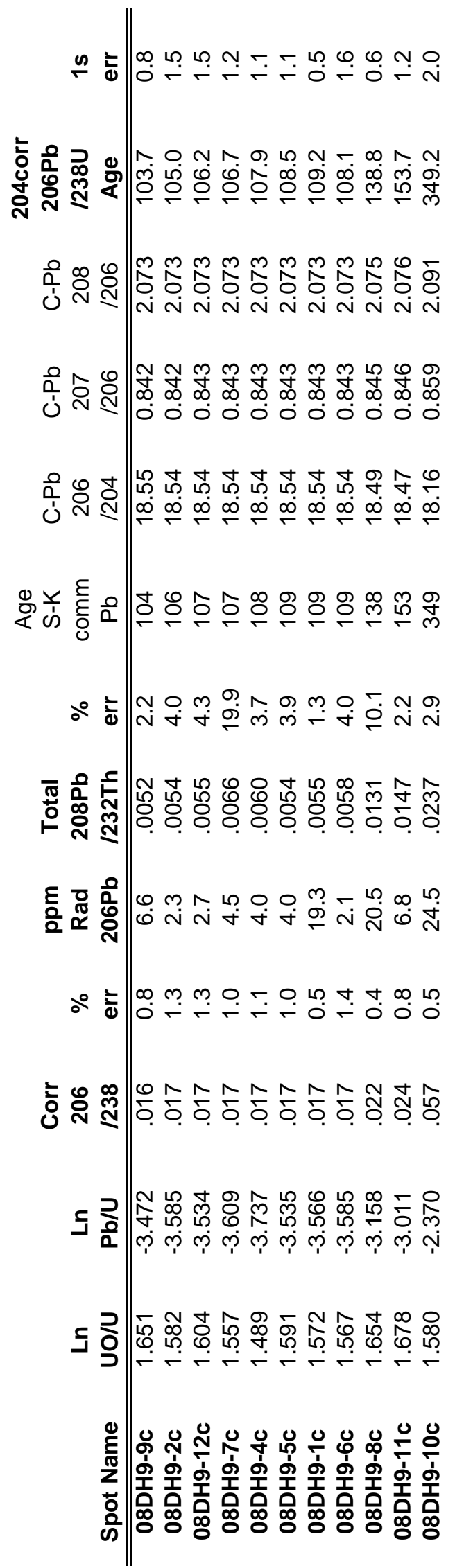



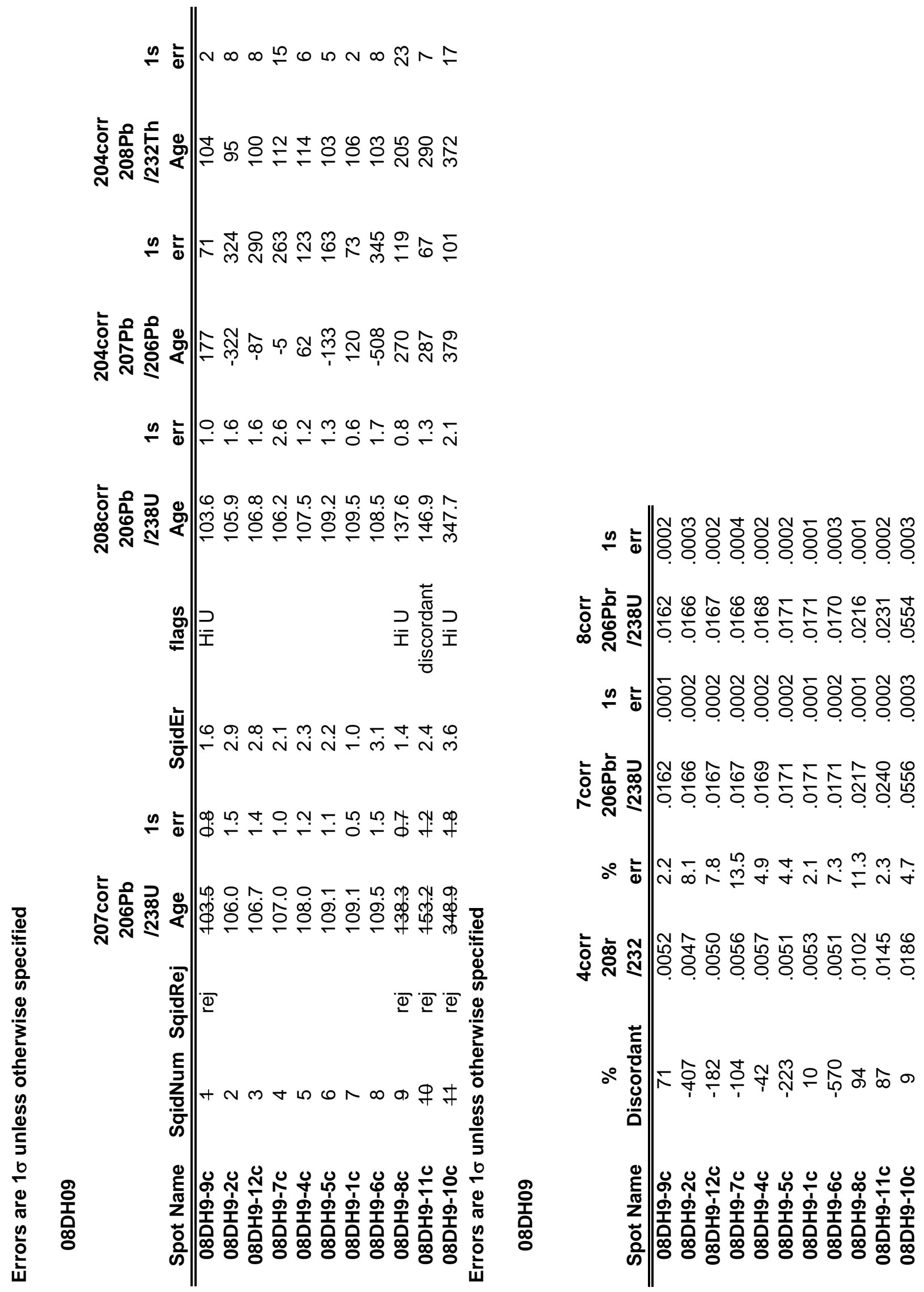

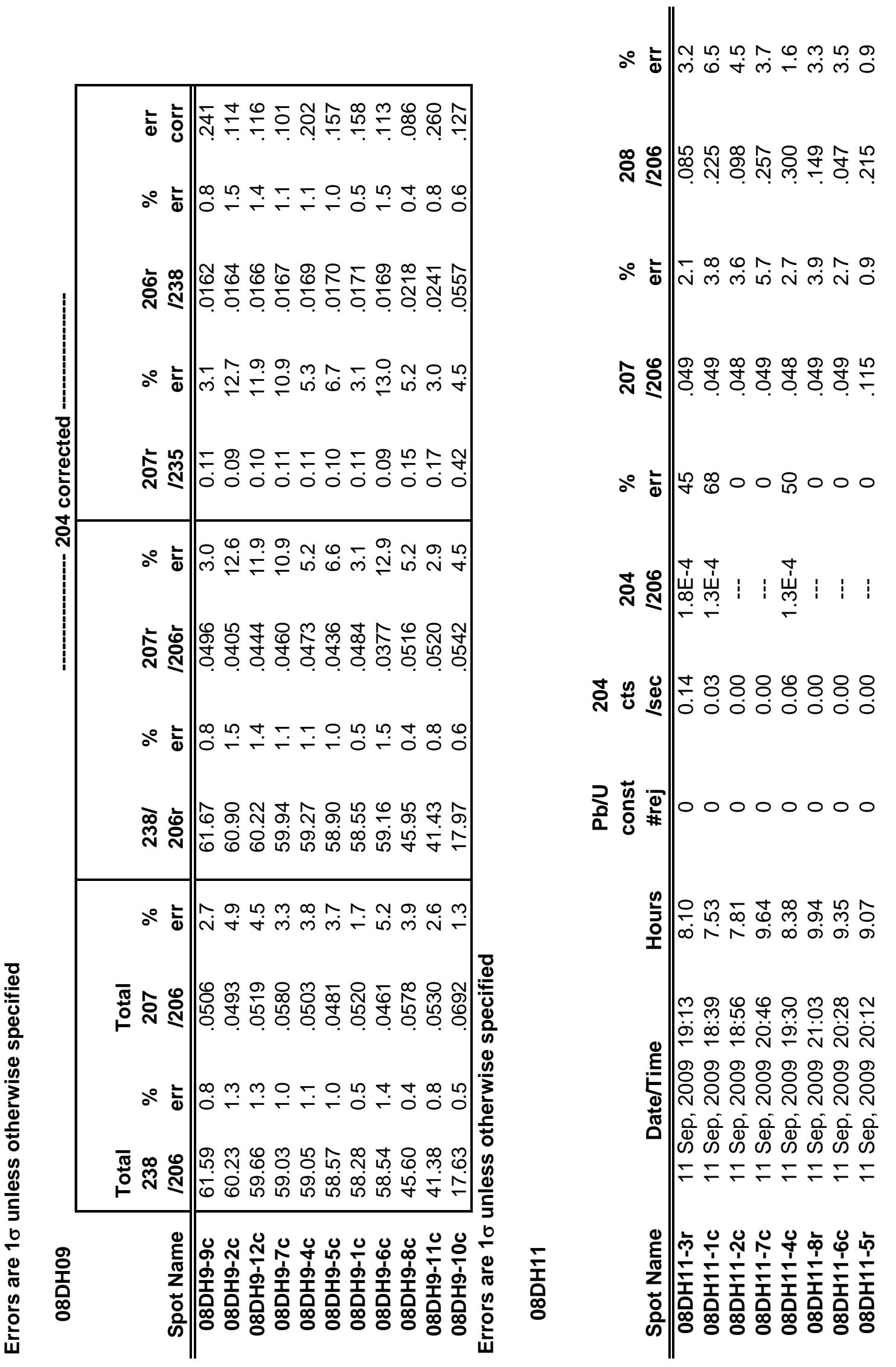


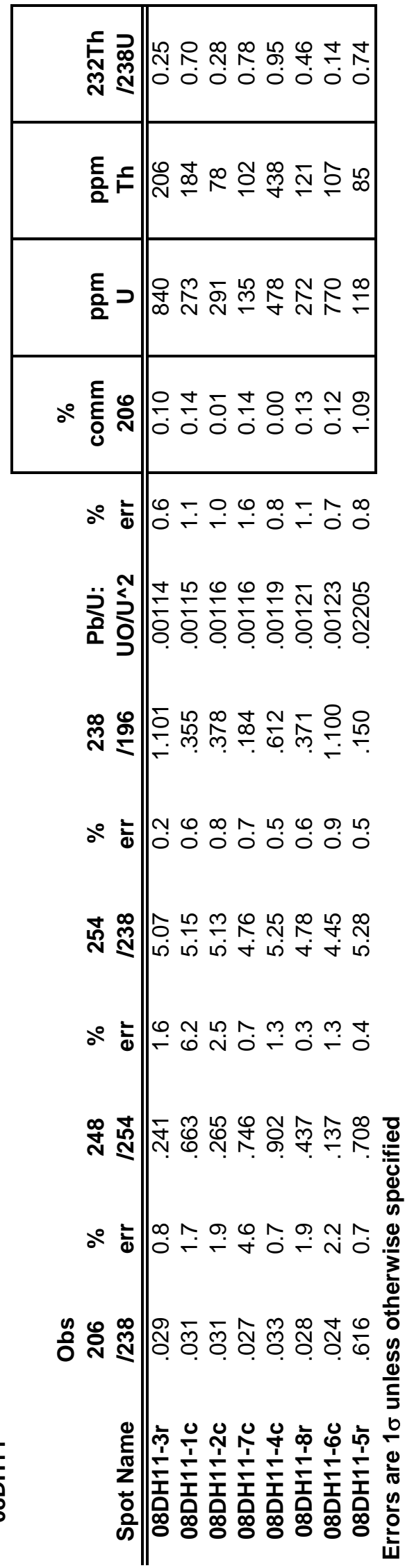

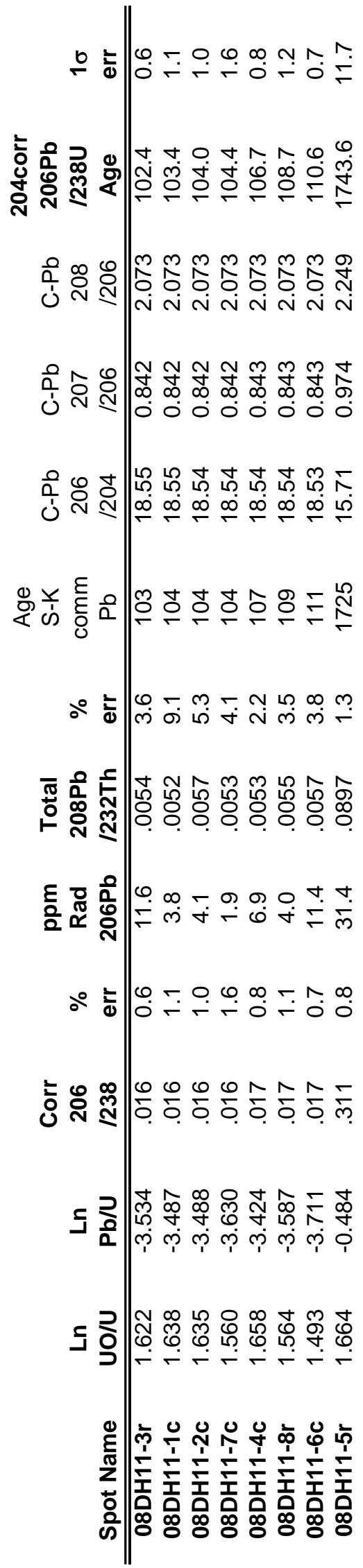



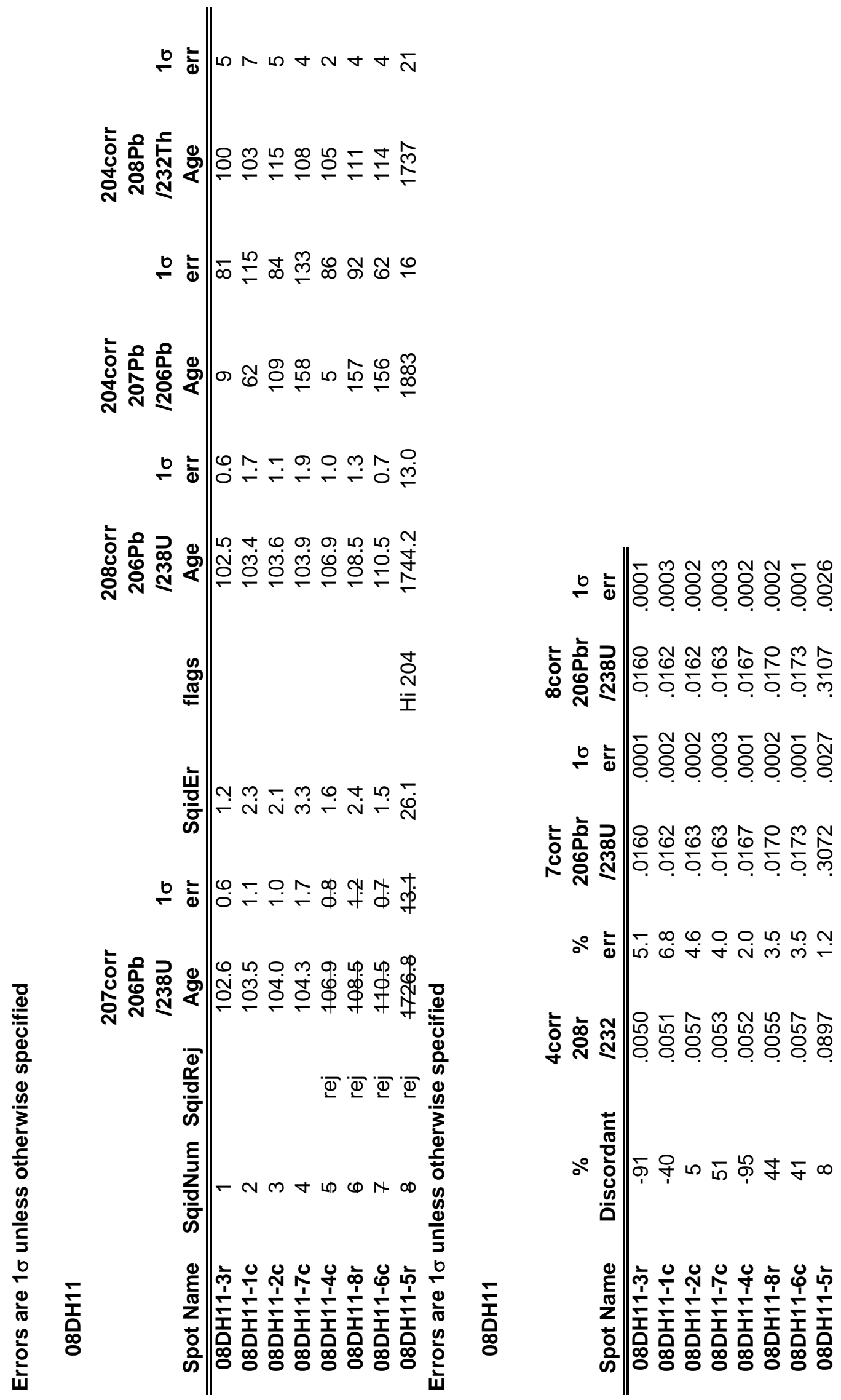

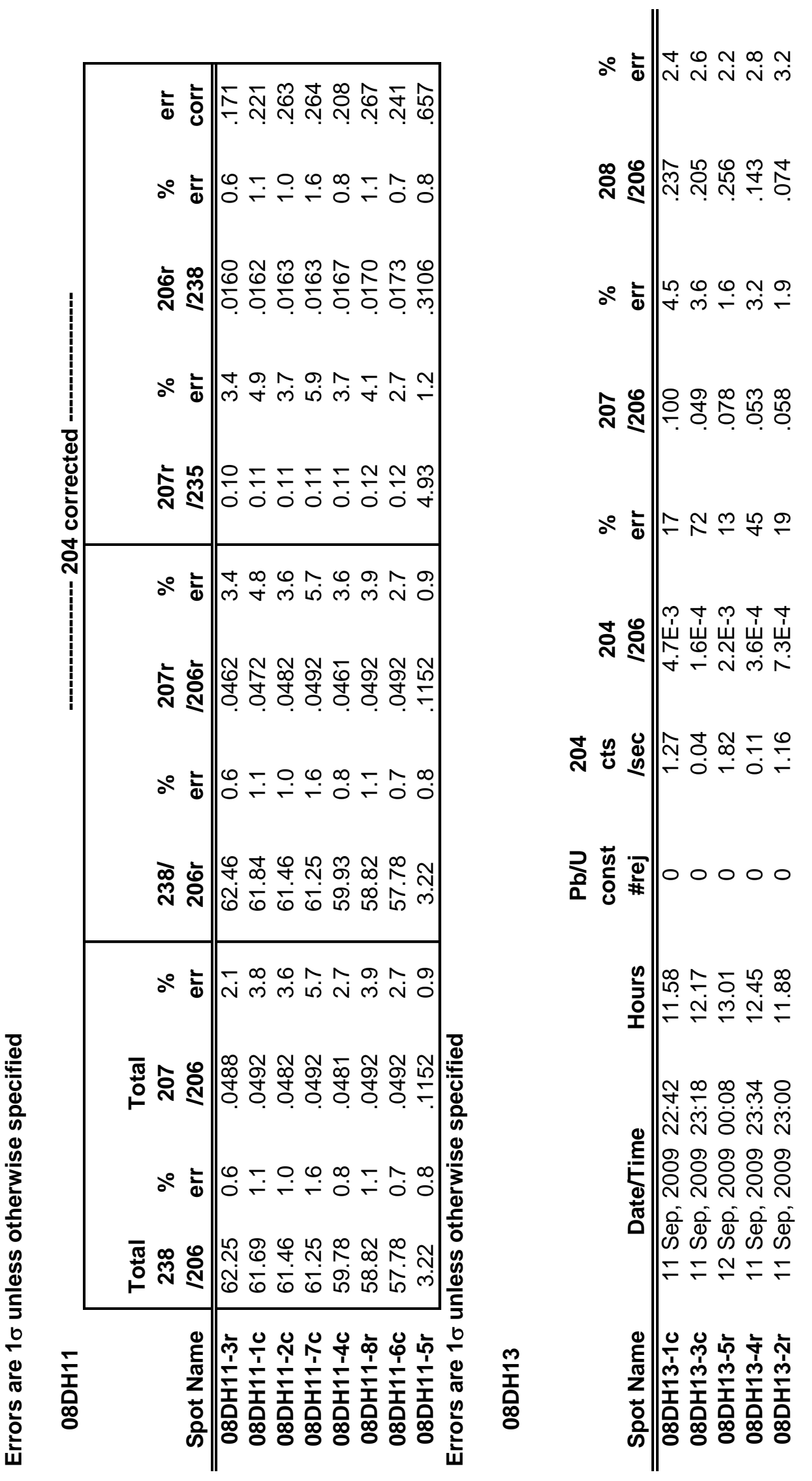

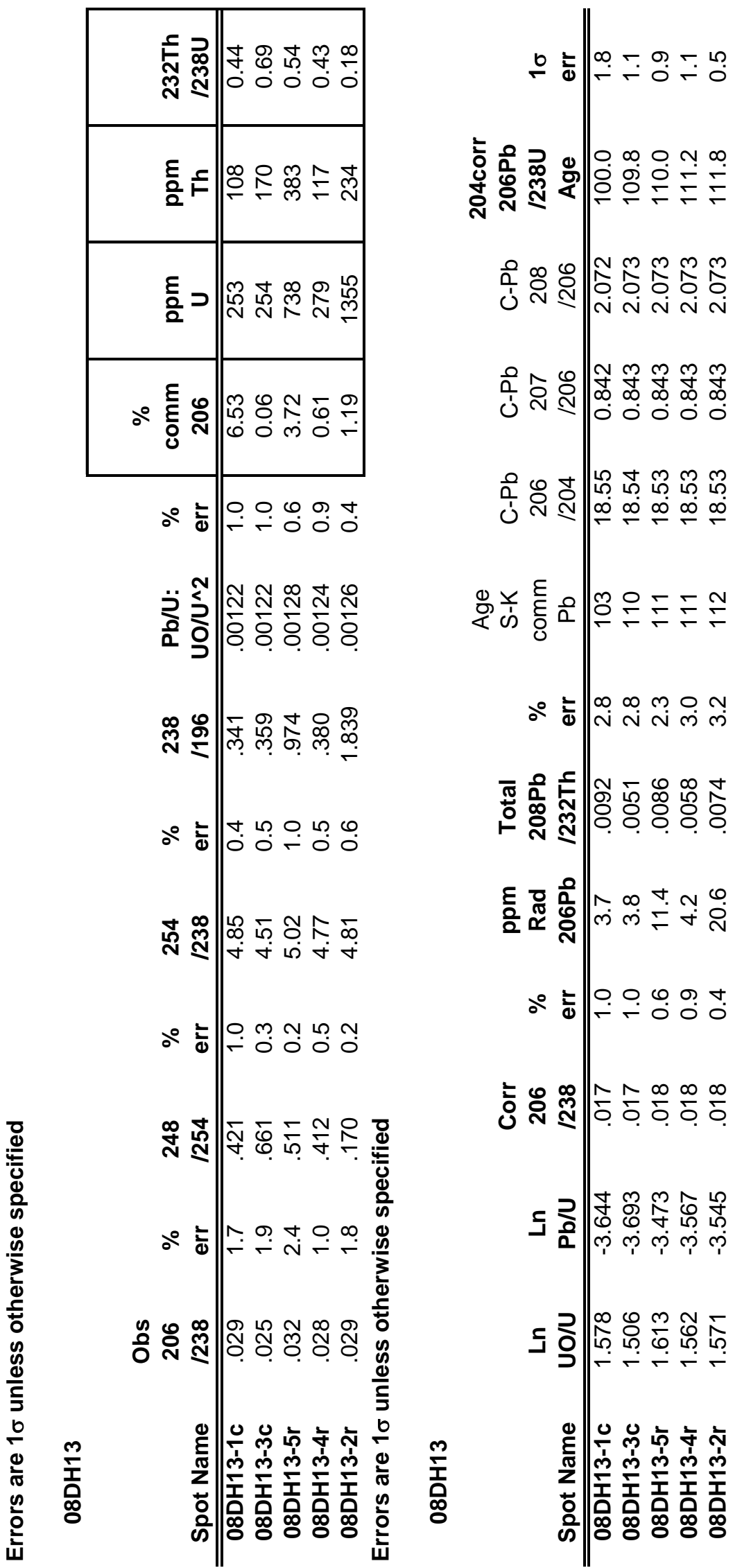


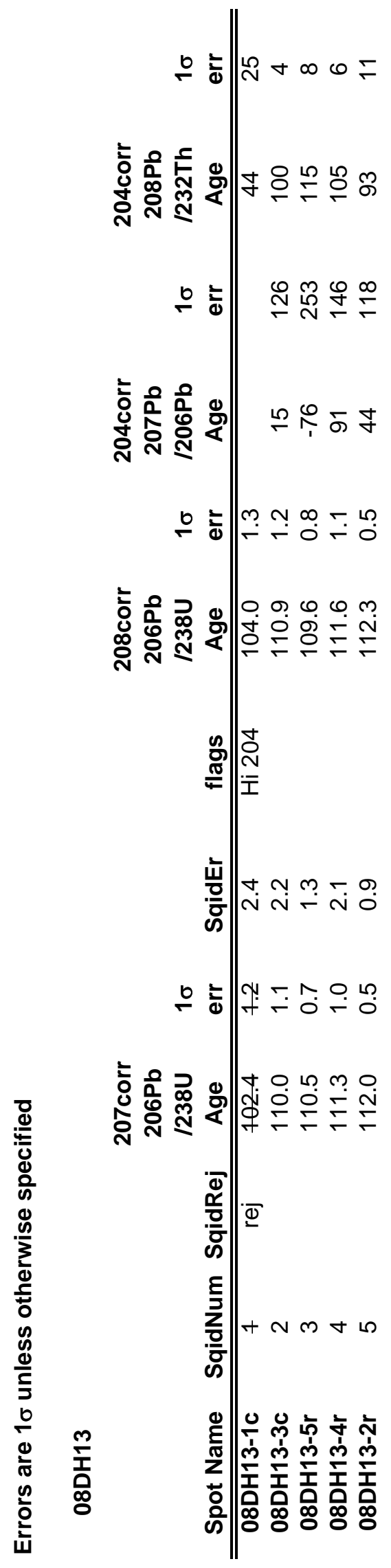



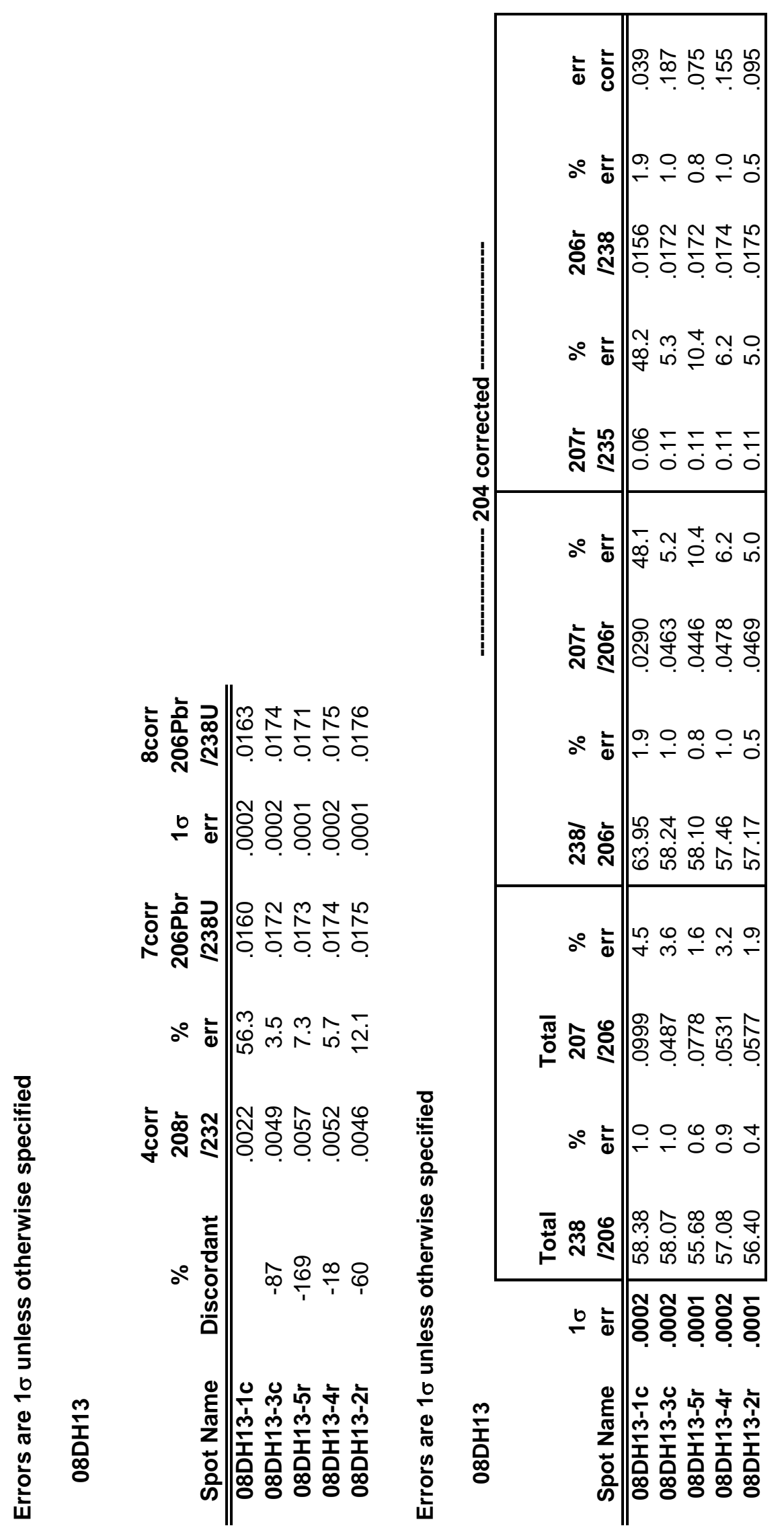


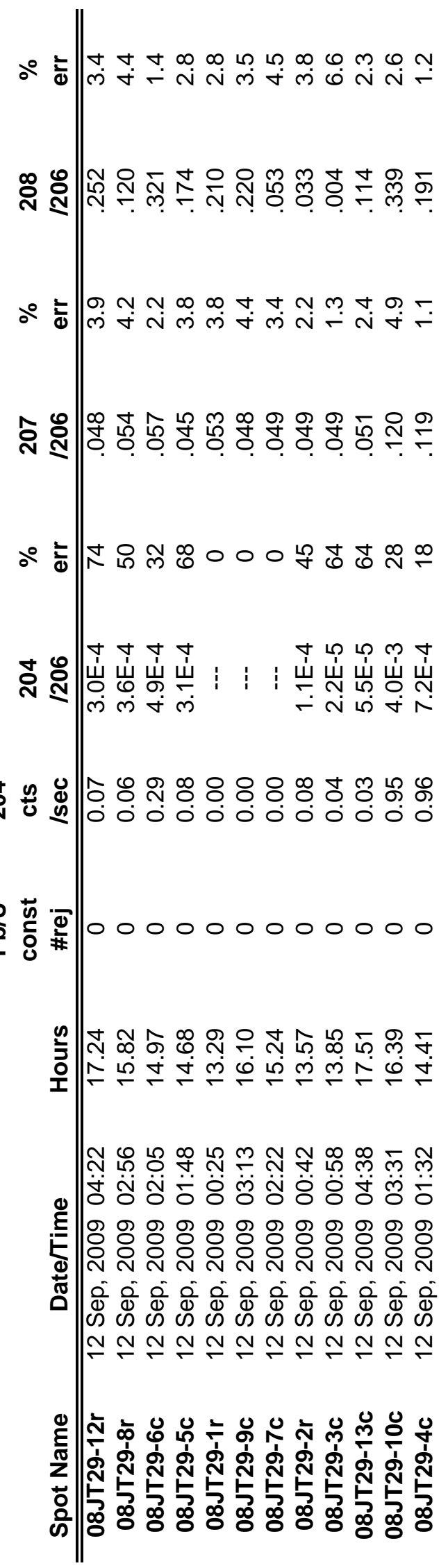




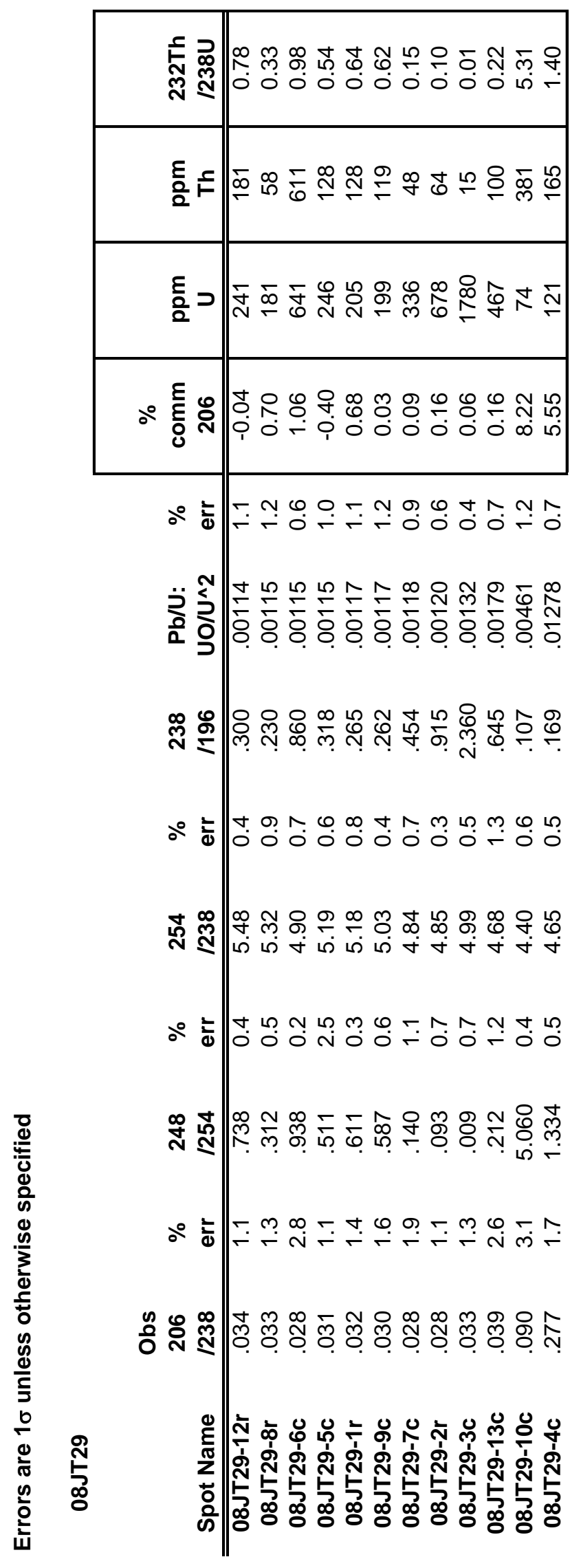




\begin{tabular}{|c|c|}
\hline$\underline{0} \div$ & 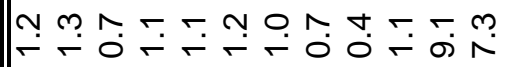 \\
\hline 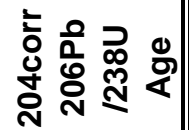 & 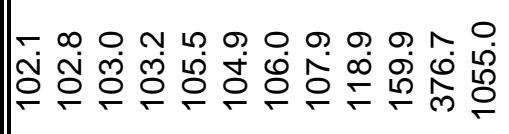 \\
\hline 웅 & 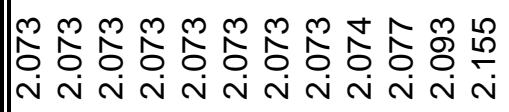 \\
\hline 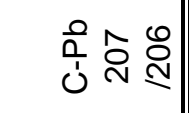 & 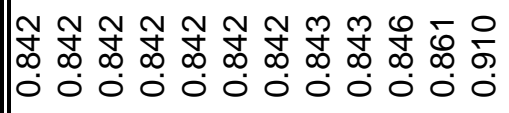 \\
\hline 음 & 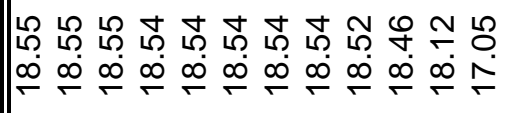 \\
\hline هั & 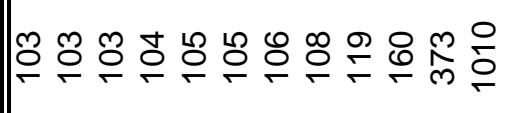 \\
\hline$\circ \frac{\vdots}{d}$ & 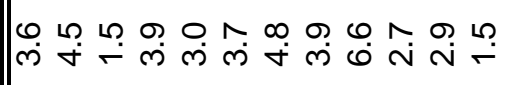 \\
\hline 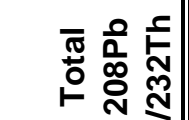 & 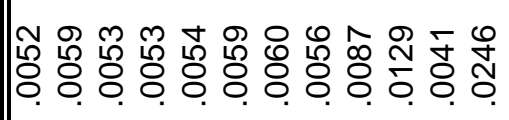 \\
\hline 등휴 융 & 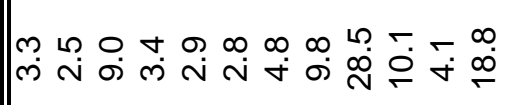 \\
\hline$\circ$ 늘 & 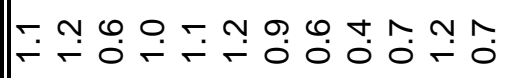 \\
\hline ১े & 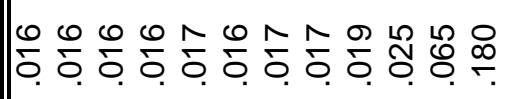 \\
\hline $5 \frac{2}{2}$ & 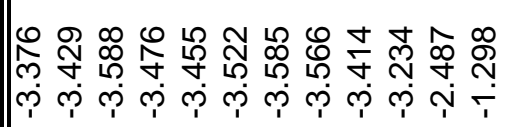 \\
\hline s ํํㅇ & 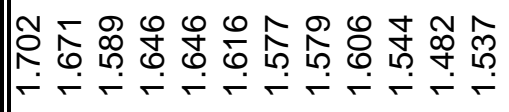 \\
\hline 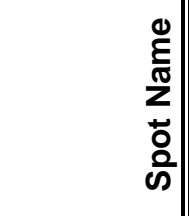 & 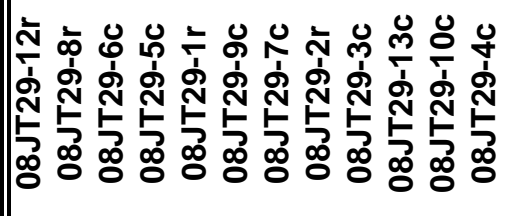 \\
\hline
\end{tabular}




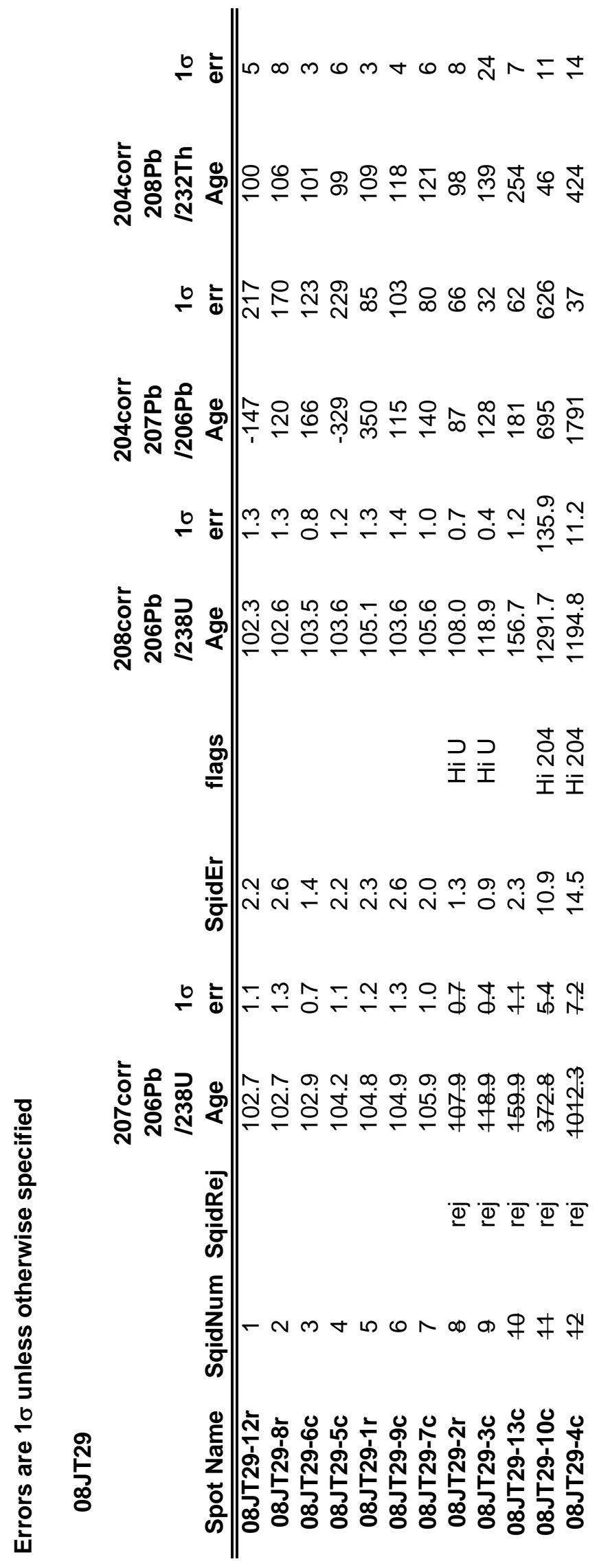




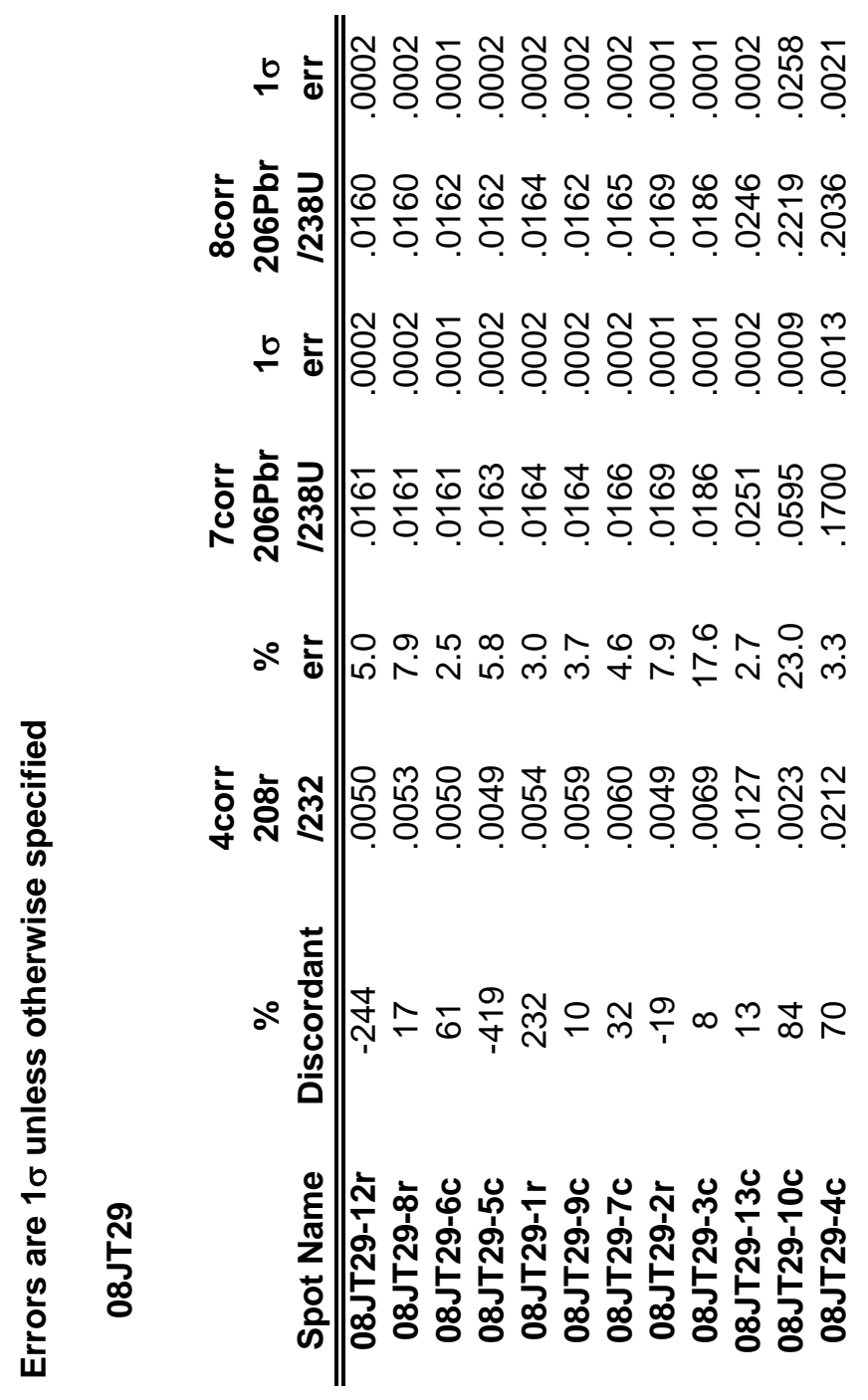




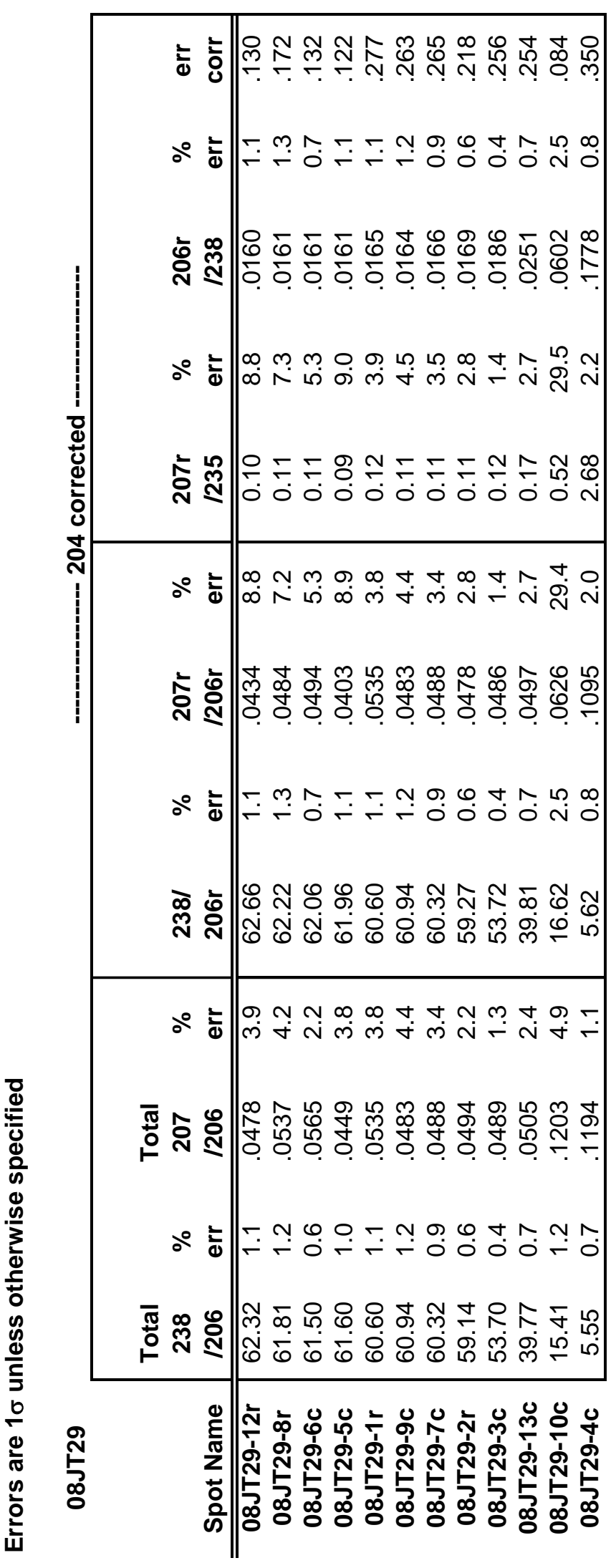




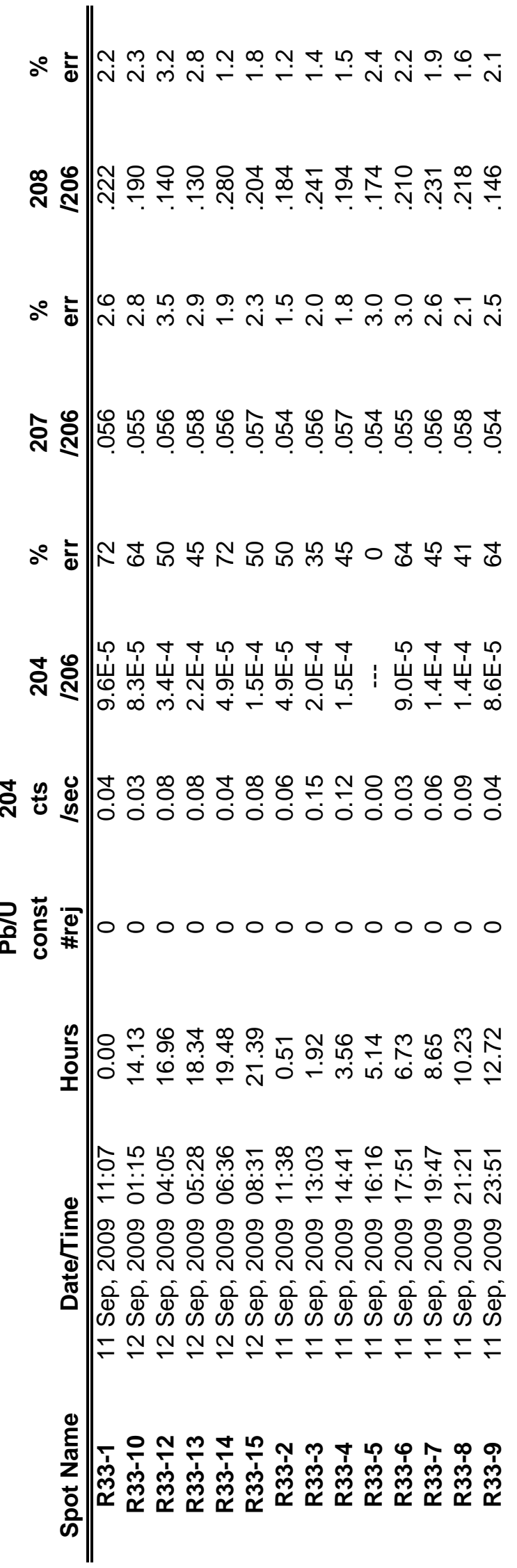




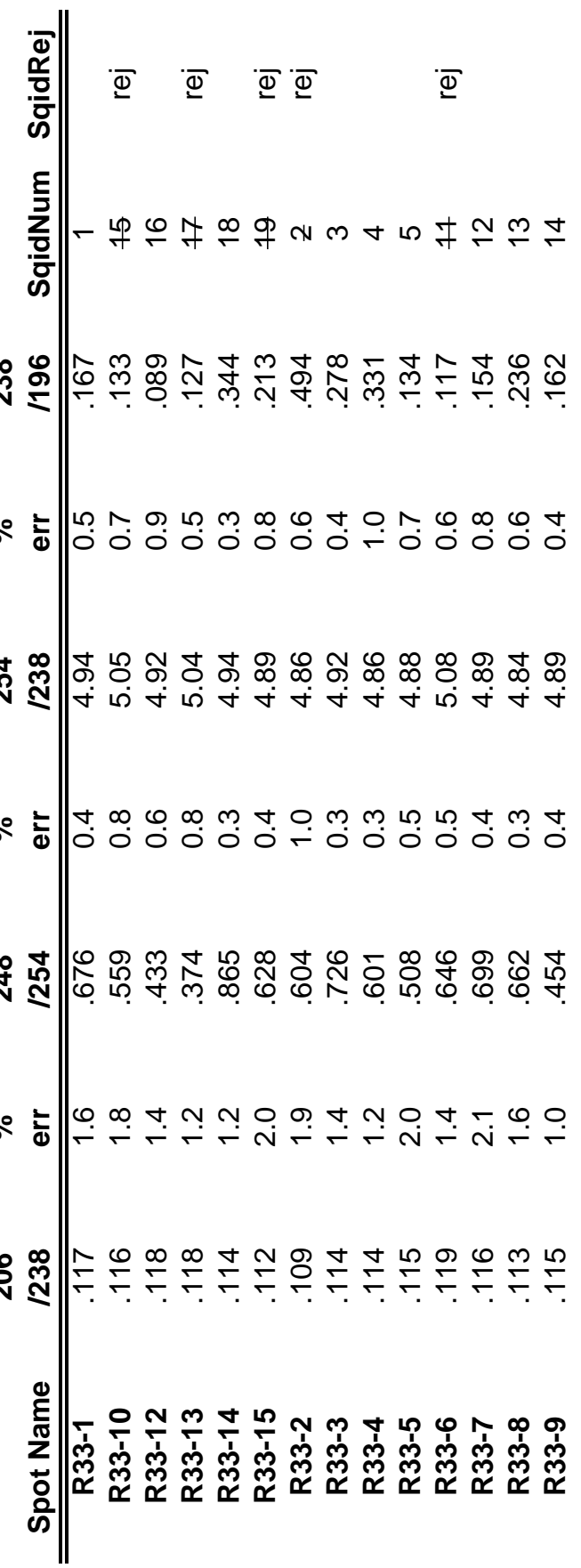




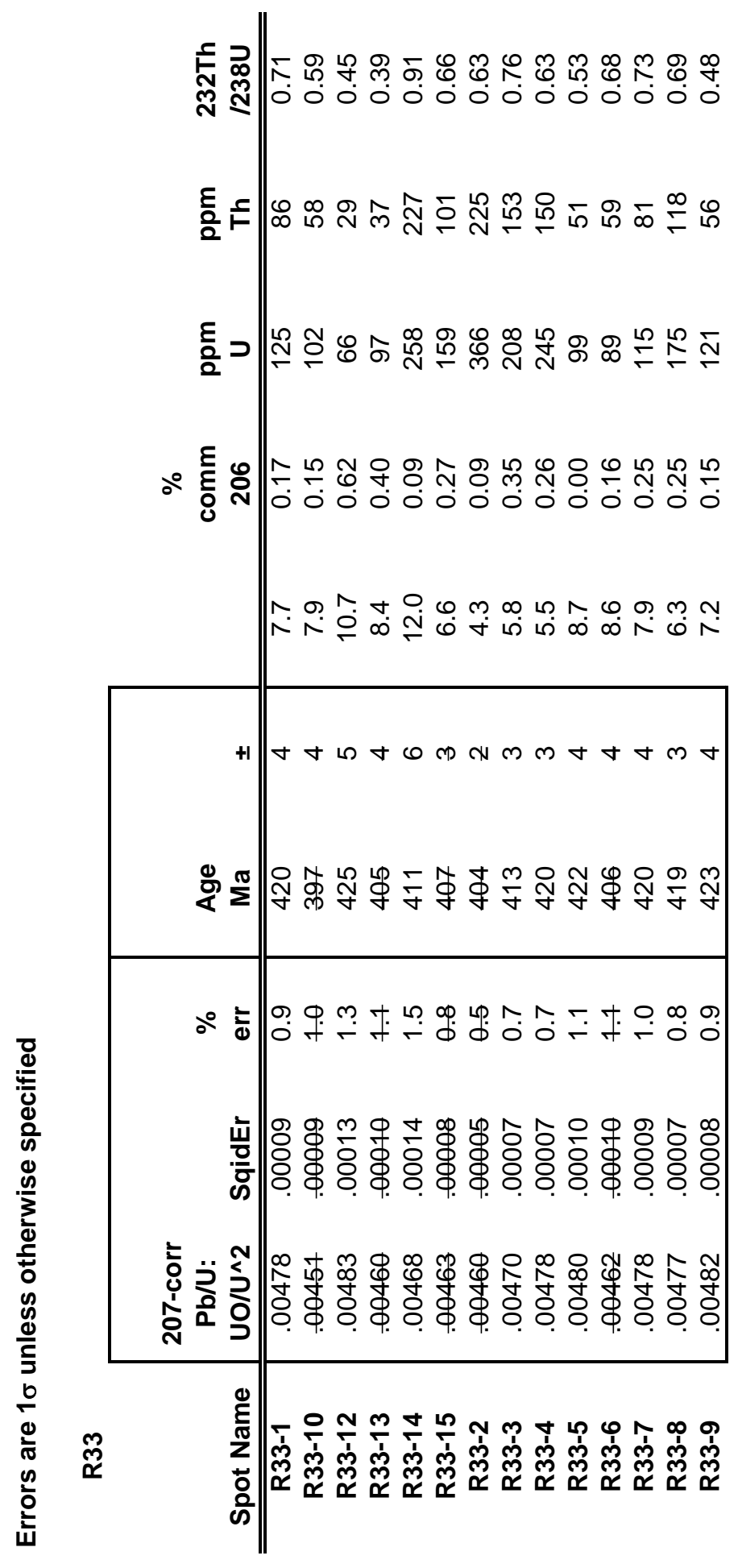




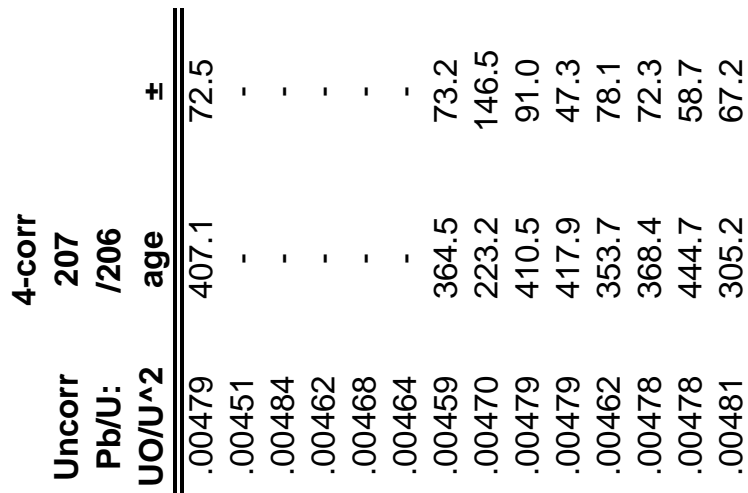

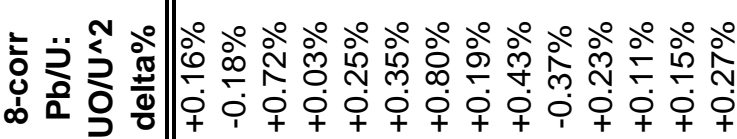

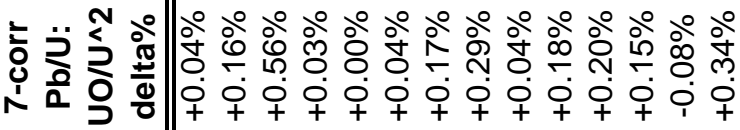

000 o

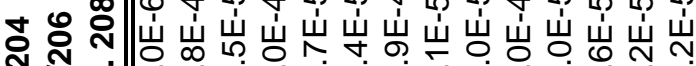

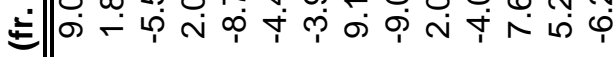

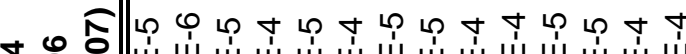

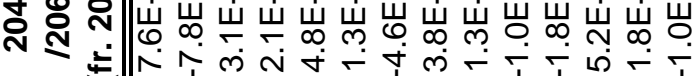

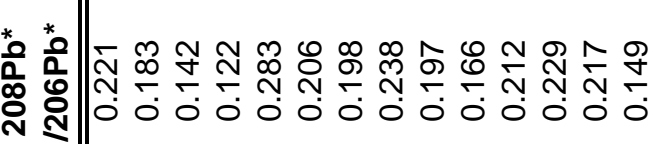

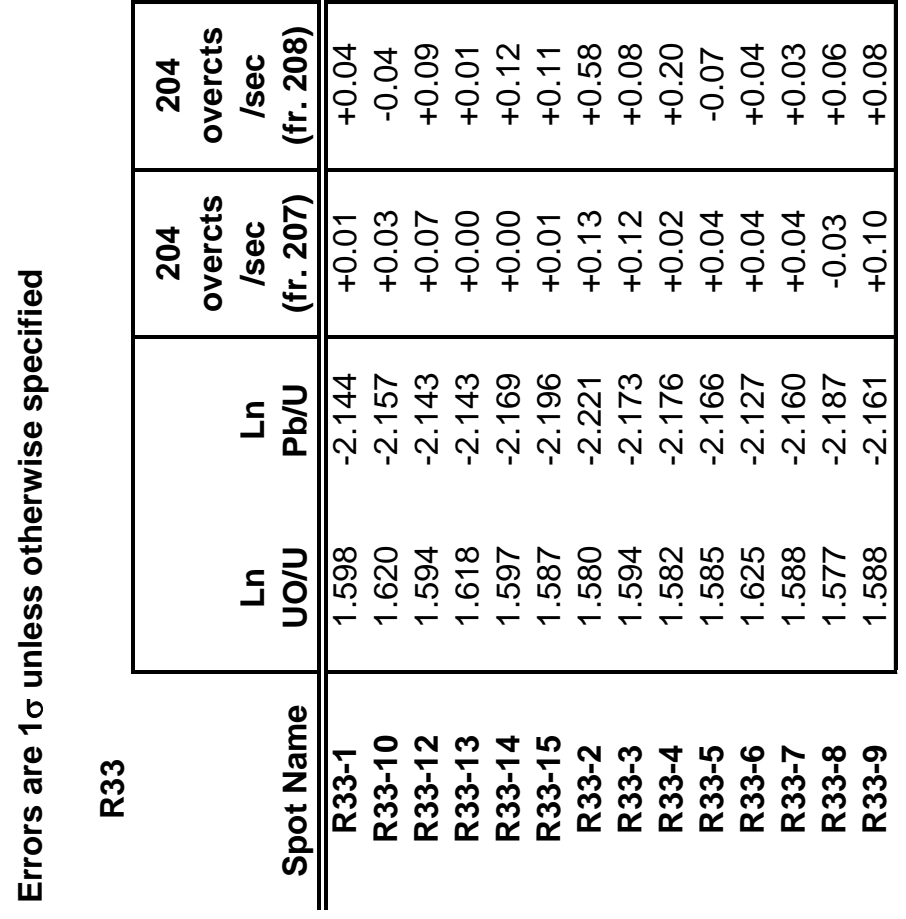


Appendix 3: Cathodoluminesence photomicrographs of detrital zircons separated from Triassic sandstone and Jurassic greywacke samples collected from the Lower Yana River.

08DH01
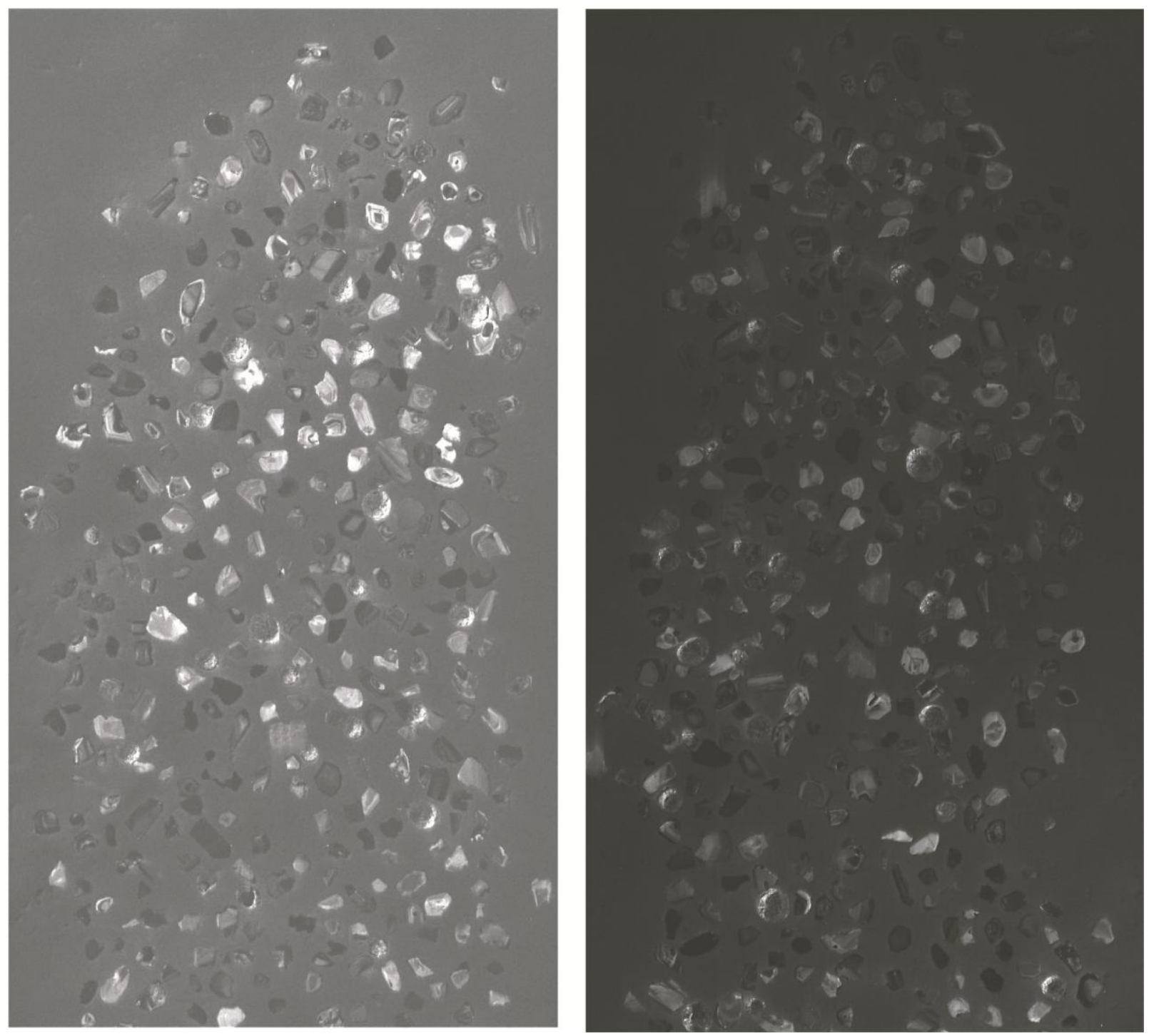

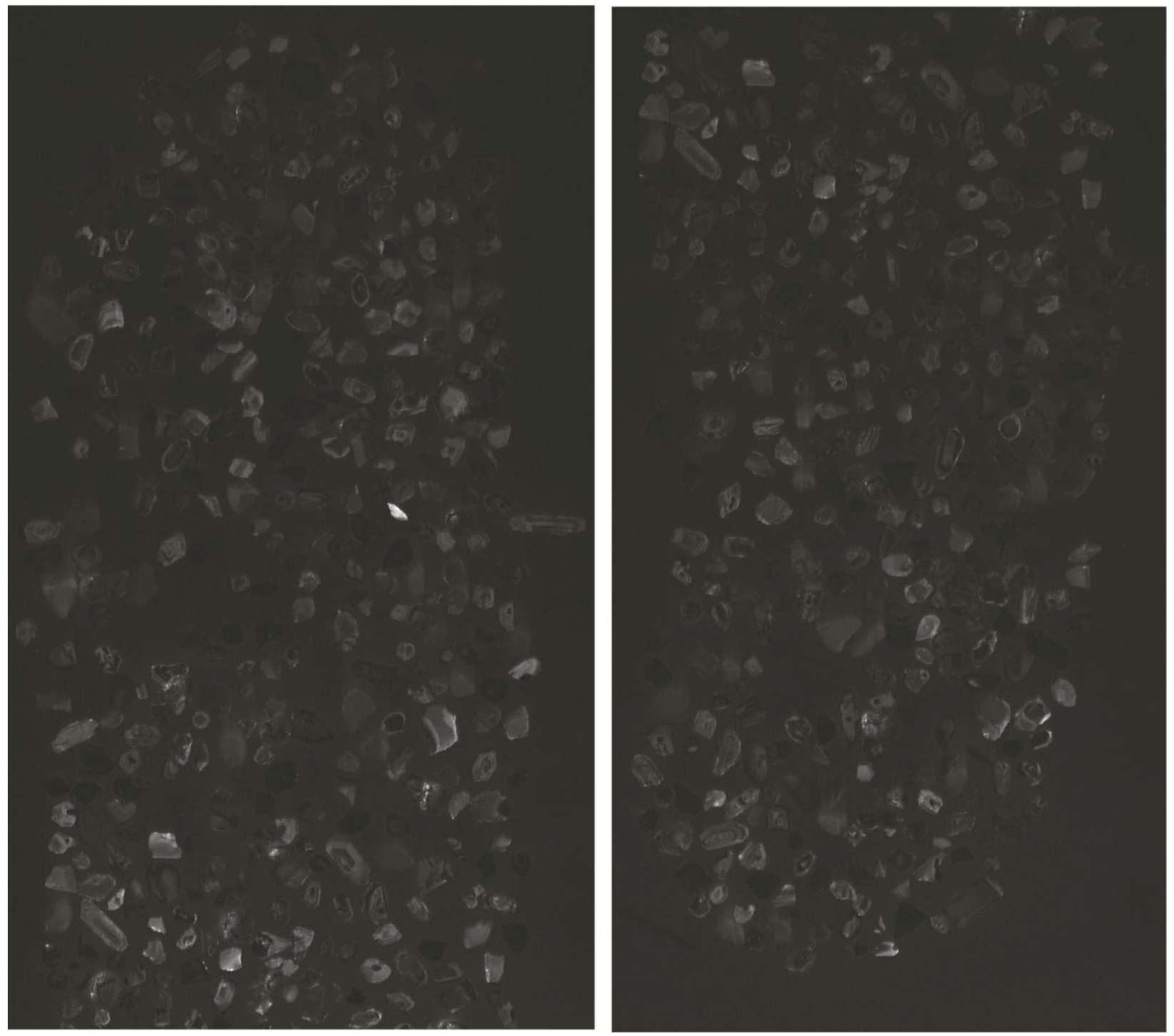
08DH03
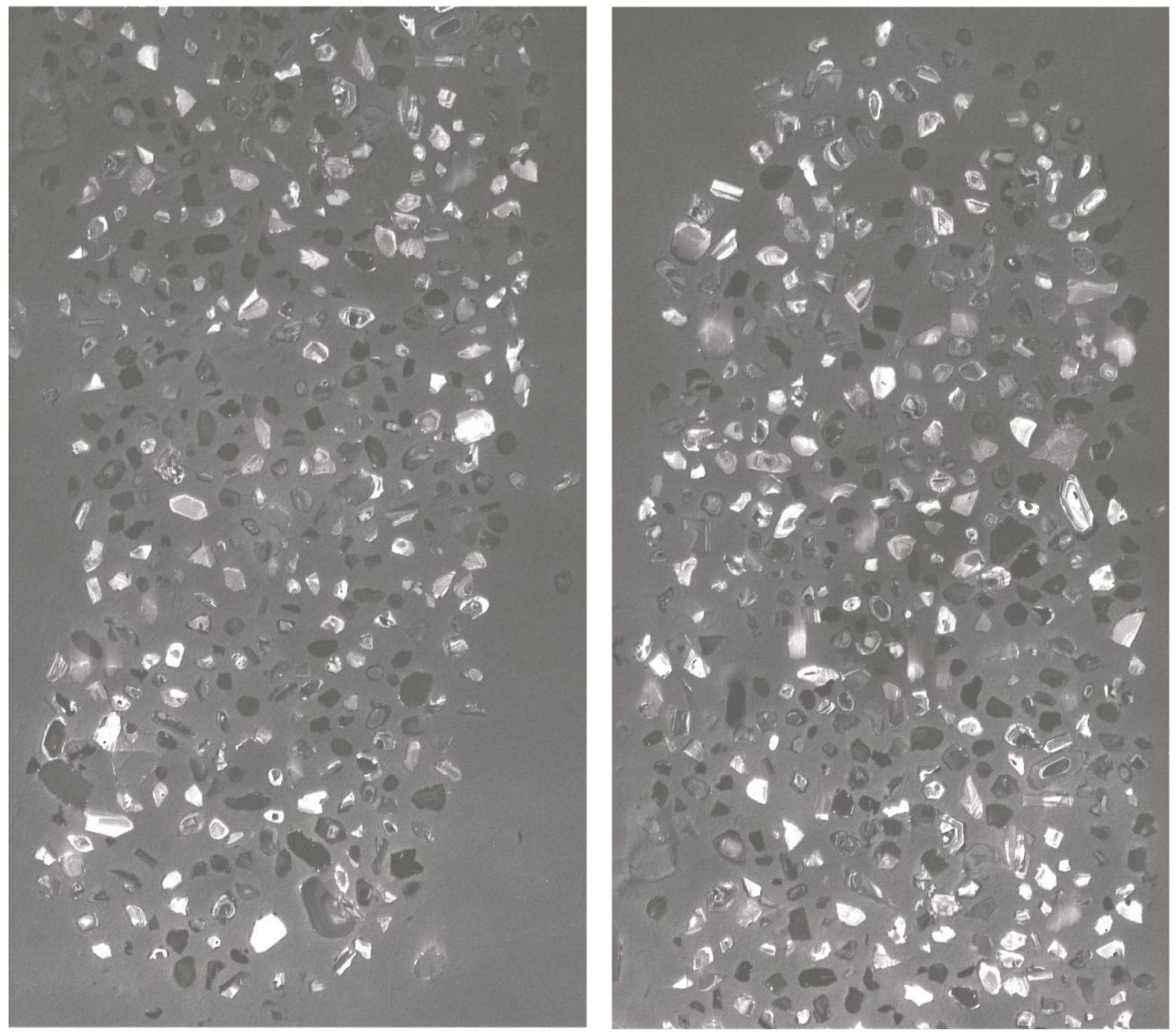
08DH029a
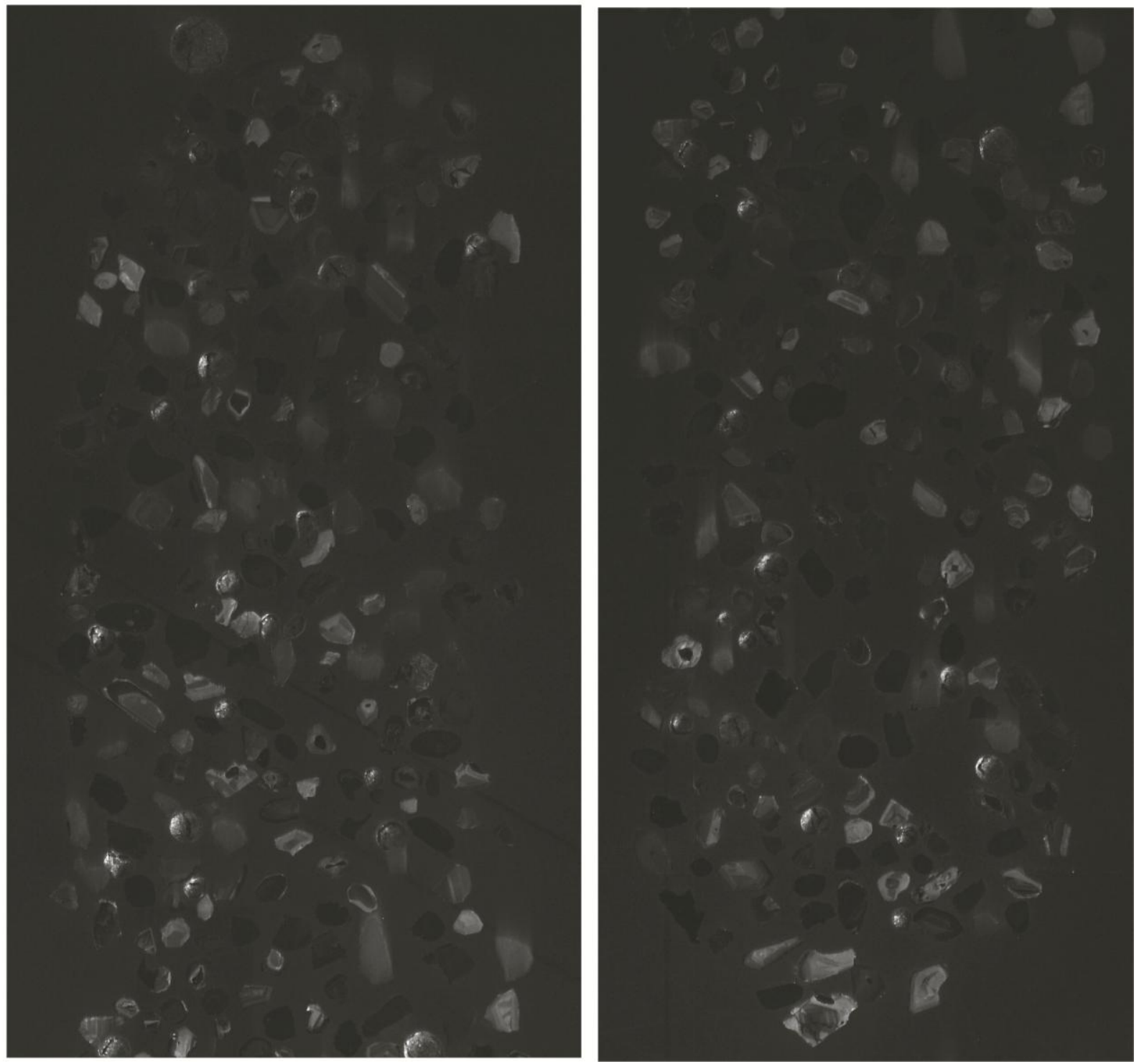

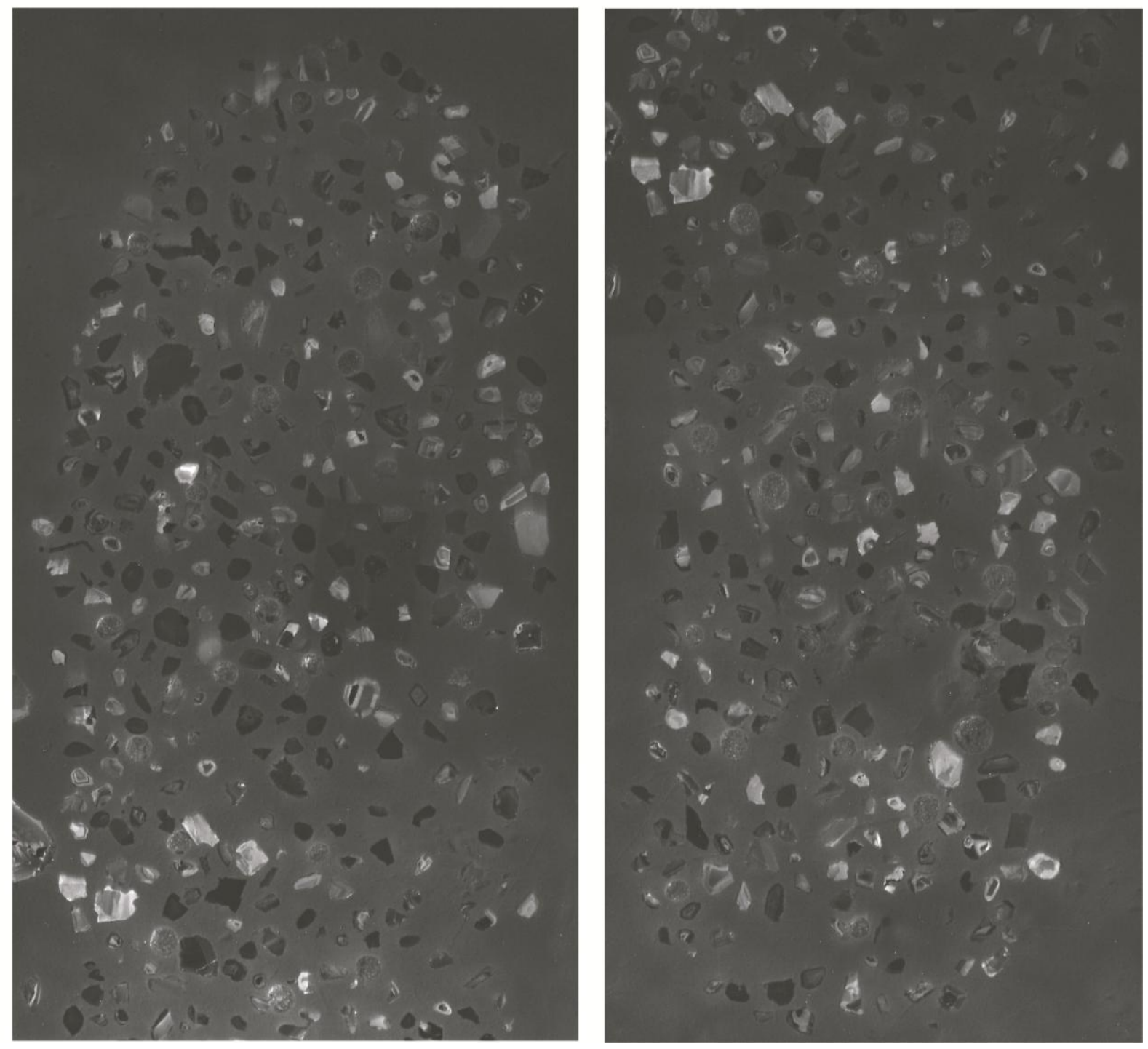
08DH032
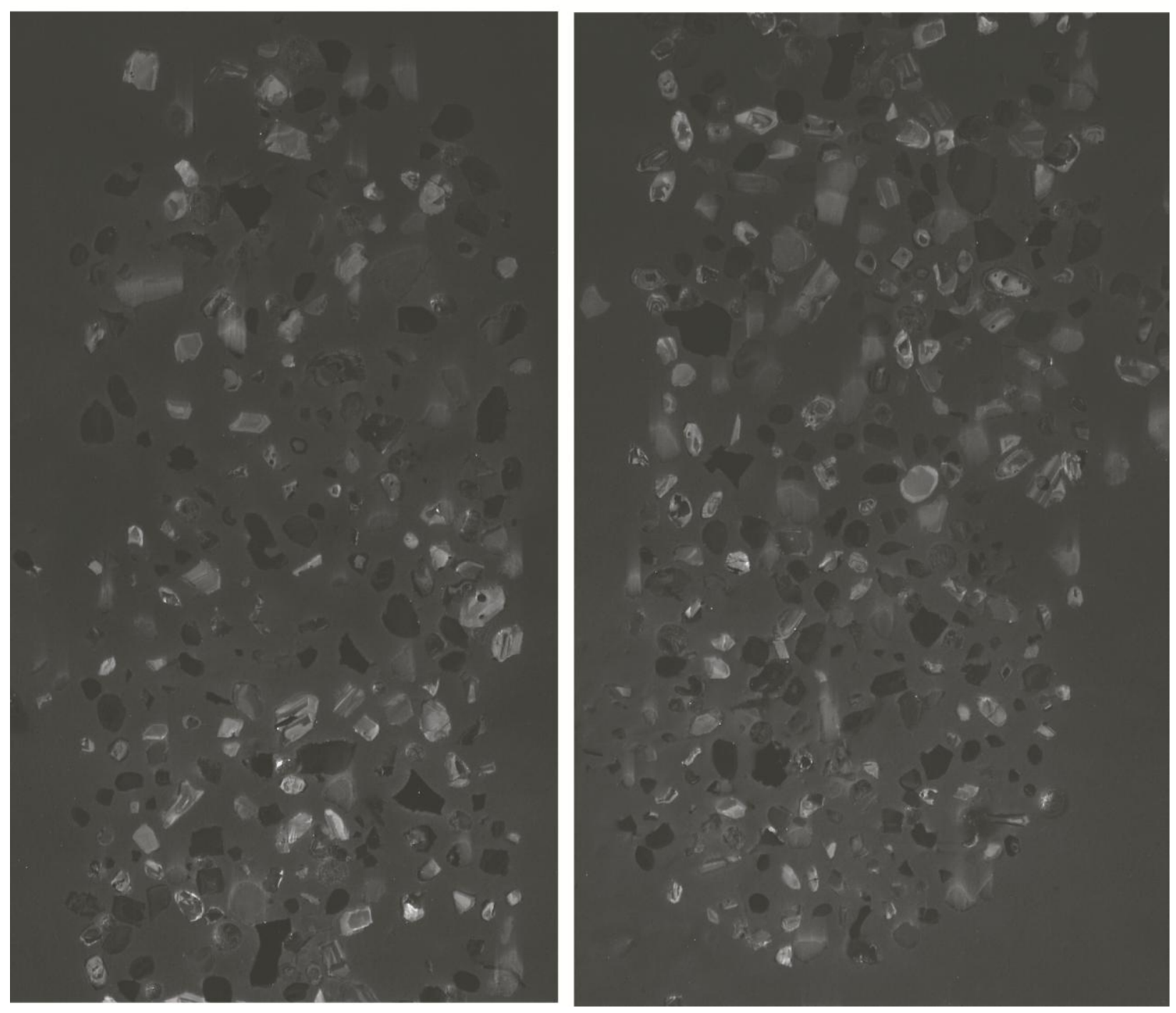

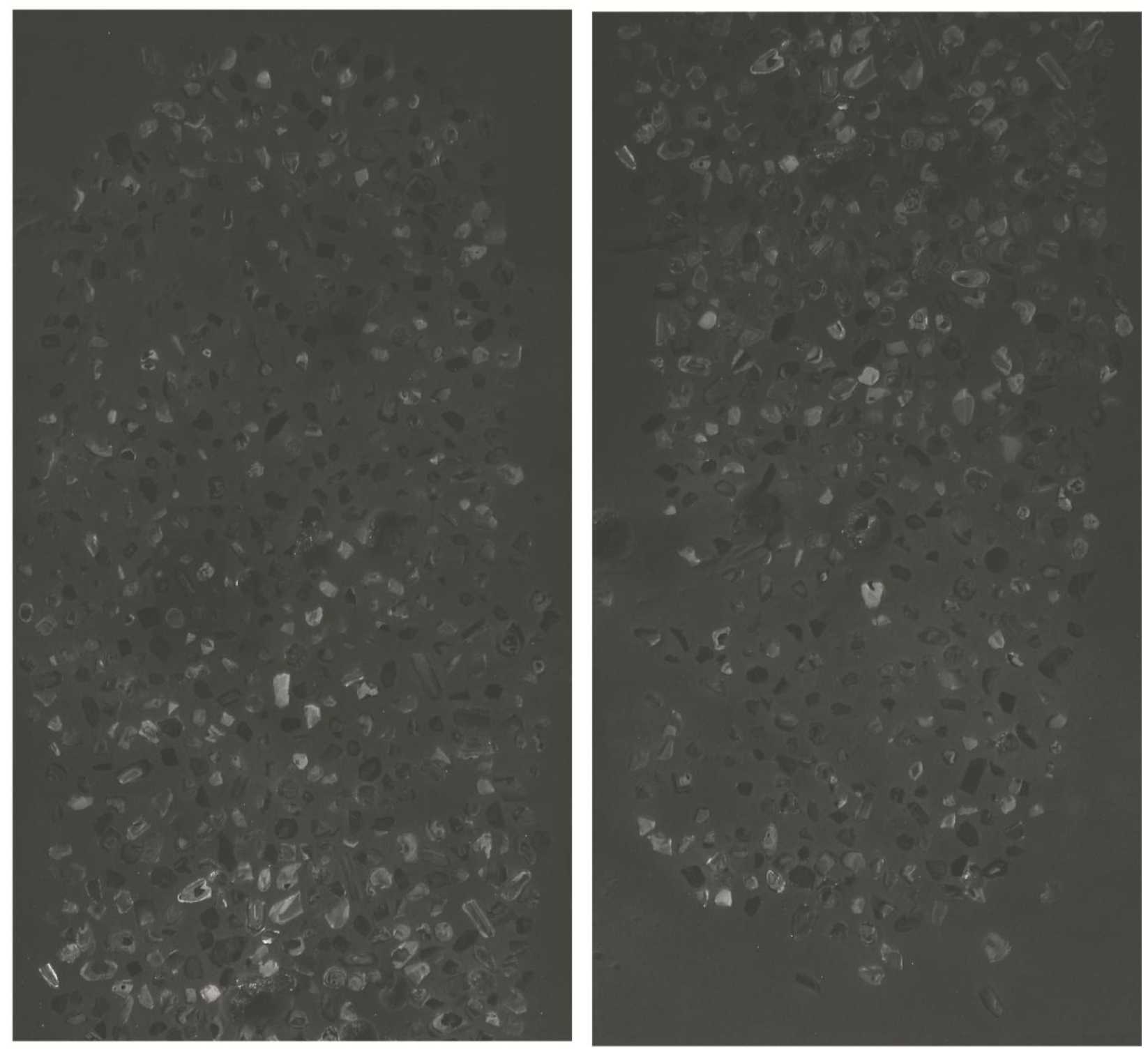
Appendix 4: Complete data from LA-MC-ICPMS analysis of detrital zircons separated from Triassic sandstone and Jurassic greywacke samples from the Lower Yana River area near the Kular Dome, northern Russia. Crossed-out ages were excluded from further analysis due to greater than $30 \%$ discordance or greater than $5 \%$ reverse discordance between ${ }^{238} \mathrm{U} /{ }^{206} \mathrm{~Pb}$ and ${ }^{207} \mathrm{~Pb} /{ }^{206} \mathrm{~Pb}$ ages.

08DH01

Isotope ratios

\begin{tabular}{|c|c|c|c|c|c|c|c|c|c|c|}
\hline Analysis & $\begin{array}{c}U \\
(\mathrm{ppm})\end{array}$ & $\begin{array}{l}206 \mathrm{~Pb} / \\
204 \mathrm{~Pb}\end{array}$ & $\mathrm{U} / \mathrm{Th}$ & $\begin{array}{l}206 \mathrm{~Pb}^{*} / \\
207 \mathrm{~Pb}^{*}\end{array}$ & $\begin{array}{c} \pm \\
(\%)\end{array}$ & $\begin{array}{c}207 \mathrm{~Pb}^{*} / \\
235 \mathrm{U}^{*}\end{array}$ & $\begin{array}{c} \pm \\
(\%)\end{array}$ & $\begin{array}{c}206 \mathrm{~Pb}^{\star} / \\
238 \mathrm{U}\end{array}$ & $\begin{array}{c} \pm \\
(\%)\end{array}$ & $\begin{array}{l}\text { error } \\
\text { corr. }\end{array}$ \\
\hline 08DH01A-1 & 211 & 19461 & 2.5 & 17.5628 & 3.4 & 0.6435 & 3.9 & 0.0820 & 1.9 & $0.4 \mathrm{~J}$ \\
\hline 08DH01A-2 & 360 & 17391 & 1.8 & 19.8616 & 2.4 & 0.2856 & 3.1 & 0.0411 & 2.1 & 0.65 \\
\hline 08DH01A-3 & 55 & 2031 & 1.1 & 19.7490 & 11.6 & 0.3133 & 12.1 & 0.0449 & 3.4 & 0.28 \\
\hline 08DH01A-4 & 130 & 5010 & 1.3 & 18.8102 & 9.4 & 0.3749 & 9.5 & 0.0511 & 1.7 & 0.17 \\
\hline 08DH01A-5 & 68 & 2394 & 1.5 & 19.6525 & 8.7 & 0.3371 & 9.0 & 0.0481 & 2.2 & 0.25 \\
\hline 08DH01A-6 & 122 & 14502 & 1.7 & 15.3509 & 2.6 & 1.1751 & 3.1 & 0.1308 & 1.6 & 0.53 \\
\hline 08DH01A-7 & 241 & 4989 & 0.6 & 19.7412 & 7.6 & 0.2634 & 7.8 & 0.0377 & 1.5 & 0.19 \\
\hline 08DH01A-8 & 211 & 60108 & 1.9 & 7.9578 & 2.2 & 6.4981 & 2.2 & 0.3750 & 0.5 & 0.23 \\
\hline 08DH01A-10 & 55 & 3135 & 2.3 & 21.1067 & 16.4 & 0.3131 & 16.4 & 0.0479 & 1.0 & 0.06 \\
\hline 08DH01A-11 & 205 & 14448 & 4.3 & 17.8497 & 2.3 & 0.6082 & 2.4 & 0.0787 & 0.8 & 0.33 \\
\hline 08DH01A-12 & 55 & 2160 & 0.9 & 22.8922 & 15.3 & 0.2217 & 15.4 & 0.0368 & 1.7 & 0.11 \\
\hline 08DH01A-13 & 75 & 4350 & 1.9 & 19.9594 & 7.2 & 0.3890 & 7.3 & 0.0563 & 0.8 & 0.10 \\
\hline 08DH01A-14 & 231 & 8205 & 1.1 & 19.9424 & 3.1 & 0.2560 & 3.4 & 0.0370 & 1.3 & 0.39 \\
\hline 08DH01A-15 & 149 & 2382 & 0.9 & 18.0903 & 6.6 & 0.2829 & 7.0 & 0.0371 & 2.4 & 0.35 \\
\hline 08DH01A-16 & 64 & 31032 & 1.9 & 7.6924 & 2.2 & 6.8633 & 2.4 & 0.3829 & 0.9 & 0.36 \\
\hline 08DH01A-17 & 143 & 13155 & 1.9 & 17.5439 & 2.2 & 0.6338 & 2.9 & 0.0806 & 1.9 & 0.65 \\
\hline 08DH01A-18 & 117 & 6390 & 1.6 & 19.9817 & 4.9 & 0.3396 & 5.1 & 0.0492 & 1.4 & 0.27 \\
\hline 08DH01A-19 & 141 & 8235 & 1.5 & 19.4695 & 3.9 & 0.3689 & 4.2 & 0.0521 & 1.6 & 0.38 \\
\hline 08DH01A-20 & 326 & 10470 & 1.9 & 19.7149 & 2.1 & 0.2881 & 2.2 & 0.0412 & 0.5 & 0.23 \\
\hline 08DH01A-21 & 442 & 77655 & 6.7 & 8.8387 & 1.7 & 5.0666 & 1.9 & 0.3248 & 0.8 & 0.43 \\
\hline 08DH01A-22 & 149 & 5133 & 0.9 & 20.3510 & 4.6 & 0.2570 & 5.0 & 0.0379 & 1.9 & 0.37 \\
\hline 08DH01A-23 & 311 & 5694 & 1.5 & 18.4303 & 15.0 & 0.2959 & 15.1 & 0.0396 & 2.0 & 0.13 \\
\hline 08DH01A-24 & 83 & 3531 & 1.2 & 20.6238 & 6.5 & 0.2756 & 6.5 & 0.0412 & 0.7 & 0.11 \\
\hline 08DH01A-25 & 537 & 40284 & 5.1 & 17.9289 & 1.6 & 0.5696 & 1.8 & 0.0741 & 0.8 & 0.47 \\
\hline 08DH01A-26 & 412 & 14859 & 1.6 & 18.9048 & 2.7 & 0.3707 & 3.7 & 0.0508 & 2.6 & 0.69 \\
\hline 08DH01A-28 & 371 & 39585 & 7.9 & 5.5103 & 1.2 & 10.1425 & 2.5 & 0.4053 & 2.2 & 0.89 \\
\hline 08DH01A-29 & 116 & 5157 & 2.4 & 17.2638 & 12.4 & 0.6213 & 12.5 & 0.0778 & 1.3 & 0.10 \\
\hline 08DH01A-30 & 416 & 29775 & 1.4 & 17.3842 & 1.6 & 0.7006 & 1.9 & 0.0883 & 0.9 & 0.50 \\
\hline 08DH01A-31 & 125 & 5175 & 0.8 & 20.4793 & 5.4 & 0.2717 & 5.9 & 0.0404 & 2.4 & 0.40 \\
\hline 08DH01A-32 & 98 & 6828 & 3.2 & 18.0005 & 4.6 & 0.5091 & 5.4 & 0.0665 & 2.9 & 0.53 \\
\hline 08DH01A-33 & 248 & 13593 & 3.5 & 18.7896 & 2.9 & 0.4532 & 3.1 & 0.0618 & 1.2 & 0.38 \\
\hline 08DH01A-34 & 237 & 12633 & 1.2 & 17.5753 & 1.9 & 0.6364 & 1.9 & 0.0811 & 0.5 & 0.26 \\
\hline 08DH01A-35 & 153 & 40836 & 1.8 & 8.5944 & 1.4 & 5.4674 & 1.5 & 0.3408 & 0.5 & 0.33 \\
\hline 08DH01A-36 & 196 & 14544 & 1.8 & 18.0818 & 3.1 & 0.5485 & 3.3 & 0.0719 & 1.2 & 0.36 \\
\hline 08DH01A-37 & 125 & 5124 & 1.6 & 16.7961 & 13.6 & 0.6415 & 13.7 & 0.0782 & 1.3 & 0.09 \\
\hline 08DH01A-38 & 133 & 5931 & 1.5 & 19.3924 & 5.6 & 0.3446 & 6.1 & 0.0485 & 2.4 & 0.39 \\
\hline 08DH01A-39 & 84 & 28221 & 1.6 & 8.6296 & 2.3 & 5.5121 & 2.5 & 0.3450 & 0.9 & 0.34 \\
\hline $08 \mathrm{DH} 01 \mathrm{~A}-40$ & 73 & 2610 & 1.0 & 20.0603 & 7.3 & 0.3104 & 7.3 & 0.0452 & 0.8 & 0.11 \\
\hline 08DH01A-41 & 97 & 12312 & 2.1 & 15.1507 & 3.3 & 1.1519 & 3.4 & 0.1266 & 0.9 & 0.26 \\
\hline 08DH01A-42 & 145 & 6921 & 1.7 & 19.6463 & 2.9 & 0.3257 & 3.0 & 0.0464 & 0.9 & 0.29 \\
\hline 08DH01A-43 & 137 & 4761 & 1.0 & 20.4673 & 4.5 & 0.2548 & 4.6 & 0.0378 & 1.1 & 0.23 \\
\hline 08DH01A-44 & 164 & 5967 & 1.1 & 20.3638 & 5.4 & 0.2546 & 5.5 & 0.0376 & 0.6 & 0.11 \\
\hline 08DH01A-45 & 48 & 4293 & 1.5 & 18.0654 & 4.7 & 0.6201 & 4.9 & 0.0813 & 1.3 & 0.26 \\
\hline 08DH01A-46 & 36 & 3897 & 1.2 & 18.0763 & 8.4 & 0.6052 & 8.5 & 0.0793 & 1.3 & 0.15 \\
\hline 08DH01A-47 & 373 & 23595 & 6.6 & 18.4118 & 2.9 & 0.4372 & 3.5 & 0.0584 & 2.1 & 0.58 \\
\hline
\end{tabular}


08DH01

Apparent Ages (Ma)

\begin{tabular}{|c|c|c|c|c|c|c|c|c|c|}
\hline Analysis & $\begin{array}{c}206 \mathrm{~Pb}^{\star} / \\
238 \mathrm{U}^{\star}\end{array}$ & $\begin{array}{c} \pm \\
(\mathrm{Ma})\end{array}$ & $\begin{array}{c}207 \mathrm{~Pb}^{*} / \\
235 \mathrm{U}\end{array}$ & $\begin{array}{c} \pm \\
(\mathrm{Ma})\end{array}$ & $\begin{array}{l}206 \mathrm{~Pb}^{\star} / \\
207 \mathrm{~Pb}^{*}\end{array}$ & $\begin{array}{c} \pm \\
(\mathrm{Ma})\end{array}$ & $\begin{array}{c}\text { Best age } \\
\quad(\mathrm{Ma})\end{array}$ & $\stackrel{ \pm}{ \pm}$ & $\begin{array}{c}\text { Conc } \\
(\%)\end{array}$ \\
\hline 08DH01A-1 & 507.9 & 9.1 & 504.5 & 15.3 & 489.2 & 74.3 & 507.9 & 9.1 & 103.8 \\
\hline $08 \mathrm{DH} 01 \mathrm{~A}-2$ & 259.9 & 5.2 & 255.1 & 7.1 & 211.1 & 55.4 & 259.9 & 5.2 & 123.1 \\
\hline 08DH01A-3 & 283.0 & 9.4 & 276.7 & 29.2 & 224.3 & 268.2 & 283.0 & 9.4 & 126.2 \\
\hline 08DH01A-4 & 321.5 & 5.2 & 323.3 & 26.4 & 335.7 & 213.0 & 321.5 & 5.2 & 95.8 \\
\hline 08DH01A-5 & 302.6 & 6.6 & 295.0 & 23.0 & 235.6 & 200.7 & 302.6 & 6.6 & 128.4 \\
\hline 08DH01A-6 & 792.6 & 12.1 & 789.0 & 16.9 & 778.9 & 55.1 & 792.6 & 12.1 & 101.8 \\
\hline 08DH01A-7 & 238.7 & 3.4 & 237.4 & 16.5 & 225.2 & 176.7 & 238.7 & 3.4 & 106.0 \\
\hline 08DH01A-8 & 2053.1 & 8.8 & 2045.6 & 19.5 & 2038.1 & 38.2 & 2038.1 & 38.2 & 100.7 \\
\hline 08DH01A-10 & 301.8 & 2.9 & 276.6 & 39.8 & 68.3 & 392.5 & 301.8 & 2.9 & 441.7 \\
\hline 08DH01A-11 & 488.5 & 3.9 & 482.4 & 9.4 & 453.3 & 51.2 & 488.5 & 3.9 & 107.8 \\
\hline $08 \mathrm{DH} 01 \mathrm{~A}-12$ & 233.1 & 3.9 & 203.4 & 28.3 & -128.5 & 379.1 & 233.1 & 3.9 & -181.4 \\
\hline 08DH01A-13 & 353.2 & 2.6 & 333.7 & 20.7 & 199.7 & 168.1 & 353.2 & 2.6 & 176.8 \\
\hline 08DH01A-14 & 234.3 & 3.1 & 231.4 & 7.0 & 201.7 & 71.8 & 234.3 & 3.1 & 116.2 \\
\hline $08 \mathrm{DH} 01 \mathrm{~A}-15$ & 235.0 & 5.6 & 253.0 & 15.7 & 423.5 & 147.1 & 235.0 & 5.6 & 55.5 \\
\hline 08DH01A-16 & 2089.9 & 15.2 & 2093.9 & 21.1 & 2097.9 & 39.0 & 2097.9 & 39.0 & 99.6 \\
\hline 08DH01A-17 & 500.0 & 8.9 & 498.4 & 11.2 & 491.5 & 47.8 & 500.0 & 8.9 & 101.7 \\
\hline 08DH01A-18 & 309.7 & 4.2 & 296.9 & 13.0 & 197.1 & 113.2 & 309.7 & 4.2 & 157.1 \\
\hline 08DH01A-19 & 327.4 & 5.1 & 318.9 & 11.4 & 257.1 & 88.7 & 327.4 & 5.1 & 127.3 \\
\hline 08DH01A-20 & 260.2 & 1.3 & 257.1 & 5.0 & 228.2 & 49.5 & 260.2 & 1.3 & 114.0 \\
\hline 08DH01A-21 & 1813.1 & 12.5 & 1830.5 & 15.7 & 1850.4 & 30.4 & 1850.4 & 30.4 & 98.0 \\
\hline $08 \mathrm{DH} 01 \mathrm{~A}-22$ & 240.0 & 4.4 & 232.3 & 10.3 & 154.4 & 108.0 & 240.0 & 4.4 & 155.5 \\
\hline 08DH01A-23 & 250.1 & 4.8 & 263.2 & 35.1 & 381.8 & 339.0 & 250.1 & 4.8 & 65.5 \\
\hline 08DH01A-24 & 260.4 & 1.8 & 247.2 & 14.4 & 123.1 & 153.3 & 260.4 & 1.8 & 211.5 \\
\hline $08 \mathrm{DH} 01 \mathrm{~A}-25$ & 460.6 & 3.7 & 457.8 & 6.5 & 443.4 & 34.9 & 460.6 & 3.7 & 103.9 \\
\hline 08DH01A-26 & 319.6 & 8.0 & 320.2 & 10.2 & 324.4 & 61.3 & 319.6 & 8.0 & 98.5 \\
\hline $08 \mathrm{DH} 01 \mathrm{~A}-28$ & 2193.6 & 41.6 & 2447.8 & 23.4 & 2666.4 & 19.4 & 2666.4 & 19.4 & 82.3 \\
\hline 08DH01A-29 & 482.9 & 6.0 & 490.7 & 48.7 & 526.9 & 273.6 & 482.9 & 6.0 & 91.6 \\
\hline 08DH01A-30 & 545.7 & 4.9 & 539.2 & 7.9 & 511.7 & 35.9 & 545.7 & 4.9 & 106.7 \\
\hline 08DH01A-31 & 255.1 & 6.0 & 244.1 & 12.8 & 139.7 & 126.9 & 255.1 & 6.0 & 182.6 \\
\hline 08DH01A-32 & 414.9 & 11.5 & 417.9 & 18.5 & 434.6 & 101.5 & 414.9 & 11.5 & 95.5 \\
\hline 08DH01A-33 & 386.3 & 4.4 & 379.5 & 9.8 & 338.2 & 64.9 & 386.3 & 4.4 & 114.2 \\
\hline 08DH01A-34 & 502.8 & 2.4 & 500.1 & 7.6 & 487.6 & 40.9 & 502.8 & 2.4 & 103.1 \\
\hline 08DH01A-35 & 1890.5 & 8.2 & 1895.5 & 13.0 & 1900.9 & 25.7 & 1900.9 & 25.7 & 99.4 \\
\hline 08DH01A-36 & 447.8 & 5.1 & 444.0 & 11.8 & 424.5 & 68.5 & 447.8 & 5.1 & 105.5 \\
\hline 08DH01A-37 & 485.1 & 5.9 & 503.3 & 54.3 & 586.8 & 296.7 & 485.1 & 5.9 & 82.7 \\
\hline 08DH01A-38 & 305.1 & 7.0 & 300.6 & 15.7 & 266.2 & 128.0 & 305.1 & 7.0 & 114.6 \\
\hline 08DH01A-39 & 1910.6 & 14.1 & 1902.5 & 21.4 & 1893.6 & 42.1 & 1893.6 & 42.1 & 100.9 \\
\hline $08 \mathrm{DH} 01 \mathrm{~A}-40$ & 284.7 & 2.2 & 274.5 & 17.5 & 188.0 & 169.0 & 284.7 & 2.2 & 151.5 \\
\hline 08DH01A-41 & 768.3 & 6.4 & 778.1 & 18.4 & 806.5 & 68.3 & 768.3 & 6.4 & 95.3 \\
\hline $08 \mathrm{DH} 01 \mathrm{~A}-42$ & 292.4 & 2.5 & 286.3 & 7.5 & 236.3 & 65.9 & 292.4 & 2.5 & 123.8 \\
\hline 08DH01A-43 & 239.3 & 2.5 & 230.4 & 9.6 & 141.1 & 106.4 & 239.3 & 2.5 & 169.7 \\
\hline $08 \mathrm{DH} 01 \mathrm{~A}-44$ & 237.9 & 1.4 & 230.3 & 11.3 & 152.9 & 127.6 & 237.9 & 1.4 & 155.6 \\
\hline 08DH01A-45 & 503.6 & 6.1 & 489.9 & 19.0 & 426.5 & 105.3 & 503.6 & 6.1 & 118.1 \\
\hline 08DH01A-46 & 492.2 & 6.2 & 480.5 & 32.5 & 425.2 & 187.2 & 492.2 & 6.2 & 115.8 \\
\hline 08DH01A-47 & 365.8 & 7.4 & 368.3 & 11.0 & 384.0 & 64.7 & 365.8 & 7.4 & 95.3 \\
\hline
\end{tabular}


08DH01

Isotope ratios

\begin{tabular}{|c|c|c|c|c|c|c|c|c|c|c|}
\hline Analysis & $\begin{array}{c}U \\
(\mathrm{ppm})\end{array}$ & $\begin{array}{l}206 \mathrm{~Pb} / \\
204 \mathrm{~Pb}\end{array}$ & $\mathrm{U} / \mathrm{Th}$ & $\begin{array}{l}206 \mathrm{~Pb}^{\star} / \\
207 \mathrm{~Pb}^{*}\end{array}$ & $\begin{array}{c} \pm \\
(\%)\end{array}$ & $\begin{array}{c}207 \mathrm{~Pb}^{*} / \\
235 \mathrm{U}^{*}\end{array}$ & $\begin{array}{c} \pm \\
(\%)\end{array}$ & $\begin{array}{c}206 \mathrm{~Pb}^{*} / \\
238 \mathrm{U}\end{array}$ & $\begin{array}{c} \pm \\
(\%)\end{array}$ & $\begin{array}{l}\text { error } \\
\text { corr. }\end{array}$ \\
\hline 08DH01A-48 & 266 & 6294 & 1.8 & 19.2425 & 2.3 & 0.3517 & 2.5 & 0.0491 & 0.8 & 0.32 \\
\hline 08DH01A-49 & 178 & 8031 & 2.3 & 19.5111 & 4.1 & 0.3534 & 4.3 & 0.0500 & 1.1 & 0.26 \\
\hline 08DH01A-50 & 107 & 5823 & 1.1 & 19.7348 & 2.8 & 0.2774 & 3.2 & 0.0397 & 1.5 & 0.47 \\
\hline 08DH01A-51 & 119 & 5130 & 1.5 & 20.9797 & 6.8 & 0.2388 & 7.5 & 0.0363 & 3.1 & 0.41 \\
\hline 08DH01A-52 & 273 & 21810 & 3.8 & 17.8539 & 2.0 & 0.5854 & 2.2 & 0.0758 & 0.8 & 0.35 \\
\hline 08DH01A-53 & 63 & 2124 & 0.4 & 20.1553 & 9.2 & 0.2773 & 9.5 & 0.0405 & 2.5 & 0.27 \\
\hline 08DH01A-54 & 55 & 5259 & 2.5 & 17.1048 & 4.2 & 0.6447 & 4.2 & 0.0800 & 0.5 & 0.12 \\
\hline 08DH01A-55 & 80 & 5871 & 1.8 & 17.4758 & 2.8 & 0.6353 & 3.2 & 0.0805 & 1.5 & 0.48 \\
\hline 08DH01A-56 & 93 & 6975 & 1.4 & 17.8375 & 3.3 & 0.6180 & 3.8 & 0.0799 & 1.8 & 0.49 \\
\hline 08DH01A-57 & 250 & 22938 & 1.6 & 17.3836 & 3.4 & 0.6648 & 3.5 & 0.0838 & 0.8 & 0.23 \\
\hline 08DH01A-58 & 182 & 7170 & 1.1 & 20.3505 & 4.6 & 0.2642 & 4.7 & 0.0390 & 0.7 & 0.15 \\
\hline 08DH01A-60 & 153 & 15432 & 1.9 & 17.5690 & 2.4 & 0.6434 & 2.4 & 0.0820 & 0.5 & 0.21 \\
\hline 08DH01A-61 & 370 & 10509 & 0.7 & 19.7878 & 3.1 & 0.2777 & 3.1 & 0.0399 & 0.5 & 0.16 \\
\hline 08DH01A-62 & 424 & 10866 & 1.9 & 18.6841 & 3.1 & 0.3625 & 3.3 & 0.0491 & 1.1 & 0.32 \\
\hline 08DH01A-63 & 105 & 3117 & 0.9 & 20.5864 & 6.6 & 0.2465 & 6.7 & 0.0368 & 1.0 & 0.14 \\
\hline 08DH01A-64 & 103 & 4329 & 1.3 & 18.3593 & 17.4 & 0.3819 & 17.4 & 0.0508 & 0.7 & 0.04 \\
\hline 08DH01A-65 & 377 & 17115 & 1.1 & 19.0604 & 0.7 & 0.3556 & 1.1 & 0.0492 & 0.8 & 0.74 \\
\hline 08DH01A-66 & 307 & 12048 & 1.5 & 19.2148 & 1.8 & 0.3445 & 2.1 & 0.0480 & 1.1 & 0.53 \\
\hline 08DH01A-67 & 49 & 5538 & 1.0 & 15.4632 & 3.3 & 1.1569 & 3.4 & 0.1298 & 1.1 & 0.31 \\
\hline 08DH01A-68 & 138 & 5244 & 1.7 & 20.1738 & 4.2 & 0.2794 & 4.4 & 0.0409 & 1.0 & 0.24 \\
\hline 08DH01A-69 & 223 & 23694 & 5.0 & 17.8604 & 2.9 & 0.6092 & 3.5 & 0.0789 & 1.8 & 0.52 \\
\hline 08DH01A-70 & 130 & 3570 & 0.8 & 19.0317 & 7.8 & 0.2728 & 7.9 & 0.0377 & 1.4 & 0.17 \\
\hline 08DH01A-71 & 131 & 1251 & 1.7 & 20.0483 & 11.3 & 0.4521 & 11.3 & 0.0657 & 1.1 & 0.09 \\
\hline 08DH01A-72 & 174 & 49899 & 1.3 & 8.9258 & 2.0 & 4.6776 & 2.1 & 0.3028 & 0.5 & 0.24 \\
\hline 08DH01A-73 & 730 & 12927 & 2.6 & 19.3017 & 1.6 & 0.3470 & 1.7 & 0.0486 & 0.7 & 0.39 \\
\hline 08DH01A-74 & 169 & 6759 & 1.2 & 18.9794 & 5.9 & 0.3425 & 6.1 & 0.0471 & 1.4 & 0.23 \\
\hline 08DH01A-75 & 133 & 14364 & 4.3 & 17.5272 & 2.7 & 0.6658 & 2.8 & 0.0846 & 0.7 & 0.26 \\
\hline 08DH01A-76 & 55 & 1938 & 1.7 & 21.3160 & 10.9 & 0.2741 & 10.9 & 0.0424 & 0.8 & 0.07 \\
\hline 08DH01A-77 & 154 & 2490 & 1.4 & 16.6099 & 4.4 & 0.6927 & 4.5 & 0.0834 & 0.5 & 0.11 \\
\hline 08DH01A-78 & 97 & 17280 & 2.9 & 10.2273 & 1.5 & 2.5494 & 1.9 & 0.1891 & 1.2 & 0.63 \\
\hline 08DH01A-79 & 91 & 5640 & 1.8 & 17.7441 & 2.5 & 0.6070 & 2.9 & 0.0781 & 1.5 & 0.51 \\
\hline 08DH01A-80 & 180 & 7632 & 2.5 & 19.2380 & 2.9 & 0.3496 & 3.2 & 0.0488 & 1.2 & 0.38 \\
\hline 08DH01A-81 & 222 & 14634 & 1.9 & 17.7457 & 1.4 & 0.5785 & 1.5 & 0.0745 & 0.5 & 0.33 \\
\hline 08DH01A-82 & 257 & 17511 & 1.8 & 17.8248 & 1.6 & 0.5887 & 1.8 & 0.0761 & 0.7 & 0.38 \\
\hline 08DH01A-83 & 134 & 3885 & 1.6 & 19.6598 & 4.3 & 0.3278 & 4.3 & 0.0467 & 0.6 & 0.15 \\
\hline 08DH01A-84 & 193 & 56268 & 1.8 & 7.9326 & 3.2 & 6.2631 & 3.8 & 0.3603 & 2.0 & 0.53 \\
\hline 08DH01A-86 & 165 & 5751 & 0.7 & 20.0389 & 3.7 & 0.2860 & 3.8 & 0.0416 & 0.7 & 0.18 \\
\hline 08DH01A-87 & 710 & 168600 & 37.5 & 6.4452 & 1.5 & 8.4541 & 2.1 & 0.3952 & 1.5 & 0.71 \\
\hline 08DH01A-88 & 82 & 7212 & 1.2 & 18.6374 & 7.9 & 0.5931 & 8.0 & 0.0802 & 1.2 & 0.15 \\
\hline 08DH01A-89 & 261 & 6489 & 0.6 & 19.6737 & 2.2 & 0.2707 & 2.3 & 0.0386 & 0.7 & 0.29 \\
\hline 08DH01A-90 & 223 & 21318 & 2.0 & 13.8887 & 2.7 & 1.5815 & 2.8 & 0.1593 & 0.5 & 0.18 \\
\hline 08DH01A-91 & 134 & 5160 & 2.4 & 20.2371 & 5.5 & 0.2701 & 5.6 & 0.0396 & 0.9 & 0.17 \\
\hline 08DH01A-92 & 229 & 6204 & 1.0 & 19.9749 & 2.8 & 0.2591 & 2.8 & 0.0375 & 0.7 & 0.23 \\
\hline 08DH01A-93 & 434 & 18894 & 2.3 & 18.7992 & 2.0 & 0.4255 & 3.7 & 0.0580 & 3.2 & 0.85 \\
\hline 08DH01A-94 & 106 & 10479 & 3.0 & 17.5957 & 3.3 & 0.6593 & 3.7 & 0.0841 & 1.8 & 0.48 \\
\hline
\end{tabular}


08DH01

Apparent Ages (Ma)

\begin{tabular}{|c|c|c|c|c|c|c|c|c|c|}
\hline Analysis & $\begin{array}{c}206 \mathrm{~Pb}^{*} / \\
238 \mathrm{U}^{*}\end{array}$ & $\stackrel{ \pm}{(\mathrm{Ma})}$ & $\begin{array}{c}207 \mathrm{~Pb}^{*} / \\
235 \mathrm{U}\end{array}$ & $\stackrel{ \pm}{(\mathrm{Ma})}$ & $\begin{array}{l}206 \mathrm{~Pb}^{\star} / \\
207 \mathrm{~Pb}^{*}\end{array}$ & $\begin{array}{c} \pm \\
(\mathrm{Ma})\end{array}$ & $\begin{array}{l}\text { Best age } \\
\quad(\mathrm{Ma})\end{array}$ & $\begin{array}{c} \pm \\
(\mathrm{Ma})\end{array}$ & $\begin{array}{c}\text { Conc } \\
(\%)\end{array}$ \\
\hline 08DH01A-48 & 308.9 & 2.4 & 306.0 & 6.5 & 284.0 & 53.3 & 308.9 & 2.4 & 108.7 \\
\hline 08DH01A-49 & 314.6 & 3.5 & 307.3 & 11.4 & 252.2 & 95.4 & 314.6 & 3.5 & 124.7 \\
\hline 08DH01A-50 & 251.0 & 3.7 & 248.6 & 7.1 & 225.9 & 65.8 & 251.0 & 3.7 & 111.1 \\
\hline 08DH01A-51 & 230.1 & 6.9 & 217.4 & 14.7 & 82.7 & 162.4 & 230.1 & 6.9 & 278.4 \\
\hline 08DH01A-52 & 471.0 & 3.5 & 467.9 & 8.2 & 452.7 & 45.4 & 471.0 & 3.5 & 104.0 \\
\hline 08DH01A-53 & 256.1 & 6.4 & 248.5 & 21.1 & 177.0 & 215.0 & 256.1 & 6.4 & 144.7 \\
\hline 08DH01A-54 & 496.0 & 2.4 & 505.2 & 16.7 & 547.1 & 91.3 & 496.0 & 2.4 & 90.7 \\
\hline 08DH01A-55 & 499.2 & 7.2 & 499.4 & 12.5 & 500.1 & 61.2 & 499.2 & 7.2 & 99.8 \\
\hline 08DH01A-56 & 495.8 & 8.8 & 488.6 & 14.6 & 454.8 & 72.8 & 495.8 & 8.8 & 109.0 \\
\hline 08DH01A-57 & 518.9 & 4.1 & 517.6 & 14.3 & 511.7 & 75.7 & 518.9 & 4.1 & 101.4 \\
\hline 08DH01A-58 & 246.6 & 1.6 & 238.0 & 9.9 & 154.4 & 107.9 & 246.6 & 1.6 & 159.7 \\
\hline 08DH01A-60 & 508.0 & 2.4 & 504.4 & 9.7 & 488.4 & 52.6 & 508.0 & 2.4 & 104.0 \\
\hline 08DH01A-61 & 252.0 & 1.2 & 248.9 & 6.9 & 219.7 & 71.5 & 252.0 & 1.2 & 114.7 \\
\hline 08DH01A-62 & 309.2 & 3.2 & 314.1 & 8.9 & 351.0 & 70.5 & 309.2 & 3.2 & 88.1 \\
\hline 08DH01A-63 & 233.0 & 2.2 & 223.7 & 13.5 & 127.4 & 156.3 & 233.0 & 2.2 & 182.8 \\
\hline 08DH01A-64 & 319.7 & 2.0 & 328.4 & 49.0 & 390.4 & 393.8 & 319.7 & 2.0 & 81.9 \\
\hline 08DH01A-65 & 309.3 & 2.4 & 308.9 & 2.9 & 305.7 & 16.3 & 309.3 & 2.4 & 101.2 \\
\hline 08DH01A-66 & 302.3 & 3.2 & 300.6 & 5.4 & 287.3 & 40.4 & 302.3 & 3.2 & 105.2 \\
\hline 08DH01A-67 & 786.4 & 7.9 & 780.5 & 18.7 & 763.6 & 68.6 & 786.4 & 7.9 & 103.0 \\
\hline 08DH01A-68 & 258.3 & 2.6 & 250.2 & 9.7 & 174.8 & 99.1 & 258.3 & 2.6 & 147.7 \\
\hline 08DH01A-69 & 489.6 & 8.5 & 483.0 & 13.3 & 451.9 & 65.4 & 489.6 & 8.5 & 108.3 \\
\hline 08DH01A-70 & 238.3 & 3.2 & 244.9 & 17.3 & 309.2 & 178.3 & 238.3 & 3.2 & 77.1 \\
\hline 08DH01A-71 & 410.5 & 4.3 & 378.8 & 35.8 & 189.4 & 262.6 & 410.5 & 4.3 & 216.8 \\
\hline 08DH01A-72 & 1705.2 & 7.5 & 1763.2 & 17.4 & 1832.7 & 36.6 & 1832.7 & 36.6 & 93.0 \\
\hline 08DH01A-73 & 305.7 & 2.0 & 302.4 & 4.5 & 277.0 & 36.4 & 305.7 & 2.0 & 110.4 \\
\hline 08DH01A-74 & 296.9 & 4.1 & 299.0 & 15.7 & 315.4 & 134.3 & 296.9 & 4.1 & 94.1 \\
\hline 08DH01A-75 & 523.7 & 3.6 & 518.2 & 11.3 & 493.6 & 59.6 & 523.7 & 3.6 & 106.1 \\
\hline 08DH01A-76 & 267.5 & 2.1 & 245.9 & 23.8 & 44.8 & 260.3 & 267.5 & 2.1 & 597.1 \\
\hline 08DH01A-77 & 516.7 & 2.5 & 534.4 & 18.6 & 610.9 & 96.2 & 516.7 & 2.5 & 84.6 \\
\hline 08DH01A-78 & 1116.5 & 12.1 & 1286.3 & 13.7 & 1582.1 & 27.3 & 1582.1 & 27.3 & 70.6 \\
\hline 08DH01A-79 & 484.8 & 7.0 & 481.6 & 11.2 & 466.5 & 55.7 & 484.8 & 7.0 & 103.9 \\
\hline 08DH01A-80 & 307.0 & 3.6 & 304.4 & 8.4 & 284.6 & 67.4 & 307.0 & 3.6 & 107.9 \\
\hline 08DH01A-81 & 462.9 & 2.2 & 463.5 & 5.7 & 466.3 & 32.0 & 462.9 & 2.2 & 99.3 \\
\hline 08DH01A-82 & 472.8 & 3.1 & 470.0 & 6.7 & 456.4 & 36.3 & 472.8 & 3.1 & 103.6 \\
\hline 08DH01A-83 & 294.5 & 1.8 & 287.9 & 10.8 & 234.7 & 98.5 & 294.5 & 1.8 & 125.5 \\
\hline 08DH01A-84 & 1983.7 & 34.0 & 2013.3 & 33.1 & 2043.8 & 56.8 & 2043.8 & 56.8 & 97.1 \\
\hline 08DH01A-86 & 262.5 & 1.7 & 255.4 & 8.5 & 190.5 & 86.0 & 262.5 & 1.7 & 137.8 \\
\hline 08DH01A-87 & 2146.8 & 27.2 & 2281.0 & 19.0 & 2403.5 & 25.0 & 2403.5 & 25.0 & 89.3 \\
\hline 08DH01A-88 & 497.1 & 5.9 & 472.8 & 30.4 & 356.6 & 179.7 & 497.1 & 5.9 & 139.4 \\
\hline 08DH01A-89 & 244.3 & 1.6 & 243.3 & 5.0 & 233.1 & 50.9 & 244.3 & 1.6 & 104.8 \\
\hline 08DH01A-90 & 952.9 & 4.4 & 962.9 & 17.3 & 986.0 & 55.8 & 952.9 & 4.4 & 96.6 \\
\hline 08DH01A-91 & 250.6 & 2.3 & 242.8 & 12.0 & 167.5 & 127.9 & 250.6 & 2.3 & 149.6 \\
\hline 08DH01A-92 & 237.6 & 1.5 & 234.0 & 5.9 & 197.9 & 64.3 & 237.6 & 1.5 & 120.1 \\
\hline 08DH01A-93 & 363.6 & 11.1 & 360.0 & 11.3 & 337.1 & 44.9 & 363.6 & 11.1 & 107.9 \\
\hline 08DH01A-94 & 520.8 & 9.1 & 514.2 & 15.1 & 485.0 & 72.5 & 520.8 & 9.1 & 107.4 \\
\hline
\end{tabular}


08DH01

Isotope ratios

$\begin{array}{ccccccccccc}\text { Analysis } & \begin{array}{c}\mathrm{U} \\ (\mathrm{ppm})\end{array} & \begin{array}{c}206 \mathrm{~Pb} / \\ 204 \mathrm{~Pb}\end{array} & \mathrm{U} / \mathrm{Th} & \begin{array}{c}206 \mathrm{~Pb}^{*} / \\ 207 \mathrm{~Pb}^{*}\end{array} & \begin{array}{c} \pm \\ (\%)\end{array} & \begin{array}{c}207 \mathrm{~Pb}^{*} / \\ 235 \mathrm{U}^{*}\end{array} & \begin{array}{c} \pm \\ (\%)\end{array} & \begin{array}{c}206 \mathrm{~Pb}^{*} / \\ 238 \mathrm{U}\end{array} & \begin{array}{c} \pm \\ (\%)\end{array} & \begin{array}{c}\text { error } \\ \text { corr. }\end{array} \\ \text { 08DH01A-95 } & 125 & 3879 & 1.8 & 18.6315 & 7.6 & 0.3486 & 7.7 & 0.0471 & 1.3 & 0.17 \\ \text { 08DH01A-96 } & 64 & 1857 & 0.8 & 20.6980 & 6.6 & 0.2459 & 6.7 & 0.0369 & 0.9 & 0.13 \\ \text { 08DH01A-97 } & 66 & 2862 & 1.0 & 19.8223 & 6.3 & 0.3100 & 6.4 & 0.0446 & 0.9 & 0.14 \\ \text { 08DH01A-99 } & 229 & 1593 & 1.1 & 19.8008 & 5.2 & 0.3271 & 5.3 & 0.0470 & 1.1 & 0.21 \\ \text { 08DH01A-100 } & 158 & 14703 & 1.4 & 17.7768 & 2.4 & 0.6307 & 2.5 & 0.0813 & 0.6 & 0.23\end{array}$

08DH01

Apparent Ages (Ma)

$\begin{array}{cccccccccc}\text { Analysis } & \begin{array}{c}206 \mathrm{~Pb}^{*} / \\ 238 U^{*}\end{array} & \begin{array}{c} \pm \\ (\mathrm{Ma})\end{array} & \begin{array}{c}207 \mathrm{~Pb}^{*} / \\ 235 \mathrm{U}\end{array} & \begin{array}{c} \pm \\ (\mathrm{Ma})\end{array} & \begin{array}{c}206 \mathrm{~Pb}^{*} / \\ 207 \mathrm{~Pb}^{*}\end{array} & \begin{array}{c} \pm \\ (\mathrm{Ma})\end{array} & \begin{array}{c}\text { Best age } \\ (\mathrm{Ma})\end{array} & \begin{array}{c} \pm \\ (\mathrm{Ma})\end{array} & \begin{array}{c}\text { Conc } \\ (\%)\end{array} \\ \text { 08DH01A-95 } & 296.7 & 3.9 & 303.6 & 20.2 & 357.3 & 171.1 & 296.7 & 3.9 & 83.0 \\ \text { 08DH01A-96 } & 233.6 & 2.0 & 223.2 & 13.4 & 114.6 & 156.9 & 233.6 & 2.0 & 203.8 \\ \text { 08DH01A-97 } & 281.1 & 2.5 & 274.2 & 15.3 & 215.7 & 146.3 & 281.1 & 2.5 & 130.3 \\ \text { 08DH01A-99 } & 295.9 & 3.2 & 287.3 & 13.4 & 218.2 & 120.8 & 295.9 & 3.2 & 135.6 \\ \text { 08DH01A-100 } & 504.0 & 2.9 & 496.5 & 9.9 & 462.4 & 54.2 & 504.0 & 2.9 & 109.0\end{array}$


08DH02

Isotope ratios

\begin{tabular}{|c|c|c|c|c|c|c|c|c|c|c|}
\hline Analysis & $\begin{array}{c}\text { U } \\
(\mathrm{ppm})\end{array}$ & $\begin{array}{l}206 \mathrm{~Pb} / \\
204 \mathrm{~Pb}\end{array}$ & $\mathrm{U} / \mathrm{Th}$ & $\begin{array}{c}206 \mathrm{~Pb}^{\star} / \\
207 \mathrm{~Pb}^{\star}\end{array}$ & $\begin{array}{c} \pm \\
(\%)\end{array}$ & $\begin{array}{c}207 \mathrm{~Pb}^{*} / \\
235 \mathrm{U}^{*}\end{array}$ & $\begin{array}{c} \pm \\
(\%)\end{array}$ & $\begin{array}{c}206 \mathrm{~Pb}^{*} / \\
238 \mathrm{U}\end{array}$ & $\begin{array}{c} \pm \\
(\%)\end{array}$ & $\begin{array}{l}\text { error } \\
\text { corr. }\end{array}$ \\
\hline 08DH02-1 & 722 & 17751 & 1.0 & 19.6547 & 1.6 & 0.2913 & 1.7 & 0.0415 & 0.7 & 0.41 \\
\hline 08DH02-2 & 372 & 7857 & 2.3 & 20.2796 & 2.5 & 0.1912 & 2.7 & 0.0281 & 0.9 & 0.34 \\
\hline 08DH02-3 & 115 & 2517 & 2.8 & 20.1464 & 6.5 & 0.1777 & 6.6 & 0.0260 & 0.8 & .12 \\
\hline 08DH02-4 & 59 & 1218 & 1.5 & 21.1901 & 17.5 & 0.1673 & 17.5 & 0.0257 & 0.6 & 0.04 \\
\hline 08DH02-5 & 277 & 5865 & 0.5 & 19.1238 & 1.1 & 0.2986 & 1.3 & 0.0414 & 0.7 & .53 \\
\hline $08 \mathrm{DH} 02-6$ & 106 & 3009 & 0.5 & 19.2102 & 4.4 & 0.3014 & 4.4 & 0.0420 & 0.7 & .16 \\
\hline 08DH02-7 & 62 & 1683 & 2.7 & 22.6277 & 20.2 & 0.1516 & 20.3 & 0.0249 & 1.9 & 0.10 \\
\hline 08DH02-8 & 821 & 51435 & 2.5 & 8.7134 & 2.4 & 4.9020 & 3.5 & 0.3098 & 2.5 & 0.73 \\
\hline 08DH02-9 & 162 & 58428 & 2.2 & 5.7375 & 2.0 & 11.5414 & 2.3 & 0.4803 & 1.0 & .45 \\
\hline 08DH02-10 & 56 & 1620 & 0.5 & 18.9039 & 7.4 & 0.2919 & 7.5 & 0.0400 & 1.4 & 0.18 \\
\hline $08 \mathrm{DH} 02-11$ & 110 & 32514 & 1.1 & 8.6022 & 2.5 & 5.2689 & 2.7 & 0.3287 & 0.9 & 0.34 \\
\hline 08DH02-12 & 160 & 4320 & 1.1 & 19.9643 & 4.9 & 0.2623 & 5.1 & 0.0380 & 1.2 & 0.24 \\
\hline 08DH02-13 & 179 & 7974 & 1.9 & 18.9937 & 2.6 & 0.3697 & 3.1 & 0.0509 & 1.6 & 0.53 \\
\hline 08DH02-14 & 846 & 1200 & 1.1 & 12.0646 & 13.5 & 0.4974 & 13.6 & 0.0435 & 1.4 & 0.10 \\
\hline 08DH02-15 & 14 & 3816 & 1.8 & 8.4329 & 3.0 & 5.7693 & 3.3 & 0.3529 & 1.4 & 0.43 \\
\hline $08 \mathrm{DH} 02-16$ & 153 & 5007 & 0.9 & 19.3498 & 2.8 & 0.3017 & 2.9 & 0.0423 & 0.7 & 0.23 \\
\hline 08DH02-17 & 486 & 111381 & 2.9 & 8.1678 & 1.6 & 5.9394 & 1.8 & 0.3518 & 0.8 & 0.42 \\
\hline 08DH02-18 & 184 & 3942 & 1.0 & 20.1606 & 4.1 & 0.1729 & 4.2 & 0.0253 & 1.2 & 0.28 \\
\hline 08DH02-19 & 134 & 939 & 1.3 & 13.5808 & 7.7 & 0.2610 & 8.0 & 0.0257 & 2.1 & 0.27 \\
\hline 08DH02-20 & 90 & 17106 & 1.4 & 9.4782 & 1.7 & 4.3671 & 1.8 & 0.3002 & 0.5 & 0.28 \\
\hline $08 \mathrm{DH} 02-21$ & 287 & 13443 & 1.3 & 18.4272 & 1.3 & 0.4211 & 1.7 & 0.0563 & 1.0 & 0.60 \\
\hline 08DH02-22 & 131 & 4779 & 0.8 & 19.3225 & 3.1 & 0.3055 & 3.2 & 0.0428 & 0.9 & 0.29 \\
\hline 08DH02-23 & 141 & 53847 & 2.3 & 6.0772 & 1.5 & 9.7856 & 1.8 & 0.4313 & 1.1 & 0.58 \\
\hline 08DH02-24 & 438 & 3993 & 0.8 & 18.4632 & 8.4 & 0.1868 & 8.5 & 0.0250 & 1.0 & 0.11 \\
\hline 08DH02-25 & 479 & 15666 & 1.0 & 7.8663 & 1.4 & 5.6106 & 3.0 & 0.3201 & 2.6 & 0.88 \\
\hline $08 \mathrm{DH} 02-26$ & 231 & 51723 & 2.7 & 5.6291 & 1.4 & 10.7669 & 2.4 & 0.4396 & 2.0 & 0.83 \\
\hline 08DH02-27 & 393 & 104733 & 1.9 & 5.7718 & 0.8 & 11.0377 & 1.4 & 0.4620 & 1.1 & 0.80 \\
\hline 08DH02-28 & 79 & 3678 & 0.8 & 19.6878 & 7.1 & 0.3243 & 7.1 & 0.0463 & 0.5 & 0.07 \\
\hline 08DH02-29 & 193 & 4380 & 0.7 & 19.2768 & 2.8 & 0.2851 & 3.0 & 0.0399 & 1.3 & 0.41 \\
\hline 08DH02-31 & 30 & 504 & 0.5 & 26.5321 & 25.2 & 0.1186 & 25.7 & 0.0228 & 4.9 & 0.19 \\
\hline 08DH02-32 & 408 & 13473 & 1.2 & 19.1797 & 1.2 & 0.3300 & 1.4 & 0.0459 & 0.8 & 0.53 \\
\hline 08DH02-33 & 433 & 13020 & 1.2 & 19.5314 & 2.1 & 0.2994 & 3.1 & 0.0424 & 2.3 & 0.74 \\
\hline 08DH02-34 & 627 & 1530 & 4.1 & 12.7729 & 4.4 & 0.7591 & 4.6 & 0.0703 & 1.5 & 0.33 \\
\hline 08DH02-35 & 387 & 10431 & 0.8 & 18.9681 & 4.7 & 0.3314 & 4.7 & 0.0456 & 0.6 & 0.13 \\
\hline 08DH02-36 & 97 & 1821 & 1.1 & 21.3265 & 13.8 & 0.1635 & 13.9 & 0.0253 & 1.8 & 0.13 \\
\hline 08DH02-37 & 394 & 10359 & 0.8 & 19.3616 & 3.3 & 0.3219 & 3.3 & 0.0452 & 0.5 & 0.15 \\
\hline 08DH02-39 & 110 & 33420 & 2.6 & 8.7953 & 1.7 & 5.1788 & 2.1 & 0.3304 & 1.2 & 0.60 \\
\hline $08 \mathrm{DH} 02-40$ & 280 & 5802 & 1.2 & 9.0562 & 1.4 & 3.8543 & 2.1 & 0.2532 & 1.5 & 0.73 \\
\hline 08DH02-41 & 157 & 4047 & 0.6 & 19.4408 & 4.4 & 0.2832 & 4.6 & 0.0399 & 1.4 & 0.31 \\
\hline 08DH02-42 & 508 & 2280 & 1.0 & 15.4178 & 3.8 & 0.3813 & 4.4 & 0.0426 & 2.2 & 0.50 \\
\hline 08DH02-43 & 237 & 9039 & 1.6 & 19.5585 & 2.5 & 0.2997 & 2.8 & 0.0425 & 1.2 & 0.44 \\
\hline 08DH02-44 & 107 & 2754 & 0.4 & 19.1113 & 4.5 & 0.2902 & 4.6 & 0.0402 & 0.9 & 0.19 \\
\hline 08DH02-45 & 165 & 6546 & 1.2 & 19.3645 & 3.5 & 0.3154 & 3.6 & 0.0443 & 0.9 & 0.25 \\
\hline 08DH02-46 & 538 & 125574 & 2.4 & 8.6638 & 1.8 & 5.2979 & 2.1 & 0.3329 & 1.0 & 0.49 \\
\hline 08DH02-47 & 23 & 6699 & 1.6 & 8.8243 & 2.7 & 5.2906 & 2.9 & 0.3386 & 1.2 & 0.39 \\
\hline
\end{tabular}


08DH02

Apparent ages (Ma)

\begin{tabular}{|c|c|c|c|c|c|c|c|c|c|}
\hline Analysis & $\begin{array}{c}206 \mathrm{~Pb}^{*} / \\
238 \mathrm{U}^{*}\end{array}$ & $\begin{array}{c} \pm \\
(\mathrm{Ma})\end{array}$ & $\begin{array}{c}207 \mathrm{~Pb}^{*} / \\
235 \mathrm{U}\end{array}$ & $\stackrel{ \pm}{(\mathrm{Ma})}$ & $\begin{array}{l}206 \mathrm{~Pb}^{\star} / \\
207 \mathrm{~Pb}^{*}\end{array}$ & $\stackrel{ \pm}{(\mathrm{Ma})}$ & $\begin{array}{c}\text { Best age } \\
\quad(\mathrm{Ma})\end{array}$ & $\stackrel{ \pm}{ \pm}$ & $\begin{array}{c}\text { Conc } \\
(\%)\end{array}$ \\
\hline 08DH02-1 & 262.3 & 1.8 & 259.6 & 3.9 & 235.3 & 35.8 & 262.3 & 1.8 & 111.4 \\
\hline 08DH02-2 & 178.8 & 1.6 & 177.7 & 4.4 & 162.6 & 59.4 & 178.8 & 1.6 & 110.0 \\
\hline 08DH02-3 & 165.2 & 1.3 & 166.1 & 10.1 & 178.0 & 152.4 & 165.2 & 1.3 & 92.8 \\
\hline 08DH02-4 & 163.6 & 1.0 & 157.0 & 25.4 & 59.0 & 419.0 & 163.6 & 1.0 & 277.4 \\
\hline 08DH02-5 & 261.6 & 1.7 & 265.3 & 2.9 & 298.2 & 24.2 & 261.6 & 1.7 & 87.7 \\
\hline 08DH02-6 & 265.2 & 1.9 & 267.5 & 10.4 & 287.9 & 99.8 & 265.2 & 1.9 & 92.1 \\
\hline 08DH02-7 & 158.4 & 3.0 & 143.3 & 27.2 & -99.9 & 501.5 & 158.4 & 3.0 & -158.6 \\
\hline 08DH02-8 & 1739.6 & 38.4 & 1802.6 & 29.2 & 1876.2 & 42.7 & 1876.2 & 42.7 & 92.7 \\
\hline 08DH02-9 & 2528.4 & 21.8 & 2567.9 & 21.4 & 2599.3 & 34.0 & 2599.3 & 34.0 & 97.3 \\
\hline $08 \mathrm{DH} 02-10$ & 253.0 & 3.4 & 260.1 & 17.3 & 324.5 & 168.7 & 253.0 & 3.4 & 78.0 \\
\hline $08 \mathrm{DH} 02-11$ & 1832.2 & 14.5 & 1863.8 & 22.8 & 1899.3 & 45.1 & 1899.3 & 45.1 & 96.5 \\
\hline 08DH02-12 & 240.3 & 2.9 & 236.5 & 10.7 & 199.2 & 114.3 & 240.3 & 2.9 & 120.7 \\
\hline 08DH02-13 & 320.2 & 5.1 & 319.4 & 8.5 & 313.7 & 59.9 & 320.2 & 5.1 & 102.1 \\
\hline $08 \mathrm{DH} 02-14$ & 274.6 & 3.6 & 409.9 & 45.9 & 1266.6 & 265.5 & 274.6 & 3.6 & 21.7 \\
\hline 08DH02-15 & 1948.2 & 23.5 & 1941.8 & 28.4 & 1935.0 & 53.2 & 1935.0 & 53.2 & 100.7 \\
\hline 08DH02-16 & 267.4 & 1.7 & 267.8 & 6.7 & 271.3 & 63.8 & 267.4 & 1.7 & 98.6 \\
\hline $08 \mathrm{DH} 02-17$ & 1943.4 & 12.9 & 1967.0 & 15.7 & 1991.9 & 29.2 & 1991.9 & 29.2 & 97.6 \\
\hline 08DH02-18 & 160.9 & 1.9 & 161.9 & 6.3 & 176.3 & 94.9 & 160.9 & 1.9 & 91.3 \\
\hline 08DH02-19 & 163.6 & 3.5 & 235.5 & 16.9 & 1031.4 & 156.7 & 163.6 & 3.5 & 15.9 \\
\hline 08DH02-20 & 1692.3 & 7.4 & 1706.1 & 14.6 & 1723.1 & 31.1 & 1723.1 & 31.1 & 98.2 \\
\hline 08DH02-21 & 352.9 & 3.4 & 356.8 & 5.0 & 382.2 & 29.7 & 352.9 & 3.4 & 92.4 \\
\hline 08DH02-22 & 270.2 & 2.5 & 270.7 & 7.6 & 274.5 & 70.2 & 270.2 & 2.5 & 98.4 \\
\hline $08 \mathrm{DH} 02-23$ & 2311.6 & 20.6 & 2414.8 & 16.9 & 2503.0 & 25.2 & 2503.0 & 25.2 & 92.4 \\
\hline 08DH02-24 & 159.3 & 1.5 & 173.9 & 13.5 & 377.8 & 189.5 & 159.3 & 1.5 & 42.2 \\
\hline 08DH02-25 & 1790.2 & 41.0 & 1917.7 & 25.6 & 2058.6 & 24.7 & 2058.6 & 24.7 & 87.0 \\
\hline $08 \mathrm{DH} 02-26$ & 2348.7 & 39.2 & 2503.2 & 22.3 & 2631.0 & 22.4 & 2631.0 & 22.4 & 89.3 \\
\hline 08DH02-27 & 2448.6 & 22.8 & 2526.3 & 13.0 & 2589.3 & 14.0 & 2589.3 & 14.0 & 94.6 \\
\hline 08DH02-28 & 291.8 & 1.4 & 285.2 & 17.8 & 231.4 & 164.8 & 291.8 & 1.4 & 126.1 \\
\hline 08DH02-29 & 252.0 & 3.1 & 254.7 & 6.9 & 280.0 & 63.4 & 252.0 & 3.1 & 90.0 \\
\hline 08DH02-31 & 145.5 & 7.0 & 113.8 & 27.6 & -507.0 & 680.0 & 145.5 & 7.0 & -28.7 \\
\hline 08DH02-32 & 289.4 & 2.1 & 289.6 & 3.6 & 291.5 & 27.7 & 289.4 & 2.1 & 99.3 \\
\hline 08DH02-33 & 267.7 & 6.0 & 265.9 & 7.2 & 249.9 & 47.7 & 267.7 & 6.0 & 107.2 \\
\hline 08DH02-34 & 438.1 & 6.4 & 573.5 & 20.3 & 1154.2 & 86.9 & 438.1 & 6.4 & 38.0 \\
\hline 08DH02-35 & 287.4 & 1.7 & 290.7 & 11.9 & 316.7 & 106.5 & 287.4 & 1.7 & 90.7 \\
\hline 08DH02-36 & 161.0 & 2.9 & 153.8 & 19.8 & 43.6 & 330.1 & 161.0 & 2.9 & 369.1 \\
\hline 08DH02-37 & 285.0 & 1.4 & 283.3 & 8.3 & 269.9 & 75.9 & 285.0 & 1.4 & 105.6 \\
\hline 08DH02-39 & 1840.1 & 19.8 & 1849.1 & 17.6 & 1859.3 & 30.0 & 1859.3 & 30.0 & 99.0 \\
\hline 08DH02-40 & 1454.7 & 19.8 & 1604.2 & 16.8 & 1806.4 & 26.0 & 1806.4 & 26.0 & 80.5 \\
\hline 08DH02-41 & 252.4 & 3.5 & 253.2 & 10.3 & 260.5 & 100.5 & 252.4 & 3.5 & 96.9 \\
\hline 08DH02-42 & 269.2 & 5.9 & 328.0 & 12.3 & 769.8 & 80.1 & 269.2 & 5.9 & 35.0 \\
\hline 08DH02-43 & 268.4 & 3.2 & 266.2 & 6.5 & 246.6 & 57.3 & 268.4 & 3.2 & 108.8 \\
\hline 08DH02-44 & 254.2 & 2.2 & 258.7 & 10.4 & 299.6 & 102.2 & 254.2 & 2.2 & 84.8 \\
\hline 08DH02-45 & 279.4 & 2.5 & 278.4 & 8.8 & 269.5 & 80.6 & 279.4 & 2.5 & 103.7 \\
\hline 08DH02-46 & 1852.4 & 16.4 & 1868.5 & 17.7 & 1886.5 & 32.4 & 1886.5 & 32.4 & 98.2 \\
\hline 08DH02-47 & 1879.9 & 18.8 & 1867.3 & 25.2 & 1853.4 & 49.1 & 1853.4 & 49.1 & 101.4 \\
\hline
\end{tabular}


08DH02

Isotope ratios

\begin{tabular}{|c|c|c|c|c|c|c|c|c|c|c|}
\hline Analysis & $\underset{(\mathrm{ppm})}{\mathrm{U}}$ & $\begin{array}{l}206 \mathrm{~Pb} / \\
204 \mathrm{~Pb}\end{array}$ & $\mathrm{U} / \mathrm{Th}$ & $\begin{array}{l}206 \mathrm{~Pb}^{*} / \\
207 \mathrm{~Pb}^{*}\end{array}$ & $\begin{array}{c} \pm \\
(\%)\end{array}$ & $\begin{array}{c}207 \mathrm{~Pb}^{*} / \\
235 \mathrm{U}^{*}\end{array}$ & $\begin{array}{c} \pm \\
(\%)\end{array}$ & $\begin{array}{c}206 \mathrm{~Pb}^{*} / \\
238 \mathrm{U}\end{array}$ & $\begin{array}{c} \pm \\
(\%)\end{array}$ & $\begin{array}{l}\text { error } \\
\text { corr. }\end{array}$ \\
\hline 08DH02-48 & 147 & 6345 & 0.9 & 19.3194 & 2.9 & 0.3335 & 3.0 & 0.0467 & 0.7 & 0.22 \\
\hline 08DH02-49 & 24 & 6831 & 1.1 & 9.3916 & 2.0 & 4.3674 & 2.1 & 0.2975 & 0.5 & 0.24 \\
\hline 08DH02-50 & 189 & 46275 & 1.9 & 8.8162 & 0.6 & 4.9636 & 1.2 & 0.3174 & 1.0 & .88 \\
\hline 08DH02-51 & 250 & 8538 & 1.7 & 5.3374 & 7.0 & 9.5647 & 7.1 & 0.3703 & 1.0 & .13 \\
\hline 08DH02-52 & 555 & 23136 & 5.9 & 18.4883 & 1.0 & 0.4157 & 1.2 & 0.0557 & 0.5 & 0.43 \\
\hline 08DH02-53 & 890 & 525 & 0.6 & 5.9474 & 27.2 & 1.1134 & 27.3 & 0.0480 & 2.0 & .07 \\
\hline 08DH02-54 & 180 & 8757 & 1.5 & 19.0208 & 2.0 & 0.3616 & 2.3 & 0.0499 & 1.1 & 0.50 \\
\hline 08DH02-55 & 44 & 1641 & 1.0 & 20.3841 & 15.5 & 0.2695 & 15.6 & 0.0398 & 2.0 & 0.12 \\
\hline 08DH02-56 & 249 & 7575 & 0.8 & 19.6230 & 3.4 & 0.2906 & 3.5 & 0.0414 & 1.1 & 0.32 \\
\hline 08DH02-57 & 583 & 42951 & 5.5 & 17.3559 & 0.9 & 0.6161 & 1.2 & 0.0776 & 0.8 & 0.67 \\
\hline 08DH02-58 & 235 & 49428 & 0.7 & 8.6677 & 1.7 & 5.2589 & 2.1 & 0.3306 & 1.3 & 0.59 \\
\hline 08DH02-59 & 529 & 67593 & 2.3 & 6.2327 & 1.7 & 9.6914 & 2.1 & 0.4381 & 1.3 & 0.60 \\
\hline $08 \mathrm{DH} 02-60$ & 244 & 1905 & 0.6 & 18.1888 & 23.3 & 0.2763 & 23.3 & 0.0364 & 0.7 & 0.03 \\
\hline 08DH02-61 & 98 & 20631 & 1.1 & 8.6726 & 1.7 & 5.3019 & 1.9 & 0.3335 & 0.8 & 0.43 \\
\hline 08DH02-62 & 48 & 1278 & 0.6 & 20.3143 & 15.9 & 0.2625 & 15.9 & 0.0387 & 0.8 & 0.05 \\
\hline $08 \mathrm{DH} 02-63$ & 225 & 7854 & 0.9 & 19.5794 & 2.9 & 0.2810 & 3.0 & 0.0399 & 0.8 & 0.26 \\
\hline $08 \mathrm{DH} 02-64$ & 277 & 10629 & 1.3 & 19.7932 & 3.4 & 0.2946 & 4.1 & 0.0423 & 2.3 & 0.56 \\
\hline 08DH02-65 & 286 & 9462 & 0.7 & 19.2143 & 1.5 & 0.3188 & 1.6 & 0.0444 & 0.6 & 0.39 \\
\hline 08DH02-66 & 92 & 3690 & 3.5 & 19.4369 & 4.9 & 0.2835 & 5.0 & 0.0400 & 0.5 & 0.10 \\
\hline 08DH02-67 & 294 & 6582 & 0.6 & 19.4076 & 2.2 & 0.2909 & 2.6 & 0.0410 & 1.4 & 0.54 \\
\hline 08DH02-68 & 265 & 6909 & 1.3 & 19.7392 & 2.5 & 0.2576 & 2.7 & 0.0369 & 1.0 & 0.36 \\
\hline $08 \mathrm{DH} 02-69$ & 210 & 67071 & 2.5 & 8.6545 & 1.2 & 5.2899 & 1.9 & 0.3320 & 1.5 & 0.78 \\
\hline 08DH02-70 & 406 & 92313 & 3.1 & 6.2587 & 1.3 & 9.9989 & 2.6 & 0.4539 & 2.3 & 0.88 \\
\hline 08DH02-71 & 111 & 3834 & 0.7 & 19.0332 & 4.3 & 0.3226 & 4.5 & 0.0445 & 1.2 & 0.26 \\
\hline 08DH02-73 & 422 & 125370 & 5.1 & 6.4466 & 1.0 & 9.1370 & 1.6 & 0.4272 & 1.3 & 0.79 \\
\hline 08DH02-74 & 76 & 25656 & 2.4 & 9.4335 & 1.3 & 4.5002 & 1.7 & 0.3079 & 1.1 & 0.62 \\
\hline $08 \mathrm{DH} 02-75$ & 594 & 13482 & 0.5 & 18.5788 & 4.0 & 0.3295 & 4.6 & 0.0444 & 2.4 & 0.52 \\
\hline 08DH02-76 & 172 & 1962 & 1.3 & 13.8657 & 13.5 & 0.4687 & 13.6 & 0.0471 & 1.2 & 0.09 \\
\hline 08DH02-77 & 404 & 12276 & 1.5 & 19.3101 & 2.0 & 0.3306 & 2.4 & 0.0463 & 1.3 & 0.55 \\
\hline 08DH02-78 & 257 & 7875 & 0.8 & 19.3806 & 2.6 & 0.3200 & 2.8 & 0.0450 & 1.0 & 0.35 \\
\hline 08DH02-79 & 150 & 5775 & 0.8 & 19.6150 & 3.8 & 0.2763 & 4.8 & 0.0393 & 2.8 & 0.59 \\
\hline 08DH02-80 & 260 & 1791 & 2.3 & 13.7359 & 8.0 & 0.4549 & 8.5 & 0.0453 & 2.8 & 0.33 \\
\hline 08DH02-81 & 87 & 16884 & 7.9 & 8.4540 & 0.9 & 5.5123 & 1.6 & 0.3380 & 1.3 & 0.84 \\
\hline 08DH02-82 & 314 & 4251 & 0.8 & 17.7286 & 5.1 & 0.3327 & 5.2 & 0.0428 & 0.8 & 0.15 \\
\hline 08DH02-83 & 185 & 39204 & 8.0 & 8.5513 & 1.5 & 5.0662 & 1.6 & 0.3142 & 0.5 & 0.31 \\
\hline 08DH02-84 & 117 & 4692 & 1.1 & 19.2835 & 4.3 & 0.3095 & 4.5 & 0.0433 & 1.5 & 0.33 \\
\hline 08DH02-85 & 275 & 10521 & 1.2 & 19.1817 & 2.4 & 0.3146 & 2.6 & 0.0438 & 1.1 & 0.43 \\
\hline 08DH02-86 & 340 & 3459 & 1.0 & 17.5261 & 14.6 & 0.3288 & 14.7 & 0.0418 & 1.7 & 0.12 \\
\hline $08 \mathrm{DH} 02-87$ & 36 & 1206 & 0.5 & 19.1342 & 11.5 & 0.2915 & 11.5 & 0.0405 & 0.5 & 0.04 \\
\hline 08DH02-88 & 714 & 5178 & 2.7 & 7.9928 & 1.1 & 6.2960 & 2.9 & 0.3650 & 2.7 & 0.92 \\
\hline 08DH02-89 & 269 & 8088 & 1.3 & 19.2791 & 1.5 & 0.2984 & 1.6 & 0.0417 & 0.6 & 0.34 \\
\hline 08DH02-90 & 67 & 2901 & 0.9 & 21.1487 & 12.2 & 0.2460 & 12.2 & 0.0377 & 0.7 & 0.06 \\
\hline 08DH02-91 & 208 & 57036 & 1.7 & 8.8361 & 1.0 & 5.0657 & 1.1 & 0.3246 & 0.5 & 0.47 \\
\hline 08DH02-92 & 134 & 5547 & 1.6 & 19.4055 & 10.9 & 0.3021 & 10.9 & 0.0425 & 0.8 & 0.08 \\
\hline 08DH02-93 & 96 & 2328 & 1.4 & 20.8678 & 10.0 & 0.1593 & 10.1 & 0.0241 & 1.8 & 0.1 \\
\hline
\end{tabular}


08DH02

Apparent ages (Ma)

\begin{tabular}{|c|c|c|c|c|c|c|c|c|c|}
\hline Analysis & $\begin{array}{c}206 \mathrm{~Pb}^{*} / \\
238 \mathrm{U}^{*}\end{array}$ & $\stackrel{ \pm}{(\mathrm{Ma})}$ & $\begin{array}{c}207 \mathrm{~Pb}^{*} / \\
235 \mathrm{U}\end{array}$ & $\begin{array}{c} \pm \\
(\mathrm{Ma})\end{array}$ & $\begin{array}{l}206 \mathrm{~Pb}^{\star} / \\
207 \mathrm{~Pb}^{*}\end{array}$ & $\begin{array}{c} \pm \\
(\mathrm{Ma})\end{array}$ & $\begin{array}{l}\text { Best age } \\
\quad(\mathrm{Ma})\end{array}$ & $\begin{array}{c} \pm \\
(\mathrm{Ma})\end{array}$ & $\begin{array}{c}\text { Conc } \\
(\%)\end{array}$ \\
\hline 08DH02-48 & 294.4 & 1.9 & 292.2 & 7.6 & 274.9 & 66.6 & 294.4 & 1.9 & 107.1 \\
\hline 08DH02-49 & 1678.8 & 7.4 & 1706.2 & 17.4 & 1740.0 & 37.5 & 1740.0 & 37.5 & 96.5 \\
\hline 08DH02-50 & 1776.9 & 16.0 & 1813.1 & 9.9 & 1855.0 & 10.1 & 1855.0 & 10.1 & 95.8 \\
\hline 08DH02-51 & 2030.6 & 16.5 & 2393.8 & 65.1 & 2719.1 & 115.6 & 2719.1 & 115.6 & 74.7 \\
\hline 08DH02-52 & 349.7 & 1.7 & 353.0 & 3.5 & 374.7 & 23.5 & 349.7 & 1.7 & 93.3 \\
\hline 08DH02-53 & 302.4 & 5.8 & 759.8 & 147.0 & 2539.2 & 466.3 & 2539.2 & 466.3 & 11.9 \\
\hline 08DH02-54 & 313.8 & 3.5 & 313.4 & 6.1 & 310.4 & 45.0 & 313.8 & 3.5 & 101.1 \\
\hline 08DH02-55 & 251.9 & 4.8 & 242.3 & 33.7 & 150.6 & 364.9 & 251.9 & 4.8 & 167.3 \\
\hline 08DH02-56 & 261.3 & 2.9 & 259.0 & 8.1 & 239.0 & 77.6 & 261.3 & 2.9 & 109.3 \\
\hline 08DH02-57 & 481.5 & 3.7 & 487.4 & 4.6 & 515.2 & 19.3 & 481.5 & 3.7 & 93.5 \\
\hline 08DH02-58 & 1841.3 & 20.0 & 1862.2 & 18.2 & 1885.7 & 31.2 & 1885.7 & 31.2 & 97.6 \\
\hline 08DH02-59 & 2342.1 & 25.1 & 2405.9 & 19.5 & 2460.3 & 28.6 & 2460.3 & 28.6 & 95.2 \\
\hline 08DH02-60 & 230.8 & 1.7 & 247.7 & 51.3 & 411.3 & 528.1 & 230.8 & 1.7 & 56.1 \\
\hline 08DH02-61 & 1855.3 & 12.9 & 1869.2 & 15.9 & 1884.6 & 30.3 & 1884.6 & 30.3 & 98.4 \\
\hline 08DH02-62 & 244.6 & 1.8 & 236.7 & 33.6 & 158.6 & 373.5 & 244.6 & 1.8 & 154.2 \\
\hline 08DH02-63 & 252.3 & 2.0 & 251.5 & 6.7 & 244.2 & 66.5 & 252.3 & 2.0 & 103.3 \\
\hline 08DH02-64 & 267.0 & 6.0 & 262.2 & 9.5 & 219.1 & 78.6 & 267.0 & 6.0 & 121.9 \\
\hline 08DH02-65 & 280.2 & 1.7 & 281.0 & 3.9 & 287.4 & 33.7 & 280.2 & 1.7 & 97.5 \\
\hline 08DH02-66 & 252.7 & 1.2 & 253.5 & 11.1 & 261.0 & 113.5 & 252.7 & 1.2 & 96.8 \\
\hline 08DH02-67 & 258.7 & 3.6 & 259.3 & 6.0 & 264.4 & 50.7 & 258.7 & 3.6 & 97.8 \\
\hline 08DH02-68 & 233.4 & 2.3 & 232.7 & 5.6 & 225.4 & 58.4 & 233.4 & 2.3 & 103.6 \\
\hline 08DH02-69 & 1848.2 & 23.6 & 1867.2 & 16.0 & 1888.4 & 21.1 & 1888.4 & 21.1 & 97.9 \\
\hline 08DH02-70 & 2412.4 & 45.5 & 2434.7 & 23.8 & 2453.3 & 21.1 & 2453.3 & 21.1 & 98.3 \\
\hline 08DH02-71 & 280.9 & 3.2 & 283.9 & 11.0 & 309.0 & 97.9 & 280.9 & 3.2 & 90.9 \\
\hline 08DH02-73 & 2293.1 & 24.3 & 2351.8 & 14.6 & 2403.1 & 16.7 & 2403.1 & 16.7 & 95.4 \\
\hline 08DH02-74 & 1730.4 & 15.9 & 1731.0 & 14.0 & 1731.8 & 24.1 & 1731.8 & 24.1 & 99.9 \\
\hline 08DH02-75 & 280.0 & 6.6 & 289.2 & 11.7 & 363.7 & 89.4 & 280.0 & 6.6 & 77.0 \\
\hline 08DH02-76 & 296.9 & 3.6 & 390.3 & 44.0 & 989.3 & 276.3 & 296.9 & 3.6 & 30.0 \\
\hline 08DH02-77 & 291.8 & 3.8 & 290.0 & 6.0 & 276.0 & 45.7 & 291.8 & 3.8 & 105.7 \\
\hline 08DH02-78 & 283.6 & 2.7 & 281.9 & 6.8 & 267.6 & 59.5 & 283.6 & 2.7 & 106.0 \\
\hline 08DH02-79 & 248.5 & 6.9 & 247.7 & 10.5 & 240.0 & 88.6 & 248.5 & 6.9 & 103.5 \\
\hline 08DH02-80 & 285.7 & 7.8 & 380.7 & 26.9 & 1008.4 & 162.6 & 285.7 & 7.8 & 28.3 \\
\hline 08DH02-81 & 1877.0 & 21.7 & 1902.5 & 13.6 & 1930.5 & 15.4 & 1930.5 & 15.4 & 97.2 \\
\hline 08DH02-82 & 270.0 & 2.0 & 291.6 & 13.2 & 468.4 & 113.7 & 270.0 & 2.0 & 57.7 \\
\hline 08DH02-83 & 1761.4 & 7.7 & 1830.5 & 13.5 & 1910.0 & 27.1 & 1910.0 & 27.1 & 92.2 \\
\hline 08DH02-84 & 273.2 & 4.0 & 273.8 & 10.9 & 279.2 & 98.5 & 273.2 & 4.0 & 97.9 \\
\hline 08DH02-85 & 276.2 & 3.1 & 277.8 & 6.4 & 291.2 & 53.9 & 276.2 & 3.1 & 94.8 \\
\hline 08DH02-86 & 263.9 & 4.4 & 288.6 & 37.0 & 493.8 & 324.0 & 263.9 & 4.4 & 53.4 \\
\hline 08DH02-87 & 255.7 & 1.3 & 259.8 & 26.4 & 296.9 & 263.6 & 255.7 & 1.3 & 86.1 \\
\hline 08DH02-88 & 2005.7 & 46.2 & 2017.9 & 25.5 & 2030.4 & 19.9 & 2030.4 & 19.9 & 98.8 \\
\hline 08DH02-89 & 263.5 & 1.4 & 265.1 & 3.8 & 279.7 & 35.0 & 263.5 & 1.4 & 94.2 \\
\hline 08DH02-90 & 238.7 & 1.7 & 223.3 & 24.4 & 63.6 & 290.5 & 238.7 & 1.7 & 375.3 \\
\hline 08DH02-91 & 1812.3 & 7.9 & 1830.4 & 9.1 & 1850.9 & 17.2 & 1850.9 & 17.2 & 97.9 \\
\hline 08DH02-92 & 268.4 & 2.2 & 268.0 & 25.7 & 264.7 & 250.0 & 268.4 & 2.2 & 101.4 \\
\hline 08DH02-93 & 153.6 & 2.7 & 150.1 & 14.2 & 95.4 & 237.0 & 153.6 & 2.7 & 161.0 \\
\hline
\end{tabular}


08DH02

Isotope ratios

$\begin{array}{ccccccccccc}\text { Analysis } & \begin{array}{c}\mathrm{U} \\ (\mathrm{ppm})\end{array} & \begin{array}{c}206 \mathrm{~Pb} / \\ 204 \mathrm{~Pb}\end{array} & \mathrm{U} / \mathrm{Th} & \begin{array}{c}206 \mathrm{~Pb}^{*} / \\ 207 \mathrm{~Pb}^{*}\end{array} & \begin{array}{c} \pm \\ (\%)\end{array} & \begin{array}{c}207 \mathrm{~Pb}^{*} / \\ 235 \mathrm{U}^{*}\end{array} & \begin{array}{c} \pm \\ (\%)\end{array} & \begin{array}{c}206 \mathrm{~Pb}^{*} / \\ 238 U\end{array} & \begin{array}{c} \pm \\ (\%)\end{array} & \begin{array}{c}\text { error } \\ \text { corr. }\end{array} \\ \text { 08DH02-94 } & 77 & 2499 & 2.0 & 21.9173 & 14.3 & 0.1701 & 14.3 & 0.0270 & 0.7 & 0.05 \\ \text { 08DH02-95 } & 141 & 35496 & 2.5 & 8.8086 & 1.5 & 4.5201 & 2.5 & 0.2888 & 2.0 & 0.81 \\ \text { 08DH02-96 } & 63 & 17250 & 0.3 & 8.5145 & 0.9 & 5.4537 & 1.6 & 0.3368 & 1.3 & 0.84 \\ \text { 08DH02-97 } & 198 & 45279 & 2.7 & 8.8846 & 1.0 & 4.6150 & 3.1 & 0.2974 & 2.9 & 0.95 \\ \text { 08DH02-98 } & 110 & 4395 & 1.2 & 20.6028 & 8.2 & 0.2537 & 8.4 & 0.0379 & 1.9 & 0.22 \\ \text { 08DH02-99 } & 884 & 106749 & 6.3 & 8.5452 & 1.9 & 4.8802 & 2.7 & 0.3025 & 1.9 & 0.71 \\ \text { 08DH02-100 } & 96 & 4020 & 0.8 & 19.0090 & 3.2 & 0.3300 & 3.7 & 0.0455 & 2.0 & 0.52 \\ \text { 08DH02-101 } & 183 & 74316 & 2.8 & 8.7320 & 0.5 & 5.0400 & 0.7 & 0.3192 & 0.5 & 0.69 \\ \text { 08DH02-102 } & 353 & 15705 & 1.3 & 18.9463 & 1.0 & 0.3711 & 1.6 & 0.0510 & 1.3 & 0.80 \\ \text { 08DH02-103 } & 844 & 16158 & 1.1 & 19.2964 & 1.7 & 0.2933 & 2.8 & 0.0411 & 2.3 & 0.80 \\ \text { 08DH02-105 } & 205 & 13005 & 1.9 & 17.3324 & 1.6 & 0.6229 & 1.7 & 0.0783 & 0.8 & 0.43 \\ \text { 08DH02-106 } & 356 & 7863 & 1.9 & 20.0707 & 1.7 & 0.1824 & 2.1 & 0.0266 & 1.2 & 0.60 \\ \text { 08DH02-107 } & 835 & 6342 & 2.2 & 5.7055 & 2.0 & 8.9366 & 2.4 & 0.3698 & 1.5 & 0.60 \\ \text { 08DH02-108 } & 190 & 5691 & 1.0 & 19.2457 & 4.1 & 0.3129 & 4.3 & 0.0437 & 1.1 & 0.25 \\ \text { 08DH02-110 } & 423 & 10050 & 2.2 & 20.0376 & 2.1 & 0.2188 & 2.7 & 0.0318 & 1.6 & 0.61 \\ \text { 08DH02-111 } & 154 & 5730 & 0.7 & 19.0679 & 2.0 & 0.3227 & 2.1 & 0.0446 & 0.8 & 0.36 \\ \text { 08DH02-112 } & 962 & 9423 & 1.7 & 17.7863 & 3.0 & 0.3463 & 3.2 & 0.0447 & 1.2 & 0.37 \\ \text { 08DH02-114 } & 82 & 2502 & 0.8 & 19.3716 & 6.7 & 0.3066 & 7.1 & 0.0431 & 2.1 & 0.30 \\ \text { 08DH02-115 } & 216 & 11295 & 1.4 & 5.2984 & 1.6 & 11.8956 & 2.7 & 0.4571 & 2.1 & 0.79 \\ \text { 08DH02-117 } & 178 & 50973 & 1.6 & 8.6683 & 1.8 & 5.3151 & 2.1 & 0.3342 & 0.9 & 0.44 \\ \text { 08DH02-118 } & 96 & 2013 & 1.0 & 20.7141 & 10.6 & 0.1704 & 10.7 & 0.0256 & 1.1 & 0.11 \\ \text { 08DH02-119 } & 864 & 9777 & 3.7 & 8.4152 & 7.6 & 4.6507 & 8.0 & 0.2838 & 2.3 & 0.28 \\ \text { 08DH02-120 } & 240 & 10047 & 1.5 & 19.1344 & 1.8 & 0.3356 & 1.9 & 0.0466 & 0.6 & 0.32\end{array}$


08DH02

Apparent ages (Ma)

$\begin{array}{cccccccccc}\text { Analysis } & \begin{array}{c}206 \mathrm{~Pb}^{*} \\ 238 \mathrm{U}^{*}\end{array} & \begin{array}{c} \pm \\ (\mathrm{Ma})\end{array} & \begin{array}{c}207 \mathrm{~Pb} / \\ 235 \mathrm{U}\end{array} & \begin{array}{c} \pm \\ (\mathrm{Ma})\end{array} & \begin{array}{c}206 \mathrm{~Pb}^{*} \\ 207 \mathrm{~Pb}^{*}\end{array} & \begin{array}{c} \pm \\ (\mathrm{Ma})\end{array} & \begin{array}{c}\text { Best age } \\ (\mathrm{Ma})\end{array} & \begin{array}{c} \pm \\ (\mathrm{Ma})\end{array} & \begin{array}{c}\text { Conc } \\ (\%)\end{array} \\ \text { 08DH02-94 } & 172.0 & 1.2 & 159.5 & 21.1 & -22.1 & 346.4 & 172.0 & 1.2 & -779.2 \\ \text { 08DH02-95 } & 1635.4 & 29.5 & 1734.7 & 20.9 & 1856.6 & 26.6 & 1856.6 & 26.6 & 88.1 \\ \text { 08DH02-96 } & 1871.2 & 21.6 & 1893.3 & 13.6 & 1917.7 & 15.3 & 1917.7 & 15.3 & 97.6 \\ \text { 08DH02-97 } & 1678.3 & 43.0 & 1752.0 & 25.6 & 1841.1 & 17.6 & 1841.1 & 17.6 & 91.2 \\ \text { 08DH02-98 } & 239.9 & 4.4 & 229.6 & 17.3 & 125.5 & 193.8 & 239.9 & 4.4 & 191.1 \\ \text { 08DH02-99 } & 1703.5 & 28.3 & 1798.8 & 22.4 & 1911.3 & 33.6 & 1911.3 & 33.6 & 89.1 \\ \text { 08DH02-100 } & 286.8 & 5.5 & 289.6 & 9.4 & 311.9 & 72.8 & 286.8 & 5.5 & 92.0 \\ \text { 08DH02-101 } & 1785.7 & 7.8 & 1826.1 & 6.2 & 1872.3 & 9.6 & 1872.3 & 9.6 & 95.4 \\ \text { 08DH02-102 } & 320.6 & 4.0 & 320.5 & 4.4 & 319.4 & 21.8 & 320.6 & 4.0 & 100.4 \\ \text { 08DH02-103 } & 259.3 & 5.7 & 261.2 & 6.5 & 277.6 & 38.5 & 259.3 & 5.7 & 93.4 \\ \text { 08DH02-105 } & 486.0 & 3.5 & 491.7 & 6.7 & 518.2 & 34.2 & 486.0 & 3.5 & 93.8 \\ \text { 08DH02-106 } & 169.0 & 2.1 & 170.2 & 3.2 & 186.8 & 38.5 & 169.0 & 2.1 & 90.5 \\ \text { 08DH02-107 } & 2028.4 & 25.4 & 2331.5 & 22.4 & 2608.6 & 32.7 & 2608.6 & 32.7 & 77.8 \\ \text { 08DH02-108 } & 275.6 & 2.8 & 276.5 & 10.3 & 283.7 & 94.3 & 275.6 & 2.8 & 97.2 \\ \text { 08DH02-110 } & 201.8 & 3.2 & 200.9 & 4.8 & 190.7 & 48.9 & 201.8 & 3.2 & 105.8 \\ \text { 08DH02-111 } & 281.4 & 2.1 & 283.9 & 5.2 & 304.8 & 45.0 & 281.4 & 2.1 & 92.3 \\ \text { 08DH02-112 } & 281.8 & 3.3 & 302.0 & 8.4 & 461.2 & 66.6 & 281.8 & 3.3 & 61.1 \\ \text { 08DH02-114 } & 271.9 & 5.6 & 271.5 & 16.9 & 268.7 & 154.9 & 271.9 & 5.6 & 101.2 \\ \text { 08DH02-115 } & 2426.8 & 43.1 & 2596.2 & 25.1 & 2731.2 & 26.8 & 2731.2 & 26.8 & 88.9 \\ \text { 08DH02-117 } & 1858.5 & 14.7 & 1871.3 & 17.5 & 1885.5 & 33.1 & 1885.5 & 33.1 & 98.6 \\ \text { 08DH02-118 } & 163.0 & 1.8 & 159.8 & 15.8 & 112.9 & 251.7 & 163.0 & 1.8 & 144.4 \\ \text { 08DH02-119 } & 1610.7 & 32.1 & 1758.4 & 66.6 & 1938.7 & 136.9 & 1938.7 & 136.9 & 83.1 \\ \text { 08DH02-120 } & 293.4 & 1.7 & 293.8 & 4.8 & 296.9 & 40.5 & 293.4 & 1.7 & 98.8\end{array}$


08DH03

Isotope ratios

\begin{tabular}{|c|c|c|c|c|c|c|c|c|c|c|}
\hline Analysis & $\begin{array}{c}U \\
(\mathrm{ppm})\end{array}$ & $\begin{array}{l}206 \mathrm{~Pb} / \\
204 \mathrm{~Pb}\end{array}$ & $\mathrm{U} / \mathrm{Th}$ & $\begin{array}{l}206 \mathrm{~Pb}^{\star} / \\
207 \mathrm{~Pb}^{*}\end{array}$ & $\begin{array}{c} \pm \\
(\%)\end{array}$ & $\begin{array}{c}207 \mathrm{~Pb}^{*} / \\
235 \mathrm{U}^{*}\end{array}$ & $\begin{array}{c} \pm \\
(\%)\end{array}$ & $\begin{array}{c}206 \mathrm{~Pb}^{\star} / \\
238 \mathrm{U}\end{array}$ & $\begin{array}{c} \pm \\
(\%)\end{array}$ & $\begin{array}{l}\text { error } \\
\text { corr. }\end{array}$ \\
\hline 08DH03-1 & 28 & 882 & 1.4 & 20.9752 & 23.6 & 0.1740 & 24.6 & 0.0265 & 7.1 & 0.29 \\
\hline 08DH03-2 & 675 & 11004 & 0.9 & 19.0099 & 3.8 & 0.3146 & 4.1 & 0.0434 & 1.7 & 0.40 \\
\hline 08DH03-3 & 235 & 4437 & 2.2 & 20.8421 & 7.6 & 0.1777 & 7.6 & 0.0269 & 1.1 & .15 \\
\hline 08DH03-4 & 50 & 9726 & 1.8 & 8.8756 & 1.6 & 5.1793 & 1.8 & 0.3334 & 0.7 & 0.41 \\
\hline 08DH03-5 & 90 & 1737 & 1.1 & 23.2990 & 24.0 & 0.1451 & 24.1 & 0.0245 & 2.6 & .11 \\
\hline 08DH03-6 & 218 & 5460 & 0.5 & 18.5219 & 23.4 & 0.3056 & 23.6 & 0.0411 & 2.8 & .12 \\
\hline 08DH03-7 & 144 & 5406 & 0.9 & 19.2901 & 4.9 & 0.3302 & 5.1 & 0.0462 & 1.2 & 0.23 \\
\hline 08DH03-8 & 39 & 1212 & 1.9 & 19.7386 & 15.1 & 0.2763 & 15.2 & 0.0395 & 1.8 & 0.12 \\
\hline 08DH03-9 & 614 & 4467 & 0.7 & 16.8316 & 3.3 & 0.3888 & 3.4 & 0.0475 & 0.9 & 0.27 \\
\hline 08DH03-10 & 139 & 35829 & 2.1 & 8.4034 & 1.5 & 5.7923 & 1.7 & 0.3530 & 0.7 & 0.40 \\
\hline 08DH03-11 & 397 & 12768 & 1.8 & 19.4001 & 1.9 & 0.2941 & 2.5 & 0.0414 & 1.7 & 0.66 \\
\hline 08DH03-12 & 60 & 16878 & 0.8 & 7.9733 & 1.5 & 6.4532 & 1.7 & 0.3732 & 1.0 & 0.55 \\
\hline 08DH03-13 & 214 & 53331 & 1.5 & 7.5634 & 0.7 & 7.0689 & 1.4 & 0.3878 & 1.2 & 0.85 \\
\hline 08DH03-14 & 254 & 14796 & 1.0 & 17.3244 & 1.7 & 0.6689 & 2.0 & 0.0840 & 1.1 & 0.55 \\
\hline 08DH03-15 & 358 & 87483 & 3.1 & 8.1472 & 1.2 & 5.9427 & 1.3 & 0.3511 & 0.5 & 0.39 \\
\hline 08DH03-16 & 154 & 4437 & 0.5 & 19.8597 & 6.1 & 0.3007 & 6.1 & 0.0433 & 0.7 & .11 \\
\hline 08DH03-18 & 81 & 2595 & 0.7 & 19.8788 & 10.9 & 0.3231 & 10.9 & 0.0466 & 1.0 & 0.09 \\
\hline 08DH03-19 & 86 & 19689 & 1.2 & 5.8405 & 1.2 & 11.0095 & 2.6 & 0.4664 & 2.3 & 0.89 \\
\hline 08DH03-20 & 203 & 65970 & 0.8 & 4.9518 & 1.1 & 15.5075 & 1.4 & 0.5569 & 0.9 & 0.64 \\
\hline 08DH03-21 & 267 & 5643 & 0.7 & 18.9136 & 2.7 & 0.3488 & 3.5 & 0.0478 & 2.2 & 0.64 \\
\hline 08DH03-22 & 207 & 6141 & 0.8 & 19.1462 & 3.2 & 0.3543 & 3.2 & 0.0492 & 0.6 & 0.18 \\
\hline 08DH03-23 & 152 & 4851 & 0.7 & 19.4963 & 6.5 & 0.3443 & 6.9 & 0.0487 & 2.2 & 0.32 \\
\hline 08DH03-24 & 176 & 3687 & 1.2 & 21.0257 & 8.0 & 0.1657 & 8.0 & 0.0253 & 1.0 & 0.12 \\
\hline 08DH03-25 & 173 & 4113 & 1.4 & 21.0361 & 9.0 & 0.1839 & 9.1 & 0.0281 & 1.5 & 0.17 \\
\hline 08DH03-26 & 226 & 7653 & 1.0 & 19.2837 & 3.6 & 0.3094 & 3.9 & 0.0433 & 1.3 & 0.33 \\
\hline 08DH03-27 & 77 & 2328 & 0.7 & 18.8437 & 6.1 & 0.3440 & 6.3 & 0.0470 & 1.4 & 0.22 \\
\hline 08DH03-28 & 25 & 471 & 1.2 & 33.4964 & 67.3 & 0.1002 & 67.4 & 0.0243 & 2.8 & 0.04 \\
\hline 08DH03-29 & 376 & 6936 & 1.5 & 20.3594 & 3.1 & 0.1756 & 3.2 & 0.0259 & 0.5 & 0.16 \\
\hline 08DH03-30 & 101 & 3849 & 0.8 & 19.1995 & 6.4 & 0.3886 & 6.5 & 0.0541 & 0.5 & 0.08 \\
\hline 08DH03-31 & 142 & 5811 & 1.1 & 18.4475 & 2.3 & 0.4340 & 2.9 & 0.0581 & 1.7 & 0.59 \\
\hline 08DH03-32 & 58 & 1521 & 2.2 & 22.8240 & 25.4 & 0.1567 & 25.5 & 0.0259 & 2.8 & 0.11 \\
\hline 08DH03-33 & 124 & 31752 & 1.5 & 7.7482 & 0.9 & 6.7666 & 1.2 & 0.3803 & 0.8 & 0.65 \\
\hline 08DH03-34 & 52 & 12105 & 0.4 & 7.6882 & 0.6 & 6.8603 & 1.9 & 0.3825 & 1.8 & 0.95 \\
\hline 08DH03-35 & 186 & 4512 & 1.3 & 18.8299 & 3.2 & 0.3694 & 3.3 & 0.0505 & 0.8 & 0.23 \\
\hline 08DH03-36 & 149 & 2625 & 0.9 & 20.9743 & 10.9 & 0.1860 & 10.9 & 0.0283 & 0.8 & 0.07 \\
\hline 08DH03-37 & 174 & 4473 & 1.2 & 8.2382 & 1.8 & 4.5907 & 3.5 & 0.2743 & 3.1 & 0.87 \\
\hline 08DH03-38 & 59 & 1638 & 1.1 & 19.8567 & 13.0 & 0.2976 & 13.1 & 0.0429 & 1.2 & 0.09 \\
\hline 08DH03-39 & 592 & 8919 & 1.2 & 17.9464 & 8.2 & 0.4081 & 8.3 & 0.0531 & 1.2 & 0.14 \\
\hline 08DH03-40 & 1042 & 129297 & 18.2 & 8.2064 & 1.1 & 6.0960 & 1.5 & 0.3628 & 1.0 & 0.67 \\
\hline 08DH03-41 & 213 & 774 & 1.6 & 11.1611 & 10.0 & 0.3193 & 10.1 & 0.0258 & 1.6 & 0.16 \\
\hline 08DH03-42 & 27 & 7485 & 1.2 & 8.0569 & 1.4 & 6.3437 & 1.5 & 0.3707 & 0.5 & 0.33 \\
\hline 08DH03-43 & 75 & 2016 & 0.5 & 20.6324 & 14.7 & 0.3083 & 14.7 & 0.0461 & 0.5 & 0.03 \\
\hline 08DH03-44 & 92 & 1479 & 1.3 & 19.9197 & 8.7 & 0.1886 & 8.8 & 0.0272 & 1.7 & 0.19 \\
\hline 08DH03-45 & 73 & 1833 & 1.0 & 21.5712 & 14.9 & 0.1629 & 15.0 & 0.0255 & 1.7 & 0.11 \\
\hline 08DH03-46 & 38 & 909 & 2.2 & 19.4718 & 14.6 & 0.1975 & 15.3 & 0.0279 & 4.8 & 0.31 \\
\hline
\end{tabular}


08DH03

Apparent ages (Ma)

\begin{tabular}{|c|c|c|c|c|c|c|c|c|c|}
\hline Analysis & $\begin{array}{c}206 \mathrm{~Pb}^{*} / \\
238 \mathrm{U}^{*}\end{array}$ & $\begin{array}{c} \pm \\
(\mathrm{Ma})\end{array}$ & $\begin{array}{c}207 \mathrm{~Pb}^{*} / \\
235 \mathrm{U}\end{array}$ & $\stackrel{ \pm}{ \pm}(\mathrm{Ma})$ & $\begin{array}{l}206 \mathrm{~Pb}^{*} / \\
207 \mathrm{~Pb}^{*}\end{array}$ & $\stackrel{ \pm}{ \pm}$ & $\begin{array}{c}\text { Best age } \\
\quad(\mathrm{Ma})\end{array}$ & $\stackrel{ \pm}{ \pm}(\mathrm{Ma})$ & $\begin{array}{c}\text { Conc } \\
(\%)\end{array}$ \\
\hline 08DH03-1 & 168.5 & 11.8 & 162.9 & 37.1 & 83.2 & 566.0 & 168.5 & 11.8 & 025 \\
\hline 08DH03-2 & 273.7 & 4.4 & 277.7 & 10.0 & 311.7 & 85.9 & 273.7 & 4.4 & 87.8 \\
\hline 08DH03-3 & 170.8 & 1.9 & 166.0 & 11.7 & 98.3 & 179.0 & 170.8 & 1.9 & 173.9 \\
\hline 08DH03-4 & 1854.9 & 11.8 & 1849.2 & 15.0 & 1842.9 & 29.1 & 1842.9 & 29.1 & 100.6 \\
\hline 08DH03-5 & 156.2 & 4.0 & 137.6 & 31.1 & -172.2 & 604.9 & 156.2 & 4.0 & -90.7 \\
\hline 08DH03-6 & 259.4 & 7.2 & 270.8 & 56.1 & 370.6 & 533.8 & 259.4 & 7.2 & 70.0 \\
\hline 08DH03-7 & 291.1 & 3.3 & 289.7 & 12.7 & 278.4 & 112.7 & 291.1 & 3.3 & 104.6 \\
\hline 08DH03-8 & 250.0 & 4.3 & 247.7 & 33.4 & 225.5 & 350.2 & 250.0 & 4.3 & 110.9 \\
\hline 08DH03-9 & 299.0 & 2.7 & 333.5 & 9.7 & 582.2 & 71.6 & 299.0 & 2.7 & 51.3 \\
\hline 08DH03-10 & 1949.0 & 11.3 & 1945.3 & 14.5 & 1941.2 & 27.6 & 1941.2 & 27.6 & 100.4 \\
\hline 08DH03-11 & 261.4 & 4.2 & 261.8 & 5.8 & 265.3 & 43.6 & 261.4 & 4.2 & 98.5 \\
\hline 08DH03-12 & 2044.3 & 16.8 & 2039.5 & 15.4 & 2034.7 & 25.8 & 2034.7 & 25.8 & 100.5 \\
\hline 08DH03-13 & 2112.5 & 21.6 & 2120.1 & 12.5 & 2127.6 & 12.8 & 2127.6 & 12.8 & 99.3 \\
\hline 08DH03-14 & 520.2 & 5.4 & 520.0 & 8.0 & 519.2 & 36.4 & 520.2 & 5.4 & 100.2 \\
\hline 08DH03-15 & 1940.1 & 8.5 & 1967.5 & 11.4 & 1996.4 & 21.5 & 1996.4 & 21.5 & 97.2 \\
\hline 08DH03-16 & 273.3 & 1.8 & 266.9 & 14.3 & 211.3 & 141.0 & 273.3 & 1.8 & 129.3 \\
\hline 08DH03-18 & 293.5 & 2.9 & 284.3 & 27.0 & 209.1 & 252.2 & 293.5 & 2.9 & 140.4 \\
\hline 08DH03-19 & 2467.6 & 46.7 & 2523.9 & 23.8 & 2569.6 & 19.4 & 2569.6 & 19.4 & 96.0 \\
\hline 08DH03-20 & 2853.9 & 20.5 & 2846.9 & 13.3 & 2842.0 & 17.6 & 2842.0 & 17.6 & 100.4 \\
\hline 08DH03-21 & 301.3 & 6.6 & 303.8 & 9.1 & 323.3 & 60.3 & 301.3 & 6.6 & 93.2 \\
\hline 08DH03-22 & 309.6 & 1.7 & 308.0 & 8.6 & 295.5 & 72.7 & 309.6 & 1.7 & 104.8 \\
\hline 08DH03-23 & 306.4 & 6.6 & 300.4 & 17.8 & 254.0 & 149.3 & 306.4 & 6.6 & 120.7 \\
\hline 08DH03-24 & 160.9 & 1.5 & 155.7 & 11.6 & 77.5 & 190.0 & 160.9 & 1.5 & 207.7 \\
\hline 08DH03-25 & 178.4 & 2.7 & 171.4 & 14.4 & 76.3 & 214.3 & 178.4 & 2.7 & 233.9 \\
\hline 08DH03-26 & 273.1 & 3.4 & 273.7 & 9.3 & 279.1 & 83.5 & 273.1 & 3.4 & 97.8 \\
\hline 08DH03-27 & 296.2 & 4.0 & 300.2 & 16.4 & 331.7 & 139.4 & 296.2 & 4.0 & 89.3 \\
\hline 08DH03-28 & 155.0 & 4.3 & 96.9 & 62.4 & -1173.9 & 2311.7 & 155.0 & 4.3 & -13.2 \\
\hline 08DH03-29 & 165.0 & 0.8 & 164.2 & 4.8 & 153.4 & 73.5 & 165.0 & 0.8 & 107.5 \\
\hline 08DH03-30 & 339.7 & 1.7 & 333.3 & 18.3 & 289.1 & 147.1 & 339.7 & 1.7 & 117.5 \\
\hline 08DH03-31 & 363.8 & 6.1 & 366.0 & 8.9 & 379.7 & 52.4 & 363.8 & 6.1 & 95.8 \\
\hline 08DH03-32 & 165.1 & 4.6 & 147.8 & 35.1 & -121.1 & 634.5 & 165.1 & 4.6 & -136.2 \\
\hline 08DH03-33 & 2077.5 & 13.7 & 2081.4 & 10.5 & 2085.2 & 15.8 & 2085.2 & 15.8 & 99.6 \\
\hline 08DH03-34 & 2088.1 & 31.6 & 2093.5 & 16.6 & 2098.9 & 10.5 & 2098.9 & 10.5 & 99.5 \\
\hline 08DH03-35 & 317.3 & 2.3 & 319.2 & 9.0 & 333.4 & 72.9 & 317.3 & 2.3 & 95.2 \\
\hline 08DH03-36 & 179.9 & 1.4 & 173.2 & 17.4 & 83.3 & 259.5 & 179.9 & 1.4 & 216.0 \\
\hline 08DH03-37 & 1562.5 & 42.7 & 1747.6 & 29.6 & 1976.7 & 31.2 & 1976.7 & 31.2 & 79.0 \\
\hline 08DH03-38 & 270.5 & 3.2 & 264.5 & 30.4 & 211.7 & 302.3 & 270.5 & 3.2 & 127.8 \\
\hline 08DH03-39 & 333.6 & 3.9 & 347.5 & 24.5 & 441.3 & 183.7 & 333.6 & 3.9 & 75.6 \\
\hline 08DH03-40 & 1995.5 & 17.5 & 1989.7 & 13.3 & 1983.6 & 20.1 & 1983.6 & 20.1 & 100.6 \\
\hline 08DH03-41 & 164.5 & 2.6 & 281.3 & 24.9 & 1416.9 & 191.5 & 164.5 & 2.6 & 11.6 \\
\hline 08DH03-42 & 2032.6 & 8.7 & 2024.5 & 13.4 & 2016.2 & 25.5 & 2016.2 & 25.5 & 100.8 \\
\hline 08DH03-43 & 290.8 & 1.4 & 272.9 & 35.1 & 122.2 & 346.9 & 290.8 & 1.4 & 238.0 \\
\hline 08DH03-44 & 173.3 & 2.9 & 175.4 & 14.2 & 204.3 & 201.8 & 173.3 & 2.9 & 84.8 \\
\hline 08DH03-45 & 162.2 & 2.8 & 153.2 & 21.4 & 16.3 & 360.6 & 162.2 & 2.8 & 997.0 \\
\hline 08DH03-46 & 177.3 & 8.3 & 183.0 & 25.7 & 256.9 & 336.1 & 177.3 & 8.3 & 69.0 \\
\hline
\end{tabular}


08DH03

Isotope ratios

\begin{tabular}{|c|c|c|c|c|c|c|c|c|c|c|}
\hline Analysis & $\begin{array}{c}\mathrm{U} \\
(\mathrm{ppm})\end{array}$ & $\begin{array}{l}206 \mathrm{~Pb} / \\
204 \mathrm{~Pb}\end{array}$ & $\mathrm{U} / \mathrm{Th}$ & $\begin{array}{l}206 \mathrm{~Pb}^{*} / \\
207 \mathrm{~Pb}^{*}\end{array}$ & $\begin{array}{c} \pm \\
(\%)\end{array}$ & $\begin{array}{c}207 \mathrm{~Pb}^{*} / \\
235 \mathrm{U}^{*}\end{array}$ & $\begin{array}{c} \pm \\
(\%)\end{array}$ & $\begin{array}{c}206 \mathrm{~Pb}^{\star} / \\
238 \mathrm{U}\end{array}$ & $\begin{array}{c} \pm \\
(\%)\end{array}$ & $\begin{array}{l}\text { error } \\
\text { corr. }\end{array}$ \\
\hline 08DH03-47 & 27 & 1002 & 1.0 & 20.8906 & 20.6 & 0.2579 & 20.9 & 0.0391 & 3.6 & 0.17 \\
\hline 08DH03-48 & 114 & 1881 & 1.1 & 20.4934 & 12.0 & 0.1923 & 12.1 & 0.0286 & 1.5 & 0.12 \\
\hline 08DH03-49 & 121 & 2259 & 1.4 & 20.2387 & 9.5 & 0.2172 & 9.5 & 0.0319 & 0.5 & 0.06 \\
\hline 08DH03-50 & 141 & 34533 & 1.3 & 8.2847 & 0.8 & 5.9385 & 1.2 & 0.3568 & 0.9 & 0.75 \\
\hline 08DH03-51 & 38 & 825 & 0.9 & 21.5457 & 26.9 & 0.1641 & 27.3 & 0.0256 & 5.0 & 0.18 \\
\hline 08DH03-52 & 131 & 1053 & 0.6 & 17.4973 & 9.3 & 0.2052 & 9.6 & 0.0260 & 2.4 & 0.25 \\
\hline 08DH03-53 & 41 & 1392 & 0.5 & 20.1075 & 15.5 & 0.3215 & 15.6 & 0.0469 & 1.6 & 0.10 \\
\hline 08DH03-54 & 114 & 32421 & 0.6 & 7.8296 & 1.1 & 6.6805 & 1.3 & 0.3794 & 0.7 & 0.53 \\
\hline 08DH03-55 & 26 & 912 & 1.2 & 23.0648 & 34.9 & 0.2516 & 34.9 & 0.0421 & 1.3 & 0.04 \\
\hline 08DH03-56 & 326 & 78765 & 1.6 & 5.4427 & 1.2 & 12.4938 & 2.7 & 0.4932 & 2.5 & 0.91 \\
\hline 08DH03-57 & 90 & 2214 & 1.1 & 21.6715 & 14.7 & 0.1875 & 14.7 & 0.0295 & 1.0 & 0.07 \\
\hline 08DH03-58 & 54 & 870 & 1.4 & 24.8087 & 37.7 & 0.1648 & 37.7 & 0.0296 & 2.0 & 0.05 \\
\hline 08DH03-59 & 183 & 2634 & 0.9 & 20.3612 & 7.8 & 0.1797 & 7.8 & 0.0265 & 0.8 & 0.10 \\
\hline 08DH03-60 & 95 & 1902 & 0.7 & 20.8074 & 12.6 & 0.1739 & 12.7 & 0.0262 & 1.7 & 0.13 \\
\hline 08DH03-61 & 345 & 6021 & 1.0 & 19.8500 & 2.0 & 0.1923 & 2.1 & 0.0277 & 0.5 & 0.25 \\
\hline 08DH03-62 & 227 & 4302 & 1.0 & 20.5128 & 7.0 & 0.1978 & 7.1 & 0.0294 & 1.1 & 0.16 \\
\hline 08DH03-63 & 56 & 1161 & 1.4 & 21.7735 & 21.6 & 0.1691 & 21.6 & 0.0267 & 1.2 & 0.06 \\
\hline 08DH03-64 & 230 & 5775 & 0.7 & 19.7293 & 4.1 & 0.2935 & 4.1 & 0.0420 & 0.5 & 0.12 \\
\hline 08DH03-65 & 119 & 55110 & 0.9 & 3.9532 & 1.0 & 22.3935 & 1.2 & 0.6420 & 0.7 & 0.57 \\
\hline 08DH03-67 & 146 & 4599 & 1.7 & 20.1203 & 6.6 & 0.2796 & 6.7 & 0.0408 & 1.4 & 0.21 \\
\hline 08DH03-68 & 398 & 5331 & 0.4 & 19.8479 & 2.3 & 0.1864 & 2.4 & 0.0268 & 0.7 & 0.30 \\
\hline 08DH03-69 & 529 & 12660 & 1.2 & 19.0344 & 1.4 & 0.3263 & 1.5 & 0.0451 & 0.5 & 0.34 \\
\hline 08DH03-70 & 44 & 816 & 0.8 & 22.9604 & 13.7 & 0.1476 & 14.0 & 0.0246 & 2.6 & 0.19 \\
\hline 08DH03-71 & 335 & 6369 & 0.8 & 19.1761 & 1.5 & 0.3187 & 1.6 & 0.0443 & 0.5 & 0.31 \\
\hline 08DH03-72 & 51 & 11445 & 0.7 & 8.5669 & 3.5 & 5.6730 & 3.8 & 0.3525 & 1.4 & 0.37 \\
\hline 08DH03-73 & 202 & 2883 & 0.8 & 17.2502 & 3.4 & 0.5085 & 4.0 & 0.0636 & 2.1 & 0.52 \\
\hline 08DH03-74 & 116 & 2013 & 0.8 & 20.4253 & 9.5 & 0.1718 & 9.5 & 0.0254 & 0.5 & 0.05 \\
\hline 08DH03-76 & 99 & 10863 & 1.1 & 14.8960 & 0.9 & 1.2592 & 2.0 & 0.1360 & 1.7 & 0.88 \\
\hline 08DH03-77 & 62 & 1575 & 0.6 & 19.4044 & 10.1 & 0.3073 & 10.3 & 0.0432 & 2.2 & 0.21 \\
\hline 08DH03-78 & 257 & 4485 & 2.1 & 19.4347 & 3.0 & 0.2839 & 3.0 & 0.0400 & 0.7 & 0.22 \\
\hline 08DH03-79 & 455 & 6066 & 0.8 & 19.4508 & 2.3 & 0.2631 & 2.6 & 0.0371 & 1.1 & 0.44 \\
\hline 08DH03-80 & 130 & 2472 & 0.4 & 19.2709 & 14.6 & 0.3255 & 14.6 & 0.0455 & 1.0 & 0.07 \\
\hline 08DH03-81 & 162 & 3969 & 1.9 & 20.1121 & 5.9 & 0.2101 & 5.9 & 0.0306 & 0.5 & 0.08 \\
\hline 08DH03-82 & 381 & 11145 & 1.3 & 19.4371 & 1.9 & 0.3105 & 2.0 & 0.0438 & 0.5 & 0.26 \\
\hline 08DH03-83 & 260 & 45462 & 0.9 & 9.2478 & 1.4 & 3.9265 & 2.0 & 0.2634 & 1.5 & 0.74 \\
\hline 08DH03-84 & 111 & 2394 & 0.8 & 19.0065 & 4.4 & 0.3218 & 4.4 & 0.0444 & 0.8 & 0.18 \\
\hline 08DH03-85 & 845 & 101577 & 2.2 & 8.1889 & 1.0 & 5.9824 & 1.1 & 0.3553 & 0.5 & 0.46 \\
\hline 08DH03-86 & 141 & 2616 & 1.2 & 20.4203 & 7.3 & 0.1749 & 7.3 & 0.0259 & 1.1 & 0.16 \\
\hline 08DH03-87 & 161 & 5181 & 1.0 & 19.5655 & 4.8 & 0.3229 & 4.8 & 0.0458 & 0.6 & 0.12 \\
\hline 08DH03-88 & 153 & 35964 & 1.9 & 9.4180 & 1.7 & 4.1670 & 4.9 & 0.2846 & 4.6 & 0.94 \\
\hline 08DH03-89 & 167 & 8514 & 2.3 & 18.3538 & 4.4 & 0.4557 & 4.5 & 0.0607 & 1.2 & 0.27 \\
\hline 08DH03-90 & 185 & 58044 & 1.9 & 8.5344 & 1.0 & 5.5744 & 1.6 & 0.3450 & 1.3 & 0.81 \\
\hline 08DH03-91 & 332 & 9567 & 1.4 & 17.7129 & 1.5 & 0.5276 & 1.9 & 0.0678 & 1.3 & 0.66 \\
\hline 08DH03-92 & 147 & 4314 & 1.8 & 19.1958 & 3.3 & 0.2875 & 3.4 & 0.0400 & 0.9 & 0.25 \\
\hline 08DH03-93 & 72 & 1992 & 1.8 & 21.8786 & 17.0 & 0.1588 & 17.1 & 0.0252 & 1.5 & 0.09 \\
\hline
\end{tabular}


08DH03

Apparent ages (Ma)

\begin{tabular}{|c|c|c|c|c|c|c|c|c|c|}
\hline Analysis & $\begin{array}{c}206 \mathrm{~Pb}^{*} / \\
238 \mathrm{U}^{*}\end{array}$ & $\stackrel{ \pm}{(\mathrm{Ma})}$ & $\begin{array}{c}207 \mathrm{~Pb}^{*} / \\
235 \mathrm{U}\end{array}$ & $\begin{array}{c} \pm \\
(\mathrm{Ma})\end{array}$ & $\begin{array}{l}206 \mathrm{~Pb}^{*} / \\
207 \mathrm{~Pb}^{*}\end{array}$ & $\stackrel{ \pm}{(\mathrm{Ma})}$ & $\begin{array}{c}\text { Best age } \\
\quad(\mathrm{Ma})\end{array}$ & $\stackrel{ \pm}{(\mathrm{Ma})}$ & $\begin{array}{c}\text { Conc } \\
(\%)\end{array}$ \\
\hline 08DH03-47 & 247.1 & 8.6 & 233.0 & 43.5 & 92.8 & 492.1 & 247.1 & 8.6 & 266.3 \\
\hline 08DH03-48 & 181.6 & 2.6 & 178.6 & 19.8 & 138.1 & 283.3 & 181.6 & 2.6 & 131.6 \\
\hline 08DH03-49 & 202.3 & 1.1 & 199.5 & 17.2 & 167.3 & 222.0 & 202.3 & 1.1 & 120.9 \\
\hline 08DH03-50 & 1967.1 & 14.9 & 1966.9 & 10.2 & 1966.6 & 13.9 & 1966.6 & 13.9 & 100.0 \\
\hline 08DH03-51 & 163.2 & 8.0 & 154.3 & 39.1 & 19.2 & 655.2 & 163.2 & 8.0 & 852.0 \\
\hline 08DH03-52 & 165.7 & 3.9 & 189.5 & 16.6 & 497.4 & 204.8 & 165.7 & 3.9 & 33.3 \\
\hline 08DH03-53 & 295.4 & 4.6 & 283.1 & 38.6 & 182.5 & 363.6 & 295.4 & 4.6 & 161.9 \\
\hline 08DH03-54 & 2073.3 & 11.9 & 2070.0 & 11.2 & 2066.8 & 19.1 & 2066.8 & 19.1 & 100.3 \\
\hline 08DH03-55 & 265.8 & 3.5 & 227.9 & 71.4 & -147.1 & 889.2 & 265.8 & 3.5 & -180.7 \\
\hline 08DH03-56 & 2584.4 & 52.8 & 2642.3 & 25.7 & 2686.9 & 19.2 & 2686.9 & 19.2 & 96.2 \\
\hline 08DH03-57 & 187.3 & 1.8 & 174.5 & 23.6 & 5.2 & 355.6 & 187.3 & 1.8 & 3633.9 \\
\hline 08DH03-58 & 188.3 & 3.7 & 154.9 & 54.3 & -331.1 & 999.6 & 188.3 & 3.7 & -56.9 \\
\hline 08DH03-59 & 168.8 & 1.3 & 167.8 & 12.1 & 153.2 & 182.2 & 168.8 & 1.3 & 110.2 \\
\hline 08DH03-60 & 167.0 & 2.8 & 162.8 & 19.1 & 102.2 & 298.5 & 167.0 & 2.8 & 163.4 \\
\hline 08DH03-61 & 176.1 & 0.9 & 178.6 & 3.4 & 212.4 & 46.6 & 176.1 & $\theta .9$ & 82.9 \\
\hline 08DH03-62 & 187.0 & 2.1 & 183.3 & 11.9 & 135.8 & 165.1 & 187.0 & 2.1 & 137.7 \\
\hline 08DH03-63 & 169.9 & 2.1 & 158.6 & 31.8 & -6.2 & 526.1 & 169.9 & 2.1 & -2752.4 \\
\hline 08DH03-64 & 265.2 & 1.3 & 261.3 & 9.5 & 226.6 & 94.8 & 265.2 & 1.3 & 117.0 \\
\hline 08DH03-65 & 3197.1 & 17.6 & 3201.0 & 12.0 & 3203.4 & 16.1 & 3203.4 & 16.1 & 99.8 \\
\hline 08DH03-67 & 257.8 & 3.5 & 250.4 & 14.9 & 181.0 & 152.9 & 257.8 & 3.5 & 142.4 \\
\hline 08DH03-68 & 170.7 & 1.2 & 173.5 & 3.8 & 212.7 & 52.4 & 170.7 & 1.2 & 80.2 \\
\hline 08DH03-69 & 284.1 & 1.4 & 286.8 & 3.6 & 308.8 & 31.0 & 284.1 & 1.4 & 92.0 \\
\hline 08DH03-70 & 156.5 & 4.1 & 139.8 & 18.2 & -135.9 & 340.9 & 156.5 & 4.1 & -115.2 \\
\hline 08DH03-71 & 279.6 & 1.4 & 280.9 & 4.0 & 291.9 & 35.2 & 279.6 & 1.4 & 95.8 \\
\hline 08DH03-72 & 1946.4 & 23.9 & 1927.3 & 32.9 & 1906.7 & 63.6 & 1906.7 & 63.6 & 102.1 \\
\hline 08DH03-73 & 397.6 & 8.0 & 417.4 & 13.7 & 528.7 & 75.4 & 397.6 & 8.0 & 75.2 \\
\hline 08DH03-74 & 162.0 & 0.8 & 160.9 & 14.1 & 145.9 & 222.2 & 162.0 & 0.8 & 111.0 \\
\hline 08DH03-76 & 822.2 & 13.3 & 827.5 & 11.0 & 841.9 & 19.2 & 822.2 & 13.3 & 97.7 \\
\hline 08DH03-77 & 272.9 & 5.7 & 272.1 & 24.6 & 264.8 & 231.9 & 272.9 & 5.7 & 103.1 \\
\hline 08DH03-78 & 253.0 & 1.6 & 253.8 & 6.8 & 261.2 & 68.3 & 253.0 & 1.6 & 96.8 \\
\hline 08DH03-79 & 235.0 & 2.6 & 237.2 & 5.4 & 259.3 & 53.1 & 235.0 & 2.6 & 90.6 \\
\hline 08DH03-80 & 286.8 & 2.7 & 286.2 & 36.5 & 280.7 & 335.5 & 286.8 & 2.7 & 102.2 \\
\hline 08DH03-81 & 194.6 & 1.0 & 193.6 & 10.4 & 182.0 & 137.7 & 194.6 & 1.0 & 106.9 \\
\hline 08DH03-82 & 276.1 & 1.4 & 274.5 & 4.7 & 261.0 & 43.3 & 276.1 & 1.4 & 105.8 \\
\hline 08DH03-83 & 1507.0 & 20.3 & 1619.2 & 16.4 & 1768.2 & 24.8 & 1768.2 & 24.8 & 85.2 \\
\hline 08DH03-84 & 279.8 & 2.1 & 283.3 & 11.0 & 312.1 & 99.6 & 279.8 & 2.1 & 89.6 \\
\hline 08DH03-85 & 1959.9 & 8.4 & 1973.3 & 9.5 & 1987.4 & 17.3 & 1987.4 & 17.3 & 98.6 \\
\hline 08DH03-86 & 164.8 & 1.9 & 163.6 & 11.1 & 146.5 & 170.3 & 164.8 & 1.9 & 112.5 \\
\hline 08DH03-87 & 288.8 & 1.7 & 284.1 & 12.0 & 245.8 & 110.6 & 288.8 & 1.7 & 117.5 \\
\hline 08DH03-88 & 1614.6 & 66.0 & 1667.5 & 40.3 & 1734.8 & 31.0 & 1734.8 & 31.0 & 93.1 \\
\hline 08DH03-89 & 379.7 & 4.5 & 381.3 & 14.5 & 391.1 & 98.3 & 379.7 & 4.5 & 97.1 \\
\hline 08DH03-90 & 1910.9 & 22.0 & 1912.2 & 14.1 & 1913.5 & 17.1 & 1913.5 & 17.4 & 99.9 \\
\hline 08DH03-91 & 422.8 & 5.2 & 430.2 & 6.8 & 470.3 & 32.1 & 422.8 & 5.2 & 89.9 \\
\hline 08DH03-92 & 253.0 & 2.1 & 256.6 & 7.7 & 289.6 & 75.4 & 253.0 & 2.1 & 87.4 \\
\hline 08DH03-93 & 160.4 & 2.4 & 149.6 & 23.8 & -17.8 & 413.7 & 160.4 & 2.4 & -901.2 \\
\hline
\end{tabular}


08DH03

Isotope ratios

$\begin{array}{ccccccccccc}\text { Analysis } & \begin{array}{c}\mathrm{U} \\ (\mathrm{ppm})\end{array} & \begin{array}{c}206 \mathrm{~Pb} / \\ 204 \mathrm{~Pb}\end{array} & \mathrm{U} / \mathrm{Th} & \begin{array}{c}206 \mathrm{~Pb}^{*} / \\ 207 \mathrm{~Pb}^{*}\end{array} & \begin{array}{c} \pm \\ (\%)\end{array} & \begin{array}{c}207 \mathrm{~Pb}^{*} / \\ 235 \mathrm{U}^{*}\end{array} & \begin{array}{c} \pm \\ (\%)\end{array} & \begin{array}{c}206 \mathrm{~Pb}^{*} / \\ 238 U\end{array} & \begin{array}{c} \pm \\ (\%)\end{array} & \begin{array}{c}\text { error } \\ \text { corr. }\end{array} \\ \text { 08DH03-94 } & 139 & 3561 & 1.4 & 18.8692 & 3.6 & 0.3333 & 3.7 & 0.0456 & 0.5 & 0.14 \\ \text { 08DH03-95 } & 161 & 5271 & 0.7 & 19.8908 & 6.8 & 0.2994 & 6.8 & 0.0432 & 0.5 & 0.07 \\ \text { 08DH03-96 } & 161 & 3546 & 1.3 & 21.0009 & 9.6 & 0.1870 & 9.7 & 0.0285 & 1.1 & 0.11 \\ \text { 08DH03-97 } & 133 & 2451 & 0.8 & 20.1707 & 7.7 & 0.1908 & 7.7 & 0.0279 & 0.5 & 0.06 \\ \text { 08DH03-98 } & 203 & 8109 & 1.0 & 18.6344 & 3.2 & 0.4140 & 3.2 & 0.0560 & 0.5 & 0.15 \\ \text { 08DH03-99 } & 188 & 5760 & 1.1 & 19.1641 & 2.6 & 0.2978 & 2.6 & 0.0414 & 0.5 & 0.19 \\ \text { 08DH03-100 } & 559 & 15144 & 0.6 & 19.2689 & 2.0 & 0.3325 & 2.7 & 0.0465 & 1.8 & 0.67\end{array}$

08DH03

Apparent ages (Ma)

$\begin{array}{cccccccccc}\text { Analysis } & \begin{array}{c}206 \mathrm{~Pb}^{*} / \\ \text { 238U* }\end{array} & \begin{array}{c} \pm \\ (\mathrm{Ma})\end{array} & \begin{array}{c}207 \mathrm{~Pb}^{*} / \\ 235 \mathrm{U}\end{array} & \begin{array}{c} \pm \\ (\mathrm{Ma})\end{array} & \begin{array}{c}206 \mathrm{~Pb}^{*} / \\ 207 \mathrm{~Pb}^{*}\end{array} & \begin{array}{c} \pm \\ (\mathrm{Ma})\end{array} & \begin{array}{c}\text { Best age } \\ (\mathrm{Ma})\end{array} & \begin{array}{c} \pm \\ (\mathrm{Ma})\end{array} & \begin{array}{c}\text { Conc } \\ (\%)\end{array} \\ \text { 08DH03-94 } & 287.5 & 1.4 & 292.1 & 9.3 & 328.7 & 82.4 & 287.5 & 1.4 & 87.5 \\ \text { 08DH03-95 } & 272.6 & 1.4 & 266.0 & 16.0 & 207.7 & 157.9 & 272.6 & 1.4 & 131.3 \\ \text { 08DH03-96 } & 181.0 & 2.0 & 174.1 & 15.5 & 80.3 & 228.9 & 181.0 & 2.0 & 225.6 \\ \text { 08DH03-97 } & 177.5 & 0.9 & 177.3 & 12.6 & 175.2 & 180.2 & 177.5 & 0.9 & 101.3 \\ \text { 08DH03-98 } & 351.0 & 1.7 & 351.8 & 9.6 & 357.0 & 72.3 & 351.0 & 1.7 & 98.3 \\ \text { 08DH03-99 } & 261.5 & 1.3 & 264.7 & 6.1 & 293.3 & 59.0 & 261.5 & 1.3 & 89.1 \\ \text { 08DH03-100 } & 292.8 & 5.1 & 291.5 & 6.8 & 280.9 & 45.6 & 292.8 & 5.1 & 104.2\end{array}$


08DH29a

Isotope ratios

\begin{tabular}{|c|c|c|c|c|c|c|c|c|c|c|}
\hline Analysis & $\underset{(p p m)}{U}$ & $\begin{array}{l}206 \mathrm{~Pb} / \\
204 \mathrm{~Pb}\end{array}$ & $\mathrm{U} / \mathrm{Th}$ & $\begin{array}{l}206 \mathrm{~Pb}^{*} / \\
207 \mathrm{~Pb}^{*}\end{array}$ & $\begin{array}{c} \pm \\
(\%)\end{array}$ & $\begin{array}{c}207 \mathrm{~Pb}^{*} / \\
235 U^{*}\end{array}$ & $\begin{array}{c} \pm \\
(\%)\end{array}$ & $\begin{array}{c}206 \mathrm{~Pb}^{*} / \\
238 \mathrm{U}\end{array}$ & $\begin{array}{c} \pm \\
(\%)\end{array}$ & $\begin{array}{l}\text { error } \\
\text { corr. }\end{array}$ \\
\hline 08DH29A-1 & 51 & 1323 & 1.6 & 20.1513 & 13.3 & 0.1776 & 13.7 & 0.0260 & 3.4 & 0.24 \\
\hline 08DH29A-2 & 158 & 71688 & 9.0 & 8.3115 & 1.7 & 5.7414 & 1.8 & 0.3461 & 0.6 & 0.34 \\
\hline 08DH29A-3 & 40 & 13692 & 1.4 & 8.5897 & 1.1 & 5.5310 & 1.3 & 0.3446 & 0.7 & 0.52 \\
\hline $08 \mathrm{DH} 29 \mathrm{~A}-4$ & 144 & 34974 & 3.3 & 9.9779 & 2.0 & 3.0589 & 4.3 & 0.2214 & 3.8 & 0.88 \\
\hline 08DH29A-5 & 281 & 16323 & 1.4 & 18.9731 & 2.8 & 0.3967 & 2.9 & 0.0546 & 0.6 & 0.21 \\
\hline $08 \mathrm{DH} 29 \mathrm{~A}-6$ & 57 & 4278 & 1.9 & 18.9824 & 5.3 & 0.4223 & 5.5 & 0.0581 & 1.2 & 0.22 \\
\hline 08DH29A-7 & 289 & 19971 & 4.2 & 19.1301 & 2.0 & 0.3412 & 2.1 & 0.0473 & 0.7 & 0.34 \\
\hline 08DH29A-8 & 87 & 3018 & 0.9 & 19.4711 & 5.3 & 0.2804 & 5.4 & 0.0396 & 0.5 & 0.10 \\
\hline $08 \mathrm{DH} 29 \mathrm{~A}-9$ & 65 & 23529 & 2.3 & 8.6695 & 1.9 & 5.4185 & 2.0 & 0.3407 & 0.6 & 0.30 \\
\hline 08DH29A-10 & 97 & 36699 & 2.8 & 8.3834 & 1.8 & 5.8277 & 1.9 & 0.3543 & 0.5 & 0.27 \\
\hline $08 \mathrm{DH} 29 \mathrm{~A}-11$ & 465 & 8991 & 1.6 & 19.4775 & 1.6 & 0.2612 & 1.7 & 0.0369 & 0.5 & 0.30 \\
\hline 08DH29A-12 & 45 & 13671 & 1.7 & 9.6266 & 3.5 & 4.3648 & 3.5 & 0.3047 & 0.5 & 0.14 \\
\hline 08DH29A-13 & 209 & 6144 & 3.0 & 20.1855 & 2.6 & 0.1728 & 2.8 & 0.0253 & 0.8 & 0.30 \\
\hline 08DH29A-14 & 335 & 166011 & 3.2 & 5.1874 & 1.4 & 14.0710 & 1.5 & 0.5294 & 0.5 & 0.34 \\
\hline 08DH29A-15 & 480 & 14253 & 2.2 & 19.5393 & 2.2 & 0.2800 & 2.3 & 0.0397 & 0.5 & 0.22 \\
\hline $08 \mathrm{DH} 29 \mathrm{~A}-16$ & 29 & 10206 & 3.0 & 8.7044 & 2.0 & 5.3615 & 2.1 & 0.3385 & 0.6 & 0.26 \\
\hline 08DH29A-17 & 177 & 60102 & 1.2 & 8.1340 & 3.0 & 6.1156 & 3.2 & 0.3608 & 1.1 & 0.33 \\
\hline 08DH29A-18 & 50 & 1770 & 2.7 & 24.6056 & 27.8 & 0.1417 & 27.8 & 0.0253 & 1.7 & 0.06 \\
\hline $08 \mathrm{DH} 29 \mathrm{~A}-19$ & 158 & 4992 & 3.2 & 19.4342 & 2.1 & 0.2740 & 2.5 & 0.0386 & 1.4 & 0.57 \\
\hline 08DH29A-20 & 699 & 190149 & 16.7 & 8.2605 & 2.4 & 5.7553 & 2.4 & 0.3448 & 0.6 & 0.24 \\
\hline $08 \mathrm{DH} 29 \mathrm{~A}-21$ & 249 & 87600 & 7.3 & 8.5441 & 2.0 & 5.6694 & 2.1 & 0.3513 & 0.5 & 0.24 \\
\hline 08DH29A-22 & 40 & 2055 & 1.4 & 19.1546 & 10.3 & 0.3691 & 10.4 & 0.0513 & 1.5 & 0.14 \\
\hline 08DH29A-23 & 91 & 3342 & 0.8 & 19.7730 & 5.4 & 0.2794 & 5.6 & 0.0401 & 1.5 & 0.26 \\
\hline 08DH29A-24 & 48 & 15057 & 1.9 & 8.5903 & 2.2 & 5.5542 & 2.3 & 0.3460 & 0.5 & 0.22 \\
\hline 08DH29A-25 & 153 & 5514 & 2.0 & 19.4894 & 4.6 & 0.2895 & 4.7 & 0.0409 & 0.8 & 0.17 \\
\hline 08DH29A-26 & 26 & 9972 & 1.9 & 8.8077 & 3.1 & 5.1313 & 3.2 & 0.3278 & 0.8 & 0.26 \\
\hline 08DH29A-27 & 83 & 22572 & 3.9 & 8.5505 & 2.4 & 5.2705 & 2.6 & 0.3268 & 0.8 & 0.32 \\
\hline $08 \mathrm{DH} 29 \mathrm{~A}-28$ & 103 & 43206 & 3.9 & 8.4812 & 2.9 & 5.6313 & 2.9 & 0.3464 & 0.5 & 0.17 \\
\hline 08DH29A-29 & 148 & 31461 & 1.9 & 6.1999 & 2.4 & 8.6772 & 2.7 & 0.3902 & 1.1 & 0.42 \\
\hline 08DH29A-31 & 21 & 1098 & 1.4 & 21.8810 & 25.6 & 0.2551 & 25.6 & 0.0405 & 1.6 & 0.06 \\
\hline 08DH29A-32 & 93 & 3819 & 1.4 & 19.2490 & 4.1 & 0.3127 & 4.2 & 0.0437 & 0.5 & 0.12 \\
\hline 08DH29A-33 & 55 & 19587 & 1.4 & 9.4158 & 2.6 & 4.4621 & 2.8 & 0.3047 & 1.1 & 0.38 \\
\hline 08DH29A-34 & 53 & 20898 & 4.4 & 8.5154 & 1.7 & 5.6585 & 1.9 & 0.3495 & 1.0 & 0.51 \\
\hline 08DH29A-35 & 149 & 56799 & 4.2 & 8.5494 & 1.8 & 5.4627 & 2.0 & 0.3387 & 1.0 & 0.47 \\
\hline $08 \mathrm{DH} 29 \mathrm{~A}-36$ & 117 & 2928 & 1.0 & 19.3036 & 3.3 & 0.2825 & 3.6 & 0.0396 & 1.3 & 0.37 \\
\hline $08 \mathrm{DH} 29 \mathrm{~A}-37$ & 188 & 47229 & 3.0 & 8.3239 & 2.4 & 5.5783 & 4.0 & 0.3368 & 3.3 & 0.81 \\
\hline 08DH29A-38 & 347 & 9864 & 2.5 & 20.5465 & 3.0 & 0.1757 & 3.1 & 0.0262 & 0.7 & 0.21 \\
\hline 08DH29A-39 & 249 & 87864 & 6.9 & 8.7147 & 2.5 & 5.2031 & 2.6 & 0.3289 & 0.6 & 0.23 \\
\hline $08 \mathrm{DH} 29 \mathrm{~A}-40$ & 94 & 6207 & 2.0 & 19.4239 & 4.7 & 0.3580 & 4.8 & 0.0504 & 0.9 & 0.20 \\
\hline $08 \mathrm{DH} 29 \mathrm{~A}-41$ & 247 & 98676 & 3.9 & 8.0012 & 1.5 & 6.2409 & 2.4 & 0.3622 & 1.9 & 0.80 \\
\hline 08DH29A-42 & 234 & 114246 & 2.2 & 5.5799 & 1.2 & 11.6793 & 1.3 & 0.4727 & 0.5 & 0.37 \\
\hline 08DH29A-43 & 252 & 6216 & 0.6 & 19.3364 & 2.3 & 0.3234 & 2.4 & 0.0454 & 0.6 & 0.24 \\
\hline 08DH29A-44 & 66 & 2688 & 3.5 & 20.1664 & 7.3 & 0.2565 & 7.4 & 0.0375 & 0.7 & 0.10 \\
\hline 08DH29A-45 & 63 & 1197 & 0.9 & 21.1291 & 18.5 & 0.1600 & 18.6 & 0.0245 & 1.8 & 0.09 \\
\hline $08 \mathrm{DH} 29 \mathrm{~A}-46$ & 289 & 85506 & 1.9 & 8.4853 & 1.6 & 5.6271 & 1.8 & 0.3463 & 0.7 & 0.42 \\
\hline
\end{tabular}


08DH29a

Apparent ages (Ma)

\begin{tabular}{|c|c|c|c|c|c|c|c|c|c|}
\hline Analysis & $\begin{array}{c}206 \mathrm{~Pb}^{*} / \\
238 \mathrm{U}^{*}\end{array}$ & $\stackrel{ \pm}{ \pm}(\mathrm{Ma})$ & $\begin{array}{c}207 \mathrm{~Pb}^{*} / \\
235 \mathrm{U}\end{array}$ & $\stackrel{ \pm}{ \pm}(\mathrm{Ma})$ & $\begin{array}{l}206 \mathrm{~Pb}^{\star} / \\
207 \mathrm{~Pb}^{*}\end{array}$ & $\begin{array}{c} \pm \\
(\mathrm{Ma})\end{array}$ & $\begin{array}{l}\text { Best age } \\
\quad(\mathrm{Ma})\end{array}$ & $\stackrel{ \pm}{(\mathrm{Ma})}$ & $\begin{array}{c}\text { Conc } \\
(\%)\end{array}$ \\
\hline 08DH29A-1 & 165.2 & 5.5 & 166.0 & 20.9 & 177.4 & 310.3 & 165.2 & 5.5 & 93.1 \\
\hline 08DH29A-2 & 1915.9 & 10.3 & 1937.6 & 15.7 & 1960.9 & 30.5 & 1960.9 & 30.5 & 97.7 \\
\hline 08DH29A-3 & 1908.6 & 11.2 & 1905.4 & 11.3 & 1901.9 & 20.2 & 1901.9 & 20.2 & 100.4 \\
\hline 08DH29A-4 & 1289.1 & 43.8 & 1422.5 & 32.6 & 1628.2 & 37.4 & 1628.2 & 37.4 & 79.2 \\
\hline 08DH29A-5 & 342.6 & 2.0 & 339.2 & 8.4 & 316.2 & 64.7 & 342.6 & 2.0 & 108.4 \\
\hline $08 \mathrm{DH} 29 \mathrm{~A}-6$ & 364.3 & 4.3 & 357.7 & 16.5 & 315.0 & 121.2 & 364.3 & 4.3 & 115.6 \\
\hline 08DH29A-7 & 298.2 & 2.0 & 298.1 & 5.4 & 297.4 & 44.8 & 298.2 & 2.0 & 100.2 \\
\hline 08DH29A-8 & 250.3 & 1.3 & 251.0 & 11.9 & 256.9 & 122.6 & 250.3 & 1.3 & 97.4 \\
\hline 08DH29A-9 & 1890.0 & 9.7 & 1887.8 & 16.9 & 1885.3 & 33.9 & 1885.3 & 33.9 & 100.3 \\
\hline 08DH29A-10 & 1955.3 & 8.4 & 1950.5 & 16.2 & 1945.5 & 32.2 & 1945.5 & 32.2 & 100.5 \\
\hline 08DH29A-11 & 233.5 & 1.1 & 235.6 & 3.5 & 256.2 & 37.0 & 233.5 & 1.1 & 91.2 \\
\hline 08DH29A-12 & 1714.8 & 7.5 & 1705.7 & 28.8 & 1694.5 & 63.6 & 1694.5 & 63.6 & 101.2 \\
\hline 08DH29A-13 & 161.0 & 1.3 & 161.8 & 4.1 & 173.5 & 61.3 & 161.0 & 1.3 & 92.8 \\
\hline 08DH29A-14 & 2738.9 & 11.2 & 2754.5 & 13.9 & 2766.0 & 22.6 & 2766.0 & 22.6 & 99.0 \\
\hline 08DH29A-15 & 250.9 & 1.2 & 250.7 & 5.1 & 248.9 & 51.1 & 250.9 & 1.2 & 100.8 \\
\hline 08DH29A-16 & 1879.3 & 9.0 & 1878.7 & 18.0 & 1878.1 & 36.6 & 1878.1 & 36.6 & 100.1 \\
\hline 08DH29A-17 & 1985.9 & 18.1 & 1992.5 & 27.9 & 1999.3 & 53.5 & 1999.3 & 53.5 & 99.3 \\
\hline 08DH29A-18 & 161.0 & 2.7 & 134.6 & 35.1 & -310.0 & 723.3 & 161.0 & 2.7 & -51.9 \\
\hline 08DH29A-19 & 244.3 & 3.5 & 245.9 & 5.6 & 261.3 & 48.1 & 244.3 & 3.5 & 93.5 \\
\hline 08DH29A-20 & 1909.7 & 9.6 & 1939.7 & 21.2 & 1971.9 & 42.4 & 1971.9 & 42.4 & 96.8 \\
\hline 08DH29A-21 & 1940.9 & 8.4 & 1926.7 & 18.0 & 1911.5 & 36.3 & 1911.5 & 36.3 & 101.5 \\
\hline 08DH29A-22 & 322.3 & 4.6 & 319.0 & 28.4 & 294.5 & 234.7 & 322.3 & 4.6 & 109.5 \\
\hline 08DH29A-23 & 253.2 & 3.7 & 250.2 & 12.4 & 221.4 & 124.5 & 253.2 & 3.7 & 114.4 \\
\hline 08DH29A-24 & 1915.7 & 8.3 & 1909.0 & 19.4 & 1901.8 & 39.6 & 1901.8 & 39.6 & 100.7 \\
\hline 08DH29A-25 & 258.6 & 2.1 & 258.2 & 10.6 & 254.8 & 105.4 & 258.6 & 2.1 & 101.5 \\
\hline 08DH29A-26 & 1827.6 & 13.2 & 1841.3 & 27.0 & 1856.8 & 55.3 & 1856.8 & 55.3 & 98.4 \\
\hline 08DH29A-27 & 1823.1 & 13.0 & 1864.1 & 22.0 & 1910.2 & 43.9 & 1910.2 & 43.9 & 95.4 \\
\hline 08DH29A-28 & 1917.3 & 8.3 & 1920.9 & 25.3 & 1924.7 & 51.8 & 1924.7 & 51.8 & 99.6 \\
\hline 08DH29A-29 & 2123.6 & 20.1 & 2304.7 & 24.2 & 2469.2 & 40.7 & 2469.2 & 40.7 & 86.0 \\
\hline 08DH29A-31 & 255.9 & 4.0 & 230.7 & 53.0 & -18.1 & 627.9 & 255.9 & 4.0 & -1415.9 \\
\hline 08DH29A-32 & 275.5 & 1.3 & 276.3 & 10.1 & 283.3 & 94.7 & 275.5 & 1.3 & 97.2 \\
\hline 08DH29A-33 & 1714.6 & 16.3 & 1723.9 & 23.4 & 1735.2 & 47.9 & 1735.2 & 47.9 & 98.8 \\
\hline 08DH29A-34 & 1932.0 & 16.7 & 1925.1 & 16.8 & 1917.5 & 30.0 & 1917.5 & 30.0 & 100.8 \\
\hline 08DH29A-35 & 1880.5 & 15.7 & 1894.7 & 17.6 & 1910.4 & 32.5 & 1910.4 & 32.5 & 98.4 \\
\hline 08DH29A-36 & 250.1 & 3.2 & 252.6 & 8.0 & 276.8 & 76.6 & 250.1 & 3.2 & 90.3 \\
\hline 08DH29A-37 & 1871.1 & 53.3 & 1912.7 & 34.8 & 1958.2 & 42.1 & 1958.2 & 42.1 & 95.5 \\
\hline 08DH29A-38 & 166.6 & 1.1 & 164.4 & 4.7 & 132.0 & 71.6 & 166.6 & 1.1 & 126.3 \\
\hline 08DH29A-39 & 1832.9 & 9.4 & 1853.1 & 22.2 & 1875.9 & 45.8 & 1875.9 & 45.8 & 97.7 \\
\hline 08DH29A-40 & 317.2 & 2.9 & 310.8 & 12.8 & 262.5 & 107.5 & 317.2 & 2.9 & 120.8 \\
\hline 08DH29A-41 & 1992.4 & 33.3 & 2010.2 & 21.3 & 2028.5 & 26.0 & 2028.5 & 26.0 & 98.2 \\
\hline 08DH29A-42 & 2495.2 & 10.3 & 2579.0 & 12.5 & 2645.6 & 20.6 & 2645.6 & 20.6 & 94.3 \\
\hline 08DH29A-43 & 285.9 & 1.7 & 284.5 & 6.0 & 272.8 & 53.8 & 285.9 & 1.7 & 104.8 \\
\hline 08DH29A-44 & 237.4 & 1.6 & 231.8 & 15.3 & 175.7 & 171.2 & 237.4 & 1.6 & 135.1 \\
\hline 08DH29A-45 & 156.1 & 2.7 & 150.7 & 26.0 & 65.8 & 443.2 & 156.1 & 2.7 & 237.2 \\
\hline 08DH29A-46 & 1916.9 & 12.3 & 1920.3 & 15.1 & 1923.9 & 28.5 & 1923.9 & 28.5 & 99.6 \\
\hline
\end{tabular}


08DH29a

Isotope ratios

\begin{tabular}{|c|c|c|c|c|c|c|c|c|c|c|}
\hline Analysis & $\underset{(\mathrm{ppm})}{\mathrm{U}}$ & $\begin{array}{l}206 \mathrm{~Pb} / \\
204 \mathrm{~Pb}\end{array}$ & $\mathrm{U} / \mathrm{Th}$ & $\begin{array}{l}206 \mathrm{~Pb}^{*} / \\
207 \mathrm{~Pb}^{*}\end{array}$ & $\begin{array}{c} \pm \\
(\%)\end{array}$ & $\begin{array}{c}207 \mathrm{~Pb}^{*} / \\
235 \mathrm{U}^{*}\end{array}$ & $\begin{array}{c} \pm \\
(\%)\end{array}$ & $\begin{array}{c}206 \mathrm{~Pb}^{*} / \\
238 \mathrm{U}\end{array}$ & $\begin{array}{c} \pm \\
(\%)\end{array}$ & $\begin{array}{l}\text { error } \\
\text { corr. }\end{array}$ \\
\hline 08DH29A-47 & 95 & 28842 & 1.7 & 8.5247 & 1.1 & 5.5544 & 1.2 & 0.3434 & 0.5 & 0.41 \\
\hline 08DH29A-48 & 83 & 4620 & 1.5 & 19.0774 & 4.7 & 0.3880 & 4.8 & 0.0537 & 1.1 & 0.23 \\
\hline 08DH29A-49 & 47 & 1365 & 2.0 & 21.6424 & 16.5 & 0.1591 & 16.7 & 0.0250 & 2.6 & 0.15 \\
\hline 08DH29A-50 & 36 & 13908 & 1.6 & 8.4765 & 1.1 & 5.5246 & 1.2 & 0.3396 & 0.5 & 0.41 \\
\hline 08DH29A-51 & 334 & 82362 & 2.9 & 8.3889 & 1.6 & 5.1022 & 2.2 & 0.3104 & 1.5 & 0.67 \\
\hline $08 \mathrm{DH} 29 \mathrm{~A}-53$ & 187 & 59526 & 2.4 & 7.8229 & 1.3 & 6.4989 & 1.4 & 0.3687 & 0.6 & 0.42 \\
\hline 08DH29A-54 & 50 & 1350 & 1.7 & 21.5464 & 20.4 & 0.1592 & 20.5 & 0.0249 & 1.0 & 0.05 \\
\hline 08DH29A-55 & 221 & 6384 & 1.9 & 19.9207 & 3.2 & 0.1826 & 3.3 & 0.0264 & 0.7 & 0.22 \\
\hline 08DH29A-56 & 161 & 47823 & 2.0 & 4.9841 & 2.2 & 13.9854 & 2.5 & 0.5055 & 1.1 & 0.44 \\
\hline 08DH29A-57 & 131 & 4857 & 4.0 & 19.8481 & 5.2 & 0.2595 & 5.5 & 0.0374 & 1.7 & 0.30 \\
\hline $08 \mathrm{DH} 29 \mathrm{~A}-58$ & 57 & 23343 & 3.2 & 8.0839 & 1.7 & 6.2282 & 1.8 & 0.3652 & 0.5 & 0.28 \\
\hline 08DH29A-59 & 47 & 1290 & 1.2 & 18.2070 & 5.5 & 0.2802 & 5.6 & 0.0370 & 1.0 & 0.19 \\
\hline 08DH29A-60 & 68 & 1719 & 3.2 & 20.7938 & 13.1 & 0.1673 & 13.3 & 0.0252 & 2.5 & 0.18 \\
\hline 08DH29A-62 & 88 & 3795 & 2.9 & 19.2904 & 6.8 & 0.3128 & 7.1 & 0.0438 & 2.2 & 0.31 \\
\hline 08DH29A-63 & 602 & 150300 & 3.9 & 8.5091 & 1.0 & 5.4709 & 1.1 & 0.3376 & 0.5 & 0.47 \\
\hline $08 \mathrm{DH} 29 \mathrm{~A}-64$ & 96 & 13122 & 5.3 & 8.2062 & 3.6 & 5.7856 & 3.6 & 0.3443 & 0.5 & 0.14 \\
\hline 08DH29A-65 & 530 & 17241 & 1.2 & 19.2876 & 1.2 & 0.2973 & 1.4 & 0.0416 & 0.7 & 0.52 \\
\hline 08DH29A-66 & 302 & 71028 & 7.0 & 8.3907 & 2.3 & 5.7265 & 2.5 & 0.3485 & 0.9 & 0.35 \\
\hline 08DH29A-67 & 235 & 83259 & 2.7 & 8.5203 & 1.7 & 5.5487 & 1.8 & 0.3429 & 0.7 & 0.40 \\
\hline 08DH29A-68 & 100 & 27939 & 2.6 & 5.9552 & 1.2 & 10.4880 & 1.3 & 0.4530 & 0.5 & 0.37 \\
\hline 08DH29A-69 & 94 & 2844 & 1.3 & 20.9843 & 10.2 & 0.1718 & 10.4 & 0.0261 & 1.6 & 0.16 \\
\hline 08DH29A-70 & 136 & 7740 & 2.1 & 18.7567 & 2.6 & 0.4023 & 2.7 & 0.0547 & 0.5 & 0.19 \\
\hline 08DH29A-71 & 229 & 74523 & 1.6 & 8.1056 & 1.8 & 6.0412 & 1.8 & 0.3551 & 0.5 & 0.27 \\
\hline 08DH29A-72 & 1239 & 253995 & 6.0 & 8.5055 & 1.7 & 5.5036 & 1.7 & 0.3395 & 0.5 & 0.30 \\
\hline 08DH29A-73 & 41 & 15612 & 2.3 & 8.7495 & 2.0 & 5.3766 & 2.1 & 0.3412 & 0.7 & 0.32 \\
\hline 08DH29A-74 & 110 & 7875 & 1.7 & 19.2705 & 4.0 & 0.3730 & 4.1 & 0.0521 & 0.9 & 0.23 \\
\hline 08DH29A-75 & 111 & 43272 & 1.8 & 8.0987 & 2.0 & 6.2685 & 2.1 & 0.3682 & 0.5 & 0.24 \\
\hline 08DH29A-76 & 225 & 7833 & 2.1 & 20.1803 & 3.1 & 0.2206 & 3.2 & 0.0323 & 0.5 & 0.16 \\
\hline 08DH29A-77 & 516 & 161814 & 3.5 & 7.8470 & 1.7 & 6.6092 & 2.0 & 0.3761 & 1.1 & 0.53 \\
\hline 08DH29A-78 & 662 & 159552 & 6.7 & 8.3760 & 0.7 & 5.7945 & 0.9 & 0.3520 & 0.6 & 0.64 \\
\hline 08DH29A-79 & 248 & 14583 & 2.9 & 10.6632 & 3.9 & 1.0781 & 10.2 & 0.0834 & 9.4 & 0.92 \\
\hline 08DH29A-80 & 344 & 86253 & 2.3 & 8.2108 & 1.9 & 6.0452 & 2.0 & 0.3600 & 0.6 & 0.31 \\
\hline 08DH29A-81 & 429 & 154320 & 5.5 & 5.9764 & 1.3 & 11.0623 & 1.4 & 0.4795 & 0.5 & 0.36 \\
\hline 08DH29A-82 & 45 & 5427 & 1.6 & 8.2147 & 1.5 & 5.8704 & 1.7 & 0.3498 & 0.8 & 0.46 \\
\hline 08DH29A-83 & 99 & 26049 & 1.3 & 8.4703 & 1.7 & 5.6132 & 1.9 & 0.3448 & 0.7 & 0.39 \\
\hline 08DH29A-84 & 70 & 1887 & 1.8 & 22.6677 & 20.7 & 0.1577 & 20.8 & 0.0259 & 1.8 & 0.09 \\
\hline 08DH29A-85 & 132 & 1566 & 1.3 & 17.3630 & 22.5 & 0.3757 & 22.6 & 0.0473 & 2.8 & 0.12 \\
\hline 08DH29A-86 & 318 & 11529 & 3.1 & 19.7832 & 1.6 & 0.2511 & 1.6 & 0.0360 & 0.5 & 0.30 \\
\hline 08DH29A-87 & 279 & 10509 & 1.2 & 19.4582 & 2.8 & 0.3026 & 2.8 & 0.0427 & 0.5 & 0.18 \\
\hline 08DH29A-88 & 94 & 12849 & 3.7 & 8.4038 & 2.6 & 5.8733 & 2.7 & 0.3580 & 0.7 & 0.26 \\
\hline 08DH29A-89 & 32 & 1008 & 2.6 & 22.5290 & 25.7 & 0.1570 & 25.8 & 0.0256 & 1.0 & 0.04 \\
\hline 08DH29A-90 & 47 & 1527 & 3.1 & 20.5612 & 11.8 & 0.1720 & 12.0 & 0.0256 & 2.5 & 0.21 \\
\hline 08DH29A-91 & 96 & 32475 & 2.9 & 8.6538 & 1.5 & 5.4061 & 1.6 & 0.3393 & 0.5 & 0.34 \\
\hline 08DH29A-92 & 214 & 76653 & 5.0 & 8.3080 & 1.1 & 5.8572 & 1.3 & 0.3529 & 0.6 & 0.44 \\
\hline 08DH29A-93 & 226 & 72117 & 1.4 & 8.1015 & 1.5 & 6.2974 & 1.6 & 0.3700 & 0.5 & 0.31 \\
\hline
\end{tabular}


08DH29a

Apparent ages (Ma)

\begin{tabular}{|c|c|c|c|c|c|c|c|c|c|}
\hline Analysis & $\begin{array}{c}206 \mathrm{~Pb}^{*} / \\
238 U^{*}\end{array}$ & $\begin{array}{c} \pm \\
(\mathrm{Ma})\end{array}$ & $\begin{array}{c}207 \mathrm{~Pb}^{*} / \\
235 \mathrm{U}\end{array}$ & $\stackrel{ \pm}{ \pm}$ & $\begin{array}{l}206 \mathrm{~Pb}^{*} / \\
207 \mathrm{~Pb}^{*}\end{array}$ & $\stackrel{ \pm}{ \pm}$ & $\begin{array}{c}\text { Best age } \\
\text { (Ma) }\end{array}$ & $\begin{array}{c} \pm \\
(\mathrm{Ma})\end{array}$ & $\begin{array}{c}\text { Conc } \\
(\%)\end{array}$ \\
\hline 08DH29A-47 & 1903.1 & 8.2 & 1909.1 & 10.6 & 1915.6 & 20.1 & 1915.6 & 20.1 & 99.3 \\
\hline 08DH29A-48 & 337.1 & 3.6 & 332.9 & 13.6 & 303.7 & 106.5 & 337.1 & 3.6 & 111.0 \\
\hline 08DH29A-49 & 159.0 & 4.0 & 149.9 & 23.3 & 8.3 & 398.9 & 159.0 & 4.0 & 1907.1 \\
\hline 08DH29A-50 & 1884.9 & 8.2 & 1904.4 & 10.6 & 1925.7 & 20.2 & 1925.7 & 20.2 & 97.9 \\
\hline 08DH29A-51 & 1742.8 & 22.4 & 1836.5 & 18.7 & 1944.3 & 29.3 & 1944.3 & 29.3 & 89.6 \\
\hline 08DH29A-53 & 2023.4 & 10.4 & 2045.8 & 12.4 & 2068.3 & 22.6 & 2068.3 & 22.6 & 97.8 \\
\hline 08DH29A-54 & 158.5 & 1.5 & 150.0 & 28.5 & 19.1 & 495.1 & 158.5 & 1.5 & 830.7 \\
\hline 08DH29A-55 & 167.8 & 1.2 & 170.3 & 5.1 & 204.2 & 73.8 & 167.8 & 1.2 & 82.2 \\
\hline 08DH29A-56 & 2637.6 & 23.8 & 2748.7 & 23.7 & 2831.4 & 36.5 & 2831.4 & 36.5 & 93.2 \\
\hline 08DH29A-57 & 236.5 & 3.9 & 234.3 & 11.5 & 212.7 & 121.1 & 236.5 & 3.9 & 111.2 \\
\hline 08DH29A-58 & 2006.6 & 8.6 & 2008.4 & 15.5 & 2010.3 & 30.2 & 2010.3 & 30.2 & 99.8 \\
\hline 08DH29A-59 & 234.2 & 2.4 & 250.8 & 12.4 & 409.1 & 122.3 & 234.2 & 2.4 & 57.3 \\
\hline $08 \mathrm{DH} 29 \mathrm{~A}-60$ & 160.7 & 3.9 & 157.1 & 19.4 & 103.8 & 310.5 & 160.7 & 3.9 & 154.8 \\
\hline 08DH29A-62 & 276.1 & 6.1 & 276.3 & 17.2 & 278.4 & 155.1 & 276.1 & 6.1 & 99.2 \\
\hline 08DH29A-63 & 1875.2 & 8.5 & 1896.0 & 9.4 & 1918.9 & 17.4 & 1918.9 & 17.4 & 97.7 \\
\hline 08DH29A-64 & 1907.5 & 8.3 & 1944.3 & 31.4 & 1983.6 & 63.9 & 1983.6 & 63.9 & 96.2 \\
\hline 08DH29A-65 & 262.7 & 1.9 & 264.3 & 3.2 & 278.7 & 27.1 & 262.7 & 1.9 & 94.2 \\
\hline 08DH29A-66 & 1927.4 & 14.2 & 1935.4 & 21.2 & 1943.9 & 41.1 & 1943.9 & 41.1 & 99.1 \\
\hline 08DH29A-67 & 1900.5 & 11.9 & 1908.2 & 15.5 & 1916.5 & 29.6 & 1916.5 & 29.6 & 99.2 \\
\hline 08DH29A-68 & 2408.5 & 10.0 & 2478.9 & 12.4 & 2537.0 & 20.8 & 2537.0 & 20.8 & 94.9 \\
\hline 08DH29A-69 & 166.4 & 2.7 & 161.0 & 15.4 & 82.1 & 243.2 & 166.4 & 2.7 & 202.6 \\
\hline 08DH29A-70 & 343.4 & 1.7 & 343.3 & 7.7 & 342.2 & 59.1 & 343.4 & 1.7 & 100.4 \\
\hline 08DH29A-71 & 1959.1 & 8.4 & 1981.8 & 15.9 & 2005.5 & 31.2 & 2005.5 & 31.2 & 97.7 \\
\hline 08DH29A-72 & 1884.3 & 8.5 & 1901.2 & 15.0 & 1919.6 & 29.9 & 1919.6 & 29.9 & 98.2 \\
\hline 08DH29A-73 & 1892.4 & 11.2 & 1881.1 & 17.9 & 1868.7 & 35.7 & 1868.7 & 35.7 & 101.3 \\
\hline 08DH29A-74 & 327.6 & 3.0 & 321.9 & 11.3 & 280.7 & 91.4 & 327.6 & 3.0 & 116.7 \\
\hline 08DH29A-75 & 2020.9 & 8.7 & 2014.1 & 18.1 & 2007.0 & 35.7 & 2007.0 & 35.7 & 100.7 \\
\hline 08DH29A-76 & 204.8 & 1.0 & 202.4 & 5.8 & 174.1 & 72.8 & 204.8 & 1.0 & 117.7 \\
\hline 08DH29A-77 & 2058.2 & 18.5 & 2060.6 & 17.6 & 2062.9 & 30.0 & 2062.9 & 30.0 & 99.8 \\
\hline 08DH29A-78 & 1944.2 & 10.1 & 1945.6 & 8.1 & 1947.1 & 12.9 & 1947.1 & 12.9 & 99.9 \\
\hline 08DH29A-79 & 516.2 & 46.5 & 742.7 & 53.6 & 1503.7 & 74.3 & 1503.7 & 74.3 & 34.3 \\
\hline 08DH29A-80 & 1982.2 & 10.4 & 1982.4 & 17.1 & 1982.6 & 33.1 & 1982.6 & 33.1 & 100.0 \\
\hline 08DH29A-81 & 2525.1 & 10.4 & 2528.4 & 13.1 & 2531.0 & 22.0 & 2531.0 & 22.0 & 99.8 \\
\hline 08DH29A-82 & 1933.4 & 13.4 & 1956.9 & 15.0 & 1981.8 & 27.2 & 1981.8 & 27.2 & 97.6 \\
\hline 08DH29A-83 & 1909.9 & 12.1 & 1918.1 & 16.1 & 1927.0 & 30.8 & 1927.0 & 30.8 & 99.1 \\
\hline 08DH29A-84 & 165.0 & 2.9 & 148.7 & 28.7 & -104.2 & 513.1 & 165.0 & 2.9 & -158.3 \\
\hline 08DH29A-85 & 298.0 & 8.0 & 323.9 & 62.8 & 514.3 & 499.1 & 298.0 & 8.0 & 57.9 \\
\hline 08DH29A-86 & 228.1 & 1.1 & 227.4 & 3.3 & 220.3 & 36.1 & 228.1 & 1.1 & 103.6 \\
\hline 08DH29A-87 & 269.5 & 1.3 & 268.4 & 6.6 & 258.4 & 63.3 & 269.5 & 1.3 & 104.3 \\
\hline 08DH29A-88 & 1972.6 & 11.9 & 1957.3 & 23.7 & 1941.1 & 47.3 & 1941.1 & 47.3 & 101.6 \\
\hline 08DH29A-89 & 163.2 & 1.5 & 148.0 & 35.5 & -89.1 & 640.4 & 163.2 & 1.5 & -183.1 \\
\hline 08DH29A-90 & 163.2 & 4.0 & 161.1 & 17.9 & 130.3 & 278.0 & 163.2 & 4.0 & 125.3 \\
\hline 08DH29A-91 & 1883.3 & 8.8 & 1885.8 & 13.5 & 1888.6 & 26.6 & 1888.6 & 26.6 & 99.7 \\
\hline 08DH29A-92 & 1948.6 & 9.4 & 1954.9 & 11.0 & 1961.6 & 20.3 & 1961.6 & 20.3 & 99.3 \\
\hline 08DH29A-93 & 2029.5 & 8.7 & 2018.1 & 14.2 & 2006.4 & 27.3 & 2006.4 & 27.3 & 101.1 \\
\hline
\end{tabular}


08DH29a

Isotope ratios

\begin{tabular}{|c|c|c|c|c|c|c|c|c|c|c|}
\hline Analysis & $\begin{array}{c}\text { U } \\
(p p m)\end{array}$ & $\begin{array}{l}206 \mathrm{~Pb} / \\
204 \mathrm{~Pb}\end{array}$ & $\mathrm{U} / \mathrm{Th}$ & $\begin{array}{l}206 \mathrm{~Pb}^{*} / \\
207 \mathrm{~Pb}^{*}\end{array}$ & $\begin{array}{c} \pm \\
(\%)\end{array}$ & $\begin{array}{c}207 \mathrm{~Pb}^{\star} / \\
235 \mathrm{U}^{*}\end{array}$ & $\begin{array}{c} \pm \\
(\%)\end{array}$ & $\begin{array}{c}206 \mathrm{~Pb}^{\star} / \\
238 \mathrm{U}\end{array}$ & $\begin{array}{l} \pm \\
(\%)\end{array}$ & $\begin{array}{l}\text { error } \\
\text { corr. }\end{array}$ \\
\hline 08DH29A-94 & 214 & 66417 & 2.3 & 7.9292 & 1.6 & 6.3659 & 1.9 & 0.3661 & 0.9 & \\
\hline 08DH29A-95 & 168 & 6810 & 1.6 & 18.9535 & 2.5 & 0.3394 & 2.5 & 0.0467 & 0.5 & .26 \\
\hline 08DH29A-96 & 53 & 1467 & 2.2 & 23.2521 & 25.2 & 0.1594 & 25.3 & 0.0269 & 2.3 & \\
\hline 08DH29A-97 & 34 & 11142 & 1.5 & 8.8052 & 1.5 & 4.1877 & 2.9 & 0.2674 & 2.6 & \\
\hline 08DH29A-98 & 107 & 10161 & 2.1 & 17.4065 & 1.8 & 0.6532 & 1.9 & 0.0825 & 0.5 & \\
\hline 08DH29A-99 & 36 & 1167 & 1.8 & 21.7170 & 33.2 & 0.2245 & 33.3 & 0.0354 & 2.6 & \\
\hline 08DH29A-100 & 52 & 1707 & 1.0 & 20.0823 & 13.0 & 0.2732 & 13.0 & 0.0398 & 0.5 & \\
\hline 08DH29A-101 & 221 & 79002 & 3.3 & 8.3118 & 1.2 & 5.8758 & 1.4 & 0.3542 & 0.7 & \\
\hline 08DH29A-102 & 81 & 40902 & 2.9 & 5.2098 & 1.8 & 13.1242 & 1.9 & 0.4959 & 0.8 & \\
\hline 08DH29A-103 & 52 & 2484 & 0.7 & 20.2567 & 12.2 & 0.3051 & 12.2 & 0.0448 & 1.0 & \\
\hline 08DH29A-104 & 79 & 4677 & 1.6 & 19.1573 & 4.6 & 0.3752 & 4.6 & 0.0521 & 0.9 & \\
\hline 08DH29A-105 & 38 & 13047 & 0.8 & 8.5209 & 1.7 & 5.5361 & 1.8 & 0.3421 & 0.5 & 0.2 \\
\hline 08DH29A-106 & 273 & 74766 & 3.5 & 8.0865 & 1.3 & 5.3042 & 3.1 & 0.3111 & 2.8 & \\
\hline 08DH29A-107 & 83 & 2586 & 2.1 & 20.4782 & 7.3 & 0.1798 & 7.4 & 0.0267 & 1.4 & \\
\hline 08DH29A-108 & 188 & 35832 & 1.6 & 6.3628 & 1.1 & 7.2257 & 7.4 & 0.3335 & 7.4 & \\
\hline 08DH29A-109 & 120 & 7347 & 1.6 & 18.7801 & 3.5 & 0.4176 & 3.5 & 0.0569 & 0.5 & \\
\hline 08DH29A-110 & 51 & 14955 & 1.7 & 8.6087 & 0.9 & 5.1735 & 1.1 & 0.3230 & 0.6 & \\
\hline 08DH29A-111 & 46 & 30585 & 3.2 & 4.6333 & 1.3 & 16.9433 & 1.4 & 0.5694 & 0.5 & \\
\hline 08DH29A-112 & 39 & 1590 & 4.8 & 19.5399 & 10.6 & 0.2722 & 10.7 & 0.0386 & 1.9 & \\
\hline 08DH29A-113 & 324 & 68802 & 1.3 & 5.3985 & 1.3 & 12.3440 & 1.4 & 0.4833 & 0.7 & \\
\hline 08DH29A-115 & 344 & 29004 & 3.7 & 17.6309 & 1.0 & 0.6145 & 1.2 & 0.0786 & 0.6 & \\
\hline 08DH29A-116 & 152 & 47355 & 5.2 & 8.2440 & 2.0 & 5.9162 & 2.1 & 0.3537 & 0.5 & 0.2 \\
\hline 08DH29A-117 & 146 & 72807 & 1.7 & 4.7534 & 0.9 & 15.8347 & 1.1 & 0.5459 & 0.5 & 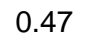 \\
\hline 08DH29A-118 & 273 & 7980 & 17.1 & 20.3910 & 3.1 & 0.1855 & 3.2 & 0.0274 & 0.6 & \\
\hline 08DH29A-119 & 172 & 57222 & 2.2 & 8.3560 & 1.0 & 5.6719 & 1.1 & 0.3437 & 0.5 & 0.4 \\
\hline
\end{tabular}


08DH29a

Apparent ages (Ma)

$\begin{array}{cccccccccc}\text { Analysis } & 206 \mathrm{~Pb}^{*} / & \pm & 207 \mathrm{~Pb}^{*} / & \pm & 206 \mathrm{~Pb}^{*} / & \pm & \begin{array}{c}\text { Best age } \\ (\mathrm{Ma})\end{array} & \begin{array}{c} \pm \\ (\mathrm{Ma})\end{array} & \begin{array}{c}\text { Conc } \\ (\%)\end{array} \\ & 238 \mathrm{U}^{*} & (\mathrm{Ma}) & 235 \mathrm{U}) & (\mathrm{Ma}) & 207 \mathrm{~Pb}^{*} & (\mathrm{Ma}) & & & \\ \text { 08DH29A-94 } & 2011.0 & 16.2 & 2027.6 & 16.6 & 2044.5 & 29.0 & 2044.5 & 29.0 & 98.4 \\ \text { 08DH29A-95 } & 294.0 & 1.4 & 296.8 & 6.5 & 318.5 & 56.1 & 294.0 & 1.4 & 92.3 \\ \text { 08DH29A-96 } & 171.0 & 3.8 & 150.2 & 35.3 & -167.2 & 635.4 & 171.0 & 3.8 & -102.3 \\ \text { 08DH29A-97 } & 1527.7 & 34.8 & 1671.6 & 24.2 & 1857.3 & 26.4 & 1857.3 & 26.4 & 82.3 \\ \text { 08DH29A-98 } & 510.8 & 2.5 & 510.5 & 7.5 & 508.8 & 39.9 & 510.8 & 2.5 & 100.4 \\ \text { 08DH29A-99 } & 224.0 & 5.8 & 205.7 & 62.2 & 0.1 & 821.1 & 224.0 & 5.8 & 244783.6 \\ \text { 08DH29A-100 } & 251.6 & 1.2 & 245.3 & 28.4 & 185.4 & 304.5 & 251.6 & 1.2 & 135.7 \\ \text { 08DH29A-101 } & 1954.7 & 11.6 & 1957.7 & 12.2 & 1960.8 & 21.8 & 1960.8 & 21.8 & 99.7 \\ \text { 08DH29A-102 } & 2596.1 & 16.9 & 2688.6 & 18.3 & 2758.9 & 29.1 & 2758.9 & 29.1 & 94.1 \\ \text { 08DH29A-103 } & 282.7 & 2.7 & 270.4 & 29.0 & 165.2 & 285.2 & 282.7 & 2.7 & 171.1 \\ \text { 08DH29A-104 } & 327.6 & 2.9 & 323.5 & 12.9 & 294.2 & 104.2 & 327.6 & 2.9 & 111.4 \\ \text { 08DH29A-105 } & 1896.9 & 8.2 & 1906.2 & 15.6 & 1916.4 & 31.2 & 1916.4 & 31.2 & 99.0 \\ \text { 08DH29A-106 } & 1746.1 & 42.1 & 1869.5 & 26.1 & 2009.7 & 23.8 & 2009.7 & 23.8 & 86.9 \\ \text { 08DH29A-107 } & 169.9 & 2.4 & 167.9 & 11.5 & 139.8 & 170.8 & 169.9 & 2.4 & 121.5 \\ \text { 08DH29A-108 } & 1855.1 & 118.7 & 2139.7 & 66.4 & 2425.3 & 17.8 & 2425.3 & 17.8 & 76.5 \\ \text { 08DH29A-109 } & 356.6 & 1.7 & 354.3 & 10.6 & 339.4 & 79.4 & 356.6 & 1.7 & 105.1 \\ \text { 08DH29A-110 } & 1804.4 & 9.4 & 1848.3 & 9.5 & 1897.9 & 17.0 & 1897.9 & 17.0 & 95.1 \\ \text { 08DH29A-111 } & 2905.2 & 11.7 & 2931.6 & 13.7 & 2949.8 & 21.6 & 2949.8 & 21.6 & 98.5 \\ \text { 08DH29A-112 } & 244.0 & 4.5 & 244.5 & 23.3 & 248.8 & 243.7 & 244.0 & 4.5 & 98.1 \\ \text { 08DH29A-113 } & 2541.7 & 15.3 & 2630.9 & 13.6 & 2700.3 & 20.6 & 2700.3 & 20.6 & 94.1 \\ \text { 08DH29A-115 } & 487.6 & 2.9 & 486.4 & 4.5 & 480.6 & 21.7 & 487.6 & 2.9 & 101.5 \\ \text { 08DH29A-116 } & 1952.4 & 8.4 & 1963.6 & 18.2 & 1975.4 & 36.3 & 1975.4 & 36.3 & 98.8 \\ \text { 08DH29A-117 } & 2808.1 & 11.4 & 2866.9 & 10.1 & 2908.4 & 15.1 & 2908.4 & 15.1 & 96.5 \\ \text { 08DH29A-118 } & 174.5 & 1.1 & 172.8 & 5.0 & 149.8 & 72.6 & 174.5 & 1.1 & 116.5 \\ \text { 08DH29A-119 } & 1904.6 & 8.2 & 1927.1 & 9.7 & 1951.4 & 17.9 & 1951.4 & 17.9 & 97.6\end{array}$


08DH30a

Isotope ratios

\begin{tabular}{|c|c|c|c|c|c|c|c|c|c|c|}
\hline Analysis & $\begin{array}{c}U \\
(\mathrm{ppm})\end{array}$ & $\begin{array}{c}206 \mathrm{~Pb} / \\
204 \mathrm{~Pb}\end{array}$ & $\mathrm{U} / \mathrm{Th}$ & $\begin{array}{l}206 \mathrm{~Pb}^{\star} / \\
207 \mathrm{~Pb}^{*}\end{array}$ & $\begin{array}{c} \pm \\
(\%)\end{array}$ & $\begin{array}{c}207 \mathrm{~Pb}^{*} / \\
235 \mathrm{U}^{*}\end{array}$ & $\begin{array}{c} \pm \\
(\%)\end{array}$ & $\begin{array}{c}206 \mathrm{~Pb}^{*} / \\
238 \mathrm{U}\end{array}$ & $\begin{array}{c} \pm \\
(\%)\end{array}$ & $\begin{array}{l}\text { error } \\
\text { corr. }\end{array}$ \\
\hline 08DH30A-1 & 109 & 3612 & 1.0 & 19.8821 & 6.1 & 0.2569 & 6.3 & 0.0370 & 1.6 & 0.26 \\
\hline 08DH30A-2 & 61 & 894 & 0.7 & 18.5733 & 9.7 & 0.2882 & 9.8 & 0.0388 & 1.6 & 0.16 \\
\hline 08DH30A-3 & 413 & 15360 & 1.4 & 19.5044 & 0.8 & 0.2841 & 3.4 & 0.0402 & 3.3 & 0.97 \\
\hline 08DH30A-4 & 75 & 27270 & 2.4 & 8.8736 & 1.5 & 4.6354 & 1.9 & 0.2983 & 1.2 & 0.63 \\
\hline 08DH30A-5 & 148 & 3645 & 1.0 & 19.2848 & 4.2 & 0.3337 & 4.3 & 0.0467 & 0.8 & 0.18 \\
\hline $08 \mathrm{DH} 30 \mathrm{~A}-6$ & 49 & 15342 & 1.1 & 8.6017 & 1.1 & 5.4792 & 2.1 & 0.3418 & 1.8 & .86 \\
\hline 08DH30A-7 & 247 & 8811 & 0.9 & 19.5689 & 3.7 & 0.2988 & 4.1 & 0.0424 & 1.7 & 0.42 \\
\hline 08DH30A-8 & 102 & 10128 & 2.8 & 8.5734 & 0.9 & 5.2483 & 2.7 & 0.3263 & 2.6 & 0.95 \\
\hline 08DH30A-9 & 197 & 6252 & 1.1 & 18.8646 & 2.0 & 0.3399 & 3.0 & 0.0465 & 2.2 & 0.74 \\
\hline $08 \mathrm{DH} 30 \mathrm{~A}-10$ & 327 & 9762 & 5.4 & 18.0525 & 2.5 & 0.4153 & 3.4 & 0.0544 & 2.3 & 0.67 \\
\hline 08DH30A-11 & 116 & 43116 & 1.1 & 5.3621 & 1.3 & 13.0750 & 1.7 & 0.5085 & 1.0 & 0.61 \\
\hline $08 \mathrm{DH} 30 \mathrm{~A}-12$ & 200 & 83694 & 10.1 & 5.1560 & 2.1 & 12.3458 & 3.2 & 0.4617 & 2.4 & 0.75 \\
\hline $08 \mathrm{DH} 30 \mathrm{~A}-13$ & 83 & 26484 & 2.2 & 8.6773 & 1.1 & 5.2871 & 1.7 & 0.3327 & 1.3 & 0.78 \\
\hline 08DH30A-14 & 156 & 83937 & 2.9 & 5.3243 & 1.9 & 13.1298 & 2.6 & 0.5070 & 1.7 & 0.66 \\
\hline 08DH30A-15 & 89 & 2661 & 1.1 & 19.2874 & 4.2 & 0.2965 & 4.4 & 0.0415 & 1.0 & 0.23 \\
\hline $08 \mathrm{DH} 30 \mathrm{~A}-16$ & 84 & 1926 & 1.2 & 20.2901 & 9.4 & 0.1720 & 10.3 & 0.0253 & 4.3 & 0.42 \\
\hline $08 \mathrm{DH} 30 \mathrm{~A}-17$ & 48 & 10863 & 2.2 & 8.5325 & 2.0 & 5.5279 & 2.6 & 0.3421 & 1.6 & 0.63 \\
\hline 08DH30A-18 & 328 & 12168 & 0.8 & 19.3580 & 1.5 & 0.2937 & 3.1 & 0.0412 & 2.7 & 0.87 \\
\hline 08DH30A-19 & 146 & 5784 & 0.9 & 19.1329 & 5.8 & 0.2934 & 6.6 & 0.0407 & 3.0 & 0.46 \\
\hline 08DH30A-20 & 201 & 5322 & 1.3 & 18.7184 & 2.9 & 0.3550 & 2.9 & 0.0482 & 0.5 & 0.17 \\
\hline 08DH30A-21 & 259 & 68766 & 4.5 & 8.9054 & 1.8 & 4.5551 & 2.0 & 0.2942 & 1.0 & 0.48 \\
\hline 08DH30A-22 & 234 & 9096 & 1.0 & 19.4327 & 2.1 & 0.2965 & 3.2 & 0.0418 & 2.5 & 0.76 \\
\hline $08 \mathrm{DH} 30 \mathrm{~A}-23$ & 182 & 7635 & 0.7 & 18.8583 & 2.0 & 0.3479 & 2.0 & 0.0476 & 0.5 & 0.27 \\
\hline 08DH30A-24 & 144 & 7140 & 2.1 & 19.3708 & 3.5 & 0.3285 & 3.7 & 0.0461 & 1.2 & 0.33 \\
\hline 08DH30A-25 & 170 & 3726 & 1.0 & 16.9503 & 17.3 & 0.4376 & 17.3 & 0.0538 & 1.2 & 0.07 \\
\hline $08 \mathrm{DH} 30 \mathrm{~A}-26$ & 50 & 2037 & 3.4 & 20.7041 & 14.1 & 0.2658 & 14.2 & 0.0399 & 1.8 & 0.12 \\
\hline $08 \mathrm{DH} 30 \mathrm{~A}-27$ & 126 & 43683 & 4.0 & 8.4929 & 1.3 & 5.7204 & 2.2 & 0.3524 & 1.8 & 0.80 \\
\hline 08DH30A-28 & 149 & 4785 & 0.8 & 19.4793 & 3.6 & 0.2882 & 3.9 & 0.0407 & 1.3 & 0.34 \\
\hline 08DH30A-29 & 189 & 40677 & 2.2 & 8.6499 & 1.3 & 5.2505 & 1.5 & 0.3294 & 0.8 & 0.51 \\
\hline 08DH30A-30 & 30 & 1269 & 1.1 & 23.4751 & 29.3 & 0.2175 & 29.4 & 0.0370 & 2.3 & 0.08 \\
\hline 08DH30A-31 & 52 & 2295 & 0.6 & 21.5141 & 20.1 & 0.2515 & 20.2 & 0.0392 & 1.6 & 0.08 \\
\hline 08DH30A-32 & 265 & 73908 & 2.9 & 6.8915 & 1.7 & 8.0954 & 1.8 & 0.4046 & 0.5 & 0.28 \\
\hline 08DH30A-33 & 162 & 49101 & 2.4 & 5.9465 & 2.3 & 10.6175 & 2.9 & 0.4579 & 1.8 & 0.62 \\
\hline 08DH30A-34 & 46 & 6264 & 0.6 & 8.3017 & 3.1 & 5.5011 & 3.4 & 0.3312 & 1.4 & 0.40 \\
\hline 08DH30A-35 & 97 & 35073 & 1.7 & 8.2626 & 2.3 & 5.7438 & 2.7 & 0.3442 & 1.3 & 0.49 \\
\hline 08DH30A-36 & 109 & 33471 & 1.5 & 8.8465 & 1.7 & 5.0859 & 3.6 & 0.3263 & 3.2 & 0.88 \\
\hline 08DH30A-37 & 143 & 65043 & 0.8 & 8.2969 & 1.8 & 5.7476 & 2.1 & 0.3459 & 1.0 & 0.48 \\
\hline 08DH30A-38 & 101 & 3363 & 1.9 & 20.2827 & 5.0 & 0.1697 & 5.3 & 0.0250 & 1.7 & 0.32 \\
\hline 08DH30A-39 & 65 & 25254 & 2.1 & 8.3602 & 2.3 & 5.5316 & 2.6 & 0.3354 & 1.2 & 0.48 \\
\hline $08 \mathrm{DH} 30 \mathrm{~A}-40$ & 62 & 18324 & 1.7 & 9.4840 & 2.6 & 4.3948 & 4.4 & 0.3023 & 3.6 & 0.81 \\
\hline 08DH30A-41 & 171 & 32652 & 1.8 & 8.9097 & 2.1 & 4.4330 & 3.4 & 0.2865 & 2.7 & 0.79 \\
\hline 08DH30A-42 & 770 & 2700 & 0.6 & 15.7067 & 7.2 & 0.3836 & 8.1 & 0.0437 & 3.6 & 0.45 \\
\hline $08 \mathrm{DH} 30 \mathrm{~A}-43$ & 137 & 5061 & 14.1 & 20.3423 & 4.8 & 0.1791 & 5.5 & 0.0264 & 2.7 & 0.49 \\
\hline $08 \mathrm{DH} 30 \mathrm{~A}-44$ & 110 & 1815 & 0.6 & 19.9118 & 6.4 & 0.1744 & 6.8 & 0.0252 & 2.3 & 0.34 \\
\hline $08 \mathrm{DH} 30 \mathrm{~A}-45$ & 58 & 3435 & 1.2 & 20.4900 & 10.4 & 0.2868 & 10.6 & 0.0426 & 2.0 & 0.19 \\
\hline
\end{tabular}


08DH30a

Apparent ages (Ma)

\begin{tabular}{|c|c|c|c|c|c|c|c|c|c|}
\hline Analysis & $\begin{array}{c}206 \mathrm{~Pb}^{*} / \\
238 \mathrm{U}^{*}\end{array}$ & $\stackrel{ \pm}{(\mathrm{Ma})}$ & $\begin{array}{c}207 \mathrm{~Pb}^{*} / \\
235 \mathrm{U}\end{array}$ & $\stackrel{ \pm}{(\mathrm{Ma})}$ & $\begin{array}{l}206 \mathrm{~Pb}^{*} / \\
207 \mathrm{~Pb}^{*}\end{array}$ & $\begin{array}{c} \pm \\
(\mathrm{Ma})\end{array}$ & $\begin{array}{c}\text { Best age } \\
\quad(\mathrm{Ma})\end{array}$ & $\begin{array}{c} \pm \\
(\mathrm{Ma})\end{array}$ & $\begin{array}{c}\text { Conc } \\
(\%)\end{array}$ \\
\hline 08DH30A-1 & 234.5 & 3.8 & 232.2 & 13.1 & 208.7 & 141.3 & 234.5 & 3.8 & 112.3 \\
\hline 08DH30A-2 & 245.5 & 3.9 & 257.1 & 22.3 & 364.4 & 219.2 & 245.5 & 3.9 & 67.4 \\
\hline 08DH30A-3 & 254.0 & 8.1 & 253.9 & 7.5 & 253.0 & 18.7 & 254.0 & 8.1 & 100.4 \\
\hline 08DH30A-4 & 1683.0 & 17.3 & 1755.7 & 15.6 & 1843.3 & 26.3 & 1843.3 & 26.3 & 91.3 \\
\hline 08DH30A-5 & 294.1 & 2.3 & 292.4 & 10.9 & 279.0 & 96.4 & 294.1 & 2.3 & 105.4 \\
\hline 08DH30A-6 & 1895.4 & 30.1 & 1897.3 & 18.3 & 1899.4 & 19.7 & 1899.4 & 19.7 & 99.8 \\
\hline 08DH30A-7 & 267.8 & 4.5 & 265.5 & 9.6 & 245.4 & 85.6 & 267.8 & 4.5 & 109.1 \\
\hline 08DH30A-8 & 1820.6 & 40.6 & 1860.5 & 23.0 & 1905.3 & 15.4 & 1905.3 & 15.4 & 95.6 \\
\hline 08DH30A-9 & 293.0 & 6.3 & 297.1 & 7.7 & 329.2 & 45.7 & 293.0 & 6.3 & 89.0 \\
\hline 08DH30A-10 & 341.4 & 7.6 & 352.7 & 10.1 & 428.1 & 56.0 & 341.4 & 7.6 & 79.7 \\
\hline $08 \mathrm{DH} 30 \mathrm{~A}-11$ & 2650.1 & 22.4 & 2685.1 & 15.9 & 2711.5 & 22.1 & 2711.5 & 22.1 & 97.7 \\
\hline 08DH30A-12 & 2446.9 & 48.7 & 2631.1 & 29.8 & 2775.9 & 34.3 & 2775.9 & 34.3 & 88.1 \\
\hline 08DH30A-13 & 1851.6 & 21.6 & 1866.8 & 14.7 & 1883.7 & 19.5 & 1883.7 & 19.5 & 98.3 \\
\hline $08 \mathrm{DH} 30 \mathrm{~A}-14$ & 2643.9 & 36.4 & 2689.0 & 24.1 & 2723.1 & 31.8 & 2723.1 & 31.8 & 97.1 \\
\hline 08DH30A-15 & 262.0 & 2.6 & 263.7 & 10.1 & 278.7 & 97.3 & 262.0 & 2.6 & 94.0 \\
\hline 08DH30A-16 & 161.1 & 6.8 & 161.1 & 15.4 & 161.4 & 220.2 & 161.1 & 6.8 & 99.8 \\
\hline $08 \mathrm{DH} 30 \mathrm{~A}-17$ & 1896.7 & 26.8 & 1904.9 & 22.3 & 1913.9 & 36.2 & 1913.9 & 36.2 & 99.1 \\
\hline 08DH30A-18 & 260.4 & 6.9 & 261.4 & 7.2 & 270.3 & 34.8 & 260.4 & 6.9 & 96.4 \\
\hline 08DH30A-19 & 257.2 & 7.6 & 261.2 & 15.1 & 297.1 & 133.0 & 257.2 & 7.6 & 86.6 \\
\hline 08DH30A-20 & 303.4 & 1.5 & 308.5 & 7.8 & 346.8 & 65.0 & 303.4 & 1.5 & 87.5 \\
\hline 08DH30A-21 & 1662.5 & 14.1 & 1741.1 & 16.8 & 1836.8 & 32.1 & 1836.8 & 32.1 & 90.5 \\
\hline 08DH30A-22 & 263.9 & 6.4 & 263.6 & 7.5 & 261.5 & 48.0 & 263.9 & 6.4 & 100.9 \\
\hline 08DH30A-23 & 299.6 & 1.6 & 303.1 & 5.3 & 329.9 & 44.3 & 299.6 & 1.6 & 90.8 \\
\hline $08 \mathrm{DH} 30 \mathrm{~A}-24$ & 290.8 & 3.5 & 288.4 & 9.3 & 268.8 & 80.0 & 290.8 & 3.5 & 108.2 \\
\hline 08DH30A-25 & 337.8 & 3.8 & 368.6 & 53.5 & 567.0 & 378.2 & 337.8 & 3.8 & 59.6 \\
\hline 08DH30A-26 & 252.3 & 4.3 & 239.3 & 30.3 & 114.0 & 333.9 & 252.3 & 4.3 & 221.3 \\
\hline $08 \mathrm{DH} 30 \mathrm{~A}-27$ & 1945.8 & 30.2 & 1934.5 & 19.3 & 1922.3 & 23.9 & 1922.3 & 23.9 & 101.2 \\
\hline 08DH30A-28 & 257.2 & 3.3 & 257.1 & 8.8 & 255.9 & 83.8 & 257.2 & 3.3 & 100.5 \\
\hline 08DH30A-29 & 1835.4 & 12.5 & 1860.9 & 12.9 & 1889.4 & 23.4 & 1889.4 & 23.4 & 97.1 \\
\hline 08DH30A-30 & 234.4 & 5.3 & 199.8 & 53.4 & -191.0 & 747.2 & 234.4 & 5.3 & -122.7 \\
\hline 08DH30A-31 & 248.1 & 3.8 & 227.8 & 41.2 & 22.6 & 487.7 & 248.1 & 3.8 & 1096.7 \\
\hline 08DH30A-32 & 2190.3 & 9.3 & 2241.7 & 16.2 & 2289.0 & 29.6 & 2289.0 & 29.6 & 95.7 \\
\hline 08DH30A-33 & 2430.4 & 37.3 & 2490.2 & 27.3 & 2539.5 & 38.6 & 2539.5 & 38.6 & 95.7 \\
\hline 08DH30A-34 & 1844.3 & 21.8 & 1900.8 & 29.0 & 1963.0 & 55.1 & 1963.0 & 55.1 & 94.0 \\
\hline 08DH30A-35 & 1906.9 & 21.6 & 1938.0 & 23.2 & 1971.4 & 41.7 & 1971.4 & 41.7 & 96.7 \\
\hline 08DH30A-36 & 1820.5 & 50.0 & 1833.8 & 30.4 & 1848.8 & 30.9 & 1848.8 & 30.9 & 98.5 \\
\hline 08DH30A-37 & 1914.8 & 16.4 & 1938.6 & 17.9 & 1964.0 & 32.5 & 1964.0 & 32.5 & 97.5 \\
\hline 08DH30A-38 & 159.0 & 2.7 & 159.2 & 7.8 & 162.3 & 117.8 & 159.0 & 2.7 & 98.0 \\
\hline 08DH30A-39 & 1864.5 & 19.9 & 1905.5 & 22.1 & 1950.5 & 40.4 & 1950.5 & 40.4 & 95.6 \\
\hline $08 \mathrm{DH} 30 \mathrm{~A}-40$ & 1702.7 & 53.3 & 1711.4 & 36.4 & 1722.0 & 47.6 & 1722.0 & 47.6 & 98.9 \\
\hline 08DH30A-41 & 1623.8 & 38.8 & 1718.5 & 28.2 & 1835.9 & 37.5 & 1835.9 & 37.5 & 88.4 \\
\hline 08DH30A-42 & 275.7 & 9.7 & 329.7 & 22.7 & 730.6 & 153.0 & 275.7 & 9.7 & 37.7 \\
\hline $08 \mathrm{DH} 30 \mathrm{~A}-43$ & 168.1 & 4.5 & 167.3 & 8.5 & 155.4 & 112.9 & 168.1 & 4.5 & 108.2 \\
\hline 08DH30A-44 & 160.4 & 3.6 & 163.3 & 10.2 & 205.3 & 148.3 & 160.4 & 3.6 & 78.1 \\
\hline 08DH30A-45 & 269.0 & 5.2 & 256.0 & 24.0 & 138.5 & 244.7 & 269.0 & 5.2 & 194.3 \\
\hline
\end{tabular}


08DH30a

Isotope ratios

\begin{tabular}{|c|c|c|c|c|c|c|c|c|c|c|}
\hline Analysis & $\underset{(\mathrm{ppm})}{\mathrm{U}}$ & $\begin{array}{l}206 \mathrm{~Pb} / \\
204 \mathrm{~Pb}\end{array}$ & $\mathrm{U} / \mathrm{Th}$ & $\begin{array}{c}206 \mathrm{~Pb}^{*} / \\
207 \mathrm{~Pb}^{*}\end{array}$ & $\begin{array}{c} \pm \\
(\%)\end{array}$ & $\begin{array}{c}207 \mathrm{~Pb}^{*} / \\
235 \mathrm{U}^{*}\end{array}$ & $\begin{array}{c} \pm \\
(\%)\end{array}$ & $\begin{array}{c}206 \mathrm{~Pb}^{*} / \\
238 \mathrm{U}\end{array}$ & $\begin{array}{c} \pm \\
(\%)\end{array}$ & $\begin{array}{l}\text { error } \\
\text { corr. }\end{array}$ \\
\hline 08DH30A-46 & 123 & 5631 & 1.2 & 19.2239 & 2.9 & 0.3277 & 3.4 & 0.0457 & 1.8 & \\
\hline $08 \mathrm{DH} 30 \mathrm{~A}-47$ & 140 & 3744 & 1.7 & 20.2929 & 5.5 & 0.1885 & 5.6 & 0.0277 & 1.0 & 0.17 \\
\hline 08DH30A-48 & 389 & 17880 & 1.3 & 19.0924 & 1.5 & 0.3189 & 2.1 & 0.0442 & 1.4 & 0.69 \\
\hline 08DH30A-49 & 84 & 2601 & 2.4 & 20.9106 & 10.4 & 0.1722 & 10.5 & 0.0261 & 1.5 & 0.14 \\
\hline 08DH30A-50 & 798 & 31992 & 2.7 & 18.7117 & 5.1 & 0.3842 & 5.3 & 0.0521 & 1.2 & 0.22 \\
\hline 08DH30A-51 & 104 & 1731 & 2.2 & 19.4541 & 8.4 & 0.1867 & 8.5 & 0.0263 & 1.5 & 0.18 \\
\hline 08DH30A-53 & 36 & 1443 & 1.6 & 23.3977 & 29.1 & 0.2332 & 29.1 & 0.0396 & 1.2 & 0.04 \\
\hline 08DH30A-54 & 231 & 12816 & 1.3 & 14.5429 & 2.5 & 1.2174 & 2.9 & 0.1284 & 1.5 & 0.49 \\
\hline 08DH30A-55 & 203 & 9282 & 1.9 & 19.4287 & 2.8 & 0.3328 & 3.2 & 0.0469 & 1.7 & 0.52 \\
\hline 08DH30A-56 & 182 & 8142 & 3.0 & 18.4662 & 2.2 & 0.4449 & 2.9 & 0.0596 & 1.8 & 0.63 \\
\hline 08DH30A-57 & 249 & 8883 & 1.4 & 19.4414 & 2.7 & 0.2848 & 3.4 & 0.0402 & 2.0 & 0.58 \\
\hline 08DH30A-58 & 232 & 5847 & 1.3 & 19.6549 & 3.5 & 0.2668 & 3.8 & 0.0380 & 1.5 & 0.38 \\
\hline 08DH30A-59 & 354 & 4542 & 0.9 & 17.7729 & 3.3 & 0.3127 & 4.1 & 0.0403 & 2.4 & 0.58 \\
\hline $08 \mathrm{DH} 30 \mathrm{~A}-60$ & 37 & 1203 & 2.2 & 21.3169 & 19.9 & 0.1610 & 20.3 & 0.0249 & 3.9 & 0.19 \\
\hline 08DH30A-61 & 282 & 5991 & 1.4 & 21.1615 & 7.1 & 0.1576 & 7.4 & 0.0242 & 2.2 & 0.29 \\
\hline 08DH30A-62 & 142 & 5103 & 1.8 & 20.2297 & 3.8 & 0.2010 & 4.8 & 0.0295 & 2.9 & 0.61 \\
\hline 08DH30A-63 & 211 & 6351 & 3.4 & 20.3780 & 3.7 & 0.1629 & 4.6 & 0.0241 & 2.7 & 0.59 \\
\hline 08DH30A-64 & 841 & 50322 & 5.7 & 8.5770 & 1.7 & 5.0429 & 2.3 & 0.3137 & 1.6 & 0.70 \\
\hline 08DH30A-65 & 1293 & 9192 & 3.4 & 16.9683 & 4.6 & 0.4928 & 5.2 & 0.0606 & 2.4 & 0.45 \\
\hline 08DH30A-66 & 315 & 9732 & 1.3 & 19.2929 & 3.1 & 0.2781 & 3.9 & 0.0389 & 2.4 & 0.61 \\
\hline 08DH30A-67 & 68 & 2025 & 3.2 & 20.8228 & 16.9 & 0.1765 & 17.0 & 0.0267 & 1.4 & 0.08 \\
\hline 08DH30A-69 & 216 & 51411 & 4.5 & 8.6437 & 2.1 & 5.4961 & 2.3 & 0.3446 & 1.1 & 0.45 \\
\hline 08DH30A-70 & 82 & 1935 & 1.5 & 20.0352 & 7.9 & 0.1757 & 8.5 & 0.0255 & 3.3 & 0.38 \\
\hline 08DH30A-71 & 53 & 2130 & 1.9 & 20.0626 & 9.7 & 0.2700 & 10.1 & 0.0393 & 2.9 & 0.28 \\
\hline 08DH30A-72 & 93 & 2304 & 2.1 & 20.8407 & 13.2 & 0.1787 & 13.2 & 0.0270 & 1.4 & 0.11 \\
\hline 08DH30A-73 & 420 & 18705 & 1.6 & 18.9097 & 1.5 & 0.3597 & 2.5 & 0.0493 & 2.0 & 0.80 \\
\hline 08DH30A-74 & 1023 & 23094 & 0.8 & 18.8592 & 1.4 & 0.3579 & 1.8 & 0.0489 & 1.1 & 0.62 \\
\hline 08DH30A-75 & 148 & 459 & 3.0 & 7.7604 & 27.5 & 0.5116 & 27.9 & 0.0288 & 4.5 & 0.16 \\
\hline 08DH30A-76 & 259 & 10428 & 1.4 & 19.3187 & 2.6 & 0.3211 & 3.0 & 0.0450 & 1.6 & 0.53 \\
\hline 08DH30A-77 & 144 & 3300 & 0.8 & 20.4698 & 5.6 & 0.1666 & 5.7 & 0.0247 & 1.2 & 0.22 \\
\hline 08DH30A-78 & 123 & 5427 & 0.9 & 19.2168 & 2.9 & 0.3309 & 3.6 & 0.0461 & 2.3 & 0.62 \\
\hline 08DH30A-79 & 419 & 130029 & 17.4 & 8.2560 & 1.8 & 6.0021 & 2.1 & 0.3594 & 1.0 & 0.48 \\
\hline 08DH30A-80 & 269 & 90669 & 5.9 & 8.4449 & 2.2 & 5.7642 & 2.4 & 0.3530 & 1.0 & 0.41 \\
\hline 08DH30A-81 & 73 & 2730 & 3.1 & 20.5753 & 11.6 & 0.2399 & 11.7 & 0.0358 & 1.8 & 0.15 \\
\hline 08DH30A-82 & 65 & 3420 & 1.0 & 20.6148 & 10.2 & 0.2579 & 10.3 & 0.0386 & 1.3 & 0.13 \\
\hline 08DH30A-83 & 141 & 2205 & 1.8 & 19.2522 & 10.3 & 0.1890 & 10.4 & 0.0264 & 1.3 & 0.13 \\
\hline 08DH30A-84 & 616 & 60606 & 2.3 & 8.7873 & 3.0 & 4.6537 & 3.4 & 0.2966 & 1.6 & 0.47 \\
\hline 08DH30A-85 & 49 & 2004 & 3.5 & 20.3515 & 12.3 & 0.2495 & 13.3 & 0.0368 & 5.0 & 0.38 \\
\hline 08DH30A-86 & 159 & 4131 & 4.3 & 22.1178 & 12.4 & 0.1500 & 12.6 & 0.0241 & 2.0 & 0.16 \\
\hline 08DH30A-87 & 229 & 6900 & 0.8 & 18.4796 & 3.6 & 0.4048 & 4.1 & 0.0543 & 2.1 & 0.51 \\
\hline 08DH30A-88 & 54 & 1824 & 3.6 & 24.4205 & 27.4 & 0.1438 & 27.4 & 0.0255 & 1.9 & 0.07 \\
\hline 08DH30A-89 & 46 & 1587 & 2.2 & 22.1550 & 19.7 & 0.1645 & 19.7 & 0.0264 & 1.6 & 0.08 \\
\hline 08DH30A-90 & 274 & 1461 & 1.2 & 12.4603 & 10.0 & 0.6661 & 10.1 & 0.0602 & 1.7 & 0.17 \\
\hline 08DH30A-91 & 44 & 1881 & 0.7 & 19.7213 & 10.0 & 0.3031 & 10.1 & 0.0433 & 1.5 & 0.15 \\
\hline 08DH30A-92 & 118 & 3876 & 1.4 & 20.9389 & 12.5 & 0.1824 & 12.5 & 0.0277 & 1.1 & 0.09 \\
\hline
\end{tabular}


08DH30a

Apparent ages (Ma)

\begin{tabular}{|c|c|c|c|c|c|c|c|c|c|}
\hline Analysis & $\begin{array}{c}206 \mathrm{~Pb}^{*} / \\
238 \mathrm{U}^{*}\end{array}$ & $\stackrel{ \pm}{(\mathrm{Ma})}$ & $\begin{array}{c}207 \mathrm{~Pb}^{*} / \\
235 \mathrm{U}\end{array}$ & $\stackrel{ \pm}{(\mathrm{Ma})}$ & $\begin{array}{l}206 \mathrm{~Pb}^{*} / \\
207 \mathrm{~Pb}^{*}\end{array}$ & $\stackrel{ \pm}{(\mathrm{Ma})}$ & $\begin{array}{c}\text { Best age } \\
\quad(\mathrm{Ma})\end{array}$ & $\begin{array}{c} \pm \\
(\mathrm{Ma})\end{array}$ & $\begin{array}{c}\text { Conc } \\
(\%)\end{array}$ \\
\hline 08DH30A-46 & 288.0 & 5.2 & 287.8 & 8.6 & 286.2 & 66.3 & 288.0 & 5.2 & 100.6 \\
\hline 08DH30A-47 & 176.4 & 1.7 & 175.3 & 9.0 & 161.1 & 128.7 & 176.4 & 1.7 & 109.5 \\
\hline 08DH30A-48 & 278.6 & 3.9 & 281.1 & 5.0 & 301.9 & 33.8 & 278.6 & 3.9 & 92.3 \\
\hline 08DH30A-49 & 166.2 & 2.4 & 161.3 & 15.7 & 90.5 & 247.8 & 166.2 & 2.4 & 183.7 \\
\hline 08DH30A-50 & 327.7 & 3.8 & 330.1 & 14.9 & 347.6 & 116.3 & 327.7 & 3.8 & 94.3 \\
\hline 08DH30A-51 & 167.6 & 2.5 & 173.8 & 13.6 & 258.9 & 193.1 & 167.6 & 2.5 & 64.7 \\
\hline 08DH30A-53 & 250.2 & 2.9 & 212.9 & 56.0 & -182.8 & 740.5 & 250.2 & 2.9 & -136.9 \\
\hline 08DH30A-54 & 778.8 & 10.6 & 808.6 & 16.3 & 891.6 & 52.6 & 778.8 & 10.6 & 87.3 \\
\hline 08DH30A-55 & 295.5 & 4.8 & 291.7 & 8.2 & 261.9 & 63.5 & 295.5 & 4.8 & 112.8 \\
\hline 08DH30A-56 & 373.1 & 6.6 & 373.7 & 9.0 & 377.4 & 50.1 & 373.1 & 6.6 & 98.9 \\
\hline 08DH30A-57 & 253.8 & 4.9 & 254.4 & 7.6 & 260.5 & 62.8 & 253.8 & 4.9 & 97.4 \\
\hline 08DH30A-58 & 240.6 & 3.4 & 240.1 & 8.2 & 235.3 & 81.6 & 240.6 & 3.4 & 102.3 \\
\hline 08DH30A-59 & 254.7 & 5.9 & 276.3 & 9.8 & 462.9 & 73.4 & 254.7 & 5.9 & 55.0 \\
\hline 08DH30A-60 & 158.5 & 6.1 & 151.6 & 28.6 & 44.7 & 480.9 & 158.5 & 6.1 & 354.4 \\
\hline 08DH30A-61 & 154.0 & 3.3 & 148.6 & 10.2 & 62.1 & 168.3 & 154.0 & 3.3 & 247.9 \\
\hline 08DH30A-62 & 187.4 & 5.4 & 186.0 & 8.1 & 168.4 & 88.7 & 187.4 & 5.4 & 111.3 \\
\hline 08DH30A-63 & 153.3 & 4.1 & 153.2 & 6.5 & 151.3 & 86.9 & 153.3 & 4.1 & 101.3 \\
\hline 08DH30A-64 & 1758.9 & 25.2 & 1826.6 & 19.7 & 1904.6 & 29.7 & 1904.6 & 29.7 & 92.4 \\
\hline 08DH30A-65 & 379.6 & 8.7 & 406.8 & 17.4 & 564.6 & 100.8 & 379.6 & 8.7 & 67.2 \\
\hline 08DH30A-66 & 246.1 & 5.7 & 249.1 & 8.5 & 278.1 & 70.2 & 246.1 & 5.7 & 88.5 \\
\hline 08DH30A-67 & 169.6 & 2.3 & 165.0 & 25.9 & 100.5 & 402.7 & 169.6 & 2.3 & 168.7 \\
\hline 08DH30A-69 & 1908.5 & 17.3 & 1900.0 & 20.2 & 1890.7 & 37.8 & 1890.7 & 37.8 & 100.9 \\
\hline 08DH30A-70 & 162.5 & 5.2 & 164.4 & 12.9 & 190.9 & 183.0 & 162.5 & 5.2 & 85.1 \\
\hline 08DH30A-71 & 248.4 & 6.9 & 242.7 & 21.8 & 187.7 & 226.1 & 248.4 & 6.9 & 132.3 \\
\hline 08DH30A-72 & 171.8 & 2.4 & 166.9 & 20.4 & 98.4 & 312.4 & 171.8 & 2.4 & 174.6 \\
\hline 08DH30A-73 & 310.4 & 6.1 & 312.0 & 6.7 & 323.8 & 34.5 & 310.4 & 6.1 & 95.9 \\
\hline 08DH30A-74 & 308.1 & 3.4 & 310.6 & 4.9 & 329.8 & 32.8 & 308.1 & 3.4 & 93.4 \\
\hline 08DH30A-75 & 183.0 & 8.2 & 419.5 & 96.1 & 2082.5 & 494.3 & 2082.5 & 494.3 & 8.8 \\
\hline 08DH30A-76 & 283.7 & 4.5 & 282.8 & 7.5 & 275.0 & 58.9 & 283.7 & 4.5 & 103.2 \\
\hline 08DH30A-77 & 157.5 & 1.9 & 156.5 & 8.3 & 140.8 & 130.8 & 157.5 & 1.9 & 111.9 \\
\hline 08DH30A-78 & 290.7 & 6.4 & 290.3 & 9.2 & 287.0 & 65.5 & 290.7 & 6.4 & 101.3 \\
\hline 08DH30A-79 & 1979.3 & 17.2 & 1976.1 & 18.3 & 1972.8 & 32.8 & 1972.8 & 32.8 & 100.3 \\
\hline 08DH30A-80 & 1949.1 & 16.5 & 1941.0 & 20.9 & 1932.4 & 39.6 & 1932.4 & 39.6 & 100.9 \\
\hline 08DH30A-81 & 226.8 & 3.9 & 218.4 & 23.0 & 128.7 & 272.9 & 226.8 & 3.9 & 176.2 \\
\hline 08DH30A-82 & 243.9 & 3.1 & 233.0 & 21.4 & 124.1 & 241.1 & 243.9 & 3.1 & 196.5 \\
\hline 08DH30A-83 & 167.9 & 2.2 & 175.8 & 16.7 & 282.9 & 235.8 & 167.9 & 2.2 & 59.3 \\
\hline 08DH30A-84 & 1674.4 & 24.0 & 1759.0 & 28.8 & 1861.0 & 54.9 & 1861.0 & 54.9 & 90.0 \\
\hline 08DH30A-85 & 233.2 & 11.5 & 226.2 & 27.0 & 154.3 & 289.6 & 233.2 & 11.5 & 151.1 \\
\hline 08DH30A-86 & 153.3 & 3.0 & 141.9 & 16.6 & -44.2 & 302.1 & 153.3 & 3.0 & -347.0 \\
\hline 08DH30A-87 & 340.6 & 7.0 & 345.1 & 12.1 & 375.8 & 80.1 & 340.6 & 7.0 & 90.6 \\
\hline 08DH30A-88 & 162.1 & 3.1 & 136.4 & 35.0 & -290.7 & 709.3 & 162.1 & 3.1 & -55.8 \\
\hline 08DH30A-89 & 168.2 & 2.7 & 154.7 & 28.3 & -48.3 & 482.2 & 168.2 & 2.7 & -348.5 \\
\hline 08DH30A-90 & 376.8 & 6.1 & 518.3 & 41.0 & 1203.2 & 196.6 & 376.8 & 6.1 & 31.3 \\
\hline 08DH30A-91 & 273.5 & 4.0 & 268.8 & 23.8 & 227.5 & 230.6 & 273.5 & 4.0 & 120.2 \\
\hline 08DH30A-92 & 176.2 & 1.9 & 170.1 & 19.6 & 87.3 & 296.5 & 176.2 & 1.9 & 201.7 \\
\hline
\end{tabular}


08DH30a

Isotope ratios

$\begin{array}{ccccccccccc}\text { Analysis } & \begin{array}{c}\mathrm{U} \\ (\mathrm{ppm})\end{array} & \begin{array}{c}206 \mathrm{~Pb} / \\ 204 \mathrm{~Pb}\end{array} & \mathrm{U} / \mathrm{Th} & \begin{array}{c}206 \mathrm{~Pb}^{*} / \\ 207 \mathrm{~Pb}^{*}\end{array} & \begin{array}{c} \pm \\ (\%)\end{array} & \begin{array}{c}207 \mathrm{~Pb}^{*} / \\ 235 \mathrm{U}^{*}\end{array} & \begin{array}{c} \pm \\ (\%)\end{array} & \begin{array}{c}206 \mathrm{~Pb}^{*} / \\ 238 \mathrm{U}\end{array} & \begin{array}{c} \pm \\ (\%)\end{array} & \begin{array}{c}\text { error } \\ \text { corr. }\end{array} \\ \text { 08DH30A-93 } & 258 & 3210 & 0.8 & 15.0411 & 18.8 & 0.4147 & 18.9 & 0.0452 & 1.8 & 0.10 \\ \text { 08DH30A-94 } & 339 & 20739 & 1.5 & 18.9521 & 2.5 & 0.3988 & 2.7 & 0.0548 & 1.0 & 0.37 \\ \text { 08DH30A-95 } & 507 & 5328 & 0.8 & 18.0581 & 4.2 & 0.3145 & 4.6 & 0.0412 & 1.9 & 0.41 \\ \text { 08DH30A-96 } & 111 & 17976 & 1.2 & 8.5040 & 1.6 & 5.5157 & 2.7 & 0.3402 & 2.3 & 0.82 \\ \text { 08DH30A-97 } & 86 & 4428 & 1.5 & 18.9655 & 3.4 & 0.3811 & 4.4 & 0.0524 & 2.9 & 0.65 \\ \text { 08DH30A-98 } & 75 & 3477 & 1.4 & 19.7910 & 6.6 & 0.2744 & 6.7 & 0.0394 & 1.3 & 0.20 \\ \text { 08DH30A-99 } & 682 & 933 & 0.8 & 10.5239 & 15.5 & 0.4750 & 15.7 & 0.0363 & 2.3 & 0.15 \\ \text { 08DH30A-100 } & 216 & 64089 & 2.5 & 8.7978 & 2.1 & 4.6585 & 3.9 & 0.2973 & 3.3 & 0.85\end{array}$

08DH30a

Apparent ages (Ma)

$\begin{array}{cccccccccc}\text { Analysis } & \begin{array}{c}206 \mathrm{~Pb}^{*} \\ 238 \mathrm{U}^{*}\end{array} & \begin{array}{c} \pm \\ (\mathrm{Ma})\end{array} & \begin{array}{c}207 \mathrm{~Pb}^{*} / \\ 235 \mathrm{U}\end{array} & \begin{array}{c} \pm \\ (\mathrm{Ma})\end{array} & \begin{array}{c}206 \mathrm{~Pb}^{*} / \\ 207 \mathrm{~Pb}^{*}\end{array} & \begin{array}{c} \pm \\ (\mathrm{Ma})\end{array} & \begin{array}{c}\text { Best age } \\ (\mathrm{Ma})\end{array} & \begin{array}{c} \pm \\ (\mathrm{Ma})\end{array} & \begin{array}{c}\text { Conc } \\ (\%)\end{array} \\ \text { 08DH30A-93 } & 285.2 & 5.1 & 352.2 & 56.3 & 821.7 & 395.9 & 285.2 & 5.1 & 34.7 \\ \text { 08DH30A-94 } & 344.0 & 3.4 & 340.7 & 7.8 & 318.7 & 56.9 & 344.0 & 3.4 & 107.9 \\ \text { 08DH30A-95 } & 260.2 & 4.8 & 277.7 & 11.1 & 427.4 & 92.6 & 260.2 & 4.8 & 60.9 \\ \text { 08DH30A-96 } & 1887.6 & 36.8 & 1903.0 & 23.5 & 1919.9 & 27.8 & 1919.9 & 27.8 & 98.3 \\ \text { 08DH30A-97 } & 329.3 & 9.2 & 327.8 & 12.4 & 317.1 & 76.7 & 329.3 & 9.2 & 103.9 \\ \text { 08DH30A-98 } & 249.0 & 3.2 & 246.2 & 14.6 & 219.3 & 151.8 & 249.0 & 3.2 & 113.5 \\ \text { 08DH30A-99 } & 229.6 & 5.2 & 394.6 & 51.3 & 1528.5 & 293.6 & 229.6 & 5.2 & 15.0 \\ \text { 08DH30A-100 } & 1677.7 & 49.0 & 1759.8 & 32.8 & 1858.8 & 37.6 & 1858.8 & 37.6 & 90.3\end{array}$


08DH32

Isotope ratios

\begin{tabular}{|c|c|c|c|c|c|c|c|c|c|c|}
\hline Analysis & $\underset{(\mathrm{ppm})}{U}$ & $\begin{array}{l}206 \mathrm{~Pb} / \\
204 \mathrm{~Pb}\end{array}$ & $\mathrm{U} / \mathrm{Th}$ & $\begin{array}{l}206 \mathrm{~Pb}^{*} / \\
207 \mathrm{~Pb}^{*}\end{array}$ & $\begin{array}{c} \pm \\
(\%)\end{array}$ & $\begin{array}{c}207 \mathrm{~Pb}^{*} / \\
235 \mathrm{U}^{*}\end{array}$ & $\begin{array}{c} \pm \\
(\%)\end{array}$ & $\begin{array}{c}206 \mathrm{~Pb}^{*} / \\
238 \mathrm{U}\end{array}$ & $\begin{array}{c} \pm \\
(\%)\end{array}$ & $\begin{array}{l}\text { error } \\
\text { corr. }\end{array}$ \\
\hline 08DH32-1 & 55 & 11562 & 1.8 & 8.3507 & 1.7 & 5.7807 & 1.9 & 0.3501 & 0.7 & 0.38 \\
\hline 08DH32-2 & 611 & 20532 & 1.2 & 18.6452 & 1.1 & 0.4031 & 1.7 & 0.0545 & 1.3 & 0.76 \\
\hline $08 \mathrm{DH} 32-3$ & 64 & 1656 & 1.1 & 19.8312 & 10.9 & 0.2617 & 11.0 & 0.0376 & 1.8 & 0.16 \\
\hline 08DH32-4 & 76 & 2382 & 1.0 & 20.9836 & 13.8 & 0.2518 & 13.9 & 0.0383 & 0.9 & 0.06 \\
\hline 08DH32-5 & 47 & 11256 & 2.3 & 8.4877 & 1.9 & 5.6868 & 2.1 & 0.3501 & 1.1 & .50 \\
\hline $08 \mathrm{DH} 32-6$ & 45 & 12768 & 1.9 & 8.5417 & 2.3 & 5.6469 & 2.5 & 0.3498 & 1.0 & 40 \\
\hline $08 \mathrm{DH} 32-7$ & 192 & 4869 & 1.2 & 19.6498 & 4.5 & 0.2772 & 4.7 & 0.0395 & 1.3 & 0.27 \\
\hline 08DH32-8 & 241 & 6195 & 1.0 & 20.0288 & 4.7 & 0.2229 & 5.0 & 0.0324 & 1.5 & 30 \\
\hline $08 \mathrm{DH} 32-9$ & 64 & 16266 & 1.0 & 8.2525 & 1.6 & 6.0212 & 1.7 & 0.3604 & 0.6 & 38 \\
\hline $08 \mathrm{DH} 32-10$ & 170 & 5262 & 0.7 & 19.9835 & 7.3 & 0.3223 & 7.6 & 0.0467 & 2.0 & 0.26 \\
\hline $08 \mathrm{DH} 32-11$ & 193 & 4461 & 1.8 & 20.8557 & 8.2 & 0.1861 & 8.3 & 0.0282 & 1.4 & .17 \\
\hline $08 \mathrm{DH} 32-12$ & 176 & 33738 & 2.3 & 8.3353 & 1.9 & 5.9046 & 2.1 & 0.3570 & 0.9 & 0.41 \\
\hline $08 \mathrm{DH} 32-13$ & 406 & 70707 & 5.0 & 8.5467 & 1.8 & 5.5182 & 1.9 & 0.3421 & 0.6 & 0.30 \\
\hline $08 \mathrm{DH} 32-14$ & 112 & 29277 & 1.4 & 8.2002 & 1.2 & 6.0372 & 1.3 & 0.3591 & 0.5 & .40 \\
\hline 08DH32-15 & 143 & 3765 & 2.2 & 18.5827 & 2.0 & 0.3374 & 2.1 & 0.0455 & 0.6 & 0.31 \\
\hline $08 \mathrm{DH} 32-16$ & 277 & 6375 & 1.2 & 18.3069 & 11.5 & 0.3911 & 11.5 & 0.0519 & 1.2 & 0.11 \\
\hline $08 \mathrm{DH} 32-17$ & 132 & 25737 & 1.7 & 8.1966 & 1.1 & 6.0628 & 1.5 & 0.3604 & 1.0 & .65 \\
\hline $08 \mathrm{DH} 32-18$ & 89 & 3525 & 1.5 & 19.4616 & 6.3 & 0.3072 & 6.4 & 0.0434 & 1.1 & 0.17 \\
\hline $08 \mathrm{DH} 32-19$ & 158 & 4926 & 1.4 & 19.0953 & 2.9 & 0.3248 & 3.2 & 0.0450 & 1.3 & 0.42 \\
\hline $08 \mathrm{DH} 32-20$ & 84 & 17379 & 1.4 & 7.3870 & 0.9 & 7.3928 & 2.7 & 0.3961 & 2.5 & 0.94 \\
\hline $08 \mathrm{DH} 32-21$ & 711 & 146892 & 9.8 & 8.3321 & 2.0 & 5.8893 & 2.4 & 0.3559 & 1.4 & 0.57 \\
\hline $08 \mathrm{DH} 32-22$ & 123 & 3090 & 1.3 & 20.3598 & 6.5 & 0.1917 & 6.5 & 0.0283 & 1.1 & 0.16 \\
\hline $08 \mathrm{DH} 32-24$ & 96 & 20439 & 0.7 & 8.6435 & 1.4 & 5.4508 & 1.5 & 0.3417 & 0.6 & 0.37 \\
\hline $08 \mathrm{DH} 32-25$ & 283 & 4785 & 0.5 & 18.8521 & 5.2 & 0.3472 & 5.2 & 0.0475 & 0.7 & 0.13 \\
\hline $08 \mathrm{DH} 32-26$ & 126 & 2382 & 2.3 & 18.8335 & 3.3 & 0.3028 & 3.5 & 0.0414 & 1.1 & 0.32 \\
\hline $08 \mathrm{DH} 32-27$ & 181 & 4629 & 0.5 & 19.5379 & 4.7 & 0.3265 & 4.8 & 0.0463 & 0.8 & 0.18 \\
\hline $08 \mathrm{DH} 32-28$ & 122 & 2382 & 0.5 & 19.7216 & 7.7 & 0.2727 & 7.9 & 0.0390 & 1.6 & 0.21 \\
\hline $08 \mathrm{DH} 32-29$ & 269 & 6597 & 0.8 & 19.2708 & 3.9 & 0.3207 & 4.0 & 0.0448 & 1.1 & 0.28 \\
\hline $08 \mathrm{DH} 32-30$ & 142 & 4788 & 1.4 & 20.0285 & 6.5 & 0.2811 & 6.6 & 0.0408 & 1.1 & 0.16 \\
\hline $08 \mathrm{DH} 32-31$ & 114 & 3153 & 2.3 & 20.6748 & 7.7 & 0.1892 & 7.9 & 0.0284 & 1.8 & 0.23 \\
\hline 08DH32-32 & 92 & 21063 & 1.2 & 8.3562 & 1.7 & 5.8497 & 2.3 & 0.3545 & 1.5 & 0.66 \\
\hline $08 \mathrm{DH} 32-33$ & 90 & 2391 & 1.7 & 20.7389 & 8.6 & 0.1849 & 8.9 & 0.0278 & 2.3 & 0.26 \\
\hline 08DH32-34 & 199 & 3705 & 3.9 & 20.6662 & 7.8 & 0.1848 & 7.9 & 0.0277 & 1.3 & 0.17 \\
\hline 08DH32-35 & 372 & 80820 & 20 & 83726 & 1.3 & 5.8799 & 1.5 & 0.3571 & 0.6 & 0.43 \\
\hline $08 \mathrm{DH} 32-36$ & 211 & 4071 & 1.7 & 20.0466 & 4.7 & 0.1923 & 5.2 & 0.0280 & 2.1 & 0.41 \\
\hline 08DH32-37 & 281 & 63597 & 4.0 & 8.2402 & 1.1 & 5.9679 & 2.3 & 0.3567 & 2.0 & 0.87 \\
\hline 08DH32-38 & 160 & 3003 & 0.7 & 19.5963 & 9.2 & 0.2633 & 9.7 & 0.0374 & 3.0 & 0.31 \\
\hline 08DH32-39 & 104 & 29736 & 1.6 & 7.6925 & 1.2 & 6.9554 & 1.5 & 0.3880 & 1.0 & 0.64 \\
\hline $08 \mathrm{DH} 32-40$ & 22 & 558 & 1.4 & 22.2553 & 95.5 & 0.1529 & 95.6 & 0.0247 & 3.1 & 0.03 \\
\hline $08 \mathrm{DH} 32-41$ & 259 & 55836 & 1.5 & & 1.5 & 8.7685 & 1.6 & 0.4232 & 0.5 & 0.31 \\
\hline 08DH32-42 & 175 & 46683 & 1.3 & 7.7985 & 1.5 & 6.6987 & 1.5 & 0.3789 & 0.5 & 0.34 \\
\hline $08 \mathrm{DH} 32-43$ & 203 & 53817 & 2.1 & 5.1711 & 2.5 & 14.4586 & 3.1 & 0.5423 & 1.8 & 0.58 \\
\hline $08 \mathrm{DH} 32-44$ & 29 & 864 & 0.6 & 31.5991 & 80.0 & 0.1340 & 80.5 & 0.0307 & 9.6 & 0.12 \\
\hline 08DH32-45 & 825 & 139995 & 12.6 & 8.5288 & 1.9 & 5.4635 & 2.6 & 0.3380 & 1.8 & 0.70 \\
\hline $08 \mathrm{DH} 32-46$ & 74 & 1467 & 0.8 & 20.6428 & 12.0 & 0.1626 & 12.2 & 0.0243 & 2.5 & 0.21 \\
\hline
\end{tabular}


08DH32

Apparent ages (Ma)

\begin{tabular}{|c|c|c|c|c|c|c|c|c|c|}
\hline Analysis & $\begin{array}{c}206 \mathrm{~Pb}^{*} / \\
238 \mathrm{U}^{*}\end{array}$ & $\stackrel{ \pm}{(\mathrm{Ma})}$ & $\begin{array}{c}207 \mathrm{~Pb}^{*} / \\
235 \mathrm{U}\end{array}$ & $\begin{array}{c} \pm \\
(\mathrm{Ma})\end{array}$ & $\begin{array}{l}206 \mathrm{~Pb}^{*} / \\
207 \mathrm{~Pb}^{*}\end{array}$ & $\stackrel{ \pm}{(\mathrm{Ma})}$ & $\begin{array}{c}\text { Best age } \\
\quad(\mathrm{Ma})\end{array}$ & $\stackrel{ \pm}{(\mathrm{Ma})}$ & $\begin{array}{c}\text { Conc } \\
(\%)\end{array}$ \\
\hline 08DH32-1 & 1935.1 & 12.0 & 1943.5 & 16.2 & 1952.5 & 30.9 & 1952.5 & 30.9 & 99.1 \\
\hline 08DH32-2 & 342.1 & 4.3 & 343.9 & 4.9 & 355.7 & 24.9 & 342.1 & 4.3 & 96.2 \\
\hline 08DH32-3 & 238.2 & 4.2 & 236.0 & 23.2 & 214.7 & 252.1 & 238.2 & 4.2 & 110.9 \\
\hline 08DH32-4 & 242.4 & 2.1 & 228.0 & 28.3 & 82.2 & 329.4 & 242.4 & 2.1 & 294.9 \\
\hline 08DH32-5 & 1934.9 & 17.9 & 1929.4 & 18.5 & 1923.4 & 33.4 & 1923.4 & 33.4 & 100.6 \\
\hline 08DH32-6 & 1933.8 & 16.5 & 1923.3 & 21.5 & 1912.0 & 41.1 & 1912.0 & 41.1 & 101.1 \\
\hline 08DH32-7 & 249.7 & 3.1 & 248.4 & 10.3 & 235.9 & 104.3 & 249.7 & 3.1 & 105.9 \\
\hline 08DH32-8 & 205.4 & 3.0 & 204.3 & 9.2 & 191.7 & 110.0 & 205.4 & 3.0 & 107.2 \\
\hline 08DH32-9 & 1984.0 & 10.9 & 1978.9 & 14.8 & 1973.6 & 28.0 & 1973.6 & 28.0 & 100.5 \\
\hline 08DH32-10 & 294.3 & 5.8 & 283.7 & 18.7 & 196.9 & 169.7 & 294.3 & 5.8 & 149.5 \\
\hline 08DH32-11 & 179.0 & 2.5 & 173.3 & 13.2 & 96.7 & 193.7 & 179.0 & 2.5 & 185.0 \\
\hline 08DH32-12 & 1967.7 & 14.6 & 1961.9 & 18.2 & 1955.8 & 34.1 & 1955.8 & 34.1 & 100.6 \\
\hline 08DH32-13 & 1896.6 & 9.4 & 1903.4 & 16.3 & 1910.9 & 32.5 & 1910.9 & 32.5 & 99.2 \\
\hline 08DH32-14 & 1977.7 & 8.5 & 1981.2 & 10.9 & 1984.9 & 20.5 & 1984.9 & 20.5 & 99.6 \\
\hline 08DH32-15 & 286.6 & 1.8 & 295.2 & 5.3 & 363.2 & 44.3 & 286.6 & 1.8 & 78.9 \\
\hline 08DH32-16 & 326.4 & 3.9 & 335.2 & 33.0 & 396.9 & 258.0 & 326.4 & 3.9 & 82.2 \\
\hline 08DH32-17 & 1984.1 & 16.4 & 1984.9 & 12.9 & 1985.7 & 20.1 & 1985.7 & 20.1 & 99.9 \\
\hline 08DH32-18 & 273.7 & 2.9 & 272.0 & 15.3 & 258.1 & 145.2 & 273.7 & 2.9 & 106.0 \\
\hline 08DH32-19 & 283.6 & 3.7 & 285.6 & 8.0 & 301.5 & 66.3 & 283.6 & 3.7 & 94.1 \\
\hline 08DH32-20 & 2150.9 & 45.9 & 2160.1 & 23.9 & 2168.8 & 16.0 & 2168.8 & 16.0 & 99.2 \\
\hline 08DH32-21 & 1962.7 & 23.4 & 1959.7 & 21.0 & 1956.5 & 35.4 & 1956.5 & 35.4 & 100.3 \\
\hline 08DH32-22 & 179.9 & 1.9 & 178.1 & 10.7 & 153.4 & 151.4 & 179.9 & 1.9 & 117.3 \\
\hline 08DH32-24 & 1894.9 & 9.4 & 1892.9 & 13.1 & 1890.7 & 25.4 & 1890.7 & 25.4 & 100.2 \\
\hline 08DH32-25 & 299.0 & 2.0 & 302.6 & 13.7 & 330.7 & 117.5 & 299.0 & 2.0 & 90.4 \\
\hline 08DH32-26 & 261.2 & 2.8 & 268.6 & 8.3 & 332.9 & 75.5 & 261.2 & 2.8 & 78.5 \\
\hline 08DH32-27 & 291.6 & 2.4 & 286.9 & 11.9 & 249.0 & 108.1 & 291.6 & 2.4 & 117.1 \\
\hline 08DH32-28 & 246.7 & 3.9 & 244.8 & 17.1 & 227.5 & 178.5 & 246.7 & 3.9 & 108.4 \\
\hline 08DH32-29 & 282.7 & 3.2 & 282.4 & 10.0 & 280.7 & 88.8 & 282.7 & 3.2 & 100.7 \\
\hline 08DH32-30 & 258.0 & 2.7 & 251.5 & 14.8 & 191.7 & 152.3 & 258.0 & 2.7 & 134.6 \\
\hline 08DH32-31 & 180.3 & 3.2 & 175.9 & 12.7 & 117.3 & 181.3 & 180.3 & 3.2 & 153.7 \\
\hline 08DH32-32 & 1956.1 & 25.5 & 1953.8 & 19.7 & 1951.3 & 30.4 & 1951.3 & 30.4 & 100.2 \\
\hline 08DH32-33 & 176.9 & 4.0 & 172.3 & 14.1 & 110.0 & 202.9 & 176.9 & 4.0 & 160.8 \\
\hline 08DH32-34 & 176.1 & 2.3 & 172.2 & 12.6 & 118.3 & 184.8 & 176.1 & 2.3 & 148.9 \\
\hline 08DH32-35 & 1968.2 & 10.7 & 1958.3 & 12.7 & 1947.8 & 23.6 & 1947.8 & 23.6 & 101.0 \\
\hline 08DH32-36 & 177.8 & 3.7 & 178.6 & 8.5 & 189.6 & 109.9 & 177.8 & 3.7 & 93.8 \\
\hline 08DH32-37 & 1966.3 & 33.4 & 1971.2 & 19.6 & 1976.2 & 19.4 & 1976.2 & 19.4 & 99.5 \\
\hline 08DH32-38 & 236.9 & 6.9 & 237.4 & 20.4 & 242.2 & 212.0 & 236.9 & 6.9 & 97.8 \\
\hline 08DH32-39 & 2113.8 & 17.1 & 2105.8 & 13.2 & 2097.9 & 20.2 & 2097.9 & 20.2 & 100.8 \\
\hline 08DH32-40 & 157.2 & 4.8 & 144.5 & 129.4 & -59.3 & 1033.8 & 157.2 & 4.8 & -265.3 \\
\hline 08DH32-41 & 2274.9 & 9.6 & 2314.2 & 14.7 & 2349.1 & 26.2 & 2349.1 & 26.2 & 96.8 \\
\hline 08DH32-42 & 2071.0 & 9.4 & 2072.5 & 13.6 & 2073.8 & 25.5 & 2073.8 & 25.5 & 99.9 \\
\hline 08DH32-43 & 2792.9 & 41.0 & 2780.3 & 29.5 & 2771.1 & 41.3 & 2771.1 & 41.3 & 100.8 \\
\hline 08DH32-44 & 195.1 & 18.5 & 127.7 & 96.9 & -997.7 & 2838.9 & 195.1 & 18.5 & -19.6 \\
\hline 08DH32-45 & 1876.8 & 29.6 & 1894.9 & 22.5 & 1914.7 & 33.7 & 1914.7 & 33.7 & 98.0 \\
\hline 08DH32-46 & 155.0 & 3.9 & 153.0 & 17.4 & 120.9 & 282.7 & 155.0 & 3.9 & 128.2 \\
\hline
\end{tabular}


08DH32

Isotope ratios

\begin{tabular}{|c|c|c|c|c|c|c|c|c|c|c|}
\hline Analysis & $\underset{(\mathrm{ppm})}{\mathrm{U}}$ & $\begin{array}{l}206 \mathrm{~Pb} / \\
204 \mathrm{~Pb}\end{array}$ & $\mathrm{U} / \mathrm{Th}$ & $\begin{array}{c}206 \mathrm{~Pb}^{\star} / \\
207 \mathrm{~Pb}^{\star}\end{array}$ & $\begin{array}{c} \pm \\
(\%)\end{array}$ & $\begin{array}{c}207 \mathrm{~Pb}^{*} / \\
235 \mathrm{U}^{*}\end{array}$ & $\begin{array}{c} \pm \\
(\%)\end{array}$ & $\begin{array}{c}206 \mathrm{~Pb}^{*} / \\
238 \mathrm{U}\end{array}$ & $\begin{array}{c} \pm \\
(\%)\end{array}$ & $\begin{array}{l}\text { error } \\
\text { corr. }\end{array}$ \\
\hline 08DH32-47 & 94 & 26508 & 0.6 & 8.2172 & 0.8 & 6.0388 & 1.0 & 0.3599 & 0.5 & 0.06 \\
\hline 08DH32-48 & 179 & 1698 & 0.7 & 18.2811 & 11.1 & 0.1979 & 11.3 & 0.0262 & 2.2 & 0.19 \\
\hline 08DH32-49 & 207 & 4833 & 3.5 & 20.3665 & 5.5 & 0.2003 & 5.5 & 0.0296 & 0.5 & .09 \\
\hline 08DH32-50 & 183 & 5205 & 0.9 & 19.5109 & 3.0 & 0.2910 & 3.1 & 0.0412 & 0.8 & 0.26 \\
\hline 08DH32-51 & 110 & 2049 & 1.1 & 21.8088 & 14.4 & 0.1598 & 14.9 & 0.0253 & 3.8 & .25 \\
\hline 08DH32-52 & 137 & 16854 & 1.1 & 9.1512 & 1.7 & 4.8865 & 1.8 & 0.3243 & 0.6 & .35 \\
\hline 08DH32-53 & 305 & 60492 & 2.5 & 8.1661 & 1.6 & 6.1739 & 1.6 & 0.3657 & 0.5 & 0.30 \\
\hline 08DH32-54 & 67 & 1719 & 2.1 & 25.3328 & 30.3 & 0.1424 & 30.7 & 0.0262 & 5.4 & .18 \\
\hline 08DH32-55 & 57 & 1722 & 1.1 & 19.1071 & 6.2 & 0.2850 & 7.0 & 0.0395 & 3.3 & .46 \\
\hline 08DH32-57 & 720 & 16554 & 1.2 & 19.6894 & 2.6 & 0.2976 & 2.9 & 0.0425 & 1.3 & 0.43 \\
\hline 08DH32-58 & 175 & 4008 & 0.9 & 18.7270 & 12.2 & 0.3519 & 12.2 & 0.0478 & 1.2 & 0.10 \\
\hline 08DH32-59 & 250 & 1338 & 1.7 & 14.5135 & 17.4 & 0.4912 & 17.8 & 0.0517 & 3.3 & .18 \\
\hline 08DH32-60 & 39 & 912 & 2.6 & 21.4575 & 24.8 & 0.1695 & 25.4 & 0.0264 & 5.4 & 0.21 \\
\hline 08DH32-61 & 260 & 71262 & 1.1 & 4.5024 & 1.6 & 18.2569 & 1.7 & 0.5962 & 0.7 & 0.42 \\
\hline 08DH32-62 & 131 & 2691 & 1.4 & 23.4355 & 19.3 & 0.1416 & 20.0 & 0.0241 & 5.2 & 0.26 \\
\hline $08 \mathrm{DH} 32-63$ & 220 & 25272 & 2.0 & 8.4984 & 1.6 & 4.8247 & 4.2 & 0.2974 & 3.9 & 0.93 \\
\hline 08DH32-64 & 432 & 2781 & 1.1 & 18.8593 & 4.9 & 0.1866 & 5.2 & 0.0255 & 1.9 & 0.37 \\
\hline 08DH32-65 & 275 & 5076 & 1.2 & 20.1143 & 3.1 & 0.1920 & 3.3 & 0.0280 & 1.0 & .31 \\
\hline 08DH32-67 & 287 & 3948 & 2.0 & 19.9839 & 3.7 & 0.1984 & 4.0 & 0.0287 & 1.5 & 0.38 \\
\hline 08DH32-68 & 355 & 87456 & 2.6 & 8.2203 & 1.3 & 6.0168 & 1.4 & 0.3587 & 0.5 & 0.35 \\
\hline 08DH32-69 & 181 & 39417 & 2.8 & 4.3742 & 3.4 & 17.9202 & 3.7 & 0.5685 & 1.5 & 0.39 \\
\hline 08DH32-70 & 106 & 2382 & 0.6 & 24.5071 & 26.0 & 0.1366 & 26.5 & 0.0243 & 5.4 & 0.20 \\
\hline 08DH32-71 & 113 & 4407 & 1.3 & 19.2431 & 5.9 & 0.3721 & 6.5 & 0.0519 & 2.7 & 0.41 \\
\hline 08DH32-72 & 133 & 2799 & 1.8 & 21.5465 & 12.2 & 0.1828 & 12.6 & 0.0286 & 3.0 & 0.24 \\
\hline 08DH32-73 & 457 & 98784 & 2.9 & 8.0122 & 2.4 & 6.4218 & 3.0 & 0.3732 & 1.8 & 0.59 \\
\hline 08DH32-74 & 167 & 8262 & 2.8 & 18.4658 & 2.6 & 0.4645 & 2.8 & 0.0622 & 1.1 & 0.39 \\
\hline 08DH32-75 & 425 & 87723 & 2.5 & 7.8322 & 1.5 & 6.6566 & 1.6 & 0.3781 & 0.5 & 0.32 \\
\hline 08DH32-76 & 78 & 1689 & 1.9 & 20.1127 & 10.5 & 0.1867 & 10.7 & 0.0272 & 2.1 & 0.20 \\
\hline 08DH32-77 & 67 & 1329 & 1.2 & 19.8483 & 11.1 & 0.1931 & 11.4 & 0.0278 & 2.3 & 0.21 \\
\hline 08DH32-78 & 291 & 18081 & 2.5 & 7.7171 & 1.8 & 6.9232 & 2.8 & 0.3875 & 2.1 & 0.76 \\
\hline 08DH32-79 & 69 & 1533 & 1.4 & 19.1785 & 6.2 & 0.2099 & 6.2 & 0.0292 & 0.5 & 0.08 \\
\hline 08DH32-80 & 535 & 2775 & 1.0 & 16.8239 & 9.1 & 0.2147 & 9.2 & 0.0262 & 1.3 & 0.14 \\
\hline 08DH32-81 & 177 & 4170 & 1.6 & 19.3698 & 4.4 & 0.2983 & 4.6 & 0.0419 & 1.3 & 0.28 \\
\hline 08DH32-82 & 168 & 37995 & 1.6 & 7.8196 & 1.1 & 6.7193 & 1.2 & 0.3811 & 0.5 & 0.42 \\
\hline 08DH32-83 & 115 & 3405 & 0.9 & 19.8250 & 7.4 & 0.2997 & 7.5 & 0.0431 & 1.1 & 0.14 \\
\hline 08DH32-84 & 234 & 62115 & 2.5 & 7.8483 & 1.1 & 6.6184 & 1.2 & 0.3767 & 0.7 & 0.53 \\
\hline 08DH32-85 & 95 & 1845 & 1.6 & 20.3732 & 10.8 & 0.1869 & 10.9 & 0.0276 & 1.0 & 0.09 \\
\hline 08DH32-86 & 886 & 23799 & 5.1 & 8.0768 & 1.2 & 6.1817 & 2.4 & 0.3621 & 2.1 & 0.86 \\
\hline 08DH32-87 & 156 & 35784 & 2.8 & 6.5464 & 1.4 & 9.4003 & 1.7 & 0.4463 & 0.9 & 0.53 \\
\hline 08DH32-88 & 121 & 43425 & 1.4 & 5.2135 & 1.0 & 14.1783 & 3.1 & 0.5361 & 2.9 & 0.95 \\
\hline 08DH32-89 & 214 & 3132 & 0.8 & 20.6457 & 8.4 & 0.1804 & 8.5 & 0.0270 & 1.5 & 0.18 \\
\hline 08DH32-90 & 55 & 1038 & 1.3 & 22.0525 & 22.3 & 0.1316 & 23.2 & 0.0210 & 6.3 & 0.27 \\
\hline 08DH32-91 & 870 & 10563 & 0.9 & 19.6679 & 2.6 & 0.2837 & 2.9 & 0.0405 & 1.3 & 0.43 \\
\hline 08DH32-92 & 56 & 8523 & 1.3 & 8.1978 & 3.1 & 6.1851 & 3.1 & 0.3677 & 0.5 & 0.16 \\
\hline 08DH32-93 & 136 & 5025 & 0.9 & 19.1052 & 3.5 & 0.3504 & 3.6 & 0.0486 & 0.7 & 0.20 \\
\hline
\end{tabular}


08DH32

Apparent ages (Ma)

\begin{tabular}{|c|c|c|c|c|c|c|c|c|c|}
\hline Analysis & $\begin{array}{c}206 \mathrm{~Pb}^{*} / \\
238 \mathrm{U}^{*}\end{array}$ & $\stackrel{ \pm}{(\mathrm{Ma})}$ & $\begin{array}{c}207 \mathrm{~Pb}^{*} / \\
235 \mathrm{U}\end{array}$ & $\stackrel{ \pm}{(\mathrm{Ma})}$ & $\begin{array}{l}206 \mathrm{~Pb}^{\star} / \\
207 \mathrm{~Pb}^{*}\end{array}$ & $\begin{array}{c} \pm \\
(\mathrm{Ma})\end{array}$ & $\begin{array}{c}\text { Best age } \\
\quad(\mathrm{Ma})\end{array}$ & $\stackrel{ \pm}{(\mathrm{Ma})}$ & $\begin{array}{c}\text { Conc } \\
(\%)\end{array}$ \\
\hline 08DH32-47 & 1981.7 & 8.5 & 1981.5 & 8.4 & 1981.2 & 14.8 & 1981.2 & 14.8 & 100.0 \\
\hline 08DH32-48 & 167.0 & 3.6 & 183.4 & 19.0 & 400.0 & 249.7 & 167.0 & 3.6 & 41.7 \\
\hline 08DH32-49 & 187.9 & 0.9 & 185.3 & 9.4 & 152.6 & 129.4 & 187.9 & 0.9 & 123.1 \\
\hline 08DH32-50 & 260.2 & 2.1 & 259.4 & 7.2 & 252.3 & 70.0 & 260.2 & 2.1 & 103.1 \\
\hline 08DH32-51 & 161.0 & 6.0 & 150.6 & 20.9 & -10.1 & 350.3 & 161.0 & 6.0 & -1595.8 \\
\hline 08DH32-52 & 1810.8 & 9.9 & 1799.9 & 15.2 & 1787.3 & 30.8 & 1787.3 & 30.8 & 101.3 \\
\hline 08DH32-53 & 2008.9 & 8.6 & 2000.8 & 14.4 & 1992.3 & 27.9 & 1992.3 & 27.9 & 100.8 \\
\hline 08DH32-54 & 166.5 & 8.9 & 135.2 & 38.9 & -385.2 & 802.2 & 166.5 & 8.9 & -43.2 \\
\hline 08DH32-55 & 249.7 & 8.0 & 254.6 & 15.8 & 300.2 & 142.1 & 249.7 & 8.0 & 83.2 \\
\hline 08DH32-57 & 268.3 & 3.3 & 264.5 & 6.8 & 231.2 & 61.1 & 268.3 & 3.3 & 116.0 \\
\hline 08DH32-58 & 301.0 & 3.6 & 306.1 & 32.3 & 345.8 & 276.1 & 301.0 & 3.6 & 87.0 \\
\hline 08DH32-59 & 325.0 & 10.4 & 405.7 & 59.4 & 895.8 & 362.6 & 325.0 & 10.4 & 36.3 \\
\hline 08DH32-60 & 167.9 & 9.0 & 159.0 & 37.4 & 29.0 & 603.0 & 167.9 & 9.0 & 578.9 \\
\hline 08DH32-61 & 3014.4 & 17.6 & 3003.4 & 16.8 & 2996.0 & 25.6 & 2996.0 & 25.6 & 100.6 \\
\hline 08DH32-62 & 153.3 & 7.9 & 134.5 & 25.2 & -186.8 & 485.8 & 153.3 & 7.9 & -82.1 \\
\hline 08DH32-63 & 1678.3 & 58.1 & 1789.2 & 35.6 & 1921.1 & 28.2 & 1921.1 & 28.2 & 87.4 \\
\hline 08DH32-64 & 162.5 & 3.1 & 173.7 & 8.4 & 329.8 & 110.4 & 162.5 & 3.1 & 49.3 \\
\hline 08DH32-65 & 178.1 & 1.8 & 178.3 & 5.4 & 181.7 & 73.0 & 178.1 & 1.8 & 98.0 \\
\hline 08DH32-67 & 182.7 & 2.7 & 183.7 & 6.7 & 196.9 & 85.5 & 182.7 & 2.7 & 92.8 \\
\hline 08DH32-68 & 1976.1 & 8.5 & 1978.3 & 12.3 & 1980.5 & 23.5 & 1980.5 & 23.5 & 99.8 \\
\hline 08DH32-69 & 2901.7 & 34.3 & 2985.5 & 36.0 & 3042.3 & 55.1 & 3042.3 & 55.1 & 95.4 \\
\hline 08DH32-70 & 154.6 & 8.2 & 130.0 & 32.4 & -299.8 & 673.3 & 154.6 & 8.2 & -51.6 \\
\hline 08DH32-71 & 326.4 & 8.6 & 321.2 & 18.0 & 283.9 & 136.2 & 326.4 & 8.6 & 115.0 \\
\hline 08DH32-72 & 181.6 & 5.4 & 170.5 & 19.8 & 19.1 & 294.8 & 181.6 & 5.4 & 952.9 \\
\hline 08DH32-73 & 2044.3 & 30.8 & 2035.3 & 26.0 & 2026.1 & 42.2 & 2026.1 & 42.2 & 100.9 \\
\hline 08DH32-74 & 389.0 & 4.2 & 387.4 & 9.1 & 377.4 & 58.7 & 389.0 & 4.2 & 103.1 \\
\hline 08DH32-75 & 2067.5 & 8.8 & 2066.9 & 13.9 & 2066.2 & 26.3 & 2066.2 & 26.3 & 100.1 \\
\hline 08DH32-76 & 173.2 & 3.7 & 173.8 & 17.2 & 181.9 & 245.9 & 173.2 & 3.7 & 95.2 \\
\hline 08DH32-77 & 176.8 & 4.1 & 179.3 & 18.7 & 212.6 & 258.1 & 176.8 & 4.1 & 83.1 \\
\hline 08DH32-78 & 2111.2 & 38.3 & 2101.6 & 24.9 & 2092.3 & 32.0 & 2092.3 & 32.0 & 100.9 \\
\hline 08DH32-79 & 185.5 & 0.9 & 193.5 & 10.9 & 291.7 & 141.5 & 185.5 & 0.9 & 63.6 \\
\hline 08DH32-80 & 166.7 & 2.1 & 197.5 & 16.6 & 583.2 & 198.8 & 166.7 & 2.1 & 28.6 \\
\hline 08DH32-81 & 264.7 & 3.4 & 265.1 & 10.8 & 268.9 & 101.7 & 264.7 & 3.4 & 98.4 \\
\hline 08DH32-82 & 2081.3 & 8.9 & 2075.2 & 10.4 & 2069.1 & 18.9 & 2069.1 & 18.9 & 100.6 \\
\hline 08DH32-83 & 272.0 & 2.9 & 266.2 & 17.6 & 215.4 & 172.1 & 272.0 & 2.9 & 126.3 \\
\hline 08DH32-84 & 2061.0 & 11.6 & 2061.8 & 11.0 & 2062.6 & 18.7 & 2062.6 & 18.7 & 99.9 \\
\hline 08DH32-85 & 175.6 & 1.7 & 174.0 & 17.4 & 151.8 & 254.6 & 175.6 & 1.7 & 115.6 \\
\hline 08DH32-86 & 1992.2 & 35.6 & 2001.9 & 21.1 & 2011.8 & 21.8 & 2011.8 & 21.8 & 99.0 \\
\hline 08DH32-87 & 2378.9 & 17.9 & 2377.9 & 15.6 & 2377.0 & 24.5 & 2377.0 & 24.5 & 100.1 \\
\hline 08DH32-88 & 2767.1 & 65.9 & 2761.7 & 29.4 & 2757.7 & 16.6 & 2757.7 & 16.6 & 100.3 \\
\hline 08DH32-89 & 171.9 & 2.6 & 168.4 & 13.2 & 120.6 & 197.2 & 171.9 & 2.6 & 142.5 \\
\hline 08DH32-90 & 134.3 & 8.4 & 125.5 & 27.4 & -37.0 & 546.6 & 134.3 & 8.4 & -363.1 \\
\hline 08DH32-91 & 255.7 & 3.1 & 253.6 & 6.5 & 233.8 & 60.4 & 255.7 & 3.1 & 109.4 \\
\hline 08DH32-92 & 2018.8 & 8.7 & 2002.3 & 27.3 & 1985.4 & 54.9 & 1985.4 & 54.9 & 101.7 \\
\hline 08DH32-93 & 305.6 & 2.1 & 305.0 & 9.4 & 300.4 & 79.6 & 305.6 & 2.1 & 101.7 \\
\hline
\end{tabular}


08DH32

Isotope ratios

$\begin{array}{ccccccccccc}\text { Analysis } & \begin{array}{c}\mathrm{U} \\ (\mathrm{ppm})\end{array} & \begin{array}{c}206 \mathrm{~Pb} / \\ 204 \mathrm{~Pb}\end{array} & \begin{array}{l}\mathrm{U} / \mathrm{Th} \\ \end{array} & \begin{array}{c}206 \mathrm{~Pb}^{*} / \\ 207 \mathrm{~Pb}^{*}\end{array} & \begin{array}{c} \pm \\ (\%)\end{array} & \begin{array}{c}207 \mathrm{~Pb}^{*} / \\ 235 \mathrm{U}^{*}\end{array} & \begin{array}{c} \pm \\ (\%)\end{array} & \begin{array}{c}206 \mathrm{~Pb}^{*} / \\ 238 U\end{array} & \begin{array}{c} \pm \\ (\%)\end{array} & \begin{array}{c}\text { error } \\ \text { corr. }\end{array} \\ \text { 08DH32-94 } & 107 & 5235 & 1.5 & 19.2944 & 5.8 & 0.3873 & 6.4 & 0.0542 & 2.6 & 0.41 \\ \text { 08DH32-95 } & 351 & 4716 & 1.7 & 20.3955 & 3.5 & 0.1675 & 3.6 & 0.0248 & 0.9 & 0.24 \\ \text { 08DH32-96 } & 155 & 45834 & 1.7 & 5.1278 & 1.2 & 14.5646 & 1.3 & 0.5417 & 0.5 & 0.39 \\ \text { 08DH32-97 } & 148 & 5943 & 1.1 & 18.9450 & 4.2 & 0.3878 & 4.5 & 0.0533 & 1.4 & 0.32 \\ \text { 08DH32-98 } & 223 & 66885 & 2.2 & 8.2240 & 1.2 & 6.0365 & 1.3 & 0.3601 & 0.5 & 0.38 \\ \text { 08DH32-100 } & 46 & 1338 & 0.8 & 19.8002 & 13.6 & 0.2552 & 14.2 & 0.0367 & 4.0 & 0.28 \\ \text { 08DH32-102 } & 67 & 2043 & 2.2 & 20.0654 & 12.4 & 0.3085 & 12.5 & 0.0449 & 1.6 & 0.13 \\ \text { 08DH32-103 } & 93 & 19728 & 1.8 & 8.2352 & 1.6 & 6.0040 & 1.7 & 0.3586 & 0.6 & 0.34 \\ \text { 08DH32-104 } & 272 & 45567 & 3.3 & 7.8909 & 1.4 & 6.5606 & 1.6 & 0.3755 & 0.8 & 0.48 \\ \text { 08DH32-105 } & 609 & 10575 & 4.5 & 8.1769 & 1.9 & 4.3816 & 4.8 & 0.2598 & 4.4 & 0.92 \\ \text { 08DH32-106 } & 154 & 3900 & 1.5 & 18.3627 & 2.9 & 0.4046 & 3.0 & 0.0539 & 1.0 & 0.32 \\ \text { 08DH32-107 } & 33 & 1068 & 0.5 & 18.9477 & 12.7 & 0.3233 & 12.7 & 0.0444 & 0.9 & 0.07 \\ \text { 08DH32-109 } & 104 & 2127 & 0.9 & 21.1265 & 11.7 & 0.1745 & 11.8 & 0.0267 & 1.1 & 0.10 \\ \text { 08DH32-110 } & 170 & 49356 & 2.6 & 8.1013 & 1.5 & 6.2430 & 1.9 & 0.3668 & 1.3 & 0.66\end{array}$

08DH32

Apparent ages (Ma)

$\begin{array}{cccccccccc}\text { Analysis } & \begin{array}{c}206 \mathrm{~Pb}^{*} \\ 238 \mathrm{U}^{*}\end{array} & \begin{array}{c} \pm \\ (\mathrm{Ma})\end{array} & \begin{array}{c}207 \mathrm{~Pb}^{*} / \\ 235 \mathrm{U}\end{array} & \begin{array}{c} \pm \\ (\mathrm{Ma})\end{array} & \begin{array}{c}206 \mathrm{~Pb}^{*} / \\ 207 \mathrm{~Pb}^{*}\end{array} & \begin{array}{c} \pm \\ (\mathrm{Ma})\end{array} & \begin{array}{c}\text { Best age } \\ (\mathrm{Ma})\end{array} & \begin{array}{c} \pm \\ (\mathrm{Ma})\end{array} & \begin{array}{c}\text { Conc } \\ (\%)\end{array} \\ \text { 08DH32-94 } & 340.2 & 8.7 & 332.4 & 18.1 & 277.9 & 133.2 & 340.2 & 8.7 & 122.4 \\ \text { 08DH32-95 } & 157.8 & 1.4 & 157.3 & 5.2 & 149.3 & 81.9 & 157.8 & 1.4 & 105.7 \\ \text { 08DH32-96 } & 2790.4 & 11.3 & 2787.2 & 12.1 & 2784.9 & 19.2 & 2784.9 & 19.2 & 100.2 \\ \text { 08DH32-97 } & 334.7 & 4.7 & 332.8 & 12.6 & 319.6 & 95.8 & 334.7 & 4.7 & 104.7 \\ \text { 08DH32-98 } & 1982.4 & 8.5 & 1981.1 & 11.5 & 1979.8 & 21.7 & 1979.8 & 21.7 & 100.1 \\ \text { 08DH32-100 } & 232.0 & 9.1 & 230.8 & 29.3 & 218.3 & 316.3 & 232.0 & 9.1 & 106.3 \\ \text { 08DH32-102 } & 283.1 & 4.5 & 273.0 & 29.9 & 187.4 & 288.9 & 283.1 & 4.5 & 151.1 \\ \text { 08DH32-103 } & 1975.5 & 9.9 & 1976.4 & 15.0 & 1977.3 & 28.9 & 1977.3 & 28.9 & 99.9 \\ \text { 08DH32-104 } & 2055.1 & 13.9 & 2054.1 & 14.4 & 2053.1 & 25.3 & 2053.1 & 25.3 & 100.1 \\ \text { 08DH32-105 } & 1489.1 & 58.2 & 1708.9 & 39.5 & 1990.0 & 34.0 & 1990.0 & 34.0 & 74.8 \\ \text { 08DH32-106 } & 338.3 & 3.2 & 345.0 & 8.8 & 390.0 & 64.1 & 338.3 & 3.2 & 86.7 \\ \text { 08DH32-107 } & 280.2 & 2.6 & 284.4 & 31.5 & 319.2 & 288.6 & 280.2 & 2.6 & 87.8 \\ \text { 08DH32-109 } & 170.1 & 1.9 & 163.3 & 17.8 & 66.1 & 280.0 & 170.1 & 1.9 & 257.3 \\ \text { 08DH32-110 } & 2014.4 & 22.1 & 2010.5 & 17.0 & 2006.5 & 25.9 & 2006.5 & 25.9 & 100.4\end{array}$


08DH33

Isotope ratios

\begin{tabular}{|c|c|c|c|c|c|c|c|c|c|c|}
\hline Analysis & $\underset{(\mathrm{ppm})}{\mathrm{U}}$ & $\begin{array}{l}206 \mathrm{~Pb} / \\
204 \mathrm{~Pb}\end{array}$ & U/Th & $\begin{array}{l}206 \mathrm{~Pb}^{*} / \\
207 \mathrm{~Pb}^{*}\end{array}$ & $\begin{array}{c} \pm \\
(\%)\end{array}$ & $\begin{array}{c}207 \mathrm{~Pb}^{*} / \\
235 \mathrm{U}^{*}\end{array}$ & $\begin{array}{l} \pm \\
(\%)\end{array}$ & $\begin{array}{c}206 \mathrm{~Pb}^{*} / \\
238 \mathrm{U}\end{array}$ & $\begin{array}{l} \pm \\
(\%)\end{array}$ & $\begin{array}{l}\text { error } \\
\text { corr. }\end{array}$ \\
\hline 08DH33-1 & 55 & 3828 & 1.9 & 17.1072 & 3.5 & 0.6900 & 3.7 & 0.0856 & 1.3 & 0.35 \\
\hline 08DH33-2 & 615 & 14895 & 3.0 & 8.4158 & 6.7 & 5.2466 & 6.8 & 0.3202 & 1.1 & .16 \\
\hline 08DH33-3 & 864 & 20412 & 2.4 & 7.3494 & 1.7 & 7.5898 & 1.8 & 0.4046 & 0.7 & .38 \\
\hline 08DH33-4 & 135 & 44541 & 10.9 & 5.5633 & 1.5 & 12.6073 & 1.6 & 0.5087 & 0.5 & 31 \\
\hline $08 \mathrm{DH} 33-5$ & 322 & 12345 & 1.4 & 17.4447 & 2.1 & 0.6590 & 2.1 & 0.0834 & 0.5 & .24 \\
\hline 08DH33-6 & 232 & 14073 & 2.0 & 14.9527 & 1.6 & 1.2441 & 2.1 & 0.1349 & 1.4 & .65 \\
\hline 08DH33-7 & 373 & 51996 & 0.5 & 8.5715 & 1.6 & 5.6209 & 1.8 & 0.3494 & 0.9 & 0.49 \\
\hline 08DH33-8 & 368 & 53754 & 4.4 & 6.1547 & 1.7 & 9.6404 & 2.2 & 0.4303 & 1.4 & .62 \\
\hline 08DH33-9 & 265 & 11604 & 2.0 & 8.8797 & 1.6 & 4.4713 & 4.2 & 0.2880 & 3.9 & .93 \\
\hline 08DH33-10 & 344 & 56472 & 3.7 & 8.9652 & 1.2 & 4.6952 & 1.4 & 0.3053 & 0.8 & .53 \\
\hline 08DH33-11 & 859 & 37605 & 1.2 & 17.3425 & 1.4 & 0.6939 & 1.5 & 0.0873 & 0.5 & 0.33 \\
\hline $08 \mathrm{DH} 33-12$ & 187 & 5871 & 1.2 & 19.7932 & 5.3 & 0.2678 & 5.3 & 0.0384 & 0.5 & 0.09 \\
\hline $08 \mathrm{DH} 33-13$ & 305 & 16353 & 3.0 & 17.7107 & 1.9 & 0.6152 & 2.2 & 0.0790 & 1.2 & .53 \\
\hline 08DH33-14 & 195 & 14292 & 4.6 & 17.4694 & 1.9 & 0.6554 & 2.1 & 0.0830 & 0.7 & .35 \\
\hline 08DH33-15 & 142 & 6891 & 1.4 & 17.9749 & 5.4 & 0.5648 & 5.6 & 0.0736 & 1.3 & 0.23 \\
\hline 08DH33-16 & 264 & 15180 & 1.5 & 18.6681 & 12.2 & 0.5198 & 12.4 & 0.0704 & 2.6 & .21 \\
\hline $08 \mathrm{DH} 33-17$ & 558 & 9006 & 2.2 & 18.4423 & 2.5 & 0.3838 & 3.2 & 0.0513 & 2.1 & 0.65 \\
\hline 08DH33-18 & 103 & 12612 & 1.2 & 13.8807 & 2.0 & 1.6355 & 2.0 & 0.1647 & 0.5 & 0.24 \\
\hline 08DH33-19 & 274 & 9285 & 1.4 & 19.9456 & 4.1 & 0.2653 & 4.3 & 0.0384 & 1.3 & .30 \\
\hline 08DH33-20 & 112 & 4218 & 0.8 & 18.7513 & 7.7 & 0.3675 & 8.0 & 0.0500 & 2.4 & .30 \\
\hline 08DH33-21 & 121 & 55620 & 1.9 & 5.2900 & 1.5 & 13.8642 & 1.6 & 0.5319 & 0.7 & 0.43 \\
\hline 08DH33-22 & 121 & 7917 & 1.3 & 17.8291 & 3.2 & 0.5769 & 3.5 & 0.0746 & 1.5 & 0.41 \\
\hline 08DH33-23 & 157 & 4629 & 0.9 & 19.7980 & 7.1 & 0.2964 & 7.2 & 0.0426 & 0.9 & .13 \\
\hline 08DH33-24 & 240 & 14868 & 2.5 & 17.9854 & 1.7 & 0.5480 & 2.3 & 0.0715 & 1.5 & 0.66 \\
\hline 08DH33-25 & 144 & 6912 & 1.5 & 19.5608 & 6.2 & 0.3678 & 6.4 & 0.0522 & 1.4 & 0.22 \\
\hline 08DH33-26 & 501 & 15048 & 2.3 & 18.8958 & 1.6 & 0.3399 & 2.1 & 0.0466 & 1.4 & 0.64 \\
\hline $08 \mathrm{DH} 33-27$ & 364 & 40614 & 1.8 & 8.9122 & 1.3 & 4.6859 & 1.7 & 0.3029 & 1.1 & 0.66 \\
\hline 08DH33-29 & 575 & 15588 & 1.5 & 19.1734 & 2.5 & 0.3366 & 2.6 & 0.0468 & 0.7 & 0.27 \\
\hline 08DH33-30 & 125 & 4968 & 1.3 & 19.6453 & 9.4 & 0.3349 & 9.5 & 0.0477 & 1.1 & 0.11 \\
\hline 08DH33-32 & 115 & 7821 & 1.2 & 17.5109 & 3.5 & 0.6328 & 3.6 & 0.0804 & 0.9 & 0.25 \\
\hline 08DH33-33 & 429 & 13203 & 0.7 & 19.5023 & 4.1 & 0.3172 & 4.3 & 0.0449 & 1.4 & 0.32 \\
\hline 08DH33-34 & 440 & 17175 & 1.4 & 19.2632 & 2.9 & 0.3622 & 3.7 & 0.0506 & 2.2 & 0.61 \\
\hline 08DH33-35 & 311 & 5775 & 1.1 & 19.0172 & 3.3 & 0.2674 & 5.0 & 0.0369 & 3.8 & 0.76 \\
\hline $08 \mathrm{DH} 33-36$ & 650 & 29559 & 3.4 & 17.4213 & 1.8 & 0.6647 & 1.9 & 0.0840 & 0.5 & 0.29 \\
\hline 08DH33-38 & 168 & 10221 & 1.1 & 17.5734 & 3.4 & 0.6461 & 3.4 & 0.0824 & 0.6 & 0.19 \\
\hline 08DH33-39 & 101 & 3759 & 1.6 & 19.4419 & 5.3 & 0.3351 & 6.0 & 0.0472 & 2.8 & 0.47 \\
\hline 08DH33-40 & 133 & 2790 & 1.4 & 20.5718 & 11.6 & 0.2539 & 12.0 & 0.0379 & 2.9 & 0.24 \\
\hline 08DH33-41 & 203 & 10944 & 1.7 & 17.3544 & 2.0 & 0.6459 & 2.6 & 0.0813 & 1.6 & 0.63 \\
\hline $08 \mathrm{DH} 33-42$ & 330 & 10560 & 1.5 & 19.1442 & 2.9 & 0.3517 & 3.0 & 0.0488 & 0.7 & 0.25 \\
\hline $08 \mathrm{DH} 33-43$ & 129 & 5952 & 1.3 & 19.0699 & 7.5 & 0.4165 & 8.0 & 0.0576 & 2.8 & 0.35 \\
\hline 08DH33-44 & 236 & 14931 & 2.1 & 17.4233 & 1.6 & 0.6275 & 1.9 & 0.0793 & 1.1 & 0.54 \\
\hline 08DH33-45 & 338 & 11313 & 0.6 & 18.2850 & 3.3 & 0.4600 & 3.3 & 0.0610 & 0.5 & 0.15 \\
\hline 08DH33-46 & 477 & 3771 & 0.8 & 19.1864 & 4.1 & 0.3436 & 4.1 & 0.0478 & 0.5 & 0.12 \\
\hline 08DH33-47 & 92 & 5292 & 0.7 & 17.5191 & 4.8 & 0.6721 & 5.0 & 0.0854 & 1.3 & 0.26 \\
\hline 08DH33-48 & 112 & 9342 & 1.1 & 14.6880 & 2.3 & 1.3805 & 2.3 & 0.1471 & 0.5 & 0.22 \\
\hline
\end{tabular}


08DH33

Apparent ages (Ma)

\begin{tabular}{|c|c|c|c|c|c|c|c|c|c|}
\hline Analysis & $\begin{array}{c}206 \mathrm{~Pb}^{*} / \\
238 \mathrm{U}^{*}\end{array}$ & $\stackrel{ \pm}{(\mathrm{Ma})}$ & $\begin{array}{c}207 \mathrm{~Pb}^{*} / \\
235 \mathrm{U}\end{array}$ & $\stackrel{ \pm}{(\mathrm{Ma})}$ & $\begin{array}{l}206 \mathrm{~Pb}^{*} / \\
207 \mathrm{~Pb}^{*}\end{array}$ & $\stackrel{ \pm}{(\mathrm{Ma})}$ & $\begin{array}{c}\text { Best age } \\
\quad(\mathrm{Ma})\end{array}$ & $\begin{array}{c} \pm \\
(\mathrm{Ma})\end{array}$ & $\begin{array}{c}\text { Conc } \\
(\%)\end{array}$ \\
\hline 08DH33-1 & 529.5 & 6.7 & 532.8 & 15.3 & 546.8 & 75.6 & 529.5 & 6.7 & 96.8 \\
\hline 08DH33-2 & 1790.9 & 17.5 & 1860.2 & 58.0 & 1938.6 & 120.1 & 1938.6 & 120.1 & 92.4 \\
\hline 08DH33-3 & 2190.0 & 12.6 & 2183.7 & 16.3 & 2177.7 & 29.3 & 2177.7 & 29.3 & 100.6 \\
\hline 08DH33-4 & 2651.0 & 10.9 & 2650.8 & 15.1 & 2650.5 & 25.4 & 2650.5 & 25.4 & 100.0 \\
\hline 08DH33-5 & 516.3 & 2.5 & 514.0 & 8.5 & 504.0 & 45.3 & 516.3 & 2.5 & 102.4 \\
\hline 08DH33-6 & 815.9 & 10.6 & 820.7 & 11.9 & 834.0 & 33.5 & 815.9 & 10.6 & 97.8 \\
\hline 08DH33-7 & 1931.9 & 14.7 & 1919.3 & 15.4 & 1905.7 & 28.0 & 1905.7 & 28.0 & 101.4 \\
\hline 08DH33-8 & 2307.2 & 26.4 & 2401.0 & 20.3 & 2481.6 & 29.3 & 2481.6 & 29.3 & 93.0 \\
\hline 08DH33-9 & 1631.3 & 55.5 & 1725.7 & 34.5 & 1842.0 & 28.1 & 1842.0 & 28.1 & 88.6 \\
\hline 08DH33-10 & 1717.5 & 11.3 & 1766.4 & 11.8 & 1824.7 & 21.8 & 1824.7 & 21.8 & 94.1 \\
\hline 08DH33-11 & 539.4 & 2.6 & 535.1 & 6.2 & 516.9 & 31.0 & 539.4 & 2.6 & 104.3 \\
\hline 08DH33-12 & 243.2 & 1.2 & 240.9 & 11.3 & 219.1 & 122.0 & 243.2 & 1.2 & 111.0 \\
\hline 08DH33-113 & 490.3 & 5.5 & 486.8 & 8.6 & 470.6 & 41.6 & 490.3 & 5.5 & 104.2 \\
\hline 08DH33-14 & 514.2 & 3.6 & 511.8 & 8.3 & 500.9 & 42.8 & 514.2 & 3.6 & 102.7 \\
\hline 08DH33-15 & 458.0 & 5.6 & 454.7 & 20.5 & 437.7 & 121.2 & 458.0 & 5.6 & 104.6 \\
\hline 08DH33-16 & 438.4 & 11.0 & 425.0 & 43.2 & 352.9 & 275.7 & 438.4 & 11.0 & 124.2 \\
\hline 08DH33-17 & 322.7 & 6.7 & 329.8 & 9.1 & 380.3 & 55.1 & 322.7 & 6.7 & 84.8 \\
\hline 08DH33-18 & 982.6 & 4.6 & 984.0 & 12.9 & 987.1 & 40.4 & 987.1 & 40.4 & 99.5 \\
\hline 08DH33-19 & 242.7 & 3.0 & 238.9 & 9.1 & 201.3 & 94.7 & 242.7 & 3.0 & 120.6 \\
\hline 08DH33-20 & 314.4 & 7.4 & 317.8 & 22.0 & 342.8 & 174.0 & 314.4 & 7.4 & 91.7 \\
\hline 08DH33-21 & 2749.5 & 15.4 & 2740.5 & 15.3 & 2733.8 & 24.0 & 2733.8 & 24.0 & 100.6 \\
\hline 08DH33-22 & 463.8 & 6.5 & 462.5 & 13.0 & 455.9 & 70.7 & 463.8 & 6.5 & 101.7 \\
\hline 08DH33-23 & 268.7 & 2.4 & 263.6 & 16.7 & 218.5 & 165.0 & 268.7 & 2.4 & 122.9 \\
\hline 08DH33-24 & 445.1 & 6.4 & 443.7 & 8.2 & 436.4 & 38.2 & 445.1 & 6.4 & 102.0 \\
\hline 08DH33-25 & 327.9 & 4.5 & 318.1 & 17.4 & 246.4 & 142.9 & 327.9 & 4.5 & 133.1 \\
\hline 08DH33-26 & 293.5 & 3.9 & 297.1 & 5.5 & 325.5 & 37.2 & 293.5 & 3.9 & 90.2 \\
\hline 08DH33-27 & 1705.6 & 16.3 & 1764.7 & 13.9 & 1835.4 & 22.7 & 1835.4 & 22.7 & 92.9 \\
\hline 08DH33-29 & 294.9 & 2.0 & 294.6 & 6.6 & 292.2 & 56.9 & 294.9 & 2.0 & 100.9 \\
\hline 08DH33-30 & 300.5 & 3.1 & 293.3 & 24.1 & 236.4 & 217.4 & 300.5 & 3.1 & 127.1 \\
\hline 08DH33-32 & 498.3 & 4.4 & 497.9 & 14.2 & 495.7 & 77.0 & 498.3 & 4.4 & 100.5 \\
\hline 08DH33-33 & 283.0 & 3.8 & 279.8 & 10.6 & 253.3 & 94.0 & 283.0 & 3.8 & 111.7 \\
\hline 08DH33-34 & 318.2 & 7.0 & 313.9 & 9.9 & 281.6 & 66.4 & 318.2 & 7.0 & 113.0 \\
\hline 08DH33-35 & 233.5 & 8.8 & 240.6 & 10.8 & 310.9 & 75.0 & 233.5 & 8.8 & 75.1 \\
\hline 08DH33-36 & 519.9 & 2.7 & 517.5 & 7.5 & 506.9 & 39.2 & 519.9 & 2.7 & 102.6 \\
\hline 08DH33-38 & 510.2 & 3.1 & 506.1 & 13.7 & 487.8 & 74.7 & 510.2 & 3.1 & 104.6 \\
\hline 08DH33-39 & 297.6 & 8.3 & 293.4 & 15.3 & 260.4 & 121.1 & 297.6 & 8.3 & 114.3 \\
\hline 08DH33-40 & 239.7 & 6.8 & 229.7 & 24.6 & 129.1 & 273.5 & 239.7 & 6.8 & 185.7 \\
\hline 08DH33-41 & 503.8 & 7.8 & 505.9 & 10.2 & 515.4 & 44.0 & 503.8 & 7.8 & 97.8 \\
\hline 08DH33-42 & 307.3 & 2.2 & 306.0 & 7.9 & 295.7 & 65.9 & 307.3 & 2.2 & 103.9 \\
\hline 08DH33-43 & 361.0 & 9.9 & 353.5 & 23.8 & 304.6 & 170.3 & 361.0 & 9.9 & 118.5 \\
\hline 08DH33-44 & 491.9 & 5.0 & 494.5 & 7.6 & 506.7 & 35.7 & 491.9 & 5.0 & 97.1 \\
\hline 08DH33-45 & 381.7 & 1.9 & 384.3 & 10.6 & 399.5 & 73.4 & 381.7 & 1.9 & 95.5 \\
\hline 08DH33-46 & 301.1 & 1.5 & 299.9 & 10.6 & 290.7 & 92.7 & 301.1 & 1.5 & 103.6 \\
\hline 08DH33-47 & 528.3 & 6.6 & 522.0 & 20.2 & 494.7 & 105.5 & 528.3 & 6.6 & 106.8 \\
\hline 08DH33-48 & 884.5 & 4.1 & 880.6 & 13.7 & 871.1 & 46.9 & 884.5 & 4.1 & 101.5 \\
\hline
\end{tabular}


08DH33

Isotope ratios

\begin{tabular}{|c|c|c|c|c|c|c|c|c|c|c|}
\hline Analysis & $\underset{(\mathrm{ppm})}{\mathrm{U}}$ & $\begin{array}{l}206 \mathrm{~Pb} / \\
204 \mathrm{~Pb}\end{array}$ & $\mathrm{U} / \mathrm{Th}$ & $\begin{array}{c}206 \mathrm{~Pb}^{\star} / \\
207 \mathrm{~Pb}^{\star}\end{array}$ & $\begin{array}{l} \pm \\
(\%)\end{array}$ & $\begin{array}{c}207 \mathrm{~Pb}^{*} / \\
235 \mathrm{U}^{*}\end{array}$ & $\begin{array}{c} \pm \\
(\%)\end{array}$ & $\begin{array}{c}206 \mathrm{~Pb}^{*} / \\
238 \mathrm{U}\end{array}$ & $\begin{array}{c} \pm \\
(\%)\end{array}$ & $\begin{array}{l}\text { error } \\
\text { corr. }\end{array}$ \\
\hline 08DH33-49 & 174 & 4416 & 0.8 & 19.8984 & 4.8 & 0.2729 & 4.9 & 0.0394 & 1.3 & 0.26 \\
\hline 08DH33-51 & 195 & 7416 & 1.3 & 18.0813 & 2.8 & 0.5035 & 3.9 & 0.0660 & 2.8 & 0.71 \\
\hline 08DH33-52 & 144 & 8241 & 1.7 & 17.8497 & 4.3 & 0.6254 & 4.5 & 0.0810 & 1.3 & 0.29 \\
\hline 08DH33-53 & 877 & 17313 & 2.1 & 19.3015 & 1.6 & 0.2993 & 1.6 & 0.0419 & 0.5 & 0.31 \\
\hline 08DH33-54 & 390 & 24201 & 2.1 & 17.2424 & 1.6 & 0.6790 & 1.6 & 0.0849 & 0.5 & .31 \\
\hline 08DH33-55 & 66 & 6984 & 1.5 & 15.6746 & 2.9 & 1.0578 & 3.0 & 0.1202 & 0.7 & 0.23 \\
\hline 08DH33-56 & 93 & 5715 & 2.0 & 17.2520 & 4.3 & 0.7127 & 4.4 & 0.0892 & 0.9 & 0.21 \\
\hline 08DH33-57 & 837 & 918 & 1.2 & 9.0672 & 38.1 & 0.7549 & 38.3 & 0.0496 & 3.9 & .10 \\
\hline 08DH33-58 & 151 & 4443 & 0.9 & 20.4352 & 8.6 & 0.2834 & 8.7 & 0.0420 & 1.1 & .13 \\
\hline 08DH33-59 & 422 & 1731 & 1.4 & 13.5497 & 2.9 & 0.5495 & 3.0 & 0.0540 & 0.7 & 0.24 \\
\hline 08DH33-60 & 605 & 15501 & 0.5 & 18.8501 & 1.7 & 0.3618 & 1.8 & 0.0495 & 0.6 & 0.33 \\
\hline 08DH33-61 & 475 & 11823 & 1.6 & 16.9544 & 2.7 & 0.6626 & 3.0 & 0.0815 & 1.4 & 0.46 \\
\hline 08DH33-62 & 255 & 20124 & 1.3 & 15.4425 & 1.8 & 1.0967 & 3.0 & 0.1228 & 2.4 & 0.80 \\
\hline 08DH33-63 & 220 & 5421 & 0.9 & 19.8219 & 5.8 & 0.2719 & 6.2 & 0.0391 & 2.3 & 0.37 \\
\hline 08DH33-64 & 112 & 14124 & 1.9 & 8.5373 & 2.7 & 4.7782 & 4.3 & 0.2959 & 3.3 & 0.78 \\
\hline 08DH33-66 & 139 & 2133 & 0.8 & 18.9860 & 8.1 & 0.2779 & 8.2 & 0.0383 & 1.4 & 0.17 \\
\hline 08DH33-67 & 404 & 11514 & 1.2 & 19.2885 & 2.5 & 0.3103 & 3.2 & 0.0434 & 2.1 & 0.65 \\
\hline 08DH33-68 & 492 & 32514 & 1.3 & 15.1524 & 1.3 & 1.1905 & 1.4 & 0.1308 & 0.5 & 0.37 \\
\hline 08DH33-69 & 496 & 13734 & 1.1 & 19.0769 & 2.4 & 0.3369 & 2.4 & 0.0466 & 0.5 & 0.21 \\
\hline 08DH33-70 & 743 & 11718 & 0.6 & 16.4979 & 4.2 & 0.6664 & 4.3 & 0.0797 & 1.2 & 0.28 \\
\hline 08DH33-71 & 79 & 2883 & 1.1 & 19.4573 & 7.4 & 0.3121 & 7.6 & 0.0440 & 1.7 & 0.22 \\
\hline 08DH33-72 & 187 & 5052 & 0.8 & 19.5289 & 3.1 & 0.2896 & 3.4 & 0.0410 & 1.4 & 0.41 \\
\hline 08DH33-73 & 1221 & 915 & 2.2 & 11.0964 & 4.4 & 0.4672 & 4.5 & 0.0376 & 1.0 & 0.23 \\
\hline 08DH33-74 & 270 & 42708 & 0.8 & 9.3496 & 1.9 & 4.4939 & 2.2 & 0.3047 & 1.1 & 0.50 \\
\hline 08DH33-75 & 102 & 2886 & 1.2 & 19.7210 & 6.9 & 0.2874 & 6.9 & 0.0411 & 0.5 & 0.07 \\
\hline 08DH33-76 & 595 & 2955 & 0.8 & 15.3170 & 11.0 & 0.4222 & 11.2 & 0.0469 & 2.0 & 0.18 \\
\hline 08DH33-77 & 145 & 5691 & 1.2 & 19.2778 & 4.8 & 0.3342 & 5.0 & 0.0467 & 1.1 & 0.22 \\
\hline 08DH33-78 & 168 & 6417 & 1.3 & 19.3406 & 4.0 & 0.3438 & 4.0 & 0.0482 & 0.7 & 0.18 \\
\hline 08DH33-79 & 821 & 23961 & 2.5 & 17.1464 & 1.7 & 0.6249 & 1.8 & 0.0777 & 0.6 & 0.35 \\
\hline 08DH33-80 & 1165 & 4863 & 3.6 & 17.0247 & 2.7 & 0.3105 & 2.8 & 0.0383 & 0.8 & 0.29 \\
\hline 08DH33-81 & 213 & 10689 & 1.5 & 17.3018 & 2.0 & 0.6563 & 2.1 & 0.0823 & 0.9 & 0.41 \\
\hline 08DH33-82 & 189 & 7656 & 1.0 & 17.3443 & 4.2 & 0.6140 & 4.4 & 0.0772 & 1.3 & 0.31 \\
\hline 08DH33-83 & 461 & 16638 & 1.4 & 18.8214 & 1.2 & 0.3679 & 1.4 & 0.0502 & 0.7 & 0.53 \\
\hline 08DH33-84 & 172 & 5529 & 1.6 & 19.0847 & 4.4 & 0.3566 & 4.4 & 0.0494 & 0.7 & 0.15 \\
\hline 08DH33-85 & 463 & 13854 & 1.6 & 19.0705 & 1.1 & 0.3428 & 1.4 & 0.0474 & 0.8 & 0.59 \\
\hline 08DH33-86 & 107 & 5958 & 1.3 & 17.9530 & 3.5 & 0.5316 & 3.6 & 0.0692 & 0.5 & 0.14 \\
\hline 08DH33-87 & 128 & 13971 & 2.4 & 11.1561 & 2.2 & 2.9691 & 2.2 & 0.2402 & 0.5 & 0.23 \\
\hline 08DH33-88 & 442 & 7779 & 0.8 & 19.5348 & 1.7 & 0.2639 & 1.9 & 0.0374 & 0.7 & 0.37 \\
\hline 08DH33-89 & 94 & 2367 & 1.0 & 19.9896 & 8.4 & 0.2499 & 8.6 & 0.0362 & 1.6 & 0.19 \\
\hline 08DH33-90 & 179 & 4146 & 0.9 & 18.6796 & 2.1 & 0.3139 & 2.1 & 0.0425 & 0.6 & 0.28 \\
\hline 08DH33-91 & 286 & 6888 & 0.5 & 19.2618 & 3.1 & 0.3436 & 3.2 & 0.0480 & 0.9 & 0.27 \\
\hline 08DH33-92 & 367 & 23928 & 1.9 & 17.7310 & 1.7 & 0.6137 & 2.0 & 0.0789 & 1.1 & 0.53 \\
\hline 08DH33-93 & 1027 & 7938 & 5.5 & 15.5272 & 5.8 & 0.8044 & 5.9 & 0.0906 & 0.5 & 0.09 \\
\hline 08DH33-94 & 274 & 12957 & 1.2 & 17.2353 & 1.6 & 0.6684 & 2.0 & 0.0835 & 1.1 & 0.54 \\
\hline 08DH33-95 & 109 & 3189 & 1.4 & 19.8252 & 7.8 & 0.2774 & 7.9 & 0.0399 & 1.6 & 0.20 \\
\hline
\end{tabular}


08DH33

Apparent ages (Ma)

\begin{tabular}{|c|c|c|c|c|c|c|c|c|c|}
\hline Analysis & $\begin{array}{c}206 \mathrm{~Pb}^{*} / \\
238 \mathrm{U}^{*}\end{array}$ & $\stackrel{ \pm}{(\mathrm{Ma})}$ & $\begin{array}{c}207 \mathrm{~Pb}^{*} / \\
235 \mathrm{U}\end{array}$ & $\begin{array}{c} \pm \\
(\mathrm{Ma})\end{array}$ & $\begin{array}{l}206 \mathrm{~Pb}^{\star} / \\
207 \mathrm{~Pb}^{*}\end{array}$ & $\begin{array}{c} \pm \\
(\mathrm{Ma})\end{array}$ & $\begin{array}{l}\text { Best age } \\
\quad(\mathrm{Ma})\end{array}$ & $\begin{array}{c} \pm \\
(\mathrm{Ma})\end{array}$ & $\begin{array}{c}\text { Conc } \\
(\%)\end{array}$ \\
\hline 08DH33-49 & 249.0 & 3.1 & 245.0 & 10.7 & 206.8 & 110.6 & 249.0 & 3.1 & 120.4 \\
\hline 08DH33-51 & 412.1 & 11.2 & 414.0 & 13.4 & 424.6 & 61.6 & 412.1 & 11.2 & 97.1 \\
\hline 08DH33-52 & 501.9 & 6.3 & 493.2 & 17.5 & 453.3 & 95.3 & 501.9 & 6.3 & 110.7 \\
\hline 08DH33-53 & 264.6 & 1.3 & 265.9 & 3.8 & 277.0 & 35.6 & 264.6 & 1.3 & 95.5 \\
\hline 08DH33-54 & 525.4 & 2.5 & 526.2 & 6.7 & 529.6 & 34.0 & 525.4 & 2.5 & 99.2 \\
\hline 08DH33-55 & 732.0 & 4.8 & 732.7 & 15.8 & 734.9 & 62.2 & 732.0 & 4.8 & 99.6 \\
\hline 08DH33-56 & 550.7 & 4.9 & 546.4 & 18.6 & 528.4 & 94.5 & 550.7 & 4.9 & 104.2 \\
\hline 08DH33-57 & 312.3 & 12.0 & 571.1 & 168.9 & 1804.1 & 721.3 & 1804.1 & 721.3 & 17.3 \\
\hline 08DH33-58 & 265.2 & 2.9 & 253.3 & 19.4 & 144.7 & 201.7 & 265.2 & 2.9 & 183.3 \\
\hline 08DH33-59 & 339.1 & 2.4 & 444.7 & 10.9 & 1036.0 & 59.4 & 339.1 & 2.4 & 32.7 \\
\hline 08DH33-60 & 311.2 & 1.8 & 313.6 & 4.8 & 331.0 & 38.3 & 311.2 & 1.8 & 94.0 \\
\hline 08DH33-61 & 504.9 & 6.8 & 516.2 & 12.1 & 566.4 & 57.8 & 504.9 & 6.8 & 89.1 \\
\hline 08DH33-62 & 746.8 & 16.6 & 751.8 & 15.7 & 766.4 & 37.3 & 746.8 & 16.6 & 97.4 \\
\hline 08DH33-63 & 247.2 & 5.7 & 244.2 & 13.6 & 215.8 & 134.2 & 247.2 & 5.7 & 114.6 \\
\hline 08DH33-64 & 1670.7 & 49.2 & 1781.1 & 36.1 & 1912.9 & 48.6 & 1912.9 & 48.6 & 87.3 \\
\hline 08DH33-66 & 242.1 & 3.3 & 249.0 & 18.2 & 314.6 & 185.1 & 242.1 & 3.3 & 76.9 \\
\hline 08DH33-67 & 273.9 & 5.7 & 274.4 & 7.8 & 278.6 & 56.1 & 273.9 & 5.7 & 98.3 \\
\hline 08DH33-68 & 792.6 & 3.7 & 796.2 & 7.5 & 806.2 & 26.6 & 792.6 & 3.7 & 98.3 \\
\hline 08DH33-69 & 293.7 & 1.4 & 294.8 & 6.2 & 303.7 & 54.3 & 293.7 & 1.4 & 96.7 \\
\hline 08DH33-70 & 494.5 & 5.8 & 518.5 & 17.7 & 625.5 & 90.0 & 494.5 & 5.8 & 79.1 \\
\hline 08DH33-71 & 277.8 & 4.5 & 275.8 & 18.3 & 258.6 & 170.1 & 277.8 & 4.5 & 107.4 \\
\hline 08DH33-72 & 259.1 & 3.5 & 258.2 & 7.6 & 250.1 & 70.4 & 259.1 & 3.5 & 103.6 \\
\hline 08DH33-73 & 238.0 & 2.4 & 389.3 & 14.5 & 1428.0 & 83.1 & 238.0 & 2.4 & 16.7 \\
\hline 08DH33-74 & 1714.7 & 16.7 & 1729.8 & 18.4 & 1748.2 & 35.0 & 1748.2 & 35.0 & 98.1 \\
\hline 08DH33-75 & 259.7 & 1.3 & 256.5 & 15.7 & 227.6 & 159.4 & 259.7 & 1.3 & 114.1 \\
\hline 08DH33-76 & 295.4 & 5.8 & 357.6 & 33.8 & 783.6 & 232.2 & 295.4 & 5.8 & 37.7 \\
\hline 08DH33-77 & 294.4 & 3.2 & 292.7 & 12.6 & 279.8 & 110.7 & 294.4 & 3.2 & 105.2 \\
\hline 08DH33-78 & 303.6 & 2.2 & 300.0 & 10.4 & 272.4 & 90.6 & 303.6 & 2.2 & 111.5 \\
\hline 08DH33-79 & 482.4 & 2.9 & 492.9 & 6.9 & 541.9 & 36.2 & 482.4 & 2.9 & 89.0 \\
\hline 08DH33-80 & 242.5 & 2.0 & 274.6 & 6.8 & 557.4 & 59.1 & 242.5 & 2.0 & 43.5 \\
\hline 08DH33-81 & 510.1 & 4.4 & 512.3 & 8.6 & 522.1 & 42.9 & 510.1 & 4.4 & 97.7 \\
\hline 08DH33-82 & 479.6 & 6.2 & 486.1 & 16.9 & 516.7 & 91.2 & 479.6 & 6.2 & 92.8 \\
\hline 08DH33-83 & 315.9 & 2.3 & 318.1 & 3.7 & 334.4 & 26.2 & 315.9 & 2.3 & 94.5 \\
\hline 08DH33-84 & 310.6 & 2.0 & 309.7 & 11.8 & 302.8 & 99.3 & 310.6 & 2.0 & 102.6 \\
\hline 08DH33-85 & 298.6 & 2.4 & 299.3 & 3.6 & 304.5 & 25.4 & 298.6 & 2.4 & 98.1 \\
\hline 08DH33-86 & 431.5 & 2.1 & 432.9 & 12.6 & 440.4 & 78.7 & 431.5 & 2.1 & 98.0 \\
\hline 08DH33-87 & 1387.9 & 6.2 & 1399.8 & 16.9 & 1417.8 & 41.3 & 1417.8 & 41.3 & 97.9 \\
\hline 08DH33-88 & 236.6 & 1.6 & 237.8 & 4.0 & 249.4 & 40.0 & 236.6 & 1.6 & 94.9 \\
\hline 08DH33-89 & 229.4 & 3.6 & 226.5 & 17.4 & 196.2 & 195.9 & 229.4 & 3.6 & 116.9 \\
\hline 08DH33-90 & 268.4 & 1.6 & 277.2 & 5.2 & 351.5 & 46.5 & 268.4 & 1.6 & 76.4 \\
\hline 08DH33-91 & 302.2 & 2.6 & 299.9 & 8.4 & 281.7 & 71.4 & 302.2 & 2.6 & 107.3 \\
\hline 08DH33-92 & 489.7 & 5.0 & 485.9 & 7.7 & 468.1 & 37.5 & 489.7 & 5.0 & 104.6 \\
\hline 08DH33-93 & 559.0 & 2.8 & 599.3 & 26.5 & 754.9 & 123.1 & 559.0 & 2.8 & 74.0 \\
\hline 08DH33-94 & 517.3 & 5.2 & 519.7 & 7.9 & 530.6 & 36.0 & 517.3 & 5.2 & 97.5 \\
\hline 08DH33-95 & 252.2 & 3.8 & 248.6 & 17.5 & 215.3 & 180.1 & 252.2 & 3.8 & 117.1 \\
\hline
\end{tabular}


08DH33

Isotope ratios

$\begin{array}{ccccccccccc}\text { Analysis } & \begin{array}{c}\mathrm{U} \\ (\mathrm{ppm})\end{array} & \begin{array}{c}206 \mathrm{~Pb} / \\ 204 \mathrm{~Pb}\end{array} & \mathrm{U} / \mathrm{Th} & \begin{array}{c}206 \mathrm{~Pb}^{*} / \\ 207 \mathrm{~Pb}^{*}\end{array} & \begin{array}{c} \pm \\ (\%)\end{array} & \begin{array}{c}207 \mathrm{~Pb}^{*} / \\ 235 \mathrm{U}^{*}\end{array} & \begin{array}{c} \pm \\ (\%)\end{array} & \begin{array}{c}206 \mathrm{~Pb}^{*} / \\ 238 \mathrm{U}\end{array} & \begin{array}{c} \pm \\ (\%)\end{array} & \begin{array}{c}\text { error } \\ \text { corr. }\end{array} \\ \text { 08DH33-96 } & 620 & 2175 & 1.0 & 12.5874 & 37.8 & 0.5244 & 37.8 & 0.0479 & 1.4 & 0.04 \\ \text { 08DH33-99 } & 180 & 28233 & 1.2 & 8.7651 & 2.1 & 5.4004 & 2.2 & 0.3433 & 0.5 & 0.24 \\ \text { 08DH33-100 } & 498 & 28593 & 1.9 & 16.4484 & 1.5 & 0.8519 & 1.8 & 0.1016 & 0.9 & 0.50 \\ \text { 08DH33-101 } & 523 & 30705 & 4.3 & 17.6232 & 2.2 & 0.6229 & 2.3 & 0.0796 & 0.7 & 0.31 \\ \text { 08DH33-102 } & 305 & 18792 & 1.9 & 17.6508 & 2.8 & 0.6455 & 2.9 & 0.0826 & 0.5 & 0.19 \\ \text { 08DH33-103 } & 560 & 22473 & 2.5 & 17.4683 & 4.3 & 0.5759 & 4.5 & 0.0730 & 1.2 & 0.26 \\ \text { 08DH33-104 } & 549 & 26469 & 6.2 & 17.4064 & 1.6 & 0.6421 & 1.7 & 0.0811 & 0.5 & 0.30 \\ \text { 08DH33-105 } & 172 & 5130 & 1.0 & 17.9483 & 7.0 & 0.4578 & 7.2 & 0.0596 & 1.5 & 0.21 \\ \text { 08DH33-106 } & 117 & 10350 & 8.1 & 17.2802 & 3.1 & 0.7347 & 3.1 & 0.0921 & 0.5 & 0.17 \\ \text { 08DH33-107 } & 469 & 21414 & 1.7 & 17.6552 & 1.2 & 0.6019 & 1.5 & 0.0771 & 0.8 & 0.53 \\ \text { 08DH33-108 } & 455 & 9837 & 1.4 & 18.8073 & 2.0 & 0.4048 & 2.2 & 0.0552 & 1.0 & 0.43 \\ \text { 08DH33-109 } & 185 & 12666 & 1.6 & 8.9235 & 1.8 & 4.8642 & 2.0 & 0.3148 & 0.8 & 0.39 \\ \text { 08DH33-110 } & 269 & 6378 & 1.0 & 18.8604 & 2.6 & 0.3531 & 2.6 & 0.0483 & 0.7 & 0.25\end{array}$

Apparent ages (Ma)

$\begin{array}{cccccccccc}\text { Analysis } & \begin{array}{c}206 \mathrm{~Pb}^{*} / \\ \text { 238U* }\end{array} & \begin{array}{c} \pm \\ (\mathrm{Ma})\end{array} & \begin{array}{c}207 \mathrm{~Pb}^{*} / \\ 235 \mathrm{U}\end{array} & \begin{array}{c} \pm \\ (\mathrm{Ma})\end{array} & \begin{array}{c}206 \mathrm{~Pb}^{*} / \\ 207 \mathrm{~Pb}^{*}\end{array} & \begin{array}{c} \pm \\ (\mathrm{Ma})\end{array} & \begin{array}{c}\text { Best age } \\ (\mathrm{Ma})\end{array} & \begin{array}{c} \pm \\ (\mathrm{Ma})\end{array} & \begin{array}{c}\text { Conc } \\ (\%)\end{array} \\ \text { 08DH33-96 } & 301.5 & 4.2 & 428.1 & 132.8 & 1183.2 & 774.6 & 301.5 & 4.2 & 25.5 \\ \text { 08DH33-99 } & 1902.6 & 8.9 & 1884.9 & 18.9 & 1865.5 & 38.6 & 1865.5 & 38.6 & 102.0 \\ \text { 08DH33-100 } & 624.0 & 5.2 & 625.7 & 8.3 & 632.1 & 33.0 & 624.0 & 5.2 & 98.7 \\ \text { 08DH33-101 } & 493.8 & 3.4 & 491.6 & 9.0 & 481.6 & 48.7 & 493.8 & 3.4 & 102.5 \\ \text { 08DH33-102 } & 511.8 & 2.7 & 505.7 & 11.5 & 478.1 & 62.8 & 511.8 & 2.7 & 107.1 \\ \text { 08DH33-103 } & 454.0 & 5.1 & 461.8 & 16.7 & 501.1 & 95.5 & 454.0 & 5.1 & 90.6 \\ \text { 08DH33-104 } & 502.5 & 2.5 & 503.6 & 6.8 & 508.8 & 35.7 & 502.5 & 2.5 & 98.7 \\ \text { 08DH33-105 } & 373.2 & 5.4 & 382.7 & 22.9 & 441.0 & 156.5 & 373.2 & 5.4 & 84.6 \\ \text { 08DH33-106 } & 567.8 & 2.9 & 559.3 & 13.4 & 524.8 & 67.1 & 567.8 & 2.9 & 108.2 \\ \text { 08DH33-107 } & 478.6 & 3.6 & 478.4 & 5.6 & 477.5 & 27.3 & 478.6 & 3.6 & 100.2 \\ \text { 08DH33-108 } & 346.5 & 3.3 & 345.1 & 6.5 & 336.1 & 45.6 & 346.5 & 3.3 & 103.1 \\ \text { 08DH33-109 } & 1764.3 & 11.9 & 1796.1 & 16.6 & 1833.1 & 32.8 & 1833.1 & 32.8 & 96.2 \\ \text { 08DH33-110 } & 304.1 & 2.0 & 307.1 & 7.0 & 329.7 & 57.9 & 304.1 & 2.0 & 92.2\end{array}$


Appendix 5: AGEPICK results for detrital zircon populations from this study and referenced from the literature. The number beside each location corresponds to location in Chapter 2, Figure 1. References listed in Chapter 2, Figure 6.

\section{TRIASSIC DATA}

\section{Verkhoyansk range (1)}

$\begin{array}{ccc}\text { MIN AGE } & \text { MAX AGE } & \text { \# GRAINS } \\ 263 & 373 & 25 \\ 407 & 646 & 46 \\ 1781 & 2104 & 9 \\ 2397 & 2508 & 5\end{array}$

\section{Lower Yana - Kular (2)}

MIN AGE MAX AGE \# GRAINS

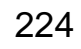

341

413

738

1759

337

387

568

825

2011

\section{Chukotka (6)}

MIN AGE

234

347

422

730

893

1617

$\begin{array}{cc}\text { MAX AGE } & \text { \# GRAINS } \\ 339 & 28 \\ 398 & 4 \\ 638 & 31 \\ 856 & 11 \\ 1241 & 8 \\ 1984 & 5\end{array}$

$\begin{array}{cc}\text { PEAK AGE } & \text { \# GRAINS } \\ \mathbf{2 9 0} & \mathbf{1 7} \\ 360 & 7 \\ 440 & 16 \\ 482 & 23 \\ 535 & 12 \\ 582 & 9 \\ 1844 & 6 \\ 2036 & 4 \\ 2454 & 4 \\ 2494 & 4\end{array}$

$\begin{array}{cc}\text { PEAK AGE } & \text { \# GRAINS } \\ \mathbf{2 4 2} & \mathbf{1 6} \\ 301 & 27 \\ 370 & 6 \\ 501 & 33 \\ 789 & 5 \\ 1851 & 11\end{array}$

$\begin{array}{cc}\text { PEAK AGE } & \text { \# GRAINS } \\ \mathbf{2 5 4} & \mathbf{5} \\ 266 & 5 \\ 303 & 20 \\ 369 & 5 \\ 460 & 9 \\ 471 & 12 \\ 497 & 14 \\ 592 & 7 \\ 619 & 4 \\ 809 & 7 \\ 1052 & 8 \\ 1829 & 5 \\ 1955 & 4\end{array}$

Wrangel Island (7)

$\begin{array}{ccccc}\text { MIN AGE } & \text { MAX AGE } & \text { \# GRAINS } & \text { PEAK AGE } & \text { \# GRAINS } \\ 220 & 335 & 19 & \mathbf{2 5 2} & \mathbf{9} \\ 382 & 472 & 9 & 285 & 13 \\ 976 & 1204 & 4 & 452 & 7 \\ & & & 1099 & 4\end{array}$


Lisburne Hills (8)

$\begin{array}{ccccc}\text { MIN AGE } & \text { MAX AGE } & \text { \# GRAINS } & \text { PEAK AGE } & \text { \# GRAINS } \\ 206 & 282 & 23 & \mathbf{2 2 7} & \mathbf{5} \\ 290 & 510 & 41 & 237 & 6 \\ 580 & 714 & 7 & 258 & 14 \\ 722 & 819 & 4 & 274 & 11 \\ 1089 & 1500 & 7 & 326 & 12 \\ 1621 & 1945 & 6 & 369 & 10 \\ & & & 436 & 17 \\ & & & 486 & 4 \\ & & & 603 & 4 \\ & & & 642 & 5 \\ & & & 777 & 4 \\ & & & 1746 & 4\end{array}$

Sadlerochit range (9)

$\begin{array}{ccccc}\text { MIN AGE } & \text { MAX AGE } & \text { \# GRAINS } & \text { PEAK AGE } & \text { \# GRAINS } \\ 402 & 701 & 65 & \mathbf{4 1 9} & \mathbf{5} \\ 848 & 1319 & 20 & 465 & 11 \\ & & & 531 & 28 \\ & & & 565 & 30 \\ & & 680 & 4 \\ & & 882 & 7 \\ & & 1065 & 7 \\ & & 1187 & 9\end{array}$

Sverdrup AE1 basin (10)

$\begin{array}{ccccc}\text { MIN AGE } & \text { MAX AGE } & \text { \# GRAINS } & \text { PEAK AGE } & \text { \# GRAINS } \\ 434 & 482 & 6 & \mathbf{4 5 5} & \mathbf{5} \\ 954 & 1462 & 26 & 1214 & 17 \\ 1549 & 2058 & 40 & 1367 & 8 \\ & & & 1661 & 12 \\ & & & 1769 & 17 \\ & & & 1849 & 4 \\ & & & 1934 & 7 \\ & & & 1989 & 6\end{array}$

Sverdrup AE2 basin (11)

$\begin{array}{ccccc}\text { MIN AGE } & \text { MAX AGE } & \text { \# GRAINS } & \text { PEAK AGE } & \text { \# GRAINS } \\ 416 & 699 & 69 & \mathbf{4 3 3} & \mathbf{4} \\ 1002 & 1365 & 12 & 474 & 6 \\ 1605 & 1693 & 4 & 569 & 44 \\ 1799 & 1908 & 5 & 661 & 5 \\ & & & 1072 & 6 \\ & & & 1133 & 7 \\ & & & 1256 & 7 \\ & & & 1655 & 4 \\ & & & 1836 & 5\end{array}$




\section{JURASSIC DATA}

Verhoyansk range (1)

$\begin{array}{ccccc}\text { MIN AGE } & \text { MAX AGE } & \text { \# GRAINS } & \text { PEAK AGE } & \text { \# GRAINS } \\ 169 & 198 & 4 & \mathbf{1 7 5} & \mathbf{4} \\ 201 & 335 & 53 & 190 & 4 \\ 430 & 565 & 25 & 219 & 6 \\ 1795 & 1971 & 10 & 232 & 8 \\ & & & 259 & 5 \\ & & & 281 & 20 \\ & & & 291 & 21 \\ & & & 312 & 6 \\ & & & 324 & 5 \\ & & & 481 & 18 \\ & & & 515 & 6 \\ & & & 549 & 4 \\ & & & 1861 & 8 \\ & & & 1930 & 4\end{array}$

\begin{tabular}{ccccc}
\multicolumn{2}{c}{ Lower Yana - Kular (2) } & & & \\
\hline MIN AGE & MAX AGE & \# GRAINS & PEAK AGE & \# GRAINS \\
147 & 210 & 42 & $\mathbf{1 6 7}$ & $\mathbf{2 0}$ \\
223 & 396 & 155 & 203 & 5 \\
1639 & 2183 & 132 & 255 & 42 \\
2281 & 3068 & 32 & 269 & 50 \\
& & & 287 & 46 \\
& & & 321 & 15 \\
& & & 1939 & 19 \\
& & & 2544 & 91 \\
& & & 2739 & 12 \\
& & &
\end{tabular}

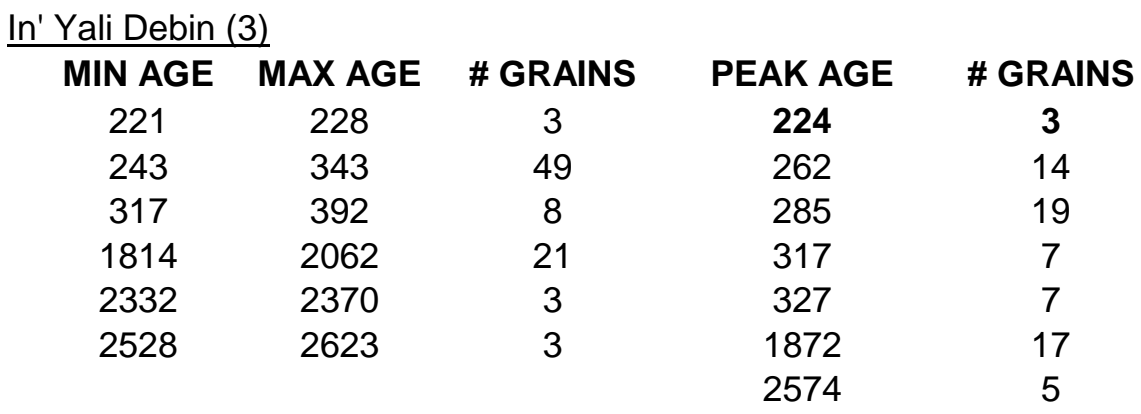


Stobovoi Island (4)

$\begin{array}{ccccc}\text { MIN AGE } & \text { MAX AGE } & \text { \# GRAINS } & \text { PEAK AGE } & \text { \# GRAINS } \\ 148 & 164 & 4 & \mathbf{1 5 5} & \mathbf{4} \\ 224 & 307 & 23 & 229 & 5 \\ 1710 & 2103 & 45 & 241 & 6 \\ 2562 & 2791 & 15 & 257 & 9 \\ & & & 282 & 10 \\ & & & 294 & 8 \\ & & & 1888 & 31 \\ & & & 2663 & 11 \\ & & & 2728 & 12\end{array}$

South Anyui Suture (5)

$\begin{array}{ccccc}\text { MIN AGE } & \text { MAX AGE } & \text { \# GRAINS } & \text { PEAK AGE } & \text { \# GRAINS } \\ 157 & 179 & 6 & \mathbf{1 6 4} & \mathbf{4} \\ 223 & 275 & 10 & 174 & 4 \\ 294 & 306 & 4 & 243 & 5 \\ 1828 & 2096 & 55 & 258 & 4 \\ 2480 & 2734 & 14 & 299 & 4 \\ & & & 1925 & 36 \\ & & & 2517 & 5 \\ & & & 2601 & 5 \\ & & & 2665 & 7\end{array}$

Chukotka (6)

\begin{tabular}{ccccc}
\cline { 1 - 3 } MIN AGE & MAX AGE & \# GRAINS & PEAK AGE & \# GRAINS \\
138 & 189 & 17 & $\mathbf{1 5 9}$ & $\mathbf{1 4}$ \\
223 & 291 & 26 & 169 & 14 \\
328 & 377 & 7 & 175 & 13 \\
1690 & 2209 & 137 & 247 & 19 \\
2650 & 2822 & 12 & 350 & 7 \\
& & & 1743 & 4 \\
& & & 1930 & 95 \\
& & & 2752 & 10
\end{tabular}


Appendix 6: Cathodoluminesence photomicrographs of zircons separated from igneous samples collected from the Bendeleben and Windy Creek plutons. Circles indicate spot location for U-Pb SHRIMP-RG analysis.

09BEN20-
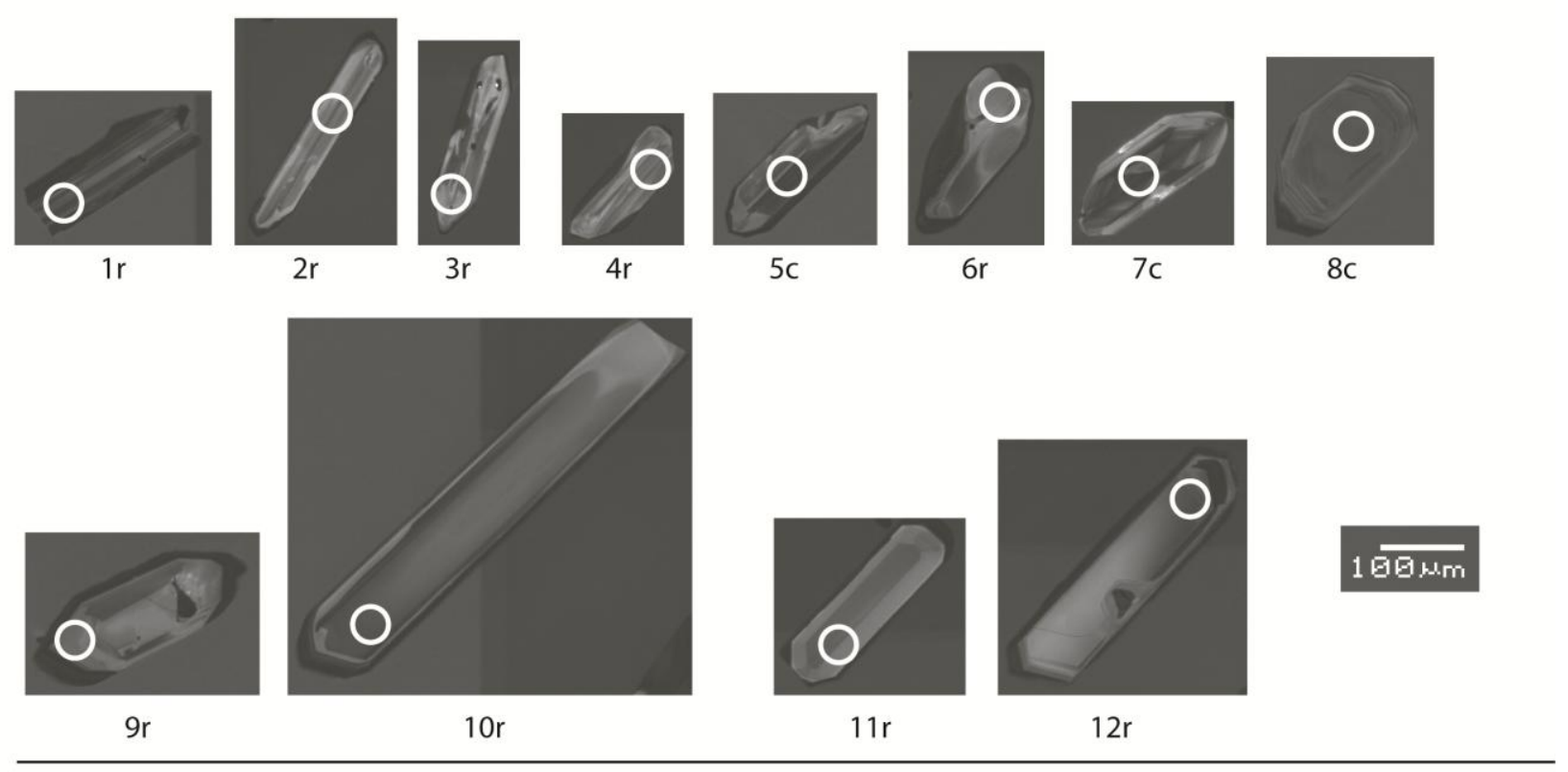

09BEN26-

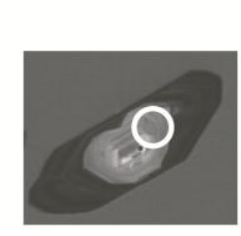

$1 \mathrm{c}$

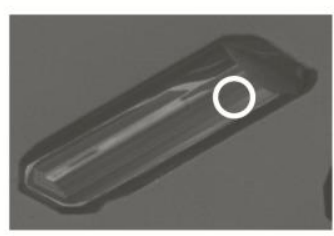

$2 r$

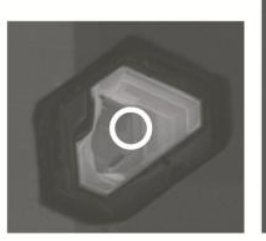

$3 c$

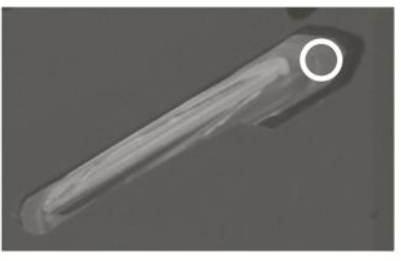

$4 r$

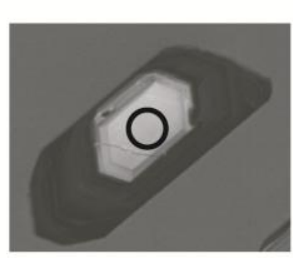

$5 c$

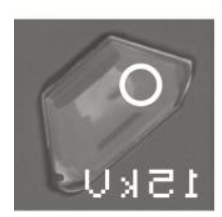

$6 r$

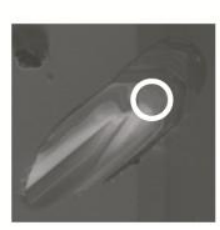

$7 r$

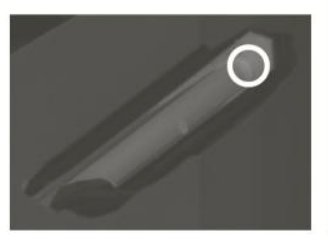

$8 r$

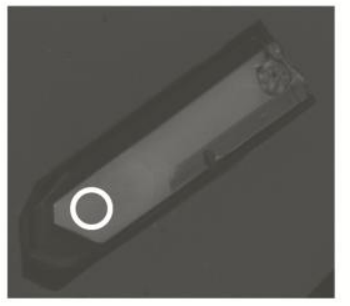

$9 r$

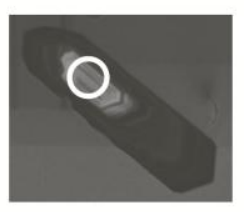

$10 c$ 
09BEN29-

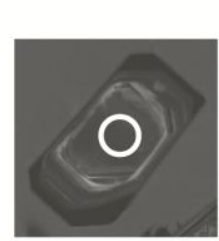

1c

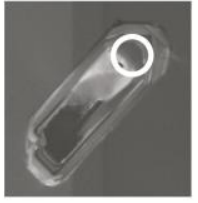

$8 r$

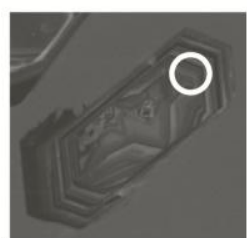

$2 r$

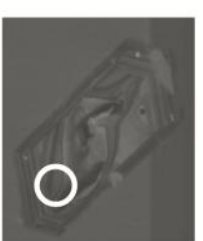

$3 r$

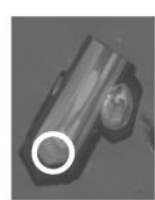

$4 \mathrm{r}$

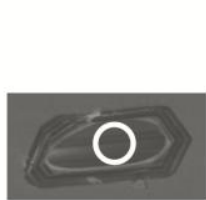

$5 c$

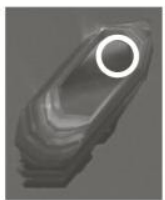

$6 r$

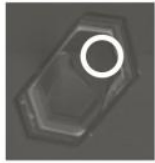

$7 r$

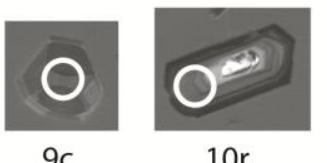

$2 \mathrm{GG \mu \textrm {m }}$

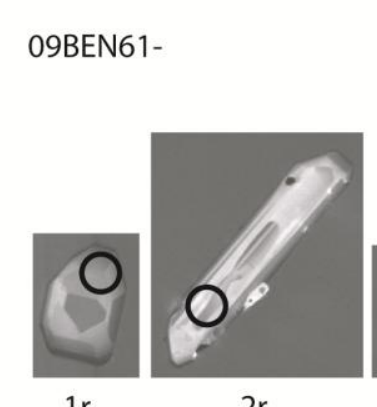

$1 \mathrm{r}$

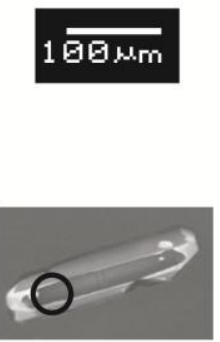

$3 r$

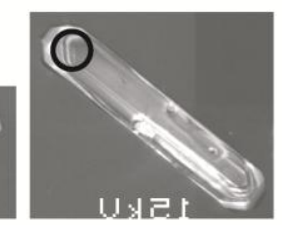

$4 r$

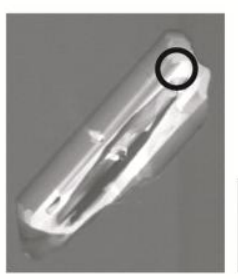

$5 r$

\section{$1 \overline{10 \mu \mathrm{m}}$}

09BEN63-

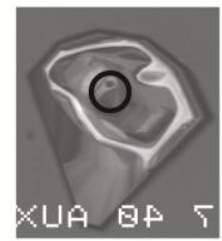

$1 \mathrm{r}$

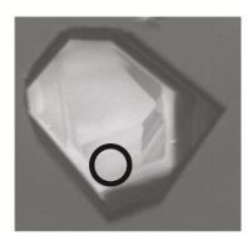

$2 c$

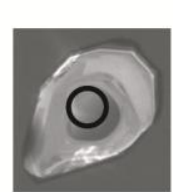

$3 c$

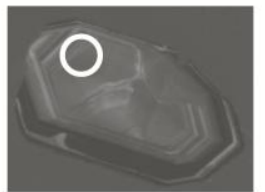

$4 r$

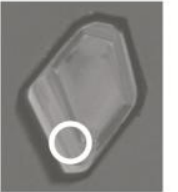

$5 r$

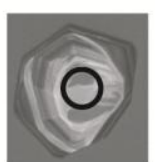

$6 c$

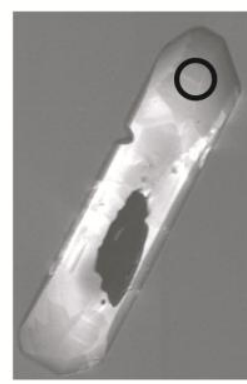

$8 r$ 
09BEN73-

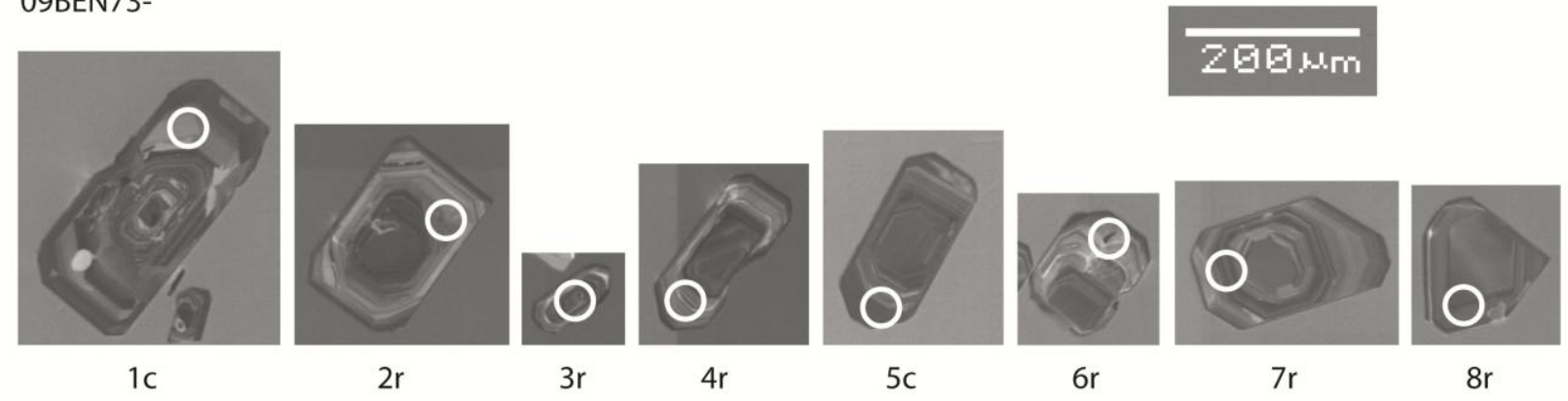

R33-

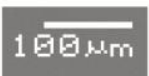

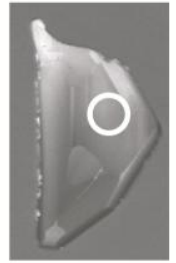

1

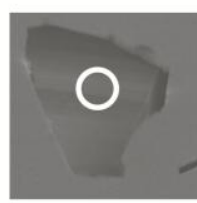

8

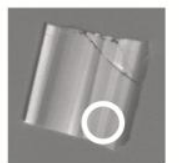

2

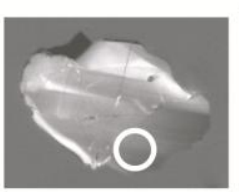

9

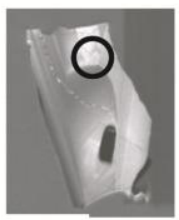

3

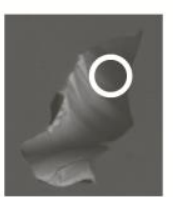

10

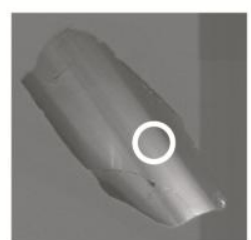

4

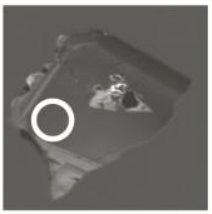

11

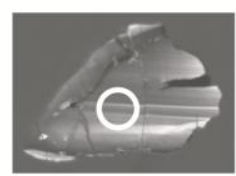

5

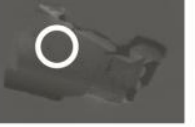

12

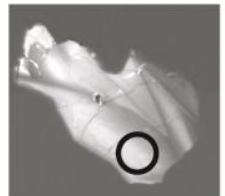

6

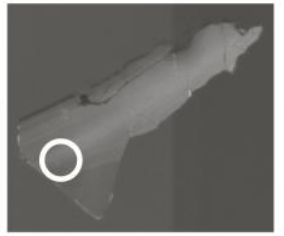

13
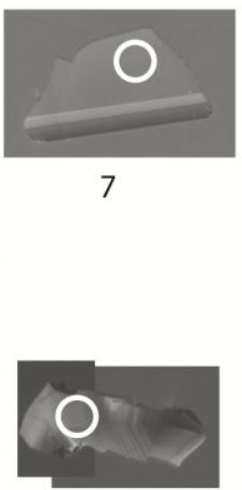

14 

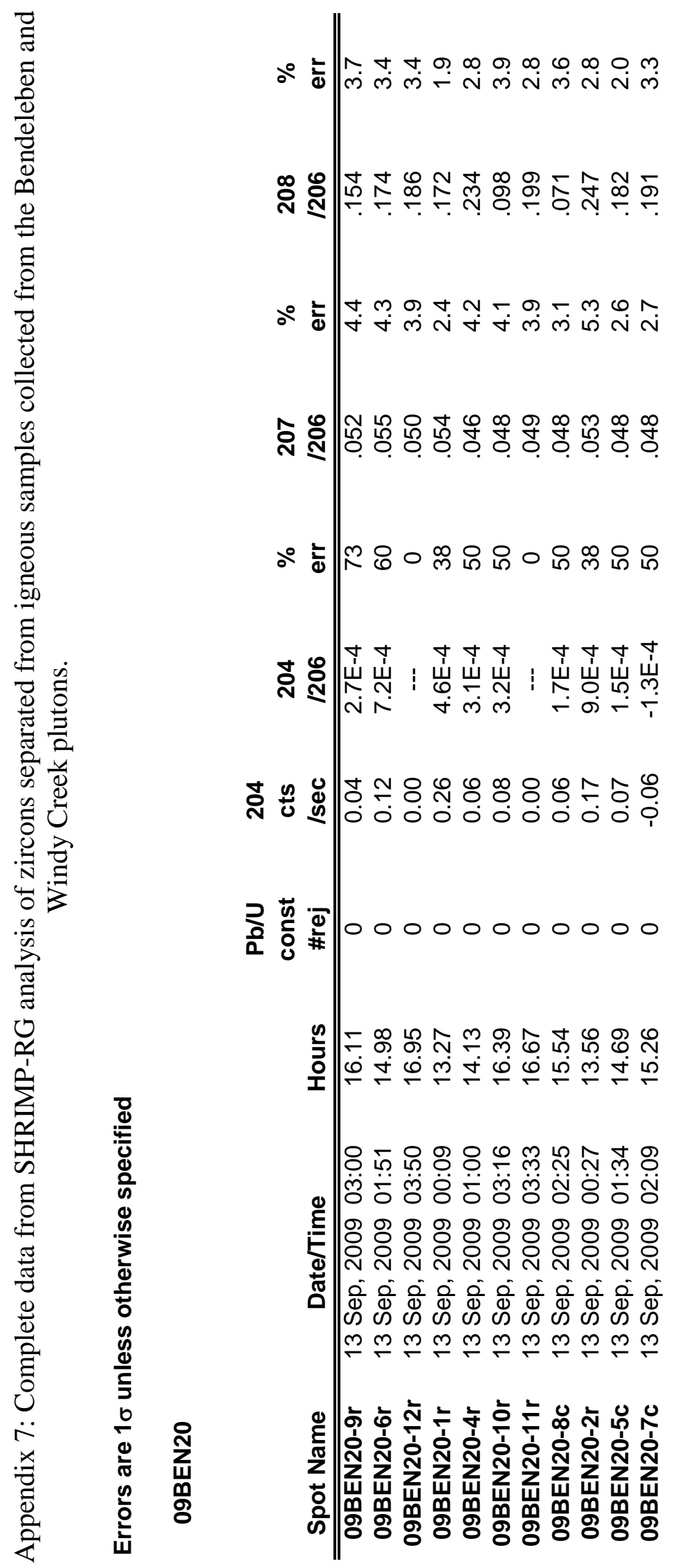


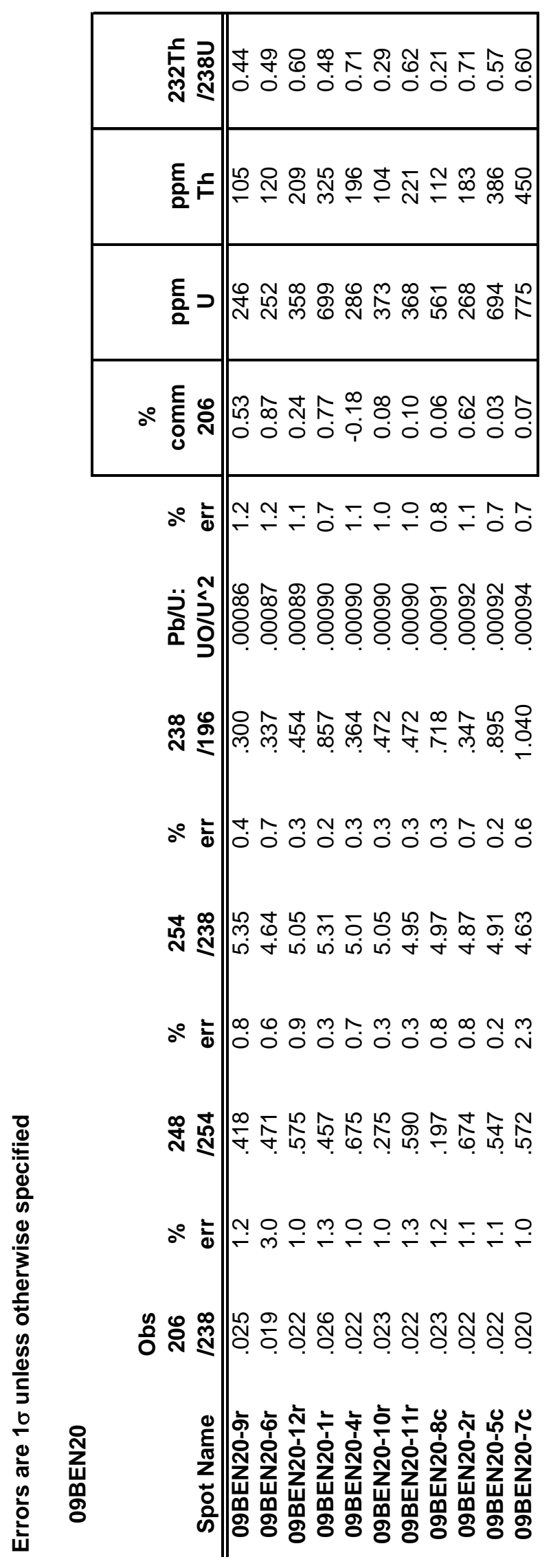




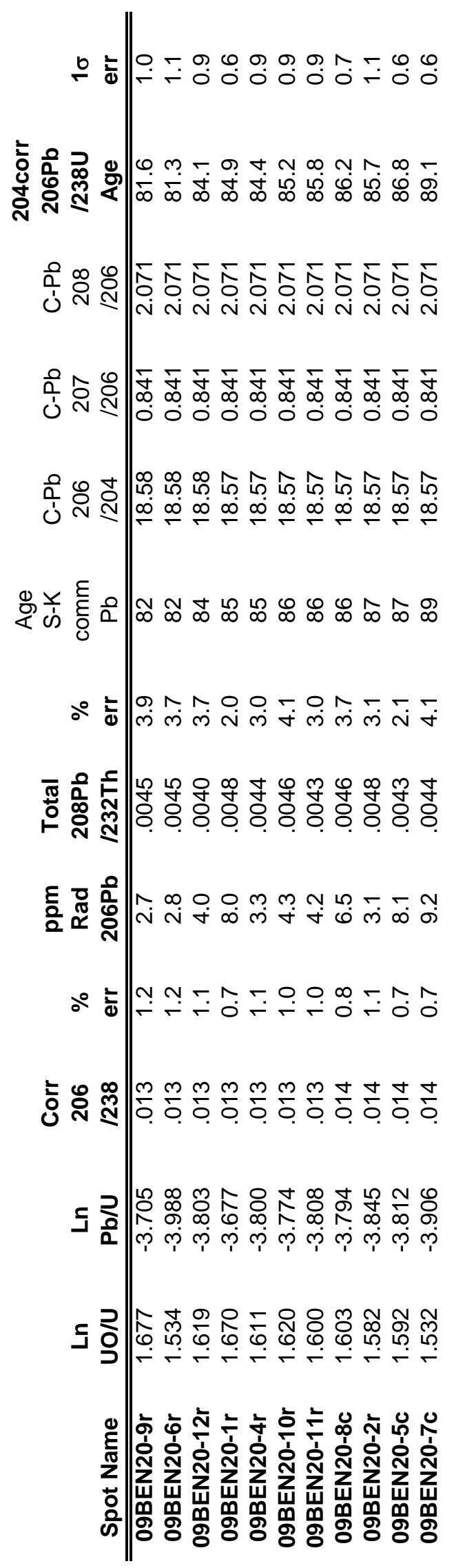




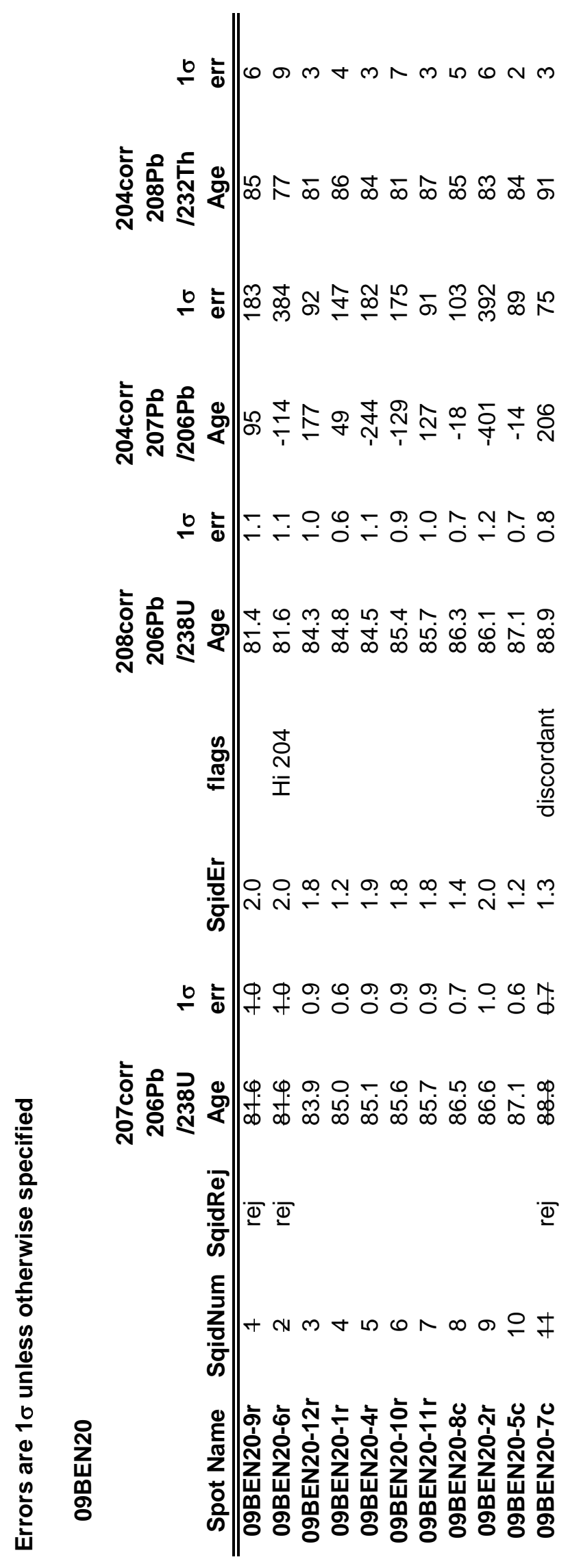




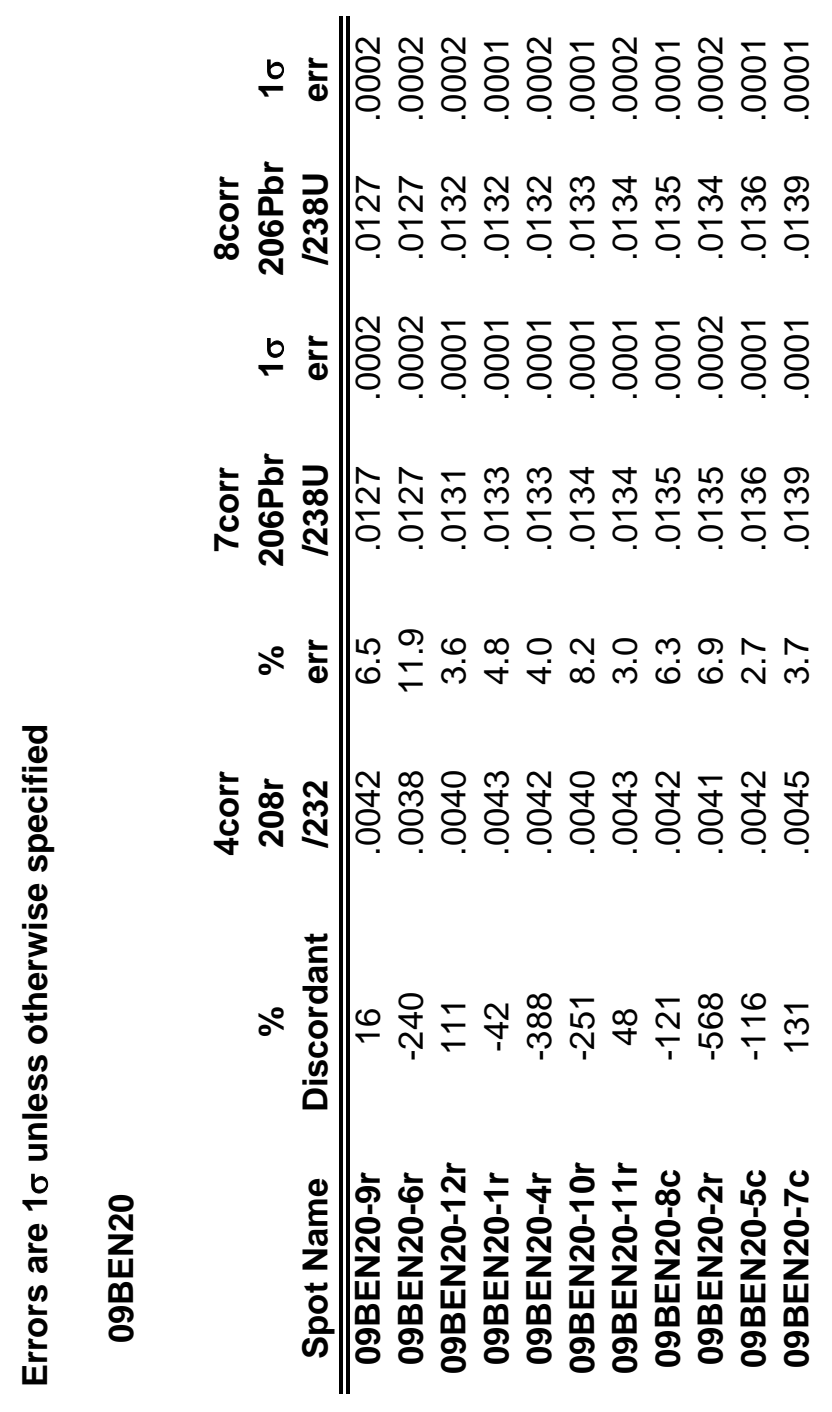




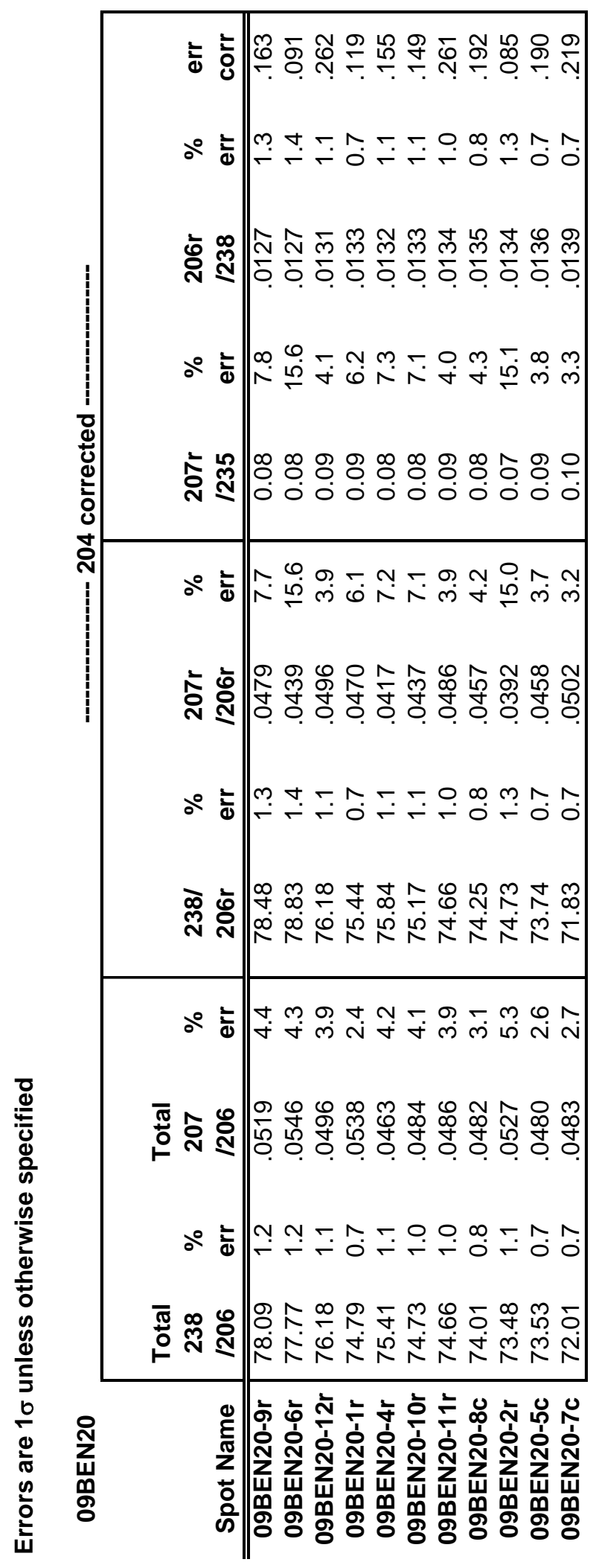




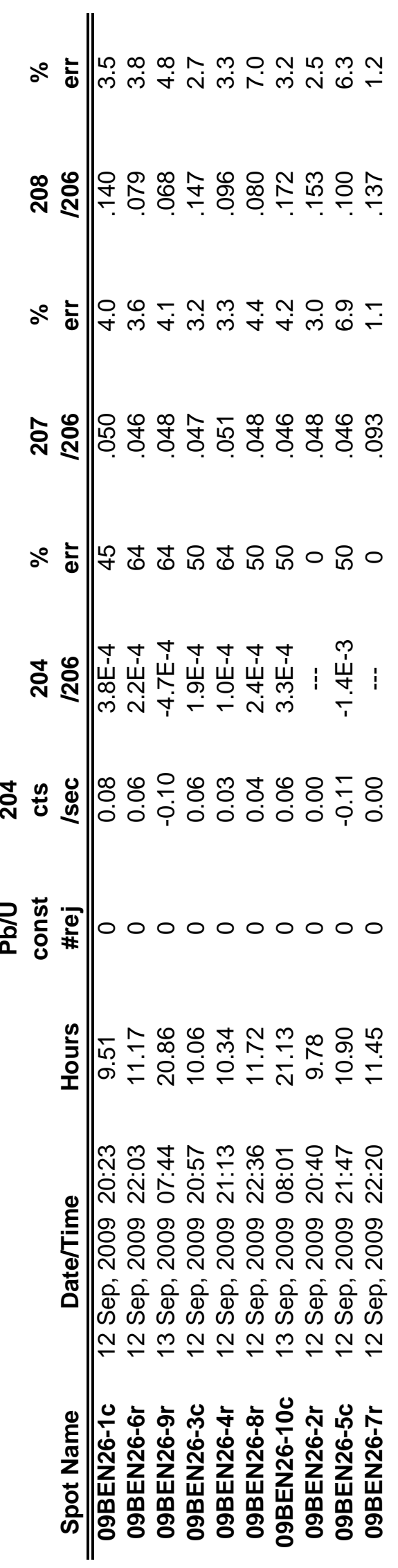



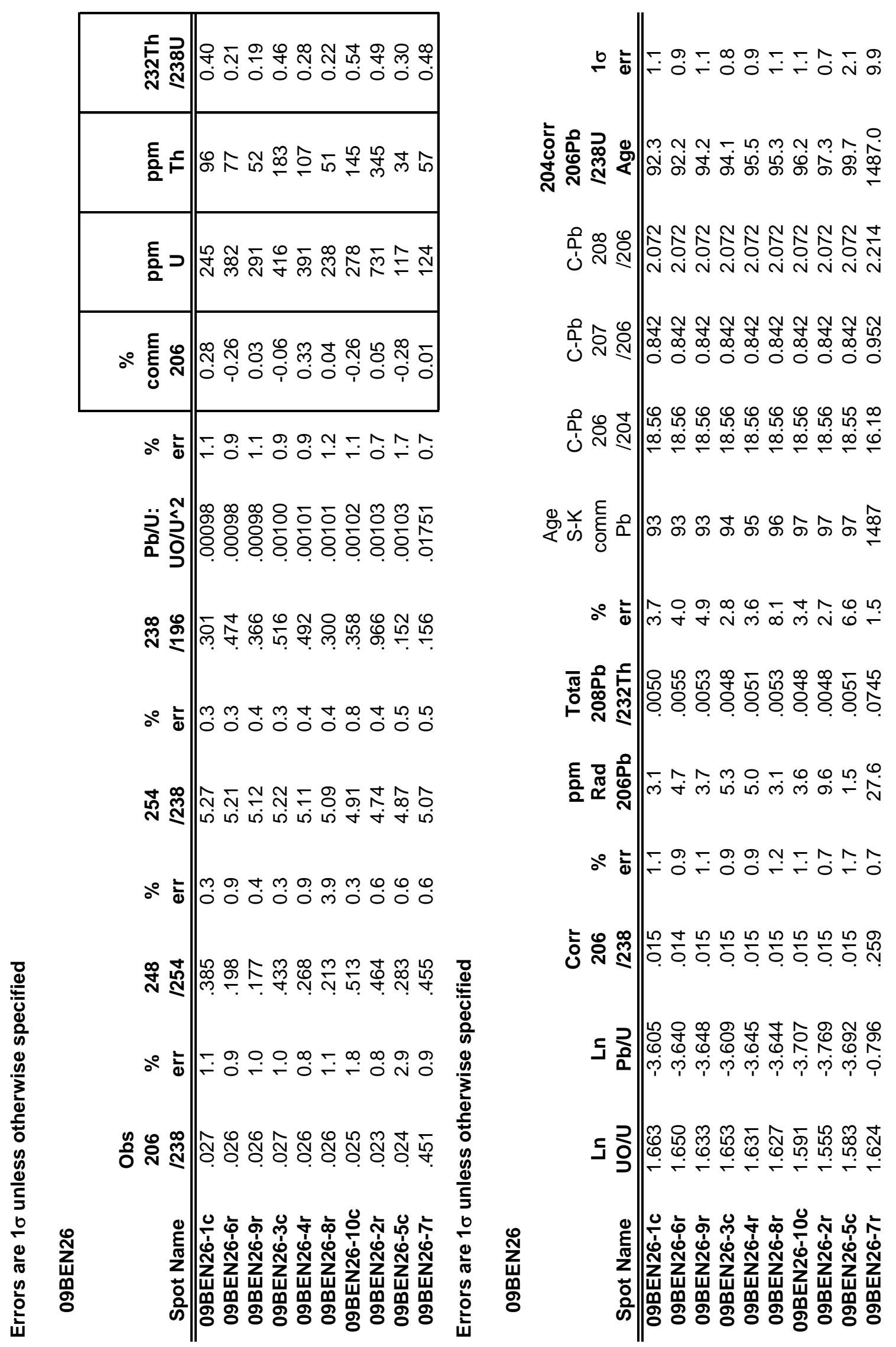


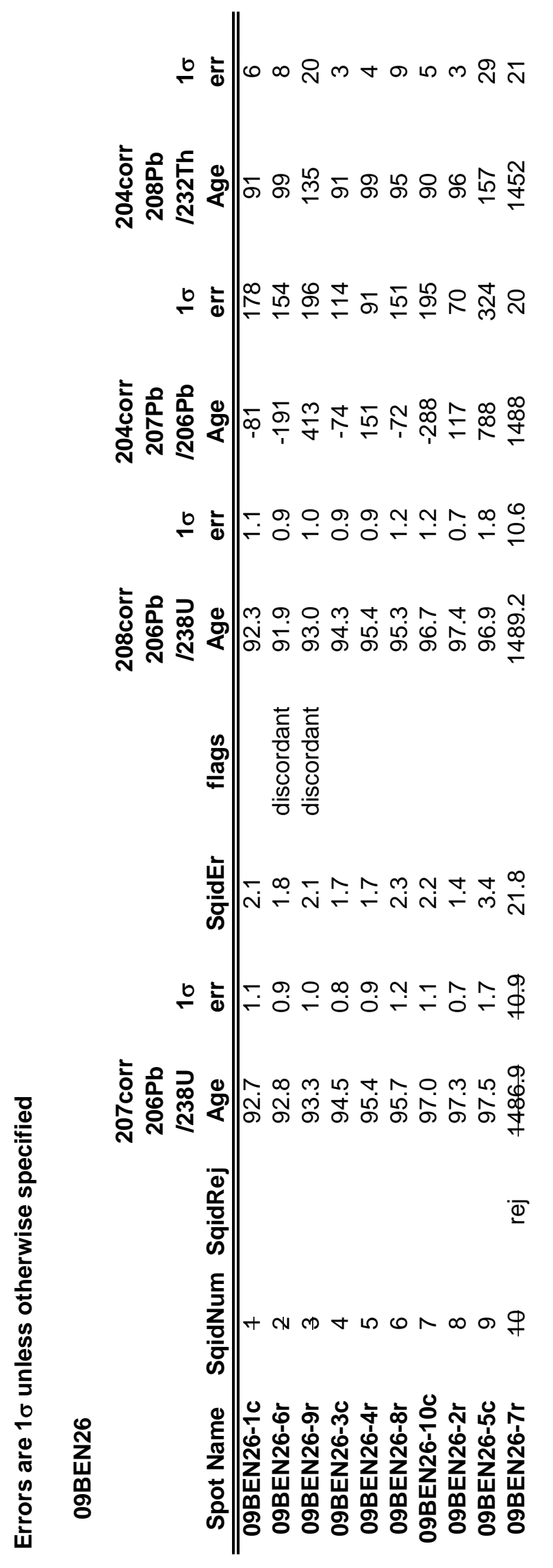




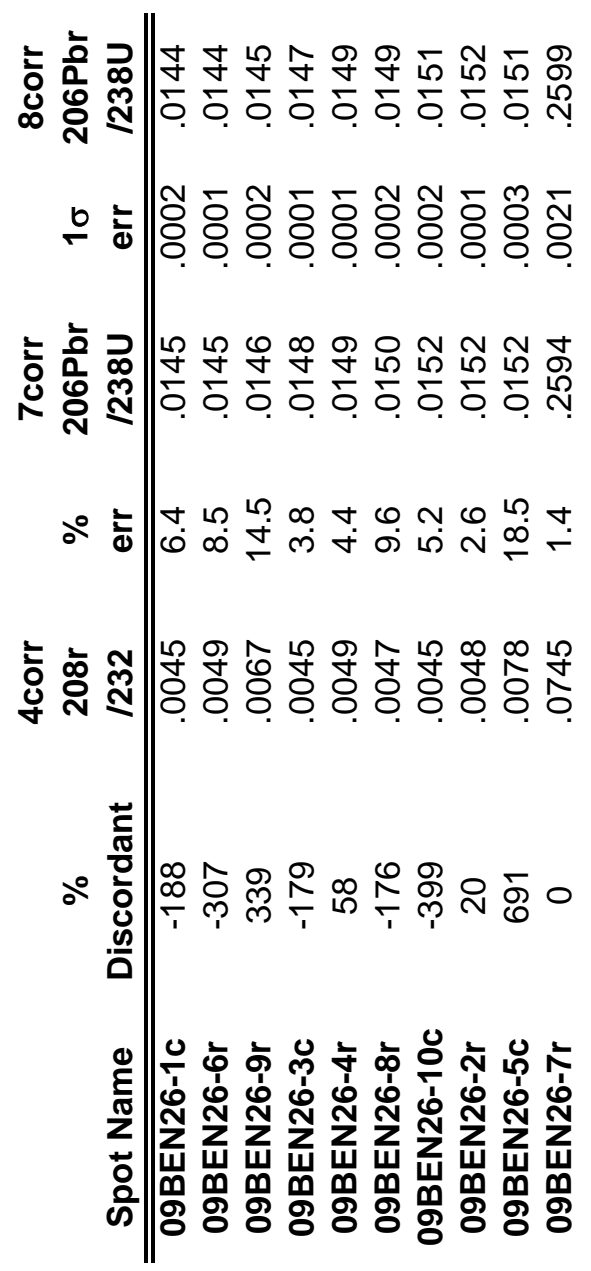




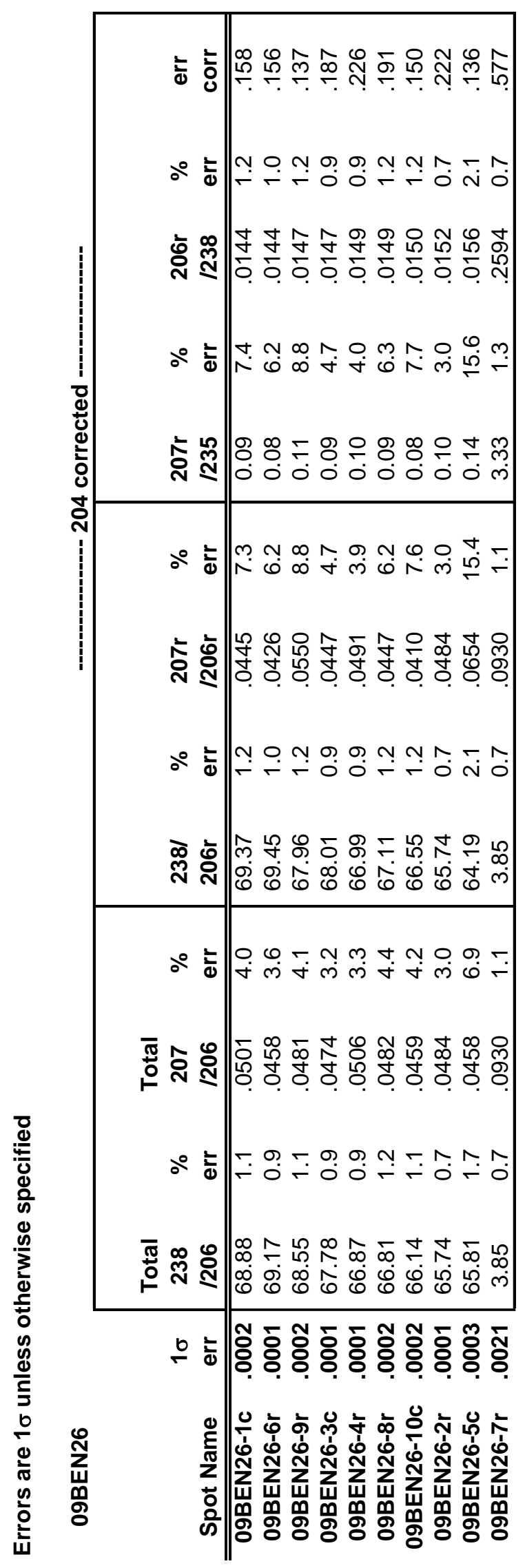




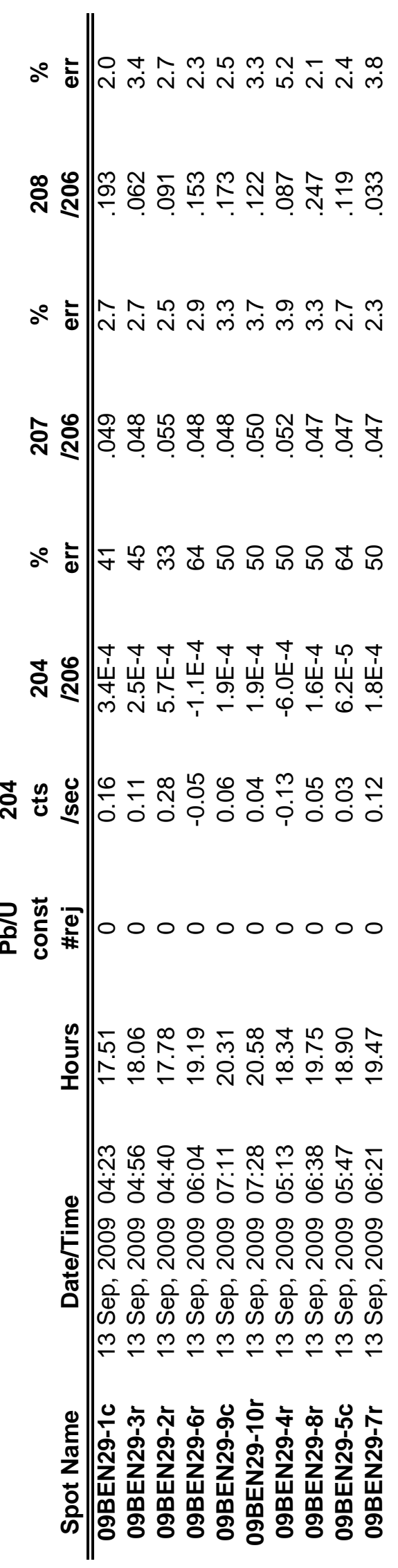



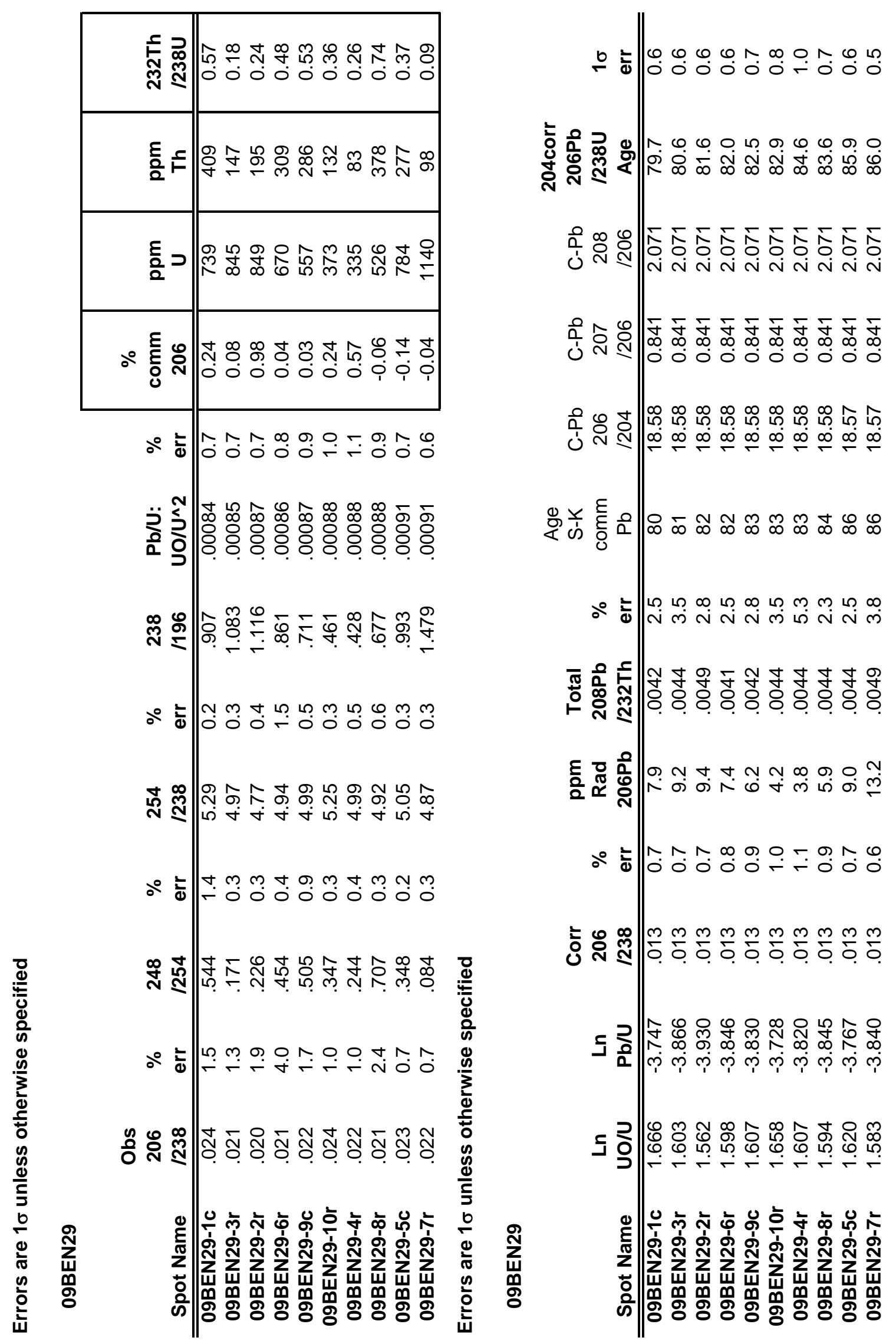


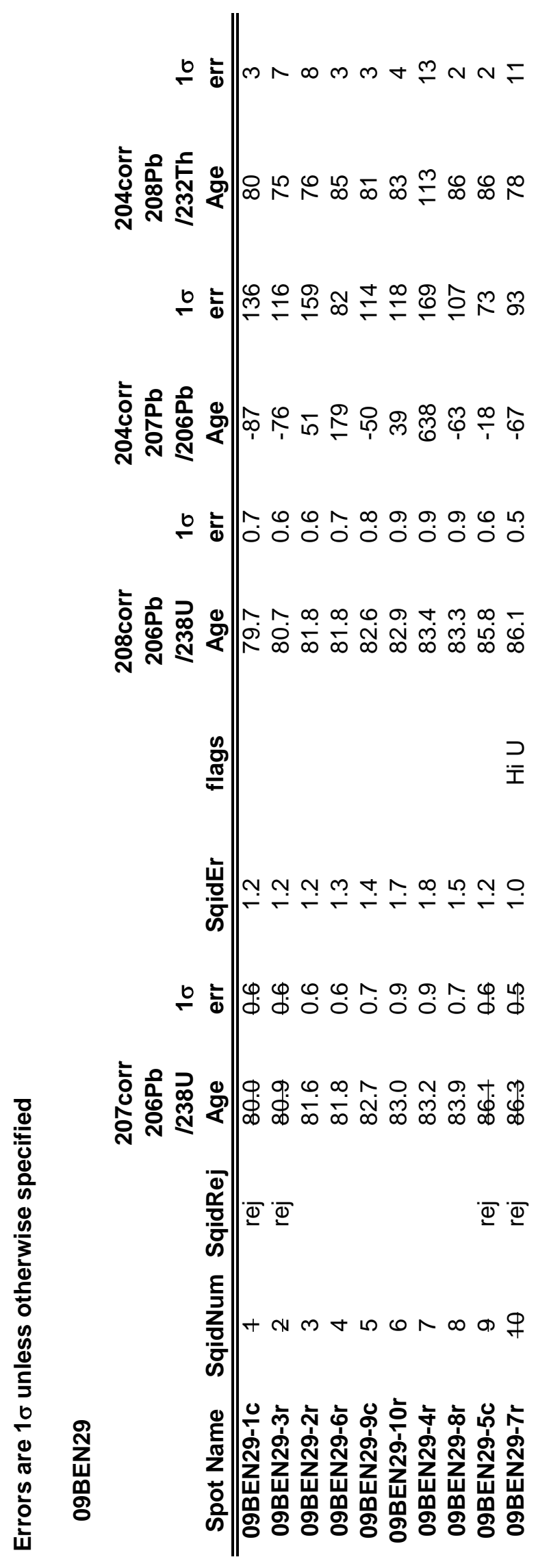




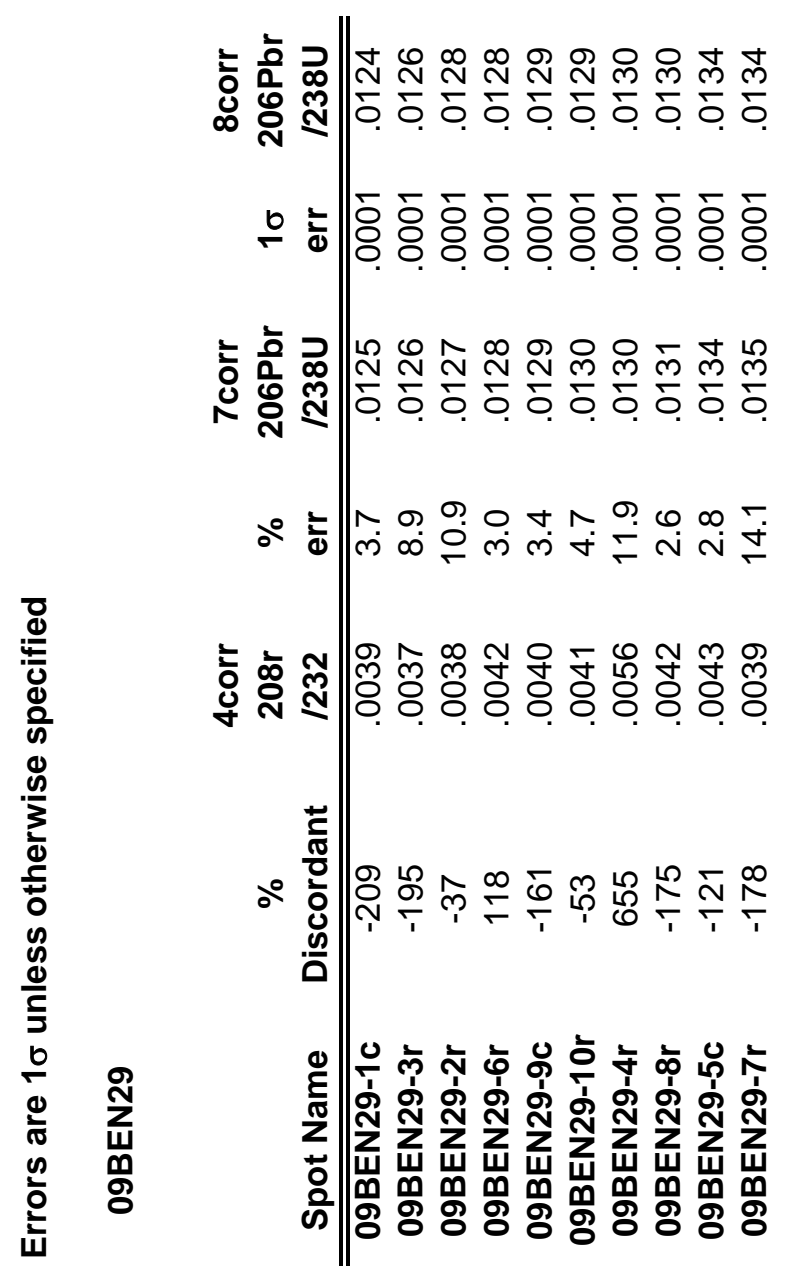




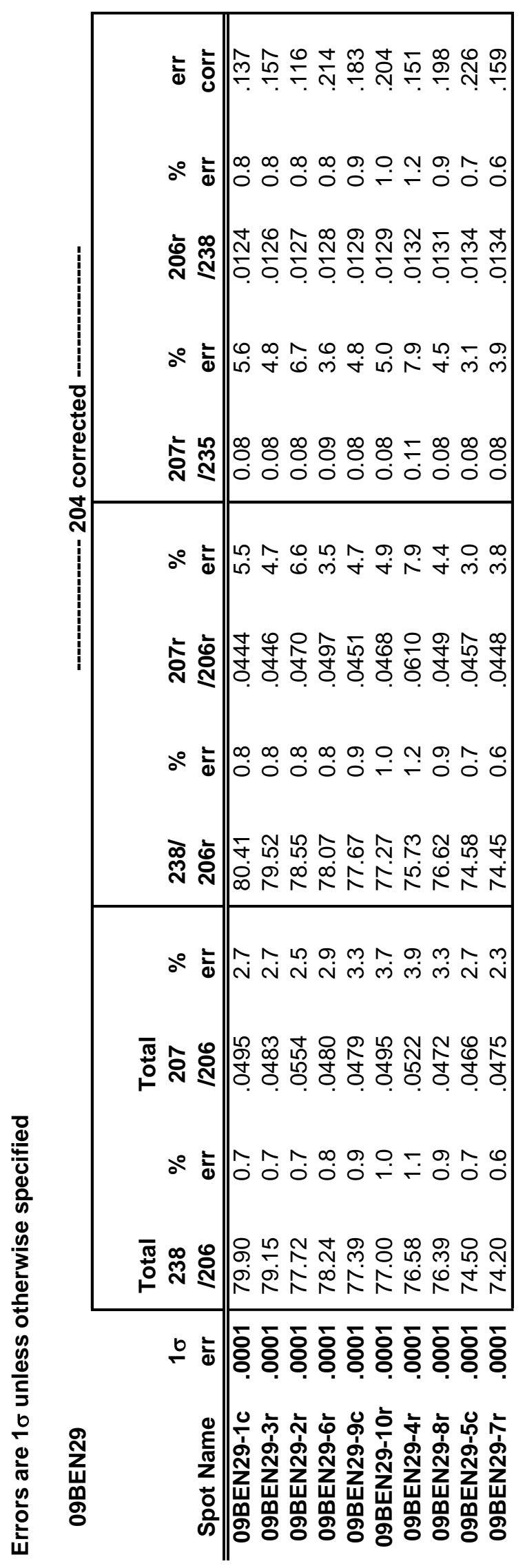



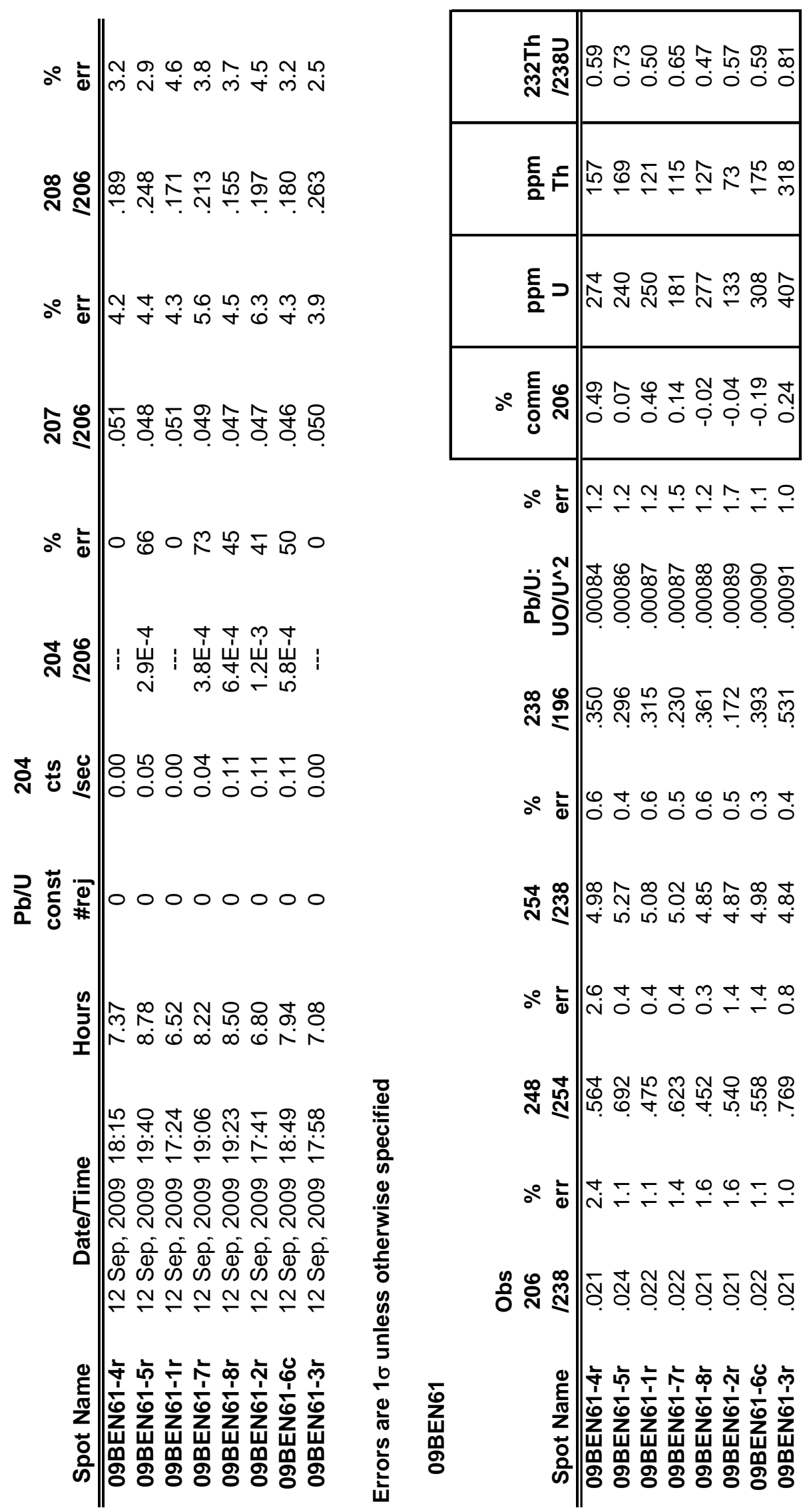

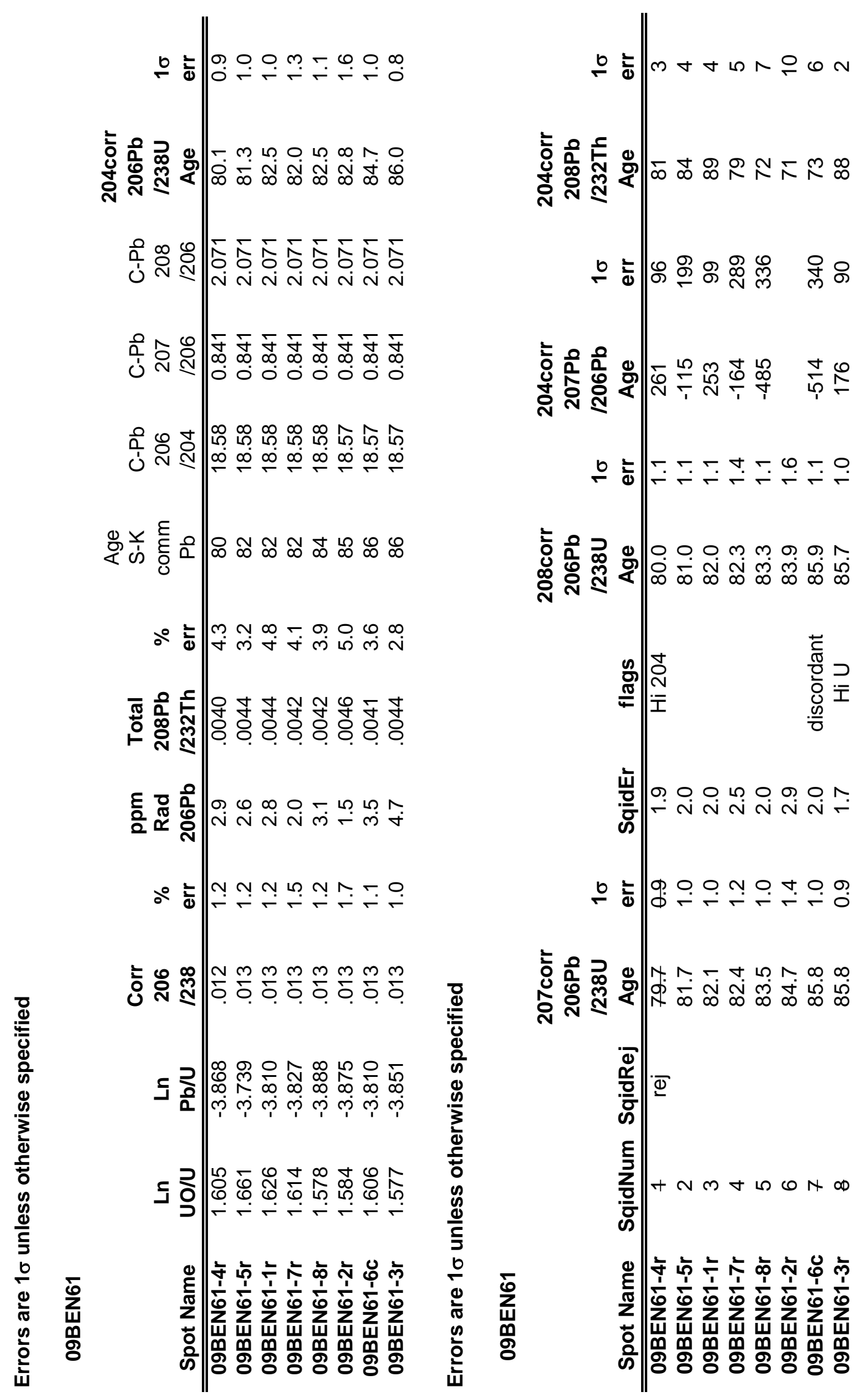

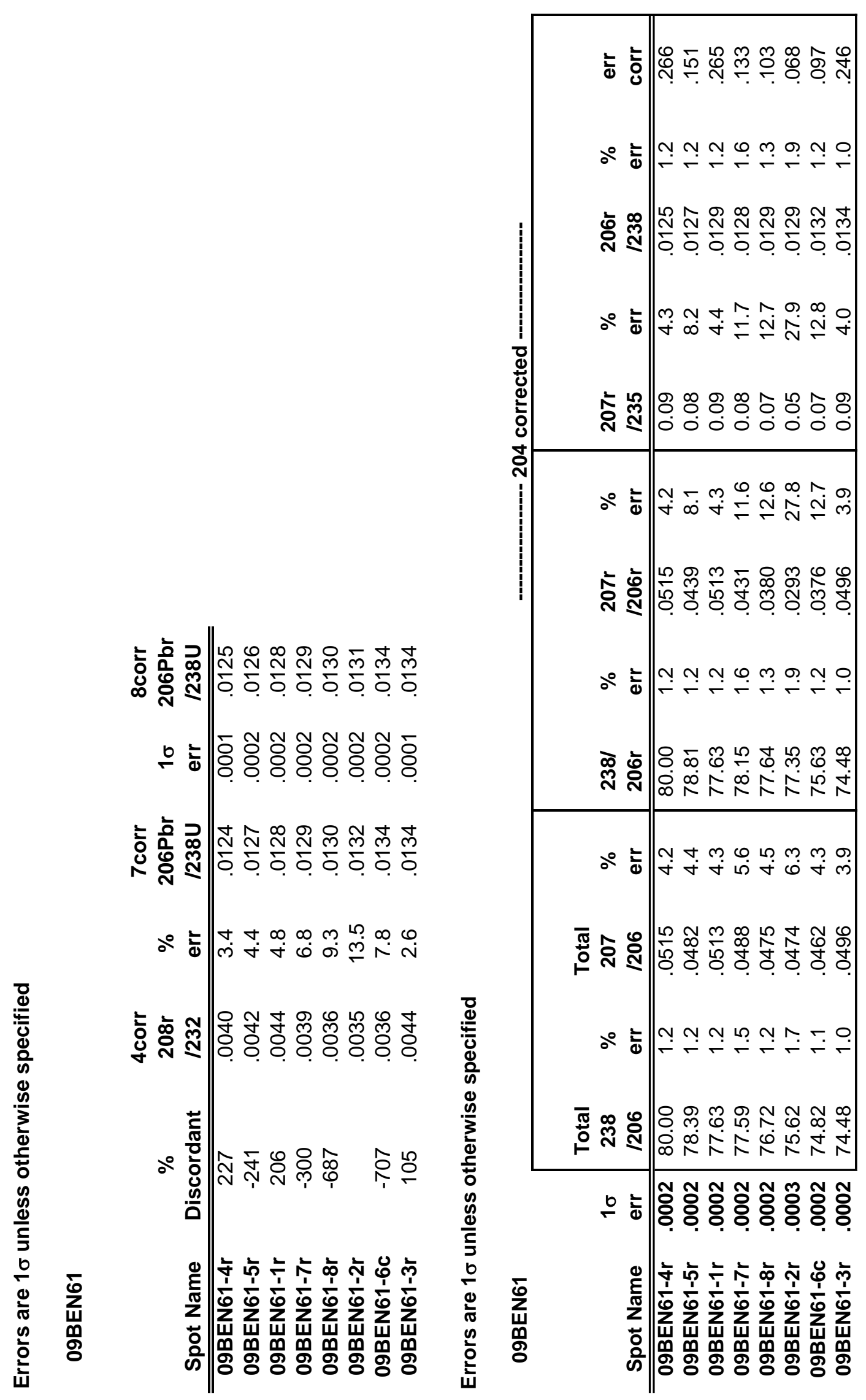


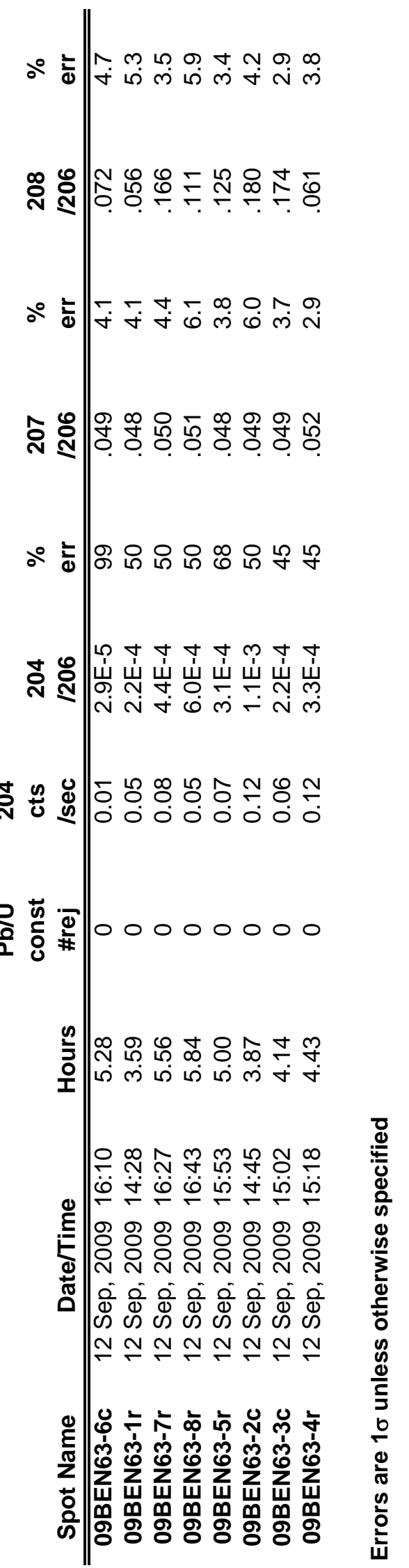

\begin{tabular}{|c|c|}
\hline 底 & 車 \\
\hline$\frac{E}{2} F$ & ৫ \\
\hline כ & 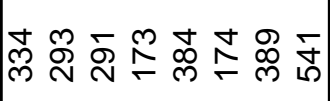 \\
\hline 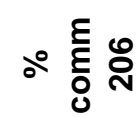 & 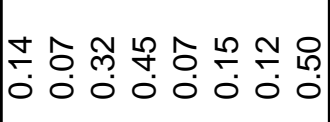 \\
\hline$\therefore$ & 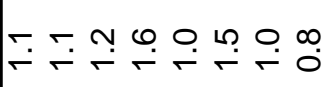 \\
\hline خ̀ & 在 o \\
\hline$\stackrel{\infty}{\sim} \stackrel{\circ}{\stackrel{\circ}{+}}$ & 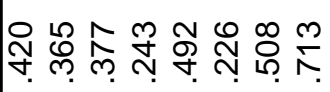 \\
\hline ○ㅎ & † \\
\hline 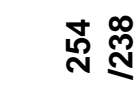 & 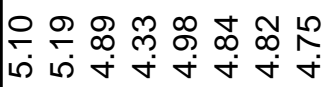 \\
\hline$\therefore$ & ب \\
\hline 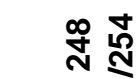 & 点 \\
\hline ㅇㅎ & مُ \\
\hline o̊ & 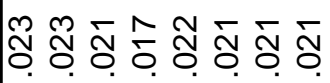 \\
\hline के & 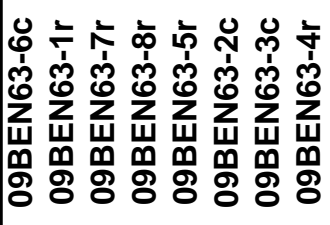 \\
\hline
\end{tabular}



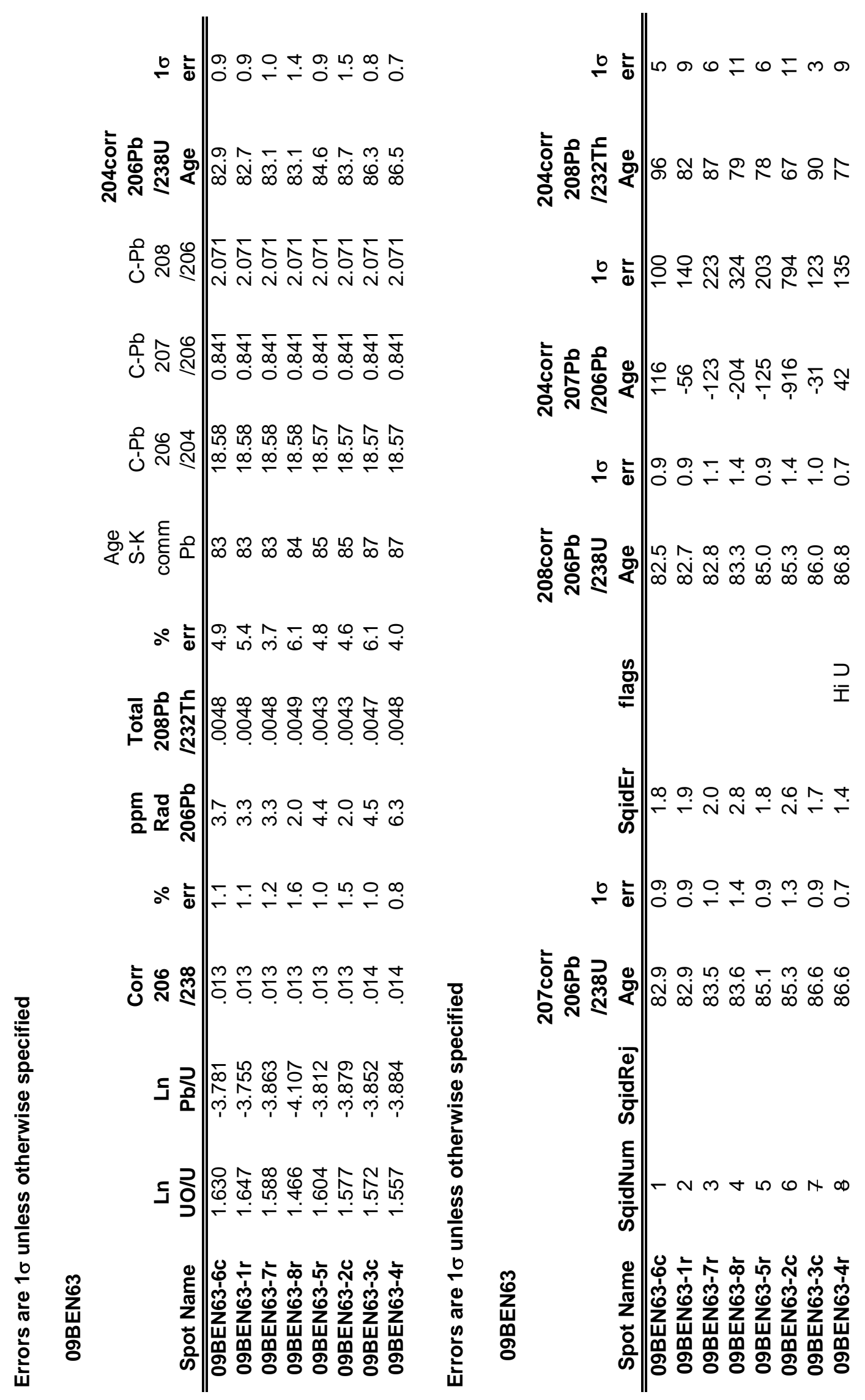

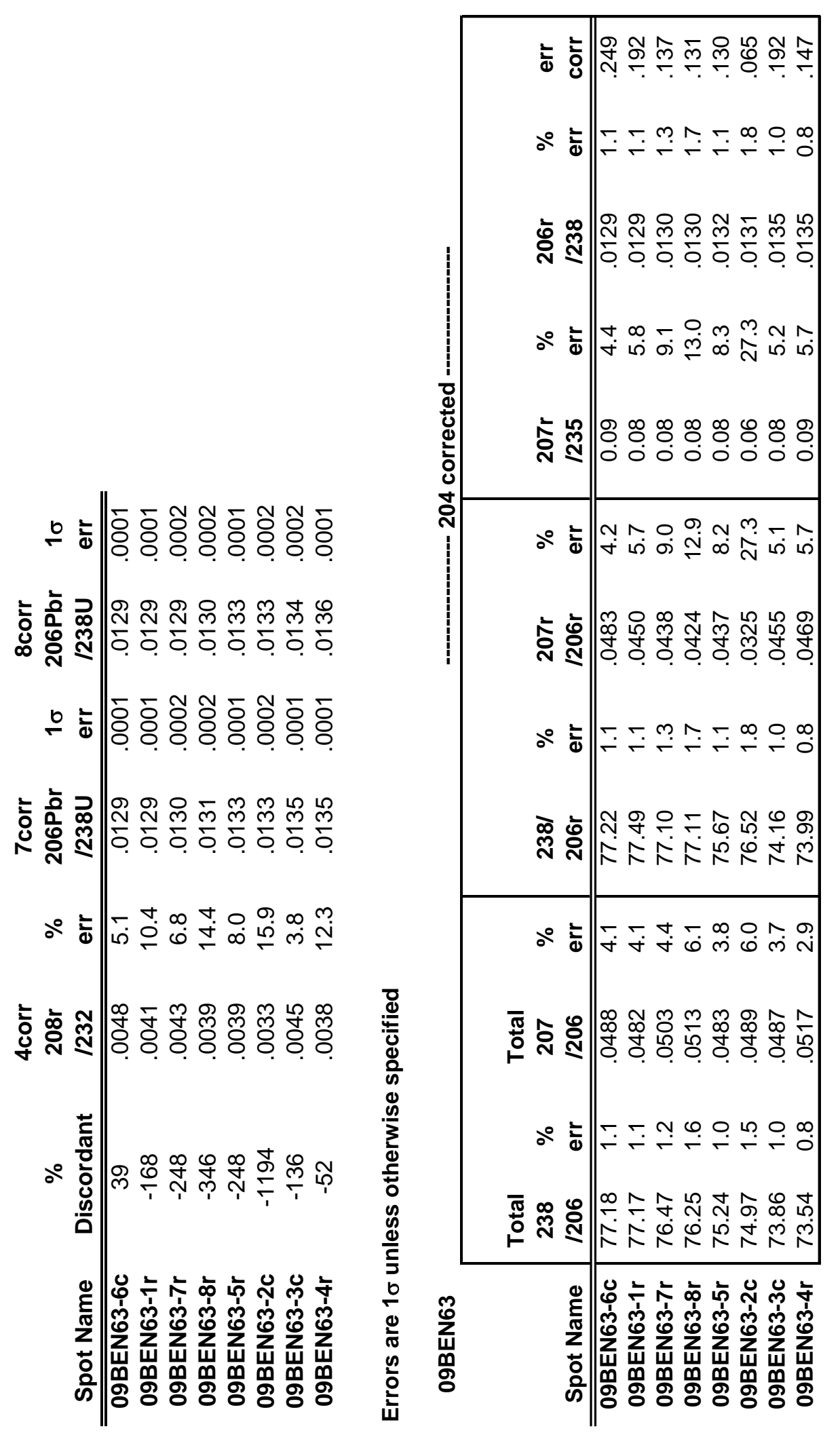

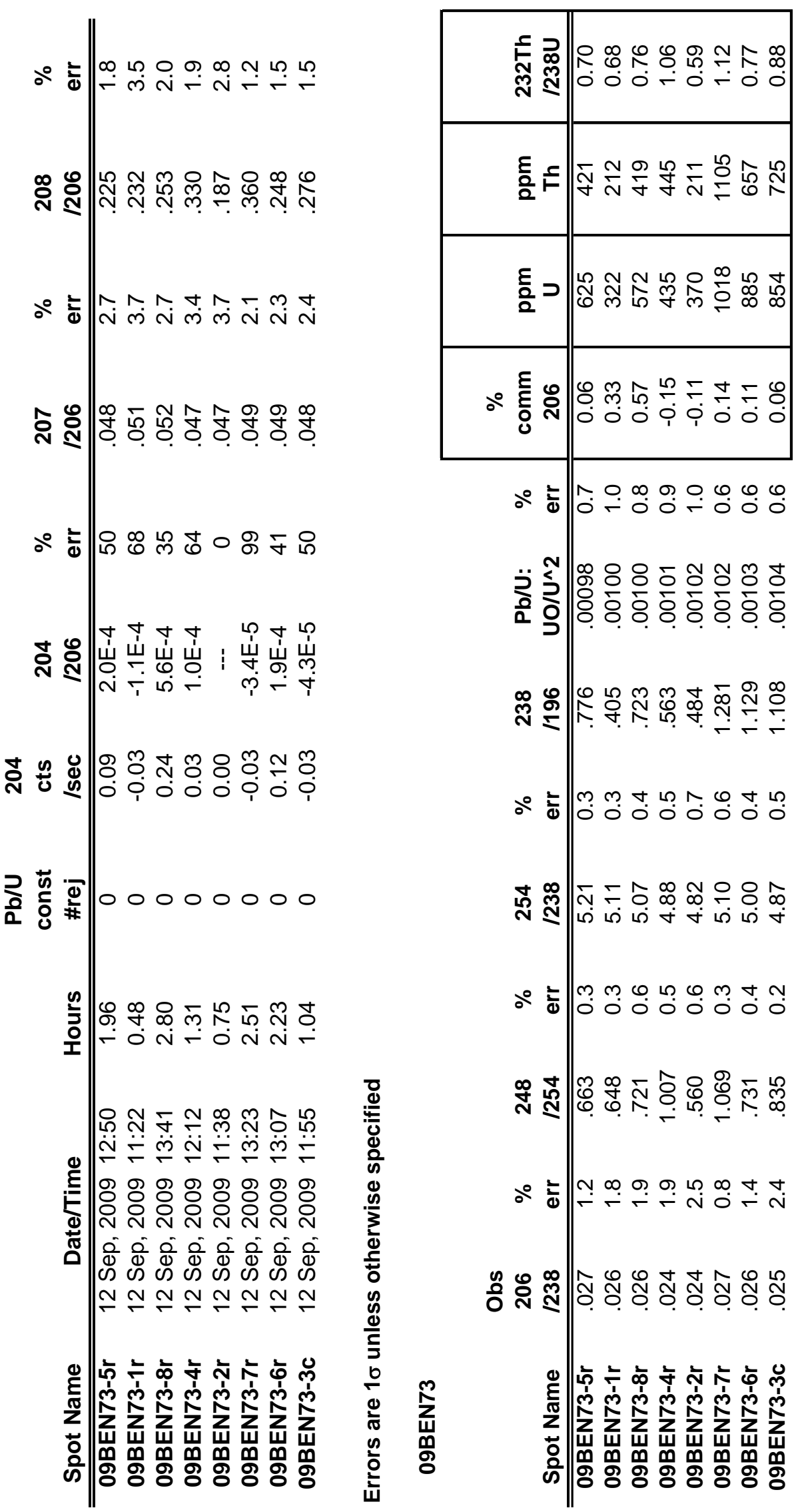

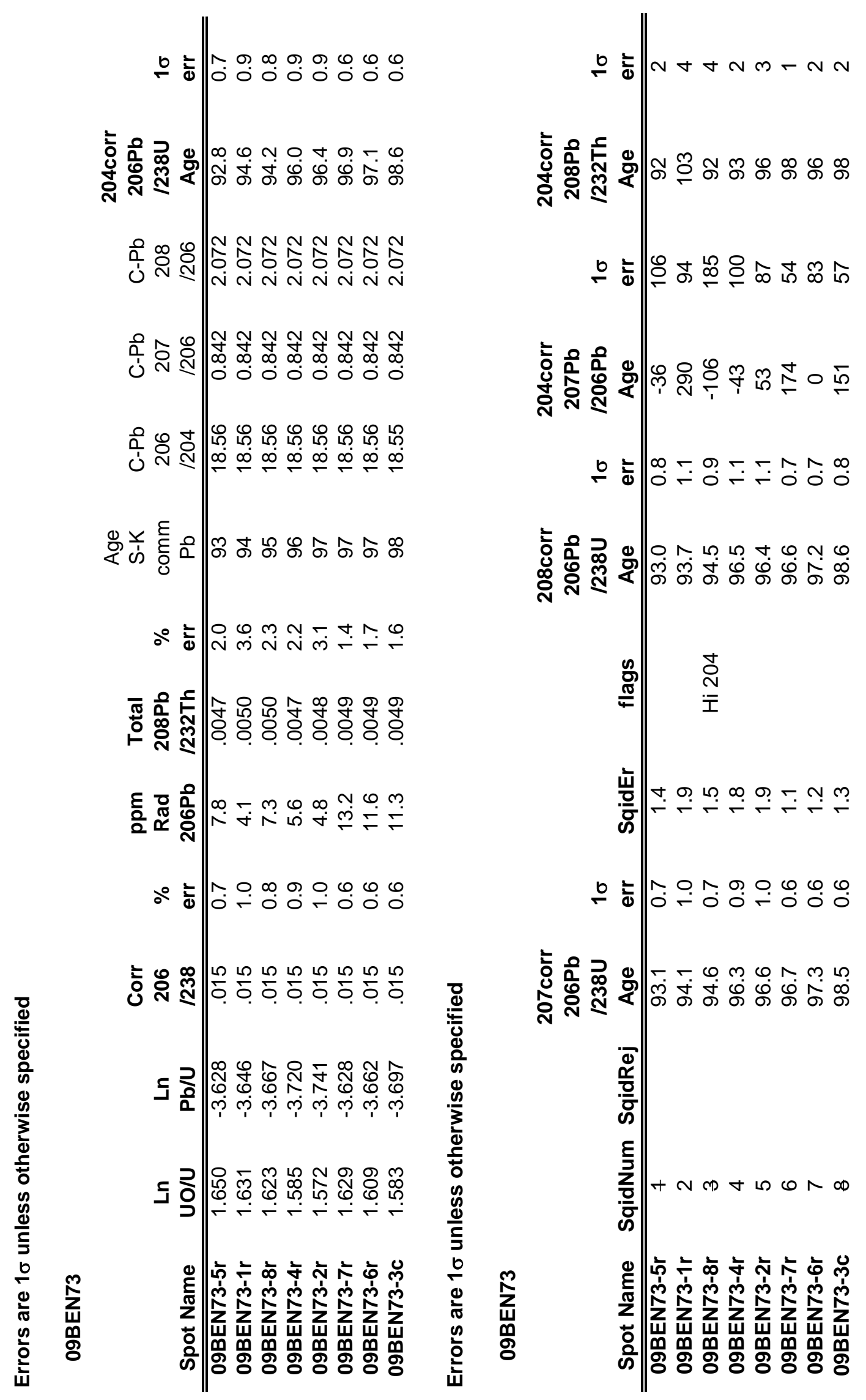

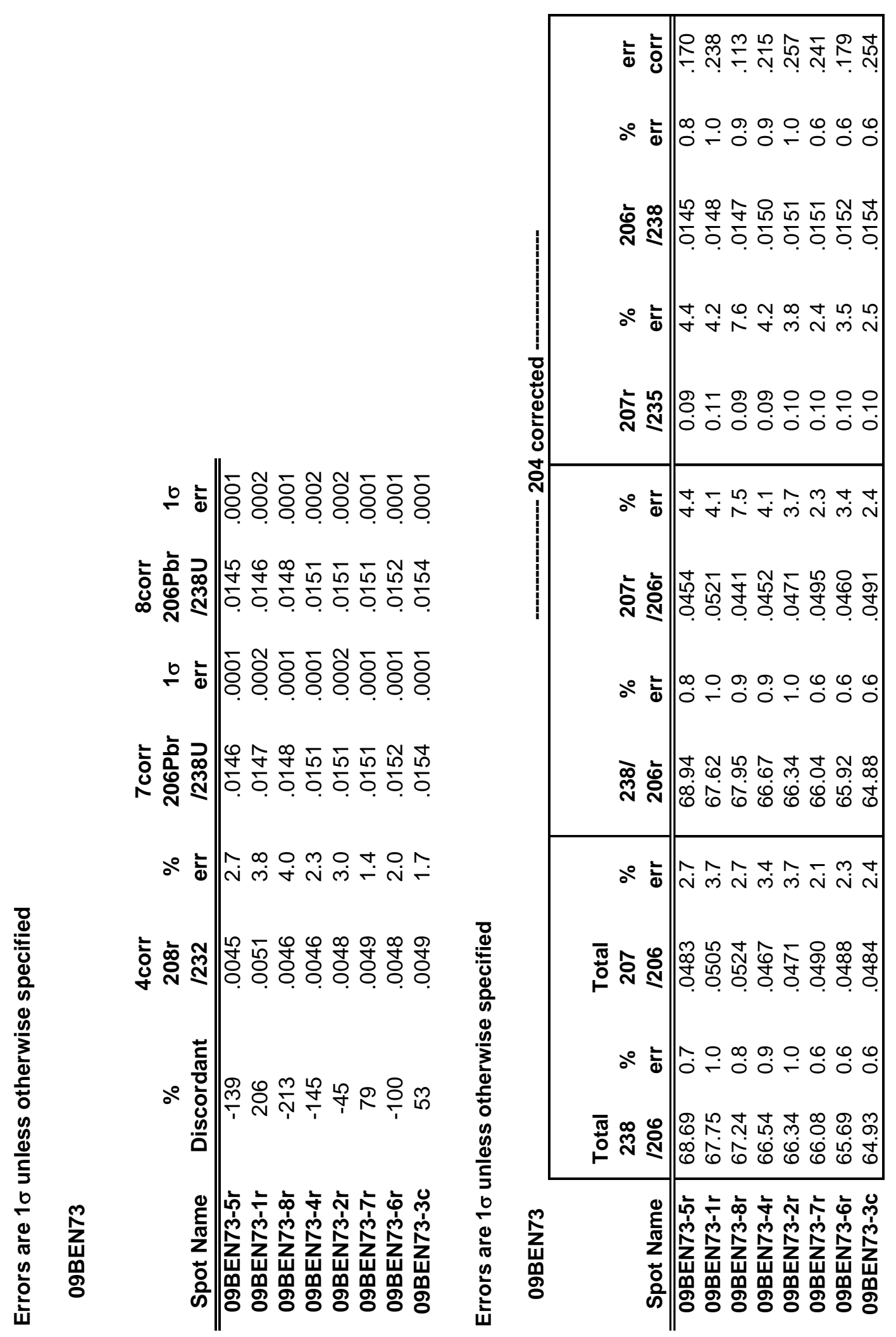


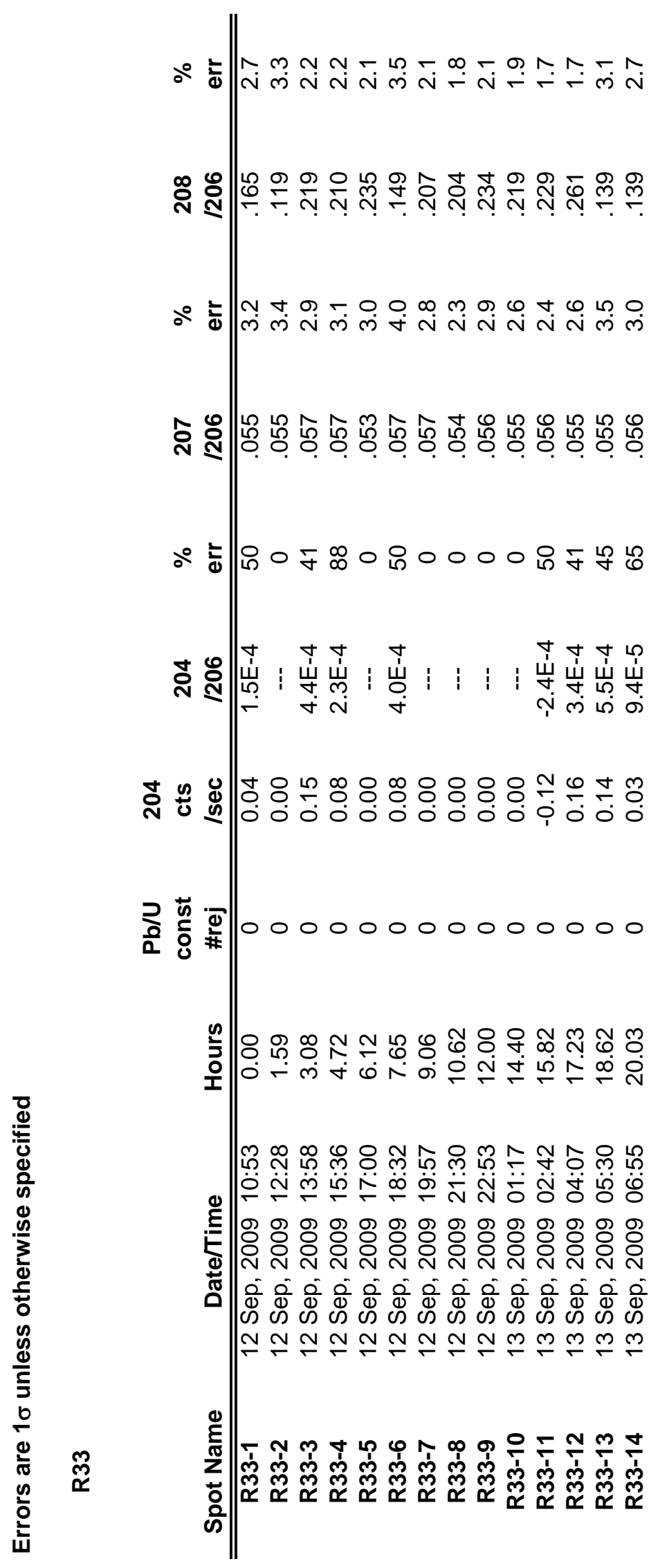




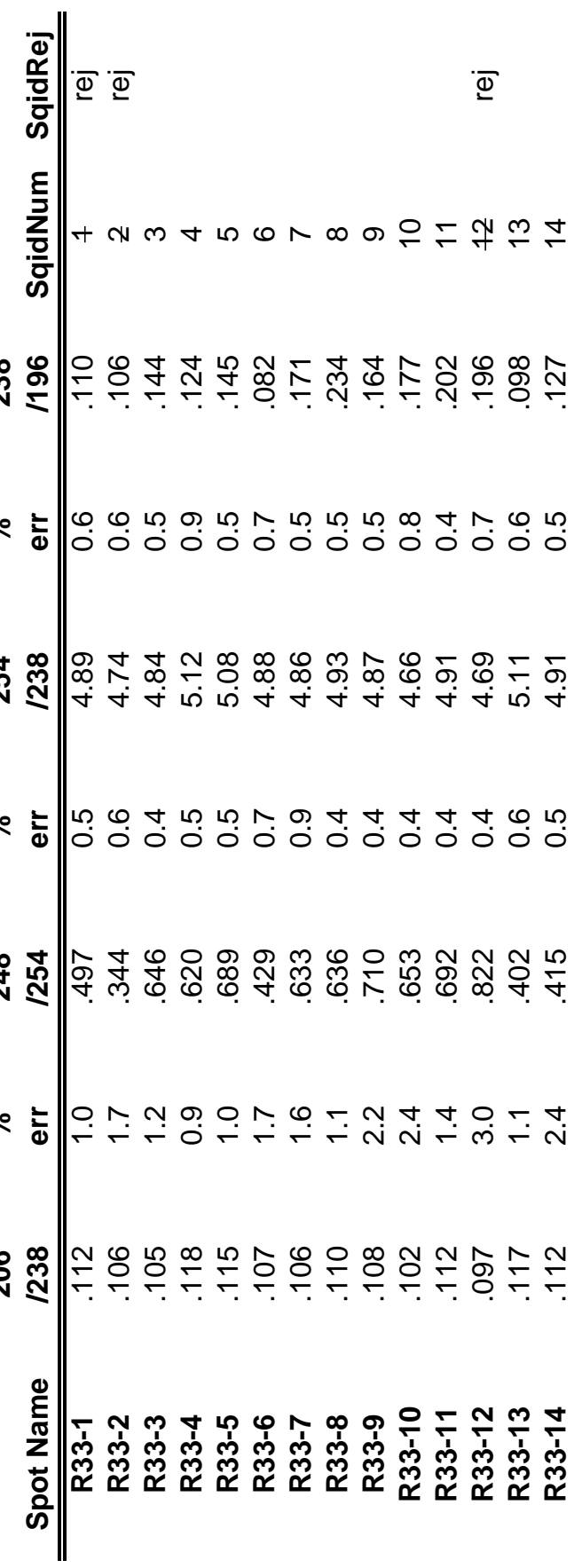




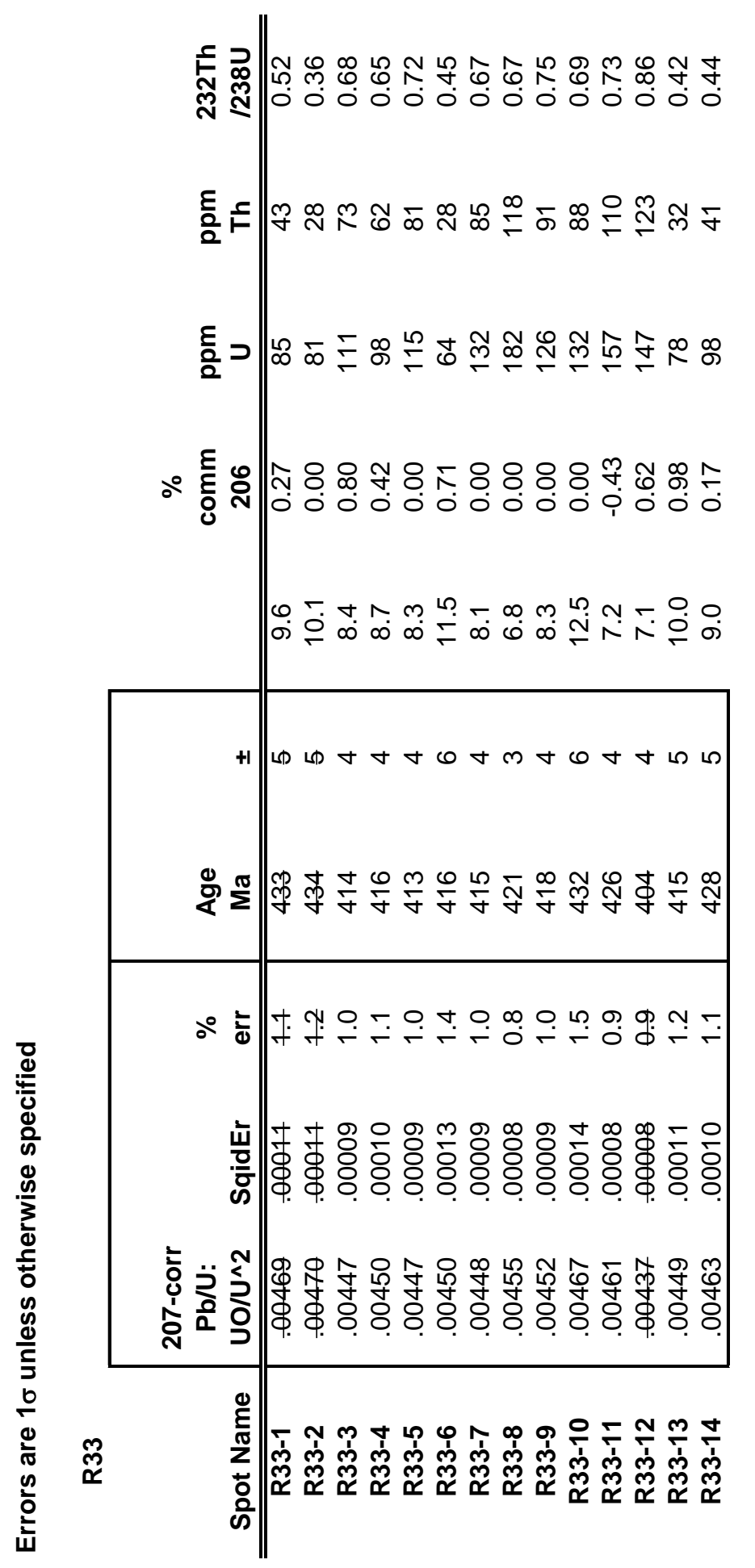




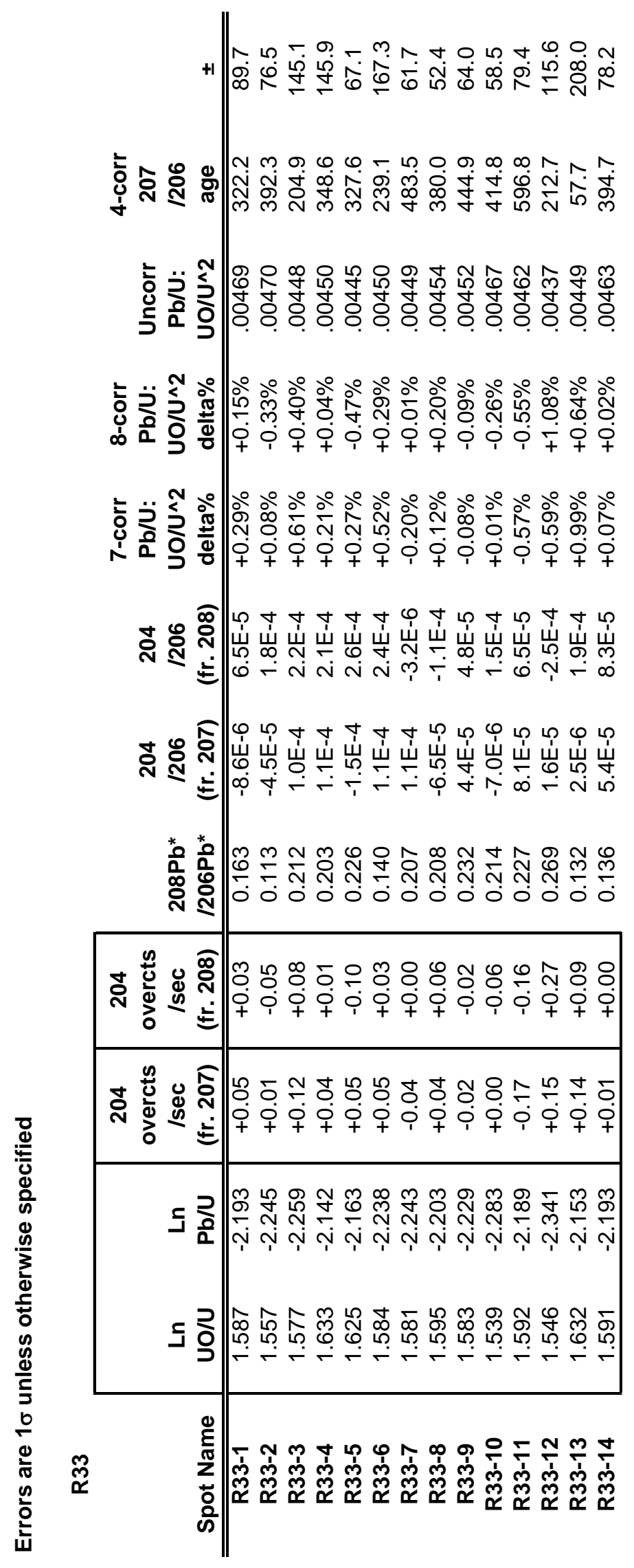


Appendix 8: Geochemistry results for samples collected from the Bendeleben and Windy Creek plutons, Seward Peninsula, Alaska. Abbreviations are: Kb-, Bendeleben pluton; af, alkali-feldspar granite; mo, monzogranite; ga, gabbro; Kwc, Windy Creek pluton alkali-feldspar granite; $\mathrm{PzPh}$, biotite-garnet schist from the Kigluaik Metamorphic Complex; Ocs, muscovite-chlorite schist from the Nome Group.

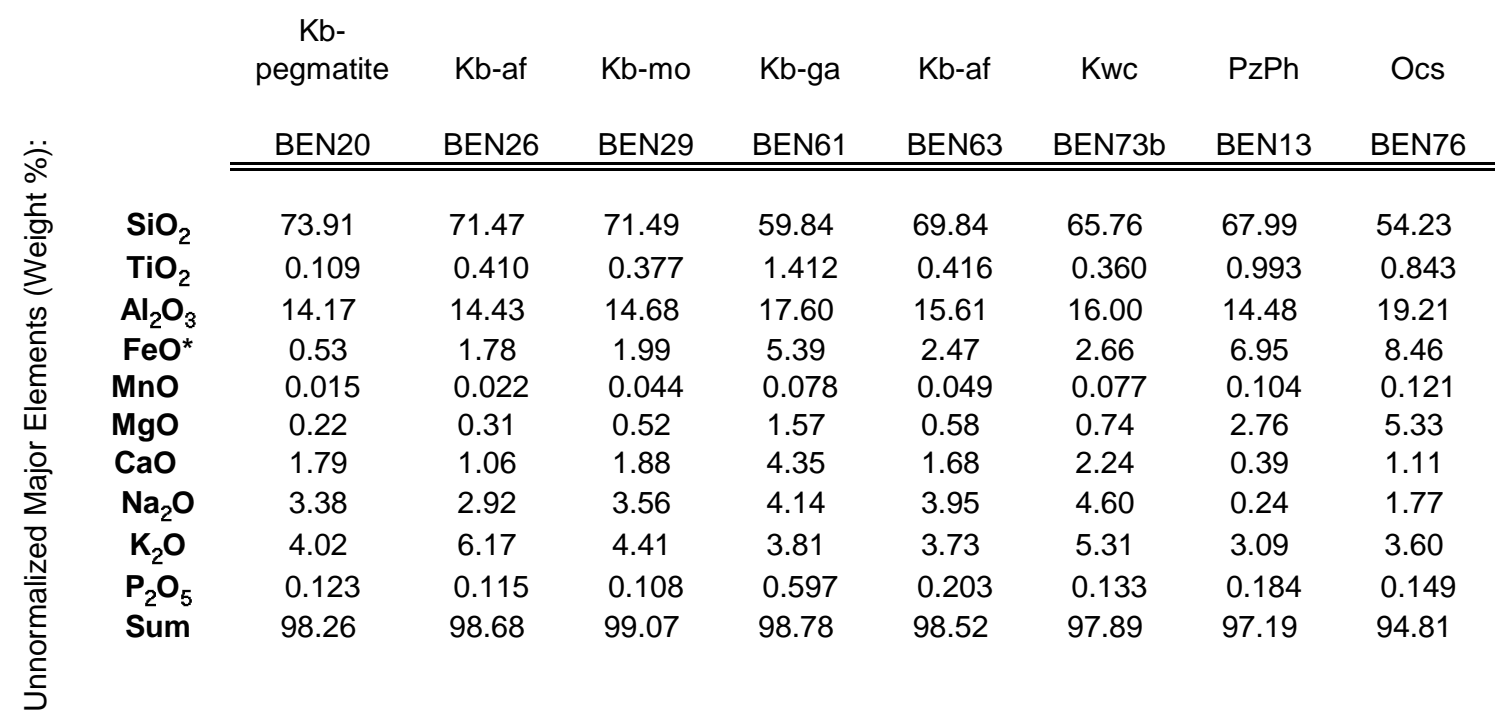

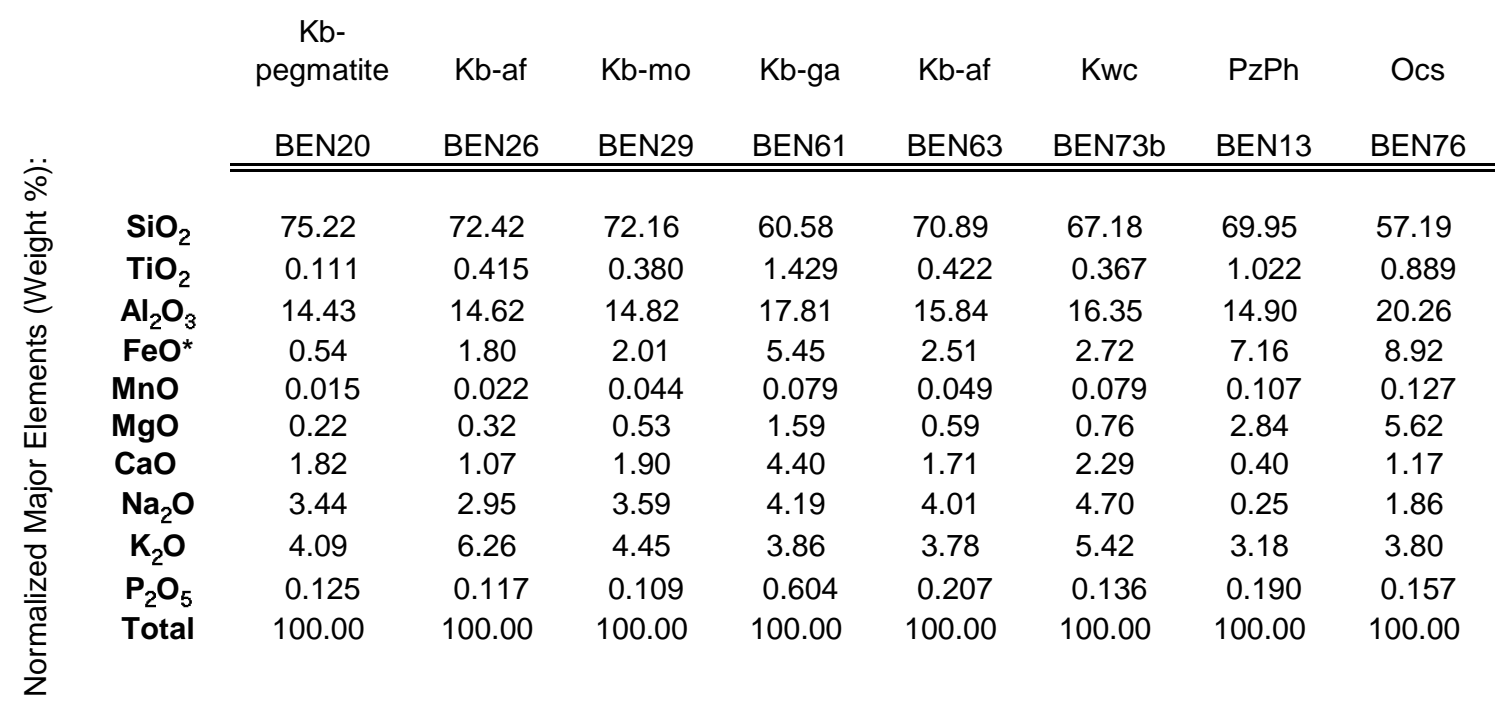




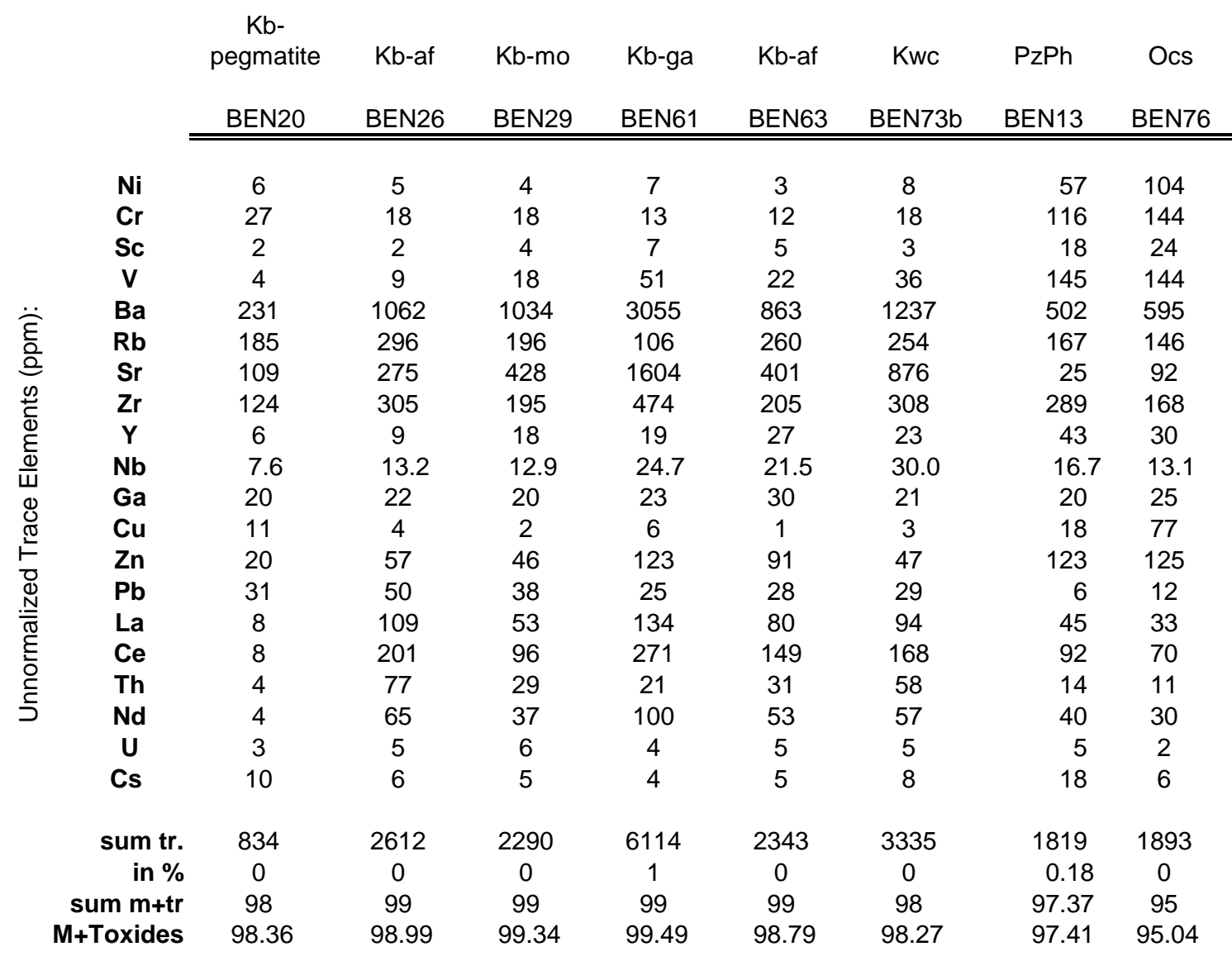




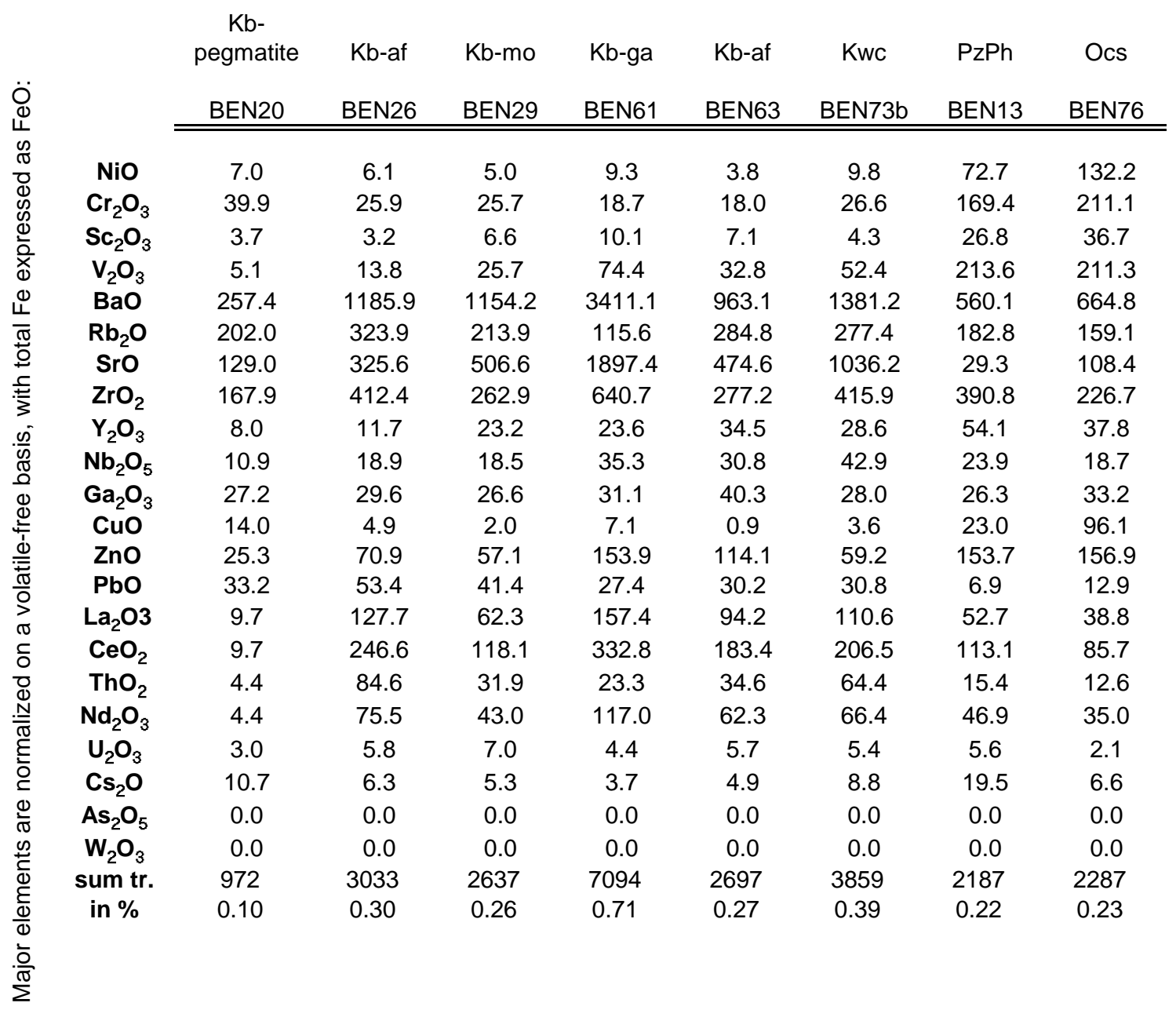
John H. 


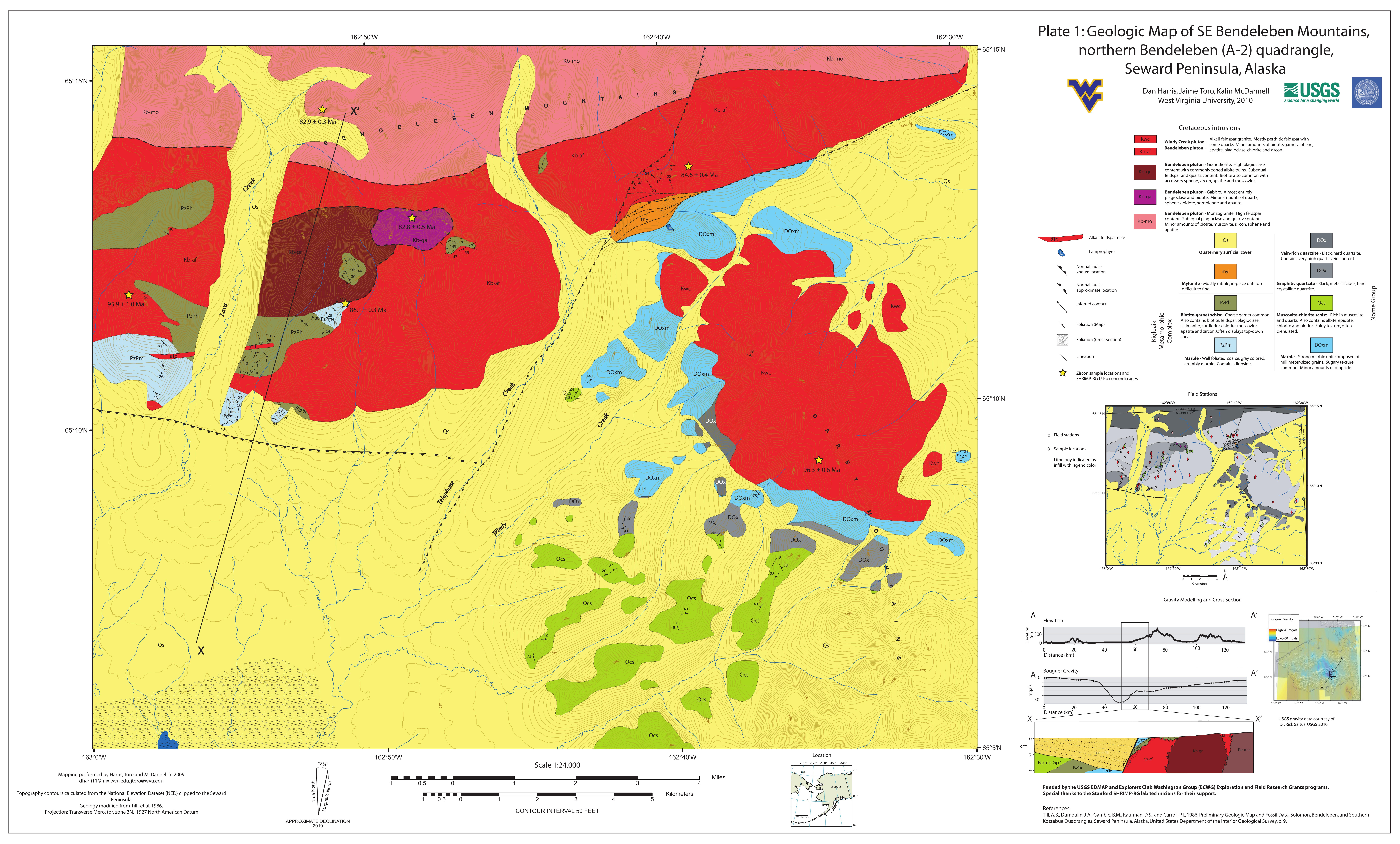

